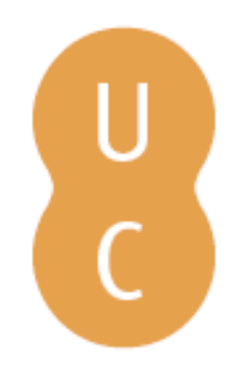

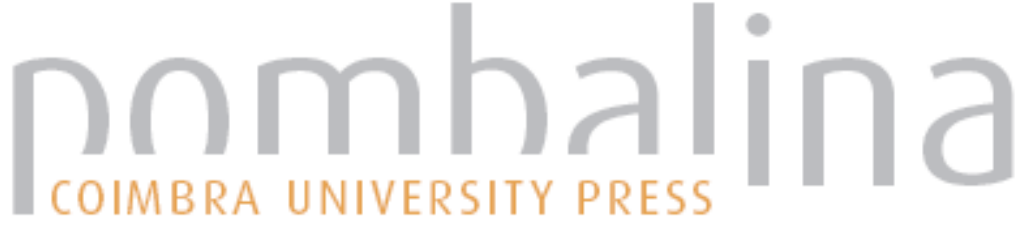

\section{Obras de Maria Helena da Rocha Pereira: estudos sobre a Grécia Antiga:} dissertações
Autor(es):
Pereira, Maria Helana da Rocha
Publicado por: Imprensa da Universidade de Coimbra
URL
persistente:
URI:http://hdl.handle.net/10316.2/38601
DOI:
DOI:http://dx.doi.org/10.14195/978-989-26-0677-4
Accessed : $\quad$ 26-Apr-2023 16:14:19

A navegação consulta e descarregamento dos títulos inseridos nas Bibliotecas Digitais UC Digitalis, UC Pombalina e UC Impactum, pressupõem a aceitação plena e sem reservas dos Termos e Condições de Uso destas Bibliotecas Digitais, disponíveis em https://digitalis.uc.pt/pt-pt/termos.

Conforme exposto nos referidos Termos e Condições de Uso, o descarregamento de títulos de acesso restrito requer uma licença válida de autorização devendo o utilizador aceder ao(s) documento(s) a partir de um endereço de IP da instituição detentora da supramencionada licença.

Ao utilizador é apenas permitido o descarregamento para uso pessoal, pelo que o emprego do(s) título(s) descarregado(s) para outro fim, designadamente comercial, carece de autorização do respetivo autor ou editor da obra.

Na medida em que todas as obras da UC Digitalis se encontram protegidas pelo Código do Direito de Autor e Direitos Conexos e demais legislação aplicável, toda a cópia, parcial ou total, deste documento, nos casos em que é legalmente admitida, deverá conter ou fazer-se acompanhar por este aviso.

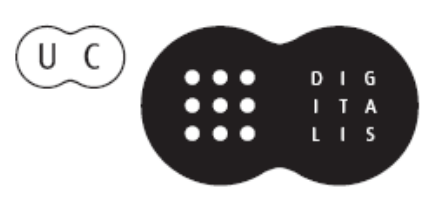




\section{OBRAS DE \\ MARIA HELENA DA ROCHA PEREIRA}

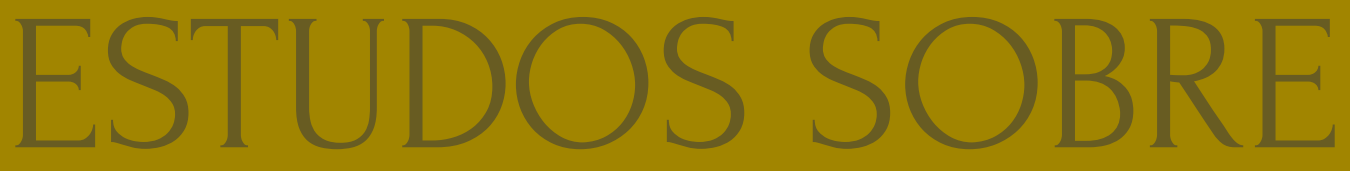

A GRECIA ANTIGA

$$
\text { DISSERTAÇÕES }
$$


(Página deixada propositadamente em branco) 
(Página deixada propositadamente em branco) 


\section{Co-EDIÇÃo}

Fundação Calouste Gulbenkian

E-mail: info@gulbenkian.pt

Imprensa da Universidade de Coimbra

E-mail:imprensauc@ci.uc.pt

Vendas online: http://livrariadaimprensa.uc.pt

\section{COORDENAÇ̃̃o EDITORIAL}

Imprensa da Universidade de Coimbra

\section{CONCEPCÃO GRÁFICA}

António Barros

INFOGRAFIA DA CAPA

Carlos Costa

\section{INFOGRAFIA}

Imprensa da Universidade de Coimbra

Pré-FORMATAÇÃo E ELABORAÇÃo doS ÍNDICES

Martinho Soares

EXECUÇÃo GRÁFICA

Gráfica de Coimbra

\section{ISBN}

978-989-26-0528-9

\section{ISBN Digital}

978-989-26-0677-4

\section{DOI}

http://dx.doi.org/10.14195/978-989-26-0677-4

\section{DEPósito LEGAL}

$366589 / 13$ 
OBRAS DE

MARIA HELENA DA ROCHA PEREIRA

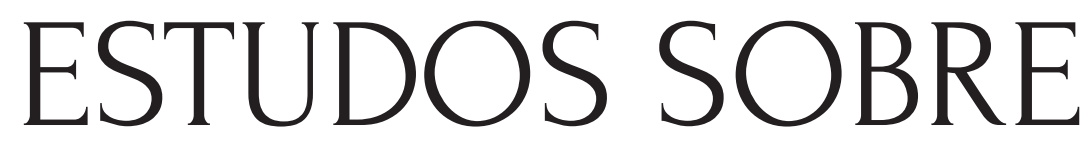

A GRÉCIA ANTIGA

DISSERTAÇÕES 
(Página deixada propositadamente em branco) 
A publicação das Obras Completas de Maria Helena da Rocha Pereira, que agora se inicia, representa um merecido testemunho de homenagem a uma figura central da vida intelectual e cultural portuguesa das últimas seis décadas.

A obra de Maria Helena da Rocha Pereira constitui, desde as suas primeiras etapas académicas, reeditadas neste primeiro volume, um monumento impressionante de rigor científico, de conhecimento exaustivo das fontes originais, de domínio seguro da bibliografia especializada em pelo menos seis línguas, mas sobretudo de capacidade de análise aprofundada, de desconstrução crítica e de formulação de hipóteses originais sobre a matéria em causa. A sua abordagem constrói-se sempre per asperam, fundamentando num aparato crítico de solidez exemplar cada passo do processo dedutivo, mas nem por isso as suas interpretações são menos inovadoras e combativas, ou se sente menos a sua convicção interior e a sua ligação apaixonada às temáticas que escolheu. A escrita de Maria Helena da Rocha Pereira é sempre uma escrita de combate, de uma luta permanente pela procura e produção de novo conhecimento.

A sua relação com o legado cultural da Antiguidade nunca se restringiu a uma reflexão puramente filológica, relegada para um passado remoto sem repercussões no presente. Para Maria Helena da Rocha Pereira, pelo contrário, a herança da Antiguidade Clássica integra o núcleo duro da Cultura Ocidental, no seu todo, não como mero património histórico venerado à distância mas como uma referência ética fundamental cuja lição é eminentemente intemporal naquilo que nos revela a cada momento da própria essência da condição humana. Nos clássicos encontra assim chaves insubstituíveis para abordar, com um olhar sempre enraizado nas grandes opções dos nossos dias, os valores maiores da cidadania, da dignidade, da consciência, da justiça, da beleza, da sabedoria.

Maria Helena da Rocha Pereira, de há muito minha estimada amiga, é uma colaboradora imprescindível da atividade da Fundação Calouste Gulbenkian em múltiplos domínios. O seu percurso cruza-se ao longo 
do último meio século com o desta instituição, tanto no campo do ensino como no da investigação e edição científicas, e nesse cruzamento a Fundação muito beneficiou do seu conselho lúcido, do seu elevado sentido deontológico e da sua dedicação ilimitada. É, pois, com orgulho que a Fundação Calouste Gulbenkian se associa a este projeto editorial, na certeza de que este constitui sem qualquer dúvida um contributo da maior relevância para a bibliografia dos Estudos Clássicos em Portugal e do pensamento português.

Artur Santos Silva JULHO DE 2013 
Numa altura em que o país tem ainda bem fresca na memória a recente e tão honrosa classificação, pela UNESCO, da Universidade de Coimbra, Alta e Sofia como Património Mundial da Humanidade, importa ainda assim recordar que essa atribuição não ficou a dever-se apenas ao património arquitetónico preservado, reconhecidamente de enorme valor, mas também ao papel central que a Universidade teve, ao longo de séculos, na projeção da cultura e língua portuguesas, contribuindo assim para que Portugal se afirmasse como agente particularmente ativo na formação da história da humanidade. Este tipo de património imaterial acaba, de resto, por ser ainda mais valioso, na medida em que não se confina a um espaço geográfico determinado, mas antes leva as suas marcas a todo o universo onde a lusofonia mantém presença perene e atuante.

Numa instituição académica, esse património imaterial vai sendo construído, ao longo de séculos, pelo contributo continuado - e tantas vezes discreto ou mesmo esquecido - de toda a estrutura universitária, sendo que parte essencial do processo decorre da qualidade da pesquisa desenvolvida e da formação facultada nesse mesmo espaço de estudo e de reflexão. Os trabalhos produzidos pela Prof. Doutora Maria Helena da Rocha Pereira, enquanto investigadora e docente, representam, precisamente, um desses paradigmas notáveis de qualidade e dedicação incondicional à ciência e à cultura - capazes por isso mesmo de construir a grandeza de uma instituição de referência dentro dos meios académicos mais exigentes.

Que a Imprensa da Universidade de Coimbra tenha a oportunidade de publicar a obra da Prof. Doutora M. H. da Rocha Pereira é seguramente um dos momentos marcantes de uma casa editorial que celebra agora os 240 anos de existência. Que o possa fazer ao abrigo de uma parceria com a Fundação Calouste Gulbenkian, trata-se por certo de uma circunstância altamente simbólica e feliz, dado que a autora dedicou dezenas de anos do seu incessante labor à colaboração com estas instituições.

Que o lançamento desta iniciativa ocorra quando é Diretor da IUC um dos inúmeros discípulos da autora será, sem dúvida, um 
mero acaso sem grande importância, mas que marcará, de forma indelével, quem já tanto beneficiou, a nível pessoal, do saber e orientação de um Mestre verdadeiramente especial. Possam agora muitos mais leitores continuar a usufruir, igualmente, de uma obra magna e sempre atual.

Delfim FerReira Leão

Coimbra, JULHo de 2013 


\section{NOTA PRÉVIA}

Encontram-se nestes dez volumes, agrupadas por assuntos, obras da autora publicadas ao longo de mais de seis décadas.

Um lugar especial é ocupado pelo primeiro tomo, que contém a tese de doutoramento (Concepções Helénicas de Felicidade no Além, de Homero a Platão) e a de concurso para professor associado (Sobre a Autenticidade do Frg. 44 Diehl de Anacreonte). Os outros são, na sua maioria, Scripta Minora. Assim, o Vol. II compreende uma série de quarenta e nove artigos, constituídos por Estudos sobre a Grécia Antiga, que, principiando por uma parte teórica de considerações sobre o mito, se ocupam em seguida de vários autores helénicos, desde Homero a Plutarco.

No terceiro se juntaram traduções com introdução e notas, de poetas gregos do séc. V a.C., desde Píndaro (sete odes) aos grandes trágicos, como Sófocles (Antígona, Ájax) e Eurípides (Medeia, As Troianas, As Bacantes).

$\mathrm{O}$ volume IV é dedicado à Arte Antiga, num total de vinte e um estudos.

No volume V juntaram-se seis artigos sobre Roma e mais dez consagrados à Europa e ao Legado Clássico.

Ao volume VI pertencem o Latim Medieval, com obras médicas de Pedro Hispano, e ainda o Regimento de Saúde Salernitano.

O volume VII contém mais obras em Latim Medieval (hagiografias dos Portugaliae Monumenta Historica: S. Rosendo, Santa Senhorinha e S. Teotónio) e, sobretudo, livros em Latim Renascentista (a Oração de Sapiência de Belchior Beleago, um breve estudo sobre As Orações de Sapiência e a Universidade e ainda Louvores Latinos ao Colóquio dos Simples e Drogas).

Ao Vol. VIII cabem trinta e nove artigos sobre a Recepção das fontes clássicas em Portugal, desde uma apreciação de ordem geral (Portugal e a Herança (lássica) até considerações sobre A situação do tradutor literário, bem como dois estudos sobre Helenismos.

No Vol. IX figuram quinze artigos sobre autores vários de Língua Portuguesa até à oração Os caminhos da harmonia de uma 
língua única, apresentada na Academia Brasileira de Letras, a convite desta, e à série de doze breves estudos subordinados ao título Camoniana Varia.

O Vol. X, por sua vez, compreende três partes distintas: um conjunto de recensões críticas publicadas em revistas nacionais e estrangeiras; a série de "Notícias e Comentários" que figuram nos sucessivos volumes das revistas Humanitas e Boletim de Estudos Clássicos; uma sequência de textos provenientes de Biblos, a publicação anual da Faculdade de Letras de Coimbra, no período em que a sua direcção estava entregue à autora destas linhas; bem como textos avulsos sobre figuras notáveis da vida universitária. No seu conjunto, encontram-se aqui dados que contribuem para os estudiosos poderem reconstituir o desenvolvimento dos Estudos Literários, e, particularmente, dos Estudos Clássicos no nosso País durante largos decénios.

Devido à presença de características que facilmente se compreendem, ficaram excluídas deste plano as seguintes obras:

- Pausaniae Graeciae descriptio. Edição crítica na Bibliotheca Scriptorum Graecorum et Romanorum Teubneriana. Leipzig, 3 vols., 1ª ed. 1978-1981; $2^{\text {a }}$ ed. 1989-1990.

- Estudos de História da Cultura Clássica. Lisboa, Fundação Calouste Gulbenkian, 2 vols.

- Vol. I. Cultura Grega, $1^{\mathrm{a}}$ ed. 1966; $11^{\mathrm{a}}$ ed. 2012.

- Vol. II. Cultura Romana, $1^{a}$ ed. 1984; $4^{a}$ ed. 2008.

- Platão, A República. Lisboa, Fundação Calouste Gulbenkian. Introdução,

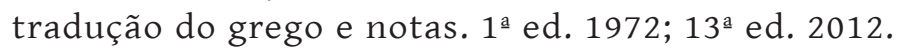

- Hélade. Antologia da Cultura Grega. Organização e tradução do grego. $1^{\mathrm{a}}$ ed., Coimbra, Instituto de Estudos Clássicos, 1959; $10^{\mathrm{a}}$ ed. Lisboa, Guimarães Editores, 2009.

- Romana. Antologia da Cultura Latina. Organização e tradução do original. $1^{\mathrm{a}}$ ed., Coimbra, Instituto de Estudos Clássicos, 1976 (com o título Res Romanae); 6르 ed. Lisboa, Guimarães Editores, 2010.

- Poesia Grega Arcaica. Antologia. (no original grego). Coimbra, Instituto de Estudos Clássicos, $1^{\text {a }}$ ed. 1979; $2^{\text {a }}$ ed. 1994.

O mesmo sucedeu com os artigos das Enciclopédias Verbo (404); Logos (42) e Biblos (18); e ainda com os editados nos fascículos do Grande Dicionário de Literatura Portuguesa e Teoria Literária de José João Cochofel (10) e com aquele que consta do Lexicon Iconographicum Mythologiae Classicae (Basileia - Paris) e outro do Dicionário Luís de Camões.

Dados estes esclarecimentos, apenas me resta agradecer à Imprensa da Universidade, ao seu Conselho Editorial e ao seu Director, Prof. Doutor Delfim Ferreira Leão, a sua disponibilidade e interesse em editar estes 
trabalhos dentro das limitações acima expostas, e bem assim à Fundação Calouste Gulbenkian, pelo seu apoio em viabilizar esta edição. E, por último, formular votos por que ela possa ainda ser útil aos estudiosos, não obstante a variedade de épocas em que os trabalhos nela contidos foram escritos.

Maria Helena da Rocha Pereira

Coimbra, Fevereiro de 2013 
(Página deixada propositadamente em branco) 
ÍNDICE GERAL 
(Página deixada propositadamente em branco) 


\section{CONCEPÇÕES HELÉNICAS DE FELICIDADE NO ALÉM DE HOMERO A PLATÃO}

NOTA PRELIMINAR

\section{1ª PARTe - A EVolução da CRençA num AlÉm Feliz}

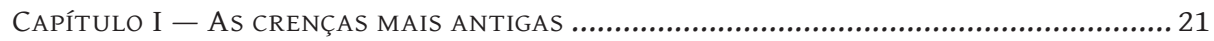

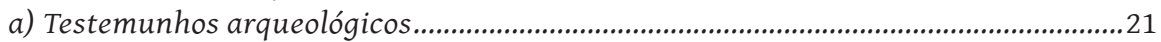

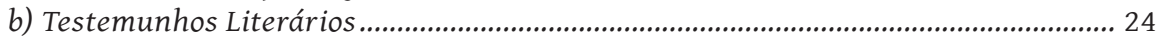

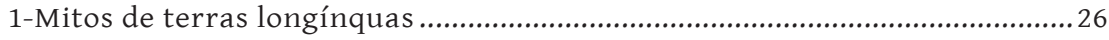

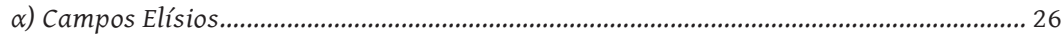

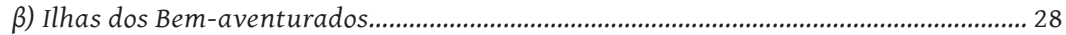

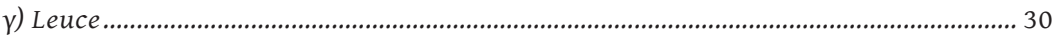

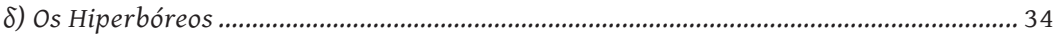

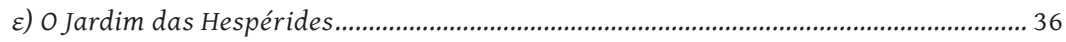

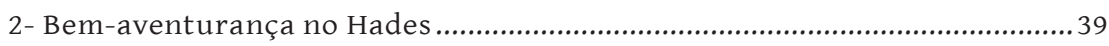

CAPítulo II — Ideias Sobre um Além Feliz Durante os Séculos Vi e V A.C. .......... 47

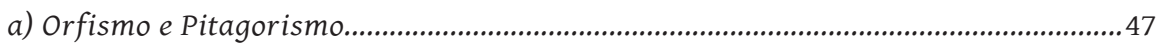

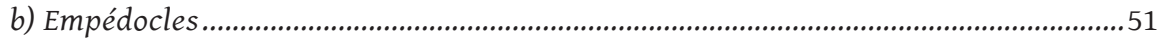

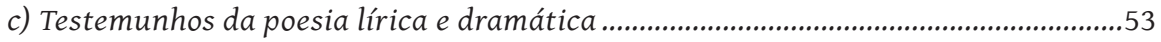

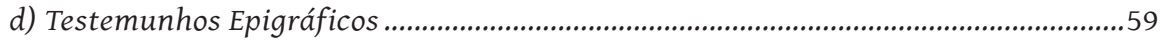

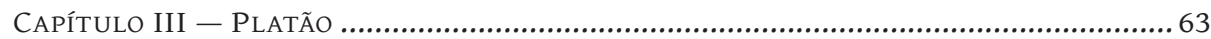

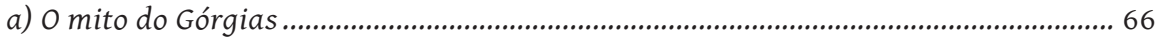

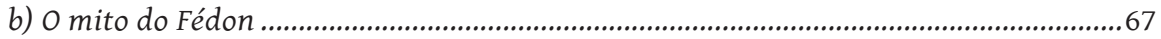

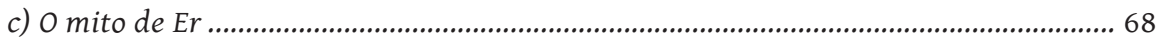

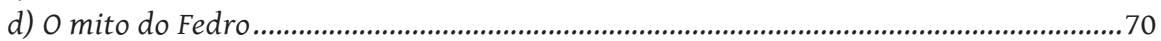

e) $O$ mito do diálogo pseudo-platónico Axíoco ...................................................................72

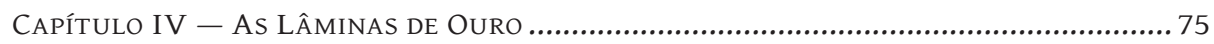




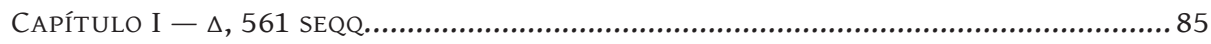

CAPítulo II — As IlHas dos Bem-AVEnturados EM Hesíodo ....................................... 91

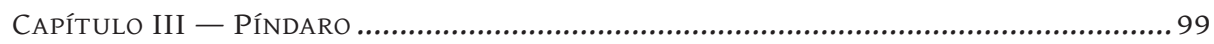

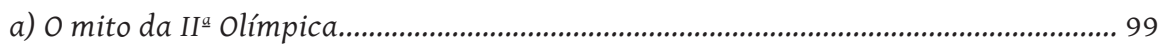

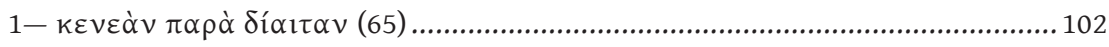

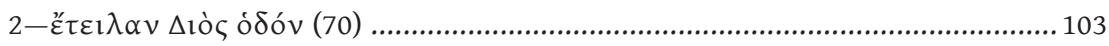

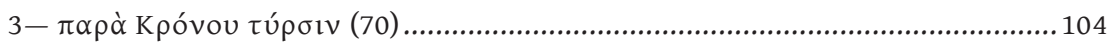

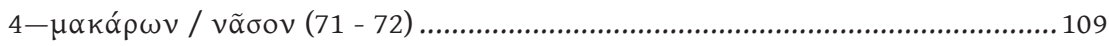

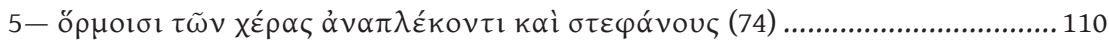

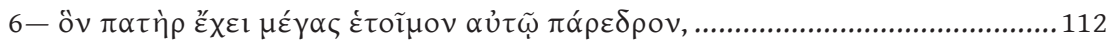

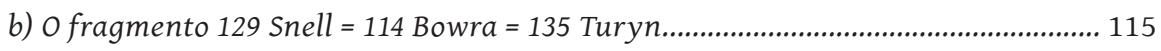

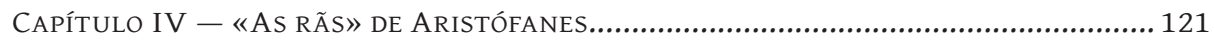

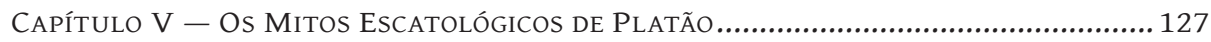

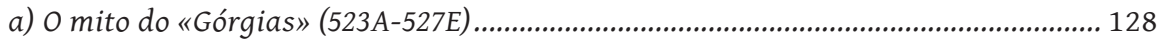

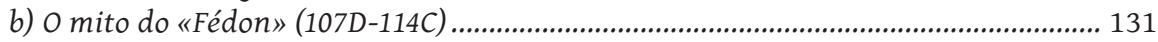

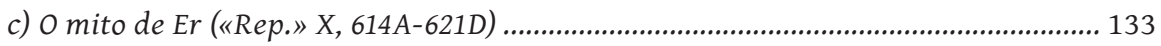

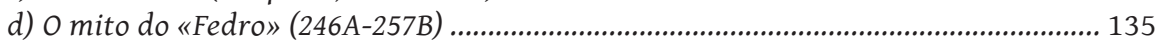

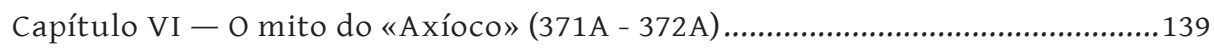

\section{3 ${ }^{\text {a }}$ PARTE - OS TEMAS}

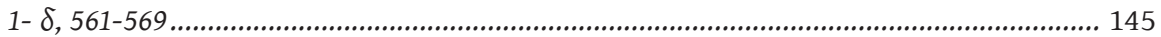

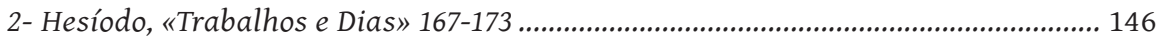

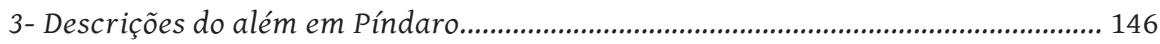

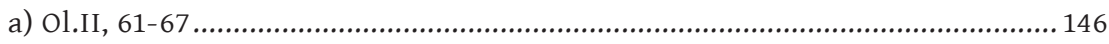

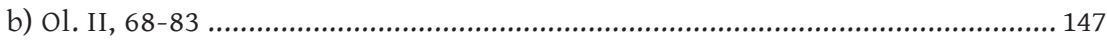

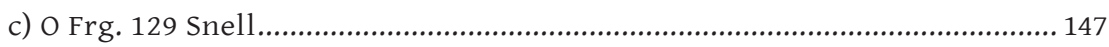

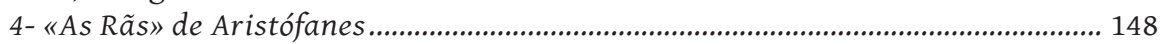

5- Os mitos escatológicos de Platão ...............................................................................149

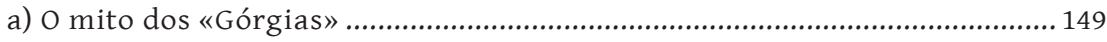

b) $\mathrm{O}$ mito do «Fédon» (107D-114C) ......................................................................... 149

c) O mito de Er (Rep. X, 614A-621D) ................................................................150

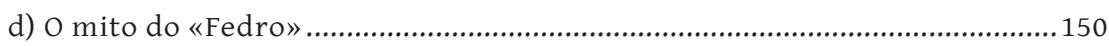

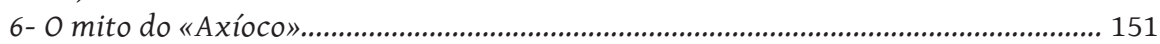

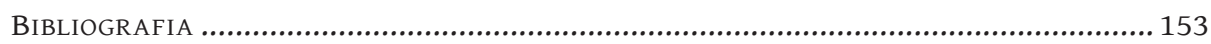

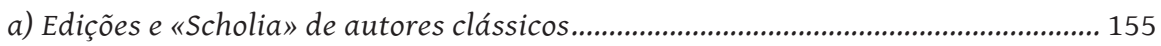

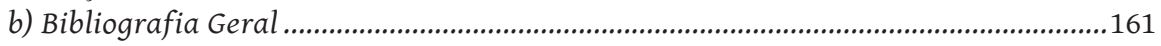




\section{SOBRE A AUTENTICIDADE DO FRAGMENTO 44 DIEHL DE ANACREONTE}

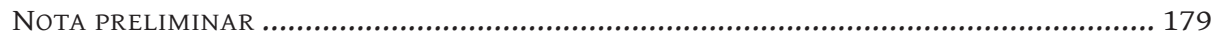

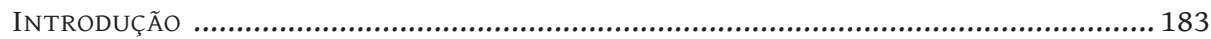

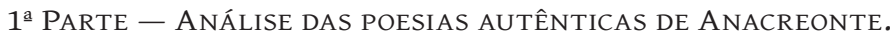

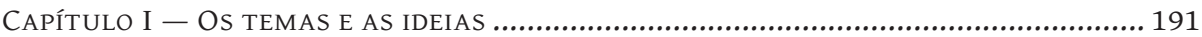

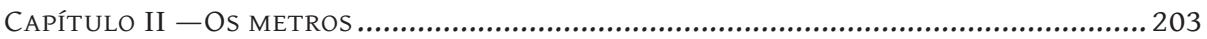

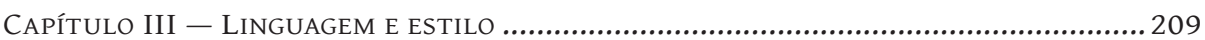

CAPÍTULO IV — COMPARAÇÃO COM AS «ANACREONTEA» .............................................. 217

2 2 PARTE- NOTÍCIA HISTÓRICA SOBRE O PROBLEMA

DA AUTENTICIDADE DO FRG. 44 DiEHL

CAPÍTULO ÚNICO — NOTÍCIA HISTÓRICA DO PROBLEMA

3a PARTE - FUNDAMENTAÇÃo DAS DÚVIDAS

SOBRE A AUTENTICIDADE DO FRG. 44 DIEHL

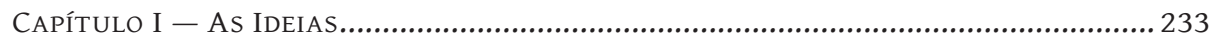

1 -Confronto com a ideologia da Anacreonte ...............................................233

2-Esboço da evolução das ideias contidas no frg. 44 Diehl..............................2235

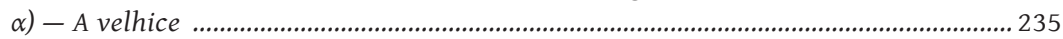

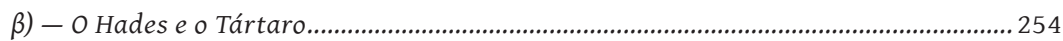

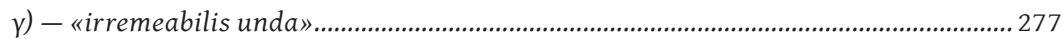

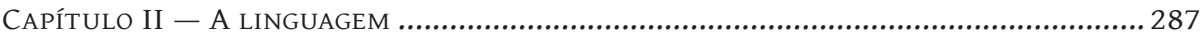

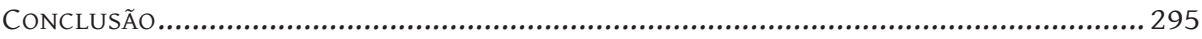

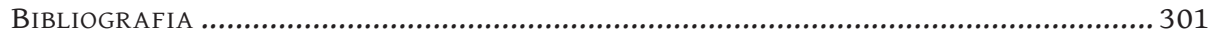

ÍNDICE DE AUTORES

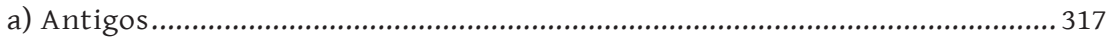

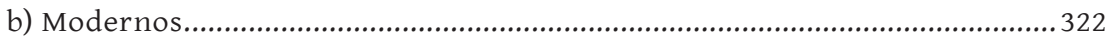

ÍNDICE DE PALAVRAS E EXPRESSÕES ANACREÔNTICAS. .................................................. 339 
(Página deixada propositadamente em branco) 


\section{CONCEPÇÕES HELÉNICAS DE FELICIDADE NO ALÉM DE HOMERO A PLATÃO}


Edições "Maranus", Porto, 1955 
DISSERTAÇÃO DE DOUTORAMENTO EM FILOLÓGIA CLÁSSICA

NA UNIVERSIDADE DE COIMBRA 
(Página deixada propositadamente em branco) 
A MEUS PAIS 
(Página deixada propositadamente em branco) 


\section{NOTA PRELIMINAR}

É sabido que os helenos nunca tiveram um corpo de doutrina estabelecido acerca do destino das almas e do modo da sua sobrevivência. Este mesmo facto fez com que diversos mitos se formassem e coexistissem durante séculos, e por vezes o mesmo autor se tornasse intérprete de mais do que uma tradição escatológica.

Para nós, a perspectiva sombria do Hades homérico é a primeira forma que essas concepções assumiram. Mas, por outro lado, quando se menciona, pela primeira e única vez na Odisseia, a possibilidade de um homem continuar a existir numa região privilegiada, a que se dá o nome de Campos Elísios, as palavras que traduzem esse pensamento dão claro testemunho da antiguidade da crença. Ao lado desta existiam outras, de que algumas perderam o significado no volver dos anos, entrando depois na mitologia sob uma rubrica diferente, e outras pela sua semelhança, vieram a confundir-se inextricavelmente com a mais antiga versão que conhecemos.

Foi sobretudo a literatura que nos preservou os documentos que permitem reconstituir estes mitos. $O$ elemento emocional que entra nestas concepções - o poeta tornava-se arauto da esperança humana - e o aspecto puramente estético de que facilmente se revestia - concretizando-se em visões deleitosas - faziam delas um tema de eleição, que quase todos os escritores aproveitaram. Deste modo, um estudo desta feição da religião grega facilmente se volve em ensaio de estética literária.

Porém a análise de uma obra de arte deve compreender todos os aspectos, desde o problema das fontes ideológicas às minúcias da crítica textual. Só depois de conhecido o fundo comum da tradição, é possível apreciar o aproveitamento que dela fizeram os autores, assim como é necessário estabelecer um texto, sobre o qual se baseie a consideração do seu estilo.

Estavam assim naturalmente determinadas duas partes do meu trabalho: a primeira tinha de estudar, de um modo geral, a evolução da 
crença num além feliz, fazendo uso de todos os dados que permitissem reconstituir esse processo; a segunda, de ocupar-se dos desenvolvimentos literários a que tais concepções deram lugar, analisando os pontos de crítica do texto cuja solução afectava a interpretação do mesmo, para considerar em seguida o seu aspecto estilístico. Encontrava-se assim aberto o caminho para a terceira parte, na qual se podiam já distinguir os temas de que cada poeta se serviu, denunciando desse modo, embora sob a influência de uma tradição literária importante, a sua própria maneira de conceber a felicidade. Depois de se terem enumerado as formas correntes dessa noção, e de ter analisado o seu tratamento literário, pareceu-me interessante procurar surpreender, através da escolha dos tópicos, o modo de pensar dos autores. E fácil é concluir que os mitos platónicos, dando expressão poética a um pensamento eminentemente filosófico, mesmo quando põe de parte a habitual argumentação dialéctica, para usar a forma livre da alegoria, imprimiram às crenças na felicidade no além um cunho que não mais se desvaneceu. Daí os limites que demarquei a este estudo. $O$ que se segue, mesmo quando embelezado pela fantasia de Plutarco, ou caricaturado pela irreverência de Luciano, apresenta um interesse diminuto e não passa de um pálido reflexo do poder criador de alguns dos maiores poetas helénicos.

Antes de concluir esta breve nota, não quero deixar de agradecer a todas aquelas entidades ou pessoas que tornaram possível este trabalho, em especial às Universidades de Coimbra e de Oxford, a quem devo a minha preparação, através dos seus mestres ilustres, dos quais é justo que saliente, pelo papel que desempenharam na minha formação clássica, o Prof. Doutor Carlos Ventura e o Prof. E. R. Dodds, D. Litt., a cujo vasto saber e nunca desmentida afabilidade não recorri nunca em vão; e ao Instituto de Alta Cultura, que, concedendo-me bolsas de estudo e outras facilidades, por duas vezes me proporcionou longas e proveitosas estadias na mais antiga cidade universitária britânica.

Coimbra, Janeiro de 1955. 
1a PARTE

A EVOLUÇÃO DA CRENÇA NUM ALÉM FELIZ 
(Página deixada propositadamente em branco) 


\section{CAPÍTULO I}

\section{AS CRENÇAS MAIS ANTIGAS}

É escassa a informação que possuímos sobre as crenças mais antigas. Das duas fontes de que dispomos para o conhecimento dessa época, a saber, a arqueológica e a literária, apenas a primeira remonta a um período pre-helénico. Nos próximos parágrafos tentarei dar um sumário dos dados mais importantes, para seguidamente os interpretar, na medida em que isso for possível.

\section{a) Testemunhos arqueológicos}

É fora de dúvida que o testemunho da arqueologia confirma a existência de uma crença em qualquer forma de sobrevivência, sem a qual não é concebível que se continuasse a abastecer os mortos de alimentos e a colocar-lhes nos túmulos objectos de que se haviam servido durante a vida. Os achados feitos em sepulturas, desde a Idade do Bronze até ao alvorecer da Idade do Ferro, provam que se supunha que uma espécie de vida no túmulo era o destino atribuído aos mortos em geral. Deve ter sido esta a concepção mais primitiva do além, não só entre a população pre-helénica, como entre outras também. Segue-se-lhe uma extensão deste conceito, segundo a qual a existência se prolonga, não já no próprio túmulo, mas numa mansão comum a todos os que deixaram a vida. Esta alteração começa a manifestar-se no final da Idade do Bronze, em diversos pontos da parte oriental do Mediterrâneo, e não é difícil acreditar que ela tenha surgido como uma consequência natural da substituição da prática da inumação pela da cremação ${ }^{1}$. Esta última aparece no período sub-micénico, sem que, contudo, se verifique uma transição

${ }^{1}$ Cf. J. A. K. Thomson, Studies in the Odyssey, p. 25; Chadwick, The Heroic Age, p. 398; Ridgeway, Early Age of Greece, cap. VII. 
brusca $^{1}$. Concomitantemente com esta evolução, as condições materiais do túmulo foram transferidas para a mansão dos mortos. Em consequência disso, tal lugar aparecia à imaginação dos vivos como uma vasta extensão de sombra, podridão e lodo. Em breve veremos a especial importância que estas características assumiram na modelação das concepções do além.

Além destes achados em sepulturas, dispomos presentemente de um pequeno número de monumentos, que parecem ter estado de algum modo relacionados com as concepções escatológicas na época pre-helénica, a saber, o sarcófago de Haghia Triada e o chamado "Anel de Nestor». Porém, nenhum deles pode ser interpretado com segurança, devido ao facto de serem ambos documentos pouco menos que isolados na época minóica e ainda a outras circunstâncias que vamos enumerar.

O sarcófago de Haghia Triada tem sido objecto de muita discussão desde o seu aparecimento, principalmente porque não se lhe conhecia paralelo, até se descobrir o larnax de Episkopi. Desnecessário será, para o nosso presente intuito, repetir aqui todas as interpretações, propostas até à data, de tão enigmático monumento, as quais se encontram inventariadas por M. P. Nilsson na sua obra Minoan-Mycenaean Religion and its Survival in Greek Religion ${ }^{2}$.

Apenas focaremos os pontos principais: parece não haver dúvida de que as cenas aí representadas estão de qualquer modo relacionadas com o destino da pessoa inumada; contudo, o que nós observamos não são cerimónias fúnebres, mas cultuais; e fácil é distinguir elementos egípcios, como as vestes dos sacerdotes e a barca, entretecidos com símbolos inegavelmente minóicos, como os machados de dois gumes, a árvore e os chifres de consagração.

Por outro lado, atribuiu-se o sarcófago, por razões de estilo, na ausência de elementos externos que permitam datá-lo, como sejam achados feitos no túmulo, ao período de transição do Minóico Recente II para o Minóico Recente III.

Combinando todos estes dados com a escassez de túmulos da época áurea da civilização minóica, e, por outro lado, com a riqueza e abundância dos monumentos fúnebres micénicos, M. P. Nilsson conclui que aquele deve ter sido executado para qualquer abastado chefe micénico, de acordo com os usos desse povo, e que, como os artistas minóicos não tinham precedentes em matéria de pinturas funerárias, se serviram dos modelos que eram do seu conhecimento, delineando assim uma cena de culto divino ${ }^{3}$.

1 Os dados encontram-se em J. Wiesner, Grab und Jenseits. Untersuchungen im Ägäischen Raum zur Bronzezeit und frühen Eisenzeit.

${ }^{2}$ Cap. XIII, The Sarcophagus from Haghia Triada, pp. 426-443 e ainda pp. 629-630.

${ }^{3}$ Pp. 442-443: «It seems that a mingling of Mycenaean veneration for the mighty Dead and Egyptian divinization of the dead, covered with a garb of Minoan divine cult, accounts satisfactorily for these astonishing funeral paintings». 
Actualmente, a presença dos Micénios em Creta, durante o Minóico Recente II e o III, acaba de ser confirmada pelo testemunho da linguística, graças à decifração da Linear B das tábuas de Cnossos $^{1}$. Tudo isto prova que houve transmissão de ideias e formas de um para outro povo.

O outro monumento arqueológico tem sido também objecto de discussão, em grau não inferior ao precedente, mas a sua autenticidade está sujeita a sérias dúvidas. Trata-se do "Anel de Nestor», no qual Sir Arthur Evans2 e outros viram a representação de uma cena do além. Na verdade, o famoso descobridor do Palácio de Minos tomou as largas zonas, que separam os quatro sectores da superfície, como o tronco e ramos da «árvore da vida» e a parte superior esquerda, com as suas borboletas e crisálidas suspensas sobre as duas figuras sentadas, como um símbolo do além feliz. M. P. Nilsson tem suspeitas acerca da autenticidade do anel, baseando-se em que as cenas parecem ter como centro natural a corte do leão, que se encontra no canto superior direito - como se me afigura evidente - e que uma zoolatria dessa espécie era desconhecida no mundo minóico. É este facto precisamente que o faz pensar que o gravador da cena transformou, por desconhecimento dos costumes da época, o que devia ser uma mesa de sacrifícios no pedestal da imagem sagrada do Leão ${ }^{3}$. Quanto à interpretação das borboletas e crisálidas como prefiguração do destino das almas, rejeita-a, por demasiado subtil para o tempo. Por estes motivos, cuja validade não podemos infirmar, somos forçados a pôr de parte, como sujeitas a caução, as informações que este monumento poderia ministrar-nos.

Nem tão-pouco podemos apoiar-nos noutras peças arqueológicas, como os anéis de ouro de Tirinto e Atenas, embora por causas diferentes. Pelo que toca ao primeiro, houve já quem visse nele uma representação da cena da partida de Menelau e Helena para os Campos Elísios ${ }^{4}$; no segundo, pensou-se poder distinguir a figura de Hermes Psicopompo. Num e noutro caso se pode objectar que eram cenas da vida comum, e não da mitologia, que se gravavam nos tempos mais antigos ${ }^{5}$ e que qualquer delas é passível de diversas interpretações, às quais assiste o mesmo grau de probabilidade.

${ }^{1}$ Cf. M. Ventris and J. Chadwick, Evidence for Greek Dialects in the Mycenaean Archives, in Journal of Hellenic Studies, vol. LXXIII, 1953, pp. 85-103, especialmente p. 84.

2 Sir Arthur Evans, 'The Ring of Nestor': a glimpse into the Minoan after-world and a sepulchral treasure of gold signet-rings and bead seals from Thisbe, Boeotia, in Journal of Hellenic Studies, vol. XLV, 1925, pp. 1-75, e Palace of Minos, vol. II, pp. 155 seqq., The Ring of Nestor.

${ }^{3}$ Minoan-Mycenaean Religion ${ }^{2}$..., p. 50.

${ }^{4}$ Uma cena semelhante aparece no anel de ouro de Creta (citado por M. P. Nilsson, ibidem), mas também, não deve ter significado mitológico.

${ }^{5}$ Cf. M. P. Nilsson, op. laud., pp. 38-39, onde se encontra uma discussão exaustiva do assunto e bibliografia. 


\section{b) Testemunhos literários}

A Ilíada parece desconhecer qualquer outra possibilidade, pelo que toca aos últimos fins do homem, que não seja ir para o Hades. Por mais honrarias de que alguém tenha sido alvo durante a vida, por motivo da sua

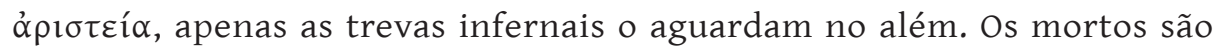

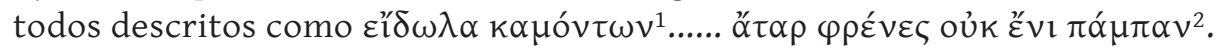
O mesmo se verifica com a Odisseia, onde são chamados $\alpha \mu \varepsilon v \eta v \alpha \grave{~} \kappa \alpha ́ \rho \eta v \alpha^{3}$; e tudo isto está em perfeita concordância com a mísera condição que se encontra tão dramaticamente retratada na famosa exclamação de Aquiles:

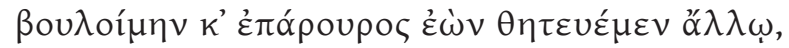

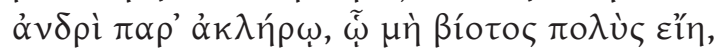

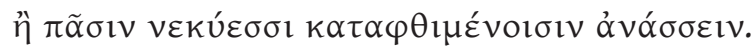

$(\lambda$ 489-491)

Os mortos podem continuar a exercer as actividades a que se haviam dedicado em vida. Assim, Aquiles é príncipe, Minos é juiz e Órion anda à caça, mas daí não lhes advém qualquer espécie de felicidade.

Se esta era a concepção popular grega do além ${ }^{4}$ ou uma invenção de Homero ${ }^{5}$, que prevaleceu sobre as ideias anteriores, é pergunta a que não é fácil responder, por falta de provas concludentes num ou noutro sentido. Tudo leva a crer que uma boa fonte de informações sobre este problema se perdeu com os poemas cíclicos, que parecem ter incluído extensas narrativas de carácter escatológico ${ }^{6}$. Porém o seu estado fragmentário não nos permite formular quaisquer hipóteses.

No estado actual dos nossos conhecimentos, tem-se por certo que não houve quebra na linha de continuidade da civilização entre Micénios e Gregos, quer na arqueologia, quer na língua. Por outro lado, as características que distinguem os Micénios do povo cuja cultura herdaram, ou seja, os Minóicos, definem, sem dúvida, uma concepção da vida diferente ${ }^{7}$. Que o seu modo de encarar a morte era igualmente

$1 \Psi 72$.

$2 \Psi 104$

${ }^{3} \kappa 521,536 ; \lambda 29,49$. etc.

${ }^{4}$ Segundo a teoria de M. P. Nilsson, Minoan-Mycenaean Religion, pp. 620-621, e outros.

${ }^{5}$ Tese de E. Rohde em Psyche.

${ }^{6}$ É conhecido, pelo menos, um caso seguro, em que se seguiu uma tradição diferente - o mito de Caronte, que constava da Mıvuác. Cf. Pausânias, X, XXVIII-XXXI, especialmente X, XXVIII, 2.

${ }^{7}$ Encontram-se inventariadas por M. P. Nilsson em Minoan--Mycenaean Religion ${ }^{2}$, pp. 17-20 e Homer and Mycenae, p. 72. Na primeira dessas obras, a p. 30, o autor 
divergente, demonstram-no os costumes funerários, uma vez que os túmulos micénicos eram construídos com extrema magnificência, que falta por completo nas sepulturas minóicas. Porém, se o carácter acentuadamente guerreiro dos monumentos micénicos está em perfeito acordo com o espírito bélico que anima a Ilíada, outro tanto não se pode afirmar acerca das práticas observadas nos funerais, pois há um único exemplo - e este tão notável que ocupa todo o penúltimo canto do poema - que se possa classificar, sem hesitações, de sobrevivência de antigos usos. Estes últimos, por sua vez, estão mais próximos do culto dos heróis, cuja ausência nos poemas homéricos é notória, do que da noção de sombras errantes no Hades, que estes definem. É de crer que fosse Homero, como supõe E. R. Dodds ${ }^{1}$, o primeiro a formular a distinção entre cadáver e fantasma. O facto é confirmado, em minha opinião, pelo uso das partículas ĩ pó na exclamação soltada por Aquiles, depois de lhe ter aparecido o fantasma de Pátroclo, as quais servem para pôr em relevo a novidade da experiência que ele acaba de sofrer:

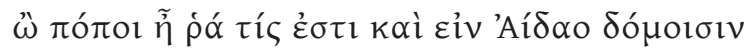

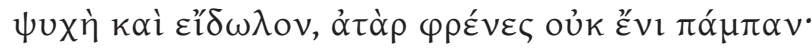

( $\Psi$ 103-104)

Em conclusão, os escassos elementos de que dispomos não nos permitem afirmar se o Hades da Ilíada estava já na tradição ou não, tanto mais que sabemos como é variável o uso que os poemas homéricos fazem de ideias e objectos micénicos².

Mas há ainda outra concepção do além de que encontramos um eco na Odisseia. Dela vamos tratar em seguida.

declara: «In the first edition of this book, I regarded Minoan and Mycenaean religion as almost identical, though not without pointing to certain differences. This was rash, for images may cover very different ideas and conceal them. The art of a cultured people develops under a number of fixed art-types, which are used constantly. When an unlettered but gifted people, having only the rudiments of art comes into contact with such a store of fixed types, it takes them over, but the underlying religious ideas may be of a quite different order. In such circumstances monuments may be deceptive, as regards religion».

${ }^{1}$ The Greeks and the Irrational, p. 136.

${ }^{2}$ Que Homero era tido por a melhor autoridade em crenças relativas ao Hades - como aliás em muitos outros assuntos - demonstra-o aquele passo da Rep. III, 386A-387B, em que Platão condena as descrições da morte pelos poetas, como uma fonte de temores para a humanidade. Todos os exemplos aí citados são homéricos! 


\section{1 - Mitos de terras longínquas}

\section{๔) Campos Elísios}

Afirma-se nos versos 561-569 do Livro IV da Odisseia que Menelau não está destinado a sofrer a morte ${ }^{1}$, mas será enviado pelos deuses para os Campos Elísios, pelo facto de ser marido de Helena e, como tal, genro do próprio Zeus. A região para onde ele será levado está situada

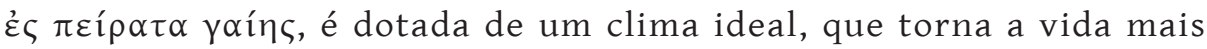

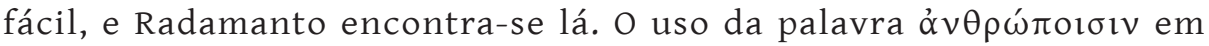
565 e ỏv $\theta \rho \omega ́ \pi$ ouc em 568 mostra que aí habitavam outros homens. Por conseguinte, há duas ideias a anotar: (1) Menelau escapa à morte; (2) aquela terra destina-se a homens privilegiados.

O clima é muito semelhante ao que é atribuído ao Olimpo em $\zeta 42$ seqq., facto que fácil é explicar pela circunstância de ambos os lugares serem

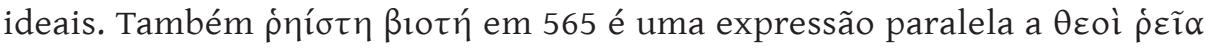

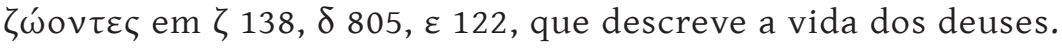

Mas isto não significa, em minha opinião, que se deva postular a identidade dos dois lugares. O emprego repetido da palavra ớv $\theta \rho \omega \pi$ or e a indicação da situação não nos deixam dúvidas sobre o assunto².

Quanto à origem desta concepção, de todo alheia às ideias sobre o além expressas noutras partes dos poemas homéricos, muito se tem discutido desde a antiguidade. Já os escoliastas procuravam elucidá-la com o auxílio da etimologia. Dou a seguir um exemplo típico dessas tentativas:

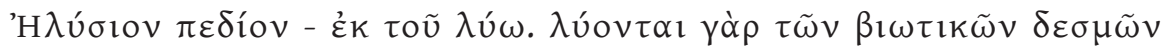

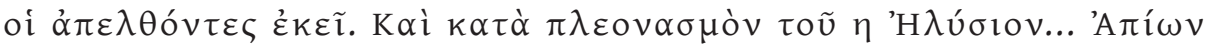

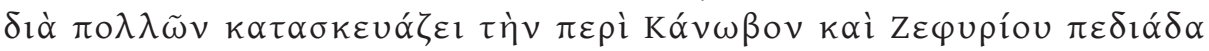

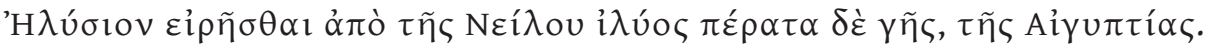

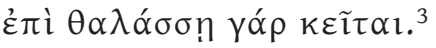

${ }^{1}$ A interpretação de que Menelau não estava destinado a morrer em Argos, mas sim mais tarde, nos Campos Elísios, não precisa de ser considerada sequer. Sobre isso veja-se E. Rohde, Psyche I, p. 76, nota 1.

${ }^{2}$ A possibilidade de certos homens se tornarem deuses é, por conseguinte, um caso diferente. Calipso promete a imortalidade a Ulisses, se ele consentir em

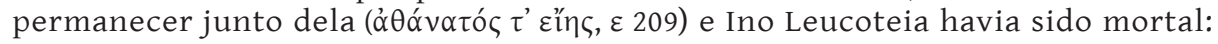

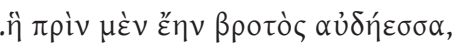

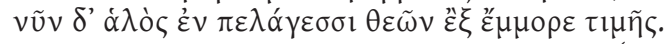

$$
\text { (ع 334-335) }
$$

${ }^{3}$ Dindorf, Scholia Graeca in Homeri Odysseam, ad locum. 
Os lexicógrafos antigos explicavam-na de idêntico modo. Assim por exemplo Hesíquio, s. u.:

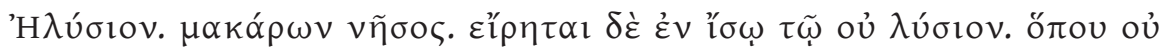

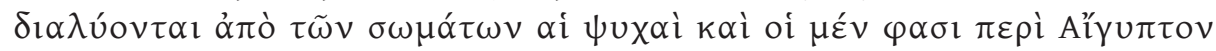

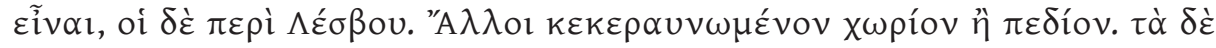

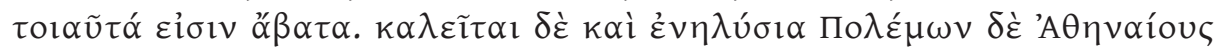

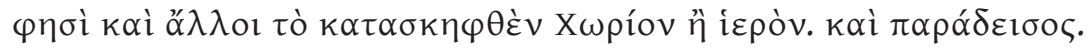

Suidas repetiu estas palavras com relativa fidelidade, acrescentando

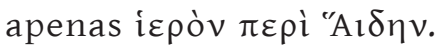

Também o Etymologicon Magnum esclarece (p. 341, 5):

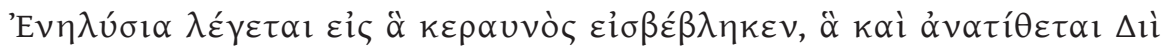

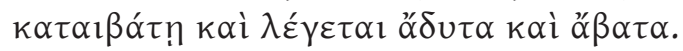

Esta etimologia foi retomada, em tempos modernos, por J. G. Vuertheim ${ }^{1}$. Também Wilamowitz considerou a palavra como um nome comum, com o sentido de "geheiligt», «unzugänglich», e não como um nome próprio².

A relacionação com a raiz ${ }^{*} \dot{\varepsilon} \lambda \cup \theta$, - que é extremamente tentadora foi proposta por Fick ${ }^{3}$ e explicada por Saussure ${ }^{4}$ como um alongamento

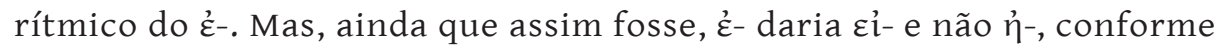
Wackernagel observou ${ }^{5}$. L. Meyer ${ }^{6}$ também reconhece a impossibilidade desta etimologia. Boisacq ${ }^{7}$ continua a atribuir-lhe o sentido fundamental de «plaine de l'arrivée» e E. Rohde ${ }^{8}$ traduz «Land der Hingegangen».

Entendo que a palavra não pode ser explicada por uma raiz grega e que a sua associação, desde os tempos mais antigos, com Radamanto, cujo nome está claramente ligado à Creta primitiva, conforme já foi demonstrado ${ }^{9}$, indica uma origem minóica. É esta também a conclusão

${ }^{1}$ Rhadamanthys, Ilithyia, Elysion, in Medelingen der Akademie van Wetenskappen te Amsterdam, 1925, LIX, p. 1.

${ }^{2}$ Glaube der Hellenen, II, p. 15, nota 1.

${ }^{3}$ Vergleichendes Wörterbuch der indogermanischen Sprachen ${ }^{3}$, Göttingen, 1874-6, I, p. 200.

${ }^{4}$ Mélanges Graux, p. 740 seqq.

${ }^{5}$ Dehnungsgesetz der griechischen Composita. Basel, 1889, p. 5.

${ }^{6}$ Griechisches Etymologisches Wörterbuch, I, p. 640.

${ }^{7}$ Dictionnaire étymologique de la Langue Grecque ${ }^{4}$, p. 322.

${ }^{8}$ Psyche, I, p. 76.

${ }^{9}$ Por L. Malien, Elysion und Rhadamanthys in Jahrbuch des kaiserlich deutschen Archäologischen Instituts, Berlin, 1913, Band XXVIII, pp. 35-51. O mesmo autor

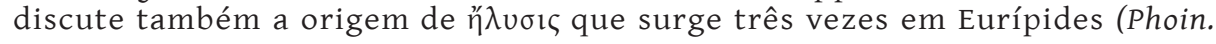


a que chegou M. P. Nilsson ${ }^{1}$, embora com base noutros argumentos, nomeadamente que a concepção do Elísio é tão estranha às ideias do além nos poemas homéricos que não pode deixar de vir de outro povo, o qual certamente seria o minóico ${ }^{2}$. É esta a proveniência que se atribui aos nomes em que entra o elemento - $v \theta$-; e a brevidade da expressão ó $\theta_{1}$ $\xi \alpha v \theta$ ò ‘ ‘P $\alpha \delta \alpha ́ \mu \alpha v \theta u \varsigma$; liga, de uma maneira indiscutível, o nome do herói com o Elísio, ao mesmo tempo que prova a difusão desta última concepção.

\section{B) Ilhas dos Bem-aventurados}

Hesíodo, nos seus Trabalhos e Dias, consagra seis versos à descrição de um lugar especial, que denomina $\mu \alpha \kappa \alpha ́ \rho \omega \nu ~ v \tilde{\eta} \sigma o l$, onde alguns homens da quarta geração, que não pereceram em Tebas ou em Tróia, foram instalados por Zeus, a fim de fruírem de uma vida agradável. A situação desta terra longínqua é idêntica à da Odisseia, como idênticos são também alguns pormenores, tais como a proximidade do Oceano, as facilidades de vida e o privilégio de escaparem à morte. Contudo existem algumas diferenças que não têm sido convenientemente postas em relevo. Quero referir-me à situação em que eles se encontram em relação ao comum da humanidade: acentua-se que

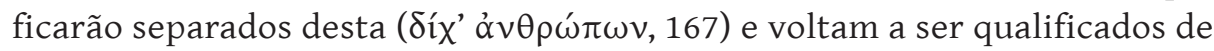
ท̆ mostra que o estado a que foram elevados é algo semelhante ao dos deuses, pois era a estes principalmente que aquele epíteto se aplicava na antiga epopeia ${ }^{3}$. Os exemplos dessa acepção são numerosíssimos, tanto em Homero

844, Hec. 67, Heracl. 1041). Wackernagel (Dehnungsgesetz, p. 37) explica o $\eta$ como proveniente de uma formação analógica de uma palavra simples a partir de uma

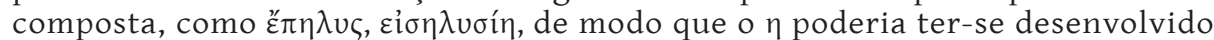
regularmente por meio desse tipo de alongamento. Malten considera a palavra como uma criação de Eurípides, a partir do composto, uma vez que não aparece em qualquer outro texto grego, com excepção de uma glossa de Hesíquio sem

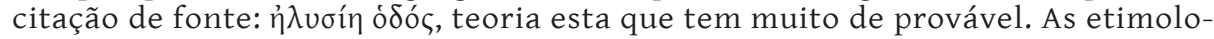

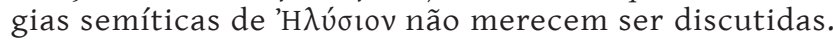

${ }^{1}$ Minoan-Mycenaean Religion, p. 623.

${ }^{2}$ Calino ignora por completo tal possibilidade, mesmo para os filhos dos deuses:

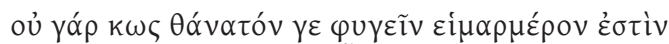

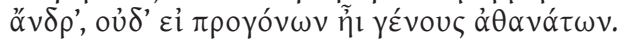

(Frag. I, 12-13 Diehl).

${ }^{3}$ A história da evolução do sentido desta palavra foi feita por L. Malten, op. laud., p. 38, nota 4, e E. Rohde, Psyche, I, p. 308, nota 1. Sobre o seu significado corrente no séc. V a. C. elucida-nos o frg. 488 Kock de Aristófanes. 
como em Hesíodo e na poesia elegíaca e lírica primitiva. Os versos 135-142 dos Trabalhos e Dias ilustram bem a futura evolução do sentido da palavra:

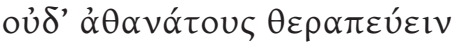

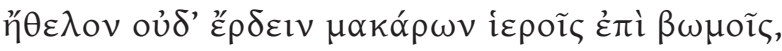

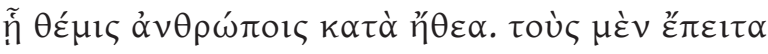

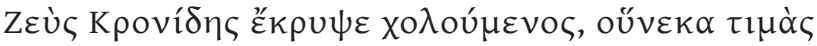

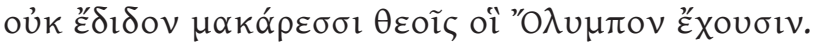

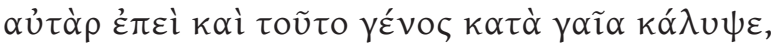

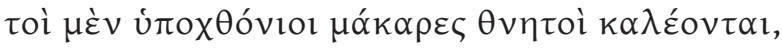

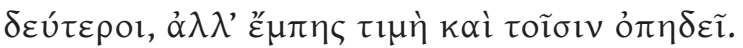

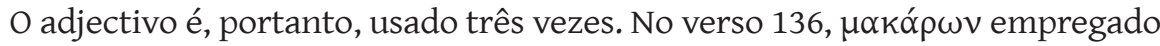
absolutamente torna manifesto que se designam os deuses. No verso 139 ape-

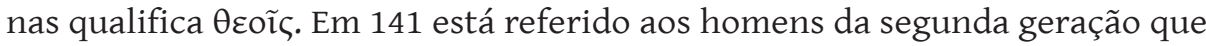

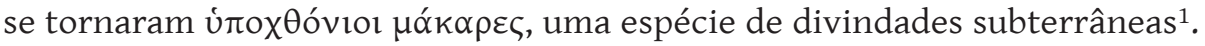

Parece-me que, no verso 171, $\mu \alpha \kappa \alpha ́ \alpha \omega v$ conserva ainda algo do primitivo significado da palavra².

Outro ponto não menos importante é que não se faz menção de Radamanto, cuja associação com os Campos Elísios em $\delta 561$ seqq. era tão estreita que

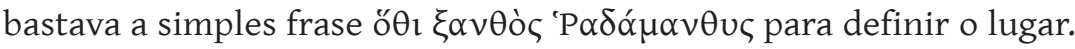

Além disso, nada sugere a possibilidade de outras quaisquer pessoas jamais serem mandadas para essas ilhas. Destinavam-se unicamente aos

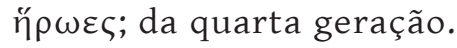

De tudo isto parece poder-se concluir que, a princípio, as concepções de Campos Elísios e Ilhas dos Bem-aventurados eram distintas. O facto de as duas mais antigas referências conhecidas darem a estas regiões privilegiadas nomes diferentes é bastante significativo.

M. P. Nilsson chama a atenção para a circunstância de as Ilhas dos Bem-aventurados dos antigos egípcios serem providas de grande abundância de alimentos, e de Hesíodo insistir na mesma qualidade ${ }^{3}$. A coincidência pode explicar-se, alegando que um solo extremamente rico representava igualmente o cúmulo

${ }^{1}$ Para a interpretação deste passo por Platão, veja-se Crat. 397E-398D. Cf. também E. Meyer in Genethliakon Robert, p. 173, e Farnell, Greek Hero-Cults and Ideas of Immortality, pp. 12-13.

${ }^{2}$ Usener (Sintflutsagen, p. 214) citada por Waser in Pauly-Wissowa, s. u. Elysion, entende que «Das Land der Götter und der Aufenthaltsort der Seligen sind nicht nur unter demselben Bilde angeschaut worden, sondern ursprünglich eins». Já não é este o caso dos Campos Elísios homéricos, mas podem talvez discernir-se alguns vestígios dessa concepção nas Ilhas dos Bem-aventurados de Hesíodo. Evidentemente que considero o verso 169 espúrio.

${ }^{3}$ Minoan-Mycenaean Religion, pp. 626-627. 
da felicidade para o povo do Delta e para o autor dos Trabalhos e Dias. Mas também é muito provável que as Ilhas dos Bem-aventurados dos egípcios fossem conhecidas dos Minóicos, como a barca e todo o estilo da cena representada no sarcófago de Haghia Triada parecem comprovar.

É de crer que fossem do conhecimento dos Minóicos duas concepções ligeiramente diferentes de um além feliz, das quais uma se teria originado nesse povo e a outra teria sido trazida do Egipto. Dada a similaridade do seu conteúdo, em breve se confundiram e, quando aproveitadas e desenvolvidas para fins literários, o quadro obtido era quase o mesmo. De tal modo que, mais tarde, já não há possibilidade de as distinguir ${ }^{1}$.

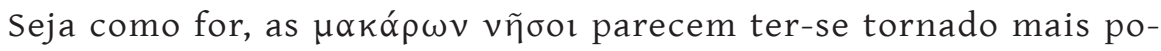
pulares, pois as encontramos mencionadas no skolion de Harmódio e Aristogéiton, em época tão antiga como seja o final do séc. VI a. C. ${ }^{2}$. Outras citações posteriores, como as de Aristófanes, Vespae, 639-640, Platão, Symposium, 179E-180B e Menexenus 235C confirmam esta asserção; para não falar dos muitos exemplos epigráficos, a partir do séc. I a. C.

\section{$\gamma)$ Leuce}

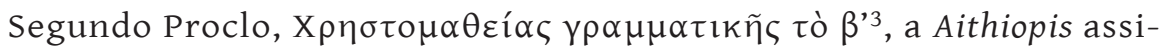
nalava um destino muito especial a Aquiles:

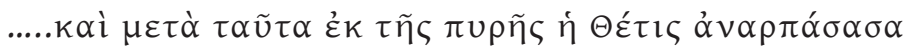

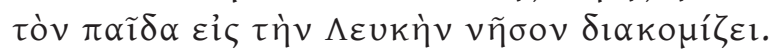

A mais antiga referência a este mito, que chegou até nós, consta do frg. 48B Bergk de Alceu:

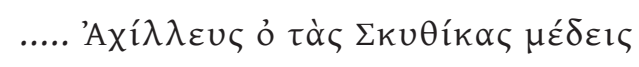

${ }^{1}$ Demonstra-o claramente o epigrama 461 da Anthologia Palatina (Appendix Noua) = Kaibel, E.g., 649:

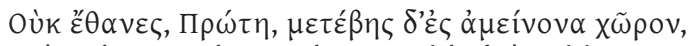

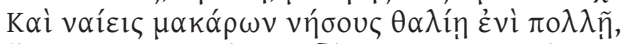

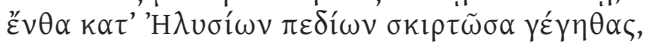

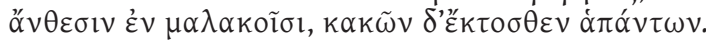

e ainda Luciano, Iup. Conf. 17, Verae Historiae, II, 14.

2 Sobre a data deste Skolion veja-se C. M. Bowra, Greek Lyric Poetry from Alcman to Simonides, pp. 416-421.

${ }^{3}$ Cod. Marc. 454. f. 4 r (p. 57-58 na edição de Kinkel dos Epicorum Graecorum Fragmenta) 
mas já os comentadores antigos tinham dúvidas se este era o herói da Ilíada ou outro do mesmo nome ${ }^{1}$.

Seguem-se-lhe três exemplos seguros do séc. V a. C.:

O primeiro é de Píndaro, Nem. IV, 49-50:

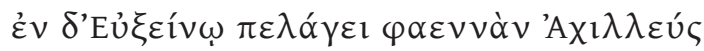

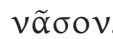

Os outros dois são de Eurípides, Andr. 1260-1262:

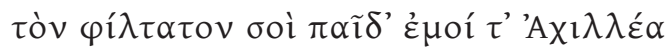

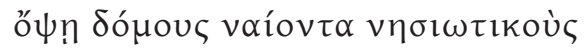

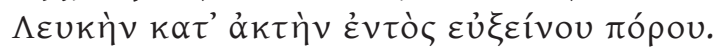

e Iph. Taur., 435-438:

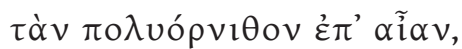

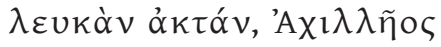

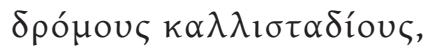

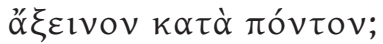

Destas citações pode inferir-se que Leuce era o nome dado a uma ilha no Ponto Euxino, onde Aquiles morava, para além da sua vida humana. Parece que esse lugar era destinado a ele só; confirma-o a tradição conservada por Quinto de Esmirna, IV, 769-779, segundo a qual Poséidon consolara Tétis, assegurando-lhe que ia criar uma ilha no Ponto para o filho da deusa marinha lá viver ${ }^{2}$. No mesmo passo afirma-se claramente que ele será honrado como um deus, e é comparado a Dioniso e Hércules:

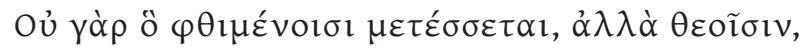

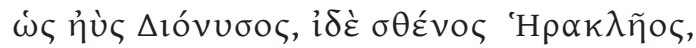

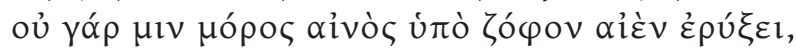

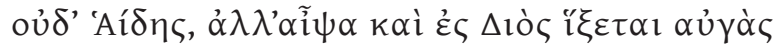

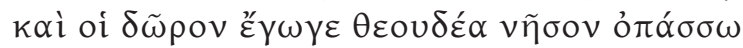

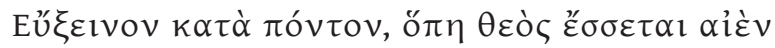

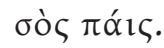

$(\delta, 770-776)$

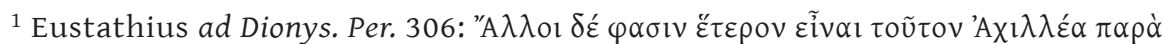

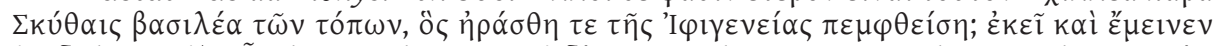

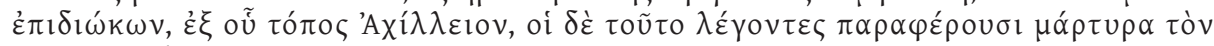

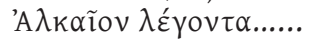

${ }^{2} \mathrm{O}$ mesmo mito se encontra também em Filóstrato, Her., $212 \mathrm{~K}$. 
Novamente se torna evidente, portanto, que a ilha lhe era inteiramente consagrada.

Com efeito, as outras referências tardias apenas mencionam pessoas directamente relacionadas com Aquiles, como sejam Helena, na qualidade de sua mulher nessa ilha ${ }^{1}$, ou Ifigénia, em sua procura ${ }^{2}$, ou ainda os heróis troianos, seus antigos companheiros ${ }^{3}$. Plínio ${ }^{4}$ e Pompónio Mela ${ }^{5}$ situavam lá o seu túmulo. Segundo Escher, esta afirmação seria incompatível com a lenda precedente ${ }^{6}$. Creio, porém, que podia ter tido origem num desenvolvimento tardio do culto do herói, que se associava naturalmente ao túmulo ou cenotáfio. Outra lenda, que nos foi transmitida por Eustátio ${ }^{7}$, conta que Orestes, quando soube que tinha matado Neoptólemo inadvertidamente, o sepultou e consagrou a sua espada, depois do que se dirigiu a Leuce, para apaziguar o espírito de Aquiles. Também isto faz lembrar o culto dos heróis.

Se examinarmos de perto o mito de Diomedes, depara-se-nos uma confusão semelhante. Dele disse Íbico que morava numa ilha no Mar Adriático, segundo o schol. Pind., Nem. X, $7^{8}$, ao passo que o skolion de Harmódio o colocava nas Ilhas dos Bem-aventurados. Grande parte dos autores tardios dão ao seu culto carácter nitidamente divino. O mesmo aconteceu com Mémnon.

Conquanto as provas sejam escassas, uma vez que as citações mais antigas se encontram em estado fragmentário (como acontece no poema cíclico e no passo de Alceu) ou são demasiado vagas (como sucede com as referências de Píndaro ${ }^{9}$ e de Eurípides), parece que estes casos devem colocar-se num nível diferente. Nos tempos primitivos, as pessoas que iam para os Campos Elísios ou para as Ilhas dos Bem-aventurados não sofriam a morte, nem recebiam culto depois. Ao passo que a cena na Aithiopis tem lugar depois de o corpo de Aquiles ter estado na pira, e só posteriormente a mãe o tornou imortal. O caso é semelhante ao do mito final da Telegoneia, que refere como Telégono, tendo matado seu pai, por engano, levou o corpo deste, juntamente com Telémaco

${ }^{1}$ Pausânias, III, XIX, 11-13; Filóstrato, Heroica, III, 26; sem indicação de lugar; Schol. Eur., Androm. 229.

2 Licofron, 186-187; 188-191; 200-201.

${ }^{3}$ Pausânias, III, XIX, 11-13; Cónon, Narr. 18.

${ }^{4} \mathrm{IV}, 16$.

${ }^{5}$ II, 98.

${ }^{6}$ In Pauly-Wissowa, s. $u$. Achilleus.

${ }^{7}$ Comment. ad Odysseam, 1696, 45. Outra referência ao seu oráculo em Arriano, p. 398,32 .

8 O próprio Píndaro diz que Atena o tornou imortal (Nem. X,7).

${ }^{9}$ No entanto, a comparação com os outros nomes citados no mesmo contexto sugere que se trata de culto dos heróis. Cf. schol. ad locum. 
e Penélope, a Circe, sua mãe, que os tornou imortais. Para E. Rohde ${ }^{1}$, trata-se de um paralelo à Entrückung de Menelau em $\delta$.

Em meu entender, a lenda tem um sentido inteiramente diferente, pelos motivos acima expostos.

De um modo geral, creio que não se pode apresentar melhor exemplo da inconsistência das crenças relativas ao além do que a variedade de destinos que foram atribuídos a Aquiles.

Já vimos que no Canto XI da Odisseia ele não é mais do que uma sombra no Hades, embora seja príncipe ${ }^{2}$. Na Aithiopis era arrebatado para Leuce. Esta versão foi seguida por muitos autores tardios, mas, antes deles, por Píndaro e Eurípides. O mesmo Píndaro que conserva este mito em Nem. IV, 49-50, diz noutro passo que Tétis o levou para as Ilhas dos Bem-aventurados, depois de ter conseguido o assentimento de Zeus (Ol. II, 79-80), e não faz suspeitar sequer da possibilidade da sua sobrevivência na descrição da cena dos seus funerais (Isth. VIII, 57-60 e ainda Paean VI, 98-99). Na imaginação popular, Aquiles vivia nas Ilhas dos Bem-aventurados pelo menos desde os fins do séc. VI a. C, porquanto o skolion de Harmódio e Aristogéiton assim o proclamava; a citação de Platão, Symposium 179E-180B parece derivar da mesma origem. Alguns autores tardios, como Apolodoro, Epitome, V, 5 e o schol. Lícofron 172, ${ }^{3}$ acrescentaram que desposou lá Medeia. Pelo menos, dois dos poetas líricos primitivos, Íbico e Simónides, mencionam o mesmo facto, mas situam-no nos Campos Elísios, como Apolónio de Rodes ${ }^{4}$. Que tivesse casado aí com Políxena, como disse Séneca ${ }^{5}$, ou com Helena em Leuce ${ }^{6}$ é questão de pouco interesse para o problema. Todas estas lendas apenas têm um significado, a saber, que havia um sentimento geral de que o mais valoroso dos Aqueus devia ter melhor sorte, de tal modo que, a despeito de todo o peso da autoridade dos poemas homéricos, a imaginação popular em breve encontrou outra possibilidade para a sobrevivência do famoso guerreiro. Esta tomou a forma do culto de

${ }^{1}$ Psyche, I, pp. 87-88. Para o mesmo autor, Leuce deve identificar-se com as

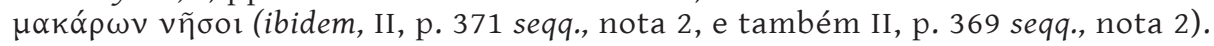

${ }^{2} \mathrm{O}$ fragmento 9, 37-38 Diehl de Tirteu mostra que nem aos grandes guerreiros se atribuía uma distinção especial no além:

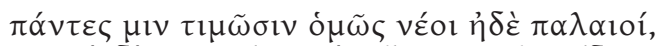

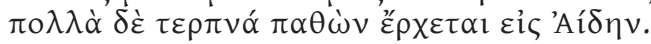

${ }^{3}$ O schol. ad 798 não dá indicação de lugar.

${ }^{4}$ Argonautica, IV, 811 seqq. e schol. ad locum.

${ }^{5}$ Troades, 942-944.

${ }^{6}$ Citado acima p. 32, n. 1. 
heróis ${ }^{1}$, que foi localizado numa ilha especial ${ }^{2}$. Outros colocaram-no naquelas regiões longínquas, onde habitavam homens de parentesco divino, pela vontade dos deuses (Campos Elísios) ou para onde tinham sido arrebatados os heróis contemporâneos da guerra de Tróia (Ilhas dos Bem-aventurados). Estas duas últimas concepções, que em breve se fundiram numa só, parecem ter prevalecido. Porém o mito de Leuce não ficou completamente esquecido; pelo contrário, foi recebendo novos acrescentos até que o encontramos rodeado de lendas marinhas, como acontece com as narrativas de Pausânias e Filóstrato e muitos outros autores tardios.

Em conclusão, julgo que este caso ilustra admiravelmente o processo pelo qual alguns mitos originariamente diferentes podiam convergir sobre a mesma pessoa e confundir-se no decorrer do tempo. É evidente que as versões tardias não ligam especial importância ao nome do lugar da sobrevivência do herói. Mas em qualquer época, nunca Leuce foi descrita como um sítio privilegiado, ao contrário do que se verificava com os Campos Elísios e as Ilhas dos Bem-aventurados.

\section{ઈ) Os Hiperbóreos}

Segundo Heródoto ${ }^{3}$, os Hiperbóreos foram mencionados pela primeira vez pelo autor dos Epigoni e por Hesíodo. O seu nome não consta dos poemas homéricos. Por sua vez, o Hino Homérico a Dioniso 4 fala deste povo e o mesmo fazem Aristeas ${ }^{5}$ e Alceu 6 . O próprio Heródoto discute a sua existência demoradamente, embora não a aceite $^{7}$. Continuaram

${ }^{1}$ Depois de ter examinado os testemunhos existentes, Farnell concluiu que o culto de Aquiles foi sempre do género do dos heróis e que, embora possa ter começado anteriormente a Homero, foi difundido pela influência das epopeias. Cf. Greek Hero-Cults and Ideas of Immortality, p. 289.

${ }^{2}$ Discordo, por conseguinte, de L. Malten, Elysion und Rhadamanthys, quando diz que deve ter sido esta a primeira tentativa de localização do país dos bem-aventurados.

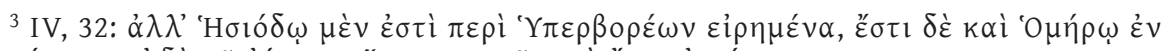

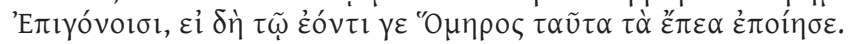

${ }^{4} \mathrm{~V}, 29$.

${ }^{5}$ Frg. 5 (Heródoto, IV, 13); frg. 6 (Heródoto, IV, 16; Pausânias, V, VII, 9 (4); frg. 7 (Pausânias, I, XXIV, 6) Kinkel.

${ }^{6}$ Frg. 1,2, 4 Bergk.

7 IV, 32-35. 
a fazer-se investigações nesse sentido até aos escritores mais tardios, mas esse aspecto da questão não interessa ao nosso presente estudo ${ }^{1}$.

O que aqui importa é considerar a descrição poética que deles faz Píndaro em P. X, 29-46, que claramente os apresenta como um povo idealizado ou mítico ${ }^{2}$. Diversas características que definem a mansão dos bem-aventurados na II ${ }^{a}$ Olímpica estão também presentes aqui. Tratarei deste ponto na II ${ }^{a}$ Parte, mas convém assinalar desde já que não há caminho, ou de barco ou a pé, que leve a esse lugar, e que as palavras finais da descrição

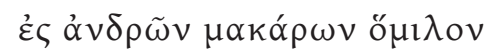

contêm o adjectivo $\mu \alpha \kappa \alpha ́ \rho \omega v$ que recorda as Ilhas dos Bem-aventurados.

Outro exemplo de uso poético deste tema é-nos fornecido por Baquílides na Ode III, 58-62, onde se lê que Apolo arrebatou a Creso e a suas filhas para os Hiperbóreos. É, tanto quanto podemos saber, um caso único. O motivo está claramente expresso:

\section{$\delta \imath^{\prime} \varepsilon \dot{u} \sigma \varepsilon ́ \beta \varepsilon \imath \alpha \nu$}

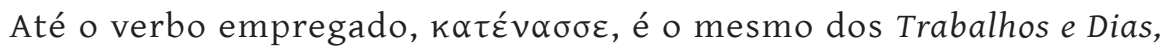
168. Além de que é fora de dúvida que tal lugar é apresentado como idêntico à mansão dos eleitos.

É provável que a descrição pindárica dos Hiperbóreos, com as suas afinidades com a das Ilhas dos Bem-aventurados, induzisse Baquílides, cerca de trinta anos mais tarde ${ }^{3}$, a colocar lá Creso e as suas filhas, criando assim um paraíso especial para os grandes devotos de Apolo, entre o povo consagrado a este deus ${ }^{4}$. É digno de nota o facto de os dois

${ }^{1}$ A enumeração completa e interpretação dos testemunhos existentes foi feita por O. Crusius no Lexikon de Roscher, col. 2805-2835. Cf. também A. H. Krappe, AПO $\Lambda \Lambda \Omega$ N KYKNOE in Classical Philology, vol. XXXVII, 1942, pp. 353-370, que favorece a identificação com Heligoland.

${ }^{2}$ Em Ol. III, 16, Isthm. VI, 23 e Paean VIII (b) 1 Snell há unicamente ligeiras referências. Contudo, aí são ainda um povo acessível, ao passo que em $P$. X estão foras de alcance. Esta incongruência foi já assinalada por E. Rohde (Der griechische Roman und seine Vorläufer, p. 312, nota). Como teremos ocasião de ver, não é o único caso em que Píndaro usou tradições diferentes.

${ }^{3}$ A mesma interpretação foi dada por A. Körte, Das Land der Hyperboreer in Archiv für Religionswissenschaft, vol. X, 1907, pp. 152-153. A Ode de Baquílides deve ter sido composta em 468 a. C., quer dizer, trinta anos mais tarde do que a $\mathrm{X}^{\mathrm{a}}$ Pítica de Píndaro.

${ }^{4}$ Sobre o «Apolo Hiperbóreo» cf. E. R. Dodds, The Greeks and the Irrational, pp. 141 e 161-162, nota 36. 
mais importantes santuários da divindade serem sugeridos $(\Delta \alpha \lambda \text { oүعvń })^{1}$

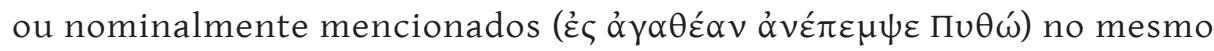
contexto, formando assim uma espécie de moldura em volta dos dois

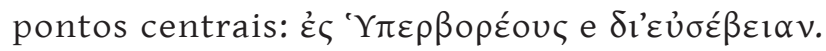

Todo o mito tendia para esta conclusão ${ }^{2}$, cuja finalidade era apresentar agradáveis perspectivas de futuro a alguém que era, ele mesmo, um grande

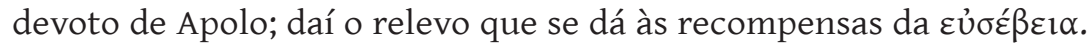

O poeta esforçava-se por consolar Hierão de Siracusa com a esperança num além feliz, exactamente como Píndaro tinha feito a Hierão na II ${ }^{\mathrm{a}}$ Olímpica, ao delinear a brilhante descrição das Ilhas dos Bem-aventurados. Na Ode III a parte central do mito é diferente, mas a conclusão é

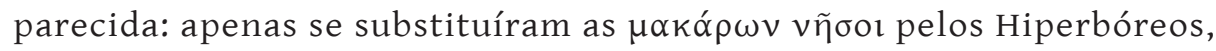
uma variante que era autorizada pela íntima associação deste povo com Apolo e que possivelmente foi sugerida pelo quadro que o próprio Píndaro havia traçado da sua maneira de viver.

Contudo, este exemplo permaneceu único ${ }^{3}$. De modo que podemos dizer que só uma vez o país dos Hiperbóreos contou entre os lugares dos bem-aventurados.

\section{ع) O Jardim das Hespérides}

Contrariamente ao que se passava com os Hiperbóreos, o Jardim das Hespérides parece ter sido, em tempos recuados, um lugar dos bem-aventurados. Nunca é mencionado nos poemas homéricos, mas

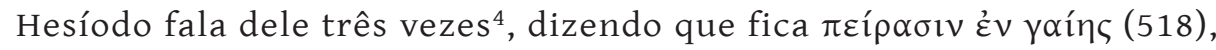

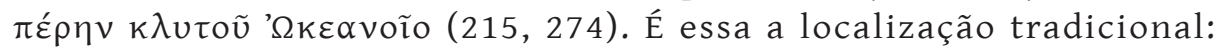
além do Oceano, nos confins da terra. As Hespérides são caracterizadas

${ }^{1}$ Sobre a relação entre as lendas dos Hiperbóreos e Delos, cf. Heródoto, IV, 33-35.

${ }^{2}$ A mesma história, com grande número de variantes, foi narrada por Heródoto, I, 86-88, para ilustrar uma máxima inteiramente diversa. Evidentemente que o ponto de vista do historiador não podia também deixar de ser outro. O pintor da famosa ânfora do Museu do Louvre parece ter conhecido o mito na versão do sacrifício voluntário, como Baquílides.

3 Otto Crusius, Aus den Dichtungen des Bacchylides in Philologus, vol. LVII, 1898 , p. 155, apresenta a sugestão de Baquílides ter recolhido esta lenda num poema sacerdotal do séc. VI a. C. A hipótese, porém, carece de provas, além de ser desnecessária.

${ }^{4}$ Teogonia, 215-216, 274-275, 517-520. Os versos 215-217 são suspeitos para A. Meyer. Porém, mesmo que fossem interpolados, não se alterava a posição do problema. 
como $\lambda ı \gamma u ́ \varphi \omega v o r ~(275,518)$; a elas está confiada a guarda das árvores que produzem os pomos dourados (215-216).

É duvidoso, por falta de provas concludentes, se deverá relacionar-se este aspecto da lenda com a fábula da Árvore da Vida, que é comum a tantos povos da Antiguidade - conforme sugere M. P. Nilsson ${ }^{1}$ - mas também nada nos leva a negar esse parentesco. Seja como for, deve tratar-se de um mito antigo, do qual só alguns ecos chegaram até nós.

Há ainda breves referências a ele em Mimnermo ${ }^{2}$, Sófocles ${ }^{3}$ e Isócrates ${ }^{4}$.

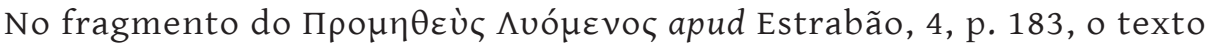
não é suficientemente claro, mas parece que se opõe a situação das

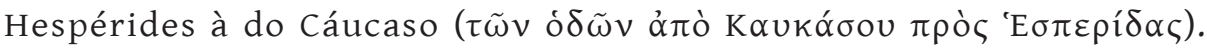
O belo passo em Eurípides, Hippolytus, 742-751, é um desenvolvimento poético da informação de Hesíodo, com alguns pormenores novos, possivelmente da autoria do poeta, como sejam as fontes de ambrósia e a exuberância de vegetação.

Comparando estes exemplos com o frg. 297 Nauck de Sófocles:

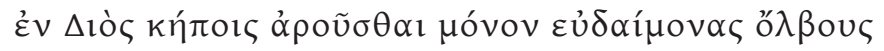

e o verso 271 das Nuvens de Aristófanes:

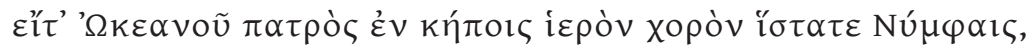

que claramente o descrevem como um jardim dos deuses, em concordância com o Frg. 33 de Ferecides ${ }^{5}$ e o verso 164 do Hino III de Calímaco ${ }^{6}$, ficaremos habilitados a compreender a relação remota entre este lugar e as $\mu \alpha \kappa \alpha ́ \rho \omega \nu v \tilde{\eta} \sigma o l$.

As Hespérides vieram a ficar intimamente associadas aos trabalhos de Hércules e é desse modo que vasos e moedas as representam mais

\footnotetext{
${ }^{1}$ Minoan-Mycenaean Religion, p. 628.

${ }^{2}$ Frg. 10, 8-9 (Diehl).

${ }^{3}$ Trachiniae, 1099-1100. Aí faz-se referência ao dragão que guardava os pomos dourados. O mesmo acontece em Eurípides, Her., 394-399; Apolónio de Rodes, IV, 1396 seqq.; Pausânias, VI, XIX, 8.

${ }^{4}$ Helena, 24.

${ }^{5}$ Apud schol. Apolónio de Rodes, IV, 1396, onde se declara que os pomos de ouro foram um presente nupcial da Terra a Hera, e que esta os plantou no jardim

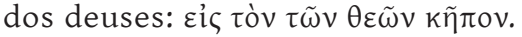

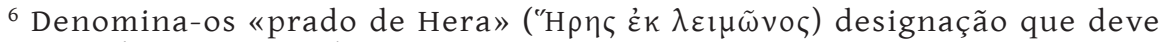
corresponder ao mesmo lugar.
} 
tarde. É muito provável que a aventura de Hércules nessa região tenha sido a primeira expressão mítica da vitória do herói sobre a morte, conforme conjecturou M. P. Nilsson ${ }^{1}$, e que, quando o significado da fábula se desvaneceu, se tenha adicionado ao ciclo o episódio da captura de Cérbero, para formar «um fim lógico e natural». Isto indica que a concepção era pre-helénica, conforme nota o mesmo investigador ${ }^{2}$.

À semelhança do que aconteceu com mitos afins, também este foi localizado em diferentes regiões por autores tardios. Um deles, o pseudo-Apolodoro, foi mesmo ao ponto de o situar entre os Hiperbóreos ${ }^{3}$ :

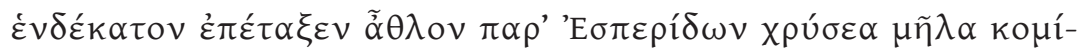

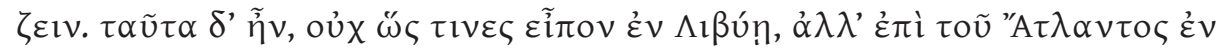
'Y

O exemplo mostra a confusão que naturalmente tendia a estabelecer-se entre países idealizados.

Há ainda outros lugares míticos que têm sido incluídos nesta série, tais como a ilha de Calipso e a de Circe, e ainda os jardins de Alcínoo, e, de um modo geral, o país dos Feaces, com base, especialmente, nas relações destes com Radamanto, mencionadas em $\eta 323^{4}$. Mas as informações desse passo da Odisseia são demasiado vagas para poderem servir de argumento, além de que os Feaces são sempre descritos como um povo real. Será mesmo difícil encontrar em qualquer outra parte do poema mais belo quadro da tranquilidade da vida familiar do que o que eles nos oferecem. Também não me parece que haja motivo suficiente para tomar as ilhas de Calipso e de Circe como primitivas terras dos mortos, a despeito da invenção tardia da Telegoneia, a que já fiz referência. Seguindo este princípio, em breve chegaríamos à conclusão de que quase todos os países descritos na primeira metade da Odisseia eram desta natureza também.

${ }^{1}$ The Mycenaean Origin of Greek Mythology, p. 214.

${ }^{2}$ Idem, ibidem, e ainda Minoan-Mycenaean Religion, p. 628. Cf. também L. Malten, Elysion und Rhadamanthys, in Jahrbuch des kaiserlich Deutschen Archäologischen Instituts, XXVIII, 1912, pp. 35 seqq.. Contestado por P. Capelle, Elysium und Inseln der Seligen, in Archiv für Religionswissenschaft, XXV, pp. 245 seqq. e XXVI, pp. 17 seqq.

${ }^{3} 2,5,11$.

${ }^{4}$ É esta a teoria de A. Schulten in Pauly-Wissowa, s. u. $\mu \alpha \kappa \alpha ́ \rho \omega v v \tilde{\eta} \sigma o l$, vol. XIV, col. 628-632. Este autor acredita na possibilidade de identificação desde os tempos homéricos. Em meu entender, a localização sempre vaga destas regiões é parte integrante do mito, que implica a falta de conhecimento directo desses lugares inacessíveis e distantes. As tentativas para os situar no mapa são tardias. 
Em conclusão, direi que estas terras longínquas, cujo acesso era apenas facultado a certos homens privilegiados, eram todas parte de velhos mitos. Alguns destes abriram caminho na tradição literária e vieram a tornar-se numa espécie de lugar comum, com o andar dos tempos, como aconteceu com os Campos Elísios e as Ilhas dos Bem-aventurados. Outros foram perdendo o seu significado com o decorrer dos anos. Mas todos tinham de comum a qualidade de dar expressão concreta ao anseio de uma vida melhor.

\section{2 - Bem-aventurança no Hades}

Além dos casos que temos estado a considerar, os quais parecem ser todos reminiscências de uma antiga tradição mitológica, surge-nos uma outra concepção, pelo menos a partir do século VII a. C. - é a que se conserva no Hino Homérico a Deméter. Aí se afirma que todos os que contemplaram os ritos sagrados de Elêusis terão um destino diferente no Hades:

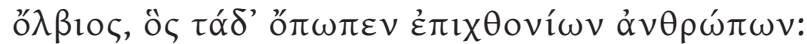

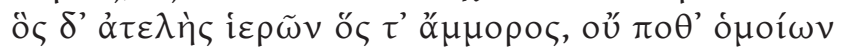

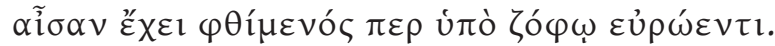

(480-482)

A mesma promessa encontra confirmação num conhecido fragmento de Sófocles (753 Nauck):

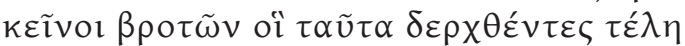

$$
\dot{\omega} \varsigma \tau \rho \imath \sigma o ́ \lambda \beta ı 1
$$

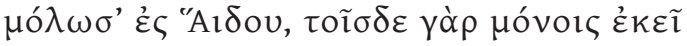

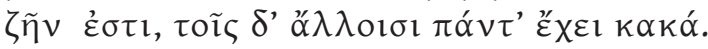

e muito provavelmente, no fragmento 121 Bowra ( = 137 Snell) de Píndaro¹:

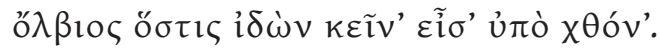

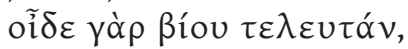

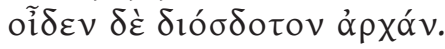

e noutros autores tardios, que não importa mencionar aqui.

${ }^{1}$ Clem. Alex., Strom. III, 518 declara que o texto se refere aos Mistérios de Elêusis; tal asserção foi impugnada, mas é hoje geralmente aceite. A semelhança de linguagem entre este passo e o do Hino Homérico a Deméter é flagrante, e é de crer que o fragmento tivesse pertencido a um treno por um ateniense, conforme Böckh demonstrou, o que constituí mais um argumento a favor dessa hipótese. 
Em todos estes três casos se declara que quem tiver visto certas cerimónias (ő $\pi \omega \pi \varepsilon v, \delta \varepsilon \rho \chi \theta \varepsilon ́ v \tau \varepsilon \varsigma, ~ i \delta \omega ́ v)$ e cumprido determinados ritos é na verdade ő $\lambda \beta ı$ ı, pois escapará aos males que há no Hades. Por conseguinte, a iniciação nos Mistérios de Elêusis garantia um lugar privilegiado no

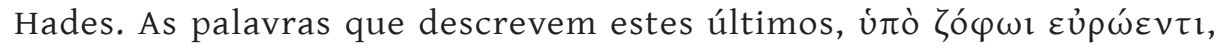
mostram que eles eram concebidos nos moldes que conhecíamos já dos poemas homéricos. Se a fórmula lhes era anterior ou não, é problema que não podemos esclarecer. De qualquer modo, é essa concepção do Hades que fornece o ponto de partida para a promessa de melhor sorte ${ }^{1}$.

Outra novidade consiste em ser esse destino especial acessível a qualquer espécie de pessoas, desde que tenham sido iniciadas nos Mistérios.

Estes dois factos concorrem para demonstrar que, na sua forma primitiva, não havia ligação entre este género de além feliz e aqueles que anteriormente analisámos.

Os Mistérios de Elêusis, que faziam estas promessas ${ }^{2}$, datam da época micénica, conforme o provam os dados arqueológicos. Demonstrou-se que o enorme telesterion continha restos desse tempo, e a forma deste confirma a opinião, implícita no uso de termos que significam «contemplar», em documentos literários, de que alguma coisa se mostrava aos iniciados ${ }^{3}$. Se tinham lugar ou não quaisquer representações de cenas infernais ou do rapto de Prosérpina, é ainda assunto de controvérsia ${ }^{4}$, uma vez que a arqueologia não nos ajuda neste ponto e os monumentos literários guardam silêncio sobre este, como sobre outros problemas relativos aos Mistérios de Elêusis.

É fora de dúvida que eles se interessavam pelos últimos fins da humanidade. Se, porém, essa parte da doutrina era essencial ou não e se era original ou adventícia, não há testemunhos suficientes para decidir. O mais antigo documento literário menciona-a como um ponto

${ }^{1}$ W. K. C. Guthrie, Orpheus and Greek Religion, cap. V, The Future Life as seen by Orpheus toca neste ponto, mas admite, entre o Elísio e esta nova concepção, uma continuidade que eu não julgo existir. Igualmente discordo de M. P. Nilsson quando diz encontrar aqui «ein Nachhall der minoischen Vorstellung von Elysion» (Geschichte der griechischen Religion, I, p. 448).

${ }^{2}$ Sobre estes, bem como sobre a importância do Hino Homérico a Deméter para a arqueologia, vide George Emanuel Mylonas, The Hymn to Demeter and her sanctuary at Eleusis, Washington University Studies, March 1942.

${ }^{3}$ Cf. Noack apud M. P. Nilsson, Geschichte der griechischen Religion, I, pp. 627-628.

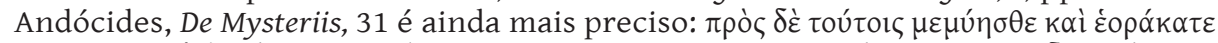

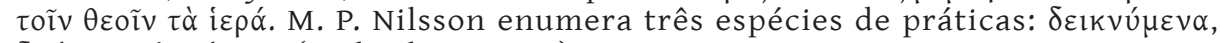
$\delta \rho \omega ́ \mu \varepsilon v \alpha, \lambda \varepsilon \gamma o ́ \mu \varepsilon v \alpha$ (op. laud., I, p. 626).

${ }^{4}$ M. P. Nilsson nega-o sem reservas (Geschichte der griechischen Religion, I, pp. 627-628). Alii alia... 
importante, mas isso não nos elucida se pertencia já ao culto na sua forma primitiva.

Quanto aos Mistérios em geral, os dados arqueológicos fazem-nos remontar, como já vimos, à época micénica. A etimologia, por sua vez, não nos fornece informações seguras. Os antigos relacionavam 'E $\lambda \varepsilon v \sigma i ́ \varsigma$ com દ่̇ $\varepsilon u ́ \theta \omega$, dando-lhe o significado de «lugar da chegada», ou seja, o lugar atingido por Deméter na sua peregrinação errante em busca da filha ${ }^{1}$. A explicação tem todo o aspecto de um caso de etimologia popular. Os filólogos modernos tentaram esclarecer a origem da palavra associando-a com o nome do Elísio ou com o da deusa da vegetação Eleithyia ${ }^{2}$, cuja origem cretense estabeleceria a ligação entre os Mistérios e a religião minóica. Quanto ao primeiro caso, é foneticamente impossível. Com relação à segunda possibilidade, Wackernagel ${ }^{3}$ considera esse nome e

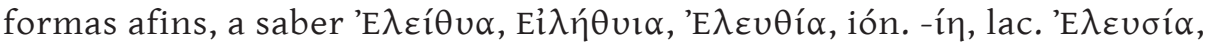

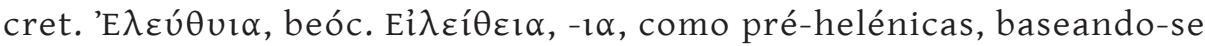

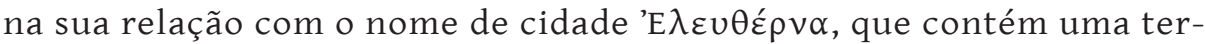
minação pré-grega usada em topónimos, mas não vê motivo para supor

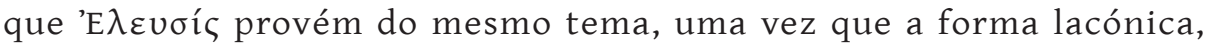

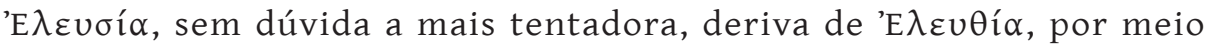
da alteração da aspirada em espirante, que é um fenómeno característico desse dialecto ${ }^{4}$. Por outro lado, o nome do festival 'E $\lambda \varepsilon v \sigma i ́ v ı \alpha$,

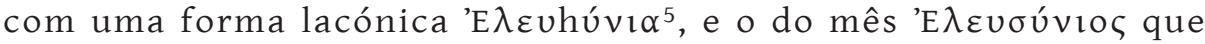
ocorre em Creta $^{6}$ e em Tera ${ }^{7}$, devem estar relacionados com o epíteto

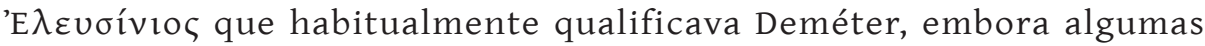
vezes se aplicasse também a outros deuses ${ }^{8}$. M. P. Nilsson apresenta a hipótese de Deméter Eleusínia ter prevalecido sobre Eleithyia e de se

${ }^{1}$ Libânio, I, 2, 471 (Foerster). O nome comum 'E $\lambda \varepsilon v \sigma i ́ s$ não aparece antes do séc. I da nossa era (Cornuto).

${ }^{2}$ A primeira tentativa foi feita por A. Rutgers van der Loeff, De ludis Eleusiniis, Diss. Leyde, 1903, pp. 13 seqq.

${ }^{3}$ Apud M. P. Nilsson, Minoan-Mycenaean Religion, pp, 521 seqq.

${ }^{4}$ Interpretação apresentada primeiro por Ross e confirmada em seguida por Keil e Foucart (citados por Dittenberg, Sylloge Inscriptionum Graecarum, I, 252). Cf. ainda Bechtel, Die griechischen Dialekte, II. Band, Berlin, 1923, pp. 302-303, e C. D. Buck, Introduction to the Study of the Greek Dialects, p. 55, § 64 e a imitação da pronúncia lacónica na Lisístrata de Aristófanes. O fenómeno encontra-se registado pela primeira vez em inscrições do século IV a. C.

${ }^{5}$ I. G. 5 (1) 213.11 (século V a. C.).

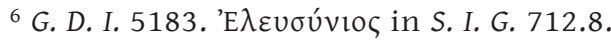

7 Test. Epict. 2, 7, 33.

${ }^{8}$ A Zeus na Iónia, segundo Hesíquio, e a Ártemis na Sicília e em Antioquia, Idem, Lib. Or. 11.109. 
ter apropriado do culto desta deusa, como Apolo fez a Hyakinthos ${ }^{1}$. A questão é bastante obscura. É quase certo que vários mitos se fundiram num só em Elêusis e que alguns deles deviam ser pre-helénicos ${ }^{2}$. Porém não nos é possível conhecer esse processo evolutivo, porquanto a nossa mais antiga informação sobre os Mistérios mostra o ciclo já completo nas suas partes essenciais ${ }^{3}$.

Em conclusão, o testemunho da arqueologia faz remontar o santuário de Elêusis à época micénica e o mais antigo documento literário declara que os Mistérios asseguravam um lugar melhor no Hades aos seus iniciados, pelo menos desde o século VII a. C. ${ }^{4}$. As próprias palavras pelas quais se exprime essa promessa parecem mostrar que ela se originou entre um povo que acreditava que um Hades sombrio como o que figura nos poemas homéricos era o último destino da humanidade. Quer isto dizer que a religião dos Mistérios encontrou um dos seus melhores apoios em encorajar a esperança dos homens num além melhor, esperança essa que tendia a desenvolver-se naturalmente com o andar dos tempos. É muito provável que outras religiões congéneres, que se praticavam noutros lugares da Grécia e especialmente na Itália do Sul e na Sicília, augurassem recompensas semelhantes aos seus mystae ${ }^{5}$.

A promessa de bem-aventurança no além não implicava necessariamente a crença em castigos; contudo, o frg. 753 Nauck de Sófocles parece confirmar a sua existência ${ }^{6}$. Porém o caso do significado da expressão famosa $\dot{\varepsilon} v \beta \circ \rho \beta o ́ \rho \omega \kappa \varepsilon \tilde{\imath} \sigma \theta \alpha$, que em geral se inclui nesta rubrica, deve

${ }^{1}$ Minoan-Mycenaean Religion, p. 522.

${ }^{2}$ Cf. M. P. Nilsson, Geschichte der griechischen Religion, I, pp. 447-448; Wilamowitz in Sitzungsberichte der Berliner Akademie, 1908, p. 331, e Glaube der Hellenen, I, p. 98. A. W. Persson, Der Ursprung der eleusinischen Mysterien, in Archiv für Religionswissenschaft, 1922, pp. 287-309 reivindica a sua origem cretense. A tese de Foucart acerca da proveniência egípcia (Les Mystères d'Eleusis, pp. 114 seqq.) quase não carece de ser mencionada.

${ }^{3}$ Dioniso não está ainda incluído. Sobre a identificação deste deus com lacchos vide E. R. Dodds, edição das Bacantes de Eurípides, p. 157.

${ }^{4}$ Sobre a data do Hino a Deméter vide a edição de Allen-Halliday dos Hinos Homéricos.

${ }^{5}$ Cf. A. J. Festugière, Les Mystères de Dionysos (suite) in Revue Biblique, vol. XLIV, 1935, pp. 366-396, especialmente p. 393.

${ }^{6}$ Contestado por M. P. Nilsson, Early Orphism and Kindred Religious Movements in Harvard Theological Review, vol. XXVIII, 1935, pp. 101-230. («The widespread fear of various punishments in Hades may have caused people to be initiated at Eleusis, but there is no evidence that these mysteries knew of punishments in the Other Life»). Que não era necessário observar regras de vida especiais demonstra-o a famosa anedota acerca da pergunta de Diógenes: Tí $\lambda \varepsilon^{\prime} \gamma \varepsilon 1 \varsigma, ~ \varepsilon ้ \varphi \eta$,

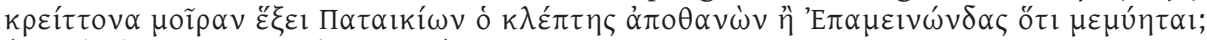
(apud Plutarco, Moralia, II, 21). 
ser encarado sob um aspecto diferente. Conforme sugere E. R. Dodds ${ }^{1}$, ela deve ter-se originado na extensão das condições do túmulo ao Hades.

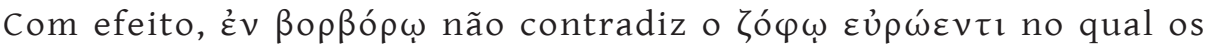

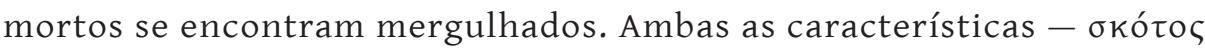

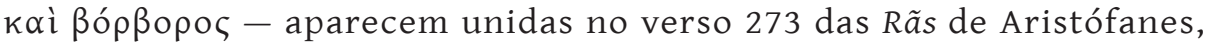
no passo em que Xântias se queixa de nada mais ver. Os versos 145-146 desenvolvem apenas o segundo destes tópicos:

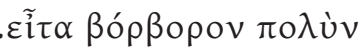

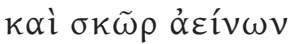

Um passo de Ésquilo (Euménides, 385-387) confirma esta hipótese, se,

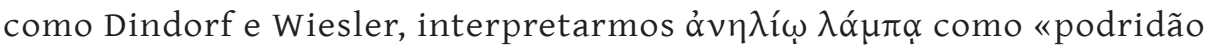
sem sol» (aplicado à morada das Erínias); com efeito, não há exemplo de $\lambda \alpha ́ \mu \pi \eta$ significar «luz», como pretendeu Sidgwick. Deve tratar-se aqui de um dos termos médicos usados pelo poeta, pois a palavra aparece duas vezes em Hipócrates ${ }^{2}$.

Há ainda um exemplo de ßó $\beta$ opos num fragmento da poesia elegíaca primitiva, atribuído a Ásio Sâmiơ ${ }^{3}$

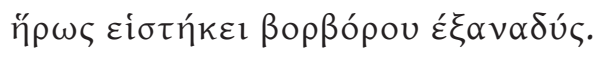

no qual Wilamowitz ${ }^{4}$ «defunctum ex Acherusia palude redeuntem agnouit», como informa Diehl no seu aparato crítico.

O estado do texto não permite muitas conjecturas. Mesmo que, de facto, aluda a um morto, não sabemos se o lugar donde ele vem é o Hades ou o túmulo. A palavra ñ acima referida acerca da origem desta ideia encontraria uma confirmação decisiva.

Evitar o ßó $\beta$ ßopos geral do Hades era uma das vantagens de se ser

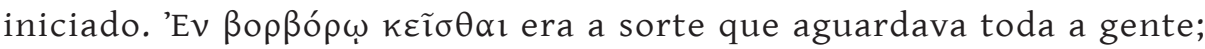
os Mistérios prometiam um lugar melhor. Com o decorrer do tempo, o sentido originário da expressão obliterou-se e esta acabou por ser tomada na acepção de castigo ${ }^{5}$.

${ }^{1}$ The Greeks and the Irrational, p. 172, nota 102.

${ }^{2}$ Citado por Prof. Dodds em aulas na Universidade de Oxford.

${ }^{3}$ V. 4 Diehl $^{3}$.

${ }^{4}$ T. G. $60^{3}$.

${ }^{5}$ Cf. M. P. Nilsson, Geschichte der griechischen Religion, I, p. 652, e History of Greek Religion, p. 218. 
O facto verificou-se não só com Elêusis, como também com outras religiões de mistérios. Daí a confusão que surge quando tentamos determinar a quais dentre eles se deve atribuir a ideia.

Nos versos 145-151 e 273-276 das Rãs de Aristófanes a referência é certamente a pessoas não iniciadas em Elêusis, conquanto a noção de castigo pelos pecados cometidos seja dominante nesses passos.

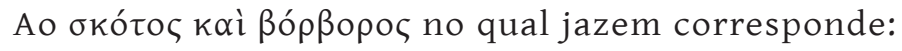

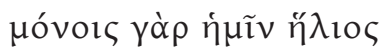

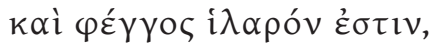

$$
\begin{aligned}
& \text { ö } \sigma \circ \mu \varepsilon \mu \cup \eta ́ \mu \varepsilon \theta^{\prime} \varepsilon \dot{v}- \\
& \sigma \varepsilon \beta \tilde{\eta} \tau \varepsilon \delta i \eta ́ \gamma o \mu \varepsilon v
\end{aligned}
$$

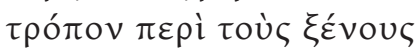

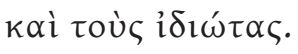

Os dois famosos passos de Platão sobre o mesmo assunto já não são tão claros. No Fédon 69 C não se dá nome especial aos Mistérios ${ }^{1}$ e em Rep. II, 363C-E, «Museu e o seu filho» pode incluir mais do que um rito dessa espécie ${ }^{2}$.

Um escritor tardio, Aristides, afirma claramente a origem eleusiniana dessa concepção ${ }^{3}$ :

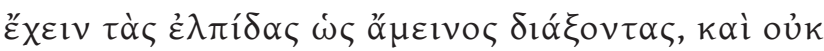

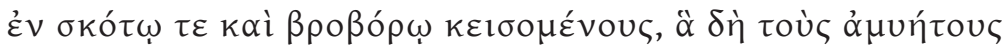

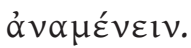

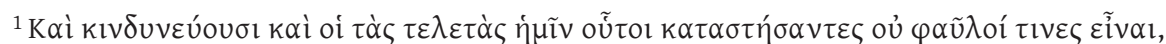

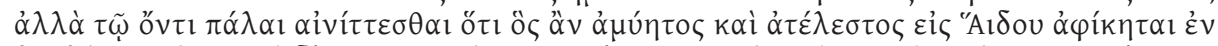

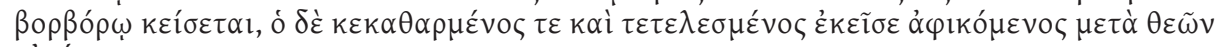

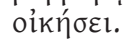

Cf. também o conhecido dito de espírito em Aristófanes, Pax, 374-375:

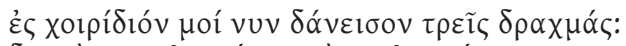

$\delta \varepsilon \tilde{\imath} \gamma \grave{\alpha} \rho \mu u \eta \theta \tilde{\eta} v \alpha i ́ ~ \mu \varepsilon \pi \rho i v ~ \tau \varepsilon \theta v \eta \kappa \varepsilon ́ v \alpha i$.

2 Sobre isto veja-se E. R. Dodds, The Greeks and the Irrational, p. 234, nota 82.

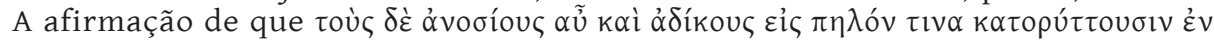

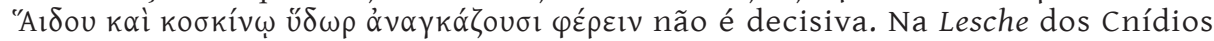
em Delfos, Polignoto pintou algumas figuras que transportavam água em vasos

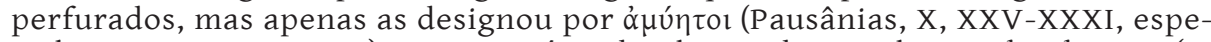
cialmente X, XXXI, 9-11). O comentário de Olimpiodoro a Platão, Phaedo, 68 C (p. 48, 20 Norvin) tem, na verdade «a not very impressive authority» (E. R. Dodds, op. laud., p. 172, nota 102).

\footnotetext{
322.10 Keil.
} 
De um modo geral, parece que a ideia de jazer no lodo pertencia ao núcleo tradicional de concepções e que a promessa de evitar esse destino foi o processo mais impressionante que os Mistérios encontraram de concretizar a melhor sorte dos iniciados. Como o culto de Elêusis é o mais antigo, é fácil de supor que foi aí que a fórmula foi criada e que mais tarde se estendeu a outros lugares. 
(Página deixada propositadamente em branco) 


\section{CAPÍTULO II \\ IDEIAS SOBRE UM ALÉM FELIZ DURANTE OS SÉCULOS VI E V A. C.}

\section{a ) Orfismo e Pitagorismo}

O movimento religioso conhecido sob o nome de Orfismo tem sido assunto de muita discussão e continua ainda a ser, em muitos aspectos, uma questão em aberto. Os testemunhos sobre a sua verdadeira natureza e importância na antiga Grécia, depois de se terem avolumado numa mole ingente de citações tardias, encontram-se agora reduzidos a proporções consideravelmente mais modestas ${ }^{1}$.

Entre os problemas que ainda aguardam resposta conta o de explicar a solução de continuidade existente entre o cantor chamado Orfeu, que Íbico ${ }^{2}$, Simónides ${ }^{3}$ e outros celebraram, e que se encontrava representado na métopa do tesouro de Sícion em Delfos, e o movimento religioso, que dele tomou o nome, cuja doutrina estava expressa em livros que circulavam nos séculos V e IV a. C. ${ }^{4}$. Estes últimos eram atribuídos a Orfeu, mas já autoridades de não menos peso do que Íon de Quios, Epígenes e Aristóteles tinham suspeitas sobre a sua autenticidade. Apesar disso, acreditou-se durante muito tempo - e há quem ainda o acredite ${ }^{5}$ - que

${ }^{1}$ Sobre a evolução das doutrinas acerca do Orfismo entre os principais especialistas e os resultados do desbaste operado no acervo de interpretações falsas ou forçadas que se haviam acumulado, vide E. R. Dodds, The Greeks and the Irrational, pp. 147-149, com as notas 79 a 96 (pp. 168-172). O alarme foi dado por Wilamowitz, Glaube der Hellenen, II, pp. 199 seqq. Sobre as possíveis origens do Orfismo vide E. R. Dodds, op. laud., nota 29 da p. 160 e 97 da p. 172.

${ }^{2}$ Frg 10 a Bergk.

${ }^{3}$ Frgs. 40 e 41 Bergk.

${ }^{4}$ Platão, Rep. II, 364 E.

${ }^{5}$ W. K. C. Guthrie, The Greeks and their Gods, p. 312. 
um poema escatológico órfico estava na base de todos os mitos sobre o além que figuram em poetas do século V a. C., bem como em Platão, e que as lâminas de ouro contêm uma amostra desse poema. Quanto a Platão, não há possibilidade de admitir que um só e mesmo modelo, seja órfico ou não, está no fundo dos seus quatro mitos escatológicos; o mesmo se verifica com os diversos tratamentos dados por Píndaro ao mesmo tema. Sobre as lâminas de ouro, não há provas suficientes para as declarar de origem órfica, como veremos mais adiante.

Por agora, consideremos as únicas informações seguras sobre os órficos, que podemos coligir de citações antigas. Assim, sabemos que se abstinham de derramar sangue ${ }^{1}$ e eram vegetarianos ${ }^{2}$, que ensinavam que o corpo era uma prisão da $a^{1 m a^{3}}$ e que o pecado podia ser purificado

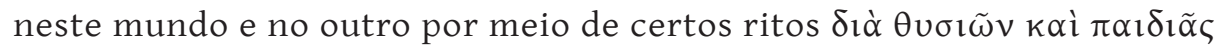
$\dot{\eta} \delta o v \tilde{\omega} v .{ }^{4}$ Este último ponto de doutrina permite-nos supor que acreditavam na transmigração, conforme observa E. R. Dodds, conquanto esse facto não esteja atestado na época clássica ${ }^{5}$. Por outro lado, a noção de catharsis estava directamente ligada à de promessas de um além feliz, as quais eram certamente parte importante da sua doutrina. Podemos mesmo admitir, seguindo M. P. Nilsson, que contrariamente ao que se passava com os Mistérios de Elêusis, os órficos insistiam mais na perspectiva dos castigos do que na das recompensas ${ }^{6}$.

A noção de penas e de justiça no mundo subterrâneo parece, todavia, ter precedido em muito o ensino dessa seita, porquanto a encontramos expressa duas vezes na Ilíada ${ }^{7}$, pelo menos para os perjuros:

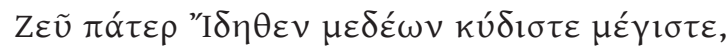

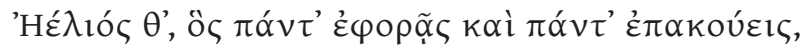

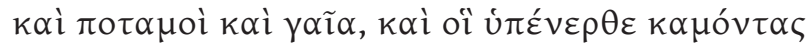

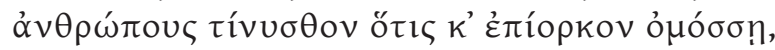

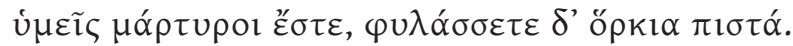

(Г 276-280)

${ }^{1}$ Aristófanes, Ranae, 1032.

${ }^{2}$ Euripides, Hippolytus, 952 seqq.

3 Platão, Cratylus, 400 C.

${ }^{4}$ Platão, Rep. II. 364E-365A.

${ }^{5}$ The Greeks and the Irracional, p. 148.

${ }^{6}$ Minoan-Mycenaean Religion, p. 631.

${ }^{7} \mathrm{Em} \lambda$, 568-571, não se trata de um julgamento. Minos, tal como Órion, apenas continua a exercer as funções que desempenhara durante a vida. Títio, Tântalo e Sísifo sofrem as consequências da sua üßpıc. O frg. 87 Bergk de Álcman parece indicar que Tântalo a princípio expiava o seu crime no Olimpo. Cf. Welcker, Alcmanis fragmentum de Tantalo in Rheinisches Museum, 1856, pp. 242-254. 
e novamente, em termos mais precisos:

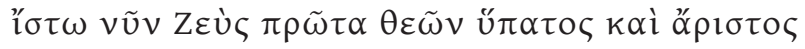

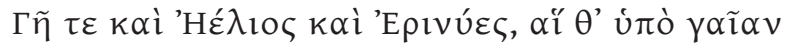

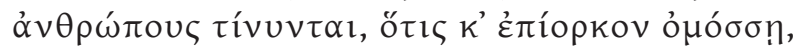

(T 258-260)

A mesma ideia, quando expressa por Ésquilo, parece derivar de fonte popular ${ }^{1}$ e não teológica, como supôs E. Rohde ${ }^{2}$ :

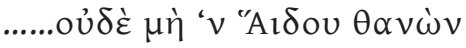

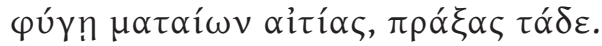

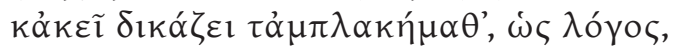

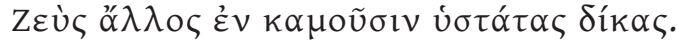

(Suppl. 228-231)

A designação aqui atribuída a Hades não diverge muito de Zعù

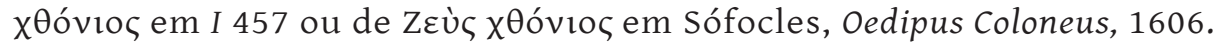

As funções exercidas em Eumenides, 273-275, são novamente as mesmas ${ }^{3}$ :

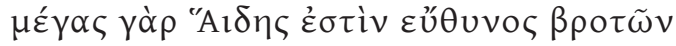

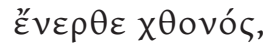

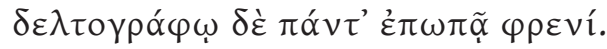

Além destes exemplos, encontramos referências ao julgamento no Hades em Supplices 414-416 e Eumenides 339-3404.

A noção de justiça e castigos no além foi crescendo em importância, como teremos ocasião de ver mais adiante. Entretanto convém acentuar que, tal

${ }^{1}$ Cf. Dieterich, Nekyia, p. 126.

2 Psyche, I, pp. 309-310 e nota 2 da p. 309.

${ }^{3}$ O fragmento 506 Nauck da Melanippe de Eurípides dá a impressão de ser uma paródia destes versos. Um outro fragmento de Ésquilo, publicado em Pap. Oxy. 2256.9 (a) também fala, no verso 21, de uma função semelhante. No entanto, aí a autora do registo parece ser $\Delta$ íkn:

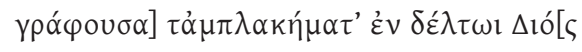

o que E. Lobel aproxima, com razão, da tradição conservada por Luciano, De

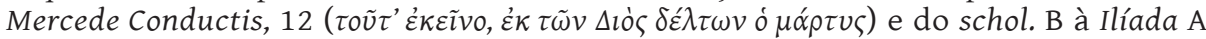

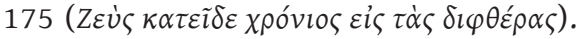

${ }^{4}$ Evidentemente que também estas afirmações foram já etiquetadas como "órficas». Sobre isso veja-se E. R. Dodds, The Greeks and the Irrational, p. 137 e p. 158 , nota 13. 
como todas as outras crenças relativas à outra vida, também esta era uma ideia corrente de que se apropriaram, remodelando-a, algumas seitas.

Muitos outros movimentos religiosos, que compreendiam ritos de iniciação e prometiam recompensas na outra vida aos seus $\mu \dot{\sigma} \sigma \alpha \alpha$ se devem ter desenvolvido na Grécia e na Itália meridional, durante os séculos VI e V a. C.

Porém o mais importante de todos parece ter sido o Pitagorismo. Que esta seita estava estreitamente ligada ao Orfismo, demonstra-o o facto de terem sido atribuídos poemas órficos a alguns dos seus mais antigos representantes, bem como ao próprio Pitágoras ${ }^{1}$.

De positivo sabe-se que compartilhavam de alguns dos preceitos órficos, como abstenção de certas qualidades de alimentos e prática de catharsis ${ }^{2}$; ensinavam também que o corpo era a prisão da alma e acreditavam na transmigração.

A mais notável diferença entre ambos é que o Orfismo nunca foi reforçado por um sistema filosófico, como o Pitagorismo. As teorias deste último sobre os números e harmonia do cosmos, por exemplo, pertencem ao nível especulativo ${ }^{3}$.

A lenda atribuía ao fundador da comunidade uma série de transmigrações e uma descida ao Hades, durante a qual ele teria presenciado os castigos ${ }^{4}$ e o julgamento ${ }^{5}$ que aí tinham lugar.

O mesmo mito foi utilizado por Aristofonte ${ }^{6}$, ao satirizar os pitagóricos. O passo é especialmente interessante, porque nos dá uma ideia da noção que tinham das recompensas no além:

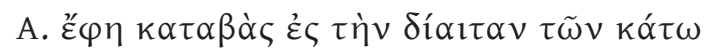

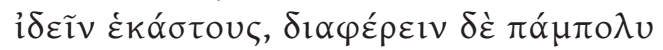

${ }^{1}$ Jâmblico, Vita Pythagorea, 28, 146-147. Íon de Quios afirmou que Pitágoras escrevera alguns poemas sob o nome de Orfeu e Epígenes atribuiu quatro composições órficas a membros da comunidade pitagórica. Não sabemos se teriam sido estes os primeiros carmes órficos que existiram. Cf. E. R. Dodds, The Greeks and the Irrational, p. 149.

${ }^{2}$ Ao que parece, por meio de $\dot{n} \pi \omega \delta \alpha$ í (Jâmblico, Vita Pyth., 64 seq., 110-114, 163 seq.; Porfírio, Vita Pyth., 33). Sobre a catharsis pela música vide Aristóxeno, frg. 26 Wehrli (citado por E. R. Dodds, op. laud., p. 99, nota 107).

${ }^{3}$ Outras diferenças menores, já assinaladas por E. R. Dodds, op. laud., nota 95, p. 171, são que o culto de Apolo era essencial para o Pitagorismo, ao passo que Dioniso era o deus do Orfismo, e que a primeira destas seitas era aristocrática, e a segunda provavelmente popular.

${ }^{4}$ Diógenes Laércio, VIII, 21.

${ }^{5}$ Idem. VIII, 35. Cf. Jâmblico, Vita Pyth. 155, 179.

${ }^{6}$ Apud Diógenes Laércio, VIII, 38 = Meineke, C. G. F. III, 364. 


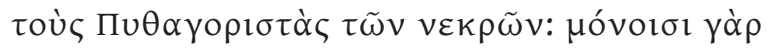

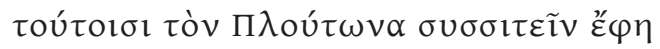

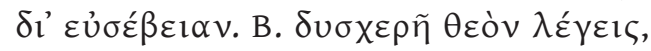

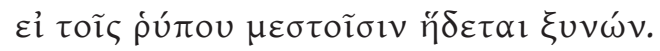

Como se vê, não estamos muito longe das palavras depreciativas de Platão na Rep. II, 363C-D, ao referir que a bem-aventurança no além, prometida por «Museu e o seu filho», consistia num perpétuo symposium no Hades. É natural que Platão visasse mais do que uma seita, ao escrever isto. Comparando este passo com a paródia de Aristofonte, é lícito concluir que as ideias dos pitagóricos acerca dos prémios pela $\varepsilon \dot{v} \sigma \varepsilon ́ \beta \varepsilon \imath \alpha$ não eram muito diferentes.

Um trecho de Aristóteles (Anal. post. B 11.94 b 33) mostra que também acreditavam em castigos no Tártaro.

De um modo geral, pode dizer-se que, seguindo os Mistérios de Elêusis, todas as outras doutrinas asseguravam um lugar especial no Hades aos seus iniciados. A noção de castigos foi tomando cada vez maior vul-

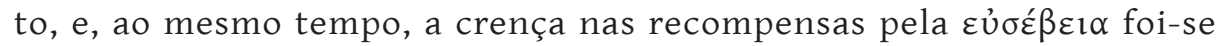
amplificando até chegar a um conceito moral de prémio pela virtude. A referência aos pecadores no Hades, em Ranae, 146-150 e 274-275' ${ }^{1}$, mostra que tal conceito devia ser corrente em Atenas, no século V a. C. Mas nada de perfeitamente definido se tinha ainda originado nesta remodelação de ideias populares, sob a influência de crenças teológicas.

\section{b) Empédocles}

A mesma doutrina da transmigração das almas se ensinava nos $K \alpha \theta \alpha \rho \mu o i ́$ de Empédocles. As teorias deste filósofo têm sido, com razão, relacionadas com o pitagorismo ${ }^{2}$ e o grande homem «dotado da sabedoria de vinte vidas humanas», que se menciona no frg. 129 Diels, tem todas as probabilidades de ser Pitágoras, conforme já foi notado. No passo em que diz, por exemplo, que «quando um homem poluiu de um modo pecaminoso as suas mãos, com sangue, ou se deixou arrastar pela discórdia,

${ }^{1}$ Uma espécie de eco destas palavras pode discernir-se na paródia da solene advertência do hierofante, 354-371. O verso 151 contém um aproveitamento cómico semelhante.

2 Principalmente por Wilamowitz in Berliner Sitzungsberichte 1929, p. 655; Tho-

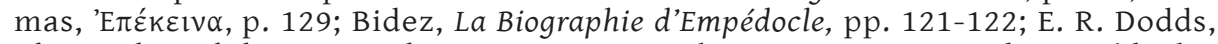
The Greeks and the Irrational, nota 81, p. 169. Sobre a interpretação de Empédocles como "a very old type of personality... already an anachronism in the V. century», em linha de continuidade com Orfeu e Pitágoras, vide op. laud., p. 146. 
ou foi perjuro, tem de andar errante três vezes dez mil períodos da mansão dos bem-aventurados, incarnando durante esse tempo em todas as espécies de formas mortais e mudando de um para outro dos caminhos penosos da vida», tudo isto por um decreto da Necessidade ${ }^{1}$, estamos muito próximos das sucessivas transmigrações e do kúk $\lambda \circ \varsigma$ 'Avó $\gamma k \eta \varsigma$ que Diógenes Laércio incluía nas doutrinas pitagóricas. ${ }^{2}$ Por outro lado, o fragmento 117 Diels, que alude às metamorfoses anteriores de Empédocles, não está em desacordo com aqueles tão discutidos versos de Xenófanes ${ }^{3}$, relativamente aos quais não há razão suficiente para duvidar que se trata das teorias pitagóricas da metempsicose.

Outro passo que tem sido sujeito a muitas interpretações é o fragmento 121 Diels, no qual se descreve um lugar estranho:

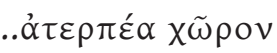

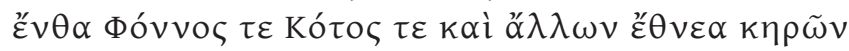

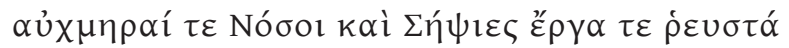

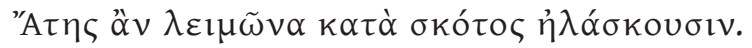

Destes versos têm pensado uns que se referem ao Hades ${ }^{4}$ outros que

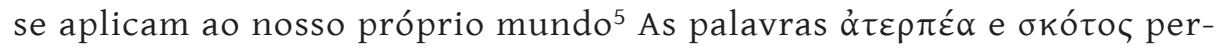
tencem, sem dúvida, ao vocabulário corrente das descrições da região infernal. Mas parece não ser este o caso de Empédocles, que empregou

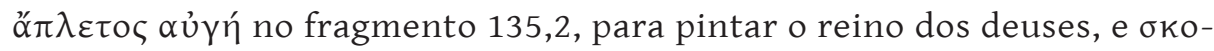

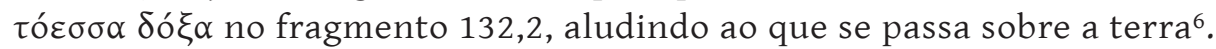
É certo que Virgílio colocou aproximadamente os mesmos males personificados à entrada do Hades, nos versos 273-281 do Canto VI da Eneida. Mas, por outro lado, tudo leva a crer que Lucrécio foi influenciado pelo passo de Empédocles de que estamos a ocupar-nos, no famoso quadro da transposição dos horrores do inferno para a vida, em De Rerum Natura, III,

${ }^{1}$ Frg. 115 Diels.

2 Pythagoras, VIII, I, § 14.

${ }^{3}$ Frg. 6 Bergk.

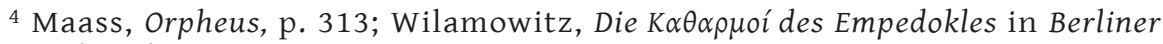
Sitzungsberichte, 1929, pp. 636-638.

${ }^{5}$ E. Rohde, Psyche, II, p. 178, nota 1; Bignone, Empedocle. pp. 493-494; W. Kranz, Die Katharmoi und die Physika des Empedokles in Hermes, vol. LXX, 1935, p. 114, nota 1; W. Jaeger, The Theology of the Early Greek Philosophers, pp. 149, 238, nota 91; E. R. Dodds, The Greeks and the Irrational, nota 114, p. 174.

${ }^{6}$ Ambos os exemplos em Walther Kranz, Die Katharmoi des Empedokles in Hermes, 1935, vol. LXX, p. 114, nota 1, e em Diels. Die Fragmente der Vorsokratiker, 1950, I, p. 360. 
978-10231. Por sua vez, os antigos concordavam em que o lugar aludido era a terra, e não o Hades ${ }^{2}$.

Mas o poeta agrigentino também era capaz de imaginar uma vida aprazível, como fez, por exemplo, ao retratar a felicidade de que se gozava na idade do Ouro, no fragmento 128.

O poema de Empédocles sobre as purificações parece nunca se ter tornado popular em época alguma, mas, em compensação, exerceu sobre os filósofos posteriores uma influência não despicienda. Teremos ocasião de o reconhecer ao tratar dos mitos de Platão.

\section{c) Testemunhos da poesia lírica e dramática}

A primitiva poesia lírica e elegíaca fala sempre do Hades em termos homéricos ${ }^{3}$ e, ao mesmo tempo que Píndaro compunha os seus versos sobre temas escatológicos, Simónides observava tristemente ${ }^{4}$ :

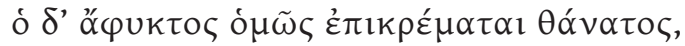

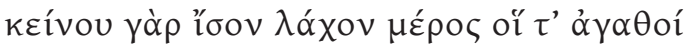

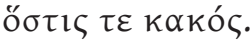

É claro que isso pode ser meramente acidental, dado o estado fragmentário em que essa espécie de poesia chegou até nós. Se não fosse o escoliasta de Apolónio de Rodes, IV, 814, nunca saberíamos que Íbico e Simónides mencionaram os Campos Elísios, pelo menos uma vez, a propósito do destino de Aquiles. E continuamos a ignorar os termos exactos em que o fizeram.

${ }^{1}$ Epicuro, III, 124, sugere mesmo e Macróbio, in Somn. Scip. I, 10, 9 seqq. apresenta essa alegoria como uma opinião corrente. Mas os versos de Empédocles devem ter sido a fonte de Lucrécio neste passo.

2 Por exemplo, Teo de Esmirna, p. 149, 4 Hiller; Calcídio in Tim. 79, p. 143, 17 Wr.; Hierocl., Ad carm. aureum 24 ad v. 54 seqq. ( $\tau \dot{\alpha} \pi \varepsilon \rho \grave{i} \gamma \tilde{\eta} v)$; Temístio, Or. XIII, 178. A única excepção é Proclo, in Tim. III, 325 Diehl, que o identifica com a planície mencionada no final do mito do Livro $\mathrm{X}$ da República de Platão.

${ }^{3}$ Por exemplo: Calino, frg, 1, 12-13; Tirteu, frg. 9, 31-32, 37-38; Mimnermo, frg. 2, 13-14; Teógnis de Mégara, 973-978; Safo, frg, 58; Alceu, frg. 82; Anacreonte, frg. 44 (edição de Diehl). Baquílides tem na Ode V, 56-175, uma bela descrição do Hades. Sobre o caso especial de arrebatamento para os Hiperbóreos, na Ode III, 59, cf. supra, pp. 34-36

${ }^{4}$ Frg. 9, 3-5 Diehl. 
No estado actual dos nossos conhecimentos, apenas Píndaro fornece importante contributo para o estudo do desenvolvimento da crença num além feliz.

Há muito se reconheceu a impossibilidade de reconstituir uma doutrina escatológica única a partir dos dados dispersos na poesia de Píndaro. Parece que deve ter feito uso de diferentes concepções, na medida em que elas se adaptavam melhor às circunstâncias de cada composição. Por conseguinte, temos de estudar separadamente os diversos trechos, embora possamos compará-los, sempre que nisso haja conveniência.

Na II. Olímpica há que distinguir duas partes, uma principalmente teórica e outra inteiramente poética. A primeira contém uma referência ao julgamento no Hades, imediatamente a seguir à morte (versos 57-60),

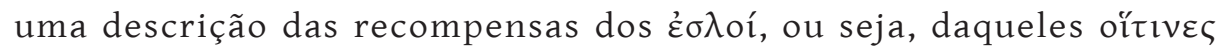

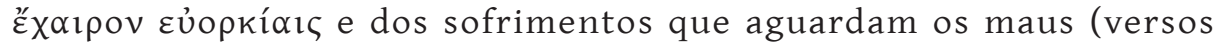
61-67), após a qual se fala dos que conservaram as suas almas afastadas do pecado durante três existências sucessivas em cada lado. A outra parte (versos 71 a 83) encerra a descrição das Ilhas dos Bem-aventurados, onde eles continuarão a viver.

Muitas são as fontes que têm sido atribuídas a este passo ${ }^{1}$. Julgo não haver dúvida de que se trata de um quadro compósito, como Thomas reconhece ${ }^{2}$. Procedamos, consequentemente, à análise de cada uma dessas partes.

Desnecessário se torna atribuir o julgamento no Hades a qualquer doutrina especial. Acabámos de ver, numa das secções precedentes, que era crença geral desde os tempos mais remotos ${ }^{3}$ Aqui não se dá nome ao juiz - apenas se designa por ¿ıc. Na Ilíada, somente o perjúrio é mencionado como um pecado passível de castigo no além, certamente devido ao facto de se invocarem as divindades que exercem vingança sobre os que infringiram os seus juramentos. É provável que, quando Píndaro define, no verso 66, a espécie de pessoas que merece uma vida

${ }^{1}$ Orfismo (Dieterich, Nekyia; L. Malten, Elysion und Rhadamanthys in Jahrbuch des kaiserlich Deutschen Archäologisehen Instituts, vol. XXVIII, pp. 35-51); Órfico-pitagorismo (M. P. Nilsson, Geschichte der griechischen Religion, I, p. 705, «unsicher»); Pitagorismo (H. J. Rose, The Ancient Grief in Greek Poetry and Life). Opinião contrária em Wilamowitz, Pindaros, pp. 248 seqq.; em Glaube der Hellenen, II, p. 57 chama-lhe apenas «die Geheimlehre an die Theron glaubt».

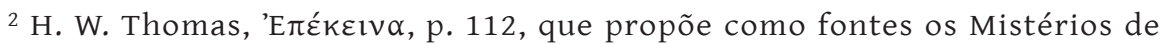
Elêusis e o Pitagorismo (no que respeita à transmigração, apenas). Cf. ibidem p. 16 , nota 50 , e p.155.

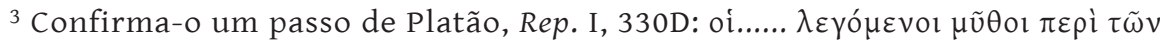

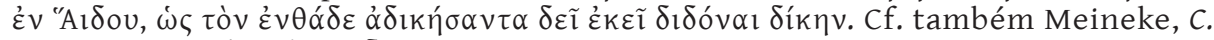

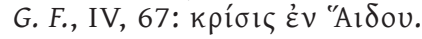




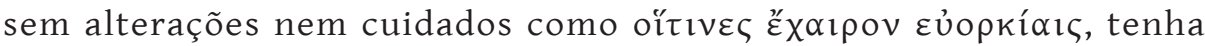
tido em mente uma reminiscência homérica.

Segue-se a descrição das duas espécies de destinos que aguardam as almas após o julgamento. O texto não dá qualquer indicação sobre o lugar, mas não é crível que o poeta se refira à vida sobre a terra, em virtude do que se lê nos versos 61-62 e 66-67. Esta ausência de localização deve-se, em meu entender, à circunstância de se dar mais importância

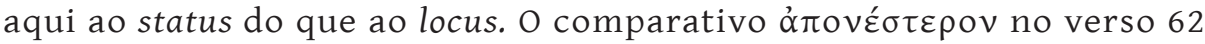

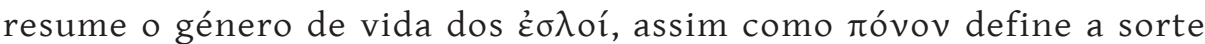
de $\tau$ oì $\delta$ ' em 67. Uma existência inalterável, tranquila, anódina parece ser o leit-motiv deste estado neutro.

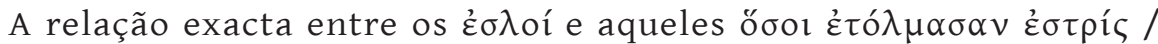

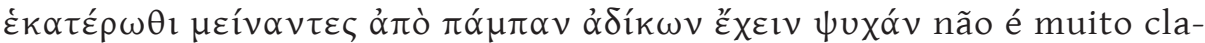
ra. Se, porém, compararmos este passo com outro de Platão (Phaedrus, 249A), conseguiremos esclarecer melhor o problema. Aí se afirma que os filósofos, quando, durante três períodos sucessivos de mil anos, escolheram o mesmo género de vida, ao fim desse tempo recebem as suas asas e seguem o seu caminho; mas os demais, quando acabaram a sua primeira vida, são julgados, e depois do julgamento alguns vão para lugares de correcção debaixo da terra e cumprem a sua pena, ao passo que os outros são elevados, por justiça, a um lugar celeste, onde vivem de maneira digna da existência que haviam levado na sua forma humana. Se abstrairmos das alusões ao mito das asas, tudo o mais coincide com a doutrina de Píndaro.

A outra parte é unicamente poética. Até onde podemos saber, é esta a primeira vez que Elísio e Ilhas dos Bem-aventurados se confundem com o além dos Iniciados. Encontra-se lá o legislador homérico, Radamanto ${ }^{1}$,

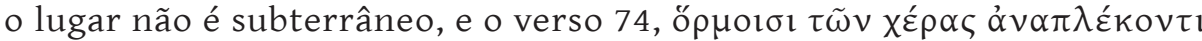

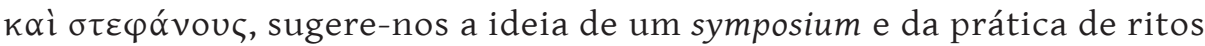
sagrados, em concordância com as concepções atribuídas a «Museu e o seu filho» por Platão na Rep. II, 363C-D.

Parece que Píndaro fez uso aqui das teorias de qualquer seita religiosa, na qual Terão estava iniciado, e as combinou com a tradição poética acerca da mansão dos bem-aventurados. Se essas teorias eram órficas ou pitagóricas, ou ambas as coisas, ou se eram ensinadas por qualquer religião de mistérios da Itália Meridional, não temos elementos

${ }^{1}$ Não creio que se deva subentender a presença de Cronos nem de Reia nas

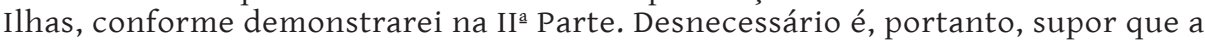
deusa se encontra lá por simetria com Prosérpina no Hades (Wilamowitz, Pindaros, pp.493-495). O seu nome é mencionado apenas como mãe de Zeus, tal como no verso 12 da mesma Ode. 
suficientes para o determinar. Mas a comparação com o passo do Fedro que citámos acima é favorável à hipótese de a base ideológica deste trecho da II ${ }^{a}$ Olímpica ser de origem pitagórica. A combinação desta com a tradição literária acerca de uma terra longínqua onde viviam os bem-aventurados foi a contribuição pessoal de Píndaro para o mito.

Agora, pela primeira vez, as Ilhas dos Bem-aventurados não são já um lugar para aqueles que foram arrebatados pelos deuses. Estão

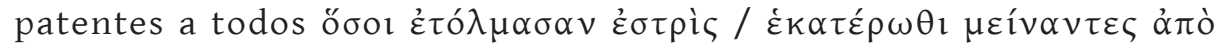

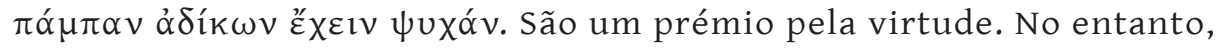
a velha e familiar tradição da «Entrückung» conserva-se ainda visível

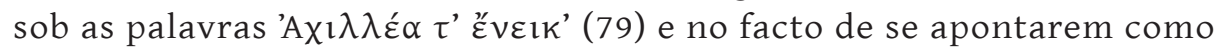
exemplos apenas heróis.

No fragmento 129 Snell, o poeta utilizou a tradição acerca da bem-aventurança no Hades. Demonstra-o não só a asserção de Plutarco

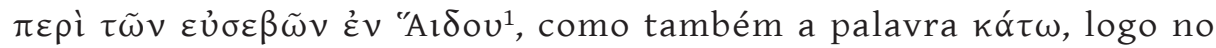
começo. O lugar é apresentado como um país aprazível, com a sua luz e as suas árvores, altares dos deuses, sacrifícios, assim como todas as distracções favoritas de um grego que dispusesse de meios de fortuna: cavalos, exercícios de ginástica, jogos de xadrez e música ${ }^{2}$.

A maneira mais natural de imaginar o além foi sempre pintá-lo como uma continuação das ocupações desta vida. Podem reconhecer-se vestígios disso até na Odisseia, conforme já dissemos. É, por conseguinte, perfeitamente lógico que, quando esse além era representado como um lugar agradável, se transferissem para o quadro todos os entretenimentos mais apreciados.

No fragmento 133 Snell há uma alusão clara à doutrina da transmigração. A «o pesar antigo» que aí se menciona deve dizer respeito ao mito de Zagreus, conforme foi demonstrado por H. J. Rose ${ }^{3}$.

Finalmente, no fragmento 137 Snell, que deve ter pertencido a um treno por um ateniense, conforme Böckh provou, é evidente que estamos em face da doutrina dos Mistérios de Elêusis, sobretudo se compararmos a linguagem em que está expressa com a que é usada no Hino Homérico a Deméter e no fragmento 753 Nauck de Sófocles.

No século $\mathrm{V}$ a. C, andavam em curso diversas doutrinas sobre o além. Píndaro deve ter feito uso de mais do que uma. Além disso adaptou às crenças teológicas do seu tempo a velha tradição mitológica sobre as

1 Consolatio ad Apoll. 120C.

2 Sobre a possível origem destes tópicos, vide infra, II ${ }^{\mathrm{a}}$ Parte, Cap. III, b).

${ }^{3}$ The Ancient Grief in Greek Poetry and Life, que se deve completar com o artigo do mesmo autor, The Grief of Persephone in Harvard Theological Review, 1943, pp. 242-250. Sobre as razões para atribuir o mito ao Orfismo primitivo, vide E. R. Dodds, The Greeks and the Irrational, pp. 155-156. 
terras longínquas, que tinha sido conservada por Homero e Hesíodo. Aliás, esta não se havia confinado exclusivamente à Literatura. No final do século VI a. C., o skolion de Harmódio e Aristogéiton dizia que o primeiro destes heróis não morrera: constava que continuava a viver

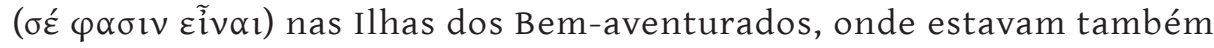
Aquiles e Diomedes. A cantiga mantinha-se fiel às velhas crenças; escapavam à morte, devido à sua eminente ópı

Outros exemplos, entre a segunda metade do século V a. C. e os começos do século IV a. C., como Aristófanes, Vespae, 639-640, Platão, Rep. VII, 519 C, Menexenus, 235C, que têm o aspecto de expressões coloquiais correntes, provam que essa concepção se tinha tornado popular. É provável que em Ranae, 85 Aristófanes aluda ainda ao mesmo ${ }^{1}$. Por outro lado, toda a primeira parte dessa comédia é uma paródia dos Mistérios de Elêusis, em cuja base está a noção de que os iniciados continuariam a celebrar os seus ritos sagrados no Hades. Num fragmento dos

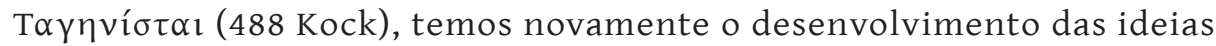
atacadas por Platão em Rep. II, 363C-D. O mesmo se verifica com os frag-

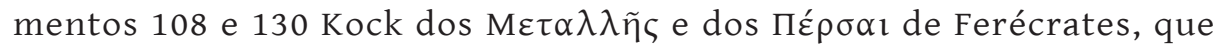
exploram o assunto ad nauseam. Fácil se torna calcular que o processo era idêntico nas outras comédias perdidas em que se descrevia o Hades.

Mas, voltando a Aristófanes, há ainda outra concepção que se reflecte nas suas peças, a qual deve ter sido igualmente crença corrente entre os seus concidadãos. É a que figura em Pax, 832-834:

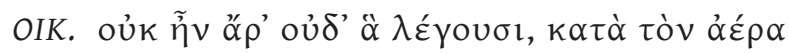

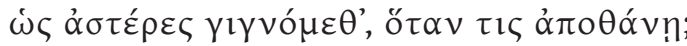

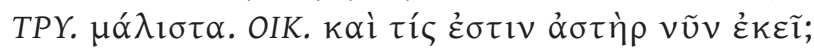

O contexto mostra que a ideia se tinha tomado popular, e os epitáfios do século V a. C. confirmam o facto ${ }^{2}$.

Aparece também várias vezes em Eupírides, como, por exemplo, em Electra, 59; Helena, 1015-1016; Orestes,1086-1087; Supplices, 531-536; frgs. 839 e 971 Nauck. Em Supplices 1140-1142 a doutrina não é tão clara:

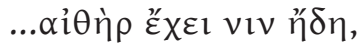
$\pi v \rho o ̀ \varsigma ~ \tau \varepsilon \tau \alpha \kappa o ́ \tau \alpha \varsigma \sigma \pi o \delta \tilde{\omega}:$

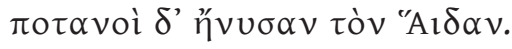

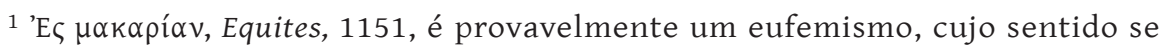

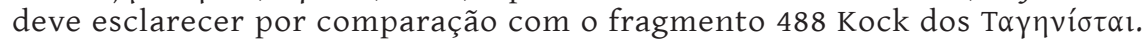

${ }^{2}$ Vide infra, na alínea Testemunhos epigráficos.
} 
Duas interpretações se podem oferecer para explicar este passo:

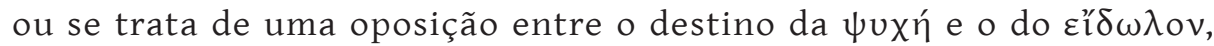
à maneira da que se estabelece para Hércules no final do Canto XI da Odisseia ${ }^{1}$ ou se está a fazer uso da doutrina pitagórica que colocava o Hades no éter ${ }^{2}$. Em face dos exemplos precedentes, a segunda hipótese parece mais provável.

No entanto, a antiga concepção do Hades como mansão subterrânea dos mortos surge com toda a frequência ${ }^{3}$. Nem à própria Alceste se atribui outro destino $(359,851-853$, etc.); nos versos 743-746, o coro alude, dubitativamente, à possibilidade de lhe ser lá concedido um lugar

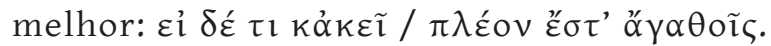

As referências às Ilhas dos Bem-aventurados surgem quando o destino das figuras do drama estava tradicionalmente ligado a elas: é o que sucede na Helena, 1676-1677, e Bacchae, 1338-1339.

Há ainda outros passos - e esses são muito provavelmente aqueles em que o poeta exprime as suas próprias convicções, e não as das suas figuras que apenas patenteiam a dúvida. É o caso dos fragmentos 638 e 833 Nauck.

Há também um trecho extremamente céptico, nos versos 191-197 do Hipólito, de cuja autenticidade se tem suspeitado, a título de ser pouco adequado à figura que o pronuncia - a ama - e de o dímetro anapéstico cataléctico do verso 190 parecer dever formar o fim natural do discurso desta ${ }^{4}$. Porém, tiradas filosóficas na boca das amas são fenómeno comum em Eurípides (cf. Medeia,119-130) e os versos já na Antiguidade eram citados como pertencentes a este passo ${ }^{5}$.

1 Versos 601-603.

${ }^{2}$ Ignora-se a época da sua formação. Jâmblico, Vita Pyth., 82, cita entre as

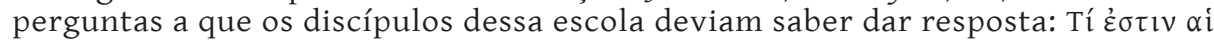

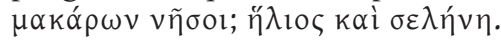

${ }^{3}$ Entre muitos outros exemplos, citarei: Electra, 122-123, 142-144, 677; Hippolytus, 829, 1366-1367, 1386 1388; Ion, 1273-1274; Iphigenia Taurica, 158-159, 184-185; frgs. 533, 534 Nauck.

${ }^{4}$ Por exemplo, por W. S. Barrett, que acrescenta a estes argumentos o de as interpolações terem começado a fazer-se muito cedo nos manuscritos.

${ }^{5}$ As obras conservadas dos outros dois grandes trágicos nunca sugerem outra possibilidade para além da morte que não sejam as trevas do Hades, com excepção do frg. 753 Nauck de Sófocles, já citado, no qual se alude ao destino privilegiado que aguarda os iniciados nos Mistérios de Elêusis. Também no

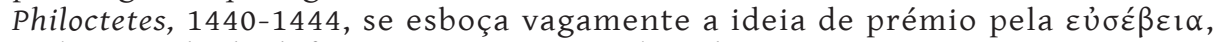
embora nada de definitivo se possa concluir destes versos:

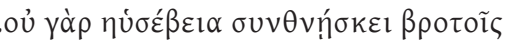

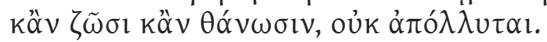

Quanto à noção de julgamento e castigos em Ésquilo, vide supra, pp. 49-50 
Todos os exemplos que temos estado a analisar mostram como este género de crenças era vago e inconsistente, a ponto de ser possível encontrar duas ou mais concepções diferentes no mesmo autor e até na mesma obra. Vamos ver em seguida que algumas dessas eram já populares, como, por exemplo, a que dizia que as almas iam para o

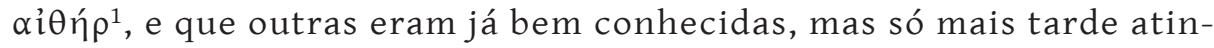
giram o auge da vulgarização, como aconteceu com a das Ilhas dos Bem-aventurados.

\section{d) Testemunhos epigráficos}

As informações que se podem colher em documentos epigráficos são extremamente escassas, porquanto apenas era costume mencionar o nome e o $\delta \tilde{\eta} \mu o \zeta$ nos epitáfios gregos, até ao século V a. C.. Entre as poucas excepções a esta regra, conta uma inscrição do século VI a. C., C. I. A. I, no 481 = Kaibel, E.G. 16, 1, proveniente de Atenas e composta por dois versos mutilados. Lê-se no primeiro:

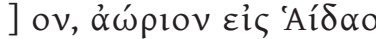

Por conseguinte, ir para o Hades era o sombrio destino que se supunha aguardar o morto, mesmo quando, como o outro verso prova, ele causara uma grande dor com a sua partida.

Depois de 500 a. C. encontram-se descrições do mundo subterrâneo feitas nos moldes tradicionais, uso esse que se prolonga até à época romana.

${ }^{1}$ A concepção de que a alma era uma parte que se soltara do éter foi atribuída a Pitágoras por Diógenes Laércio, VIII, 28:

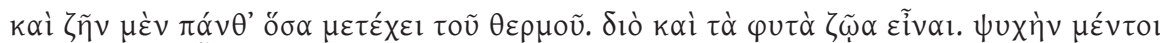

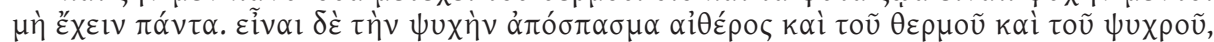

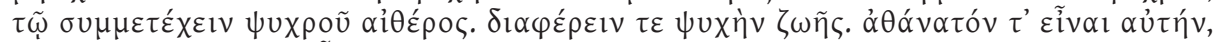

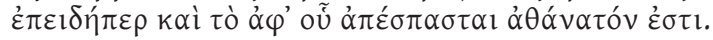

A propósito desta teoria, E. R. Dodds cita (The Greeks and the Irrational, nota 112 , p. 174) a definição de alma como um sopro ou ar quente, no frg. 2 de Anaxímenes, a qual tendia a flutuar, elevando-se, quando solta pela morte na

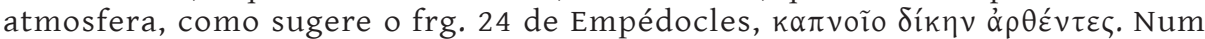
epitáfio do século IV a. C. do Pireu (Kaibel, E. G., 41, citado adiante) parece

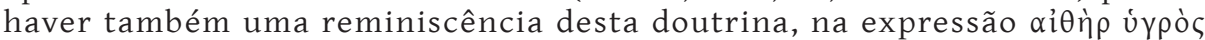
हैх $\chi$ l, principalmente.

Sobre o đïńp em epitáfios, vide infra 60-61 
Ainda no século V a. C. aparece outra noção diferente, que é a de que

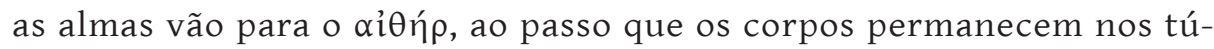
mulos. O primeiro exemplo conhecido é o famoso epitáfio dos Atenienses caídos em Potideia, do século V a. C.:

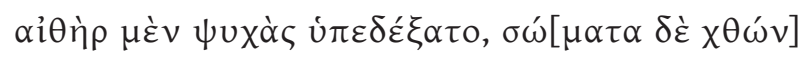

$$
\text { (C. I. A., I, } 442 \text { = Kaibel, E. G., } 21 \text { b, 1) }
$$

A mesma ideia figura novamente num epitáfio do século IV a. C, encontrado no Pireu:

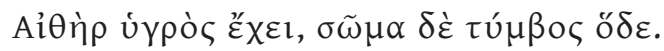

(Kaibel, E. G., 41)

e em muitos outros exemplos, que se estendem até à época romana.

A partir do século IV a. C. encontram-se também inscrições que denunciam influência de Elêusis ${ }^{1}$. A crença na imortalidade não se afirma nunca antes dessa mesma época. Os velhos mitos dos Campos Elísios e das Ilhas dos Bem-aventurados parecem ter atingido grande voga entre o século I a. C. e o século I da nossa era ${ }^{2}$, conquanto se conheçam exemplos até um período muito tardio ${ }^{3}$.

Por conseguinte, o interesse dos testemunhos epigráficos resulta do facto de eles provarem que, de entre todas as concepções de que temos estado a ocupar-nos, nenhuma estava suficientemente divulgada para figurar em epitáfios nos tempos mais recuados, excepto o quadro sombrio do Hades. A circunstância de a bem-aventurança prometida aos iniciados nos Mistérios de Elêusis ou noutros ser só raramente mencionada torna manifesto que estes não tiveram nunca a influência preponderante que alguns autores lhes têm atribuído ${ }^{4}$. Apenas a ideia

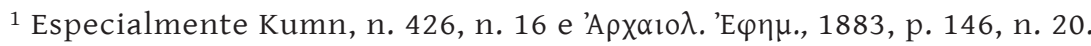

${ }^{2}$ Por exemplo, I. G. R. 4, 1579 (Teos); E. G. 107 (Atenas); E. G. 338, 1-2 (Cízico); E. G. 648 (Roma); E. G 649 (Roma); E. G. 414 (incerti loci); E. G. 511 a (Acrida, Epiro); E. G. 618 a (Roma).

${ }^{3}$ Encontra-se um tratamento exaustivo do assunto em C. M. Kaufmann, Die Jenseitshoffnungen der Griechen und Römer nach den Sepulchralinschriften, Freiburg in Breisgau, 1897, e R. Lattimore, Themes in Greek and Roman Epitaphs, The University of Illinois Press, Urbana, Illinois, 1942.

${ }^{4}$ Cf. A. J. Festugière, L'Idéal Religieux des Grecs et l'Évangile, Paris, 1932 (Cap. V, Les Croyances Populaires en l'Immortalité). 


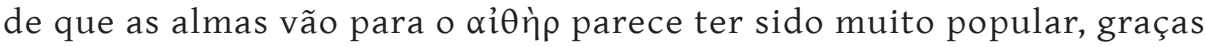
à influência do epitáfio dos heróis de Potideia ${ }^{1}$.

Porém, de um modo geral, é de crer que os epitáfios tenham seguido uma espécie de moda, e por isso talvez nem sempre sejam um guia seguro para as ideias populares. Se não soubéssemos por outras fontes que o mito das Ilhas dos Bem-aventurados estava largamente difundido na Atenas do século V a. C., pensaríamos que tal fenómeno não ocorrera antes do século I a. C., pelo testemunho das inscrições. E, evidentemente, o acaso desempenha um grande papel na recuperação das provas epigráficas ${ }^{2}$.

${ }^{1}$ Penso que esta crença deve parte da popularidade de que gozou ao facto

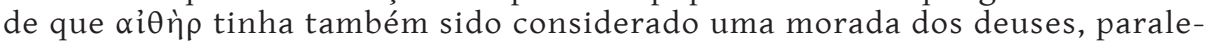
lamente ao Olimpo e a oủpavó, , desde que a Odisseia, $\varepsilon$ 50, dissera, a propósito de Hermes, que

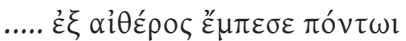

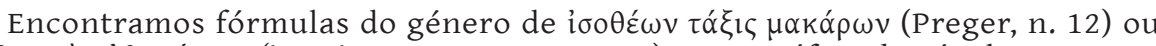

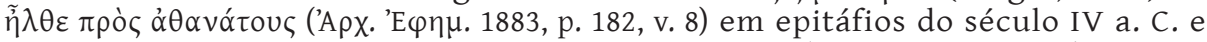
pode até ler-se uma vez que a alma foi para o Olimpo (E. G. 159 - Atenas) ou para junto de Zeus (Kaibel in Rheinisches Museum, XXXIV, 1879, 718 a, 3-4 - Óstia).

${ }^{2}$ Das artes plásticas não pode derivar-se qualquer informação para o nosso assunto. O grande quadro de Polignoto na Lesche dos Cnídios em Delfos (Pausânias, $\mathrm{X}, \mathrm{XXV}$-XXXI) apenas tratava do Hades e, conquanto representasse o destino dos

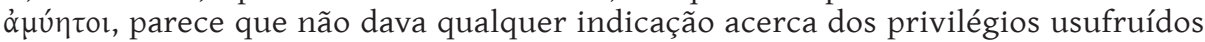
pelos $\mu \varepsilon \mu u \eta \mu \varepsilon ́ v o l$. Mais tarde, nos começos do século IV a. C., foram pintadas algumas cenas do mundo infernal em vasos da Itália Meridional, mas os bem-aventurados não encontravam aí lugar. No entanto, a presença dos três juízes tradicionais nalguns deles implica a possibilidade de recompensas para os bons. 
(Página deixada propositadamente em branco) 


\section{CAPÍTULO III}

\section{PLATÃO}

Como muitos outros dos seus contemporâneos, Platão servia-se, por vezes das designações tradicionais para exprimir a ideia de um além feliz, como acontece, por exemplo, na Republica VII, 540B-C, ao dizer que os que souberam ser bons guardiões da $\pi$ ó $ı$ ı iriam para as Ilhas dos Bem-aventurados ${ }^{1}$, ao passo que na mesma obra, VI, 498C, apenas se afirma que aos que bem viveram será certamente atribuído um destino em proporção com os seus méritos, e em Leges, 904B-905B não se dá nome especial a esse lugar. A mesma esperança se encontra expressa em Phaedo, 63B-C.

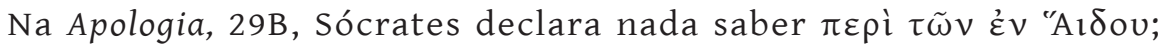
mais adiante, o dilema apresentado em $40 \mathrm{C}$ condu-lo à concepção

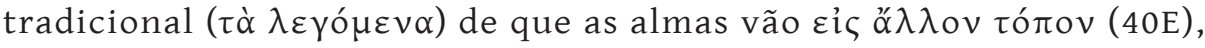
onde todas se reúnem. O facto mais digno de nota neste passo é que, conquanto seja do Hades que se fala e se nomeiem alguns dos seus mais conhecidos habitantes, os termos em que se imagina a sobre-

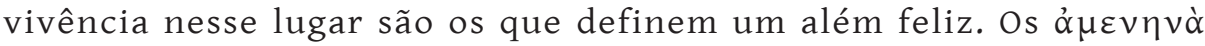
кó $\eta v \alpha$ homéricos não estão presentes, nem por um momento, no

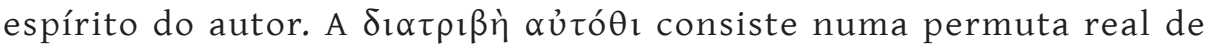
pensamentos e ideias (41B).

A ideia de uma melhor sorte para os bons na outra vida está associada à noção de julgamento no Hades. Esta última é também mencionada na Apologia, 41A-C. É aí que, pela primeira vez, até onde podemos saber, se atribuem nomes aos juízes, e o único caso em que eles são quatro.

\footnotetext{
${ }^{1}$ Terão culto como $\delta \alpha i ́ \mu o v \varepsilon \varsigma$, se a pítia concordar, ou apenas como $\varepsilon \hat{v} \delta \alpha i ́ \mu o v \varepsilon \varsigma$

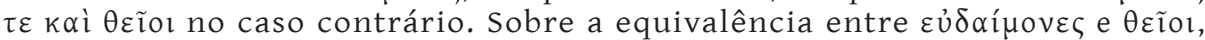
cf. Theaet. 176E. Outros exemplos de referências às Ilhas dos Bem-aventurados encontram-se em Symposium, 179E-180B, Menexenus, 235C, Rep. VII, 519C.
} 
Vimos já que a crença no julgamento no além se pode fazer remontar até Ésquilo, e mesmo nessa altura parecia não ser novidade ${ }^{1}$. Para esse poeta, o juiz é o próprio Hades, ao passo que Píndaro se limita a designá-lo pelo pronome indefinido $\tau ı \varsigma$, talvez para evitar proferir o nome de tão temido deus ${ }^{2}$.

$\mathrm{Na}$ Apologia, $41 \mathrm{~A}$, encontramos Minos, Éaco, Radamanto e Triptólemo como juízes dos mortos, e o próprio Platão apresenta a ideia como tradicional:

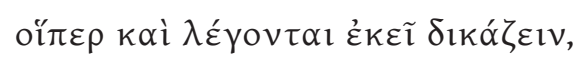

É esta a única vez que se nos depara o nome de Triptólemo nessa situação. O facto tem sido explicado, com bastante probabilidade, como uma concessão feita ao auditório ático, pois essa figura estava intimamente relacionada com os Mistérios de Elêusis ${ }^{3}$.

Minos estava destinado a ser juiz no Hades, desde que no Canto XI da Odisseia fora representado na continuidade do exercício das funções que lhe haviam incumbido durante a vida.

Radamanto, como legislador tradicional dos Campos Elísios, estava naturalmente associado ao irmão, uma vez que se pensou que as almas tinham de passar pelo tribunal, antes de atingirem as Ilhas dos Bem-aventurados.

${ }^{1}$ Cf. também Leges, 959B, onde se afirma que os que deixaram esta vida serão

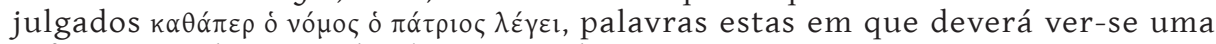
referência à doutrina de Elêusis, e vide supra, pp. 48-50.

${ }^{2}$ Sobre o temor que causava o nome do deus infernal, temos dois preciosos testemunhos: o frg, 246.10 Kock, versos 10-14 (de Filémon?):

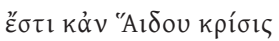

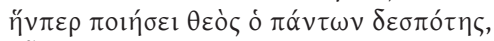

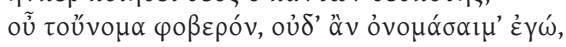

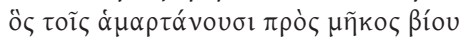

$\delta i \delta \omega \sigma$.

e um passo de Platão, Cratylus, 403A:

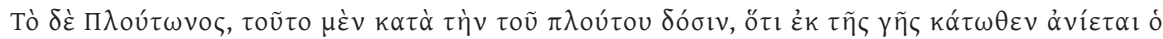

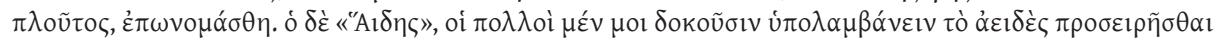

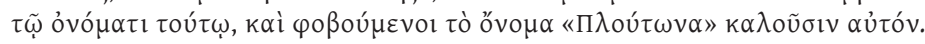

${ }^{3}$ Porém os pintores de vasos do século IV a. C, na Itália Meridional, incluíam-no por vezes entre os três juízes infernais. O facto deve ser devido à influência ática, que também está patente na técnica desses artistas. Num vaso de Altamura, Triptólemo aparece representado juntamente com Éaco e Radamanto, e no de Karlsruhe figura só com Éaco, talvez devido à circunstância de esse vaso estar quebrado. No famoso krater de Nova-Iorque, Hades está sentado no lugar do juíz, como em Ésquilo, mas deve tratar-se de um caso especial, porquanto está em causa o crime de Teseu e Pirítoo. Para uma interpretação completa deste importante documento, vide P. Jacobsthal, The Nekyia Krater in New-York, in Metropolitan Museum Studies, vol. V, 1934, pp. 117 seqq. 
O mais difícil de explicar é Éaco. Dele dissera Píndaro que ditava as suas sentenças mesmo aos deuses:

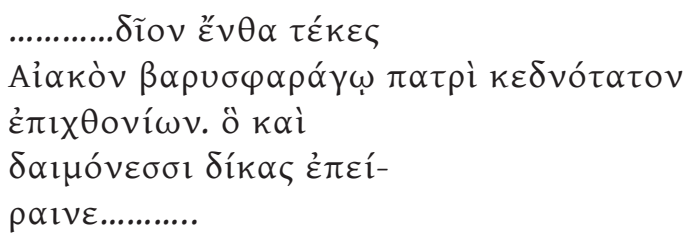

(I., VIII, 21-24)

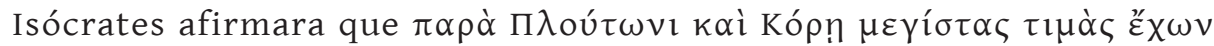

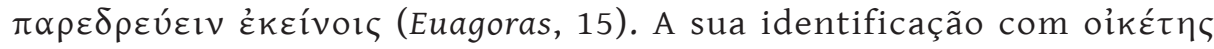
“Aıঠou nas Rãs é duvidosa, visto que só aparece nos escólios e manuscritos de menor valor ${ }^{1}$. Contudo, mais tarde podemos ver que Éaco era invocado nessa qualidade num papiro mágico ${ }^{2}$.

No mito do Górgias, diz-se que Radamanto julga os naturais da Ásia, Éaco os da Europa, e que Minos preside ${ }^{3}$. No Fédon apenas se afirma que

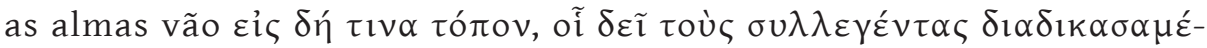

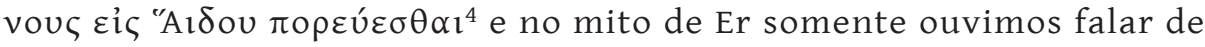
$\delta ı \kappa \alpha \sigma \tau \alpha ́ \varsigma^{5}$; o mesmo se verifica com o mito do Fedro ${ }^{6}$.

O facto de os juízes dos infernos só serem designados pelos seus nomes na Apologia e no Górgias e o modo por que o são na primeira destas obras mostram que Platão usara uma ideia corrente, que mais tarde abandonou? .

As noções de julgamento e subsequente separação das almas, de acordo com os seus méritos, e de penas temporárias, habitualmente em relação com a metempsicose, estão todas presentes no fundo dos mitos platónicos do além; unicamente, a importância que assumem varia em função do lugar que ocupam no desenvolvimento do aspecto que se considera. Desse modo, no mito do Górgias, toda a atenção se concentra à volta da ideia de justiça, ao passo que no do Fédon o ponto principal é a ordem do cosmos e a situação que as almas ocupam nesse todo, e no

${ }^{1}$ Cf. Wilamowitz, Glaube der Hellenen, II, p. 184 nota 2.

2 Papyri Graecae Magicae IV, 1417.

3 524A.

4 107D.

${ }^{5} 614 \mathrm{C}$.

6 249A-B.

${ }^{7}$ Os três juízes, como modelos de rectidão, figuram em Isócrates, Panathen., 205 e em Demóstenes, XVIII, 127. Radamanto, apenas, em Eurípides, Cyclops, 273-274. Sobre o mesmo, cf. ainda Píndaro, P. II, 73-75. 
mito de Er o problema da transmigração e da escolha do destino é o mais proeminente ${ }^{1}$. O mito do Fedro ilustra a doutrina das ideias puras e da anamnese, mantendo-se num nível cosmológico.

\section{a) O mito do Górgias}

Se analisarmos mais de perto cada um dos mitos, em breve poderemos concluir que o do Górgias é o que está mais dependente da tradição épica, como já Thomas notou ${ }^{2}$. Ouvimos falar primeiramente da partilha dos reinos, tal como Homero a refere em 0 187-195, e, depois, das Ilhas dos Bem-aventurados, como a mansão dos bons, e do Tártaro, como a prisão dos que terão de ser castigados. Ambas as designações pertenciam ao núcleo tradicional e é nesse sentido consagrado que Platão as usa. Os juízes encontram-se num prado $(\lambda \varepsilon \imath \mu \omega ́ v)$, que por sua vez está situado

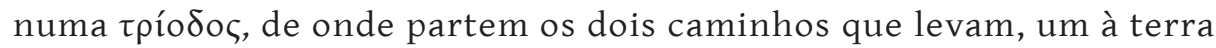
dos eleitos e outro ao lugar de castigo dos maus ${ }^{3}$.

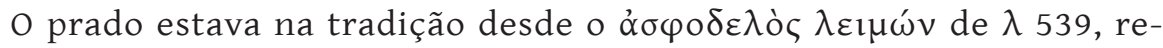
petido em $\omega$ 13; temos depois os prados dos iniciados no Hades das Rãs

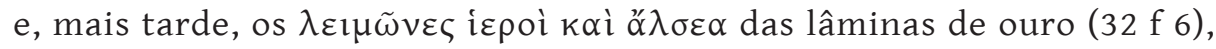
o de um fragmento citado por Proclo como órfico (Frg. 222 Kern) e de

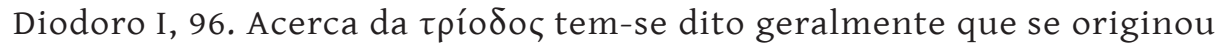
no ensino pitagórico; e figura também nas já citadas lâminas de ouro. Mas podemos explicá-la simplesmente como uma necessidade topográfica, que por força tinha de derivar da ideia de que as almas seguiam para dois destinos opostos, de acordo com o seu comportamento na vida.

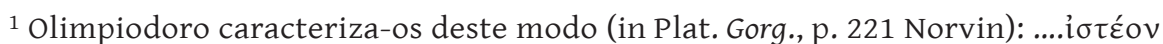

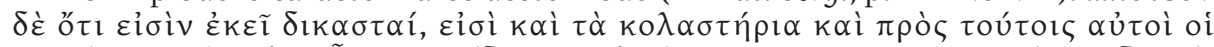

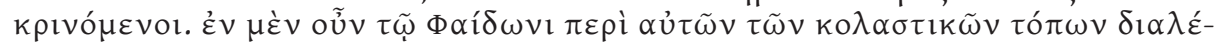

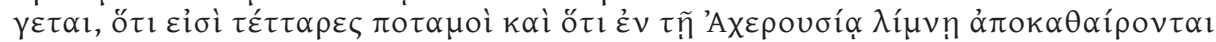

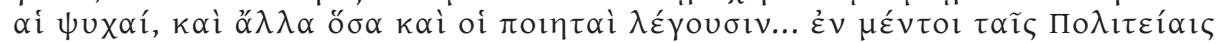

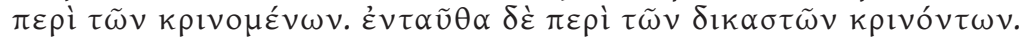

Neste ponto, tinha razão, mas é evidente que não podemos dar-lhe crédito

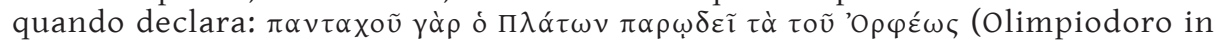
Plat. Phaedonem Commentaria, p. 58 Norvin), apresentando inúmeros excertos de poesia órfica da época helenística para provar a sua asserção. A tese de H. W. Thomas é, fundamentalmente, um desmentido deste capcioso depoimento.

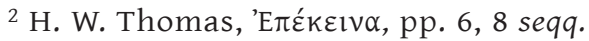

${ }^{3}$ H. W. Thomas, op. laud., p. 12, nota 32 , supõe que as Ilhas dos Bem-aventurados estão no mundo infernal, como o lugar dos iniciados no Hino Homérico a

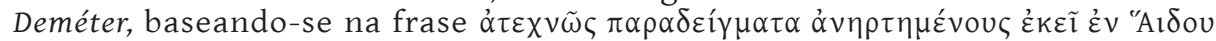

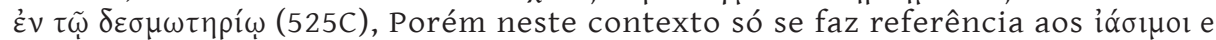

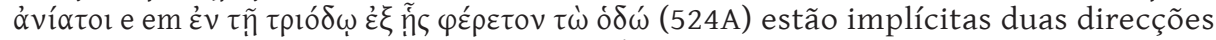
opostas. Mas o caso em si não tem grande importância. 
Porém a particularidade de as marcar como curáveis ou incuráveis e de lhes assinalar castigos temporários ou perpétuos, conforme o caso, é provavelmente de origem pitagórica.

O desenvolvimento da ideia de justiça, exposto na alegoria dos três juízes indigitados para julgar os homens depois de mortos, e não em vida, parece ser o contributo pessoal de Platão para a construção do mito ${ }^{1}$.

\section{b) O mito do Fédon}

No mito do Fédon o interesse principal reside na exposição da teoria da ordenação do cosmos. Faz-se menção, evidentemente, do julgamento e do Hades (107D-E), mas sem se insistir nesses pontos. O propósito do

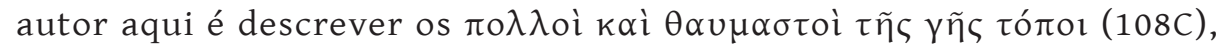
o que não tarda a fazer.

O quadro da verdadeira terra, com a sua beleza irradiante, contrasta com a descrição das cavernas, em que vivemos ${ }^{2}$, e do abismo do Tártaro. A exposição acerca dos rios, que correm de e para esse sítio, conserva alguns traços da tradição, que se tornam mais evidentes quando os vemos relacionados com o destino das almas, uma vez que é nos pântanos do Aqueronte que estas permanecem por um maior ou menor período de tempo, aguardando a transmigração (113 A), e são lançadas fora pelo Piriflegetonte ou pelo Cócito, segundo a natureza dos seus crimes. Todo o lugar está impregnado de dramática ansiedade, que lhe vem dos gritos dos condenados (114A).

Uma das mais interessantes novidades é que os justos são agora recompensados com uma vida na verdadeira terra e os filósofos habitarão

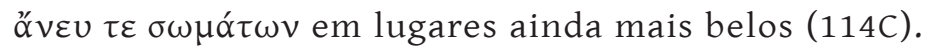

O problema das fontes deste mito foi já exaustivamente discutido por Thomas ${ }^{3}$ pelo que se torna desnecessário analisá-lo de novo aqui.

${ }^{1}$ Tem-se discutido se a metempsicose está implícita neste mito (P. Friedländer, Platon, I, 1928, pp. 210 seq. e 214 seq.) ou não (Wilamowitz, Platon, I, p. 226; von

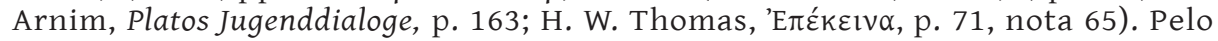
menos, a teoria não se encontra explicitamente mencionada.

${ }^{2}$ A ideia é aparentada com a do mito da caverna em Rep. VII 514A-517B, como Thomas justamente observou, op. laud. pp. 84 e 89.

${ }^{3}$ Op. laud., pp. 85-96. Entre as fontes prováveis contam os escritos de Diógenes de Apolónia, Anaxágoras, Empédocles e Arquitas. As conclusões de Thomas encontram-se resumidas a pp. 96-97: «Diese Vorstellungen aus der Wissenschaift und Naturphilosophie seiner Zeit hat Platon natürlich gekannt, und Anregungen für seine mythisch-phantasievollen Kombination mögen ihm die vorhandenen Verstellungselemente sicher geboten haben, aber im einzelnen sind die Analogien sämtlich so schawach, dass man nicht von Vorbildern Platons sprechen kann». 
É altamente provável que Platão tenha feito uso de alguns elementos que eram parte da doutrina dos filósofos iónicos, mas muito da teoria exposta deve ter sido original, como o mostra a refutação de Aristóteles, em Meteor. II 2. 355 b 32 seqq., da descrição platónica do Tártaro como nascente comum de todas as águas.

Mas o próprio Platão nos fornece algumas informações sobre o assunto. Em meu entender, as palavras de Símias, que antecedem directamente a exposição sobre a forma e estado de equilíbrio da terra, destinam-se a acentuar que o autor estava ao par das teorias cosmológicas do seu tempo, mas tinha uma que lhe era própria:

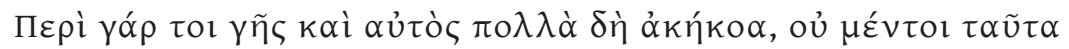

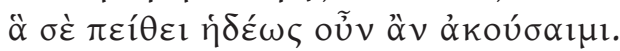

A descrição da verdadeira terra é introduzida pela palavra que

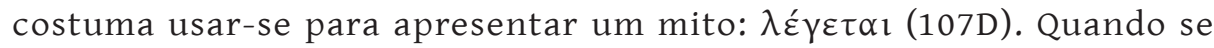
chega à exposição acerca dos rios, a tradição poética é mencionada

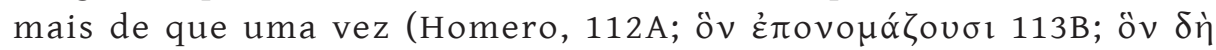

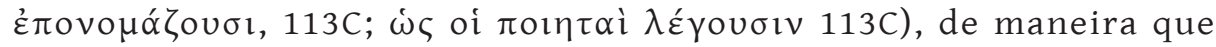
nos leva a concluir que Platão estava a adaptar antigas ideias às novas formas do seu pensamento.

De sua invenção era também a descrição da verdadeira terra e a ideia da presença dos deuses nos templos sobre ela existentes, como causa máxima de felicidade para os homens.

\section{c) O mito de Er}

No mito final da República, o lugar de acção já não é o Hades, ou a verdadeira terra, os кoĩ $\lambda \alpha$ e o Tártaro, mas a totalidade do cosmos. Há duas partes principais na narrativa: a primeira forma o cenário cosmológico, a segunda consagra-se quase exclusivamente ao problema do livre arbítrio na transmigração.

O todo é apresentado como uma história contada por um panfílio, Er, filho de Armeno, facto que só por si é indicativo da origem de algumas das ideias, conforme já se disse 1 . Por outro lado, o convívio de Platão com magos caldaicos é já ponto assente, e a presença de Eudoxo de

\footnotetext{
${ }^{1}$ Bidez, Eos ou Platon et l'Orient, cap. VI, Le Mythe d'Er. Contestado por Thomas,

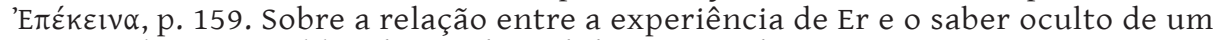
xamã, vide E. R. Dodds, The Greeks and the Irrational, pp. 210 e 225, nota 8.
} 
Cnido na Academia deve estar relacionada com o conhecimento que o filósofo tinha das teorias orientais sobre a astronomia ${ }^{1}$.

Os duplos xó $\sigma \mu \alpha \tau \alpha$ que conduzem ao céu e à terra e a ida e vinda e saudações das almas são pormenores comuns a alguns mitos iranianos do Avesta, ao passo que as cores dos pesos do fuso correspondem aproximadamente aos símbolos dos planetas, do Sol e da Lua, entre os sacerdotes caldaicos ${ }^{2}$. Nos movimentos dos pesos e no canto harmónico das sereias reflectem-se ideias pitagóricas ${ }^{3}$. Também a Ananke era uma concepção dessa mesma escola ${ }^{4}$, como o era igualmente a possibilidade de reincarnação em forma humana ou animal ${ }^{5}$. Esta última doutrina era comum a Empédocles ${ }^{6}$.

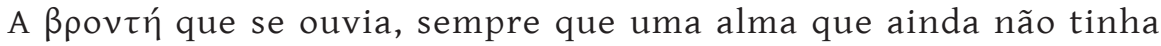
acabado de cumprir a sua pena no Tártaro tentava subir até ao prado (615E), parece ser uma reminiscência da doutrina que Aristóteles atribuiu

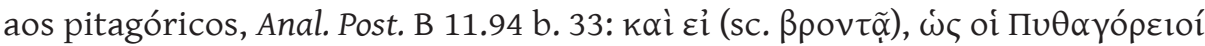

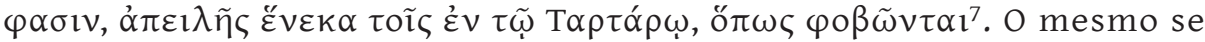

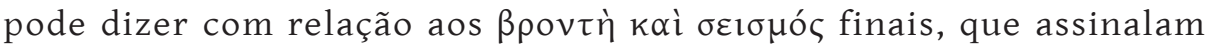
o começo de uma nova incarnação das almas, em 621B; prova-o uma informação conservada por Eliano, de que os pitagóricos explicavam os tremores de terra como $\sigma u ́ v o \delta o \varsigma \tau \tilde{\omega} v \tau \varepsilon \theta v \varepsilon \omega ́ \tau \omega v^{8}$. Finalmente, na

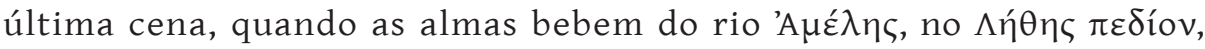
é de crer que as ideias pitagóricas tenham actuado na mente do escritor.

As Parcas derivam da tradição mitológica. Mas a parte central, e mais importante, em que se descreve a escolha dos destinos por algumas personalidades muito conhecidas, deve ser inteiramente nova. O papel

${ }^{1} \mathrm{O}$ papiro encontrado na biblioteca do filósofo epicurista Filodemo informa-nos de que um hóspede caldaico estava presente nos últimos momentos de Platão (citado por J. Bidez, op. laud.).

2 Observação de Bidez, Les Couleurs des Planètes dans le Mythe d'Er, Bruxelles, 1935.

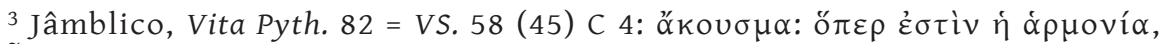

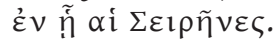

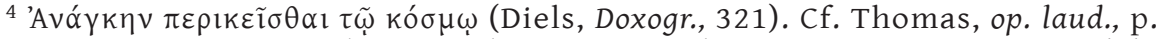

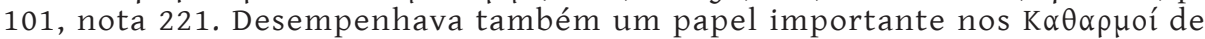
Empédocles (frg. 115 Diels).

${ }^{5}$ Sobre a dificuldade de reconciliar a reincarnação em animais com a teoria platónica da alma, vide E. Rohde, Psyche, II, pp. 276 seq., nota 4, e Thomas, op. laud., pp. 74-75.

${ }^{6}$ Frag. 117 Diels.

7 VS. 58 (45) C 1.

${ }^{8}$ Var. Hist. IV, 17 = VS. 58 (45) C 2. Cf. Thomas, op. laud., p. 77 e a bibliografia citada nesse lugar. Para uma discussão exaustiva das fontes do mito, vide ibidem, pp. 97-107, 
do livre arbítrio nesta escolha é acentuado com toda a solenidade: Aitía

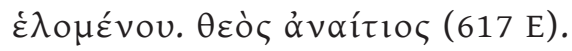

Sobre a parte cosmológica do mito, tem-se suposto que ela descreva uma representação mecânica do céu ${ }^{1}$ e a coluna de luz em 616B tem sido diversamente identificada, desde a antiguidade, com a Via Láctea ou o eixo do mundo. Thomas reconcilia os dois pontos de vista: baseando-se nas indicações fornecidas pelo texto do $\mathrm{Timeu}^{2}$, conclui que o eixo do cosmos, que era por sua vez uma parte da alma do mundo e o centro da ordem do universo, tomava o aspecto de uma coluna de luz para os que chegavam. Em meu entender, não deve insistir-se demasiado na base astronómica do mito. $O$ autor parece ter-se servido dela apenas na medida em que lhe fornecia um cenário para o seu tema central da escolha dos destinos. É essa também a razão pela qual os motivos usuais dos mitos escatológicos são quase completamente postos de parte. Os juízes são anónimos e

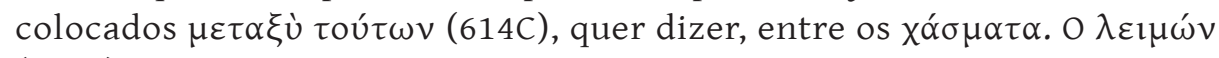
(614E) tornou-se um lugar de reunião das almas que vêm das aberturas.

Os castigos no Tártaro, que constavam de Phaedo 114A, são aqui subs-

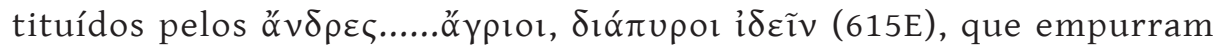
as almas e as torturam, e a esperança no perdão dos ofendidos, que ainda brilhava em Phaedo 114B, desvaneceu-se agora completamente, para dar lugar a sentimentos de terror (616A). Portanto, devem ter sido utilizados na elaboração deste mito elementos de proveniência diversa, mas o conjunto evidencia uma unidade, que não teria sido possível, se as linhas mestras da construção não fossem da invenção platónica.

\section{d) O mito do Fedro}

Uma grande parte do mito do Fedro é estranha ao assunto aqui tratado; por conseguinte, apenas os passos que lhe dizem respeito serão considerados.

Baseando-se na semelhança entre as designações $\dot{\alpha} \lambda \eta \theta \varepsilon i ́ \alpha \varsigma, \pi \varepsilon \delta$ íov

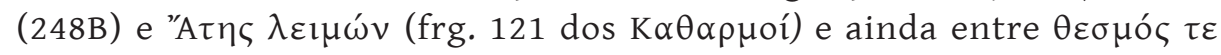

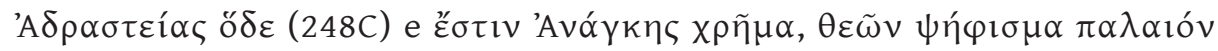
(frg. 115), Diels ${ }^{3}, \mathrm{Kranz}^{4}$ e Thomas $^{5}$ reconheceram uma grande influência

${ }^{1}$ E. Franck, Plato und die sogenannten Pythagoreer, Halle, 1923, p. 344, nota 69 (apud Thomas, op. laud., p. 103).

2 34B-40C.

${ }^{3}$ VS. 31 (21) C 1.

${ }^{4} \mathrm{Kranz}$ in VS. $\mathrm{I}^{5}$.

${ }^{5}$ Op. laud., p. 125. 
de Empédocles. Quanto ao primeiro caso, vimos já que o prado do filósofo agrigentino não deve situar-se no Hades ${ }^{1}$. O segundo ponto deve estar certo; podemos mesmo adicionar-lhe a personificação de Ananke no mito de Er. O exílio da companhia dos deuses é também uma reminiscência dos versos finais do frg. 115 de Empédocles, onde o poeta se declara puyò

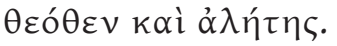

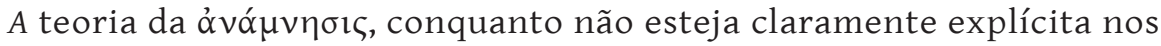
K $\alpha \Theta \alpha \rho$ pó, segundo a interpretação dada ao prado de Ate, está certamente implícita e constitui, por sua vez, a parte central do mito do Fedro.

Porém a finalidade da ở vó $\mu v \eta \sigma ı \varsigma$ aqui é completamente diferente da que tinha no mito de Er. Aí ela actuava nas almas naqueles estranhos lugares onde estas se saudavam, e atingia a sua máxima potência no momento em que escolhiam os seus novos destinos, para desaparecer logo que bebiam

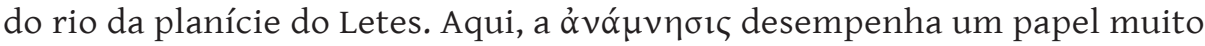
importante no comportamento das almas depois de terem caído na terra.

$O$ aspecto mais interessante deste mito é, em meu entender, a tentativa que faz de traduzir em imagens as ideias puras, que as almas se esforçam por alcançar.

O cenário é todo novo ${ }^{2}$, e apenas escassos fragmentos das concepções tradicionais restam aqui e ali, como o $\alpha \lambda \eta \theta \varepsilon i ́ \alpha \varsigma \pi \varepsilon \delta i ́ o v(248 \mathrm{~B})$, onde $\pi \varepsilon \delta i ́ o v$ é uma reminiscência do vocabulário escatológico, e o $\lambda \varepsilon \imath \mu \omega ́ v$, que dá o melhor pasto à alma (248B), e ainda os castigos subterrâneos (249A, 256D). Por outro lado, a ideia de rolar durante nove mil anos à volta e por baixo da terra, com o espírito delirante (257A), não é fácil de explicar. Era costume marcar a duração das penalidades com números ${ }^{3}$, mas o processo de expiação é diferente e só poderá ser compreendido no plano cosmológico de todo o mito.

Há um julgamento (249A) e as almas podem reincarnar em animais ou regressar à sua condição humana (248B-249B). Os filósofos recebem uma recompensa especial, como aliás em todos os outros mitos platónicos. Neste, consiste em se tornarem novamente alados e seguirem o

${ }^{1}$ Supra, pp. 61-62.

${ }^{2}$ A interpretação astronómica que depois deu a Academia não nos interessa aqui.

3 Píndaro diz que "no nono ano» Perséfone liberta as almas que expiaram a

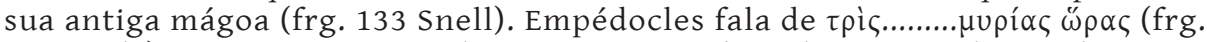
115 Diels). Em Rep., X, 615A, há uma viagem de mil anos por baixo da terra. Os números do Fedro concordam com os do mito de Er, quanto ao período de transmigração das pessoas vulgares; porém os filósofos têm de escolher a mesma vida durante três épocas sucessivas com a mesma extensão, a fim de reaverem as suas asas (248E-249B). A $\pi \varepsilon p ı n ́ \lambda v \sigma ı \varsigma$ pitagórica (Heródoto II, 123) durava três mil anos. Os múltiplos de três são frequentes nestes casos. 
seu caminho, depois do terceiro período de mil anos (249C), ao passo que os outros têm de ser julgados e submetidos a mais transmigrações.

Comparando os mitos escatológicos, verificamos que Platão não seguiu sempre o mesmo modelo em todos eles, facto que, só por si, seria a negação da tese de Dieterich, de que um poema órfico estava na base dos quatro ${ }^{1}$.

A noção de julgamento depois da morte, naturalmente seguido de recompensas e castigos, que é comum a todos, estava na tradição helénica. A crença na transmigração, que é fundamental para o mito de Er e o do Fedro, está atestada, pelo menos, para os pitagóricos ${ }^{2}$ e Empédocles.

Podemos facilmente assinalar diversos estádios no modo platónico de considerar o além. $O$ mito do Górgias mantém-se, em grande parte, próximo da tradição épica, e, conquanto introduza a noção de almas curáveis e incuráveis, parece ter excluído a transmigração; o Fédon incorpora crenças escatológicas numa teoria do cosmos, em que são refundidas algumas doutrinas geográficas; o mito de Er parece combinar princípios astronómicos, talvez de origem oriental, com ensinamentos pitagóricos sobre a ordenação do mundo, para assim formar o cenário para o momento supremo da escolha dos destinos; as mesmas preocupações astronómicas estiveram presentes na elaboração do fundo em que se desenrola o mito do Fedro, que constitui uma exemplificação da teoria da anamnese e das ideias puras. Deste modo, a mitologia e a tradição foram gradualmente postas de parte.

\section{e) O mito do diálogo pseudo-platónico Axíoco}

Diferente é o caso do diálogo pseudo-platónico Axíoco, que tem o aspecto de um catálogo das crenças que se tinham acumulado no decorrer dos séculos.

Pensam alguns autores que a escatologia deste mito depende da de Possidónio ${ }^{3}$. Outros entendem, com mais probabilidade, que estamos em face de uma fusão de velhas crenças tradicionais com teorias do Orfismo, Pitagorismo e da religião dos Mistérios ${ }^{4}$. Cumont chama a atenção

\footnotetext{
${ }^{1}$ Nekyia, p. 125.

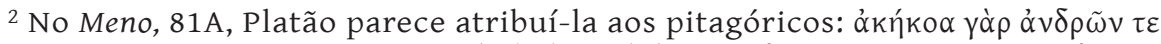

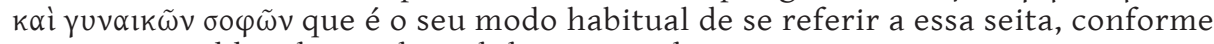
nota E. R. Dodds, The Greeks and the Irrational, p. 225, nota 5.

${ }^{3}$ K. Meister, De Axiocho, 1915; J. Carcopino, La Basilique Pythagoricienne de la Porte Majeure, Paris, 1927.

${ }^{4}$ Chevalier, Étude Critique du Dialogue Pseudo-Platonicien de l'Axiochos e Ettig, Acheruntica.
} 
para o facto de o úróyeıov estar relacionado de perto com uma antiga concepção astrológica síria; esta circunstância, combinada com a semelhança existente entre o Hades do Axíoco e o dos babilónios, ajudaria a esclarecer os motivos da escolha da figura de Góbrias para narrar o conto $^{1}$. Julgo que, na verdade, há influências orientais no quadro, mas foram sobretudo as literárias que prevaleceram.

O facto mais interessante é talvez a $\pi \rho \circ \delta \delta \rho i ́ \alpha$ dada aos iniciados

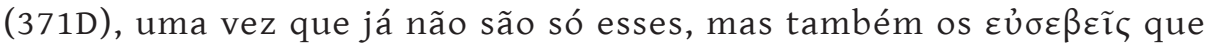
têm direito a um destino melhor no além.

A situação do Hades é descrita com precisão e de um modo que indica uma época tardia: a sua extensão iguala a da terra e ocupa o hemisfério inferior (371B). Os rios e juízes encontram-se reduzidos apenas a dois, por razões desconhecidas.

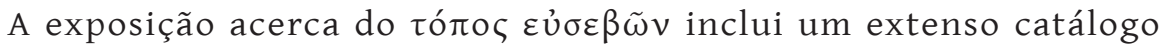
dos entretenimentos desta vida. No Tártaro figuram todos os pecadores conhecidos, com a particularidade de os portadores de vasos perfurados,

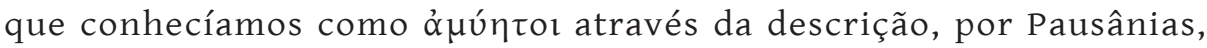
da pintura de Polignoto na lesche dos Cnídios em Delfos ${ }^{2}$ e do Górgias, 493B-C, estarem agora identificados com as Danaides e de serem as Poenae que queimam, com os seus archotes, os condenados, que animais selvagens lambem. É esta a única parte da imaginária do Hades que não é antiga, e que fácil é assinalar como um produto da arte helenística.

${ }^{1}$ Les Enfers selon l'Axiochos in Comptes-Rendus des Séances de l'Académie des Inscriptions et Belles Lettres, 1920, pp. 272-285.

2 Pausânias, X, XXXI, 9-11. 
(Página deixada propositadamente em branco) 


\section{CAPITULO IV}

\section{AS LÂMINAS DE OURO}

Existe ainda uma outra espécie de testemunho das crenças no além que merece ser considerado: trata-se daquele que nos fornecem as tão discutidas lâminas de ouro. Até agora, encontraram-se em túmulos onze desses documentos e, conquanto a sua data varie entre o século IV a. C. e o II da nossa era, o seu conteúdo mantém-se sensivelmente o mesmo, de tal maneira que nos autoriza a crer que pertenciam a um só e mesmo poema.

A doutrina que neles se exprime tem sido diversamente atribuída ao Orfismo ${ }^{1}$, Órfico-pitagorismo ${ }^{2}$, Pitagorismo ${ }^{3}$ ou certos mistérios da Itália Meridional, provavelmente báquicos ${ }^{4}$, embora sob a influência do Pitagorismo também ${ }^{5}$.

Porém agora, com o aparecimento da nova lâmina de Farsália, a posição do problema alterou-se, pois fica demonstrado que, pelo menos no século IV a. C. esse culto não estava confinado à Itália Meridional e Creta, conforme se supunha. É de crer que estivesse bastante difundido e que só o acaso tenha sido responsável pelo aparecimento dos primeiros testemunhos na Magna Grécia.

${ }^{1}$ Comparetti, Laminette Orphiche; Olivieri, Lamellae Aureae Orphicae; O. Kern, Orphicorum Fragmenta, p. 104, 32; W. K. C. Guthrie, Orpheus, pp. 171-182 e The Greeks and their Gods, pp. 371-375; M, P. Nilsson, Geschichte der griechischen Religion, I, pp. 644 e 777; P. Frutiger, Les Mythes de Platon; S. Eitrem, Opferritus und Voropfer der Griechen und Römer, in Videnskapselskapets Skriften, II, Hist.-Filos. Klasse, 1914, n 1, pp. 53-55.

${ }^{2}$ A. Dieterich, Nekyia, p. 125; K. Ziegler in Pauly-Wissowa, s. u. «Orphische Dichtung».

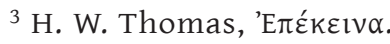

${ }^{4}$ Wilamowitz, Glaube der Hellenen, II, p. 102; A. Festugière, Les Mystères de Dionysos (suite) in Revue Biblique, vol. XLIV, 1935, pp. 366-396.

${ }^{5} \mathrm{~J}$. Wieten, De tribus laminis aureis quae sepulcris Thurinis sunt inuentae, Amstelodami, 1915. 
Por outro lado, a semelhança da doutrina exposta nas diferentes lâminas, independentemente da época a que pertencem, permite-nos supor que tais ideias podiam igualmente ser anteriores ao século IV a. C. De qualquer modo, não é arriscado pensar que eram, pelo menos, contemporâneas dos mitos de Platão.

Examinemos agora os próprios documentos. Podem repartir-se em quatro grupos diferentes, que devem representar passos diversos do poema. Um deles compreende a lâmina de Petélia ${ }^{1}$, as três de Eleuterna ${ }^{2}$ e a recém-descoberta de Farsália ${ }^{3}$. A outro pertence uma das lâminas de Túrios ${ }^{4}$. Três outras, achadas também em Túrios $^{5}$ e uma aparecida em Roma ${ }^{6}$ podem agrupar-se noutra secção. Por último, há ainda uma outra lâmina de Túrios ${ }^{7}$, cujo texto oferece grandes dúvidas, a despeito das muitas tentativas feitas para o esclarecer. Diels supõe que contém um hino a Deméter. O conjunto parece ser apenas uma longa enumeração de deuses com os seus atributos. No entanto, a comparação com o conteúdo das outras e a convicção de que elas devem ter sido gravadas de memória, e não copiadas de um original, conforme mostrarei adiante, leva-me a pensar que o poema que serviu de base continha uma extensa

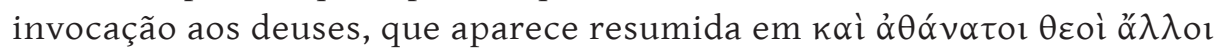

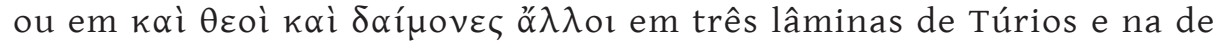
Roma, e apenas se conservou completa naquela de que estamos a tratar.

o primeiro grupo é o mais interessante, por conter uma descrição da paisagem do além. Em frente do palácio do Hades, declaram as lâminas de Petélia e de Farsália, há duas fontes, das quais uma está guardada por $\varphi v ́ \lambda \alpha \kappa \varepsilon \varsigma$, e um cipreste branco.

Todos estes pormenores não são fáceis de explicar, principalmente desde que se verificou que, ao passo que a lâmina de Petélia adverte o morto de que não deve aproximar-se da fonte do lado esquerdo, mas

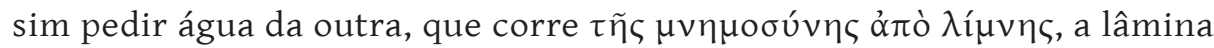
de Farsália inverte as suas posições respectivas, dizendo que a nascente

${ }^{1}$ Kaibel, IGIS, 638; Olivieri, a ${ }^{1}$, p. 12; G. Murray, apud J. Harrison, Prolegomena to the Study of Greek Religion, I.

${ }^{2}$ Collitz, Griechische dialektische Inschriften, 4959a; Olivieri, b ${ }^{1}$, p. 14; G. Murray, op. cit., II, III, IV.

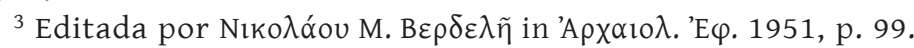

${ }^{4}$ Kaibel, IG, XIV, 642; Olivieri A ${ }^{2}$, p. 16; G. Murray op. cit., V.

${ }^{5}$ Kaibel, Inscr. Gr. S. et It. 641, 1, 2, 3; Olivieri, A (p. 4), B (p. 9), C (pp. 10-11); G. Murray, op. cit., VII, VIII, IX.

${ }^{6}$ Comparetti in Atene e Roma, VI, 1903, pp. 161-170; Olivieri B2 , p. 18; G. Murray, op. cit., X.

${ }^{7}$ Comparetti, Laminette orphiche; Olivieri, d, p. 22; G. Murray, op. cit., VI. 
que se deve evitar é $\varepsilon \dot{v} \delta \varepsilon \xi \xi \ltimes$. A única explicação possível para este facto é que os excertos do poema conservados nas lâminas não eram copiados, mas escritos de cor, o que deu lugar às muitas variantes que se lhes conhecem. É provável que o homem que gravou a de Farsália apenas se recordasse de que um dos pontos principais era a fonte do lado direito, e por isso mencionou-a em primeiro lugar, sem se dar conta de que assim alterava o significado ligado à sua orientação.

A identificação da árvore não é fácil de fazer com segurança. Com toda a razão escreveu A. B. Cook: «it is hardly to be explained as a white poplar, despite the name $(\lambda \varepsilon \cup \kappa \eta ́)$ and the chthonian associations of that tree; yet another possibility would be to suppose that the $\lambda \varepsilon v \kappa \dot{\eta}$

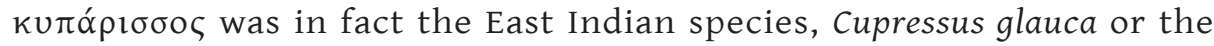
Cupressus niuea. On the whole, however, it seems most likely that the tree of the tablets was a miraculous cypress, its peculiarity consisting in its assimilation to that other Borderland tree, the white poplar ${ }^{1}$. O mesmo autor acrescenta que esta paisagem é muito semelhante à do Elísio celta.

Após esta descrição, começa o discurso do morto aos $\varphi u ́ \lambda \alpha \kappa \varepsilon \varsigma$, parte do qual se conserva também nas lâminas de Eleuterna. A frase

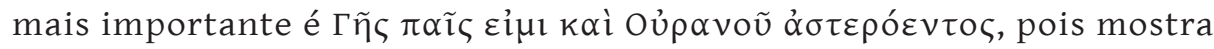
a relação entre a doutrina aqui expressa e a que se contém nas outras lâminas, uma vez que a genealogia apresentada é a mesma que se atri-

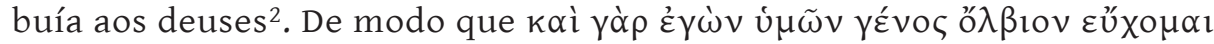

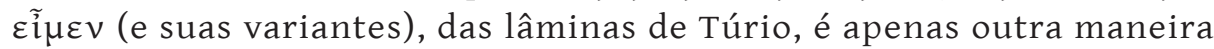
de exprimir a ascendência divina. O regresso a essa mesma origem é

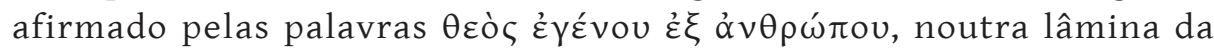

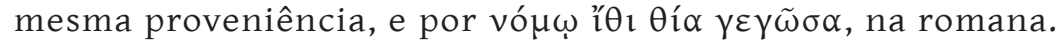

A lâmina de Petélia acrescenta ainda que o morto, depois de beber da fonte da memória, reinará entre os heróis.

A nova lâmina, de Farsália, omite este pormenor, mas atribui um nome

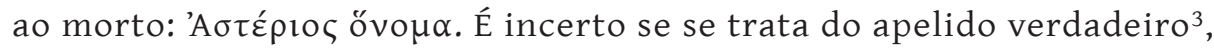

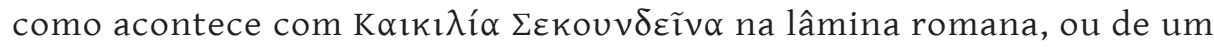
nome genérico, dado a todos os mystae, para significar a origem celeste da alma, mas a segunda hipótese parece mais provável.

A lâmina de Túrios que coloquei no grupo II está muito mutilada. Con-

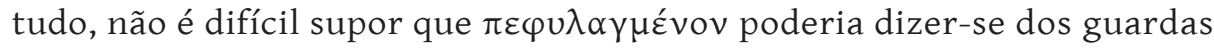

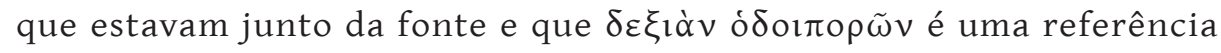

\footnotetext{
${ }^{1}$ Zeus, A Study in the Ancient Religion, vol. III, pp. 420 seqq.

${ }^{2}$ Cf. Hesíodo, Theogonia, 45, 105-106.

3 Sobre o nome próprio 'A $\sigma \varepsilon \dot{p} \rho ı \varsigma$, vide Pape, Wörterbuch der griechischen Eigennamen, s. u.
} 
à mesma orientação que se aconselhava na lâmina de Petélia. Segue-se uma alusão aos sofrimentos passados e ao estado actual da alma, a mis-

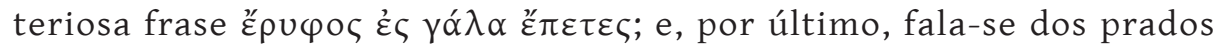
e bosques de Perséfone como de um lugar aprazível.

As quatro lâminas do grupo III contêm o discurso feito pelo morto aos deuses. Insiste-se especialmente no estado de pureza da alma. Esta afirma ainda que se escapou da penosa roda e regressou ao seio da deusa

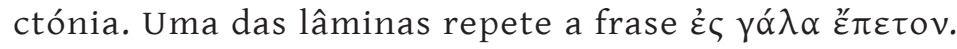

A teoria que afirma a origem pitagórica destas concepções apoia-se nos seguintes argumentos:

(1) As fontes são uma representação concreta das ideias de $\lambda \hat{\theta} \theta \eta$ e $\mu \nu \eta ́ \mu \eta$, que eram familiares aos Pitagóricos ${ }^{1}$.

(2) o cipreste era uma árvore sagrada para essa seita ${ }^{2}$;

(3) era hábito pitagórico colocar «passes» nos túmulos ${ }^{3}$.

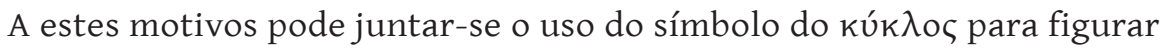
a vida humana, que foi atribuído a Pitágoras por Diógenes Laércio ${ }^{4}$. Além disso, a palavra kepauvóv, que consta do texto do grupo III, pode também explicar-se por um passo já citado de Aristóteles, que a associa à doutrina da transmigração ${ }^{5}$. A preferência por $\delta \varepsilon \xi$ ıóv, como o melhor caminho, entre os Pitagóricos, está assinalada noutro fragmento do mesmo filósofo ${ }^{6}$.

A teoria da influência báquica, combinada com esta, foi sustentada por J. Wieten, baseando-se especialmente na interpretação de Épı como símbolo de Dioniso, como consta de uma glossa de Hesíquio

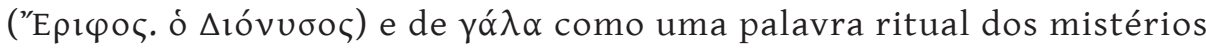
desse deus - e não a Via Láctea, como também já foi proposto ${ }^{7}-$ conforme se pode deduzir de um passo de Tito Lívio, I, 13,12 e de Cássio Hermina, Non s. u. lacte, p. 483 (= Peter, Fr. H. R. 36), Além disso, toma

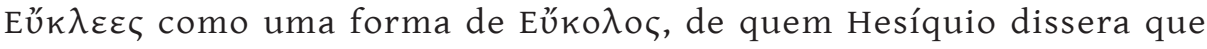
era Hermes $\pi \alpha \rho \alpha \grave{~ M \varepsilon \tau \alpha \pi o v \tau i ́ v o l \varsigma . ~}$

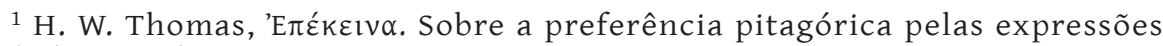
simbólicas, vide Diógenes Laércio, VIII, 17-18.

${ }^{2} \mathrm{~J}$. Wieten, De tribus laminis aureis quae sepulcris Thurinis sunt inuentae, pp. 17 seqq., cita Jâmblico, V. P., 154-155.

${ }^{3}$ Idem, ibidem, p. 18. O texto citado é o de Diodoro, V, 28 e Jâmblico, V.P. 178.

${ }^{4}$ VIII, 1, 14. Citado por E. R. Dodds (em aulas na Universidade de Oxford).

${ }^{5}$ Aristóteles, Anal. Post. B 11.94 b. 33.

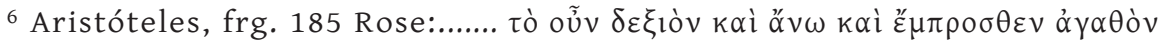

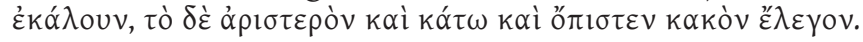

7 Por Dieterich, Nekyia. Mas Delatte (apud J. Wieten, op. laud.) demonstrou que a Via Láctea era, para os Pitagóricos, o ponto de passagem, não o de chegada, das

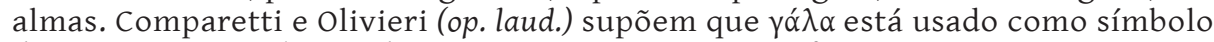
da inocência. Nenhuma destas interpretações é satisfatória. 


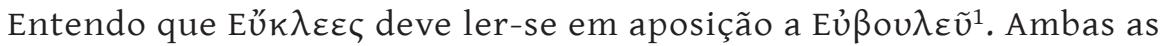
palavras aparecem sem partícula copulativa numa das lâminas e ambas podiam ser dirigidas a Hades como um eufemismo (cf. Hesíquio e Suidas, s. u. u.), de modo que nenhum outro deus é mencionado individualmente, além dos componentes do par ctónio². O sentido da expressão épıpos

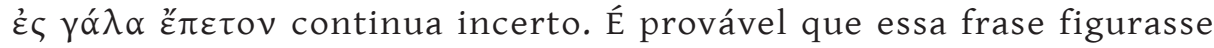
num contexto no qual fosse inteligível, mas, justamente pelo seu valor simbólico e pela sua forma incompreensível aos não-iniciados, em breve fosse isolada dele e adoptada como uma das fórmulas mágicas de maior efeito, que não se devia esquecer.

Em face da escassez de provas e do estado do texto, apenas podemos concluir que as lâminas de ouro conservam alguns fragmentos de um poema mais extenso, que se destinavam a servir de guia à alma do morto que acreditara nessa doutrina. Da natureza das variantes que apresentam, deduz-se que pelo menos os trechos mais importantes tinham sido aprendidos de cor por quem os gravou, donde resultaram as divergências mencionadas. O interesse maior das lâminas de ouro reside no facto de serem o único documento cultual dessa época, de que temos conhecimento. Se o fundo de doutrina que lhes assiste é pitagórico ou não, é ponto difícil de estabelecer, mas é, pelo menos, muito provável que assim seja.

\section{ADDENDA}

Desde a primeira edição deste livro, em Janeiro de 1955, apareceram mais lâminas de ouro, em número que excede em muito o das onze aqui descritas e analisadas. Os lugares onde foram encontradas as primeiras distribuíam-se pela Magna Grécia (Petélia, Túrios), Sicília, Roma, Creta e Tessália. Depois surgiram, ano após ano, mais vinte e oito lâminas, num espaço geográfico muito alargado, que abrange, para além da Magna Grécia, Hipónion (na Calábria), da Sicília (Entela), de Creta (Milopótamos, Retímnon) e da Tessália (Pelina, Feras), um exemplo em Lesbos, três na Acaia, dois na Élide, nove na Macedónia e ainda dois de local incerto.

Todos estes achados foram sucessivamente descritos e discutidos em artigos de revistas da especialidade. Presentemente, existe já uma boa

${ }^{1}$ Cf. J. Harrison, Prolegomena to the Study of Greek Religion ${ }^{3}$, p. 587. Contestado por Olivieri, op. laud., p. 100; L. Malten, in Archiv für Religionswissenschaft, 1909, p. 440.

2 Os nomes dos dois deuses infernais aparecem frequentemente associados na Odisseia, v. g. k 491, 534, 564; $\lambda$ 47. Cf. ainda Ilíada, I, 457, 569. A influência da linguagem dos poemas homéricos sobre a das lâminas de ouro foi já assinalada por Olivieri, entre outros. 
edição Teubneriana por A. Bernabé, Poetae Epici Graeci. Orphicorum et Orphicis similium testimonia et fragmenta fasc. I et II, München, Saur, 2003-2004, e outra comentada por Fritz Graf e Sarah Iles Johnston, Ritual Texts for the Afterlife. Orpheus and the Bacchic Gold Tablets, London, Routledge, 2007.

Para a questão que aqui nos ocupa, diremos apenas que o conteúdo de várias destas lâminas é frequentemente semelhante, ou até mesmo igual, ao das já conhecidas. Outras ainda constam de umas linhas muito incompletas, ou mesmo só do nome do possuidor.

Ao primeiro grupo, ou seja, às lâminas cujo texto é quase coincidente com o das que anteriormente juntei, por conterem uma descrição da paisagem do além (o palácio do Hades, duas fontes, uma das quais guardada por $\varphi v ́ \lambda \alpha \kappa \varepsilon \zeta$ e com um cipreste branco ao lado) podemos associar a lâmina de Hipónion, embora notemos desde já que os dois versos finais contêm uma informação muito importante: que depois de ter bebido do Lago da Memória, o iniciado seguirá pela via sagrada, por onde transitam outros mistas e bacchoi ${ }^{1}$. Este é um dos dados em que se apoiam os defensores da relação entre os iniciados nestes mistérios e o culto de Baco (ao passo que a presença do Pitagorismo está hoje geralmente excluída). Ora essa relação principiou a ser estabelecida por Domenico Comparetti desde os finais do século XIX e encontra agora uma confirmação na lâmina de Pelina e também na de Anfípolis ${ }^{2}$. Na de Pelina, Baco é apresentado como um libertador. E reaparece, embora alterada, a enigmática frase épı $\varphi$ o

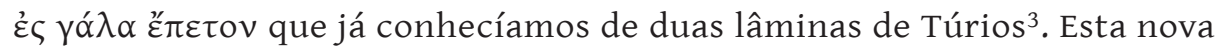
forma substitui o animal que salta ou cai no leite: primeiro por um touro e depois por um carneiro.

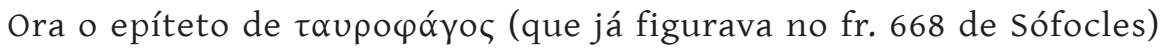
aparece num passo de As Rãs de Aristófanes (v. 357) atribuído a Cratino. No seu comentário à edição da peça, Dover ${ }^{4}$ considera-o como uma forma de assimilar esse comediógrafo ao próprio deus.

Mas o epíteto em questão não está sozinho. Como já vimos, logo a seguir à referência ao touro que saltou para o leite, vem uma que apenas substitui o animal por outro, que passou a ser o carneiro. Para estas alterações, não se encontra uma explicação satisfatória. Apenas podemos admitir a hipótese de Sarah Johnston ${ }^{5}$, de entre as muitas soluções propostas, a melhor será a de que a frase "caiu no leite" ou "saltou para o leite" quer dizer "ficar no

\footnotetext{
${ }^{1}$ N. 1 na edição de Graf - Johnston, à qual nos reportaremos sempre.

${ }^{2}$ N.os 26 e 30 .

${ }^{3}$ N.os 3 e 5.

${ }^{4}$ Aristophanes, Frogs, Oxford 1993, p. 240.

${ }^{5}$ Op. cit., cap. 4.
} 
meio da abundância" ou "iniciar um novo começo", e que era uma maneira de afirmar a ventura dos iniciados ${ }^{1}$. Por sua vez, é importante sublinhar, como fez Graf, que o facto de aqueles três versos quebrarem o ritmo dos hexâmetros só poderia ter uma explicação: é que se tratava de uma exclamação que reproduzia as fórmulas rituais².

Deve salientar-se, por outro lado, que as lâminas mais expressivas são as que contêm a descrição do além, a que já aludimos. São aquelas a que Sarah Johnston chama "geográficas", por oposição a outras, que são catárticas. Quando completas, englobam a referência à bem edificada casa de Hades, ao cipreste branco, às duas fontes - uma, perigosa, da qual muitas almas se apressam a beber, outra, a do Lago da Memória, que as levará pelo bom caminho. Mantém-se a ocasional confusão entre a localização dessas fontes (à direita ou à esquerda) e o enigma acerca do "cipreste branco". Diversas conjecturas têm sido formuladas, das quais a mais provável parece a de Zuntz, que supõe que $\lambda \varepsilon \cup$ kó não se refere simplesmente à cor branca, mas ao brilho que a árvore projecta no sombrio além ${ }^{3}$.

Outras lâminas contêm apenas o nome do iniciado (como 23, 24 e 32-36) ou um nome e declaração de que é um $\mu u ́ \sigma \tau \alpha \varsigma$ (21-22). Uma (19) está ainda por publicar.

Por último, lembremos que tudo o que se relaciona com a figura de Orfeu é sujeito a interpretações díspares, e mais ainda quando se liga à de um dos deuses mais estranhos - Dioniso - envolto na tradição de uma proveniência asiática, como se lê nessa peça extraordinária que é $A s B a-$ cantes de Eurípides, quando agora se sabe que o seu nome já figurava no século XIII a.C., em tabuinhas em Linear B, juntamente com os de outros deuses micénicos, e que havia uma inscrição votiva num templo de Ceos, onde o seu culto se efectuara sem descontinuidade desde o século XV a.C.

Quanto à difusão das lâminas de ouro, há ainda uma questão que foi levantada por Gordon": como explicar que um objecto dispendioso - visto que as lâminas eram sempre de ouro - pudesse ser adquirido por tantos iniciados em tantos lugares dispersos? A esta questão económica seja-me permitido acrescentar outra: a relativa uniformidade destes textos não pode nem deve pôr-se em paralelo, como muitas vezes tem sido feito, com a riqueza e variedade dos quatro mitos escatológicos de Platão, que analisámos no capítulo anterior.

${ }^{1}$ A autora refere (p. 207, n. 61) os principais proponentes desta tese: Zuntz, Graf, Bernabé e Jiménez San Cristóbal.

${ }^{2}$ Ritual Texts for the Afterlife, cit. p. 138.

${ }^{3}$ Persephone. Three Essays on Religion and Thought in Magna Graecia, Oxford 1971, apud Sarah Johnston, op. cit., p. 109.

${ }^{4} \mathrm{Na}$ recensão a esta obra em Greece and Rome 55 (2008), 305. 
(Página deixada propositadamente em branco) 
2 a PARTE ANÁLISE DAS DESCRIÇÕES LITERÁRIAS 
(Página deixada propositadamente em branco) 


\section{CAPÍTULO I}

\section{$\delta, 561$ seqq.}

Pelo facto de conterem a mais antiga referência, no que nos resta da Literatura Grega, a outra espécie de vida no além que não seja a existência no Hades, os versos 561-569 do Livro IV da Odisseia têm dado lugar a muitas discussões sobre a sua autenticidade. Bekker e Hennings omitiram-nos, Nitzsch excluiu 562-569 e Kirchhoff e Fick atetizaram 565-568. Acentuou-se o facto de eles serem aparentemente irreconciliáveis com o Canto XI e até com certos passos escatológicos da Ilíada. É inegável que, através dos poemas homéricos, se supõe sempre que o Hades é o último fim de tudo para toda a gente. Mas em $\delta 569^{1}$ expõe-se claramente a razão pela qual Menelau terá um destino especial:

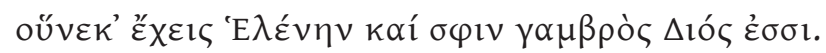

Por conseguinte, o privilégio de Menelau escapar à morte deve-se ao seu parentesco com um deus e não tem nada de comum com a sorte das pessoas vulgares. Portanto, não há contradição com as ideias

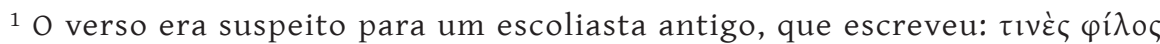

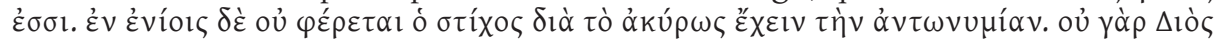

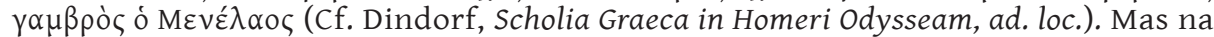
verdade, em $\Gamma 199$ e 418 afirma-se que Helena é filha de Zeus. Também Bérard é de opinião que no verso 569 "nous avons le type du vers ajouté $\sigma \alpha \varphi \eta v \varepsilon i ́ \alpha \varsigma$ \ápıv» (Introduction à l'Odyssée, II, p. 358) e mete-o entre parênteses rectos na sua edição Budé. Acrescenta ainda (p. 359): «Ce pronom opıv ne signifie rien... Certains proposaient de rapporter ce pronom à un mot du vers précédent, ávínolv, qui est un verbe à la troisième personne du singulier, mais dont ils faisaient (on ne sait comment) un datif pluriel ảvínoıv...». Entendo que $\sigma \varphi \imath v$ não é destituído de sentido, antes tem o significado que Merry e Stanford lhe atribuem nas suas res-

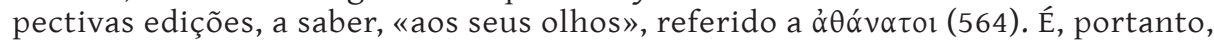
um dativo não-reflexo, que exprime a pessoa interessada no caso (cf. Schwyzer, Griechische Grammatik, II, p. 190).
} 
expressas em $\psi$ 69-81, em $\psi$ 103-107, ou mesmo em $\lambda$. É um caso único, com relação aos heróis da Ilíada e da Odisseia. O argumento de que a profecia acerca do destino de Menelau é supérflua no contexto não é válido num poema como este ${ }^{1}$.

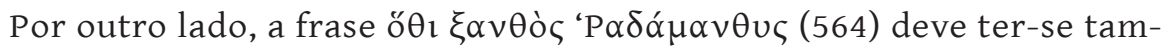
bém em linha de conta. O facto de nada mais se lhe ter acrescentado, nem mesmo um verbo, indica que se tratava de uma concepção muito conhecida, conforme E. Rohde ${ }^{2}$ e M. P. Nilsson ${ }^{3}$ notaram. É este, em meu entender, o argumento mais decisivo em favor da antiguidade dessa crença.

Mas, mesmo que rejeitemos as teorias que condenam todo o passo, temos ainda de considerar as dos editores que, como Kirchhoff, excluem os versos 565-568, quer dizer, aqueles mesmos que contêm a descrição do

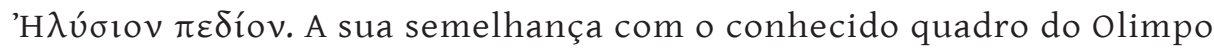
em $\zeta 42-46$ (que, por sua vez, eram suspeitos para Bergk e outros e foram omitidos por Bérard) faz com que alguns filólogos tenham dúvidas acerca da sua autenticidade. Porém, agora que as antigas ideias sobre fórmulas e repetições homéricas foram refundidas ${ }^{4}$ podemos subscrever sem receio a opinião de van Leeuwen: «Splendidos tamen uersus... non facile quisquam patiatur sibi eripi».

Com efeito, se procurarmos referências ao Olimpo em toda a extensão dos poemas homéricos, em breve concluiremos que esta é a mais pormenorizada.

Habitualmente, a mansão dos deuses é descrita por meio de um epíte-

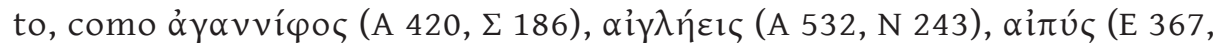

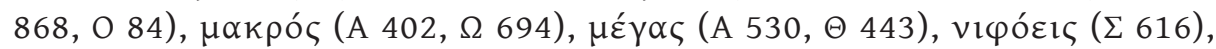

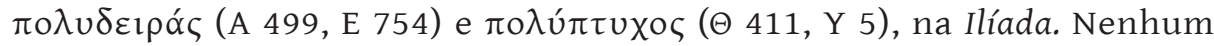
destes casos, ou outros semelhantes, que omiti, está em desacordo com a descrição de $\zeta$, nem com outras indicações sobre a morada dos deuses.

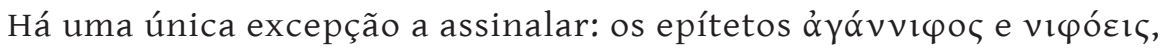

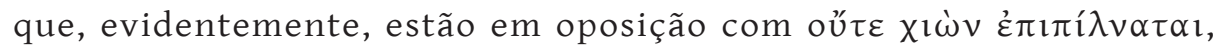
em $\zeta 44$. Já foi notado que o Olimpo, sempre que figura na Ilíada parece ser a alta montanha da Tessália que tem esse nome, e que na verdade

${ }^{1}$ Apresentado por E. Rohde, Psyche, p. 70, nota 1.

${ }^{2}$ Idem, ibidem, I, p. 77.

${ }^{3}$ M. P. Nilsson, Geschichte der griechischen Religion, I, p. 303: «Gerade die Kürze des Ausdrucks ö $\theta$ ı $\xi \alpha v \theta$ ò ‘ 'P $\alpha \delta \alpha ́ \mu \alpha v \theta u \varsigma$ zeigt dass es eine typische wohlbekannte Verbindung war». P. Capelle, que não aceita o passo como homérico, supõe que

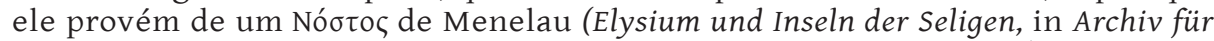
Religionswissenschaft, XXV, 1917, pp. 245-264 e XXVI, 1918, pp. 17-40).

${ }^{4}$ Milman Parry, Studies in the Epic Technique of Oral Versemaking, I. Homer and Homeric Style in Harvard Studies in Classical Philology, vol. XLI, 1930; e também M. P. Nilsson, The Mycenaean Origin of Greek Religion, cap, I, pp. 19-20. 
estava coberta de neves, de onde se derivavam esses epítetos. Uma pequena alteração deve ter ocorrido na Odisseia, onde esse nome ${ }^{1}$ figura apenas dezassete vezes - contra setenta e sete exemplos na Ilíada - em contextos que não atribuem à mansão dos deuses as condições habituais das grandes elevações ${ }^{2}$. Parece estar situado acima da atmosfera da vida humana e mais alto do que as nuvens. Pode servir de exemplo o seguinte passo, $v$ 102-105:

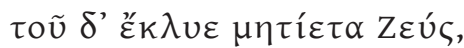

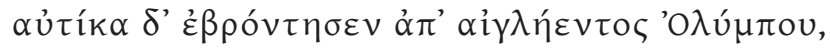

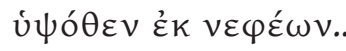

Nos outros casos, o Olimpo é apenas qualificado de $\mu \alpha \kappa \rho o ́ \varsigma$ ( $\kappa 307$, o 43, v 73, $\omega$ 351) ou mencionado sem epíteto (v 55), por vezes na bem

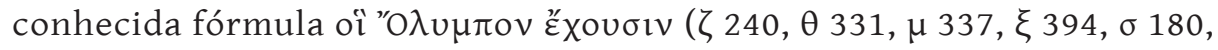
$\tau 43)^{3}$. A única excepção é constituída por $\lambda$ 313-316, onde o Olimpo é, sem dúvida, apresentado como a montanha que os gigantes tentaram colocar sob o Ossa, na sua luta contra os deuses. Mas esses versos pertencem a uma interpolação, que quase todos os filólogos reconhecem como tal. $O$ caso de $\alpha 102=\omega 488$ pode explicar-se como uma repetição da fórmula de A 44 e $\Omega 121 \kappa \alpha \tau^{\prime}$ 'O $\lambda$ ú $\mu \pi$ oro $\kappa \alpha \rho \eta ́ v \omega v^{4}$.

Por conseguinte não é necessário admitir, como Eustátio ${ }^{5}$, que há neve, chuva e vento nas vertentes do Olimpo, mas não no cume, onde fica a mansão dos deuses. Em minha opinião, a diferença provém de uma evolução do pensamento, que corre paralela ao desenvolvimento da concepção das divindades. Todos reconhecem que estas são mais humanas e vivas na Ilíada. A sua morada pode ser $\alpha i \pi v ́ \varsigma^{6}, \mu \varepsilon \varepsilon \alpha \zeta^{7}, \mu \alpha-$ крó $\varsigma^{8}$, mas fica realmente sobre uma montanha. Na Odisseia há uma

${ }^{1} \mathrm{Cf}$. Autenrieth, Schulwörterbuch zu den Homerischen. Gedichten, 11. verbesserte Auflage besorgt von Dr. Adolf Kaegi, Leipzig und Berlin, Teubner, 1908, s. u.

${ }^{2}$ Sobre o significado originário de Olimpo e a sua identificação, veja-se também M. P. Nilsson, Homer and Mycenae, pp. 268-269 e The Mycenaean Origin of Greek Mythology, pp. 228-234.

3 Outras designações da morada, dos deuses, como oủpavós, ๔ïńp, não interessam aqui.

${ }^{4}$ Outras fórmulas de sentido equivalente encontram-se em $\Lambda 77, \Upsilon 22, \Theta 25$, $\Xi 225, \mathrm{~T} 114, \Xi 154$.

${ }^{5}$ Commentarii ad Homeri Odysseam, Lipsiae, 1825.

${ }^{6} \mathrm{E} 367,868, \mathrm{O} 84$.

${ }^{7}$ A $530, \Theta 443$.

${ }^{8}$ A 402, E 399, $\Theta 199,410, \Sigma 142, \Omega 694$, etc. 
tendência para tornar os deuses mais abstractos e mais distantes dos seres humanos. De onde, em $\zeta$ 42-43:

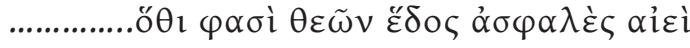

है $\mu \mu \varepsilon v \propto 1$

processo este de introduzir uma descrição que tem causado certa surpresa ${ }^{1}$.

Quanto à objecção de V. Bérard, de que $\gamma \lambda \alpha u \kappa \tilde{\omega} \pi \imath \varsigma$, do verso 47, nunca se encontra só, excepto num passo de $\Theta$ (certamente 420), já atetizado pelos antigos ${ }^{2}$, fácil é argumentar que, embora essa seja de facto a regra, os exemplos não-suspeitos de $\Theta 373, \Theta 406, \beta 433, \gamma 135$, v 389 demonstram que, como o qualificativo era usado só para Atena (diversamente do que se passava com outros epítetos dos deuses), não havia obrigatoriedade de repetir o nome para se ser claro.

Acresce que a preferência por descrições da natureza é uma característica da Odisseia, conforme já tem sido notado. Basta lembrar o exemplo de Esquéria, que é contemplada por Hermes à sua chegada à ilha de Calipso ( $\varepsilon$ 55-74). Podemos mesmo comparar essa descrição com a dos jardins de Alcínoo, por um lado, e com os versos que retratam o Olimpo e os Campos Elísios, por outro, o que nos reconduzirá ao nosso ponto de partida.

Os quatro lugares são descritos como dotados de uma beleza excepcional, que lhes é conferida pela exuberância da natureza. Sobre a situação dos Campos Elísios e do Olimpo somos informados de uma

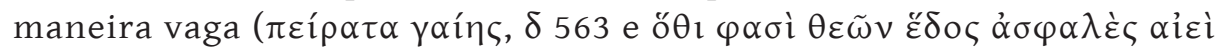
है $\mu \mu \varepsilon v \alpha 1, \zeta 42-43)$. O mesmo acontece com Esquéria, que é definida

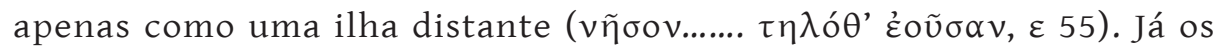
jardins de Alcínoo estão mais próximos da humanidade: diz-se que ficam

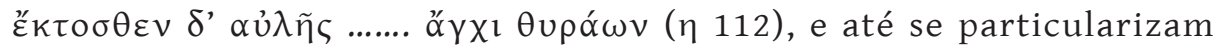

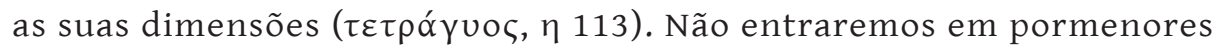
aqui $^{3}$, mas convém notar que em $\eta$ 112-131 temos uma descrição mi-

${ }^{1}$ Discordo das conclusões de Mackrodt, Der Olymp in Ilias und Odyssee, Altenburg, 1882, quando diz, seguindo La Roche, que $\varphi \alpha \sigma i ́$ tem «den Stempel der Unechtheit», porque só afirmações claras são próprias da poesia épica, e observa que esse verbo apenas é empregado, em contexto semelhante, em passos duvidosos, como B 783 e $\Omega$ 615. Entendo que o uso de $\varphi \alpha \sigma i ́$ neste verso é intencional, para implicar a ideia de que o conhecimento directo do Olimpo não foi concedido a ninguém, o que é uma maneira de sugerir a impossibilidade de jamais contemplar esse formoso lugar.

${ }^{2}$ Introduction à l'Odyssée, II, p. 55. Bérard supõe que se trata de uma interpolação hesiódica e talvez mesmo de um resto de poesia mais antiga. Nenhuma destas hipóteses é fácil de provar.

${ }^{3}$ Para uma discussão da topografia do jardim e das prováveis interpolações, veja-se V. Bérard, op. cit., III, pp. 36 seqq. 
nuciosa de um belo jardim, à qual não faltam as notações de carácter prático: $\pi \varepsilon \rho i \delta^{\prime}$ ' ع́ $\rho \chi \varsigma$ (113), árvores que produzem frutos maravilhosos,

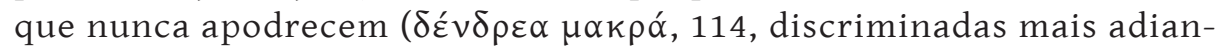

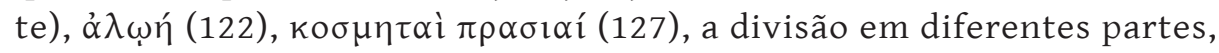
a preparação do vinho e, finalmente, as duas fontes (129-131), uma das quais era para os usos do palácio. Este último pormenor traz-nos de novo à vida corrente.

$\mathrm{Na}$ ilha de Calipso também há árvores, mas são apenas parte do

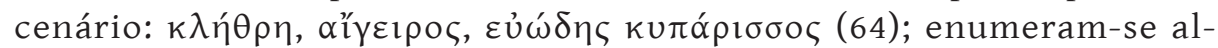
guns pássaros (65-67) e faz-se menção de uma videira à porta da gruta da ninfa (68-69), de quatro fontes que deitam água pura (70-71) e prados cobertos de violetas e aipo $(72-73)^{1}$. Os dois últimos tópicos, ou seja, as fontes e o prado florido, passarão para as descrições de outros países fabulosos.

Consideremos agora os dois quadros mais semelhantes, o do Olimpo e o dos Campos Elísios. É digno de nota o facto de o processo literário adoptado ser semelhante. É assim que se mencionam as qualidades negativas em primeiro lugar:

\author{
$\delta 561-569$ \\ oủ vipetóৎ (566)

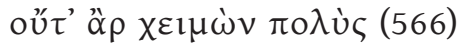

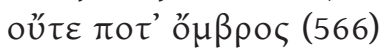 \\ $\zeta 42-47$

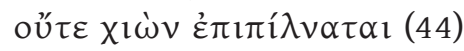

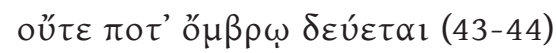

A descrição de $\delta$ opõe depois outros factos a estes, por meio de $\dot{\alpha} \lambda \lambda^{\prime}$ (567), a mesma partícula que aparece em $\zeta$ a separar as duas partes. Porém aqui pode notar-se uma pequena diferença: os ventos, cuja ausência fora

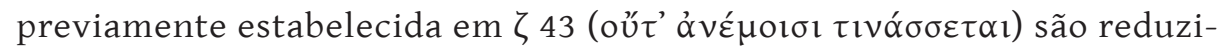
dos ao zéfiro, em $\delta 567$, o mesmo vento brando que fazia amadurecer os frutos nos jardins de Alcínoo ( $\eta 119)^{2}$. Acentua-se depois a proximidade do Oceano (568) e a sua presença refrescante ỏv $\alpha \psi u ́ x \varepsilon ı v ~(568)$.

1 O Rei do Egipto, Ptolomeu Euergetes II (247-222 a. C.) propôs a lição oíou, em vez de íou, baseando-se em que as violetas não costumam crescer nos prados (vide edição de Stanford, I, p. 296). Mas ambas as flores escolhidas tinham um

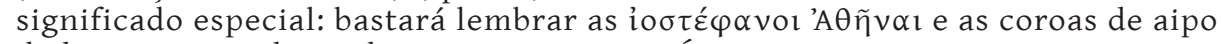
dadas aos vencedores dos Jogos Nemeios e Ístmicos.

${ }^{2}$ No resto dos poemas homéricos, o zéfiro é sempre indicado como um vento perigoso (para V. Bérard, esta coincidência era uma prova da origem egípcia dos dois mitos; mas o regime dos ventos diverge suficientemente, de umas para outras partes do mundo helénico, para dispensar tal hipótese). Sobre a relação entre este facto e a provável cidade natal de Homero, vide Stanford, I, p. 325. 
É interessante notar que a parte correspondente da descrição do olimpo segue um modelo diverso. Insiste-se especialmente no brilho do ar que envolve essa região:

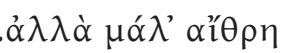

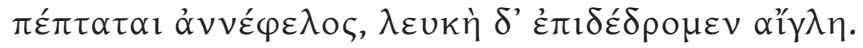

Outra diferença estilística reside no facto de se fazer uso de verbos (dando assim lugar a «rimas», que eram altamente apreciadas pelos antigos comentadores), ao passo que em $\delta$ se empregam adjectivos com o verbo copulativo subentendido.

o género de vida que os deuses levam no Olimpo é mencionado em último lugar:

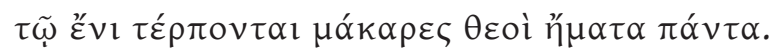

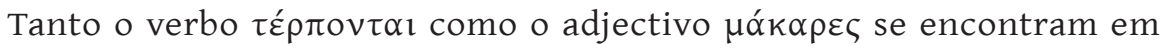
quase todas as descrições posteriores de um além feliz. Por isso, mais interessante se torna observar que ambas as palavras faltam na mais antiga versão literária dessa concepção. Com efeito, apenas se pode ler em $\delta$ 565:

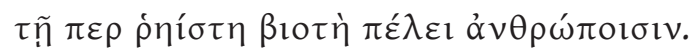

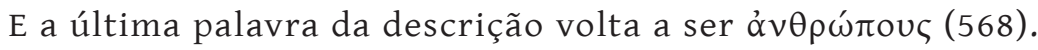

Depois de termos comparado estes quatro episódios, podemos concluir que todos eles são tentativas para imaginar um quadro de vida melhor, na qual a natureza é mais amável para os homens. Essa excelência manifesta-se ou através da contínua maturação dos frutos (jardins de Alcínoo) ou apenas pela beleza da paisagem (ilha de Calipso) ou pela amenidade do clima (Olimpo e Campos Elísios). Alguns dos tópicos empregados são comuns, outros específicos, como vimos resumidamente. É provável que o modelo dos jardins de Alcínoo fosse de origem minóica, conforme já se propôs ${ }^{1}$; o que se pode, pelo menos» afirmar é que os frescos recuperados em Cnossos e noutros lugares da ilha de Creta mostram igual riqueza de vegetação. Mas, de um modo geral, entendo que em todos eles o poeta não fez mais do que dar livre curso à tendência humana para idealizar uma vida melhor.

\footnotetext{
${ }^{1}$ A hipótese é de Stanford, na sua edição comentada da Odisseia, I, p, 325.
} 


\section{CAPÍTULO II \\ AS ILHAS DOS BEM-AVENTURADOS EM HESÍODO}

Como a curta referência a um além feliz, prometido apenas aos iniciados, no final do Hino Homérico a Deméter (480-482), não contém um único elemento descritivo, além da afirmação de que o lugar que lhes é destinado fica também no Hades, não temos de considerar esses versos neste ponto.

O exemplo mais antigo, que chegou até nós, de colocação em ilhas, da mansão dos bem-aventurados ${ }^{1}$ é o que se encontra em Hesíodo, Op. et

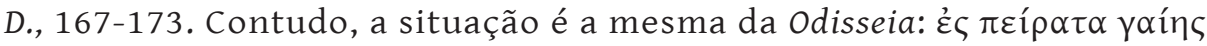
(168). E, conforme E. Rohde observou ${ }^{2}$, nada nos impede de supor que os Campos Elísios de Homero ficassem numa ilha também. Seja como for, o que importava era que tal região fosse muito distante e dificilmente

${ }^{1}$ Conquanto Capelle suponha (Elysium und Inseln der Seligen in Archiv für Religionswissenschaft, XXVI, 1918, p. 33) que as palavras originais do texto homérico

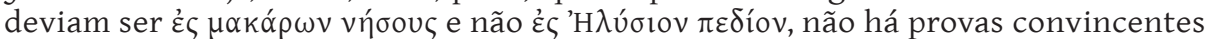
para aceitar tal argumento.

${ }^{2}$ E. Rohde, Psyche, I, pp. 104-105: «Die 'elysische Flur' uns als eine Insel zu denken, nötigt der Name nicht, er verbietet es auch nicht... nur eine Insel, rings vom Meere umgeben, gibt das Bild eines völlig von der Welt getrennten, unberufenen, unzugänglichen Zufluchtsorts». Que os poetas posteriores não viram a diferença entre as Ilhas dos Bem-aventurados e os Campos Elísios de Homero, de tal modo que, quando manifestamente pensavam no passo da Odisseia (como o prova a linguagem empregada), eram capazes de situar Menelau nas Ilhas, demonstra-o o seguinte epigrama do Peplus Aristoteleus:

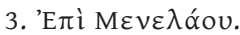

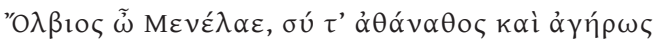

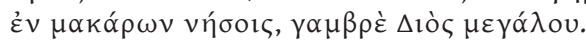

Sobre a diferença originária entre os dois lugares, vide supra, pp. 28-30. 
acessível. No passo de Hesíodo de que estamos a tratar, acentua- se que vivem longe dos contactos humanos vulgares:

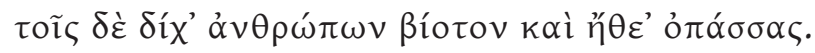

A descrição em si limita-se a um pequeno número de indicações. Insiste-se especialmente na felicidade do seu estado: $\alpha$ k $\eta \delta \delta \dot{\alpha} \alpha \theta u \mu o ̀ v$

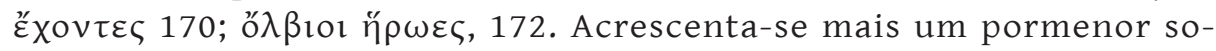
bre a situação desse lugar: $\pi \alpha \rho$ ' ' $\Omega \kappa \varepsilon \alpha v o ̀ v ~ \beta \alpha \theta u \delta i ́ v \eta v$ (171). Os últimos dois versos contêm os elementos descritivos mais importantes de todo este passo: a terra oferece-lhes os seus doces frutos três vezes no ano (172-173). Este é o ponto mais alto no sonho de felicidade de um lavrador: um solo que produz espontaneamente as mais ricas colheitas, e isso com uma frequência superior à dos mais privilegiados lugares da bacia do Mediterrâneo, com os quais os gregos estavam familiarizados. Não é de admirar que este esboço de uma vida de bem-aventurança esteja muito mais próximo do quadro de um estado onde se observam as normas da Justiça, Op. et D., 225-237. Ambas as descrições terminam com o mesmo hemistíquio homérico:

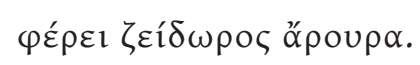

que torna uma ainda mais próxima da outra. Mas, neste segundo caso, temos um quadro baseado na vida real, embora num mais alto grau de perfeição, e por conseguinte o desenvolvimento do tema faz-se num sentido diferente: acentua-se principalmente a nota da fecundidade através da abundância de fruta nas árvores e prosperidade de vida para homens e gados. O contraste vem logo a seguir, por meio da enumeração dos males que se abatem sobre um estado injusto (238-247): doenças, fome, esterilidade e destruição completa. Estes tópicos provinham, conforme observa P. Mazon na sua edição ${ }^{1}$, de um esquema tradicional, que aparece pela primeira vez na Odisseia $\tau$ 109-114, e no qual julga ver restos de antigas fórmulas religiosas.

Nos versos 42-44 sugere-se o mesmo tipo de vida ideal para um lavrador:

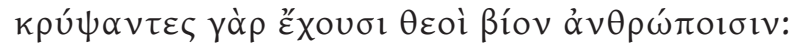

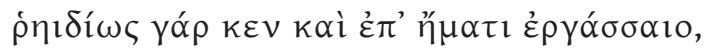



\footnotetext{
${ }^{1}$ Edição Budé, 1951, p. 95, nota I.
} 
Este passo conduz-nos directamente a um outro aspecto da concepção de Hesíodo acerca da evolução da humanidade, que está expressa no muito conhecido e não menos discutido mito das cinco raças. Aí encontramos uma condição humana para o passado correspondente à felicidade de que gozam os heróis nas Ilhas dos Bem-aventurados. Porém, neste caso, situa-se na terra:

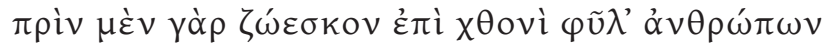

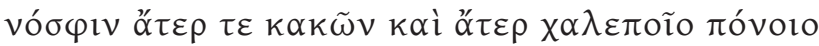

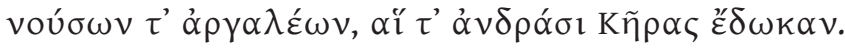

(Op. et D., 90-92)

Estes primeiros versos fornecem apenas uma pintura negativa, cujas linhas principais são desenvolvidas um pouco mais adiante, numa descrição completa da raça de ouro (109-126). Mas, se a expressão vó $\sigma \varphi \imath v$ ó $\tau \varepsilon \rho \tau \varepsilon$

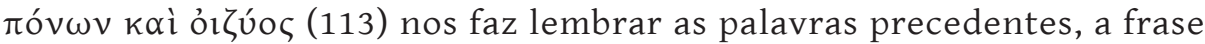

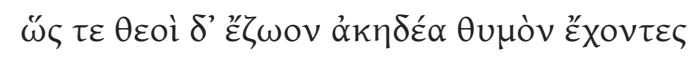

aproxima-se manifestamente do verso $170^{1}$ que caracteriza o estado de espírito dos heróis que foram para as Ilhas dos Bem-aventurados. Sobre a condição especial dos homens da idade do ouro, acrescentam-se mais algumas notas:

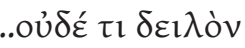

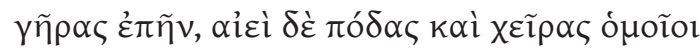

e ainda

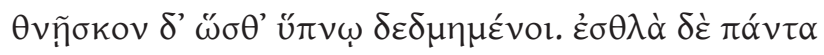

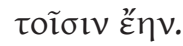

O próprio vocabulário nos faz lembrar descrições de uma vida feliz

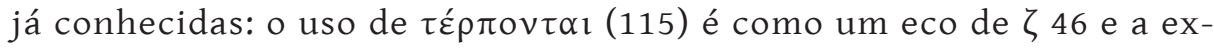

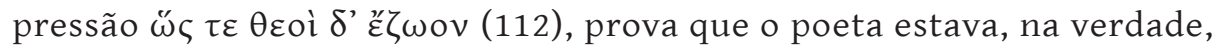

${ }^{1}$ Sigo o texto tradicional de Hesíodo, pondo de parte, por conseguinte, as lições de Diodoro neste passo, as quais aliás não afectam o sentido geral do contexto. 
a pensar na maneira de viver dos deuses; depois as palavras $\kappa \alpha \kappa \tilde{\omega} v$

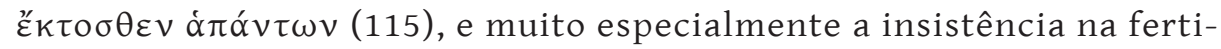
lidade da terra, novamente por meio da mesma fórmula:

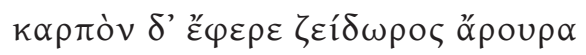

embora amplificada pelo verso seguinte

$\alpha$

Na verdade, o único pormenor novo é a menção de festas

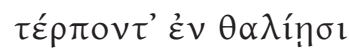

criando assim um tópico diferente para futuras descrições, conforme veremos adiante.

Evidentemente que não é de admirar a semelhança de todos estes passos, uma vez que todos eles pretendem delinear o quadro de um nível de vida melhor, ou projectada no passado, como é o caso do mito da idade do ouro e de um pequeno número de alusões dispersas à mesma lenda, também citadas acima, ou apresentada simplesmente como um destino especial, concedido somente a certos heróis ${ }^{1}$, como acontece com as Ilhas dos Bem-aventurados. Ambos os temas foram extremamente bem sucedidos através de toda a Literatura Grega e Latina. É muito provável que um e outro fossem motivos tradicionais, mas para nós, é este o seu primeiro tratamento literário².

Seja como for, é interessante acentuar a insistência com que Hesíodo fala da felicidade derivada da riqueza das colheitas e da ausência de necessidade de cultivar os campos.

Ainda falta discutir um grupo de versos incompletos, que os melhores manuscritos omitem, mas foram conservados no Papiro de Genebra (B Rzach). Estes referem-se a Cronos, como soberano dos bem-aventurados, e à sua libertação das cadeias que o prendiam. $O$ acrescento divide-se em duas partes, a primeira das quais consiste no verso 169,

${ }^{1}$ Apenas os heróis da quarta geração tiveram acesso a elas e nada leva a crer que tal distinção voltasse a ser conferida.

${ }^{2}$ Sobre isto veja-se o artigo de H. C. Baldry, Who invented the golden age? in Classical Quarterly, New Series, vol. II, n. ${ }^{\circ} 1-2$, January-April 1952, pp. 83-92. 
que também consta de alguns códices deteriores. Contrariamente, $169^{\mathrm{b}-\mathrm{e}}$ apenas figuram no citado Papiro de Genebra ( século V da nossa era).

A própria posição dos versos no poema tem sido matéria de controvérsia: Pepmüller coloca-os a seguir a 171, Weil, Rzach e P. Mazon depois de 173, como nos escólios de Proclo.

Conquanto 169 tenha sido confirmado por Marcelo Sidónio, Epigr. Gr. ed. Kaibel 1046, 9 e Zenóbio, III, 86, todos os melhores manuscritos o omitem (os do grupo $\Omega, \Psi, \Phi$, na classificação de Rzach) e não posso

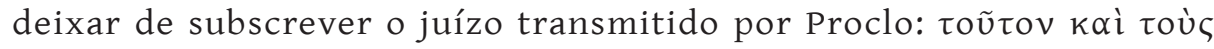

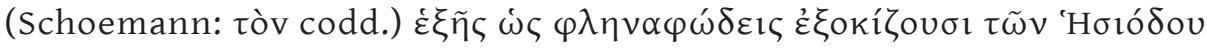
- e isso, não só baseando-me na tradição manuscrita, mas também em motivos de ordem ideológica. Os editores modernos são unânimes em rejeitá-los todos.

Observando o caso mais de perto, há vários pontos a considerar. Em primeiro lugar, afirma-se no verso 169 que os bem-aventurados vivem

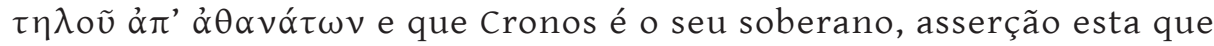
é contrária à do verso 851 da Teogonia ${ }^{1}$ :

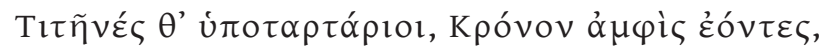

Foi a presença de Cronos que acarretou a explicação contida em $169 \mathrm{~b}$ acerca da libertação do deus, mito esse que é certamente mais tardio. Os restantes três versos $\left(169^{\mathrm{c}-\mathrm{e}}\right)$ acentuam a nota da felicidade dos heróis.

A relação entre Cronos e as Ilhas dos Bem-aventurados pode ter sido motivada pelo mito da Idade do Ouro, como supuseram E. Rohde ${ }^{2}$ e M. P. Nilsson ${ }^{3}$. E. Rohde acrescenta ainda: «Es ist schwer zu sagen, welche von ihnen die andere beeinflusst haben mag» ${ }^{4}$, porquanto pode ser que só por mero acaso não conheçamos o mito da Idade do Ouro antes de Hesíodo. De qualquer modo, essa relação não estava estabelecida nos Trabalhos e Dias.

Em resumo, procurei traçar um paralelo entre a descrição de Hesíodo da Idade do Ouro, em Op. et D. 109-126, e a das Ilhas dos Bem-aventurados, ibidem, 167-173. Tal paralelo foi ainda alargado ao quadro do estado

\footnotetext{
${ }^{1}$ Considero esse episódio autêntico, na sua maior parte, e não vejo razão para acreditar, como Jacoby e Mazon, que oito poetas diferentes trabalharam na sua elaboração.

${ }^{2}$ Psyche I, pp. 105-106.

${ }^{3}$ Geschichte der griechischen Religion, I, p. 485.

${ }^{4}$ Op. laud., I, p. 106.
} 
justo, ibidem, 225-2371. Este processo mostrou-nos que a causa principal de felicidade parecia residir na fertilidade do solo, que é, afinal, o

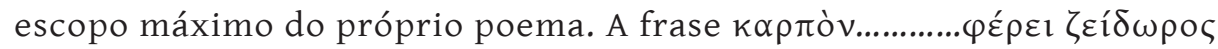
ópoup $\alpha$ encontra-se, com variantes mínimas, em todos os três passos. $\mathrm{O}$ outro tópico fundamental do estado de beatitude está também expres-

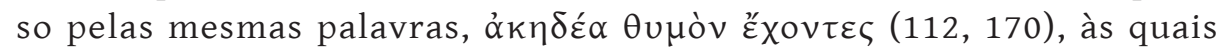
corresponde عịńv em 228.

Por outro lado, tudo isto se assemelha ao estado dos deuses na Odisseia, $\zeta 42$ seqq. e ao dos habitantes dos Campos Elísios em $\delta 561$ seqq.

Se compararmos $\delta 561$ seqq. com Op. et D. 167 seqq., pode concluir-se que em- ambos os casos os bem-aventurados não têm de sofrer a morte, são simplesmente arrebatados: («entrückt», para empregar a palavra

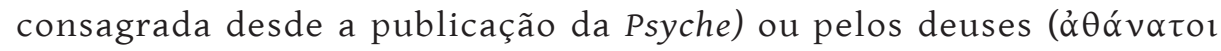

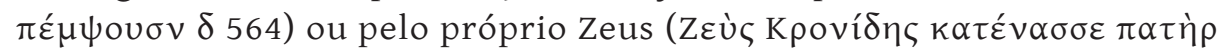
Op. et D. 168 ). No caso de Hesíodo, o destino especial que coube em sorte a alguns heróis da quarta geração é apontado como um facto histórico, pois parece não ser acessível a mais ninguém. $O$ emprego do verbo que

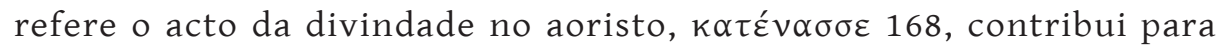
acentuar o facto de a decisão ter sido tomada por uma vez ${ }^{2}$. Os versos seguintes têm todos os verbos no presente, porquanto aquele privilegiado

${ }^{1}$ A esta série pode adicionar-se o mito do Jardim das Hespérides, mencionado na Teogonia 215-216, 274-275, 518. Dos três passos, o mais interessante para o assunto em causa é $215-216$, onde se diz que as filhas da Noite moram para além do Oceano e tomam conta das maçãs de ouro e das árvores que as produzem:

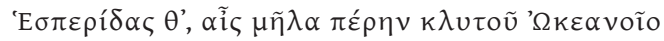

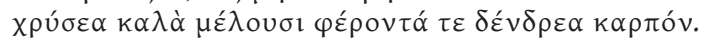

Os outros dois passos não fazem mais do que repetir que habitam para além do Oceano, e qualificá-las de $\lambda$ ıүú $\varphi \omega v o l$. Deve ainda observar-se que em 275 se

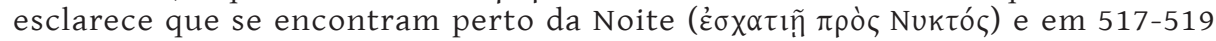
acrescenta-se que é no lugar onde Atlas segura o mundo; ambas as afirmações concordam com um discutido passo da Teogonia, 744-757. Sobre a situação das Hespérides no Ocidente longínquo cf. os conhecidos versos de Mimnermo, que descrevem a viagem da taça dourada de Hélios

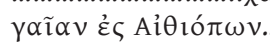

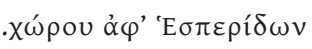

(Frg. 10 Diehl, vv. 8-9)

Sobre outras localizações deste jardim fantástico e as relações deste mito com o dos Campos Elísios e o das Ilhas dos Bem-aventurados, vide supra, pp. 40-43. O pseudo-Apolodoro, 2.5.11 confunde-o com o dos Hiperbóreos.

${ }^{2}$ O particípio ỏ đá $\sigma \sigma \alpha \varsigma, 167$ está fora da questão, pois tinha de estar no aoristo, em virtude de exprimir anterioridade em relação ao verbo principal. 


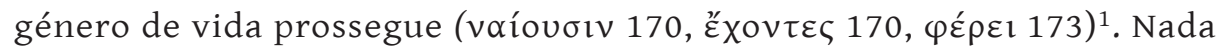
leva a crer, por conseguinte, que haja possibilidade de outras pessoas irem para esses lugares. O mito serve apenas para fornecer uma conclusão semelhante à dos das raças precedentes.

Portanto, até esta altura, apenas o Hino Homérico a Deméter falava de um além feliz como de um futuro que aguardava os iniciados. Em Hesíodo, diversamente do que acontece com $\delta 569$, não há um motivo

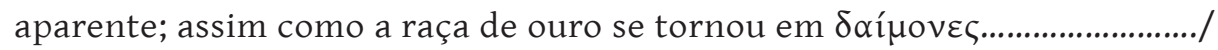

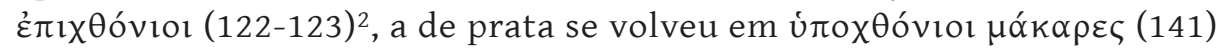
e a de bronze foi para o Hades (153-155), a quarta geração pereceu junto de Tebas (161-163) ou de Tróia (164-165) e parte dela foi recompensada com outra existência (ßíotov, 167) nas Ilhas dos Bem-aventurados 3 .

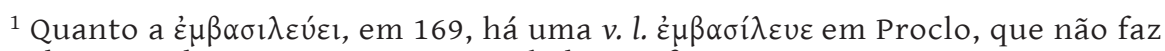
sentido. Considero esse verso interpolado, conforme expus acima.

${ }^{2}$ Sobre a interpretação platónica do sentido de $\delta \alpha i ́ \mu o v \varepsilon \varsigma$ neste passo, vide Cratylus, 397E-398C. E. Meyer in Genethliakon Robert, p. 173 supõe que pertenciam a outra versão da história de Cronos.

${ }^{3}$ C. Pascal em Le Credenze d'Oltretomba nelle Opere Letterarie dell' Antichità Classica, Catania, 1912, vol. II, cap. XX, diz que o frg. 26 Diehl $^{3}$ de Sólon se refere provavelmente à vida no Elísio. Esta teoria tem sido contestada. Também discordo dela, por dois motivos: (1) a descrição menciona apenas factos da vida corrente, como o processo de alimentação e as facilidades que a terra oferece para esse fim e (2) um passo de Platão, no Critias, 113A-B, é claro índice de velhas lendas em curso sobre a Atlântida ou qualquer outro país fabuloso, mas de modo algum associado com a mansão dos mortos. Evidentemente que só a recuperação eventual do resto dos iambos de Sólon poderia elucidar-nos sobre a questão de uma maneira decisiva. 
(Página deixada propositadamente em branco) 


\section{CAPÍTULO III PÍNDARO}

Entre os diversos passos de Píndaro, já considerados na I⿳亠口冋 Parte, em que se fala do além dos bem-aventurados, há apenas dois que, pela sua extensão e pelos elementos descritivos que contêm, importa analisar aqui. Como são bastante diferentes, começarei por estudar cada um separadamente, para depois poder compará-los.

\section{a) O mito da II ${ }^{\mathrm{a}}$ Olímpica}

Todo o mito da $\mathrm{II}^{a}$ Olímpica tem dado lugar a muitas discussões sobre a sua verdadeira interpretação. Comecemos pela parte teórica, ou seja, a que vai do verso 56 a 70 .

A primeira dificuldade em esclarecê-la provém da controvérsia em

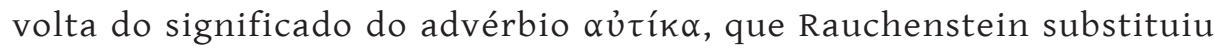
por $\alpha \tilde{u} \tau \imath \varsigma$, emenda essa que foi acatada por vários comentadores que se lhe seguiram, mas que me parece desnecessária.

A confusão em todo este passo origina-se principalmente no emprego repetido e assimétrico da partícula $\delta \varepsilon$. Para tentar esclarecê-lo, começarei por analisá-lo. A fim de facilitar esse trabalho, dividi-lo-ei em secções diferentes, cada uma das quais constitui um todo em si, mas

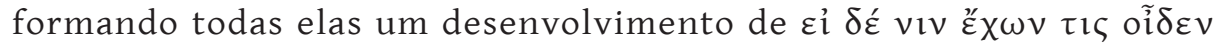

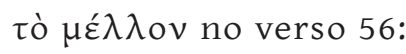

Penalidade das almas más, a seguir ao julgamento debaixo da terra:

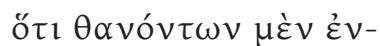

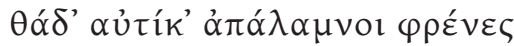

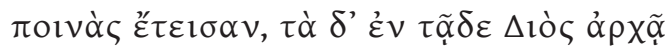




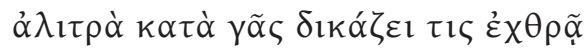

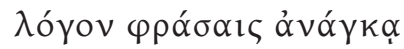

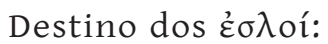

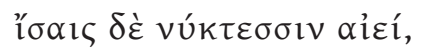

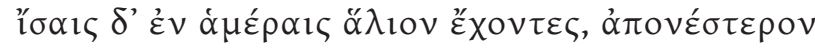

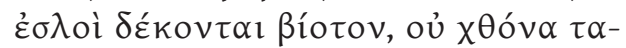

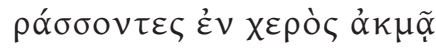

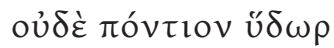

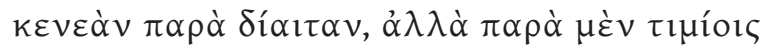

$\theta \varepsilon \tilde{\omega} v$ oĭ́

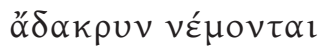

$\alpha i \tilde{\omega} v \alpha$

$(61-67)$

Destino dos maus:

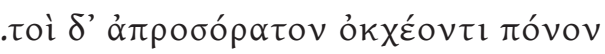

(67)

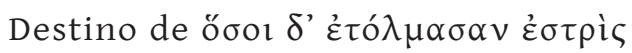

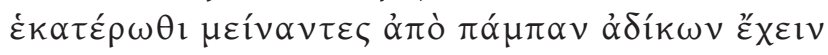

$u x \alpha ́ v$

(68 a 83$)$

Nota-se que há uma alternativa entre os bons e os maus, como entre a luz e a sombra.

Entendo que $\dot{\varepsilon} v \theta \alpha ́ \delta \varepsilon$ se liga a $\theta \alpha v o ́ v \tau \omega v$, formando assim contraste com $\kappa \alpha \tau \grave{\alpha} \gamma \tilde{\alpha} \varsigma^{1}$; que $\alpha \dot{\pi} \alpha \dot{\lambda} \lambda \alpha \mu v o l$ deve significar «injusto», conforme a interpretação de Liddell-Scott e outros, e não "fracos», no sentido

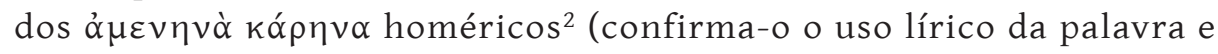

1 Assim pensa Deubner in Hermes, vol. XLIII, 1908, p. 630. H. W. Garrod in

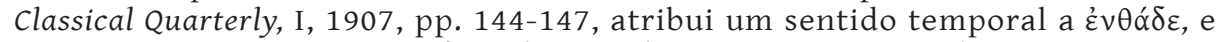
toma o conjunto como significando «imediatamente». Em minha opinião, o uso

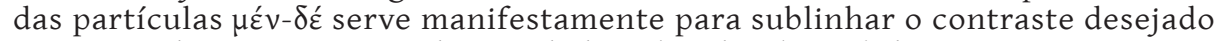
e a noção de sequência imediata é dada pelo advérbio $\alpha u ̉ \tau i ́ k \alpha$.

${ }^{2} \mathrm{O}$ primeiro sentido foi aceite por Wilamowitz, Pindaros, pp. 248-249; M. P. Nilsson, Geschichte der griechischen Religion, I, p. 655, nota 7; W. J. Goodrich in 


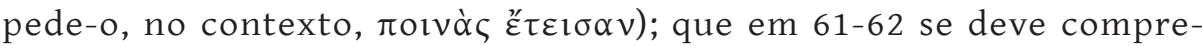
ender que os dias são sempre iguais e as noites também, construindo,

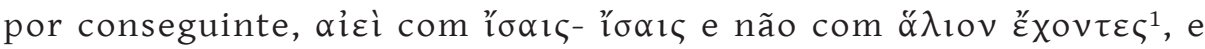
excluindo a hipótese de gozarem o dia quando é noite sobre a terra e vice-versa ${ }^{2}$, ou de terem perpetuamente a luz do sol ${ }^{3}$ (como já observei, ao analisar o conteúdo ideológico deste passo, na I ${ }^{\mathrm{a}}$ Parte, a noção de igualdade inalterável é o motivo principal desta felicidade incolor); e que o segundo termo de comparação, que se deve subentender com

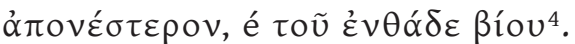

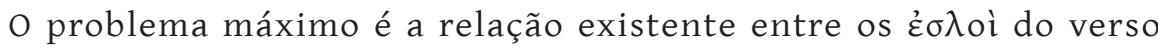

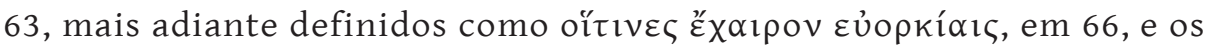
que tiveram a força moral de se absterem de toda a injustiça (ả $\pi$ ò $\pi \alpha ́$ -

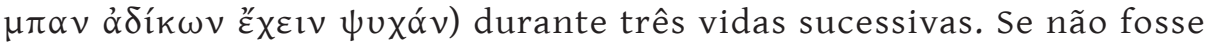

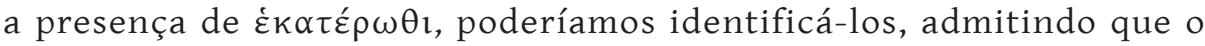
que se diz a seguir descrevia um paraíso definitivo, por oposição ao precedente, de 61 a 67. Porém o advérbio em questão implica claramente a crença na metempsicose. Que Píndaro a aceitava como um meio de purificação, demonstra-o o frg. 133 Snell, onde se diz que Perséfone manda as almas que pagaram a sua pena pela "antigo pesar» ${ }^{5} \dot{\varepsilon} \zeta$ $\tau$ òv

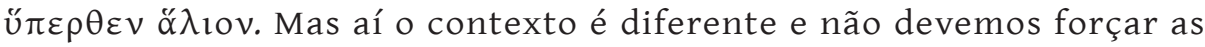
diversas versões escatológicas de Píndaro a uma unidade que não têm.

De qualquer modo, parece-me muito difícil admitir, como geralmente se tem feito, desde o tempo de Aristarco, que este passo da II ${ }^{a}$ Olímpica dê a entender que se podem cometer pecados também no outro mundo. Não se conservam testemunhos em autor nenhum que nos habilitem a

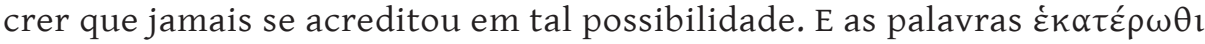
$\mu \varepsilon \hat{v}$ $\alpha \nu \tau \varepsilon \zeta$ não nos obrigam a aceitar tão extravagante doutrina.

Por outro lado, a descrição de 61-67 não convém à vida neste mundo, mas ao mesmo tempo não dá qualquer indicação sobre a sua localização.

Mas, se compararmos este passo com um de Platão, Phaedrus 249A, compreenderemos que as primeiras são as almas sujeitas ao julgamento,

Classical Quarterly, II, 1908, pp. 31-33. O segundo foi defendido por E. Rohde, Psyche, II, pp. 208-209, nota 3, e Garrod in Classical Quarterly, I, 1907, pp. 144-147.

${ }^{1}$ Como em Bergk ${ }^{3}$ (equinócio) e Wilamowitz (ausência de estações). A variante de Wilamowitz parece-me melhor.

${ }^{2}$ Interpretação de Mommsen.

${ }^{3}$ Interpretação de Moscópulo e Böckh.

${ }^{4} \mathrm{E}$ não uma referência às penalidades dos maus, como propôs Dissen.

${ }^{5} \mathrm{Cf}$. a interpretação dada por H. J. Rose a tão discutido fragmento em The Ancient Grief in Greek Poetry and Life e The Grief of Persephone in Harvard Theological Review, 1943, pp. 247-250. 
ao passo que as segundas são as completamente puras ${ }^{1}$. Esta interpretação parece-me a mais satisfatória.

Por conseguinte, nesta primeira parte tenta-se descrever uma vida isenta de cuidados, sem trabalho nem sofrimento, em moldes semelhantes, portanto, aos do quadro da Idade do Ouro. Ao que parece, têm um sol especial ${ }^{2}$, dias sempre iguais e noites, também, não precisam de se esforçar para conseguir extrair a sua alimentação da terra ou do mar; passam uma existência pacífica e sem lágrimas.

Isto conduz-nos ao primeiro ponto de crítica textual que desejo discutir, antes de entrar na análise da concepção propriamente dita.

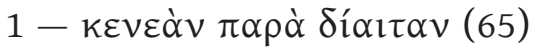

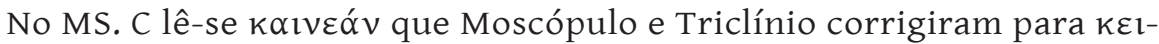

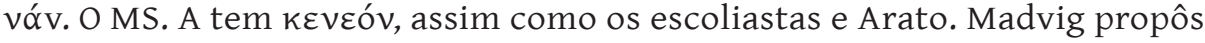

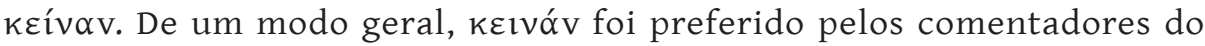
século XIX (Gildersleeve, Fennell) e Farnell ainda o conserva, ao passo que

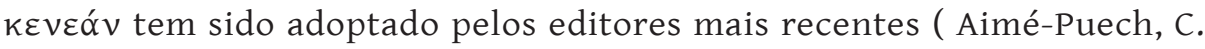
M. Bowra, A. Turyn, B. Snell, Galiano) Liddell-Scott também lêm keıvóv.

Como Farnell, penso que o demonstrativo não seria tolerável, por causa do sentido. Portanto a escolha fica limitada a duas fórmulas poé-

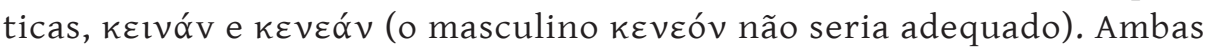
estavam na tradição homérica e ambas foram usadas por Píndaro ${ }^{3}$. Por outro lado, a sinizese pode torná-las metricamente iguais. Contudo, é conveniente atentar em que no esquema métrico deste passo:

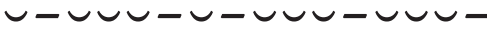

1 Vide supra, p. 71-72.

${ }^{2}$ A comparação com o frg. 133 Snell ( $(\xi \zeta \tau o ̀ v ~ u ̋ \pi \varepsilon \rho \theta \varepsilon v ~ \alpha ̋ \lambda ı v)$ favorece esta hipótese. Os escoliastas bizantinos interpretaram o passo de outro modo, como já se disse.

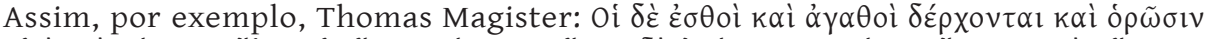

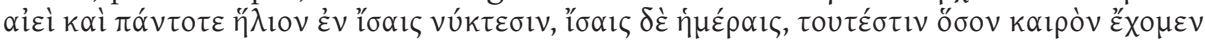

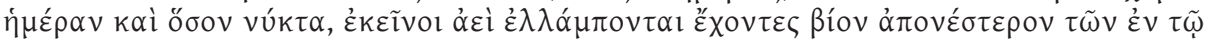
ßíw. Em Moscópulo encontra-se uma paráfrase semelhante, que ainda esclarece:

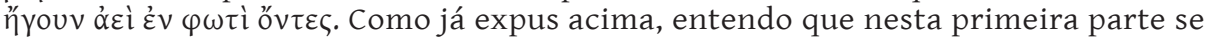
refere principalmente a nota da inalterabilidade das condições de vida dos bons.

${ }^{3} \mathrm{Um}$ caso semelhante ocorre na Ol. III, 45, onde o MS. Dac e os schol. têm

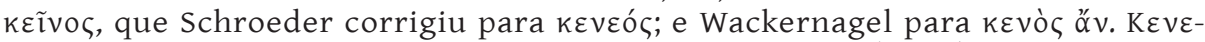
ó $\varsigma$ no genitivo plural deve ler-se no frg. 140 a, verso 55- (Snell) $=192$, verso 29

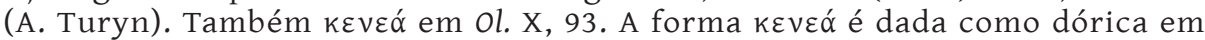
Gregório Coríntio, Dial. Dor. 34, mas isso pouco nos ajuda, pois os dialectos são essencialmente fictícios em literatura, e muito em especial no poeta tebano. 
a única razão para se marcar uma syllaba anceps no metro iâmbico é precisamente este verso 65 , porquanto são longos os lugares correspondentes através de toda a ode.

A lição de Moscópulo e Triclínio parece-me preferível, embora não se possa apresentar nenhum argumento decisivo, devido ao facto de o poeta ter usado ambas as formas e de a métrica não excluir definitivamente uma ou outra possibilidade.

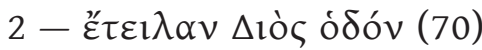

Aqui as dificuldades têm a sua origem no próprio facto de se mencionarem a seguir dois lugares desconhecidos. Tanto o caminho de Zeus como a torre de Cronos não constam de mais nenhum autor.

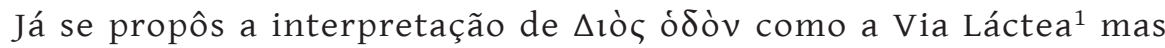
tal concepção é bastante mais tardia. Outros entendem, como Farnell, que tal expressão pode sugerir viagens frequentes de Zeus às Ilhas dos Bem-aventurados, para estar em comunhão com estes últimos². Fennell, na sua edição, diz encontrar aqui uma reminiscência idêntica à que figura no mito do Fedro, especialmente em 246E. Mesmo que não aceitemos este segundo argumento, pois a narrativa de Platão se desenrola num nível cosmológico inteiramente diverso, a hipótese de Farnell tem bastante de verosímil, como se verá adiante.

O mesmo Fennell encontra um paralelo para este caminho no frg. 30 Snell, no qual se declara que as Parcas levaram Témis a Zeus:

$$
\begin{aligned}
& \text {. }
\end{aligned}
$$

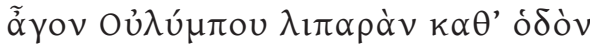

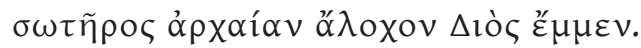

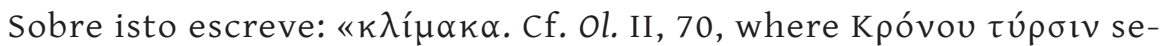

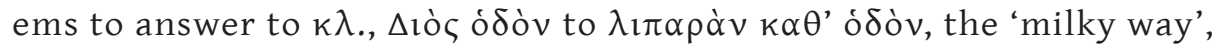
cf. Ov. Met. I, 168-171» ${ }^{3}$

\footnotetext{
${ }^{1}$ Apresentada por Böckh, Opusc. II, 708. Quinto de Esmirna, XI, 224 seqq., descreve um caminho semelhante, que conduz do céu ao 'H $\lambda$ ú $\sigma$ ıov $\pi \varepsilon \delta$ íov (citado por E. Rohde, Psyche, II, p, 213, nota 2, que observa com razão que os bem-aventurados não vinham do céu).

${ }^{2}$ The Works of Pindar, vol. II, p. 19

${ }^{3}$ Pindar, The Nemean and Isthmian Odes... by C. A. M. Fennell, p. 220, nota 7.
} 


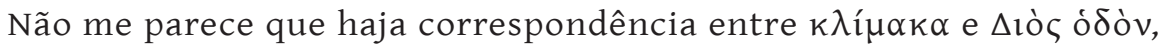
a não ser que ela se baseie na comum qualidade de serem ambos os lugares dificilmente acessíveis. Sendo assim, poderíamos acrescentar que o caminho que Témis tem de seguir é semelhante, em situação, ao dos

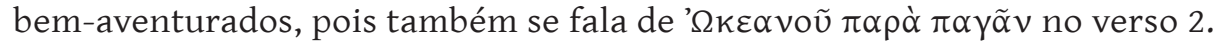

Entendo, porém, que a expressão deve antes comparar-se à $\theta \alpha u \mu \alpha \sigma \tau \alpha \grave{\alpha} v$ ódòv, que na $P$. X, 30 leva aos Hiperbóreos, cujo país tem muito de comum com as Ilhas dos Bem-aventurados, pois é também um lugar fabuloso. Um caminho maravilhoso, que às pessoas vulgares não era dado percorrer, conduzia a esse local de magia. Aquele de que estamos a tratar parecia estar directamente relacionado com Zeus, porquanto os habitantes das Ilhas

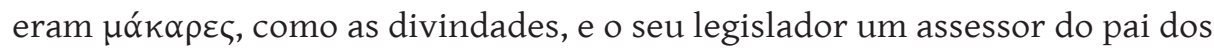
homens e dos deuses. Não é de estranhar que deste último tomasse o nome.

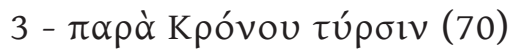

O significado de $\tau u ́ p \sigma \imath v$ não oferece qualquer dúvida: designa sempre uma fortaleza. Contudo, conforme já tem sido notado, os bem-aventurados vivem numa região longínqua, mas não fortificada ${ }^{1}$. O problema tem de buscar a solução, por conseguinte, no sentido da preposição $\pi \alpha \rho \alpha ́$ no contexto. Das três construções possíveis de $\pi \alpha \rho \alpha$, importa aqui lembrar que, quando rege acusativo, pode significar:

I. ao lado de, junto, perto.

II. ao longo de.

III. além de.

Uma das traduções mais aceites tem sido «ao longo de». Mas no Lexicon Pindaricurn de Rumpel encontramos ad como equivalente latino. E Gildersleeve deu a interpretação seguinte ${ }^{2}$ :

"Not 'along', as in prose, but 'to the neighborhood of' as if $\pi \alpha \rho \grave{\alpha}$ Kpóvou, 'to the court of Kronos', who presides over the happy isles».

\footnotetext{
${ }^{1}$ Não se conhece por enquanto outro exemplo de emprego desta palavra em Píndaro. Cf. Rumpel, Lexicon Pindaricum, s. u., que agora se deve completar com

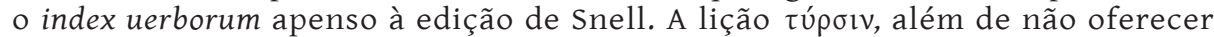
variantes, está confirmada por Olimpiodoro, Schol. in Platonis Phaed., p. 91 Fickh e Hérmias Alexandrino, Schol. in Platonis Phaedrum ad 248E Couvreur. O escoliasta

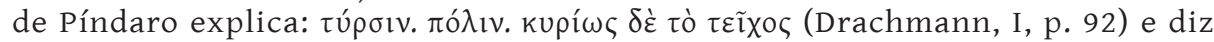
que é o título que o poeta dá às Ilhas dos Bem-aventurados. Nesse caso, para que designá-las logo a seguir pelo nome consagrado?

${ }^{2}$ Pindar, The Olympian and Pythian Odes... by R. L. Gildersleeve, ad locum.
} 


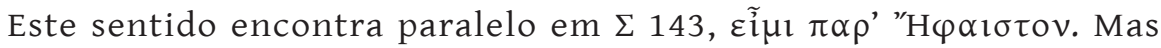
baseia-se na suposição de que Cronos governava as Ilhas dos Bem-aventurados. Já vimos que o verso dos Trabalhos e Dias em que se falava disso não é de Hesíodo ${ }^{1}$, e vamos ver que o deus cujo nome tem de subentender-se nos versos 76-77 desta mesma Ode não é Cronos. Por outro lado, sabemos que o mesmo Cronos fora sempre colocado pelos poetas anteriores a Píndaro no Tártaro, debaixo da terra, entre os Titãs ${ }^{2}$, num lugar além do Oceano, por vezes. Apresento a seguir alguns exemplos:

Ilíada, $\Theta$,477-481:

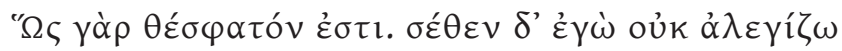

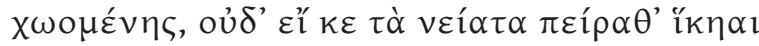

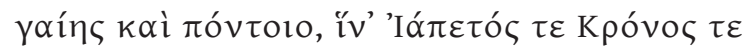

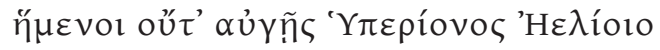

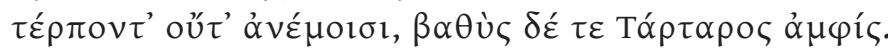

Ilíada, $\Xi, 200-204:$

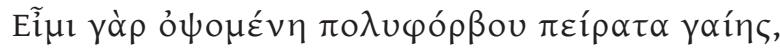

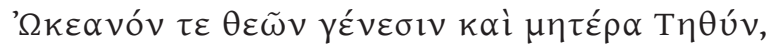

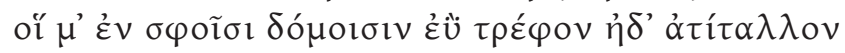

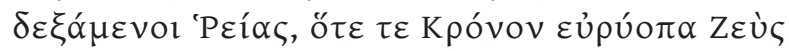

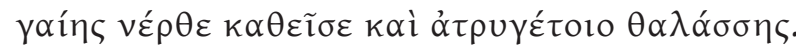

Ilíada, $\Xi, 273-274$ : . .ív $\alpha v \tilde{\omega} \ddot{\imath} v$ ö $\pi \alpha v \tau \varepsilon \varsigma$

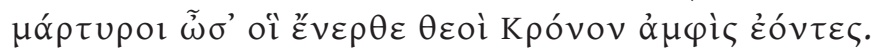

Ilíada, O, 225:

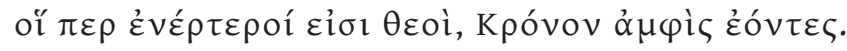

Hesíodo, Teogonia, 850-851:

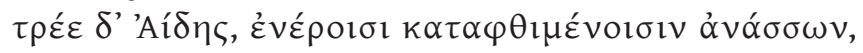

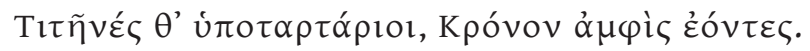

Destes passos se conclui que Cronos estava com os Titãs no Tártaro. Que este último era uma fortaleza confirma-o $\Theta 13-16$ :

${ }^{1}$ Portanto as conclusões atingidas por H. C. Baldry no seu artigo Who invented the golden Age? in Classical Quarterly, 1952, pp. 83-92, quanto à fusão do mito da idade do ouro com o da soberania de Cronos sobre as Ilhas dos Bem-aventurados, devem colocar-se em época mais tardia da literatura grega.

${ }^{2}$ Encontra-se ainda um eco deste mito em Platão, Cratylus, 404A. 


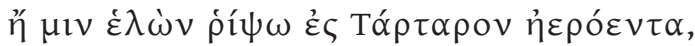

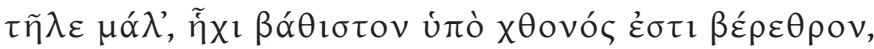

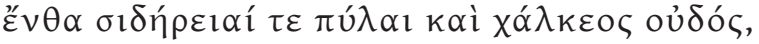

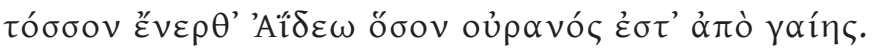

Os versos da Ilíada citados acima, $\Xi 200-204$, precisam que essa fortaleza

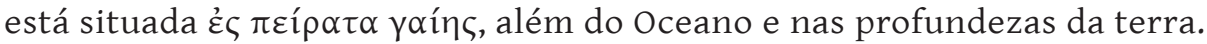

A mesma localização e forma é atribuída ao Tártaro pelos versos 720 seqq. da Teogonia ${ }^{1}$ nos quais, depois de se desenvolver o famoso passo de $\Theta$ 13-16, se afirma:

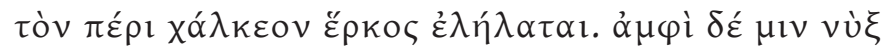

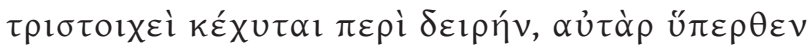

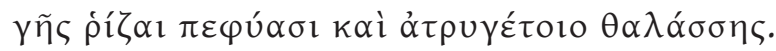

(726-728)

e, alguns versos mais adiante:

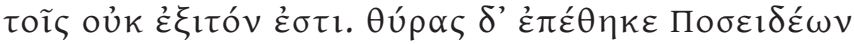

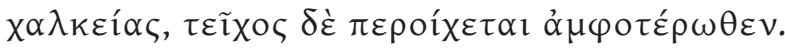

Outros passos, cuja autenticidade tem sido contestada, referem que aí se encontram também as raízes da terra, do mar e do céu (vv. 736 seqq.).

É este o modelo tradicional, que deve ter sido familiar a Píndaro, não o do verso 169 dos Trabalhos e Dias. O verso 291 da IV ${ }^{a}$ Pítica demonstra que ele também conhecia o mito da libertação dos Titãs:

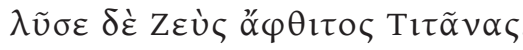

mas isso não nos impede de supor que na II $^{a}$ Olímpica o poeta seguiu a velha tradição. Um exemplo semelhante do uso de duas versões diferentes do mesmo mito aparece-nos na mesma Ode, nos versos 79-83, onde se diz que Aquiles foi para as Ilhas dos Bem-aventurados, ao passo que em N. IV, 49-50, lemos que se encontra numa ilha no Ponto Euxino: .’’ $َ \grave{\alpha} \rho$

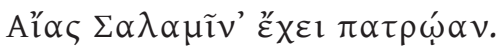

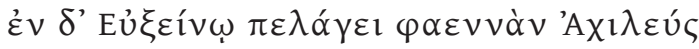

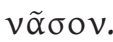

${ }^{1}$ Discuti este passo em Humanitas, vol. V-VI, 1953-4, Acerca do Hades em Hesíodo. 
seguindo, portanto, outra tradição, que também chegou até nós através de Pausânias, III, XIX, 11-13, que dá à ilha o nome de Leuce, e de outros autores ${ }^{1}$.

Se procurarmos referências ao Tártaro no próprio texto de Píndaro, podemos verificar que o poeta o imaginou como um lugar profundo ( $\varepsilon \varsigma$

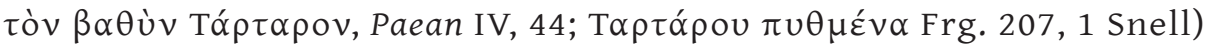

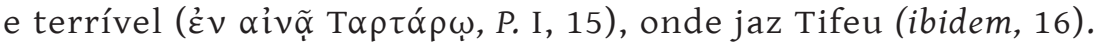

Não se encontram outras menções do Tártaro nas obras que nos restam deste poeta da luz ${ }^{2}$.

Por outro lado, as referências dispersas a Cronos não nos habilitam a formar uma ideia concreta das suas funções, porquanto em todos os outros passos ele é nomeado como pai de Zeus ${ }^{3}$, de Poséidon ${ }^{4}$ ou de Quíron ${ }^{5}$ ou em relação com certos dados topográficos ${ }^{6}$.

Quanto a Radamanto, apenas aparece outra vez, como juiz incorruptível:

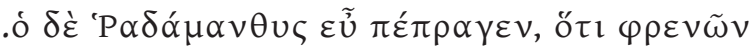

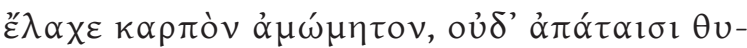

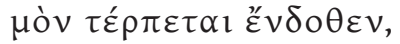

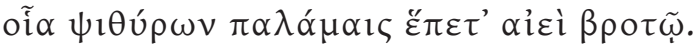

(P. II, 73-75)

Comparando quanto ficou dito até agora com o já citado verso 30 da $\mathrm{X}^{\mathrm{a}}$ Pítica, podemos concluir que $\Delta$ iò ó ó óv era certamente um caminho especial e privilegiado que levava a lugares maravilhosos. E, como Cronos não estava nas Ilhas dos Bem-aventurados, mas no Tártaro, é concebível que a sua morada ficasse na passagem, uma vez que ambos os sítios se encontravam nas margens do Oceano e nos confins da terra. O Tártaro foi sempre imaginado como uma fortaleza; por conseguinte,

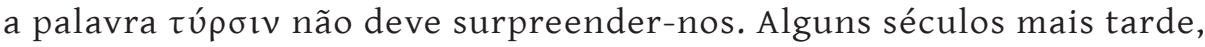
Virgílio escolheu o seu equivalente latino para lhe descrever o aspecto externo no Canto VI da Eneida:

${ }^{1}$ Cf. supra, pp. 30-32.

${ }^{2}$ Até as referências ao Hades são proporcionalmente escassas; o único passo em que se contém uma breve descrição é OI. IX, 33-35.

${ }^{3}$ Por exemplo, Ol. IV, 6; VII, 67; P. I, 71; III, 57; IV, 23; N. I, 16; IX, 19, 28; X, 76.

${ }^{4}$ Ol. VI, 29; IX, 56; P. II, 25, etc.

${ }^{5}$ P. IV, 115.

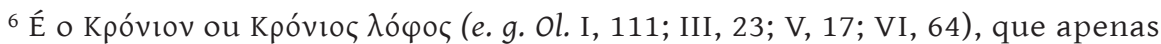
tem interesse geográfico, pois designava uma colina a N. W. do vale de Olímpia. Sobre os ritos que aí se executavam, cf. M. P. Nilsson, Geschichte der griechischen Religion, I, p. 481. 
stat ferrea turris ad auras,

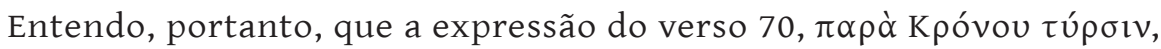
significa que tinham de passar ao longo da torre de Cronos. Tomo pois a preposição num dos seus sentidos habituais, após um verbo de movimento. Tal valor pode exemplificar-se em Píndaro, nos seguintes casos:

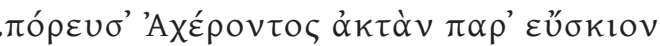

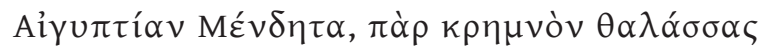

(Frg. 201, 1 Snell) $)^{1}$

e em Homero e outros autores é extremamente frequente. Esta interpretação pode oferecer uma dificuldade, porquanto o हैv $\theta \alpha$ que se segue tem

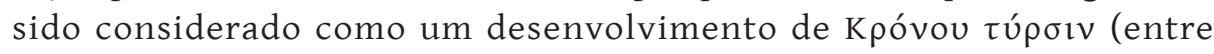
outros, por Böckh apud Rumpel, Lexicon Pindaricum, s. u.). Conquanto o uso de Píndaro forneça grande número de paralelos para essa acepção, há casos que provam que ع́v $\theta \alpha$ pode ser empregado numa relação mais distante e vaga com o que se disse anteriormente, conforme acontece em Ol. VII, 69-74, ou com o que estava na mente do poeta, como em N. X, 19-24:

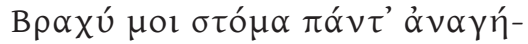

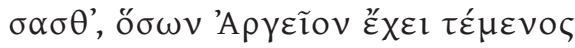

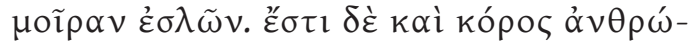

$\pi \omega \nu \beta \alpha \rho \dot{s} \alpha \dot{\alpha} \nu \tau \iota \alpha ́ \sigma \alpha \imath$.

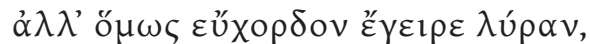

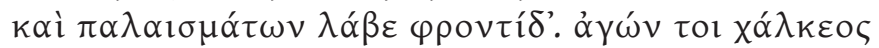

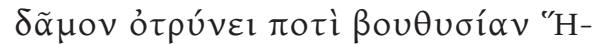

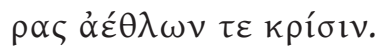

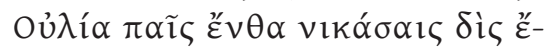

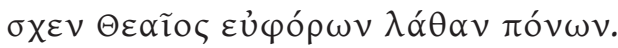

e no Péan V, 37-45:

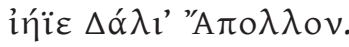

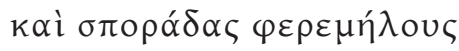

\footnotetext{
${ }^{1}$ Sobre a inexactidão geográfica que este verso reflecte, cf. Élio Aristides, or. Aỉurtíos 112 (II, p. 298, 21 Keil), citado por A, Turyn na sua edição (= Frg. 241).
} 


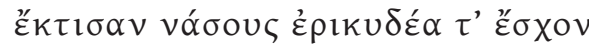

$$
\begin{aligned}
& \Delta \tilde{\alpha} \lambda o v, \dot{\varepsilon} \pi \varepsilon \dot{l} \sigma \varphi \mathrm{vv} \text { 'A } \sigma_{0} \lambda \lambda \omega v \\
& \delta \tilde{\omega} \kappa \varepsilon v \text { ó } \chi \rho \nu \sigma o \kappa o ́ \mu \alpha \varsigma
\end{aligned}
$$

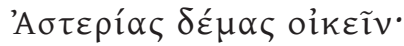

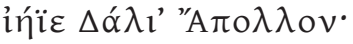

$$
\begin{aligned}
& \Lambda \alpha \tau o ́ o \zeta ~ \varepsilon ้ v \theta \alpha \mu \varepsilon \pi \alpha \tilde{i} \delta \varepsilon \varsigma
\end{aligned}
$$

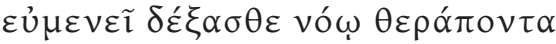

$$
\begin{aligned}
& 4 \text { - } \mu \alpha \kappa \alpha ́ \rho \omega \nu ~ / ~ v \tilde{\alpha} \sigma o v(71-72)
\end{aligned}
$$

Todos os manuscritos que incluem este passo da II $^{a}$ Olímpica apresentam a lição $\mu \alpha \kappa \alpha ́ \rho \omega v$ / vã $\sigma o v$ com excepção apenas de G,

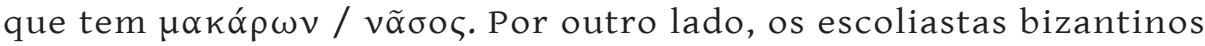
confirmam esta variante isolada, explicando-a como um acusativo do plural dórico.

Discuti já noutro lugar ${ }^{1}$ a possibilidade de admitir esta v. l., que tem a vantagem de se conformar com a tradição. Considerei aí outros exemplos discutíveis de acusativo dórico, já citados por Fennell na sua edição, a saber, Ol. I, 53 e N. III, 24, 29. Como o resultado métrico é o mesmo², a escansão dos versos em que se encontram não nos ajuda ${ }^{3}$.

O único exemplo certo do singular num contexto idêntico é o que se lê no verso 1677 da Helena ${ }^{4}$ :

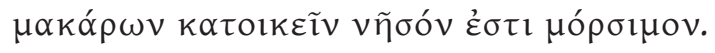

que é manifestamente uma reminiscência da Odisseia, $\delta 567$ seqq., quanto ao teor da profecia. Aqui o texto é seguro, de modo que temos de

${ }^{1}$ Notas a um Passo de Píndaro in Humanitas, IV, 1952, pp. 7-12.

${ }^{2}$ Cf. M. Lejeune, Traité de Phonétique Grecque, pp. 112-113 e C. D. Buck, Introduction to the Study of the Greek Dialects ${ }^{1}$, p. 63.

${ }^{3}$ Para uma discussão de vestígios de metagrammatismos em Píndaro, cf. J. Irigoin, Histoire du Texte de Pindare, pp. 25-26.

${ }^{4}$ A outra referência conhecida a um além feliz, em Eurípides, dá um nome genérico ao lugar:

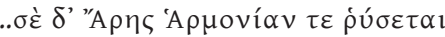

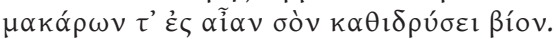

(Bacchae, 1338-1339)

Cadmo, a quem a professia é dirigida, não a considera uma benção. Cf. edição das Bacantes de E. R. Dodds, pp. 222 e 224-225. 
aceitar o singular ${ }^{1}$. No artigo de que falei acima, sugeri a hipótese de o verso de Píndaro se ter alterado muito cedo em vãoov, por se não ter compreendido o acusativo dórico, dando assim origem à forma que aparece em Eurípides.

Com efeito, se procurarmos citações das Ilhas dos Bem-aventurados através da Literatura Grega, facilmente concluiremos que o seu número foi sempre plural, como convém ao carácter vago desse lugar. Só mais tarde, quando o desenvolvimento dos conhecimentos geográficos fez com que se tentasse atribuir uma situação concreta a cada nome, podemos encontrar uma asserção, como a de Plutarco na Vita Sertorii, VIII, de que tais Ilhas eram duas. Na época clássica, em qualquer outro autor, depara-se-nos sempre o indefinido do plural ${ }^{2}$. Todas estas razões me levam a crer que o acusativo dórico representa a lição genuína, embora esta possa ter sido alterada tão cedo que já Euripides a conhecesse numa forma diferente.

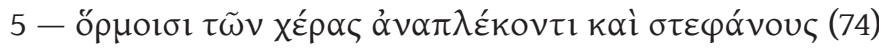

É este um dos mais discutidos versos de Píndaro. Darei, por isso, primeiramente um resumo da questão.

${ }^{1}$ Exemplos tardios, como o que se conserva numa inscrição da época romana (E. Pottier-Am. Hauvette-Besnault, Inscriptions d'Erythrée et de Thrace in Bulletin de Correspondance Hellénique, IV, 1880, pp. 177-180), não interessam aqui.

${ }^{2}$ Enumero a seguir as citações das Ilhas dos Bem-aventurados que se encontram até ao século IV a. C. (além das que já foram analisadas): o skolion de Harmódio e Aristogéiton (Frg. 8 Bergk-Hiller); Aristófanes, Vespae, 639-640; Platão, Symposium, 179E-180B, Menexenus 235C, Rep. VII, 519C, 540B-C. Em Heródoto, III, 26, depara-se-nos um caso muito especial: aí se afirma que o nome do grande oásis do deserto de El-Khargeh devia traduzir-se em

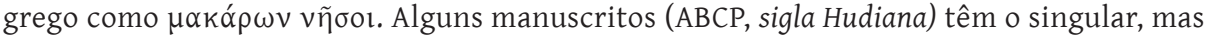
os restantes códices, Eustátio in Odysseam, p. 1509 e Olimpiodoro apud Phot. Bibl. 61 a Bekker apresentam a lição vñ̄ol. Entre os editores modernos, o texto Budé e o Teubner têm o sin-

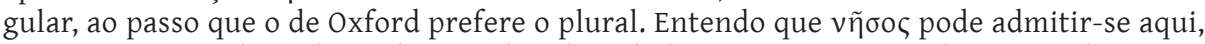
sem com isso implicar discordâncias das ideias helénicas correntes, pelo motivo de o oásis ser só um e de Heródoto estar a traduzir uma palavra egípcia, conforme foi demonstrado por W. Spiegelberg, Die Übersetzung des Wortes Oase bei Herodot III, 26 in Zeitschrift für Ägyptische Sprache und Altertumskunde, 42. Band, 1. Heft, 1906, p. 85 (para uma opinião diferente, veja-se C. Sourdille, La Durée et l'Étendue du Voyage d'Hérodote en Égypte, p. 168, nota 3). Além disso, os oásis eram mansões dos mortos para os antigos egípcios (cf. G. Maspero, Études de Mythologie et d'Archéologie Égyptiennes, vol. II, p. 422 seqq., Le nom antique de la Grande-Oasis, et les idées qui s'y rattachent), e Estrabão, 7. 91 compara-os a ilhas (citado por How e Wells, Commentary on Herodotus, I, p. 263). Para uma discussão da probabilidade de identificação

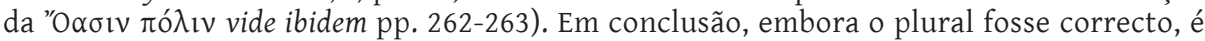
mais natural encontrar aqui o singular:

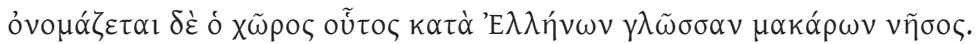


O verbo da frase ( $\alpha \dot{v} \alpha \pi \lambda \varepsilon \dot{\kappa} \kappa o v \tau \imath$ ) está aparentemente construído com dois

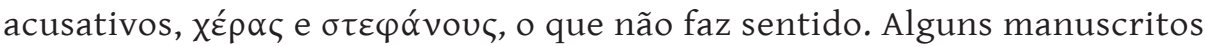

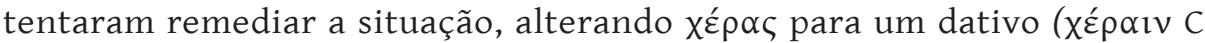

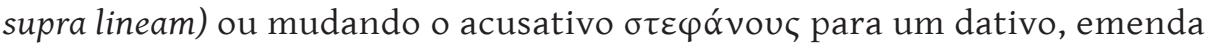
essa que figura em alguns códices como uma correcção (em L, C e N) e é confirmada, além disso, pelos escoliastas bizantinos. Isto significa que a falta de simetria na construção apareceu como um erro a muitos copistas. O mesmo aconteceu a alguns editores do século XIX, como Fennell e

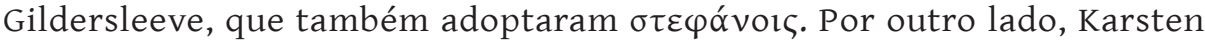

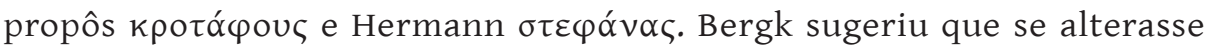

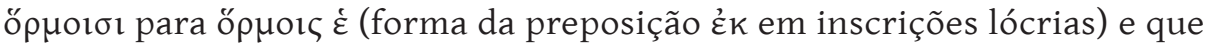
se tomassem ő $\mu$ oı $\sigma$ e $\sigma \tau \varepsilon \varphi \alpha ́$ voıৎ, como acusativos eólicos; esta emenda tem o inconveniente de ir buscar formas a dois dialectos para explicar um

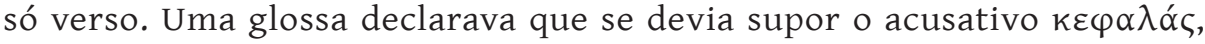

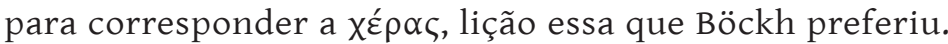

Com efeito, őphor usava-se propriamente para o pescoço e peito, e

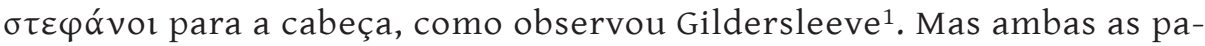

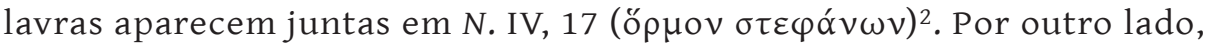
um passo citado por Fennell na sua edição ${ }^{3}$ contém um bom exemplo demonstrativo do uso de trazer nas mãos grinaldas de flores:

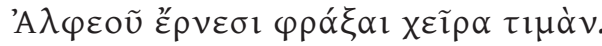

$$
\text { (I. I, 66) }
$$

Parece-me, portanto, que se deve considerar este caso como um dos usos pindáricos da assimetria, de modo que ỏva $\alpha \lambda \varepsilon_{\varepsilon} \kappa o v \tau \imath$ foi primeito empregado no seu sentido próprio de «entretecer», "entrelaçar», tendo

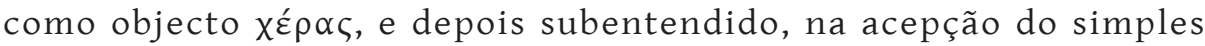
$\pi \lambda \varepsilon \dot{\kappa} \omega \omega$ «tecer ${ }^{4}$, o mesmo verbo que encontramos, por exemplo, em I. VIII, 66-67:

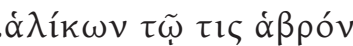

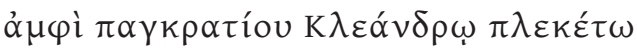

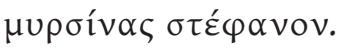

${ }^{1}$ Pindar, The Olympian and Pythian Odes... by R. L. Gildersleeve, p. 151.

${ }^{2}$ Farnell, no seu comentário, diz que este exemplo não convém (vol. II, p. 19). Trata-se, na verdade, de um valor figurado, mas mostra o nexo entre as duas palavras.

${ }^{3}$ P. 35.

${ }^{4}$ Por zeugma, como Galiano observa na sua edição de Píndaro, Olímpicas, vol. I, ad locum. Aimé-Puech também dá a mesma interpretação. 
Em suma, o passo alude a um símbolo característico da concepção helénica de felicidade: as coroas de flores que eram usadas na celebração de um symposium ${ }^{1}$ ou pelos mystae nas suas procissões ${ }^{2}$. Ambas as ideias podem ter sido combinadas aqui.

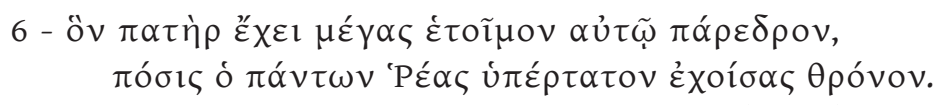

(76-77)

É também passo muito discutido, pelo que começarei por dar um resumo das mais notáveis variantes e correcções.

Quase todos os manuscritos lêm aqui:

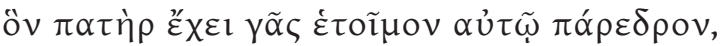

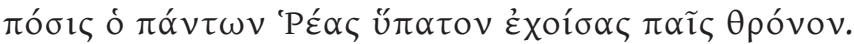

Como os versos não ofereciam bom sentido nem métrica, propuseram-se diversas emendas, desde tempos antigos. Assim, os escoliastas

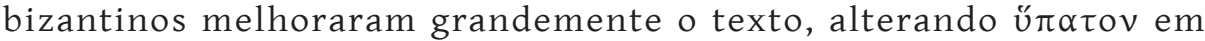

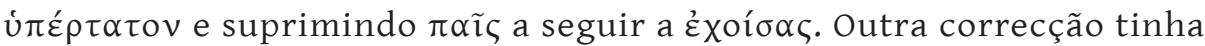

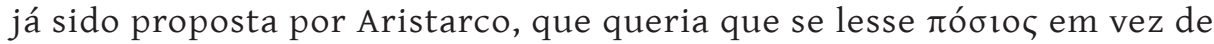

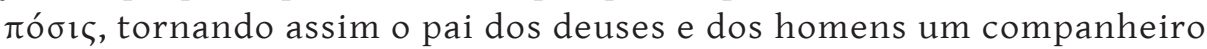
de bebidas de Radamanto; tal proposta, evidentemente, não encontrou aceitação. Por outro lado, Dídimo entendeu que era a Cronos que os versos se referiam. Esta interpretação também causa dificuldades, porquanto o primeiro destes dois versos se refere claramente ao facto de Radamanto ser o assessor de seu pai Zeus, e o segundo menciona o esposo de Reia como sendo aparentemente o mesmo deus. ${ }^{3}$ Para resolver esta aporia, Dissen e Schneidewin propuseram aceitar a lição de ma-

${ }^{1}$ Para uma descrição de um symposium, por um poeta anterior a Píndaro, com $\sigma \tau \varepsilon \dot{\varepsilon} \varphi$ v vor e todos os prazeres que lhe competiam, veja-se um frg. de Xenófanes em Diehl, Anthologia Lyrica, I, 1-12.

Os Hiperbóreos, em P. X, 40, usam coroas de louro:

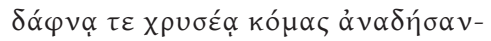

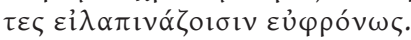

${ }^{2} \mathrm{O}$ mesmo hábito foi transferido para os iniciados no Hades por Aristófanes, Ranae, 324-336. Porém, em Platão, Rep. II 363C-E, é provável que outras seitas religiosas estejam também incluídas.

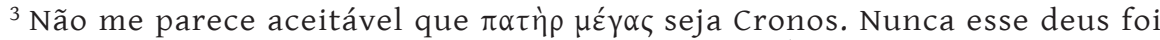
considerado dessa forma senão em época muito tardia (por exemplo, H, Orph. 13, 
nuscritos interpolados, lendo portanto Kpóvoৎ em vez de yã ৎ no verso 76, a despeito de tal modificação contradizer abertamente uma bem definida teogonia. Editores do século XIX, como Fennell e Gildersleeve, aceitaram esse texto com relutância. Fennell acrescentou em nota que suspeitava que $\pi \alpha \tau \rho$ ó $\varsigma$ era a lição original, a qual teria desaparecido por estar a seguir a $\pi \alpha \tau \eta ́ \rho$, donde teria resultado a alteração do paren-

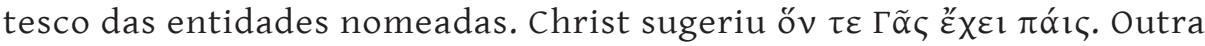

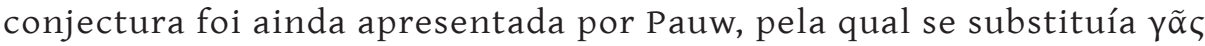

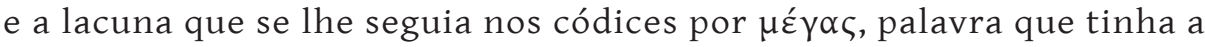
vantagem de lembrar um bem conhecido epíteto homérico dos deuses. A decifração do Pap. Oxyrh. 2092, onde se continha o adjectivo $\mu \tilde{\varepsilon} \gamma \alpha \zeta$, veio demonstrar que se tratava de uma emenda brilhante. Infelizmente, o mesmo papiro omite o verso 77 , de modo que temos de resolver o problema com os nossos próprios recursos.

Seja como for, o texto tal como está não é satisfatório. Que Radamanto era filho de Zeus é facto seguro, desde que a Ilíada assim o afirmara ( $\Xi 321-322)$, e que estava associado a um lugar longínquo, onde certas pessoas privilegiadas viviam felizes, declarava-o a Odisseia, em $\delta 564$ seqq. O bom senso deste herói fora enaltecido por Teógnis, como sendo algo de excepcional ${ }^{1}$. Tudo isto está em perfeita concordância com o que se diz nos versos 75 e 76. Mas o verso seguinte está em desacordo flagrante com toda a mitologia, pois que afirma que o seu pai era também o esposo de Reia, a deusa do mais alto trono.

Penso que o verso pode ser facilmente emendado, de modo a fazer sentido sem alterar o metro, se o lermos desta maneira:

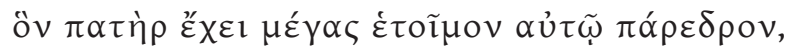

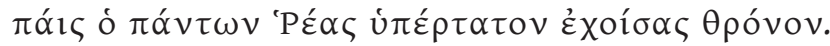

A palavra đó $1 \varsigma$, que está em aposição ao sujeito do verso precedente, apenas tem de alterar a sua posição, passando para o começo da linha, a fim de se obter a verdadeira genealogia do deus: é filho de Reia e o grande pai de Radamanto, que actua como seu assessor, exactamente como Témis em Ol. VIII, 21-23:

1), Ao passo que a Zeus. era dado constantemente esse título. O próprio Píndaro nos fornece disso uma prova no frg. 57 Snell:

$\Delta \omega \delta \omega \vee \alpha \tilde{\imath} \varepsilon \mu \varepsilon \gamma \alpha \sigma \theta \varepsilon v \varepsilon \varepsilon$

$\dot{\alpha} \rho 1 \sigma \tau o ́ \tau \varepsilon \chi \nu \alpha \pi \alpha ́ \tau \varepsilon \rho$

${ }^{1}$ Cf. Diehl, Anthologia Lyrica, I, 701:

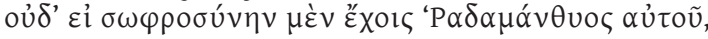




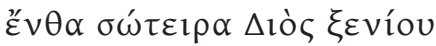

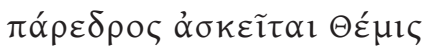

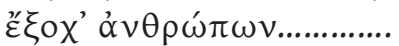

Explica-se assim a presença de đó́ı no verso, tal como figura nos manuscritos, deslocado do lugar que lhe competia, desde que alguém escre-

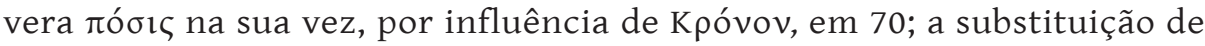

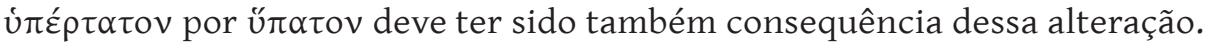

Deste modo, o verso 77 é todo ele um desenvolvimento à volta do nome de Zeus. Esta maneira de o designar está de acordo com a invocação que lhe é dirigida no verso 12 da mesma Ode:

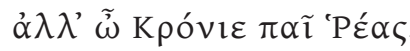

e ainda encontra paralelo no frg. 144 Snell:

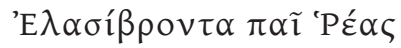

A métrica não se alterava, ainda que lêssemos $\pi \alpha \tilde{\imath} \varsigma$, que formaria a primeira sílaba de um crético, sem a resolução implicada por đóoıc. No entanto, pode-se conservar a correspondência exacta com os outros epodos, escandindo $\pi \alpha i \tilde{\iota}$ como nos poemas homéricos e em Safo. Embora se não encontrem outros exemplos do dissílabo em Píndaro, o facto de ele estar na tradição épica é suficiente para fazer admitir a possibilidade do seu uso pelo poeta.

Agora que examinámos os pontos mais controversos do mito da $\mathrm{II}^{\mathrm{a}}$ Olímpica, é possível coligir os elementos descritivos que nele se contêm e indicar as suas fontes prováveis.

No primeiro lugar privilegiado de que se fala, a ideia de felicidade é

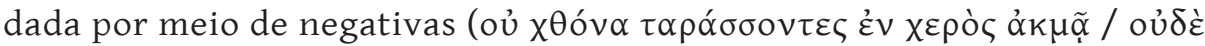

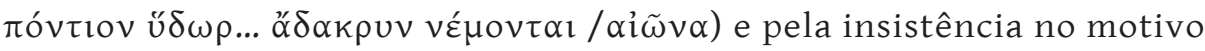

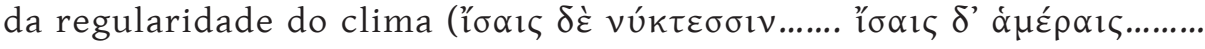
dỉzí.............................).

E finalmente, no verso 70 e seguintes, encontra-se a descrição de um sítio ainda superior. A brisa oceânica sopra em sua volta; há flores de ouro, algumas em árvores, outras trazidas pela água ${ }^{1}$ e os bem-aventurados co-

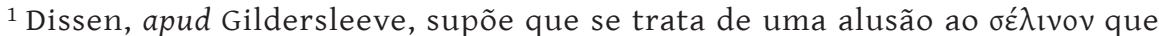
coroava os vencedores dos Jogos Ístmicos; a planta crescia em lugares pantanosos,

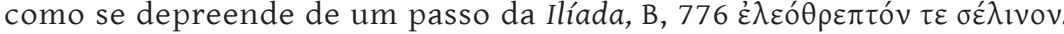


roam as suas cabeças de grinaldas, que eles mesmos entrelaçaram. Vivem sob a legislação de Radamanto, que é o assessor de Zeus. Segue-se uma breve enumeração desses heróis (Peleu, Cadmo, Aquiles).

o primeiro elemento - brisa do Oceano - e o último - a presença de Radamanto - ascendem claramente à concepção homérica de $\delta 561$ seqq. Mas há duas novidades: as flores de ouro e as coroas com que elas se tecem.

Quanto ao segundo ponto, parece ter sido usado para servir um duplo propósito: ajudar a sugerir a ausência de trabalho, visto que não se menciona qualquer outra ocupação, e insinuar a continuidade, no além, dos banquetes que alegravam esta vida.

As flores de ouro dão a nota de brilho que não costuma faltar na poesia de Píndaro. Aliás, o adjectivo xpuбoũ c era sem dúvida favorito do poeta, como símbolo de excelência. De um modo geral, pode dizer-se que a palavra se usava muitas vezes com relação aos deuses ${ }^{1}$. Daí, por extensão, servia para qualificar quanto se prendesse com um modo de vida semelhante.

\section{b) $O$ fragmento 129 Snell $=114$ Bowra $=135$ Turyn}

O famoso fragmento 129 Snell, conservado por Plutarco em Consolatio ad Apoll. 35, p. 120C, trata igualmente da felicidade no além.

Mas, ao passo que na $\mathrm{II}^{\mathrm{a}}$ Olímpica se explicava com algum pormenor o caminho seguido para lá chegar e que a região estava rodeada pelo mar de todos os lados, aqui nada mais se sabe excepto que fica kó $\tau \omega$ e isso, talvez, devido ao estado fragmentário do texto ${ }^{2}$. o facto adverte-nos de que Píndaro não se conformava sempre com os mesmos esquemas e de que via neste género de poesia escatológica mais uma oportunidade para criar beleza do que um pretexto para expor as suas próprias ideias sobre o além.

o primeiro verso tem sido diferentemente interpretado, ou no sentido de que recebem os raios solares com toda a força, enquanto é noite na terra, ou no do que têm luz especial, mesmo quando é escuro aqui. Conquanto tenha havido uma teoria na Antiguidade, corrente entre os egípcios ${ }^{3}$, de que o sol brilhava entre os mortos, quando era noite sobre a terra, essa

${ }^{1}$ Cf. H. L. Lorimer, Gold and Ivory in Greek Mythology in Greek Poetry and Life, pp. 14-33.

2 O fragmento 137 Snell implica a mesma situação.

${ }^{3}$ E. Wikén, Die Kunde der Hellenen von dem Lande und den Völkern der Apenninen Halbinsel bis 300 v, Chr., Diss. Lund. 1937, supõe que a ideia era de origem helénica (citado por Ch. Picard, Les religions préhelléniques (Crète et My cènes), Paris, Presses Universitaires de France, 1948, p. 216). 
ideia não era doutrina aceite entre os gregos na época de Píndaro ${ }^{1}$, e o estilo conciso do poeta favorece a segunda hipótese. Por outro lado, a luz brilhante, como característica de um lugar especial e excelente ${ }^{2}$ era já

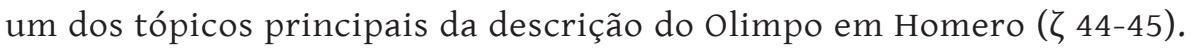

Os três versos seguintes são dedicados à paisagem: há prados de rosas vermelhas e árvores umbrosas de incenso, em frente da sua cidade ( $\pi \rho 0-$

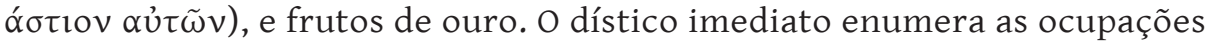
dos bem-aventurados: os cavalos e exercícios de ginástica, xadrez e a música

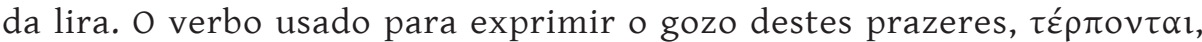
lembra também o verso 46 do Canto VI da Odisseia.

Sem dúvida que se transferiram para o além os entretenimentos favoritos de um grego abastado, como sejam os cavalos e os exercícios físicos ${ }^{3}$. Mas é interessante notar que já se encontrou um tabuleiro de xadrez num túmulo micénico ${ }^{4}$. Quanto à lira, deve ser um contributo

${ }^{1}$ A ideia de o Sol poder brilhar entre os mortos foi apresentada como uma severa vingança na Odisseia, $\mu, 382-383$ :

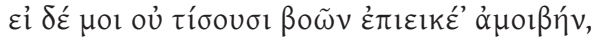

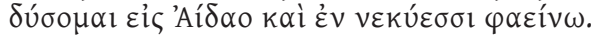

O facto de se ter suspeitado da autenticidade deste passo não diminui o seu interesse.

2 Sobre o significado da luz para os antigos, veja-se o artigo de Rudolf Bultmann, Zur Geschichte der Lichtsymbolik im Altertum in Philologus, Band 97. Heft 1/3,

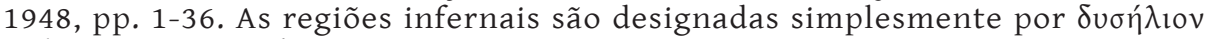

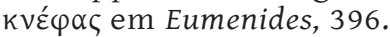

${ }^{3}$ Como sugere E. R. Dodds, The Greeks and the Irrational, pp. 137-138 e p. 159, nota 14 , talvez a ideia se tivesse originado nos sacrifícios de cavalos na pira crematória, como os que na Ilíada se executam em honra de Pátroclo. Sobre a prática de queimar animais, especialmente esses, com o falecido dono, vide J. Wiesner, Grab und Jenseits. Untersuchungen im Ägäischen Raum zur Bronzezeit und frühen Eisenzeit,

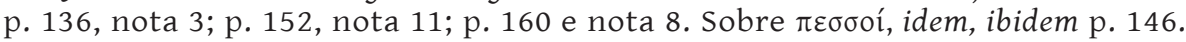

${ }^{4}$ Encontra-se no Museu de Herakleion, em Creta. Heródoto, II, 122-123, ao contar o mito egípcio da catábase de Rampsinito, acrescenta que ele jogou os

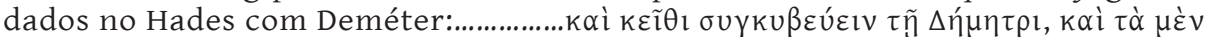

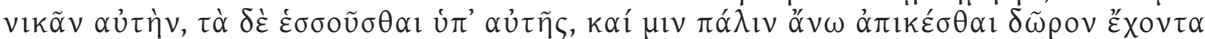

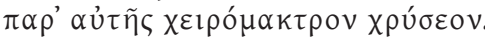

Mas esta espécie de jogo com a própria deusa deve estar relacionada com cenas mágicas, comuns em contos populares. Os egípcios apreciavam muito esse entretenimento, pois tem-se encontrado grande número de dados em túmulos (British Museum Guide, pp. 87 e 178). Row e Wells, no seu Commentary on Herodotus, I, p. 225, citam a história de Satni, conservada num papiro ptolomaico, que ganhou o livro mágico depois de vencer num jogo, e também o mito relatado por Plutarco (De Is. et Os., c. 12) de que Hermes ganhou a Selene (Ísis), ao xadrez, a septuagésima segunda parte de cada dia e que com isso se fizeram cinco «dias intercalados». Sobre o apreço em que os egípcios tinham os jogos desse género, vide Erman-Ranke, Aegypten und Aegyptisches Leben in Altertum, pp. 290 seqq. 
pessoal do poeta, que contrasta com um passo de Teógnis de Mégara (I, 973-976 Diehl), em que ele se queixa de que nenhum homem encontrará deleite no Hades:

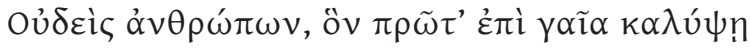

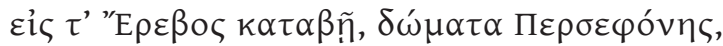

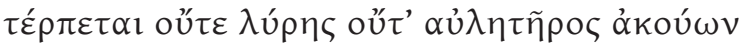

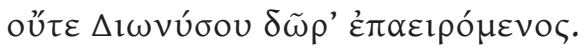

Estes versos pertencem a um tempo em que as perspectivas de um além feliz estavam confinadas aos heróis ou aos iniciados. Portanto não admira que nem todos os poetas mencionassem tal possibilidade.

A suposição de que as ocupações desta vida continuariam na outra era tão antiga como natural. Podem ainda descobrir-se vestígios dela no episódio de Minos, no Canto XI da Odisseia (Minos é juiz no Hades, porque exercera essas funções durante a vida) e nos versos 1160-1161 do Agamémnon, entre outros exemplos.

Voltando ao fragmento 129, há ainda mais alguns pontos a considerar. Particularmente interessante, sob o ponto de vista estilístico, é o verso 7 (5 em A. Turyn), que termina com uma arrojada metáfora:

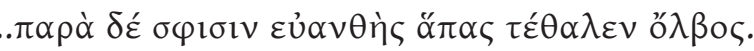

pela qual a costumada referência à fertilidade do solo é transferida para um nome abstracto, a própria felicidade (ő $\lambda \beta$ ○), por meio do emprego do

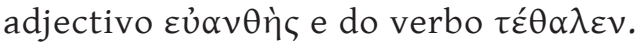

O verso seguinte introduz um novo dado, a saber, a menção de um aro-

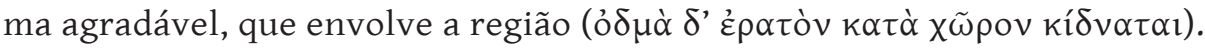
$\mathrm{O}$ fragmento termina com uma referência à continuidade dos sacrifícios feitos nos altares dos deuses. É mais uma maneira de pôr em evidência a virtude da $\varepsilon \dot{\sigma} \varepsilon_{\beta} \beta \varepsilon \alpha^{1}$, que distingue os bem-aventurados.

Pelo que toca à crítica textual, apenas dois pontos requerem atenção

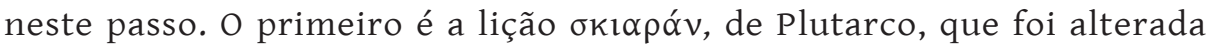

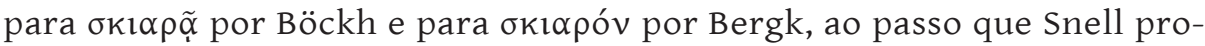

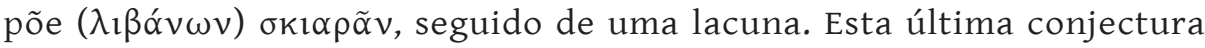
difere da de Bergk em que, fazendo concordar o adjectivo com $\lambda_{\imath} \beta a ́ v v \omega v$, lhe atribui sentido activo, contrariamente ao que sucede com okı $\rho$ óv, que tem de se tomar como passivo, qualificando $\pi \rho o \alpha ́ \sigma \tau ı v$. Sendo este adjectivo formado com um sufixo que permite indiferentemente um ou

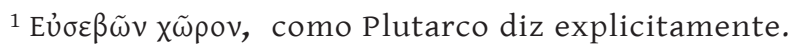


outro valor ${ }^{1}$, ambas as correcções são possíveis. Porém a de Snell, se por um lado tem a vantagem de ser, paleograficamente muito fácil, pois a acentuação é geralmente omissa nos manuscritos, tem o inconveniente de alterar também a palavra precedente. Parece-me que a conjectura de Böckh, também adoptada por A. Turyn, é preferível. porque estabelece o desejado paralelismo com os outros dativos.

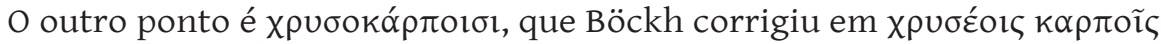

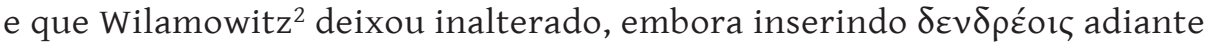

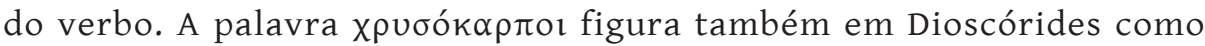
substantivo, com o significado de uma determinada espécie de hera de bagas amarelas, o que fez com que Paton ${ }^{3}$ sugerisse que podia ser o visco ou «Ramo de Ouro». Como Farnell, penso que a correcção de Wilamowitz é

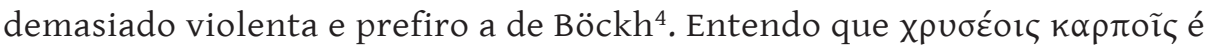

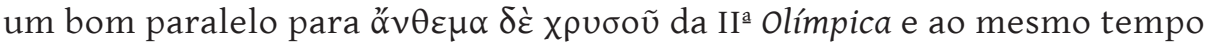
uma reminiscência dos frutos de ouro do jardim das Hespérides.

Em conclusão, deve acentuar-se que muitos dos elementos desta descrição não são novos ${ }^{5}$. Mas o que é realmente novo, e característico de um grande poeta, é a maneira de os apresentar.

1 O próprio Píndaro dá um exemplo disso em Ol. III, 14 ( $\sigma \kappa \imath \propto \rho \tilde{\alpha} v \pi \alpha \gamma \tilde{\alpha} v)$ e 18 ( $\sigma \kappa \iota \alpha \rho o ́ v ~ \tau \varepsilon ~ \varphi u ́ \tau \varepsilon \cup \mu \alpha)$.

${ }^{2}$ Pindaros, p. 497.

${ }^{3}$ The Golden Bough in Classical Review, XXV, 1911, p. 205.

${ }^{4}$ Adoptada também por Aimé-Puech, A. Turyn e C. M. Bowra.

${ }^{5}$ Alguns deles são comuns à descrição da terra dos Hiperbóreos, em $P$. X, 29-48. É um país ao qual conduz um caminho maravilhoso (30). Há festas e sacrifícios, presta-se culto à Musa, canta-se e toca-se flauta. Os Hiperbóreos celebram festas coroados de áureos louros, não sofrem doenças nem velhice, penas ou guerras. Estão livres do tribunal de Némesis. Todos estes dados fazem lembrar o mito da II alímpica e o fragmento 129 Snell. Há ainda um último pormenor que sublinha o efeito, graças ao emprego do próprio adjectivo que é característico destas descrições:

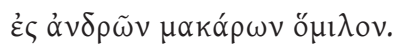

Este passo ajuda-nos a compreender melhor os versos 58-62 da Ode III de Baquílídes, onde se diz que Apolo arrebatou Creso e suas filhas para os Hiperbóreos (cf. supra, pp. 35-36). A descrição de Píndaro é inteiramente poética e nada tem de comum com muitas outras informações que podemos coligir noutros autores. Apenas fez uso de um certo número de tópicos característicos de lugares fabulosos.

Alguns elementos destas descrições são também comuns à que se contém no discutidíssimo óstracon de Safo, que se conserva na Biblioteca Laurenziana-Medicea de Florença e foi publicado pela primeira vez por Medea Norsa, Dai Papiri della Società Italiana in Annali della Scuola Normale Superioce di Pisa, Lett., Scíenze e Filosofia, Serie II, vol. VI, pp. 1-15, Bologna, 1937, e discutida depois por R. Pfeiffer, Vier Sappho-Strophen auf einem Ptotemäischen Ostrakon in Philologus, Band 92, 1937, pp. 117-123, W. Schubart, Bemerkungen zu Sappho, in Hermes, 73. Band, 1938, pp. 297-306 e A. Turyn, The 


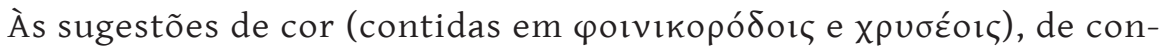

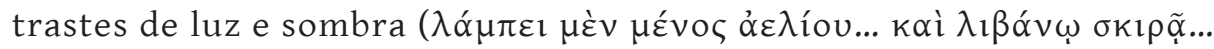

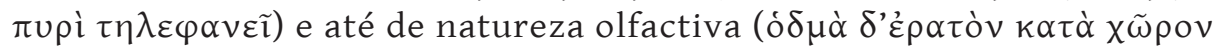

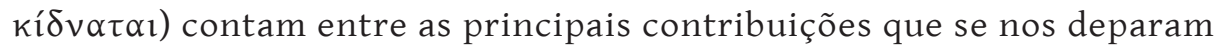
nesta breve citação.

Os outros passos em que Píndaro expõe concepções do além não pertencem a este capítulo, porquanto se mantêm num nível puramente teórico.

Sapphic Ostrakon in Transactions and Proceedings of the American Philological Association, vol. LXXIII, 1942, pp. 308-318. A. Turyn argumenta que, embora seja evidente que é o $\tau \varepsilon ́ \mu \varepsilon v o \varsigma$ da deusa que se descreve, está pintado nas cores convencionais do paraíso grego e aponta os elementos comuns: templo, bosque, altares, incenso, água fresca, rosas, sombras, sossego, prado florido, aroma aprazível. Conclui que uma fonte comum, a saber, os poemas órficos, deve ter fornecido o fundo do quadro. Não vejo a necessidade desta hipótese e subscrevo inteiramente o juízo de R. Pfeiffer, de que não se trata aqui de «Märchenland» ou «Zaubergarten», mas da mais pura e sentida beatitude. Por outro lado, se seguíssemos o critério de A. Turyn, seríamos forçados a acreditar que o frg. 1 Diehl de Xenófanes que, depois de mencionar $\varepsilon \dot{u} \tilde{\omega} \delta \varepsilon \varsigma \mu \tilde{v} \rho \circ$

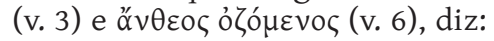

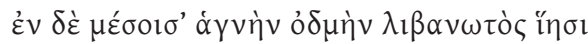

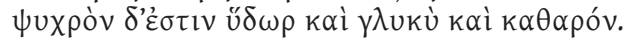

e mais adiante, vv. 11-12:

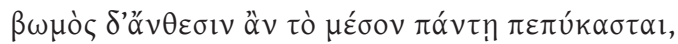

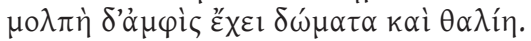

é, não a descrição de um symposium, como nos informa Ateneu, 11, 462c mas um poema "órfico». Alguns destes elementos ocorrem ainda no frg. 128 Diels de Empédocles, na descrição da Idade do Ouro:

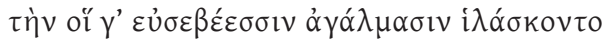

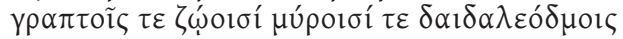

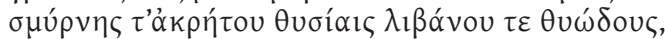

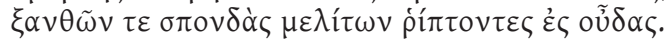

Apenas é lícito concluir que os tópicos que pertenciam a cenas do culto dos deuses eram habitualmente transferidos para qualquer descrição de um lugar de bem-arventurança, quer este fosse imaginado no passado, ou no futuro, ou simplesmente um momento de poesia pura, como parece ser o caso no fragmento de Safo. 
(Página deixada propositadamente em branco) 


\section{CAPÍTULO IV}

\section{«AS RÃS» DE ARISTÓFANES}

Durante os séculos V e IV a. C., a comédia parece ter feito largo uso dos temas escatológicos, para divertimento da audiência. Conquanto apenas As Rãs tenham chegado completas até nós, sabemos que, além de

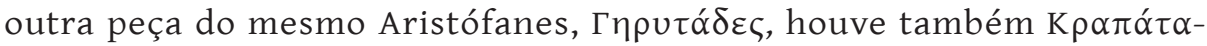

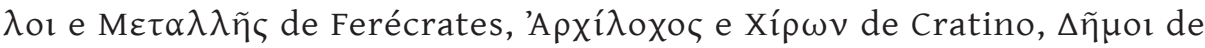
Êupolis e talvez ainda Moṽ $\sigma \alpha$ le Frínico. É extremamente provável que em todas essas comédias se parodiassem as crenças na outra vida, para fazer rir as pessoas dos seus própris temores e esperanças. Mas, como os fragmentos de todas essas obras são tão escassos que poucas informações nos ministram, temos de nos limitar aos elementos que se podem coligir de As Rãs ${ }^{1}$. Por outro lado, o único extracto, desse género, um pouco mais extenso, que chegou até aos nossos dias, a saber, o frg. 108

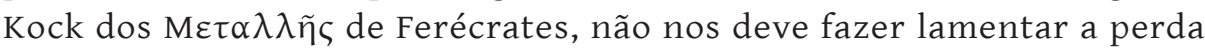
de produções literárias dessa espécie. Os rios de sopa e peixe e outros requisitos do paraíso alimentar, que aí se descreve, são desprovidos de interesse para o assunto que me propus, embora tenham importância para nos ajudar a compreender melhor certos escritos de Luciano.

O caso de Aristófanes, porém, é diferente, porque nunca deixa de ser um artista, mesmo quando está unicamente a meter a ridículo as ideias dos outros.

É evidente que a sua descrição de um além feliz não pode ser analisada da mesma maneira que as dos outros poetas. Não se deve esquecer

${ }^{1}$ É duvidoso se As Rãs são ou não uma paródia do Peirithoos perdido de Eurípides. L. Radermacher nega resolutamente tal possibilidade (na sua edição de As Rãs, Einleitung). G. Murray pensa que os versos 464 seqq. podem ser uma paródia do referido drama (The Athenian Drama: III, Euripides, na tradução de As Rãs, depois reimpressa em The Frogs of Aristophanes, notas ad locum). A perda dessa tragédia inibe-nos de pronunciar um juízo definitivo. 
que muitas vezes há jogos de palavras sobre assuntos do dia e ridículos ocasionais, que deixaram de ser inteligíveis para nós.

De um modo geral, as ideias populares devem ter prevalecido sobre as filosóficas ${ }^{1}$. Por isso mesmo, a comédia tem um alto interesse, porque nos dá um conspecto do que deviam ter sido as concepções mais correntes sobre o além entre os atenienses médios, no final do século $\mathrm{V}$ a. $\mathrm{C}$. O primeiro ponto a notar é que, conquanto Aristófanes mencione algures na mesma peça, assim como noutras ${ }^{2}$ também, as Ilhas dos Bem-aventurados, estas não são sequer consideradas no corpo da obra. Há um lugar privilegiado, mas é no Hades, e destina-se aos iniciados. Por conseguinte, destes dois mitos relativos à bem-aventurança no além, um dos quais aparece pela primeira vez, na literatura, nos Trabalhos e Dias e outro no Hino Homérico a Deméter ${ }^{3}$ é do último apenas que temos de tratar aqui.

É ponto assente que são os rituais e concepções dos iniciados nos Mistérios de Elêusis que se parodiam nesta peça, porquanto são claramente designados mais do que uma vez (por exemplo, 337-338 e 382-386). Até que ponto chegou a imitação, é que não é possível delimitar. A maior parte dos comentadores é de opinião que foram os Grandes Mistérios que serviram de modelo. Por sua vez, T. G. Tucker tentou provar que

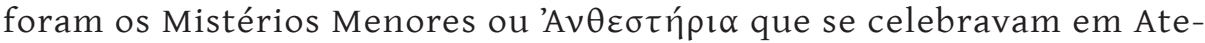
nas ${ }^{4}$. Entendo que não há vantagem em procurar identificar as flores,

${ }^{1}$ No prólogo à sua edição, L. Radermacher escreveu: «Es ist eine Mischung voa volkstümlichen und theologischen Anschauungen».

${ }^{2}$ Um exemplo seguro em Vespae, 639-640. O facto de o coro dizer que teve a impressão de que o julgamento decorria nas Ilhas dos Bem-aventurados, tão maravilhoso era o discurso que ouvira, implica o conhecimento desse mito por parte dos espectadores. A expressão દ́ $\zeta \mu \alpha \kappa \alpha \rho i ́ \alpha v$ em Equites, 1151, já não é tão

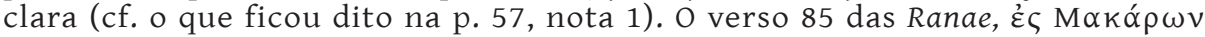
$\varepsilon \dot{\omega} \omega x i ́ \alpha v$ parece conter uma referência à mesma concepção, segundo informa o

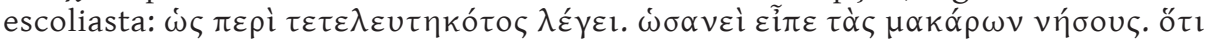

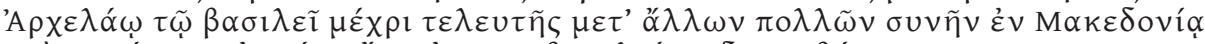

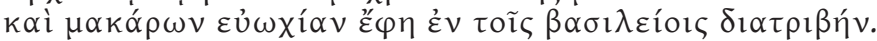

Deste modo torna-se uma «Kontamination aus beiden Redewendungen", como nota Süss na sua edição (Bonn, 1911). Merry sugere um jogo de palavras

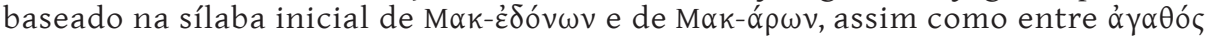
(84) e 'Aүá $\theta \omega v$ (83) (ed. de Oxford, Clarendon Press). Encontra-se paralelo para tais jogos de palavras - que são extremamente frequentes em Aristófanes - na

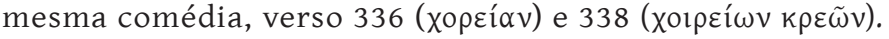

${ }^{3}$ Entre o Hino Homérico a Deméter e Aristófanes, o que resta da literatura grega apenas fornece duas referências à mesma ideia, a saber, o frg. 753 Nauck (= frg. 837 Pearson) de Sófocles e, provavelmente, o frg. 137 Snell de Píndaro (=121 Bowra).

${ }^{4} \mathrm{Na}$ introdução à sua edição, Londres, 1906. A interpretação deste comentador baseia-se, em parte, na lição $\delta \imath^{\prime}$ áyopã (adoptada por Apolodoro Tarsense) no verso 320, em vez de $\Delta$ layópac (segundo Aristarco). O assunto encontra-se discutido em Radermacher, op. laud., p. 181, que cita Wilamowitz, Die Textgeschichte 
o prado e a época do ano, como faz esse editor, porquanto, Aristófanes apenas pintou uma paisagem, idealizada e trabalhou sobre aspectos gerais do ritual de Elêusis.

Também já se afirmou que há dois Hades distintos em As Rãs, separados por uma porta, e que o poeta não teve sequer a preocupação de os reconciliar ${ }^{1}$. Isso é exacto em certa medida, mas julgo que no começo da catábase, desde o aparecimento de Caronte, no verso 180, até ao encontro de Dioniso com Xântias, no outro lado do lago, as ideias tradicionais acerca do Hades não estão menos inextricavelmente fundidas com as inovações de Aristófanes, para fins cómicos, do que, por exemplo, na segunda parte, no episódio de Éaco, cujas palavras ameaçadoras, quando Dioniso bate à porta, vangloriando-se de ser Hércules, são um catálogo dos mais conhecidos, horrores do mundo infernal ${ }^{2}$.

Seja como for, a parte do Hades onde decorre a acção, desde o verso 271 a 459 (parte essa que já fora sumariamente delineada por Hércules em 145-164) retrata sem dúvida o Hades dos iniciados, embora no estilo próprio da comédia. Nesse lugar há duas secções que facilmente se podem distinguir, uma onde os criminosos são castigados ${ }^{3}$ e outra onde

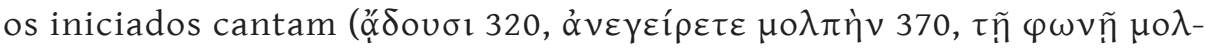

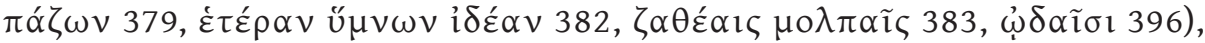

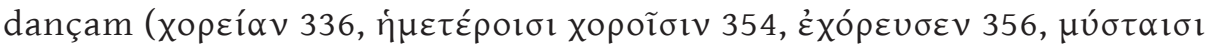

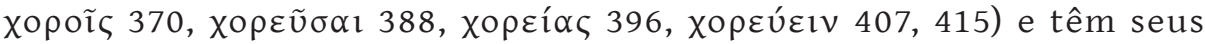

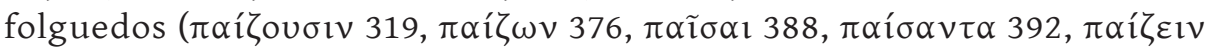
407, $\pi \alpha i ́ \zeta \omega \nu 415, \pi \alpha i ́ \zeta o v \tau \varepsilon \varsigma$ 442, 452). É essa segunda parte que interessa considerar neste capítulo. Além das atitudes já referidas, mencionam-se

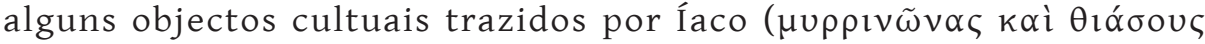

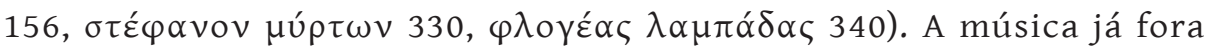

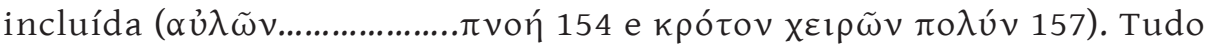
isto deve ter feito parte das cerimónias que se celebravam em Elêusis.

der griechischen Lyriker, pp. 80 seqq.. A segunda alternativa, que também é a do escoliasta, está mais no espírito da comédia.

${ }^{1}$ Cf. L. Radermacher, Das Jenseits im Mythos der Hellenen. Untersuchungen über antiken Jenseitsglauben, cap. I.

${ }^{2}$ Cf. M. P. Nilsson, Geschichte der griechischen Religion, I, p. 769.

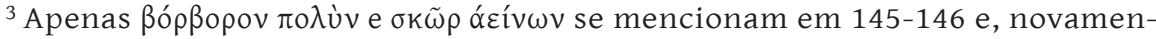

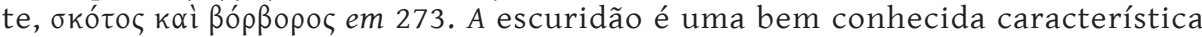
do Hades, desde os tempos mais antigos. Mas acerca de ßó $\beta$ ßo pensa-se em geral que pertence estritamente à linguagem religiosa. A expressão દ̇v $\beta о \rho \beta o ́ \rho \omega ~ \kappa \varepsilon \tilde{\sigma} \sigma \theta \alpha$ s seria aplicada para descrever a sorte dos não iniciados nos infernos. Discuti já esta questão na I⿳a Parte (pp. 2-45). Aqui apenas desejo pôr em relevo o facto de serem pecadores, e não somente pessoas iniciadas, os que sofrem essa penalidade (vv. 145-151). 
A característica mais notável da mansão dos iniciados é a luz brilhante que têm, proveniente não só dos $\operatorname{archotes}^{1}$, como também do Sol, que os ilumina:

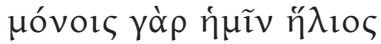

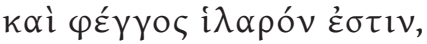

Outros elementos da paisagem são já bem conhecidos, como o $\lambda \varepsilon \imath \mu \omega ́ v$

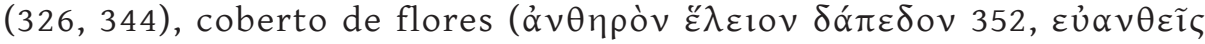

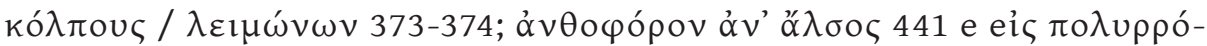

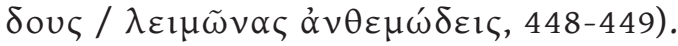

${ }^{1}$ Mencionada no verso 340, num passo duvidoso, em 344 ( $\varphi \lambda$ $\lambda$ ì $\varphi \varepsilon ́ \gamma \gamma \varepsilon \tau \alpha 1 ~ \delta \dot{\varepsilon}$ $\lambda \varepsilon \imath \mu \omega ́ v)$ e, de novo num texto pouco seguro, em 351. Quanto ao verso 340, a maioria dos manuscritos e a edição aldina lêem:

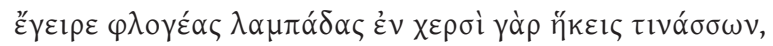

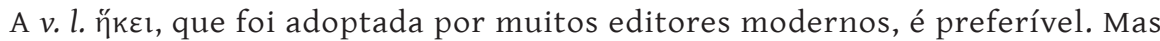
o verso tem sílabas a mais, pelo que se têm experimentado diversas correcções. Assim, Bergk, na edição Teubner, pontua de modo diferente, separando o imperativo do resto da linha, e depois transpõe $\tau \iota v \alpha ́ \sigma \sigma \omega v$ para outro lugar e mete-o entre parênteses:

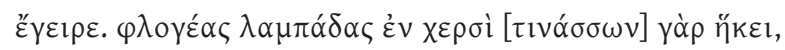

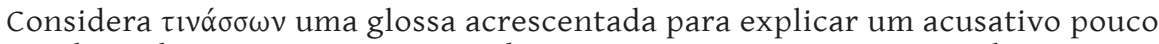
habitual. Tucker seguiu-o. Outros editores, como Van Leeuwen, Kock e Rogers,

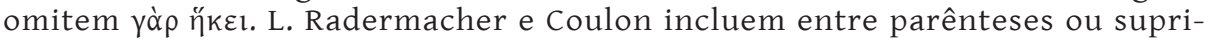
mem mesmo $\lambda \alpha \mu \pi \alpha ́ \delta \alpha \varsigma$, apoiando-se na v. l. de um escoliasta. Esta última solução é difícil de admitir, porquanto não há exemplos de $\varphi \lambda$ altera-se a métrica. Esta exige, para perfeita correspondência com a estrofe, a

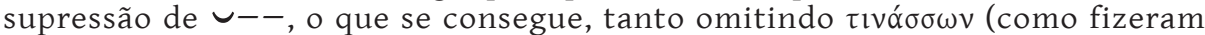

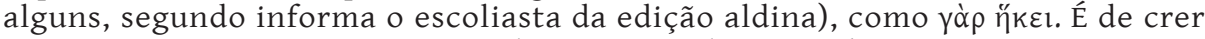
que ou o particípio, ou a partícula com o verbo no indicativo se originassem numa glossa marginal. E, dentre as duas possibilidades, a segunda é sem dúvida

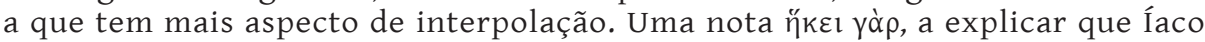
se aproximava, teria sido incorporada no texto por algum copista que houve por bem dar uma feição mais poética à ordem das palavras, invertendo-a, mas não reparou na alteração métrica subsequente. No verso 351, $\varphi \lambda \dot{\varepsilon} \gamma \omega \nu$ também

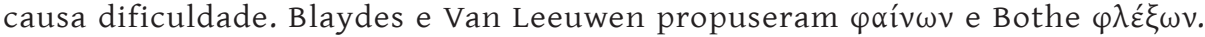

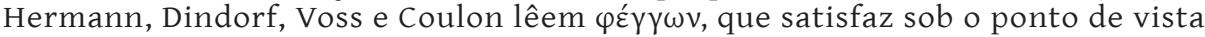
da métrica e do estilo. Radermacher e Hall e Geldart retêm $\varphi \lambda \varepsilon^{\prime} \gamma \omega v$. Conquanto a lição dos manuscritos apresente uma palavra mais comum nesta construção, a métrica favorece $\varphi \varepsilon ́ \gamma \gamma \omega v$ cujo uso está exemplificado nesta peça pelo verso 344 . Há uma certa insistência na ideia de luz incandescente através desta antístrofe:

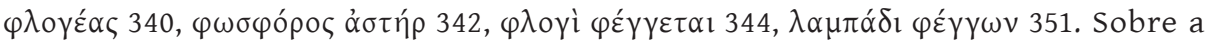
métrica de todo este passo, vide M. Platnauer, Antistrophic Variation in Aristophanes in Greek Poetry and Life, p. 250 (Ionic). 
Afirma-se também que habitam muito perto do palácio de Plutão, em 162-163:

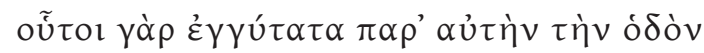

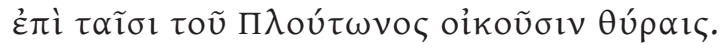

e, de novo, nos versos 434-436:

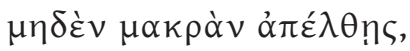

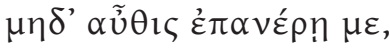

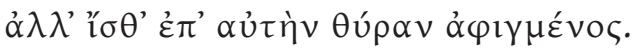

e sabem tudo aquilo sobre que Dioniso deseja ser informado (161).

Em resumo, pode dizer-se que prados cobertos de rosas, um sol brilhante, danças com coroas de flores e archotes, tudo isso constitui a felicidade dos iniciados, que parece consistir em continuar a celebração dos Mistérios no Hades ${ }^{1}$. O quadro é algo semelhante àquele em que

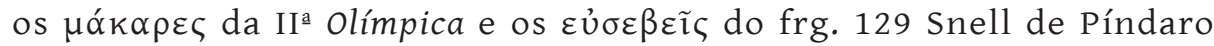
gozavam a bem-aventurança no além.

Há ainda outro lugar mencionado em As Rãs, que costuma andar associado com esse mesmo estado; trata-se de um dos nomes que figuram na discutida enumeração de Caronte, no verso 186:

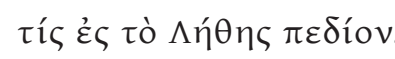

Aí ainda não se designa o rio, que depois havia de tornar-se famoso, mas unicamente os Campos do Olvido, expressão esta em certo modo

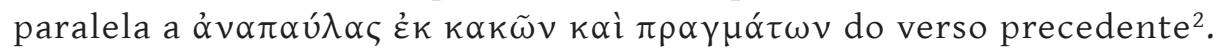

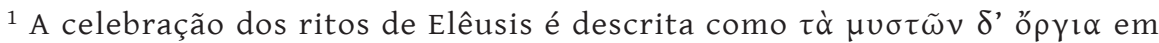
Eurípides, Hercules, 613.

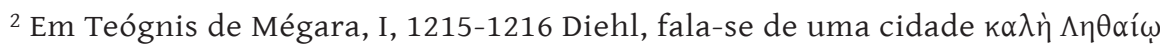
$\kappa \varepsilon \kappa \lambda_{\imath} \mu \varepsilon v \eta \pi \varepsilon \delta$ í $\omega$. O contexto mostra, porém, que se deve tratar de um dos muitos lugares desse nome que havia na Grécia, talvez do que estava situado ao pé de Lebadeia, na Beócia. Cf. Pape, Wörterbuch der griechischen Eigennamen, s. u.

Em Safo, $\varepsilon^{\prime}, 4,11-13$ Lobel,

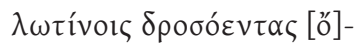

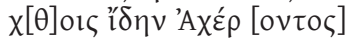

encontra-se uma maneira de descrever o Hades que não tem paralelo conhecido na literatura grega: parece adoptar-se a flor-de-lótus como um belo símbolo poético do olvido. Cf. o efeito de comer lótus no episódio dos lotófagos, na Odisseia. É curioso notar que se vêem muitas dessas flores nas paisagens do Livro dos Mortos dos Egípcios. 
Mas também é provável que ao mesmo tempo o conjunto fosse um jogo de palavras, conforme G. Murray sugere ${ }^{1}$, baseado na semelhança de sons, em volta de uma proposta, «made by some member of the war party, to take the offensive against Sparta by sailing round the Laconian coast - as Tolmides had done - and landing at $\Lambda \varepsilon u ́ k \eta \pi \varepsilon \delta i ́ o v, ~ " O v o u ~ \gamma v \alpha ́ \theta o \varsigma$ (Strabo, 8, 363), and Toívapov».

As Rãs reflectem diversas concepções do além, como já disse. Todas elas serviram a mesma finalidade de fazerem as pessoas rir dos seus próprios temores, como também das suas esperanças, mas as que foram utilizadas para o Hino dos Iniciados ficaram transformadas em poesia do mais puro lirismo.

${ }^{1}$ The Athenian Drama. III. Euripides (que inclui uma tradução de As Rãs, depois reimpressa em The Frogs of Aristophanes), comentário ad locum. 


\section{CAPÍTULO V \\ os MITOS ESCATOLÓGICOS DE PLATÃo}

O destino das almas e as questões com ele relacionadas são um tema muito comum nos diálogos de Platão. Aqui,porém, apenas me ocuparei daqueles passos em que é possível colher elementos descritivos respeitantes à bem-aventurança no além.

Deve, no entanto, notar-se, antes de mais nada, que o uso que Platão faz da tradição varia de acordo com o fim que o autor se propõe atingir em determinada ocasião ou ainda com outros motivos desconhecidos. Assim, os juízes no além, que se diz serem quatro na Apologia 41A (exemplo único que chegou até ao nosso conhecimento), encontram-se reduzidos a três no Gorgias 524A; a etimologia popular que associava o nome do Hades com ảzı rejeitada no Cratylus 404B.

Uma das concepções mais conhecidas de um além feliz exprimia-se frequentemente no mito das Ilhas dos Bem-aventurados. Platão serviu-se dele, como de um modo de dizer corrente, no Menexenus 235C, onde se diz por ironia que os rhetores falavam tão maravilhosamente bem e enalteciam por tal forma a vida do Estado, que durante quatro ou cinco dias pareceu a Sócrates que não habitava na terra, mas nas Ilhas dos Bem-aventurados. Novamente no Symposium, 179E-180B se faz referência ao mito de Aquiles ter sido transportado para esse lugar distante, como prémio pela sua coragem e lealdade (uma versão diferente, portanto, da da II Olímpica de Píndaro).

Outro exemplo ainda aparece na Republica, VII, 519C, onde se diz que os que dedicaram a sua vida ao estudo não desejam tornar-se chefes

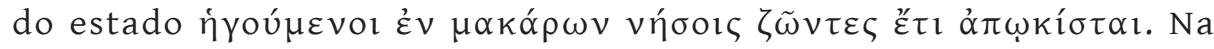
mesma obra, VII, 540B-C supõe-se que os homens públicos que, depois de terem ganho uma boa soma de conhecimentos, tomaram conta do governo, para benefício dos seus concidadãos, merecem passar mais 
tarde para as Ilhas dos Bem-aventurados. ${ }^{1}$ Finalmente, no Phaedo 115D, lê-se que Sócrates acredita que irá para um país especial, que define

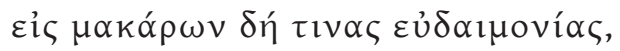

$O$ adjectivo $\mu$ ák $\alpha \rho$ pode referir-se igualmente aos deuses e aos bem-aventura-

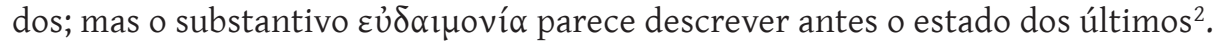

A mesma concepção das Ilhas dos Bem-aventurados foi ainda usada no mito escatológico que parece ter sido o mais antigo, do modo que vamos ver em seguida.

\section{a) O mito do «Górgias» (523A-527E)}

Embora a cronologia das obras de Platão continue a ser um ponto controverso, o mito escatológico do Górgias parece ser mais antigo do que os outros três, e nisso concorda com o critério linguístico de ordenação dos diálogos, conforme observa P. Frutiger ${ }^{3}$.

Está colocado sob a autoridade de Homero, cujo nome se repete mais de uma vez ${ }^{4}$. No entanto, a crença num julgamento no além, à qual se faz referência logo a seguir, está talvez implícita em Homero (Г 276-280; T 258-260), mas não no passo citado no Górgias, porquanto Minos é juiz no Canto XI da Odisseia (quer esses versos sejam uma interpolação ou não), mas num sentido diferente do que tem aqui.

${ }^{1}$ É curioso notar que o povo atribuía uma recompensa semelhante, por feitos políticos, a Harmódio, no skolion já citado, do final do século VI a. C.

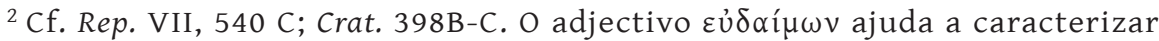
o género de vida que levam as almas que regressam aos astros, em Tim. 42B. Cf. ainda Eurípides, Bacchae, 72-77:

$$
\begin{aligned}
& \tilde{\omega}
\end{aligned}
$$

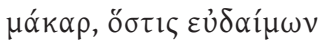

$$
\begin{aligned}
& \tau \varepsilon \lambda \varepsilon \tau \dot{\alpha} \varsigma, \theta \varepsilon \tilde{\omega} v \varepsilon \dot{\delta} \delta \dot{\omega} \varsigma
\end{aligned}
$$

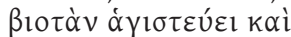

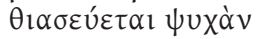

$$
\begin{aligned}
& \varepsilon \dot{~ \varepsilon ้ ~ o ̋ ~} \rho \varepsilon \sigma \sigma l \beta \alpha \kappa \chi \varepsilon u ́ \omega v
\end{aligned}
$$

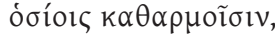

com o comentário de E. R. Dodds ad locum, na sua edição dessa tragédia, pp. 72-73:

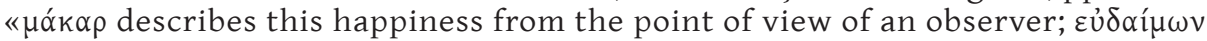
(one of the keywords of the play) gives it from the experient's point of view and suggests the reason for it ('having a good $\delta \alpha i ́ \mu \omega v ') »$.

${ }^{3}$ Les Mythes de Platon, Étude philosophique et littéraire.

${ }^{4}$ Cf. H. W. Thomas, 'E $\pi \varepsilon ́ \kappa \varepsilon ı v \alpha$. Untersuchungen über das Überlieferungsgut in den Jenseitsmythen Platons, pp. 6, 8 seqq. 
Os elementos descritivos que se podem colher no texto são a bifurcação ( $\dot{v} \tau \tilde{n} \tau \rho ı$ ó $\delta \omega$ 524A) e o prado (ibidem), no qual ela se situa, e de onde dois caminhos distintos levam as almas, ou ao Tártaro, que é classificado de $\delta \varepsilon \sigma \mu \omega \tau$ ńpıov (523B), ou às Ilhas dos Bem-aventurados.

Tem-se feito remontar a origem do $\lambda \varepsilon \iota \mu \omega ́ v$ ao $\alpha \sigma \varphi \circ \delta \varepsilon \lambda$ òv $\lambda \varepsilon \iota \mu \tilde{\omega} \nu \alpha$ de $\lambda 539^{1}$ e de $\omega$ 13. Um prado fazia também parte da mansão dos

${ }^{1}$ O significado da denominação homérica tem oferecido dúvidas. O schol. propunha já uma v. l. $\sigma \pi \circ \delta \varepsilon \lambda o ́ v$, para dar o sentido de "campo de cinzas». Outro ponto

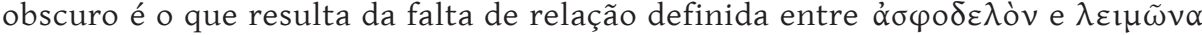
porquanto as duas palavras estão em aposição. Cf. V. Bérard, Introduction à l'odyssée, vol. I, p. 198. Por sua vez, Stanford comenta na sua edição, ad locum: «The asphodelus ramosus is a lean, spiky plant with inconspicuous flowers, and is most commonly found in desolate ground». O facto de Plínio, Historia Natutalis, XXI, 68, afirmar que se plantava nos túmulos (citado por Stanford, ibidem) também não é concludente, porque pode tratar-se de um uso tardio. Para uma discussão completa da matéria, veja-se o artigo de G. Soury, La vie de l'au-delà. Prairies et Gouffres in Revue des Études Anciennes, 1944, pp. 169-178.

A planta era extremamente vulgar e fácil de obter na Grécia antiga (como o prova o verso 41 dos Trabalhos e Dias de Hesíodo), tanto como o é na actual. Este facto, combinado com o uso da mesma expressão em dois passos do Hino Homérico a Hermes (221 e 344), que Liddell-Scott traduzem por "the flowery mead", e onde na verdade não há qualquer relação com o Hades, leva-me a crer que estamos em presença de uma fórmula épica, paralela a $\lambda \varepsilon \iota \mu \omega ̀ v \alpha ̉ v \theta \varepsilon \mu o ́ \varepsilon ı$, que

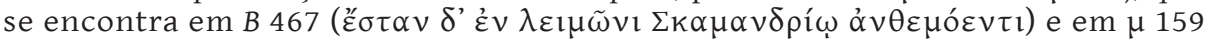

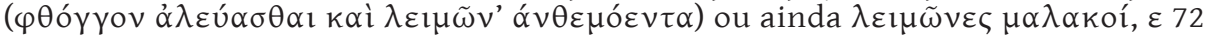

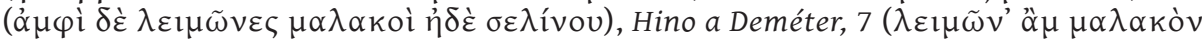

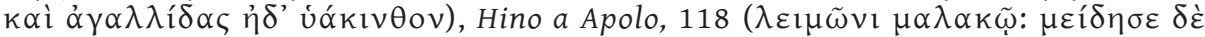

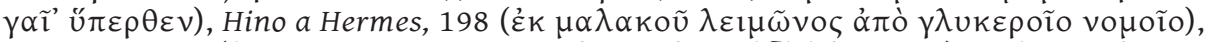

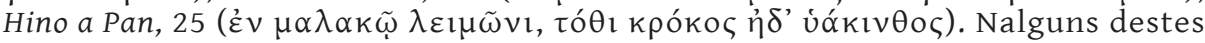
exemplos especificam-se as flores pelos seus nomes. O mesmo acontece com $\dot{\alpha} \sigma \varphi \circ \delta \varepsilon \lambda$ òv $\lambda \varepsilon \iota \mu \tilde{\omega} v \alpha$, que certamente era considerada apenas como uma fórmula para designar um prado. Coisa semelhante se verifica nas obras de Camões, para quem os campos estavam quase sempre esmaltados de boninas. Bastará citar alguns exemplos (para as Éclogas, os números e páginas são os da edição da série Acta Vniuersitatis Conimbrigensis, Coimbra, 1953):

Os campos esmaltando de boninas

(Écloga II, «Ao longo do sereno», p. 351)

O campo, como dantes, não se esmalta

De boninas azuis, brancas, vermelhas:

(Écloga V, «A quem darei queixumes», p. 385)

De boninas que o prado ameno veste

(Écloga III, «Passado já algum tempo que os amores», p. 369)

Qual campo revestido de boninas

(Lusíadas, I, 58)

Em todos estes passos, como noutros ainda, bonina é um simples sinónimo de flor, conforme demonstrou Augusta Gersão Ventura, Subsídios para o estudo da 
iniciados em As Rãs de Aristófanes (326, 344, 373-374, 448-449) e não é alheio de todo ao cenário do frg. 129 Snell de Píndaro, embora não esteja explicitamente designado. Consta também de uma das lâminas de Túrios. Fazia parte, por conseguinte, do núcleo tradicional das representações do além. Mas em Platão passou a ser apenas o lugar onde se executavam os julgamentos.

Deve-se notar que não há indicações sobre a situação desse prado, nem das Ilhas dos Bem-aventurados, nem do Tártaro. Não é de crer que sejam subterrâneos, pois o costumado advérbio kó $\tau \omega$ não aparece. Tem de concluir-se que são simplesmente opostos ao lugar

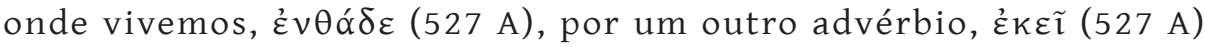
ou $\dot{\varepsilon} \kappa \varepsilon \tilde{\imath} \sigma \varepsilon(527 \mathrm{~B})$.

Acrescenta-se ainda que os que vão para as Ilhas dos Bem-aventurados

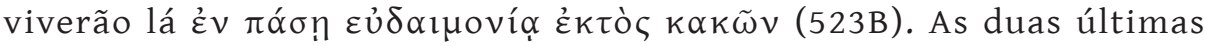
palavras lembram imediatamente o verso 115 dos Trabalhos e Dias, onde Hesíodo descreve a condição humana na Idade do Ouro:

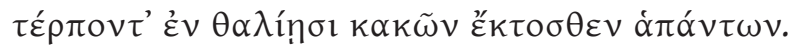

Evidentemente que não é forçoso supor que se trata de uma fórmula estereotipada, mas o exemplo serve para provar que a noção de bem-aventurança, quer fosse referida ao passado ou projectada no futuro, se concretizava facilmente em termos semelhantes.

As Ilhas dos Bem-aventurados eram governadas por alguns $\dot{\varepsilon} \pi \iota \mu \varepsilon \lambda \eta \tau \alpha i ́$ (523B), a que não são dados nomes. E não há mais indicações sobre esse lugar privilegiado.

Em conclusão, no mito do Górgias o interesse concentra-se à volta do julgamento das almas e dos destinos que lhes competem. Essas são as verdadeiras novidades da narração: que há três juízes, dos quais um tem a jurisdição suprema, e cujos nomes são discriminados, e que há castigos, tanto para as almas incuráveis, como para as que são susceptíveis de cura. Não se oferece qualquer descrição da mansão

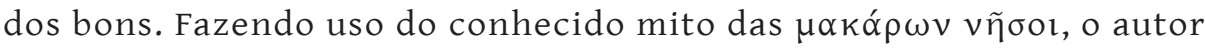
não precisava de entrar em pormenores. Somente quando apresenta paisagens e lugares da sua invenção é que o poeta se compraz em lhes definir os contornos.

Flora Camoniana, IV, Coimbra, 1933. A bonina, que é uma flor dos campos vulgar, deve ter produzido no poeta quinhentista uma impressão semelhante à que o asfodelo causou aos antigos. 
b) O mito do «Fédon» (107D-114C)

O mito do Fédon compõe-se de diversas partes, das quais apenas algumas dizem respeito ao tema deste capítulo. Tentarei primeiro delimitá-las, para depois analisar os passos que interessam.

Como habitualmente, há uma introdução, que começa com as palavras $\lambda \dot{\varepsilon} \gamma \varepsilon \tau \alpha \iota$ $\delta \dot{\varepsilon}$ oü $\tau \omega \varsigma$ (107D). Essa parte apresenta o esquema de toda a narrativa: refere-se ao julgamento das almas, conduzidas por um

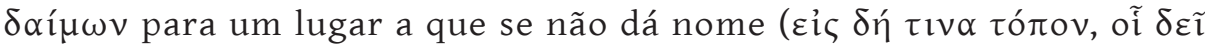

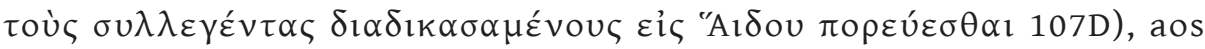
castigos que deverão purificar os maus, e ao prémio que recebem os bons,

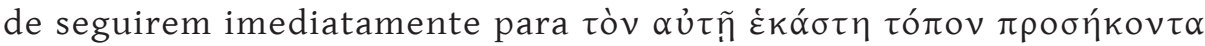
(108C); depois, à constituição da terra, com uma região superior, melhor e mais bela do que a nossa, e os lugares corruptos onde habitamos, que não são mais do que uma imagem degradada daquela (108C-110B).

Após esta breve comparação, começa a descrição propriamente dita

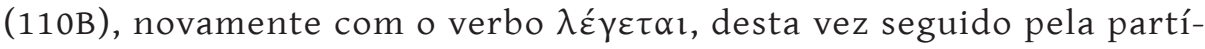
cula toívuv, que responde ao convite, anteriormente endereçado por Símias a Sócrates, para continuar a sua narrativa. Agora, em vez dos termos genéricos que se nos deparavam na primeira parte, tais como

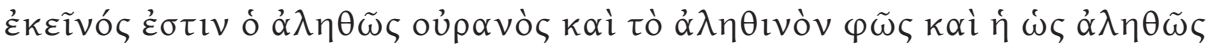

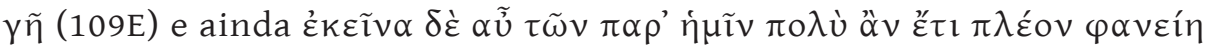
$\delta i \alpha \varphi \varepsilon ́ \rho \varepsilon \imath v$ (110A), surge o quadro completo da terra, principiando por uma exposição sobre a sua forma e cores, quando vistas do exterior. É aqui que se encontra a primeira sugestão cromática, que é imediatamente desenvolvida (110C): os tons são semelhantes aos usados pelos pintores, mas mais brilhantes e mais puros. Discriminam-se expressamente a

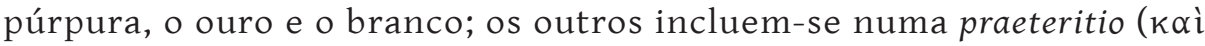

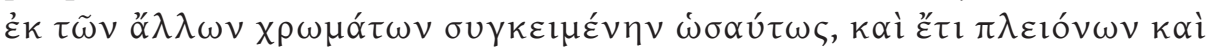

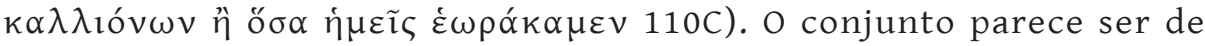
uma cor uniforme, devida à mistura de todos esses cambiantes cheios de brilho com os vapores exalados das cavernas em que vivemos.

A seguir à noção de cor, aparece a nota da abundância, da plenitude

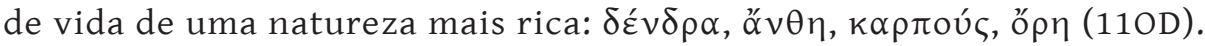
Até as pedras têm o seu lugar, insistindo-se novamente na beleza das suas tonalidades, na sua transparência, no seu toque macio. Estes tópicos novos trazem consigo outro: o das pedras preciosas (entre as quais se

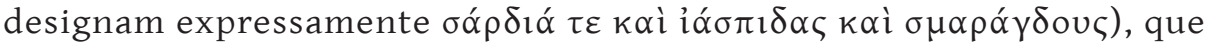
vêm acrescentar o seu fulgor a este quadro irradiante de luz (110D-E), mais adiante completado com o ouro e a prata (11OE), de molde a constituir um espectáculo que dá felicidade contemplar (111A). Há também animais, em maior variedade, e, finalmente, seres humanos (111A). Sobre 
estes diz-se que parte mora $\mathcal{\varepsilon} v \mu \varepsilon \sigma o \gamma \alpha i ́ \alpha$, outros junto do ar (que para

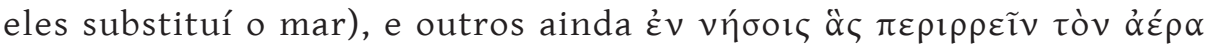

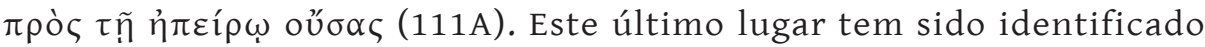
com as Ilhas dos Bem-aventurados ${ }^{1}$. Na verdade, podíamos estar em face de uma tentativa de reconciliação de tradições divergentes acerca do local da mansão dos eleitos. Tal conjectura parece-me desnecessária. Julgo que a intenção do autor era muito simplesmente dar a entender que, como nós, esta raça de homens superiores podia viver no interior do continente, à beira-mar ou em ilhas. De passagem, acentua ainda a diferença entre as regiões cercadas pela água comum e as rodeadas de ar (111B). Esses seres são também superiores pela qualidade dos seus sentimentos e intelecto (111 B). Têm templos, onde os deuses habitam de verdade, e com eles têm comércio. O Sol e a Lua vêem-se tal como

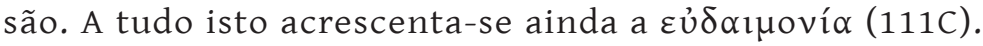

Logo a seguir vem a descrição da terra onde vivemos, com o Tártaro nos seus mais íntimos recessos, e uma exposição da teoria acerca do curso das águas, com os quatro rios principais (111C-113D), que nos conduz novamente ao lugar sem nome onde as almas se encontram para serem julgadas. Esse episódio não nos interessa aqui ${ }^{2}, c$ com excepção da última parte, onde se faz referência àquelas ồ $\delta$ ó $\xi \omega \sigma l$

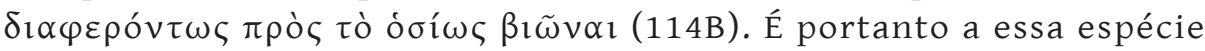
de almas que é dado habitar na verdadeira terra, aquela que anteriormente se descrevera:

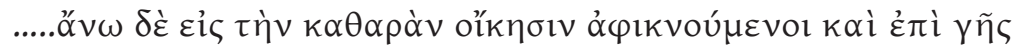
oỉklópevor.

Entre estas, porém, há ainda uma classe que se deve distinguir, a daqueles que se consagraram inteiramente à filosofia e que assim se purificaram por completo. Esses viverão para sempre, incorpóreos, em lugares demasiado maravilhosos para se poderem descrever:

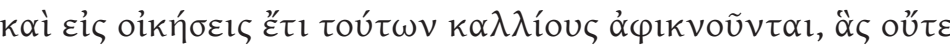

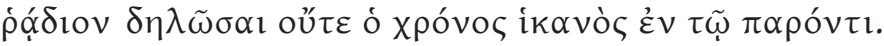

\footnotetext{
${ }^{1} \mathrm{Na}$ edição Budé, por exemplo (de L. Robin).

${ }^{2}$ Deve notar-se que também aqui, como no Górgias, há uma classe de pecadores que é susceptível de se purficar, e, o que é mais, alguns deles parecem ser castigados pelos seus crimes e, ao mesmo tempo, recompensados pelo bem que fizeram (113D).
} 
De um modo geral, a parte do mito que diz respeito ao assunto em causa é a descrição da verdadeira terra, que se encontra enquadrada na tentativa de cosmografia. Platão imaginou-a como um lugar onde se gozava uma vida de bem-aventurança, embora fale de outro ainda melhor e mais belo, no final, conforme acabámos de ver. Como todos os sítios desse género, é superior em tudo àquele em que habitamos. Mas no Fédon insiste-se em especial nos efeitos de luz e cor. Aos tópicos tão conhecidos já das belas árvores, flores e frutos, acrescentam-se agora os das pedras preciosas, ouro e prata, maior variedade de animais e homens mais bem dotados, e estabelece-se a equivalência entre a nossa água e o ar deles, e entre o nosso ar e o seu éter. A ideia dos templos dos deuses não é nova, mas é-o a da presença destes últimos e a do seu convívio com os homens. A palavra $\varepsilon \hat{\delta} \delta \iota \mu o v i ́ \alpha$, com a qual se encerra essa parte da narrativa (111C), põe em relevo o significado do conjunto: o seu sentido mostra claramente como esta maneira de viver está integrada nas bênçãos da presença divina e resume o sentimento de felicidade completa, de que lhes é dado gozar.

\section{c) O Mito de Er («Rep.»X, 614A-621D)}

Ao analisarmos este mito, que apresenta uma concepção do universo absolutamente diferente da do anterior, vamos deter-nos com mais demora naqueles passos que se prendem directamente com o tema em estudo.

Como todos os outros mitos escatológicos, divide-se em três partes, das quais a primeira forma a introdução (614A), a do meio contém a narrativa (614B-621B) e a última a conclusão, que consiste numa exortação à virtude (621C-D).

O primeiro lugar que se menciona recebe apenas a designação de

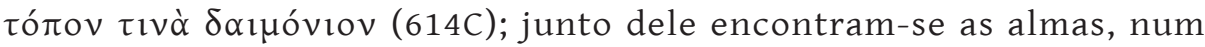
prado $(\lambda \varepsilon \imath \mu \omega ́ v$ 614E, 616B). É aí que estão os juízes e que se vêem duas aberturas em baixo e duas em cima (614C). Essas aberturas ( $\chi \alpha ́ \sigma \mu \alpha \tau \alpha$ ) marcam o caminho que as almas seguem: duas são para descer ou subir para o céu, depois de a sentença lho ter ordenado, e as outras duas para ir para a terra ou regressar de lá.

O encontro das almas e suas conversas dá lugar à descrição de castigos, que conduz ao caso particular de Ardieu. Este, ao mesmo tempo, oferece um exemplo de penalidades perpétuas, que se desenrolam num quadro impressionante e dramático, em que há almas a quem é recusada

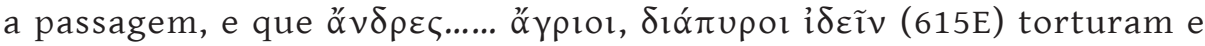
empurram novamente para o abismo. 
A parte que se segue trata da estrutura do universo.

O primeiro elemento a ser notado é $\varphi \tilde{\omega} \varsigma . . .$. oĩov kíov $\alpha . . . . . . \lambda \alpha \mu \pi \rho$ ó $\tau \varepsilon-$

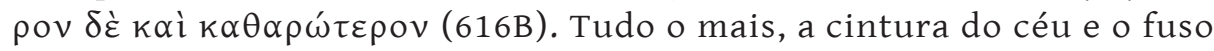
da Necessidade, com um gancho de diamante e pesos encaixados uns nos outros, cada um dos quais com uma cor diferente ( $\pi$ oıkí $\lambda$ ov, $\lambda \alpha \mu \pi \rho o ́ \tau \alpha \tau o v$, $\xi \alpha v \theta o ́ \tau \varepsilon \rho \alpha, \lambda \varepsilon \cup \kappa o ́ \tau \alpha \tau o v, u ̉ \pi \varepsilon ́ \rho v \theta \rho o v)$, mas alguns parecidos, as sereias a tocar, acompanhadas pelo canto das Parcas, tudo isto denuncia uma concepção astronómica, que foi revestida de forma poética. Quanto à cor dos pesos, que parecem ser usados como símbolos dos planetas, do Sol e da Lua, já vimos ${ }^{1}$ que estava de acordo com os ensinamentos dos sacerdotes caldaicos sobre o assunto. Como é costume da língua grega, descreve-se mais o brilho do que a tonalidade propriamente ${ }^{2}$.

A cena seguinte é preenchida com a narrativa da escolha das sortes e do comportamento das almas nessa ocasião, de acordo com a sua passada experiência (617D-619E). Em breve surgem os exemplos ilustrativos de figuras célebres, numa espécie de réplica do Canto XI da Odisseia, quase com os mesmos heróis em cena, mas em atitudes diferentes. Uma vez que o seu destino foi confirmado pelas Parcas e ratificado por Ananke, as almas seguem para o $\Lambda \eta \theta_{\eta} \varsigma \pi \varepsilon \delta$ íov (621A), onde bebem do rio Ameles e adormecem. Após a meia-noite, são despertas por um trovão e um tremor de terra e fogem como estrelas. Esta metáfora de natureza cósmica põe fim à narrativa da maneira mais adequada. O acordar de Er termina o mito (621B).

O $\tau \tilde{\eta} \varsigma \Lambda \eta ́ \theta \eta \varsigma ~ \pi \varepsilon \delta$ íov que aqui se menciona em relação com a metempsicose, não era novo na literatura grega. É de crer até que se tivesse tornado popular, porquanto fora citado por Aristófanes entre as localidades do Hades (Ranae, 186). Platão aplica o mesmo nome ao próprio rio, por extensão, algumas linhas mais adiante:

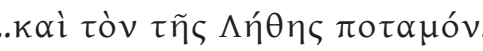

\section{(621 C)}

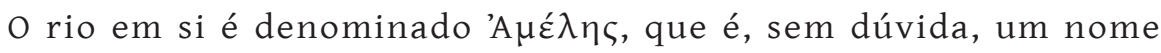
significativo, não menos do que Letes. É interessante notar que, mais tarde, o curso de água conservará a denominação da planície e andará especialmente associado aos Campos Elísios. Porém no mito de Er temos um tipo de paisagem completamente oposto, pois é $\kappa \varepsilon v o ̀ v \delta \varepsilon ́ v \delta \rho \omega \nu \tau \varepsilon$

\footnotetext{
${ }^{1}$ Cf. supra p. 69.

${ }^{2}$ Cf, J. Bidez, Les Couleurs des Planètes dans le Mythe d'Er le Pamphylien.
} 


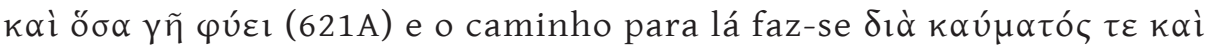
$\pi v i ́$ ous $\delta \varepsilon \imath v o \tilde{v}(621 \mathrm{~A})$.

Se procurarmos colher elementos acerca da mansão dos bem-aventurados (que, como no Fédon, pode ser temporária), depara-se-nos uma grande escassez de informações. Apenas podemos saber que o seu caminho é fácil e celeste (619E), que levavam uma vida agradável e vêem

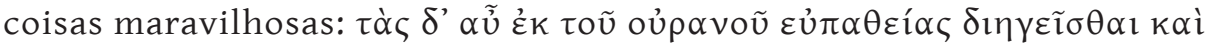

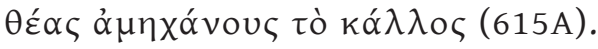

Aqui toda a atenção do poeta se concentra no sistema do cosmos, castigos e destino das almas. Escolheu a descrição do universo, com a sua harmonia de cores, formas e sons, para desenvolver o tema da beleza e da ordem, e os castigos para contraste daquele. A felicidade dos bem-aventurados só podia ser descrita por meio de praeteritio, para não perturbar o equilíbrio da composição.

\section{d) O mito do «Fedro» (246A-257B)}

O famoso mito do cocheiro e dos seus dois cavalos constitui a quarta narrativa escatológica dos diálogos de Platão.

Aqui a atenção está voltada principalmente para o passado das almas, a fim de explicar a teoria da reminiscência da beleza. Como nos mitos do Fédon e de Er, a cosmologia alterna a cada passo com a mais pura invenção poética.

Assim, a procissão dos deuses e das almas (246D-247E), que por momentos parece apoiar-se na teoria astronómica da revolução dos planetas $^{1}$, recebe um cunho poético com a descrição daquele úđepoupóvio

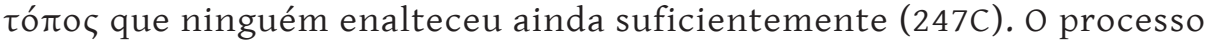
que Platão usa para sugerir a sua beleza é talvez uma das suas mais soberbas realizações estilísticas. O lugar é designado, algumas linhas mais abaixo, por $\tau$ ò $\alpha \lambda \eta \theta \varepsilon i ́ \alpha \varsigma . . . . . \pi \varepsilon \delta$ íov (248B) e identificado com a Verdade

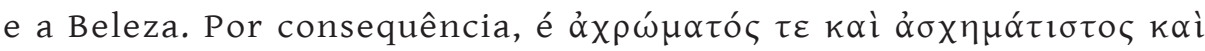

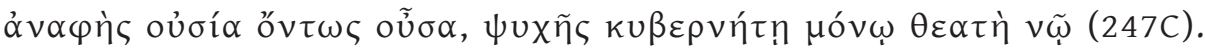
Este processo de definir por meio de negativas põe em relevo a impossibilidade da percepção sensorial. O gozo dessa pura abstracção invade a alma aos poucos, e os sentimentos que daí resultam são que $\alpha \hat{\gamma} \alpha \pi \tilde{\alpha} \tau \varepsilon$

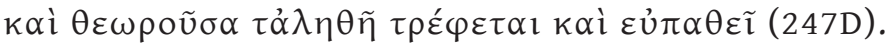

O conhecimento que a alma adquire é definido de maneira muito semelhante:

${ }^{1}$ Cf. E. R. Dodds, The Greeks and the Irrational, p. 261, nota 53. 


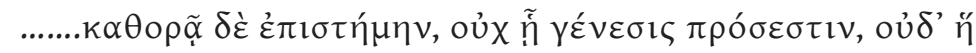

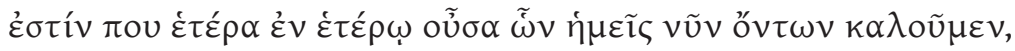

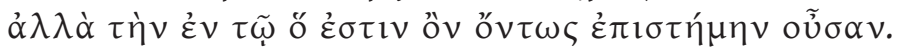

(247D-E)

Mais adiante (250B), descreve-se a própria Beleza:

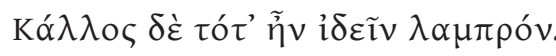

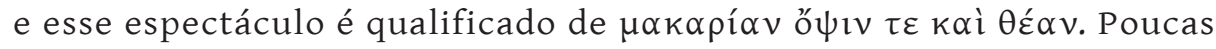
linhas depois, o uso de termos pertencentes à religião dos Mistérios sublinha o efeito deste todo:

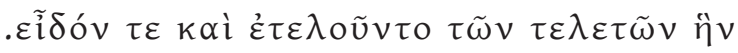

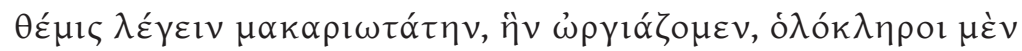

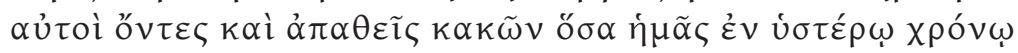

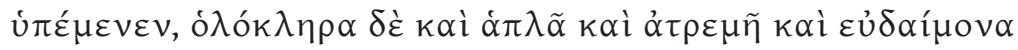

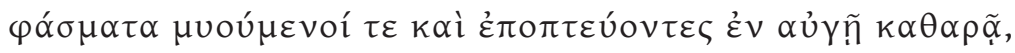
$\kappa \alpha \theta \alpha \rho \circ$ ö $v \tau \varepsilon \varsigma \kappa \alpha i ̀ ~ \alpha ُ \sigma \eta ́ \mu \alpha v \tau o 1$.

$(250 B-C)$

Citei todo este passo, apesar de extenso, para mostrar até que ponto as reminiscências da linguagem do culto penetraram nele: o adjectivo $\mu \alpha k_{\alpha} \alpha \rho$ (no superlativo), que a princípio se usava para descrever a condição dos deuses e depois um estado semelhante para os homens (cf.

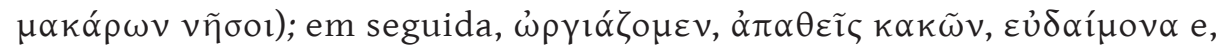

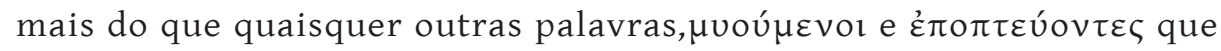
lembram insistentemente os ritos de iniciação ${ }^{1}$.

Conquanto o mito esteja construído com um sistema de imagens completamente novo, notam-se pelo menos duas concessões à tradição antiga: a uma delas já se fez referência - é o uso de $\operatorname{c} \delta$ díov para desig-

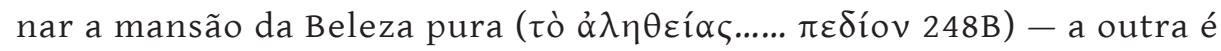
o $\lambda \varepsilon \imath \mu \omega ́ v$ que se destina a traduzir em termos materiais o processo de

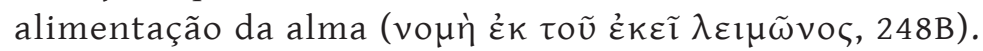

A parte da narrativa em que se conta a queda das almas, o despertar da reminiscência da Beleza e a luta entre o cocheiro e os seus dois cavalos (249C-256A) não precisa de ser considerada aqui. Apenas me ocuparei do passo que se refere ao seu destino.

${ }^{1}$ A linguagem é muito semelhante à que é usada em Symposium $210 \mathrm{~A}$, como observa L. Robin (edição Budé). 
As almas que terminaram a sua primeira existência são julgadas e afirma-se (249A-B) que algumas delas expiam as suas culpas debaixo

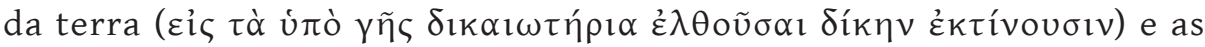
que provaram ser justas vão para certo lugar celeste, onde levarão uma

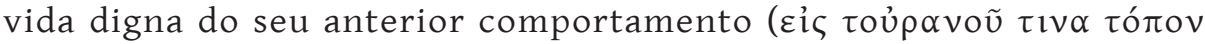

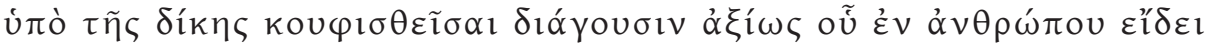

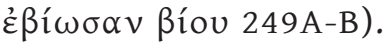

Portanto, a região assinalada aos bons é apenas vagamente designada, conquanto se indique explicitamente que fica no céu. Cerca do final do mito, fala-se novamente do destino que aguarda as almas, de acordo com o uso que fizeram dos dons do amor. Aquelas que se comportaram de um modo filosófico são elevadas nas suas asas e ganham uma vitória completa, como os atletas olímpicos; as que tiveram um procedimento mediano não obtêm as suas asas, mas, como recompensa pelo esforço para as ganhar, são isentas de ir para as trevas dos lugares subterrâneos,

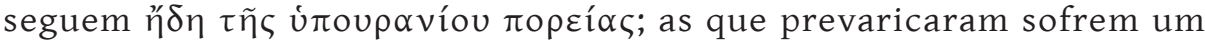
castigo terrível: andarão a rolar durante nove mil anos à volta e por baixo da terra, em estado de loucura (256D-257A).

Deve notar-se que, embora se possam discernir alguns vestígios dos castigos tradicionais na escuridão dos lugares infernais, as recompensas, bem como as penalidades, são de natureza essencialmente astral.

Em conclusão, o mito do Fedro, nas partes que dizem respeito ao presente estudo, não contém uma descrição minuciosa das regiões a que alude, mas antes procura sugeri-las, por meio de negativas. Podem apontar-se, aqui e ali, alguns vestígios da antiga tradição, mas, de um modo geral, a narrativa funda-se num processo estilístico inteiramente novo, que procura afastar todo o contacto com os símiles habituais. Agora o cenário é o céu. As cores desvaneceram-se, e as formas também. Apenas se conservou a luz radiante da própria Beleza.

Comparando os quatro mitos escatológicos de Platão, podemos concluir que seguem um plano diferente e que se situam em níveis diversos ${ }^{1}$.

${ }^{1} \mathrm{O}$ mito da Atlântida, contado no Crítias 112E-121C, está de certo modo relacionado com estes, na medida em que se descreve uma região fabulosa e bela. Os tópicos de exuberância da vida animal e vegetal (114D-115B, 117B), da abundância de rios e fontes, da existência de santuários e culto da justiça, pertencem ao núcleo tradicional. A descrição minuciosa da geografia e história do país constitui a parte exclusiva do mito. Deve, contudo, acentuar-se que se imagina sempre esse povo como formado por homens vivos, sujeitos até à degradação (120E seqq.) e não se exigiam qualidades ou títulos especiais para habitar entre eles.

O tema da Idade do Ouro, que está também relacionado com este, foi igualmente tratado por Platão duas vezes, nas Leis IV, 713A-714B e no Político 269A-274E. No segundo desenvolvimento (271D-272B) encontram-se algumas características 
O mito do Górgias está claramente ligado à tradição homérica, embora já nele se evidenciem alguns traços novos. O do Fédon constrói um vasto cenário geográfico, onde a luz, a cor e a forma desempenham o papel mais importante. No mito de Er depara-se-nos uma cosmologia, na qual os efeitos visuais e auditivos ocupam um lugar não menos proeminente, embora o problema central não deixe nunca de ser o da escolha do destino. O mito do Fedro coloca definitivamente a cena no céu e retira deliberadamente todos os pormenores que possam sugerir objectos materiais.

que lembram a descrição de Hesíodo, mas quase todos os pormenores são muito diferentes desta. De comum há a produtividade das árvores e a ausência de necessidade de cultivar a terra. Insiste-se, porém, nas condições sociais: a inexistência de leis, de posse de mulheres ou crianças, de vestuário ou camas, e a vida passada ao ar livre. O último traço-a erva que oferece um leito macio-acentua a identificação do homem antigo com a natureza. É curioso notar que esta descrição de um passado de bem-aventurança presa à terra nada tem de comum com o mesmo estado de espírito no Fedro, que está associado ao céu. O poeta podia sempre criar algo de completamente novo, mesmo trabalhando sobre temas tradicionais. Os mitos escatológicos são disso a melhor prova. 


\section{CAPÍTULO VI \\ O MITO DO «AXÍOCO»(371A - 372A)}

Ainda que o Axíoco fosse considerado um diálogo autêntico de Platão, haveria razão suficiente para pensar que o mito com que termina fora acrescentado por uma mão muito mais tardia. Mas não há sequer necessidade de formular tal hipótese, porquanto a autoria da obra foi já negada na Antiguidade e continua a sê-lo modernamente.

A estrutura, o pensamento e o estilo, que nela se encontram, levaram a essa conclusão $0^{1}$. Essas mesmas diferenças são comuns à parte final, que em seguida vamos analisar.

Uma breve introdução (371 A) coloca o conto sob a autoridade do mago Góbrias, o qual, por sua vez, teve conhecimento dele através de seu avô, que o lera em tábuas de bronze provenientes dos Hiperbóreos. Tudo isto pretende acentuar a remota antiguidade do mito, assim como as suas origens lendárias.

Depois começa a narração sem mais preâmbulos. Na primeira parte diz-se que as almas vão para um lugar sombrio, debaixo da terra

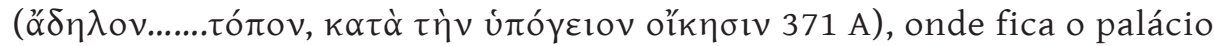
de Plutão. Estes tópicos são antigos, mas não platónicos (o filósofo diz

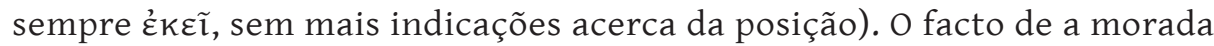
do deus dos infernos ser designada por $\beta \alpha \sigma i ́ \lambda \varepsilon \imath \alpha$ também denota uma época tardia. Por outro lado, $\delta \tilde{\omega} \mu \alpha$ 'Aí $\delta \alpha o$ teve sempre grandes portões; mas nunca ninguém se lembrou de descer a pormenores do género de particularizar que estes tinham chaves de ferro (371B). Mencionam-se ainda dois dos mais conhecidos rios do Hades - o Aqueronte e o Cócito - que transportam as almas que vão ser julgadas. Há dois juízes, cujos

${ }^{1}$ A enumeração completa dessas particularidades foi feita por M. Chevalier, Étude critique du dialogue pseudo-platonicien l'Axiochos sur la mort et l'immortalité de l'âme, Lyon, 1914. 
nomes são também indicados - Minos e Radamanto ${ }^{1}$ - sentados no $\pi \varepsilon \delta i ́ o v ~ \alpha ̉ \lambda \eta \theta \varepsilon i ́ \alpha \varsigma$, expressão esta que conhecíamos do Fedro, mas num contexto diferente. Aqui o sentido de $\alpha \dot{\alpha} \lambda \hat{\theta} \theta \varepsilon \imath \alpha$ é logo esclarecido nas próximas linhas: as almas são interrogadas acerca do seu comportamento durante a vida, sem que haja possibilidade de iludir as perguntas.

A parte que se segue descreve $\tau o ̀ v ~ \tau \tilde{\omega} v \varepsilon \dot{v} \sigma \varepsilon \beta \tilde{\omega} v \chi \tilde{\omega} \rho v^{2}$. Enumeram-se os seguintes tópicos: clima suave, que faz produzir toda a espécie de frutos, nascentes de água pura, prados com toda a qualidade de flores, de matizes variegados, conversas com filósofos, teatros para os poetas, representações coreográficas e musicais, symposia e festas que se oferecem espontaneamente, à maneira das dos coregas; ausência de sofrimento, vida agradável; nem excesso de invernia, nem de calma: um ar brando, temperado pelos raios do Sol. Um lugar especial ( $\pi \rho o \varepsilon \delta \rho i ́ \alpha)$ é apanágio dos iniciados, que aí prosseguem na celebração dos seus ritos sagrados, os mesmos que Hércules e Dioniso haviam presenciado, antes de descerem ao Hades.

Tudo isto é dito numa enumeração contínua, como num catálogo. E um catálogo é na verdade, porquanto todos os mais conhecidos tópicos da bem-aventurança no além estão aqui reunidos.

Embora muitos deles sejam comuns a descrições similares - uma vez que todas procuram imaginar um lugar ideal - alguns acusam claramente a sua origem. Assim, a fertilidade da terra é dado importante em Hesíodo, os prados cobertos de flores aparecem em Píndaro (mas o poeta

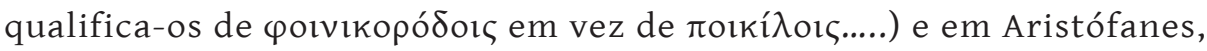

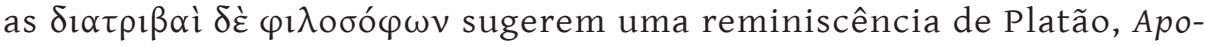
logia, 41C, os banquetes e danças eram uma ideia muito conhecida dos mystae de Elêusis e de outros ${ }^{3}$; e, a encerrar a lista, a nota da ausência dos excessos do frio ou do calor dá a impressão de ser uma paráfrase de $\delta$ 566. As fontes eram parte do aprazimento dos jardins de Alcínoo e da ilha de Calipso; essa parece ser também a sua função aqui, e não, por exemplo, a que lhes é adstrita nas lâminas de ouro.

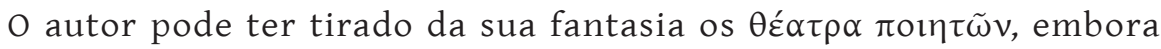
eles tenham o ar de um simples desenvolvimento do tema da música das

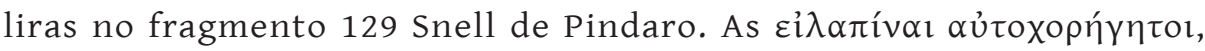
que são novidade, não podem considerar-se uma invenção muito feliz.

A tudo isto tinha ainda de acrescentar-se alguma coisa: havia que conservar a noção de um lugar especial, reservado aos iniciados, des-

${ }^{1}$ Tal como os rios, também os juízes estão reduzidos a dois. As suas funções não estão discriminadas.

${ }^{2}$ Esta designação não está atestada antes do século II a. C. (CIG. I, n. 2449).

${ }^{3}$ Cf. Platão, Rep. II, 363C-D. 
de o Hino Homérico a Deméter. Para os distinguir, o autor confere-lhes a $\pi \rho \circ \delta \rho \rho i ́ \alpha$; nessa situação continuam a celebrar os seus ritos sagrados.

A secção seguinte trata dos castigos, de uma maneira que causa certa confusão: diz-se que os pecadores vão para o Érebo e o Caos, através do Tártaro, para onde são conduzidos pelas Erínias. A menção do Tártaro arrasta um novo catálogo, desta vez dos criminosos célebres. Lêm-se os nomes de Tântalo, Títio e Sísifo e, antes deles ainda, o das Danaides. Este último caso assume particular importância, porquanto o mito das

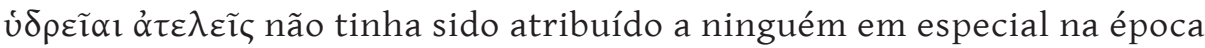
clássica. Ainda em Platão (Górgias 493B-C), onde a história é imputada a qualquer italiano ou siciliano, a penalidade não é adstrita a uma figura definida. Na Nékvia de Polignoto ${ }^{1}$ apareciam com a designação de ớúñol. A primeira vez que receberam nome próprio foi na época romana, conforme já foi notado ${ }^{2}$.

Em 372A depara-se-nos o último traço desta descrição: os condenados são lambidos por animais selvagens e queimados pelos archotes das Poenae (os brandões acesos tinham sido anteriormente atributos correntes das Erínias, não daquelas entidades abstractas) e assim são atormentados por toda a espécie de males.

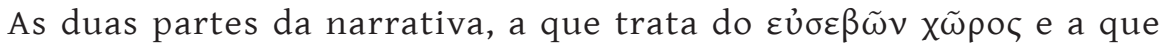
descreve o $\chi \tilde{\omega} \rho \circ \zeta$ $\alpha \sigma \varepsilon \beta \tilde{\omega} v$ são, por conseguinte, como dois catálogos de toda a espécie de prazeres e de horrores que a imaginação poética e a popular ${ }^{3}$ tinham acumulado no decorrer dos séculos. Até o processo de apresentar essa enumeração - frases curtas, principiando por um adjectivo ou um substantivo, todas correndo paralelas, numa construção de uma uniformidade monótona - acentua essa característica do mito.

O Axíoco tem sido quase unanimemente atribuído ao século I a. C; por conseguinte, a sua data está fora da meta que me propus. Se analisei aqui o seu mito, foi por causa da sua íntima correlação com as obras platónicas e porque, de um modo geral, a estratificação, que nele está contida, de ideias sobre o além, nos dá um bom exemplo do pouco interesse que tais concepções teriam para a literatura, se os maiores poetas da Grécia não tivessem pensado que se podia surpreender através delas um reflexo de eterna beleza. Cada um dos autores, cujas criações estudámos, fê-lo à sua maneira, embora trabalhando sobre um esquema tradicional; nessa diversidade residiu o interesse da análise do desenvolvimento do tema.

\footnotetext{
${ }^{1}$ Pausânias, X, XXXI, 9-11.

${ }^{2} \mathrm{Cf}$. M. Chevalier, op. laud.

${ }^{3}$ Muitos destes tópicos encontram-se também em inscrições. Cf. Lattimore, Themes in Greek and Roman Epitaphs.
} 
(Página deixada propositadamente em branco) 
$3^{\text {a }}$ PARTE
OS TEMAS 
(Página deixada propositadamente em branco) 
Agora que analisámos todos os desenvolvimentos do quadro da bem-aventurança no além, desde Homero a Platão, estamos habilitados a compreender, através dos temas preferidos por cada poeta, como a ideia de felicidade podia ser expressa de maneiras tão variadas, a despeito do peso de uma importantíssima tradição literária, de molde a reflectir a feição particular do espírito de cada autor.

$$
1-\delta, 561-569
$$

Nos tempos homéricos, uma das principais diferenças entre os deuses e os homens era que os primeiros gozavam de uma vida livre de dificul-

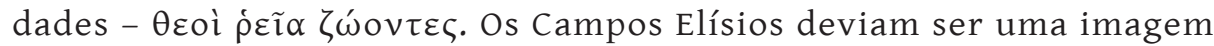
dessa condição, e, por conseguinte, tomaram os seus traços distintivos da própria morada dos imortais. Daí as semelhanças na descrição dos dois lugares, que tivemos ocasião de observar.

O tema da facilidade de $v_{i d a}{ }^{1}$, que evolucionou naturalmente para o da excelência do clima ${ }^{2}$, foi certamente o mais antigo de todos. Como acessório deste, desenvolveu-se o tema da frescura agradável ${ }^{3}$ e da presença do Oceano ${ }^{4}$. As condições naturais do clima grego e o género de vida que este determinava postulavam esses dois tópicos, sem que haja necessidade de pressupor importação estrangeira para os justificar. O tema da distância ${ }^{5}$, para sugerir a dificuldade do acesso a esse lugar, era o complemento necessário para sublinhar a qualidade única da existência que aí se levava.

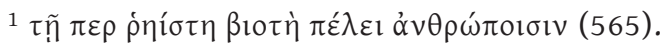

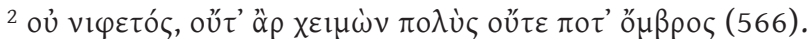

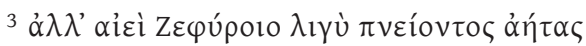

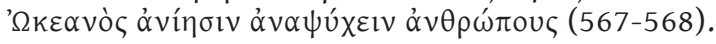

${ }^{4}$ Idem.

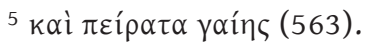




\section{2 - Hesíodo, «Trabalhos e Dias», 167-173}

O mesmo tema da inacessibilidade, acrescido do relevo dado à separação da humanidade ${ }^{1}$, bem como o da presença do Oceano ${ }^{2}$, encontram-se também na descrição de Hesíodo.

O tema da facilidade de vida desenvolveu-se agora no da fertilidade do solo ${ }^{3}$, que concretizava, para o autor de um poema agrário, os benefícios mais relevantes que dela se derivam. E, pela primeira vez, entrou no quadro da bem-aventurança no além uma nota de felicidade de ordem moral, sob a forma do tema da ausência de cuidados ${ }^{4}$.

\section{3 - Descrições do além em Píndaro}

Mais uma vez temos de tratar separadamente das descrições escatológicas deste poeta.
a) Ol. II, 61-67

Neste primeiro quadro insiste-se acima de tudo na nota da igualdade e regularidade de vida. O tema da excelência do clima reduziu-se à uniformidade do tempo e das estações ${ }^{5}$ e o motivo da facilidade de vida transformou-se no da ausência de trabalho ${ }^{6}$. Este último é agora expresso por um adjectivo ${ }^{7}$ que sublinha o tom neutro em que está composto todo o quadro.

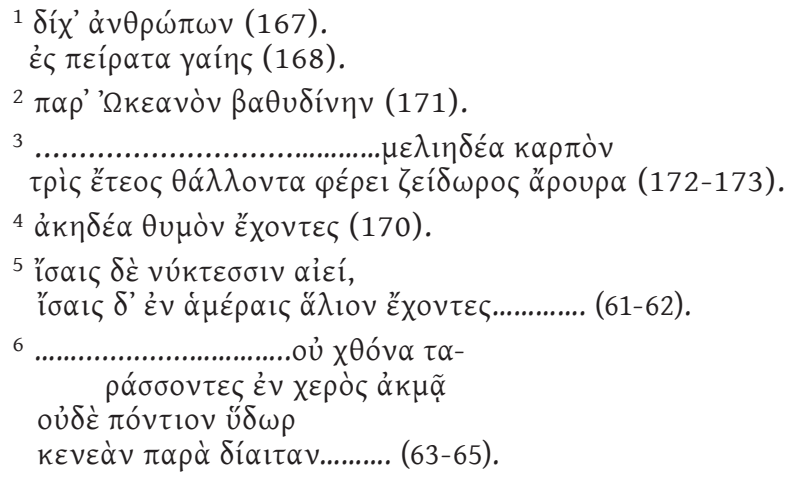




\section{b) Ol. II, $68-83$}

A segunda parte do mito opõe as suas cores brilhantes à acromia da descrição precedente.

Muitos dos temas homéricos e hesiódicos estão novamente presentes. Entre eles, o de uma frescura agradável, proveniente das brisas do Oceano $^{1}$. O tema da facilidade de vida, que em Hesíodo consistia na fertilidade do solo, desenvolveu-se aqui no motivo puramente decorativo de uma paisagem aprazível ${ }^{2}$ cuja beleza é acentuada pela irradiação de luz ${ }^{3}$, que é característica da noção pindárica da perfeição.

O tema da ausência de cuidados é apenas sugerido por meio da alusão às actividades dos bem-aventurados ${ }^{4}$, que não são mais do que a continuação das ocupações mais agradáveis desta vida.

\section{c) O Frg. 129 Snell}

O mesmo tema da continuação das actividades deleitosas da vida está largamente desenvolvido neste fragmento. A selecção inclui não só os interesses habituais de um grego rico, como também o gosto particular do poeta pela música ${ }^{5}$.

O tema da excelência do clima encontra-se novamente expresso em termos de uma bela paisagem ${ }^{6}$ e, de acordo com o estilo de Pindaro, os motivos de luz e brilho têm uma parte importante

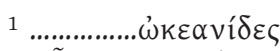

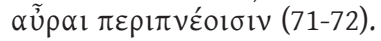

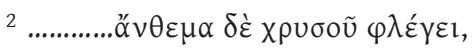

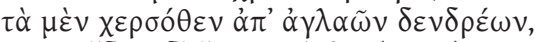
ư $\delta \omega \rho \delta^{\prime} \alpha^{\prime} \lambda \lambda \alpha \varphi \varepsilon^{\prime} \rho \beta \varepsilon l(72-73)$.

$3 \stackrel{\alpha}{\alpha} v \varepsilon \varepsilon \mu \alpha \delta \dot{\varepsilon} \chi \rho \cup \sigma o \tilde{v} \varphi \lambda \varepsilon \dot{\gamma \varepsilon l}(72)$

$\alpha \dot{\alpha} \lambda \alpha \alpha \tilde{\omega} v \delta \varepsilon v \delta \rho \varepsilon \dot{\omega} \omega v(73)$.

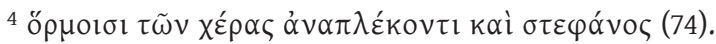

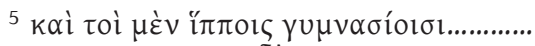

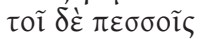

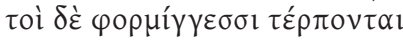

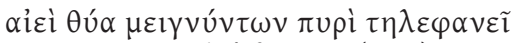

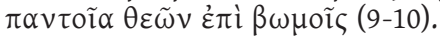

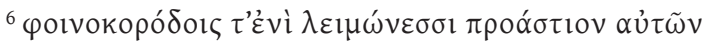
$\kappa \alpha i \lambda_{i} \beta \alpha ́ v \omega \sigma \kappa i \alpha \rho \tilde{\alpha}$

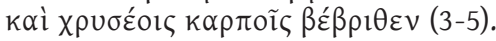


na descrição ${ }^{1}$. Mas o deleite não é percebido apenas através de sensações visuais e auditivas: um aroma agradável espalha-se por toda a região ${ }^{2}$.

Por conseguinte, diversos temas se combinaram para levar à plenitude do gozo da vida, através dos sentidos. Até o motivo da ausência de cuidados foi transformado num prazer positivo, que se exprime numa arrojada metáfora ${ }^{3}$ na qual o nome abstracto que define a condição moral dos bem-aventurados está acompanhado de um epíteto e de um verbo que costumavam ser empregados para descrever a própria natureza.

\section{4 - «As Rãs» de Aristófanes}

As Rãs têm o especial interesse de nos deixar surpreender alguns aspectos da concepção de felicidade no além para os iniciados de Elêusis. Esta exprime-se como uma continuação das ocupações mais aprazíveis da vida, as quais naturalmente consistiam no prosseguimento da celebração dos mistérios, com as actividades acessórias da música ${ }^{4}$ e da dança ${ }^{5}$.

O motivo da beleza da paisagem não está ausente ${ }^{6}$ nem tam-pouco a insistência no gozo da luz ${ }^{7}$.

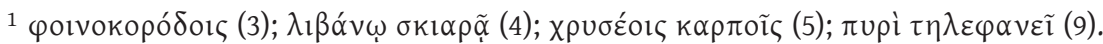

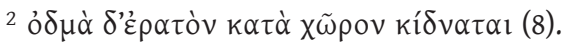

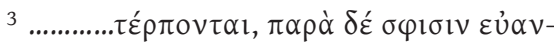

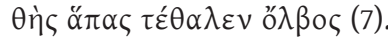

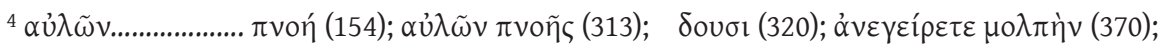

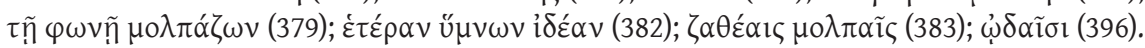

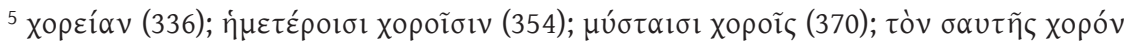

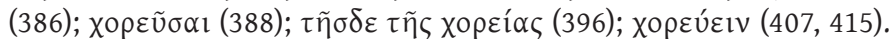

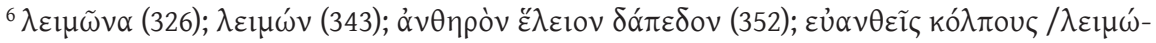

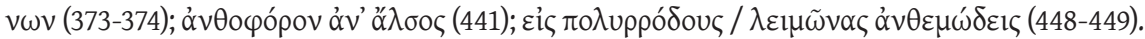

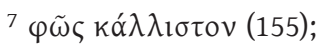

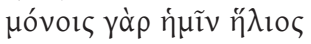

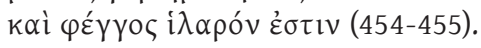

E, com grande insistência, no hino de Íaco: $\varphi \lambda$

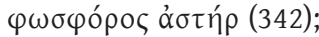

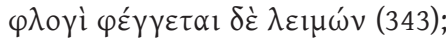
$\lambda \alpha \mu \pi \alpha ́ \delta 1 ~ \varphi \varepsilon ́ \gamma \gamma \omega \nu(351)$. 


\section{5 - Os mitos escatológicos de Platão}

a) O mito do «Górgias»

As Ilhas dos Bem-aventurados mencionam-se duas vezes no Górgias ${ }^{1}$ sem que sejam acompanhadas de qualquer descrição. Apenas o tema da felicidade moral gozada pelos que lá habitam se encontra expresso, em termos que sugerem a semelhança com a condição dos deuses ${ }^{2}$.

\section{b) O mito do «Fédon»}

$\mathrm{Na}$ descrição da verdadeira terra deparam-se-nos novamente muitos dos velhos tópicos já conhecidos. O tema da exuberância de vida, que tem grande relevo, inclui não só a fertilidade do solo ${ }^{3}$ como um mais alto nível na existência dos seres animados ${ }^{4}$ e até nos minerais ${ }^{5}$, e ainda o tópico da excelência do clima ${ }^{6}$. As notações de cor e brilho ocupam um lugar proeminente ${ }^{7}$; adiciona-se um tema novo - o da pureza ${ }^{8}$.

Tema novo também é o motivo da presença real dos deuses nos seus templos ${ }^{9}$. Este tópico do gozo proveniente do convívio com seres divinos é consequência do princípio geral de que tudo quanto há sobre a verdadeira terra é $\dot{\omega} \varsigma \dot{\alpha} \lambda \eta \theta \tilde{\omega} \varsigma$, mas, ao mesmo tempo, toca uma nota de felicidade moral até aí desconhecida. 'A $\lambda \eta \theta$ ńs e $\kappa \alpha \theta \alpha \rho$ ó $\varsigma$ são as duas qualidades primaciais que distinguem esse mundo do nosso.

1523 B; 526 C.

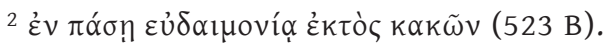

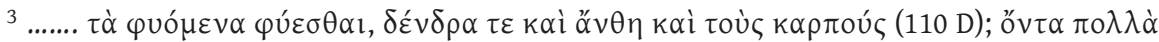

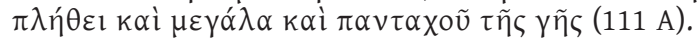

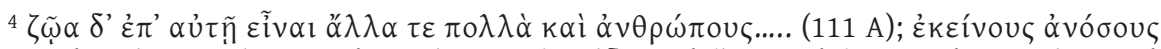

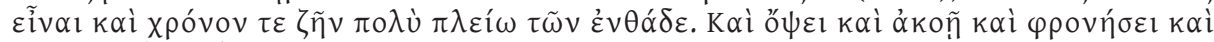
$\pi \tilde{\alpha} \sigma 1 \ldots . . . .(111 \mathrm{~B})$;

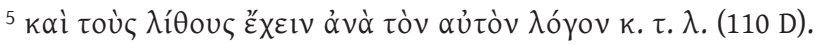

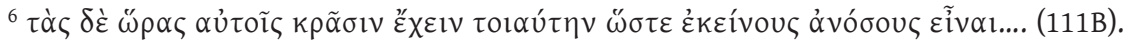

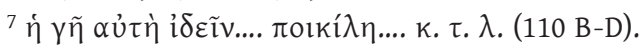

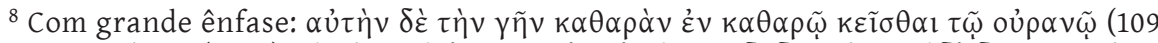

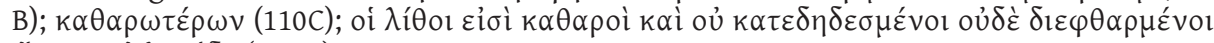

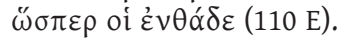

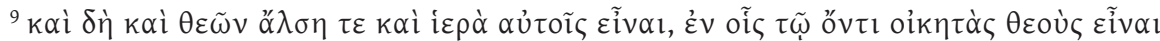

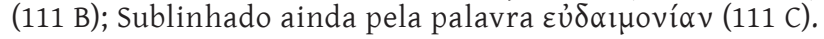


A mansão ainda mais bela, para onde apenas os filósofos merecem seguir, descreve-se pelo processo da praeteritio ${ }^{1}$. Contudo, apresenta um tópico completamente novo, o de que viverão incorpóreos nesses lugares ${ }^{2}$.

É uma consequência da teoria do $\sigma \tilde{\omega} \mu \alpha-\sigma \tilde{\eta} \mu \alpha^{3}$ que abre um caminho novo para as representações platónicas da felicidade no além.

\section{c) O mito de Er}

Como o mito do Górgias, também o de Er só se refere ao além feliz em termos breves, e a maior parte das vezes por meio de uma praeteritio. Assim, as almas que descem do céu apenas falam de gozo moral ${ }^{4}$ e de espectáculos para os quais não há palavras ${ }^{5}$. Mais tarde, lemos que as recompensas são o oposto das penalidades acabadas de descrever ${ }^{6}$.

Apenas o tema da pureza se pode inferir da palavra que descreve a condição das almas que descem do céu ${ }^{7}$.

\section{d) O mito do «Fedro»}

A breve referência à vida digna da sua anterior existência, que levam as almas boas depois do julgamento ${ }^{8}$, é pouco elucidativa.

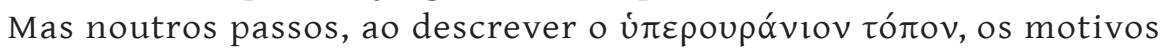
de luz e brilho desempenham o papel mais importante ${ }^{9}$.

Depois, os elementos fornecidos pela percepção sensorial são gradualmente afastados, até chegar àquela ausência completa de dados objectivos, feita por meio de negativas, que é a mais notável característica do estilo deste mito, e prepara o tema da felicidade numa forma incorpórea ${ }^{10}$ já anunciado pelo Fédon.

$\mathrm{Na}$ concepção de uma existência bem-aventurada, deixaram-se para trás os tópicos habituais de felicidade e exuberância de vida, para atingir aqui o gozo exclusivamente intelectual das ideias puras.

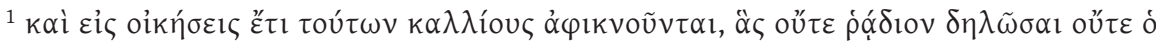

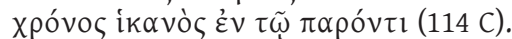

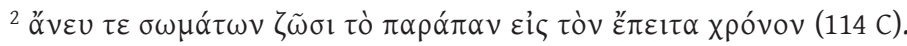

${ }^{3}$ Cf. Phaedrus, $250 \mathrm{C}$.

${ }^{4}$ Eủ $\pi \alpha \theta \varepsilon \dot{a} \alpha \varsigma(615 \mathrm{~A})$.

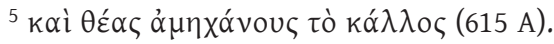

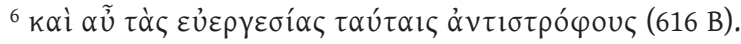

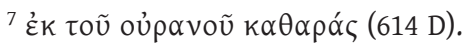

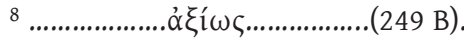

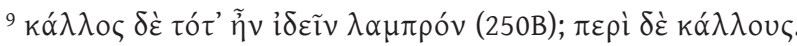

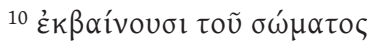
(256 D).
} 


\section{6 - O mito do «Axíoco»}

Todos os velhos temas da fertilidade do solo ${ }^{1}$, da frescura aprazível ${ }^{2}$, beleza da paisagem ${ }^{3}$ e continuação das actividades agradáveis desta vida ${ }^{4}$, assim como o da excelência do clima ${ }^{5}$, se encontram reunidos no mito do Axíoco. O motivo da felicidade moral está também expresso ${ }^{6}$.

Em conclusão, pode afirmar-se que a escolha de temas para sugerir a noção de felicidade reflecte não só o humano desejo geral de uma vida melhor, como também as concepções pessoais de cada autor.

É que todos eles trabalharam sobre dados comuns, que a princípio eram impostos pela tradição mitológica, mas em breve se transformaram num motivo literário em contínuo desenvolvimento. Analisar o contributo especial que cada poeta apresentou e relacionar os aspectos para ele predominantes com a sua psicologia é surpreender a própria essência da noção de felicidade para alguns dos espíritos mais esclarecidos da antiga Hélade.

É assim que em Homero os bem-aventurados gozam de facilidades de vida que os tornam semelhantes aos deuses. Um país de clima ideal, de onde o esforço e o sofrimento físico estivessem banidos - os dois temas fundamentais da Odisseia, a cada passo recordados no epíteto mais

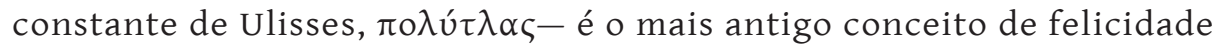
no além, que se nos depara.

Para Hesíodo é sobretudo a espontânea fertilidade do solo que constitui o bem-estar da geração privilegiada que habita nas Ilhas dos Bem-aventurados. A um poema de exaltação do trabalho agrícola convinha em absoluto um ideal também agrário.

Em Píndaro, o poeta da luz, não nos surpreende que esta seja elemento constante em todas as suas descrições escatológicas. Um lugar colorido e brilhante, onde ao prazer físico dos jogos que contribuíam para o desenvolvimento da beleza do corpo se juntava o deleite espiritual da música, era, para o poeta tebano, a concretização de uma vida ideal.

Aristófanes empresta aos iniciados de Elêusis o mesmo amor pela luz, pelo canto e pelas danças. Continuar a celebrar os ritos sagrados no além era sem dúvida o conceito de felicidade dos próprios mystae,

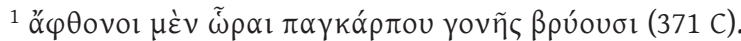

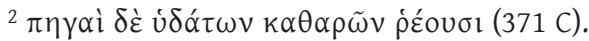

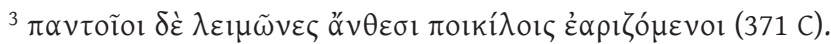

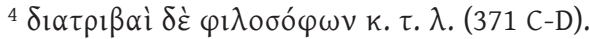

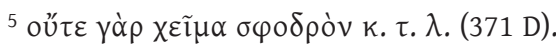

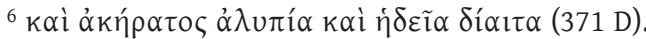


mas foi sobretudo o aspecto visual, estético, dessas manifestações, que mais impressionou o poeta de As Rãs.

É ainda a mesma nota do gozo da beleza através de sensações, sobretudo de natureza visual, que Platão refere ao longo do mito do Fédon. Porém, mesmo aí, já há dois tópicos novos que prenunciam a evolução do pensamento do filósofo neste particular: a presença real dos deuses e a libertação das almas dos corpos em que viviam, como elementos de felicidade máxima. Esta ascensão gradual ao domínio da abstracção vai culminar no mito do Fedro, onde, na ausência de dados materiais, as almas gozam, juntamente com as divindades, da contemplação das ideias puras.

A noção de que a bem-aventurança no além devia ser de natureza puramente intelectual surgiu, pela primeira vez, do cérebro de um filósofo, como era de esperar. Representa uma meta alcançada na evolução do pensamento escatológico, cuja importância não é demais encarecer. Porém as outras concepções, que acabámos de ver, de tal modo reflectem o amor pela beleza da forma e das cores, o desejo de gozo da vida física em toda a sua plenitude, que menosprezá-las seria pôr de parte uma das características mais marcantes do espírito helénico. 
BIBLIOGRAFIA 
(Página deixada propositadamente em branco) 


\section{A) EDIÇÕES* E SCHOLIA DE AUTORES CLÁSSICOS}

\section{APOLODORO}

JAMES GEORGE FRAZER, Apollodorus, The Library, with an English translation by... The Loeb Classical Library. London, Heinemann, 1921, 2 vols.

\section{APOLÓNIO DE RODES}

W. MOONEY, The Argonautica of Apollonius Rhodius, edited with introduction and commentary by... Dublin University Press, 1912.

H. KEIL, Scholia uetera e codice Laurentiano edidit... Apolonii Argonautica emendauit, apparatum criticum et prolegomena adiecit R. MERKEL, Lipsiae, sumptibus et typis B. G. Teubneri, 1854.

\section{ARISTÓFANES}

THEODOR KOCK, Ausgewählte Komödien des Aristophanes. Drittes Bändchen, Die Frösche, Sammlung griechischer und lateinischer Schriftsteller mit deutschen Anmerkungen herausgegeben von M. Haupt und H. Sauppe. Berlin, Weidmannsche Buchhandlung, Dritte Auflage, 1887.

BENJAMIN BICKLEY ROGERS, The Comedies of Aristophanes, edited, translated and explained by... IX. The Frogs, X. The Ecclesiazusae. London, George Bell \& Sons, 1902.

* Para não alongar demasiado a lista, omiti as citações das edições teubnerianas, oxonienses e Budé, que foram consultadas sempre que existiam. 
J. VAN LEEUWEN, Aristophanis Ranae cum prolegomenis et commentariis edidit... Lugduni Batauorum, apud A. W. Sijthoff, 1895.

W. W. MERRY, Aristophanes. The Frogs, with introduction aud commentary by... 5. edition, Oxford, at the Clarendon Press [repr. 1947].

G. MURRAY, The Frogs of Aristophanes, translated into English rhyming verse by... London, George Alien and Sons, 1908 [anteriormente incluído na obra do mesmo autor, The Athenian Drama, III, Euripides, London, George Allen and Sons, 1902].

L. RADERMACHER, Aristophanes, Frösche. Einleitung, Text und Kommentar von... Zweite Auflage mit einem Nachwort, Zusätzen aus dem Handexemplar des Verfassers und weiteren Hinweisen besorgt von WALTHER KRAUS. Wien, Österreichische Akademie der Wissenschaften, Phil.-Hist. Klasse, Sitzungsberichte, 198. Band, 4 Abh., 1954.

WILHELM SÜSS, Die Frösche des Aristophanes mit ausgewählten antiken Scholien herausgegeben von... Kleine Texte für theologische und philologische Vorlesungen und Übungen herausgegeben von Hans Lietzmann. 66. Bonn. A. Marcus und E. Weber‘s Verlag, 1911.

T. G. TUCKER, The Frogs of Aristophanes edited with introduction, commentary and critical notes by... London, Macmillan and Co. Ltd., 1906.

W. J. M. STARKIE, The Clouds of Aristophanes, with introduction, English prose translation, critical notes and commentary, including a new transcript of the scholia of the Codex Venetus Marcianus 474. London, Macmillan and Co. Ltd., 1911.

WILLIAM G. RUTHERFORD, Scholia Aristophanica, London, Macmillan and Co., 1896, 3 vols.

TH. KOCK, Comicorum Atticorum Fragmenta, 1880-88, 3 vols.

A. MEINEKE, Fragmenta Comicorum Graecorum, 1839-57, 5 vols.

\section{CALÍMACO}

RUDOLFUS PFEIFFER, Callimachus edidit... Vol. I, Fragmenta, 1949; Vol. II, Hymni et Epigrammata, 1953. Oxonii, e typographeo Clarendoniano.

\section{ÉSQUILO}

A. SIDGWICK, Aeschylus, Eumenides with introduction and notes by... 2. Edition. Oxford, at the Clarendon Press, 1895. 


\section{EURÍPIDES}

E. R. DODDS, Euripides, Bacchae edited with introduction and commentary by... The Plays of Euripides. Oxford, at the University Press, 1944.

A. Y. CAMPBELL, Euripides, Helena edited with commentary and general remarks by... University Press of Liverpool, 1950.

A. NAUCK, Tragicorum Graecorum Fragmenta, Editio Secunda. Lipsiae, in aedibus B. G. Teubneri, 1889.

E. SCHWARTZ, Scholia in Euripidem collegit recensuit edidit... Berolini, typis et impensis Georgii Reimer, 1887-91, 2 vols.

FILÓsOFOS (fragmenta)

HERMANN DIELS, Die Fragmente der Vorsokratiker. 6. verbesserte Auflage herausgegeben von WALTHER KRANZ. Berlin, Weidmannsche Verlagsbuchhandlung, 1951. 3 vols.

HERMANNUS USENER, Epicurea edidit... Lipsiae in aedibus B. G. Teubneri, 1887.

\section{HESÍODO}

FELIX JACOBY, Hesiodi Carmina. Pars I. Theogonia, Berolini apud Weidmannos, 1930.

F. A. PALEY, The Epics of Hesiod with an English commentary. London, 1883.

T. A. SINCLAIR, Hesiod, Works and Days. London, Macmillan, 1932.

U. VON WILAMOWITZ MOELLENDORF, Hesiodos Erga erklärt von... Berlin, Weidmannsche Buchhandlug, 1928.

HISTORIADORES (fragmenta)

FELIX JACOBY, Die Fragmente der griechischen Historiker. Berlin, Weidmannsche Buchhandlung, I, 1923. 
HOMERO

P. VON DER MÜHLL, Homeri Odyssea recognouit... Editiones Helueticae. Basileae, in aedibus Helbing und Lichtenhahn, [1946].

W. B. STANFORD, The Odyssey of Homer. London, Macmillan, 1950, 2 vols.

W. DINDORF, Scholia Graeca in Homeri Odysseam. Oxford, 1855.

EUSTATHIUS, Commentarii ad Homeri Odysseam. Leipzig, 1825-26, 2 vols.

\section{HINOS HOMÉRICOS}

T. W. ALLEN, W. R. HALLIDAY, E. E. SIKES, The Homeric Hymns edited by ... 2. edition. Oxford, at the Clarendon Press, 1936.

\section{INSCRIÇÕES}

A. BOECKIUS, Corpus Inscriptionum Graecarum, Academiae Litterarum Regiae Borussicae. Berolini, vol. I, 1828.

A. KIRCHHOFF, Corpus Inscriptionum Atticarum, Academiae Litterarum Regiae Borussicae. Inscriptiones Atticae Euclidis anno uetustiores. Berolini, apud Georgium Reimerum, 1873.

W. DITTENBERGER, Sylloge Inscriptionum Graecarum, 3. ed., 1915-24, 4 vols.

KAIBEL, Epigrammata Graeca. Berlin, 1878.

ALEXANDER OLIVIERI, Lamellae Aureae Orphicae, edidit commentario instruxit... Kleine Texte für Vorlesungen und Übungen herausgegeben von Hans Lietzmann. 133. Bonn, A. Marcus und E. Weber's Verlag, 1915.

\section{LÍCOFRON}

G. KINKEL, Lycophron, Alexandra recensuit, scholia uetera codicis Marciani addidit... Lipsiae, in aedibus B. G. Teubneri, 1880.

LÍRICOS (praeter Pindarum)

J. H. EDMONDS, Lyra Graeca, The Loeb Classical Library. London, Heinemann, [repr. 1952], 3 vols. 
E. LOBEL,'A $\lambda \kappa \alpha i ́ o v ~ M \varepsilon ́ \lambda \eta$. The Fragments of the Lyrical Poems of Alcaeus edited by... Oxford, at the Clarendon Press, 1927.

R. JEBB, Bacchylides, The Poems and Fragments. Cambridge, at the University Press, 1905.

F, G. KENYON, The Poems of Bacchylides, London, 1897.

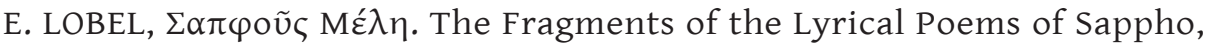
edited by... Oxford, at the Clarendon Press, 1925.

\section{MITÓGRAFOS}

ANTONIUS WESTERMANN, Mythographi. Scriptores Poeticae Historiae Graecae edidit... Brunsvigae, 1843.

PÍNDARO

L. R. FARNELL, The Works of Pindar, translated with literary and critical commentaries. London, Macmillan, 1930, 3 vols.

C. A. M. FENNELL, Pindar, The Olympian and Pythian Odes with notes explanatory and critical, introduction and introductory essays by... new edition. Cambridge University Press, 1893.

- Pindar, The Nemean and Isthmian Odes with notes explanatory and critical, introduction and introductory essays by... new edition, Cambridge University Press, 1899.

M. FERNÁNDEZ-GALIANO, Píndaro, Olímpicas. Clásicos Emerita Griegos y Latinos con notas. Consejo Superior de Investigaciones Científicas. Madrid, 1944, 2 vols.

B. L. GILDERSLEEVE, Pindar, The Olympian and Pythian Odes, with an introductory essay, notes and indexes by... Harper's Classical Series for Schools and Colleges, American Book Company, New York, Cincinnati, Chicago, [1885].

A. TURYN, Pimdari Carmina cum Fragmentis edidit... Academia Polona Litterarum et Scientiarum. Cracoviae, 1948.

A. B. DRACHMANN, Scholia Vetera in Pindari Carmina, Leipzig, Teubner, 1903. 3 vols.

PLATÃO

WILLY THEILER, Platonis Gorgias edidit... Editiones Helueticae. Bernae, A. Francke, AG, s. a. 
OLAUS GIGON, Platonis Phaedo edidit... Editiones Helueticae. Bernae, A. Francke, AG, [1943].

WILLIAM NORVIN, Olympiodori Philosophi in Platonis Gorgiam Commentaria edidit... Lipsiae, Teubner, 1936.

C. E. FINCKH, Olympiodori Scholia in Platonis Phaedonem. Heilbronnae, 1847.

WILLIAM NORVIN, Olympiodori Philosophi in Platonis Phaedonem Commentaria edidit... Lipsiae, Teubner, 1913.

P. COUVREUR, Hermiae Alexandrini in Platonis Phaedrum Scholia. Bibliothèque de l'École des Hautes Études, vol. 133. Paris, Bouillon, 1901. 


\section{B) BIBLIOGRAFIA GERAL}

J. T. ADDISON, La Vie après la Mort dans les Croyances de l'Humanité. Paris, Payot, 1936.

T. W. ALLEN, Homer. The Origins and Transmission. Oxford, at the Clarendon Press, 1924.

E. AMÉLINEAU, L'Enfer Égyptien et l'Enfer Virgilien. Étude de Mythologie Comparée. Paris, Impr. Nationale, 1915.

C. BAILEY, Some Greek and Roman Ideas of a Future Life. Cambridge University Press, 1915.

H. C. BALDRY, Who Invented the Golden Age? in Classical Quarterly, N. S., vol. II, n. ${ }^{\circ}$ 1-2, Jan.-April 1952, pp. 83-91.

F. BAR, Les Routes de l'Autre-Monde. Descentes aux Enfers et Voyages dans l’Au-Delà. Paris, Presses Universitaires, 1946.

S. E. BASSETT, The Second Necyia in Classical Journal, vol. XIII, 1918, pp. 521-526.

—, The Second Necyia Again in American Journal of Philology, 1923, pp. 44-52.

BEAUVOIS, L'Elysée Transatlantique et l'Éden Occidental in Revue de l'Histoire des Religions, t. VII et VIII, 1883, pp. 273-318, 673-727.

FRIEDRICH BECHTEL, Die griechischen Dialekte. Berlin, Weidmannsche Buchhandlung, II. Band, 1923.

V. BÉRARD, Introduction à l'Odyssée. Paris, Les Belles Lettres, 1933. 3 vols.

—, L’Odyssée d'Homère. Étude et Analyse. Paris, Mellotée, [1931].

S. BEZDECHI, La Théorie des Peines Futures chez Platon et Jean Chrysostome in Anuarul Institutului de Studi Clasice, Cluj. Cartea Româneasca, vol. II, 1933-35, pp. 1-33 [em romeno, com resumo em francês].

J. BIDEZ, La Biographie d'Empédocle. Université de Gand, 1899.

—, Les Couleurs des Planètes, dans le Mythe d'Er. Extrait des Bulletins de l'Académie Royale de Belgique, Classe des Lettres. Bruxelles, 1935.

—, Eos ou Platon et l'Orient. Gifford Lectures, Saint Andrews. Bruxelles, 1945. 
ETTORE BIGNONE, Empedocle. Studio critico. Traduzione e commenta delle testimonianze e dei frammenti. Torino, Fratelli Bocca Editori, 1916.

L. BLOCH, Zum homerischen Hymnus auf Demeter in Philologus, 1892, pp. 65-71.

C. M. BOWRA, Greek Lyric Poetry from Alcman to Simonides. Oxford, at the Clarendon Press, 1926.

PIERRE BOYANCÉ, La Religion Astrale de Platon à Cicéron in Revue des Études Grecques, vol. LXV, no 306-8, 1952, pp. 312-50.

C. D. BUCK, Introduction to the Study of the Greek Dialects, Revised edition. Ginn and Co. Boston, New York, Chicago, London.

RUDOLF BULTMANN, Zur Geschichte der Lichtsymbolik im Altertum in Philologus, Band 97, Heft 1/3, 1948, pp. 1-36.

P. CAPELLE, Elysium und Inseln der Seligen in Archiv für Religionswissenschaft, XXV, 1927, pp. 245-264; XXVI, 1928, pp. 17-40.

JÉRÔME CARCOPINO, La Basilique Pythagoricienne de la Porte Majeure, Paris, L'Artisan du Livre, 1927.

JOAQUIM DE CARVALHO, Notícia Histórico-Filosófica in Platão, Fédon, Diálogo sobre a imortalidade da alma, $2^{a}$ edição corrigida e aumentada. Coimbra, Atlântida, 1954.

H. MUNRO CHADWICK, The Heroic Age. Cambridge, at the University Press, 1912.

J. CHEVALIER, Étude Critique du Dialogue Pseudo-Platonicien l'Axiochos sur la Mort et sur l'Immortalité de l'Âme, Thèse... Lyon, 1914.

J. COMAN, Le Rapport des Idées Égyptiennes et Orphiques sur le Sort de l’Âme dans l'Au-Delà, Bucaresti, Graiul Românesc, 1934,

A. B. COOK, Zeus. A Study in Ancient Religion. Cambridge, at the University Press. Vol. II, 1925; vol. III, 1940.

C. C. COUlTER, The Happy Otherworld and Fairy Mistress Themes in the Odyssey in Transactions and Proceedings of the American Philological Association, vol. LVI, 1925, pp. 37-53.

OTTO CRUSIUS, Aus den Dichtungen des Bakchylides in Philologus, Band LVII (N. F., Bd. XI), 1898, pp. 150-183.

FR. CUMONT, Les Enfers selon l'Axiochos in Comptes-Rendus des Séances 
de l’Académie des Inscriptions et Belles Lettres, 1920, pp. 272-285.

-, Lucrèce et le Symbolisme Pythagoricien des Enfers in Revue de Philologie, t. XLIV, 1920, pp. 229-240.

—, Les Religions Orientales dans le Paganisme Romain. 4. éd. Paris, Paul Geuthner, 1929.

—, Recherches sur le Symbolisme Funéraire des Romains. Paris, Paul Geuthner, 1942.

—, Lux Perpetua, Paris, Paul Geuthner, 1949.

M. M. DANIEL, A Future Life as Represented by the Greek Tragedians in The Classical Review, vol. IV, 1890, pp. 81-95.

P. DECHARME, Mythologie de la Grèce Antique, 3. éd., revue et corrigée. Paris, Garnier Frères.

K. DEICHGRÄBER, Eleusinische Frömmigkeit und Homerische Vorstellungswelt im Homerischen Demeterhymnus. Akademie der Wissenschaften und der Literatur. Abhandlungen der Geistes- und Sozialwissenschaftlichen Klasse. N. ${ }^{\circ}$, 1950, pp. 501-538.

DELANDINE, L'Enfer des Peuples Anciens ou Histoire des Dieux Infernaux, de leur Culte, de leurs Temples, de leurs Noms, de leurs Attributs. Avec la description des morceaux célèbres de peinture, gravure et sculpture des artistes anciens qui ont représenté ces divinités. Paris, 1784.

LUDWIG DEUBNER, Totengericht (Pind. Ol. II 57-60) in Hermes, XLIII. Band, 4. Heft, 1908 , pp. 638-642.

H. DIELS, Himmels- und Höllenfahrten von Homer bis Dante in Neue Jahrbücher für das Klassische Altertum, 1922, pp. 239-254.

A. DIETERICH, Nekyia. Beiträge zur Erklärung der neuentdeckten Petrusapokalypse. Leipzig, Teubner, 1. Aufl. 1893; 2. Aufl. 1913.

E. R. DODDS, The Greeks and the Irrational. Sather Classical Lectures. University of California, 1951.

A. DÖRING, Die eschatologischen Mythen Platons in Archiv für Geschichte der Philosophie. Band VI, Heft 4. 1893, pp. 475-490.

DRACHMANN, Pindari Carmina recensuit Otto Schroeder in Berliner Phi- 
lologische Wochenschrift, 21. Jahrgang, n. ${ }^{\circ}$ 21, 25. Mai 1901, col. 640-647. JACQUELINE DUCHEMIN, Essai sur le Symbolisme Pindarique: Or, Lumière et Couleurs, in Revue des Études Grecques, vol. LXV, 1952, nº 304-305, pp. 46-58.

R. EGGER, Aus der Unterwelt der Festlandkelten in Wiener Jahreshefte, Band XXXV, 2. Heft, 1943, pp. 99-137.

S. EITREM, Opferritus und Voropfer der Griechen und Römer in Videnskapsselskapets Skriften, II, Hist.-Filos. Klasse, nº 1, Kristiania, 1914.

- The Necromancy in the Persai of Aeschylos in Symbolae Osloenses, vol. VI, 1928, pp. 1-16.

-, La Magie Comme Motif Littéraire chez les Grecs et les Romains in Symbolae Osloenses, 1941, pp. 39-83.

A. ERMAN, Aegypten und Aegyptisches Leben im Altertum neu bearbeitet von HERMANN RANKE. Tübingen, J. C. B. Mofar (Paul Siebeck), 1922.

-, Die Religion der Aegypter, Ihr Werden und Vergehen in vier Jahrtausenden. Berlin und Leipzig, Walter de Gruyter \& Co., 1934,

G. ETTIG, Acheruntica Siue Descensuum apud Veteres Enarratio in Leipziger Studien, XIII, 1891, pp. 251-410.

ARTHUR EVANS, The Palace of Minos. London, Macmillan \& Co. Ltd., 1926-36, 4 vols.

—, «The Ring of Nestor»: a glimpse into the Minoan afterworld and a sepulchral treasure of gold signet-rings and beadseals from Thisbe, Boeotia in Journal of Hellenic Studies, vol. XLV, 1925, pp. 1-75.

L. R. FARNELL, Greek Hero-Cults and Ideas of Immortality. The Gifford Lectures. Oxford University Press, 1921.

K. FEHR, Die Mythen bei Pindar. Diss. Zürich, 1936.

A. J. FESTUGIÈRE, L'Idéal Religieux des Grecs et l'Évangile, Paris, Librairie Lecoffre, 1932.

—, Les Mystères de Dionysos (suite) in Revue Biblique, vol. XLIV, 1935, pp. 366-396.

J. G. FRAZER The Golden Bough: a Study in Magic and Religion. 3. ed., 1911-15, 12 vols. 
C. FRIES, Zur orphischen Nekyia-interpolationen in Philologische Wochenschrift, 1927, col. 1598.

P. FRUTIGER, Les Mythes de Platon. Étude philosophique et littéraire. Thèse... Genève, Paris, Alcan, 1930.

E. GALLETIER, Études sur la Poésie Funéraire Romaine d'après les Inscriptions. Paris, Hachette, 1922.

H. W. GARROD, On Four Passages of Pindar in Classical Quarterly, vol. I, 1907, pp. 144-147.

J. GIRARD, Le Sentiment Religieux en Grèce, d'Homère à Eschyle. Paris, Hachette, 1869,

W. J. GOODRICH, A Passage of Pindar Reconsidered in Classical Quarterly, vol. II, 1908, pp. 31-33.

E. GRAF, Ad aureae aetatis fabulam symbola in Leipziger Studien zur Classischen Philologie, VIII, pp. 1-84.

GREGORII CORINTHII ET ALIORVM GRAMMATICORVM, Libri de Dialectis Linguae Graecae quibus additur nunc primum editus Manuelis Moschopuli Libellus de Vocum Passionibus recensuit et cum notis Gisb. Koenii, Fr. Jac. Bastii, Jo. Franc. Boissonadi suisque edidit Godofr. Henr. Schaeffer. Lipsiae, sumtibus Jo. Aug. Gottl. Weigel, 1811, 2 vols.

J. G. GRIFFITHS, In Search of the Islands of the Blest in Greece and Rome, vol. XVI, 1947, pp. 122-126.

W. H. GRUNDIG, De Inferorum in Graeca Comoedia Partibus. Diss. Leipzig, Extr. in Jahrbuch der Philosophischen Fakultät zu Leipzig, 1921, pp. 23-26.

E. GRISET, L'Elisio i Prischi Elleni. Pinerolo, Chiantore Mascarelli, 1929.

A. M. GUILLEMIN, Une Imitation de Lucrèce par Virgile in Humanités (Classes de Lettres), X, 1934, pp. 183-186.

W. K. C. GUTHRIE, Orpheus and Greek Religion, A Study of the Orphic Movement. London, Methuen and Co. Ltd., 1935.

—, The Greeks and their Gods, London, Methuen and Co. Ltd.

F. HOMMEL, Die Inseln der Seligen im Mythus und Sage der Vorzeit, München, 1901.

J. IRIGOIN, Histoire du Texte de Pindare. Paris, Klincksieck, 1952. 
J. ITHURRIAGUE, La Croyance de Platon à l'Immortalité et à la Survie de l’Âme Humaine. Paris, Gamber, 1931.

GEORG IWANOWITSCH, Opiniones Homeri et Tragicorum Graecorum de Inferis per Comparationem Excussae. Diss... Erlangen. Berolini, 1894.

P. JACOBSTHAL, The Nekyia Krater in New York in Metropolitan Museum Studies, vol. V, 1934, pp. 117 seqq.

WERNER JAEGER, The Theology of the Early Greek Philosophers. The Gifford Lectures, 1936. Oxford, at the Clarendon Press, 1947.

G. JÉQUIER, Le Livre de ce qu'il y a dans l'Hadès. Bibliothèque de l'École des Hautes Études. Paris, Emile Bouillon, Éditeur, 1894.

HUGO JURENKA, Der Mythus in Pindars erster Olympischer Ode und Bakchylides III in Philologus, Band LIX, Heft 2 (N. F., Band XIII, H. 2), 1900, pp. 313-315.

C. M. KAUFMANN, Die Jenseitshoffnungen der Griechen und Römer nach den Sepulcralinschriften. Ein Beitrag zur monumentalen Eschatologie, Freiburg in Breisgau, Herdersche Verlagshandlung, 1897.

KARL KERÉNYI, Pythagoras und Orpheus, Berlin, 1937.

—, Zu Verg, Aen. VI, Pindar, Platon und Dante in Philologische Wochenschrift, 1925, col. 279-288 [resumo em alemão de uma obra escrita em húngaro].

OTTO KERN, Orphicorum Fragmenta, Berolini, apud Weidmannos, 1922.

A. KÖRTE, Das Land der Hyperboreer in Archiv für Religionswissenschaft, X. Band, I. Heft, 1907, pp. 152-153.

WALTHER KRANZ, Die Katharmoi und die Physika des Empedokles in Hermes, vol. 70, 1935, pp. 111-119.

—, Empedokles, Antike Gestalt und Romantische Neuschöpfung. Erasmus Bibliothek. Zürich, Artemis Verlag, 1949.

ALEXANDER H. KRAPPE, AחO $\Lambda \Omega$ N KYKNO $\Sigma$ in Classical Philology, vol. XXXVII, n. ${ }^{\circ}$, 1942, pp. 353-370.

J. KROLL, Gott und Hölle. Der Mythus vom Descensuskampfe. Leipzig, Teubner, 1932.

A. K. LAKE-MICHELS, The Golden Bough of Plato in American Journal of Philology, 1945, pp. 59-63. 
R. LATTIMORE, Themes in Greek and Roman Epitaphs. Illinois Studies in Language and Literature, vol. 28, 1942.

K. LEHRS, Vorstellungen der Griechen über das Fortleben nach dem Tode in Populäre Aufsätze aus dem Altertum. Leipzig, Teubner, 1875, pp. 303-362.

ISIDORE LÉVY, La Légende de Pythagore de Grèce en Palestine. Paris, Champion, 1927.

-, Les Croyances Égyptiennes, Grecques et Juives sur la Vie d'Outre-Tombe in Revue de l'Université de Bruxelles, vol. XXXIV, 1929, pp. 403-429.

CURTIUS LIEDLOFF, De Tempestatis, Necyomanteae, Inferorum Descriptionibus quae apud Poetas Romanos primi p. Ch. saeculi leguntur. Diss. Lipsiae, 1864.

IVAN LINFORTH, The Arts of Orpheus, Berkeley and Los Angeles, University of California Press, 1941.

W. L. LORIMER, Gold and Ivory in Greek Mythology in Greek Poetry and Life, Essays presented to Gilbert Murray, Oxford University Press, 1936, pp. 14-33.

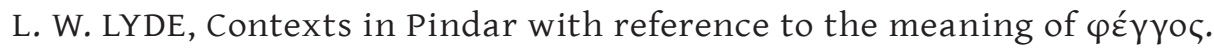
Manchester University Press, 1935.

V. D. MACCHIORO, La Catabasi Orfica in Classical Philology, vol, XXIII, 1928, pp. 239-249.

R. MACKRODT, Der Olymp in Ilias und Odyssee. Altenburg, Oskar Bonde, 1882.

L. MALTEN, Elysion und Rhadamanthys in Jahrbuch des kaiserlich Deutschen Archäologischen Instituts, Band XXVIII, 1913, pp. 35-51.

-, W. von Otto, Der griechische Mensch und die Nachwelt in Gnomon, 20. Band, Heft 3, 1944.

M. TH. - H. MARTIN, Traditions Homériques et Hésiodiques sur le Séjour des Morts in Annuaire de l'Association pour l'Encouragement des Études Grecques en France, vol. XII, 1878, pp. 1-21.

C. MASPERO, Études de Mythologie et d'Archéologie Égyptiennes. Bibliothèque Égyptologique. Paris, Ernest Leroux, 1893.

P. MASQUERAY, Euripide et ses Idées. Paris, Hachette, 1908.

MARTINUS MEISTER, De Axiocho Dialogo. Dissertatio Inauguralis philologica. Vratislaviae, Wilh. Gottl. Korn, 1915. 
J. MESK, Tantalos bei Pindar in Charisteria Rzach, Reichenberg, 1930, pp. 142-147.

KARL MEULI, Odyssee und Argonautika. Untersuchungen zur griechischen Sagengeschichte und zum Epos. Berlin, Weidmannsche Buchhandlung, 1921.

E. MEYER, Hesiods Erga und das Gedicht von den fünf Menschengeschlechtern in Genethaliakon Robert. Berlin, Weidmannsche Buchhandlung, 1910, pp. 157-188.

JEAN MONNIER, La Descente aux Enfers. Étude de Pensée Religieuse, d'Art et de Littérature. Thèse... Paris, 1904.

G. E. MYLONAS, The Hymn to Demeter and her Sanctuary at Eleusis. Washington University Studies, 1942.

W. NESTLE, Euripides, der Dichter der griechischen Aufklärung. Stuttgart, W. Kohhammer, 1901.

M. P. NILSSON, The Mycenaean Origin of Greek Mythology, Sather Classical Lectures, vol. 8. Cambridge, at the University Press, 1932.

—, Homer and Mycenae. London, Methuen and. Co. Ltd., 1933.

-, Early Orphism and Kindred Religious Movements in Harvard Theological Review, vol. 28, 1935, pp. 181-230.

-, Geschichte der griechischen Religion. Handbuch der Altertumswissenschaft herausgegeben von Walter Otto. München, C. H. Beck'sche Verlagsbuchhandlung. Band I, 1941, Band II, 1950.

—, The Immortality of the Soul in Greek Religion in Eranos, 1941, pp. 1-16.

-, The Minoan-Mycenaean Religion and its Survival in Greek Religion. 1. ed. Lund, 1927; 2. revised ed. Lund, 1950. ${ }^{\not \alpha}$

E. NORDEN, Vergilstudien. I. Die Nekyia; ihre Komposition und Quellen in Hermes, Band XXVIII, 1893, pp. 360-406.

—, P. Vergilius Maro Aeneis Buch VI, erklärt von... 3. Auflage. Leipzig, Teubner, 1926.

MEDEA NORSA, Dai Papiri della Società Italiana in Annali della R. Scuola Normale Superiore di Pisa, Ser. II, vol. VI, 1937, pp. 1-15.

ANTONIUS-FRIDERICUS OZANAM, De Frequenti apud Veteres Poetas Heroum ad Inferos Descensu, Theses... Parisiis, 1839. 
A. PARROT, Le Refrigerium dans l'Au-Delà. Paris, Ernest Leroux, 1937.

CARLO PASCAL, Le Credenze d'Oltretomha nelle Opere Letterarie dell'Antichità Classica. Catania, Francesco Battiato, 1912, 2 vols.

—, Dioniso. Saggio sulla Religione e la Parodia Religiosa, in Aristofane. Catania, Francesco Battiato, 1911.

MILMAN PARRY, Studies in the Epic Technique of Oral Verse-Making. I. Homer and Homeric Style in Harvard Studies in Classical Philology, vol. XLI, 1930.

W. R. PATON, «The Golden Bough» in Classical Review, vol. XXV, 1911, p. 205.

Q. PATRONI, Tra Sogni ed Ombre in Compagnia d'Omero in Atene e Roma, vol. VII, n. ${ }^{\circ} 1-2,1926$, pp. 1-81.

PAULY-WISSOWA, Real Enzyclopädie der Klassischen Altertumswissenschaft. Stuttgart, J. B. Metzlerscher Verlag, s. u. u. Elysion, $\mu \alpha \kappa \alpha ́ \rho \omega v ~ v \tilde{\eta} \sigma o 1$, Orphische Dichtung, Rhadamanthys.

AXEL PERSSON, Der Ursprung der eleusinischen Mysterien in Archiv für Religionswissenschaft, XXI. Band, pp. 287-309.

—, The Religion of Greece in Prehistoric Times. Sather Classical Lectures. University of California Press, 1942.

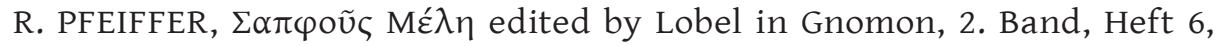
1926.

—, Vier Sappho-Strophen auf einem Ptolemäischen Ostrakon in Philologus, 92. Band, 1937, pp. 117-125.

CHARLES PICARD, Les Religions Préhelléniques (Crète et Mycènes). Collecttion «Mana». Paris, Presses Universitaires, 1948.

E. DES PLACES, Pindare et Platon. Paris, Beuchesne et ses Fils, 1949.

M. PlATNAUER, Antistrophic Variation in Aristophanes in Greek Poetry and Life, Essays presented to Gilbert Murray. Oxford University Press, 1936, pp. 241-256.

E. POtTIER - AM. HAUVETTE-BeSNAUlt, Inscriptions d'Érythrées et de Théos in Bulletin de Correspondance Hellénique, vol. IV, 1880, pp.179-180. 
L. RADERMACHER, Das Jenseits im Mythos der Hellenen. Untersuchungen über antiken Jenseitsglauben, Bonn, A. Marcus und E. Weber's Verlag, 1903.

-, Aristophanes' Frösche. Einleitung in Anzeiger der Akademie der Wissenschaften in Wien, LVIII. Band, 1921, pp. 47-49.

SALOMON REINACH, Cultes, Mythes et Religions. Paris, Leroux, 1906, 5 vols.

E. RICHARDSON, The Myth of Er (Plato, Republic, 616B) in Classical Quarterly, vol. XX, 1926, pp. 113-133.

A. DE RIDDER, L'Idée de la Mort en Grèce à l'Époque Classique. Thèse... Paris, 1896.

WILLIAM RIDGEWAY, The Early Age of Greece. Cambridge, at the University Press, vol. 1, 1901; vol. II, 1931.

C, ROBERT, Die Nekyia des Polygnot. Halle, Max Niemeyer, 1892.

E. ROHDE, Der griechische Roman and seine Vorläufer. Leipzig, 2. Auflage, 1900; 3. Aufl., 1914.

—, Psyche. Seelencult and Unsterblichkeitslehre der Griechen. 9. und 10. Auflage milt einer Einführung von Otto Weinreïch. Tübingen, J. C. B. Mohr (Paul Siebeck), 1925.

A. RÖMER, Zur Kritik und Exegese der Frösche des Aristophanes in Rheinisches Museum, 1908, pp. 341-369.

W. H. ROSCHER, Ausführliches Lexikon der Griechischen und Römischen Mythologie. Leipzig, Teubner, 1884-1890, s. u. u. Acchilles, Hesperides, Hyperboreer, Leuke.

H. J. ROSE, The Ancient Grief in Greek Poetry and Life, Essays presented to Gilbert Murray. Oxford University Press, 1936, pp. 79-96.

—, The Grief of Persephone in Harvard Theological Review, 1943, pp. 247-250.

J. RUMPEL, Lexicon Pindaricum. Lipsiae, Teubner, 1883.

W. SCHUBART, Bemerkungen zu Sappho in Hermes, 73. Band, 1938, pp. 297-306.

P. SCHUBERT, Die Eschatologie des Posidonius. Diss.... Bonn. Leipzig, 1927.

C. SCHUCHHARDT, Jenseitsglauben in der europäischen Vorgeschichte. 
Ist Homers Unterweltsbild nordisch? in Forschungen und Fortschritte, Berlin, 1940, n. ${ }^{\circ} 12$, pp. 13-15.

A. SCHULTEN, Die Inseln der Seligen in Geographische Zeitschrift, XXXII. Band, 1924-1926, pp. 229-247,

F. SOLMSEN, Chaos and «Apeiron». Estratto dagli Studi Italiani di Filologia Classica, N. S., vol. XXIV, fasc. 3-4, Firenze, Felice Le Monnier, 1950.

C. SOURDILLE, La Durée et l'Étendue du Voyage d'Hérodote en Égypte. Paris, Ernest Leroux, 1910.

G. SOURY, La Vie de l'Au-Delà, Prairies et Gouffres in Revue des Études Anciennes, 1944, pp. 169-178.

W. SPIEGELBERG, Die Übersetzung des Wortes Oase bei Herodot, III, 26 in Zeitschrift für Aegyptische Sprache und Altertumskunde, 42. Band, 1. Heft, 1906, p. 85.

J. A. STEWART, The Myths of Plato. London, Macmillan, 1905.

F. STREINZ, De Necyia Homerica in Programm des Staats-Ober-Gymnasiums zu Klagenfurt, 1896.

H. W. THOMAS, 'E $\pi \varepsilon ́ \kappa \varepsilon \imath v \alpha$, Untersuchungen über das Überlieferungsgut in den Jenseitsmythen Platons, Diss. Müchen, 1938.

J. A. K. THOMSON, Studies in the Odyssey, Oxford, at the Clarendon Press, 1914.

A. TURYN, The Sapphic Ostrakon in Transactions and Proceedings of the American Philological Association, vol, 73, 1942, pp. 308-318.

M. VENTRIS AND J. CHADWICK, Evidence for Greek Dialects in the Mycenaean Archives in Journal of Hellenic Studies, vol. LXXIII, 1935, pp. 84-103.

J. G. VUERTHEIM, Rhadamanthys, Ilithyia, Elysion in Mededeelingen der Koninklijke Akademie van Wetenschappen te Amsterdam, LIX, Serie A, 1925, n. 1 [com um resumo em alemão].

C. WELCKER, Alcmanis Fragmentum de Tantalo in Rheinisches Museum, 1856, pp. 242-254.

JOSEPH WIESNER, Grab und Jenseits. Untersuchungen im Ägäischen Raum zur Bronzezeit und frühen Eisenzeit. Religionsgeschichtliche Versuche 
und Vorarbeiten. XXVI. Band. Berlin, Alfred Töpelmann, 1938.

JAN HERMANNUS WIETEN, De Tribus Laminis Aureis quae in Sepulchris Thurinis Sunt Inuentae. Specimen litterarium inaugurale. Amstelodami, apud J. Clausen, 1915.

U. VON WILAMOWITZ-MOELLENDORF, Homerische Untersuchungen. Berlin, Weidmannsche Buchhandlung, 1884.

—, Die Ilias und Homer. Berlin, Weidmannsche Buchhandlung, 1916.

_, Platon. Berlin, Weidmannsche Buchhandlung, 1919, 2 vols.

_, Pindaros. Berlin, Weidmannsche Buchhandlung, 1922.

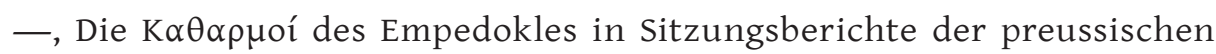
Akademie der Wissenschaften. Berlin, 1929, pp. 626-661.

—, Der Glaube der Hellenen. Berlin, Weidmannsche Buchhandlung 1931, 2 vols.

AUGUSTUS WINKLER, De Inferorum in Vasis ltaliae Inferioris Repraesentationibus. Diss. Vratislaviae, 1888.

W. J. WOODHOUSE, The Composition of Homer's Odyssey. Oxford, at the Clarendon Press, 1930.

A. M. YOUNG, The Frogs of Aristophanes as a Type of Play in Classical Journal vol. XXIX, 1933-34, pp. 23-32.

TH. ZIELINSKY, La Guerre à l'Outretombe chez les Hébreux, les Grecs et les Romains in Mélanges Bidez, Bruxelles, 1934, pp. 1023-1042. 


\section{SOBRE A AUTENTICIDADE DO FRAGMENTO 44 DIEHL DE ANACREONTE}


Edições "Maranus", Porto, 1961 
DISSERTAÇÃO DE CONCURSO PARA PROFESSOR EXTRAORDINÁRIO

DO 1을 GRUPO DA 1a SECÇÃO DA

FACULDADE DE LETRAS DE COIMBRA 
(Página deixada propositadamente em branco) 
A MEUS PAIS

A MINHA IRMÃ 
(Página deixada propositadamente em branco) 


\section{NOTA PRELIMINAR}

O estudo que apresento versa uma questão de autoria de um pequeno poema, cuja expressão amaneirada me impressionou como nota dissonante no conjunto de fragmentos de Anacreonte, desde o dia, já longínquo, em que o ouvi comentar, pela primeira vez, ao Prof. R. Pfeiffer, nas suas aulas sobre Lírica Grega Arcaica.

Muitos outros trabalhos, entretanto, ocuparam a minha atenção, motivo por que só agora me foi possível examinar o problema. Pude assim verificar que, além dos habituais critérios linguísticos e literários, que ajudam a debater as questões de autenticidade, e do exame crítico das fontes transmissoras, havia que analisar e situar no tempo o substrato ideológico que informa o fragmento.

Deste modo, um ensaio, que essencialmente respeitaria à história literária, tem de envolver aspectos muito curiosos e característicos do pensamento e da cultura grega em geral. Esta a razão por que mais de uma vez foi necessário ultrapassar os limites cronológicos da época arcaica, em busca de paralelos, porventura mais tardios, que esclarecessem o conteúdo do pequeno texto e permitissem sugerir a data da sua composição. 
(Página deixada propositadamente em branco) 
Antes de terminar esta breve nota, quero agradecer aos meus antigos Professores na Universidade de Oxford, E. R. Dodds e Ed. Fraenkel, as sugestões e indicações bibliográficas com que generosamente me auxiliaram, e ao Instituto da Alta Cultura o ter-me facilitado mais uma estadia de um mês nas bibliotecas daquela cidade universitária britânica. 
(Página deixada propositadamente em branco) 


\section{INTRODUÇÃO}

É sabido que grande número de problemas de atribuição e autenticidade na lírica grega arcaica está longe de ter obtido uma solução satisfatória. E os leitores habituais dos Oxyrhinchus Papyri sentem, tanto como os seus editores, as dificuldades que cada novo volume apresenta. Por vezes, é a extrema brevidade do fragmento recém-descoberto que não fornece elementos suficientes para a identificação do mesmo. Outras, são as referências dos antigos ou a métrica que sugerem uma atribuição provisória. Lembremos, como casos recentes, os excertos contidos no Pap. Berol. 16.139 e Pap. inv. 20 do Museu Ashmoleano de Oxford, que B. Snell incluiu na sua primeira ${ }^{1}$ e segunda ${ }^{2}$ edição de Píndaro como dubia, com os números 336 e 343, respectivamente, e, que acaba de acolher, com os números 24 e 25, entre os ditirambos, na sétima impressão de Baquílides ${ }^{3}$ depois da análise feita por Lobel ${ }^{4}$.

As dificuldades de atribuição não são, porém, apenas consequência da descoberta de papiros em estado fragmentário, sem indicação de autor. Em todos os tempos houve problemas de autenticidade, mesmo em relação a textos de grande envergadura. Lembremos, por exemplo, que Proclo declarou apócrifa a República de Platão, e Panécio nada menos do que o Fédon!

A questão agrava-se singularmente, quando se trata de autores apenas conhecidos por tradição indirecta, e, portanto, quase só através de fragmentos. É o caso de todos os líricos do cânon alexandrino,

${ }^{1}$ Pindari Carmina cum Fragmentis edidit Bruno Snell. Lipsiae in aedibus B. G. Teubneri, 1953.

${ }^{2}$ Idem, ibidem, 1955.

${ }^{3}$ Bacchylidis Carmina cum Fragmentis post Fr. Blass et Guil. Suess septimum edidit Bruno Snell. Lipsiae in aedibus B. G. Teubneri, 1958.

${ }^{4}$ Ox. Pap. 23 (1956), p. 28.

${ }^{5}$ Para este e outros exemplos, veja-se o artigo de Manuel Fernández Galiano, «Los problemas de autenticidad en la literatura griega» in Revista de la Universidad de Madrid, vol. I, n, ${ }^{\circ}$ 2, 1952, pp. 213-238. 
com excepção de Píndaro - e, esse mesmo, chegado até nós sob a forma de antologia. Aos poucos, a recuperação intermitente de papiros tem reparado algumas lacunas, por vezes de uma forma espectacular, como sucedeu quando, em 1879, F. G. Kenyon publicou o papiro A do British Museum, de Baquílides; outras vezes, abrindo novos horizontes ao conhecimento da obra do poeta, como acontece com os inúmeros fragmentos de muitos outros sub-géneros da lírica coral (que não os epinícios), cultivados por Píndaro, e trechos reveladores do tão mal conhecido e tão importante Estesícoro ${ }^{1}$.

Diferente é, porém, pelo menos até à data, a posição de Anacreonte.

O número de fragmentos novos encontrados é restrito: apenas o papiro de Oxirinco $2321^{2}$ com catorze, e talvez o $2322^{3}$, com dois. Inútil será entrar aqui na respectiva análise, que já foi feita mais do que uma $v e z^{4}$, e tem conduzido a conclusões diversas, como habitualmente sucede, quando se trabalha sobre textos mutilados. Frisemos apenas que pouco trazem de novo à interpretação da obra do poeta ${ }^{5}$, porquanto, dos quatro fragmentos que o seu mais recente editor, B. Gentili, imprime como composições das quais é possível compreender o sentido (fr. 60

${ }^{1}$ Publicados por E. Lobel no vol. 23 (1956) dos Oxyrhinchus Papyri e estudados por Werner Peek, «Die Nostoi des Stesichoros» in Philologus, Band 102, Heft 3/4, 1958, pp. 169-177.

${ }^{2}$ Lobel propõe, embora dubitativamente, a identificação do v. 13 do fr. 1 com a informação de Eustátio, 1329, 34 (fr. 157 Bergk) e do frg. 2 com o frg. 57 Bergk. Sobre as dificuldades desta última, ele mesmo adverte o leitor no comentário da p. 59. Gentili julga-a improvável (na sua edição de Anacreonte, Romae, in aedibus Athenaei, 1958, pp. 195-196).

${ }^{3}$ Publicados também por E. Lobel e C. H. Roberts in The Oxyrhinchus Papyri, Part XXII, 1954, pp. 54-63. Lobel dá como duvidosa a atribuição do conteúdo do Pap. 2322, que B. Gentili considera autêntico e Gallavotti não. Cf. a nota seguinte.

${ }^{4}$ Especialmente por Paul Maas, «Anakreon und Ibykus» in Acme, 1955, VIII, 2-3, pp. 113-114; L. Alfonsi, "Sul nuovo Anacreonte» in Aegyptos, 1955, 35, pp. 201-205; C. Gallavotti "Anacreonte e la chioma recisa» in La Parola del Passato, 1955, XL, pp. 41-47; idem, «Un restauro di Anacreonte», ibidem, pp. 47-50; K. Latte in Gnomon, 1955, 27, pp. 495-497; R. Merkelbach in Archiv für Papyrusforschung, 1956, 16, pp. 96-98; E. Paratore in La Fiera Letteraria, XI, 4, 1956, pp. 5 e 7; W. Peek, "Neue Bruchstücke frühgriechischer Dichtung» in Wissenschaftliche Zeitschrift der Univetsität Halle, 1956, 5, pp. 196-202; A. Barigazzi, «Sul nuovo Anacreonte» in Athenaeum, 1956, 34, 1-2, pp. 139-151; B. Gentili, «I nuovi frammenti papiracei di Anacreonte» in Maia, 1956, VIII, pp. 181-196 (depois reproduzido e actualizado, como apêndice à sua edição de Anacreonte, cit., 1958, pp. 179-218); B. Snell in Antike und Abendland, 1957, 6, pp. 150 seqq. ; C. Gallavotti in Gnomon, 1957, 29, pp. 420 seqq.; e C. M. Bowra, Greek Lyric Poetry, pp. 278-282 e 286-289. Acrescente-se ainda a breve discussão de D. L. Page na sua crítica à edição de Gentili in The Classical Review, December 1959, pp. 235-237.

${ }^{5}$ As principais novidades são de ordem métrica. Vide A. M. Dale, «Greek Metric 1936-1957» in Lustrum, 2, 1957, pp. 5-51, especialmente p. 7. 
e 65, respectivamente 1 e 4 de Oxy. Pap. 2321, e 71 e 72, como desdobramento do fr. 1 de Oxy. Pap. 2322, de cuja autoria, aliás, Lobel duvida), o primeiro é mais um exemplo de carme erótico de espírito satírico; o segundo retoma as imagens do frg. 27 Diehl, se é que não foi escrito pouco depois daquele, conforme sugere Gentili ${ }^{1}$; o terceiro e o quarto, que devem, sem dúvida, separar-se em dois poemetos distintos, como fazem Latte, Peek e Gentili, são de autenticidade controversa, por motivos relacionados com a sua linguagem e estilo.

Embora haja muito de casual na recuperação dos textos em papiros, parece que a afirmação de Wilamowitz, de que a glória das Anacreontea ${ }^{2}$ e a evolução da ética ${ }^{3}$ fizeram esquecer o poeta arcaico, permanece, grosso modo, válida. Só assim se explica que a obra autêntica do vate de Teos, suficientemente popular para este ser representado em vasos mais do que uma vez ${ }^{4}$ e frequentemente citado pela comédia ${ }^{5}$, e tão

${ }^{1}$ Pp. 48-49. «Una variazione dello stesso tema», afirma a p. 202.

2 «Es ist wohl kein Zufall, dass Aegypten keinen Rest gebracht hat: die Anakreonteen hatten das Interesse an den echten Liedern zerstört»-lê-se em Sappho and Simonides, p. 110. Gentili, na introdução à sua edição, p. IX, já fala de um desmentido parcial a esta asserção, dado pelos dois novos papiros.

${ }^{3}$ Ibidem, pp. 155-156.

${ }^{4}$ Cf. ed. Gentili e bibliografia aí citada, p. XXIII e n. 60, e p. 84. Aos três vasos citados por S. Papaspyridi-Karouzou, "Anacréon à Athènes» in Bulletin de Correspondance Hellénique, 1942-1943, LXVI-LXVII, pp. 248-254, e por G. M. A. Richter, Attic Red-Figured Vases, A Survey, New Haven, 1946, pp. 44 e 58, acresce o do Museu de Copenhague. Os vasos são: um fragmento de calyx-krater pelo Pintor de Cleófrades, em Roma (Beazley, $A R V$, p. 123 n. ${ }^{\circ} 29$ ); uma lekythos assinada pelo oleiro Gales, Gallatin, CV, est. 23, 3-4, em Siracusa; uma kylix de Oitos, em Londres, Beazley, ARV, p. 40, n. ${ }^{\circ} 69$ (verso). Cf. ainda Ch. Picard, "Art et Littérature: sur trois exégèses» in Revue des Études Grecques, 1948, pp. 344-349. A taça de Oltos (c. 515 a. C.) e a lekythos do Pintor de Gales (c. 490 a. C.) encontram-se também reproduzidos e descritos por Karl Schefold, Die Bildnisse der antiken Dichter, Redner und Denker, Basel, Benno Schwabe \& Co. Verlag, 1943, pp. 50-51. A estátua conservada na Glyptotek Ny Carlsberg de Copenhague, considerada como uma cópia da da Acrópole, feita na época dos Antoninos, figura a pp. 64-65. A pp. 172-173, n. 15, pode ainda ver-se uma moeda de bronze, de Teos, cunhada c. 90 p. C, com a efígie do poeta.

${ }^{5}$ Aristófanes, Dait., fr. 223, p. 449 Kock = Ath. 15.646a (citado adiante, p. 28) e Thesm. 160-163:

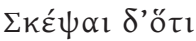

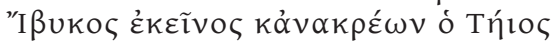

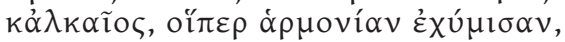

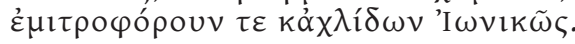

É curioso notar que a associação de Alceu e Anacreonte como autores célebres de skolia é comum aos dois passos. 
admirado que tinha a sua estátua na Acrópole ${ }^{1}$, fosse obliterada em proveito das suas imitações.

O problema da relação entre Anacreonte e as Anacreontea, levantado pouco depois do aparecimento da edição príncipe daquelas, em 1554, está suficientemente estudado e esclarecido. Limitar-me-ei, portanto, a resumir os pontos principais.

Logo após a sua publicação, surgem dúvidas, pela deficiente indicação de fontes dada por Henri Étienne, que só informa vagamente ter visto o códice na Universidade de Lovaina ${ }^{2}$. Apenas três anos depois, já Fr. Robortellus, no seu Liber de arte s. ratione corrigendi antiquos libros, Patav., 1557, p. 26, declara que se trata unicamente de «insulsos quosdam posterioris aeui lusus» ${ }^{3}$. E assim, enquanto os poetas, de Ronsard a Goethe, de Leopardi a Castilho, traduzem ou imitam as Anacreontea, os eruditos discutem a sua autenticidade. Em 1776, Fischer julga que escassamente haverá na colecção um poema de Anacreonte. Barnes e Baxter reagem, mas Bentley fundamenta criticamente as suas dúvidas. Seguem-no vários outros, até que Bergk ${ }^{4}$ nega decididamente a autoria de qualquer dos poemetos. E, se F. G. Welcker ainda atribui alguns ao escritor arcaico, Duentzer ${ }^{5}$ regressa em breve à opinião de Bergk. Importante a selecção e classificação de Stark ${ }^{6}$. Wolf, Mueller e Bernhardy juntam-se lhe, mas, em 1840, Lindau torna a defender a autenticidade, alterando os versos conforme era necessário. Rose admite a existência de poemas genuínos, ao lado dos outros.

Que todas as odes publicadas por Henri Etienne são apócrifas, com excepção de alguns fragmentos contidos de p. 52 em diante, ninguém duvida actualmente ${ }^{7}$. Problema que continua ainda em aberto é se

${ }^{1}$ Maximus Tyrius, XXXVII, p. 42 Hob. Pausânias I, 25, 1. O assunto foi estudado por G. Hafner, "Anakreon und Xanthippos» in Jahrbuch des Deutschen archäologischen Instituts, Berlin, 1956, LXXI, pp. 1-28.

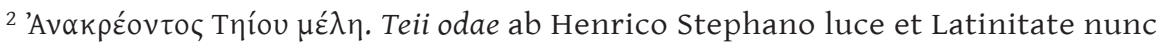
primum donatae. Lutetiae apud Henricum Stephanum, MDLIIII. Prefácio.

${ }^{3}$ Citado por Holly, Quaestiones Anacreonteae, Marburg, 1855, p. 8. Nesta exposição, seguimos principalmente o resumo deste autor, no capítulo I desse livro.

${ }^{4}$ Lipsiae, 1834.

${ }^{5}$ «Über die mutmassliche Entstehung unserer Sammlung der sogenannten Anakreonteen» in Zeitschrift für die Altertumswissenschaft, 1836, Nr. 94, Sp. 754-760, especialmente Sp. 757.

${ }^{6}$ Carolus Bernhardus Stark, Quaestionum Anacreonticarum Libri Duo, Lipsiae apud Voigt et Fernan, 1846.

${ }^{7}$ É curioso que é a partir desse ponto que H. Étienne afirma:

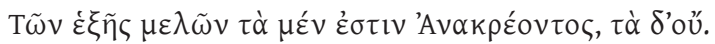


todas as citações feitas pelos antigos como sendo de Anacreonte lhe pertencem de facto. O caso é especialmente agudo num poeta como este, cuja temática interessou a uma numerosa hoste de imitadores em todos os tempos, desde a antiguidade até aos contemporâneos ${ }^{1}$, e cujo estilo se prestava ao decalque. Além de que os seus transmissores são muito tardios. Aristófanes ${ }^{2}, \mathrm{Crítias}^{3}$, Platão ${ }^{4}$ quase só nos informam sobre alguns dos seus temas. A mais antiga citação que chegou até nós encontra-se incorporada numa das muitas paródias contidas nas Aves de Aristófanes ${ }^{5}$ - é o primeiro verso do frg. 52 Diehl:

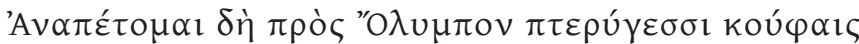

A que se lhe segue é já do séc. III a. C. - os dois versos reproduzidos

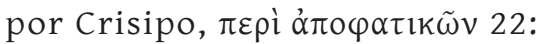

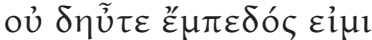

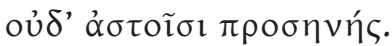

A maioria é constituída por citações do séc. II, III, e até IV. Um grande contingente é fornecido pelos escoliastas e pelos lexicógrafos do período bizantino. Até mesmo o papiro de Oxirinco 2321 é apenas do começo do séc. II da nossa era.

Por outro lado, o facto de conhecermos deste autor unicamente fragmentos, de que só um ou outro poderão considerar-se odes completas, dificulta extremamente a questão.

${ }^{1}$ Lembremos que ainda há pouco João Maia incluiu uma «Anacreontea» no seu livro de poemas Écloga Impossível, Lisboa, Círculo de Poesia, 1960. As mais antigas imitações portuguesas que conhecemos são as de António Ferreira (vide o nosso estudo «Alguns Aspectos do Classicismo de António Ferreira» in Humanitas, XI-XII, 1960, pp. 80-111, especialmente pp. 93-95). Para a Itália, leia-se o trabalho de L. A. Michelangeli, Anacreonte e la sua fortuna nei secoli, con una rassegna critica su gl' imitatori e i traduttori italiani delle "Anacreontee», Bologna, Zanichelli, 1922.

${ }^{2}$ Cf. nota 2 da p. 85.

${ }^{3}$ Vide infra p. 193-194 e nota 2 da p. 193.

${ }^{4}$ Phaedrus $235 \mathrm{c}$ e ainda Charmides 157e. O pseudo-Platão, Theages $125 \mathrm{~d}$-e (frg. 118 Bergk) refere-se a uma canção dada como bem conhecida, mas de cujo texto pouco ou nada diz. De qualquer modo, o diálogo deverá atribuir-se ao séc. III-II a. C. (cf. Platon, tome XIII, 2e. partie, Dialogues Suspects. Texte établi et traduit par Joseph Souilhé, Paris, Les Belles Lettres, 1930, pp. 141-142).

${ }^{5}$ V. 1373. Omitimos o frg. 86 Diehl, referido em Plut. 1002 e 1075:

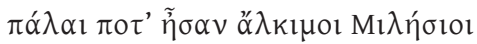

cuja autenticidade é duvidosa. 
Para estudar o problema da autenticidade do frg. 44 Diehl = 43 Bergk, tentaremos, no entanto, em primeiro lugar, delinear um esboço da temática de Anacreonte, partindo dos fragmentos cuja extensão permita classificá-los com alguma segurança. Ao mesmo tempo, iremos anotando as ideias que os informam, para reconstruirmos, na medida do possível, a mundividência do poeta. Veremos as relações com a métrica, e o modo de expressão, e acusaremos as semelhanças e divergências em relação às Anacreontea. Numa segunda parte, historiaremos as doutrinas apresentadas sobre o fragmento em causa. Analisaremos seguidamente o seu conteúdo sob o ponto de vista ideológico e estilístico, depois de o ter aproximado, tanto da obra reconhecidamente autêntica, como da de seus antecessores e contemporâneos, que estudaremos em função da temática envolvida. Deste modo, coligiremos elementos que nos permitam avaliar da autoria do excerto. 
1ํㅗㄹ PARTE

ANÁLISE DAS POESIAS AUTÊNTICAS DE ANACREONTE 
(Página deixada propositadamente em branco) 


\section{CAPÍTULO I \\ OS TEMAS E AS IDEIAS}

É nosso intento analisar, nesta primeira parte, apenas os fragmentos de Anacreonte cuja autenticidade nunca suscitou dúvidas fundamentadas, e, dentre esses, aqueles de que resta o suficiente para se fazer ideia do seu conteúdo.

Deste modo, ficam excluídos, pela primeira cláusula, os seguintes (além do 44 Diehl, de que nos ocuparemos noutro capítulo):

7 Diehl $=$ mel. adesp. 78 Bergk $=186$ Gentili

(atribuído por Crusius, negado por Bergk) ${ }^{1}$

$20 \mathrm{D}=35 \mathrm{~B}=117 \mathrm{G}$

(negado por Hecker)

$28 \mathrm{D}=65 \mathrm{~B}=37 \mathrm{G}$

(negado por Bergk na primeira edição, transferido depois para as Anacreontea e, na quarta edição, colocado dubitativamente entre os carmes genuínos; Weber igualmente lhe nega a autenticidade)

51a $\mathrm{D}=124 \mathrm{~B}=91 \mathrm{G}$

(negado por Blass)

$56 \mathrm{D}=36 \mathrm{~B}=187 \mathrm{G}$

(atribuído a Alceu por Wilamowitz e Sitzler; a Alceu ou Safo por Lobel-Page; duvidoso para Gentili)

$64 \mathrm{D}=72 \mathrm{~b} \mathrm{~B}=188 \mathrm{G}$

(atribuído por conjectura por Bergk; duvidoso para Gentili)

$82 \mathrm{D}=92 \mathrm{~B}=49 \mathrm{G}$

(negado por Holly e Weber; duvidoso para Bergk).

\footnotetext{
${ }^{1}$ Para as referências exactas, veja-se o aparato crítico de Bergk, Diehl e Gentili, ad loc. Designaremos pela respectiva maiúscula cada um destes editores. Um número não acompanhado de indicação de proveniência dirá sempre respeito a Diehl.
} 
$86 \mathrm{D}=85 \mathrm{~B}=53 \mathrm{G}$

(duvidoso para Wilamowitz, que o atribuiu a Timocreonte de Rodes, e para Bergk)

$92 \mathrm{D}=78 \mathrm{~B}=76 \mathrm{G}$

(atribuído a Álcman por Sitzler)

$95 \mathrm{D}=80 \mathrm{~B}=80 \mathrm{G}$

(atribuído a Hipónax por Knox)

99 Bergk

(Meineke deu-o como composto por um Anacreonte o Moço)

Pap. Oxy. 221, col. VII, 5-12 = $190 \mathrm{G}$

(atribuído a Píndaro por Grenfell e Hunt; a Anacreonte por Platt e Ludwich; duvidoso para Gentili)

Pap. Oxy. $2322=71,72,73 \mathrm{G}$

(duvidoso para Lobel; negado por Gallavotti; aceite por Latte, Peek, Snell, Merkelbach, Gentili) ${ }^{1}$.

Suprimindo os epigramas, de autoria controversa na sua quase totalidade ${ }^{2}$, e ainda os fragmentos que constam apenas de uma linha, ou até de duas, mas que não chegam a formar uma frase completa - e que só ocasionalmente podem ser úteis - restam-nos uns trinta e cinco excertos para servir de base ao nosso trabalho.

Principiaremos por coligir, nos passos conservados, algumas indicações de carácter auto-biográfico.

A mais conhecida, a do frg. 8 Diehl, faz lembrar o frg. 22 Diehl de Arquíloco, e, como ele, deve estar incompleta:

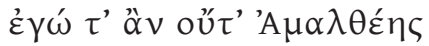

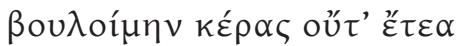

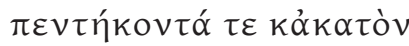

$$
\begin{aligned}
& \text { Т } \alpha \rho \tau \eta \sigma \sigma o \tilde{v} \beta \alpha \sigma \imath \lambda \varepsilon \tilde{v} \sigma \alpha \text { l. }
\end{aligned}
$$

Este é o negativo do quadro: ausência de ambição ${ }^{3}$. o fragmento de elegia que tem o número 96 em Diehl é mais completo, pois que, ao gosto alheio, contrapõe o do autor:

${ }^{1}$ A edição de Bergk refere ainda a suspeita de inautenticidade lançada por Welcker in Rheinisches Museum, XI, 230 seqq., sobre a segunda estrofe do frg. 5 (14 Bergk). Diehl já nem sequer menciona esta hipótese no seu aparato, nem tão-pouco Gentili.

${ }^{2}$ C. M. Bowra, Early Greek Elegists ${ }^{2}$, pp. 180-181, admite a possibilidade de alguns serem autênticos (100, 101, 107 e 108 Diehl).

${ }^{3}$ Sobre os motivos usados (cornucópia de Amalteia, reino de Tartessos) vide C. M. Bowra, Greek Lyric Poetry, pp. 291-292. 


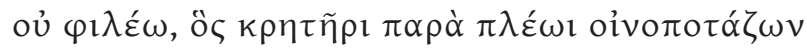

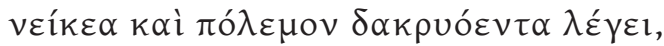

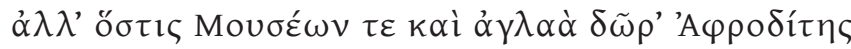

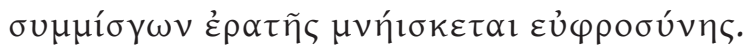

As canções que o poeta considera próprias dos banquetes não são as de tema bélico, mas aquelas em que se mistura a arte das Musas com o amor, no meio da amável alegria ${ }^{1}$. Há, sem dúvida, uma certa semelhança entre este ideal e o expresso no frg. 12 Diehl de Estesícoro, como já foi notado, entre outros, por Gentili, na sua edição de Anacreonte. Somente, a inspiração do nosso poeta não se eleva a assuntos divinos; apenas pretende que a boa disposição do festim parta dos temas escolhidos.

Porque estes são agradáveis é que o poeta sente que devia ser apreciado pelos seus ouvintes e suspira, no frg. 32 Diehl:

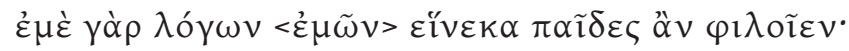

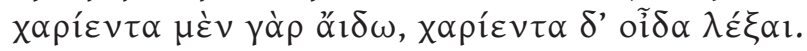

Tais palavras estão de acordo com os testimonia de autores antigos, de que salientamos apenas alguns dos mais expressivos:

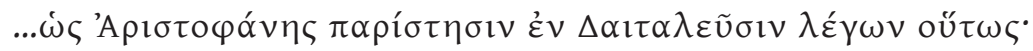

«Ã

(Athen. 15.646 a)

O mesmo autor, em 13.600 d, refere deste modo a temática de Anacreonte ${ }^{2}$ :

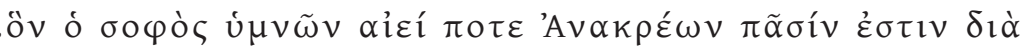

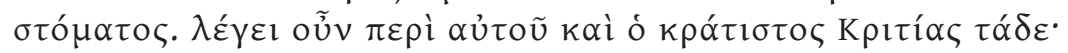

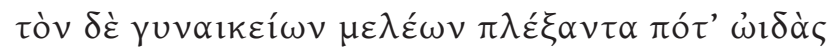

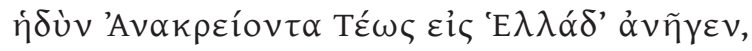

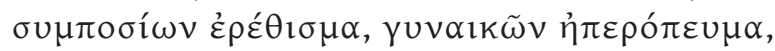

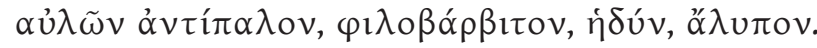

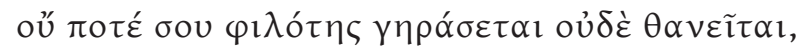

${ }^{1} \mathrm{O}$ frg. 65 Diehl confirma a antipatia do poeta por quantos têm um carácter sombrio e difícil.

${ }^{2}$ Os versos de Crítias foram analisados por Wilamowitz, Sappho und Simonides,

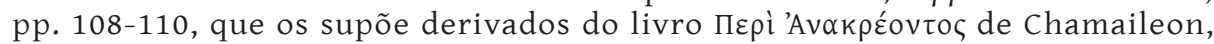
citado pelo mesmo Ateneio, 1599 Bergk, P. L. G., II, p. 283, admite uma lacuna entre o verso 4 e o 5 . 


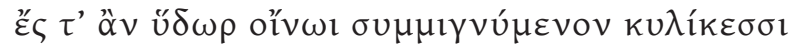

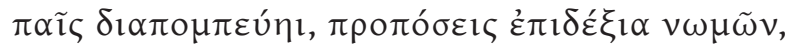

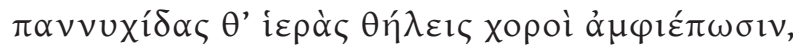

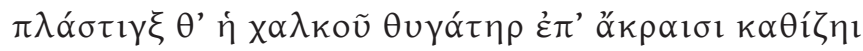

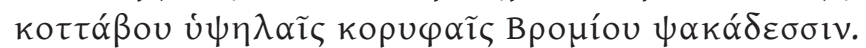

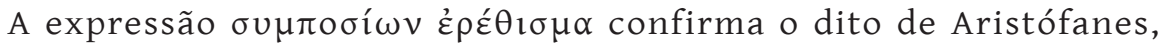
referido no excerto anterior, e, de um modo geral, os versos 3-4 caracterizam com exactidão as preferências do autor.

Da sua predilecção pela vida de banquetes em estreita ligação com o elemento erótico, cantos e danças, se fizeram eco as artes plásticas, quer a cerâmica, representando-o acompanhado de komastai, a cantar ao som da lira, em vasos de figurais vermelhas do último quartel do séc. VI e primeiro do $\mathrm{V}$ a. $\mathrm{C}^{1}$, quer a escultura, figurando-o do seguinte modo:

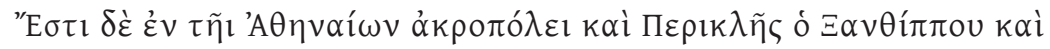

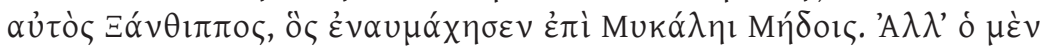

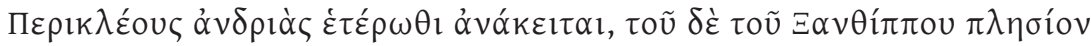

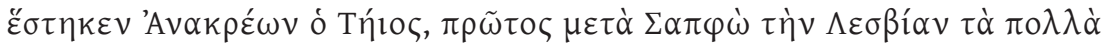

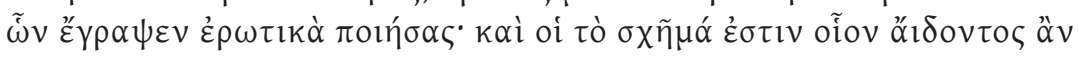

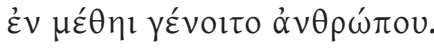

(Pausânias, I, 25, 1)

Também os dois epigramas de Leónidas ${ }^{2}$ fazem análoga representação do poeta, quer o seu modelo tenha sido uma estátua, quer uma pintura, conforme conjecturou Wilamowitz, com maior probabilidade ${ }^{3}$.

Com o testemunho de Pausânias, acima citado, concorda ainda o de um escritor que viveu dois séculos depois, Himério:

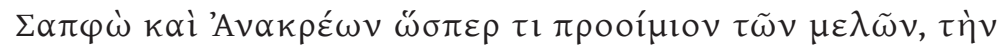

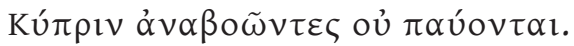

(Or. 19 Schenkl)

${ }^{1}$ Cf. supra, nota 4 da p. 185, e a descrição de Wilamowitz, Sappho und Simonides, p. 102 e n. 1, e, modernamente, as de Karl Schefold, Die Bildnisse der antiken Dichter, Redner und Denker, pp. 50 e 64.

2306 e 307 da Anthologia Planudea.

${ }^{3}$ Sappho und Simonides, pp. 103-105. Sobre a identificação da estátua da Acrópole, veja-se a edição de Pausânias por Hitzig e Bluemner, Berolini, 1896, vol. I, p. 276, e ainda Wilamowitz, op. cit., p. 106; ou, mais recentemente, G. Hafner, «Anakreon und Xanthippos» in Jahrbuch des Deutschen archaelogischen Instituts, Berlin, 1956, 71, pp. 1-28, e Karl Schefold, Die Bildnisse der antiken Dichter, Redner und Denker, p. 64. Gisela M. A. Richter, Greek Portraits. II. To what extent were they faithful likenesses?, Bruxelles, Collection Latomus, XXXVI, 1959, p. 39, aceita também que o original desta cópia romana fosse do século $\mathrm{V}$ a. C. 
Em Roma, a impressão de conjunto revelada através de um texto de Cícero é a mesma:

Nam Anacreontis quidem tota poesis est amatoria,

(Tusc. Disp. IV. 71)

Este mesmo motivo levou Platão a chamar-lhe oopó ৎ no Fedro ${ }^{1}$, ao falar das autoridades, anteriores a Sócrates, que haviam tratado do amor.

O que acabámos de ver está de acordo, em grande parte, com os escassos testemunhos auto-biográficos de Anacreonte que chegaram até nós ${ }^{2}$. É igualmente adequado para nos revelar as principais directrizes da sua poesia ${ }^{3}$.

Estas podem agrupar-se em três assuntos principais: o amor, os banquetes, a troça. Designaremos as composições correspondentes, à maneira grega, respectivamente, por erotika, sympotika e skoptika. A predilecção por estes temas, se mais não soubéssemos acerca do poeta, já nos daria um perfil moral suficientemente nítido e nos faria compreender por que era muito apreciado como autor de skolia. ${ }^{4}$. Mas vejamos separadamente cada um deles.

Os erotika abrangem diversos fragmentos consagrados à Moũ $\sigma \alpha$ $\pi \alpha \imath \delta ı k n ́(3,4,40 \mathrm{Diehl})$, à confissão de uma nem sempre bem sucedida reincidência no $\operatorname{amor}^{5}(5,17,26,45,79 \mathrm{Diehl})$, ao desespero, que o leva a

${ }^{1} 235 c$.

${ }^{2}$ Omitimos informações como as do já citado Ateneio X, 429b, quando afirma

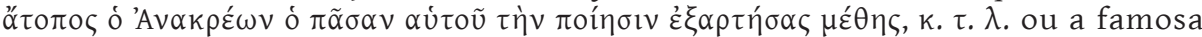
pergunta de Séneca, Ep., 88, 37, libidinosior Anacreon an ebriosior uixerit. O assunto encontra-se estudado, em relação com a evolução da ética antiga, por Wilamowitz, Sappho und Simonides, pp. 102-112.

${ }^{3}$ Dos seus partheneia, nada sabemos de positivo. O Oxy. Pap. 221, col. VII, 5-12, é pouco claro. O passo de Luciano, Ver. Hist. II, 113, é uma simples paródia. E o já

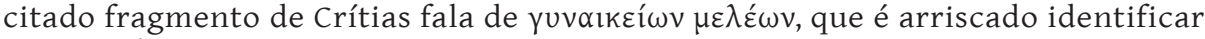
com partheneia.

${ }^{4}$ «Seine Lyrik gehört unmittelbar mit dem zusammen, was man in Athen Skolien nennt» - como afirmou Wiiamowitz, Sappho und Simonides, p. 120.

Sobre os três tipos de skolia que os antigos distinguiam (hinos aos deuses, antes de principiar o symposion; cantigas à desgarrada, em que cada conviva entoava um verso; odes dos grandes poetas, destinadas a essas ocasiões festivas) é essencial o testemunho de Dicearco (schol. in Plat. Gorg. 451e), citado por A. H. Harvey, «The Classification of Greek Lyric Poetry» in The Classical Quarterly, New Series, vol. V, N. 3-4, July-October 1955, pp. 157-175, especialmente p. 164.

${ }^{5}$ B. Snell, Die Entdeckung des Geistes, p. 101, caracteriza bem este sentimento, em contraste com o de Safo:

«So meisterhaft Anakreon seine Liebe in immer neuen Bildern malt, der Gedichtsanfang: «Wieder liebe ich...» hat seine ursprüngliche Kraft eingebüsst. Sappho's Liebe ist derart, dass der Satz nur bedeuten kann: 
ambicionar a morte como única libertação possível (42 Diehl), ao gracioso ataque à jovem trácia que o desdenha (88 Diehl) e que ele quer ensinar a viver na corte de Samos ${ }^{1}$, e a quem repudia, talvez, no frg. 98 Diehl. Nalgumas composições, a velhice é apresentada como um obstáculo a que o seu amor seja correspondido: é o caso dos frgs. 5 e 53 Diehl. O frg. 39 Diehl parece descrever, por metáfora, os movimentos assustados de uma

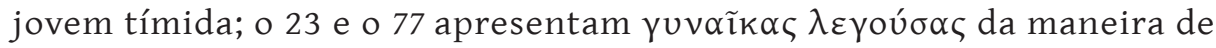
que falou Hermógenes, $\pi \varepsilon \rho i$ i $\delta \varepsilon \tilde{\omega} v$, II, 3, p. 323 seq. Rabe.

No frg. 69 Diehl, o poeta saciado toca a lira, em honra da $\varphi \hat{i} \lambda \eta 1 . . . \pi \alpha 1 \delta i$ $\dot{\alpha} \beta \rho \tilde{l}^{2}$. Estamos, pois, já no ambiente dos komastai.

Outros poemas têm como cenário o próprio symposion, mas entrelaçam os dois temas. É o caso do conhecido frg. 27 Diehl, que transcrevemos no texto e arranjo estrófico de Bergk, em quatro dímetros iónicos anaclómenos:

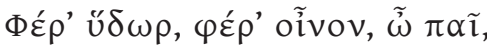

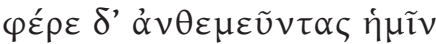

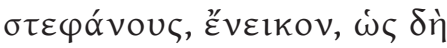

$$
\begin{aligned}
& \pi \rho o ̀ \varsigma ~ " Е \rho \omega \tau \alpha \pi u k \tau \alpha \lambda i\langle\zeta \omega \text {. }
\end{aligned}
$$

O frg. 4 do Pap. Oxy. 2321 (= 65 Gentili) usa o mesmo verbo do quarto verso logo de começo, convida também ao symposion nas últimas linhas, mas é produto de uma situação psíquica diversa: o poeta felicita-se por haver escapado à influência de Eros, e pretende mesmo comemorar essa vitória. Eis a transcrição adoptada por Gentili, depois das várias correcções propostas pelo próprio, e, sobretudo, por Lobel, Peek, Barigazzi:

_ $\chi \alpha] \lambda \varepsilon \pi \tilde{\omega} \varsigma \delta^{\prime} \dot{\varepsilon} \pi v \kappa \tau \alpha{ }^{\prime} \lambda_{1} \zeta o[v$

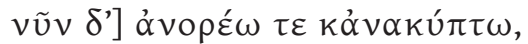

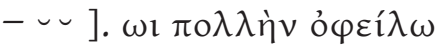

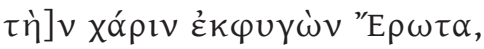

$\Delta \varepsilon \dot{]}] v v \sigma \varepsilon \pi \alpha \nu \tau \alpha \dot{\alpha} \pi \alpha \sigma l, \delta \varepsilon \sigma \mu[\tilde{\omega} \nu$

es ist mein immer wiederkehrendes Schicksal, dass ich lieben und leiden muss: sie begreift damit das Gesetz ihres Wesens, den Rythmus ihres Empfindens. Bei Anakreon klingt es leicht fertig, wenn er fünfmal sagt: «Wieder habe ich mich verliebt....

Para uma opinião contrária, veja-se C. M. Bowra, Greek Lyric Poetry, p. 283, n. 1.

${ }^{1}$ Segundo a interpretação de Wilamowitz, Sappho und Simonides, pp. 117-120. Para outra opinião, veja-se C. M. Bowra, Greek Lyric Poetry, pp. 271-272, que situa o poema na época da permanência de Anacreonte em Abdera.

${ }^{2} \mathrm{O}$ passo está corrupto. Wilamowitz propõe que se leia um nome próprio,

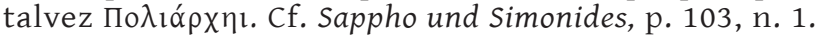




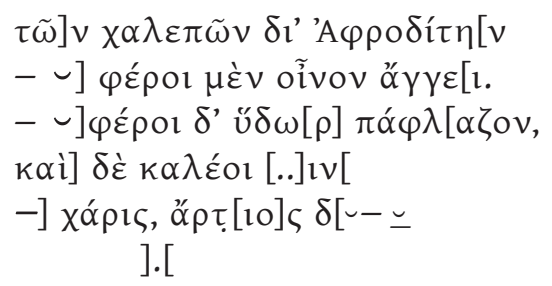

A semelhança vocabular com o frg. 27 foi logo notada por Lobel na editio princeps do texto ${ }^{1}$. Gentili compara do mesmo modo as duas composições e supõe que esta foi escrita a seguir à outra ${ }^{2}$.

Curioso é também assinalar a presença de uma invocação a Dioniso, em meio da euforia da libertação de Eros e dos pesados liames de Afrodite. Com efeito, as três divindades figuram como companheiras de folguedos no frg. 2 Diehl:

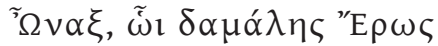

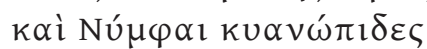

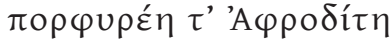

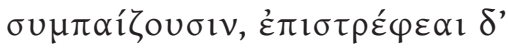

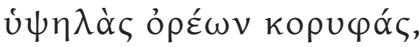

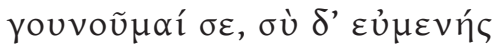

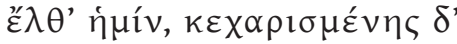

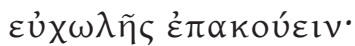

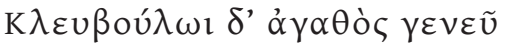

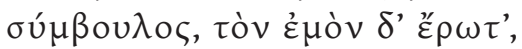

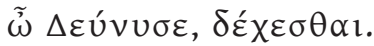

Mas como explicar que estes mesmos deuses sejam comuns àquele fragmento e ao que acabámos de citar, e que costuma ser considerado um hino?

Muito antes de se descobrir este papiro de Oxirinco, a resposta encontrava-se na interpretação dada por Wilamowitz à ode transcrita: o poema foi também elaborado para um symposion, para o qual se convida o deus ${ }^{3}$ e a sua comitiva; o próprio facto de Eros não fazer parte

${ }^{1}$ The Oxyrhinchus Papyri, Part XXII, 1954, p. 59.

${ }^{2}$ Pp. 48-49 e 202 da sua edição. Para D. L. Page, o verso 7 marca possivelmente o início de um novo poema (na recensão à obra anterior, in The Classical Review, vol. IX, no 3, December 1959, p. 237).

${ }^{3}$ Num lugar onde se bebia, estava o deus no seu ambiente, pelo menos desde o tempo de Arquíloco: 
do culto, nem tão-pouco Afrodite, prova que não se trata de um hino. A introdução da figura da deusa é da responsabilidade do poeta ${ }^{1}$.

Encontram-se também referências a Dioniso noutros passos: à sua voz tonitruante (frg. 11 Bergk), à sua comitiva de ménades (frg. 48 Diehl), como termo de comparação para os comastas (frg. 131 Bergk, segundo a correcção de Wilamowitz) ou ainda numa exortação a celebrar condignamente a festa do deus:

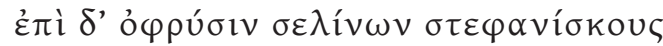

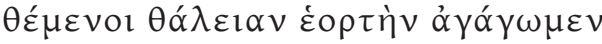

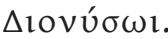

(frg. 37 Diehl)

Nenhuma nos autoriza, na verdade, a ver no frg. 2 Diehl mais do que uma associação ocasional das duas divindades.

Como é sabido, as coroas enfeitavam os Gregos em todas as grandes manifestações da sua vida: nos sacrifícios, nos casamentos, nos banquetes $^{2}$. Outros fragmentos de Anacreonte lhes fazem referência: o 33 e o 76 Diehl e o 123 Bergk. Estes conduzem-nos de novo, segundo tudo

Cfr. também, para a associação de Cípria e Dioniso, o frg. 20 Diehl de Sólon e o 20 b Snell, vv. 5-9, de Baquílides, e ainda, embora mais tardios, os versos 68-72 do Ciclope de Eurípides.

1 «Hier wird wirklich der Gott mit seinem Gefolge eingeladen; aber es ist kein Kultlied, denn Eros ist überhaupt keine Person für den Gottesdienst, und Aphrodite hat mit Dionysos keine Kultgemeinschaft. Aber dieser Gott kommt ja wirklich alle zwei Jahre zu den trieterischen Festen in die Menschenwelt, und zu ihm, der nicht nur beseligenden Rausch, sondern jede Begeisterung weckt, gehören in der Empfindung und der Phantasie des Dichters die Götter, die er neben ihm nennt, weil sie ihn auch begeistern. Wohin er den Gott ruft, sagt et nicht, aber wir fühlen es leicht: die Gesellschaft der Zechbrüder ist versammelt; es ist wohl in der Frühlingszeit, da dem Gotte von den Ioniern die Anthesterien gefeiert werden.... Und daneben die Nymphen im Tanze, die ihren Herrn ja auch auf den Vasen begleiten, und Aphrodite : sie hinzuzufügen ist dem Dichter eigentümlich.» (Sappho und Simonides, p. 115). C. M. Bowra, Greek Lyric Poetry, pp. 283-284, segue na mesma esteira. Cf. ainda Hermann Fränkel, «Eine Stileigenheit der frühgriechischen Literatur» in Nachrichten von der Gesellschaft der Wissenschaften zu Göttingen, Phil.-hist. Klasse, 1924, p. $85=$ Wege und Formen frühgriechischen Denkens, München, C. H. Beck, 1960, p. 60: «Nach dem Vorbild der irdischen Festen, mehr als nach Glauben und Mythos, ist ja der Götterthiasos zusammengestellt». A explicação de Gentili, na introdução à sua edição, p. XXI, não é satisfatória.

$\mathrm{O}$ autor da Anacreontea XLIII também juntou as três divindades.

${ }^{2}$ Cf. M. P. Nilsson, Geschichte der griechischen Religion, München, Beck, 1941, vol. I, p. 116. Um bom testemunho antigo é o frg. 81b Lobel-Page de Safo. 
leva a crer, ao ambiente do symposium, onde se joga o kóttabos siliciano ${ }^{1}$, onde se serve o vinho em medidas adequadas ${ }^{2}$.

Este último ponto encontra-se claramente expresso no frg. 43 Diehl = $63 \mathrm{Bergk}$, no qual ambos os editores supuseram uma lacuna, ao passo que Von der Mühll in Hermes, LXXV, 1940, pp. 422-425, crê que se trata de dois poemas diferentes, cantados em momentos diversos do banquete. A dificuldade provém do facto de Ateneio citar as duas partes separadamente ${ }^{3}$. Os termos em que as referências são feitas provam, porém, que se trata de um mesmo poema, como demonstrou Ed. Fraenkel ${ }^{4}$. As instruções aí fornecidas são muito importantes, para se conhecer a atitude do poeta:

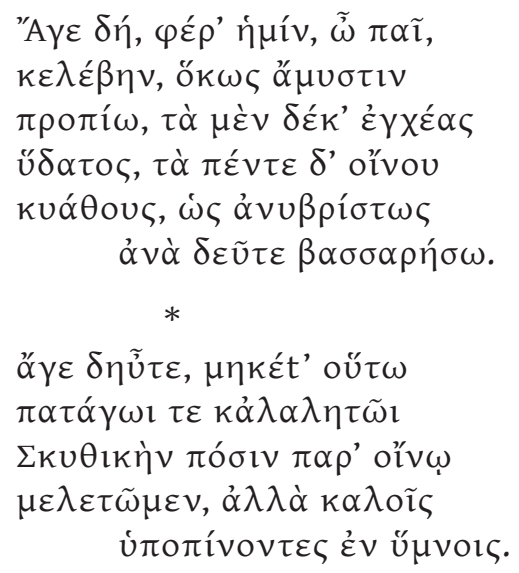

Especialmente significativas são $\alpha v v \beta p i ́ \sigma \tau \omega \varsigma$, na primeira parte, e $\dot{\alpha} \lambda \lambda \grave{\alpha}$

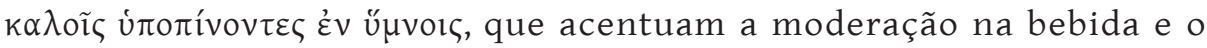
carácter requintado dos entretenimentos que a acompanham.

${ }^{1} \mathrm{Frg} .41$ Diehl. O kóttabos foi celebrado em verso por um poeta, já citado, do séc. V a. C , Crítias (frg. 1 Bergk= 1 Diehl) e pintado em vasos gregos de figuras vermelhas (Cat. Campan., IV. D. 862. Tillyard, Hope Vases 245, est. 34 e 32, sítula da Apúlia em Dublin, Museu Nacional. Tillyard, Hope Vases, 230, est. 32, krater de sino da Apúlia, no Museu de Eton College). O assunto foi estudado por Otto Jahn, «Kottabos auf Vasenbildern» in Philologus, 1867, p. 206. A estes acrescentei o krater pelo Pintor de Manchester, pertencente a uma colecção particular de Lisboa (em artigo publicado in Archivo Español de Arqueologia, XXXI, 1958, pp. 165-168). Ateneio, XV, 666b, ocupou-se também deste entretenimento. Muitos autores clássicos o mencionam; o próprio Aristófanes faz-lhe diversas referências nas suas comédias (Ach. 525; Nub. 1073; Pax 343, 1244).

${ }^{2}$ Frg. 22 e 58 Diehl.

${ }^{3} \mathrm{X}, 427 \mathrm{a}$; XI, 475c.

${ }^{4}$ Horace, Oxford, at the Clarendon Press, 1957, p. 179, n. 2. 
Um contemporâneo do nosso poeta, Xenófanes, também se exprimira de modo semelhante, mas com muitos mais pormenores, acerca do comportamento a observar durante o banquete, de que ele era uma espécie de mestre de cerimónias ${ }^{1}$. Não se trata, portanto, de uma atitude isolada. O que é interessante notar é que, a despeito destes repetidos protestos de moderação, não foi através deles, mas de outros, como talvez o frg. 99 Diehl, que o viram os pintores de vasos do final do séc. VI a. C. e o escultor da estátua da Acrópole (possivelmente do tempo de Péricles) e ainda mais a posteridade, como se evidenciou através dos testemunhos atrás citados e como claramente se patenteia nas Anacreontea.

A terceira das facetas mais características do poeta de Teos é a revelada pelas composições trocistas, skoptika, que, embora muitas vezes executadas no espírito de Arquíloco, aparecem também em medidas eólicas.

A mais célebre até há pouco conhecida era a invectiva contra Ártemon (frg. 54 Diehl), em que se contrasta, com uma precisão gráfica, a figura boçal do antigo pobretão com os requintes de efeminado luxo com que agora ele pretende disfarçar a sua grosseria. A esta veio juntar-se recentemente o frg. 1 do Papiro de Oxirinco 2321 (= $60 \mathrm{Gentili),} \mathrm{onde} \mathrm{de} \mathrm{igual} \mathrm{modo} \mathrm{se} \mathrm{estabelece} \mathrm{um} \mathrm{contraste} \mathrm{cheio}$ de ironia, mas, desta vez, entre a aparente inocência e brandura de Herotima e o seu real comportamento ${ }^{2}$. Também o frg. 55 Diehl deve

${ }^{1}$ Elegia 1 Diehl. Sobre esta, veja-se C. M. Bowra, Problems in Greek Poetry, cap. «Xenophanes on Songs at Feasts».

${ }^{2}$ Considero que o verso final do papiro:

$$
\lambda \varepsilon \omega \varphi] \text { ó } \rho \varepsilon, \lambda \varepsilon \omega \varphi o ́ \rho ' ~ ' H \rho o[\tau] i ́ \mu \eta,
$$

pertence ainda ao poema. Se, como Latte, Merkelbach, Bowra e Page, supusermos que é já o início de um novo carme, e virmos uma oposição irreconciliável entre a figura tímida, descrita nos primeiros versos, e a cortesã impudica do último, será possível aceitar que $\kappa \alpha \lambda \lambda \imath \pi \rho o ́ \sigma \omega \pi \varepsilon \pi \alpha i ́ \delta \omega v$ se dirige a um jovem. Mas tal oposição não é irreconciliável; pelo contrário, é um malicioso quadro, que opõe as aparências de um carácter timorato à realidade de um procedimento escandaloso, como notaram Paratore e Gentili. A. Barigazzi, «Sul nuovo Anacreonte» in Athenaeum, N. S., Vol. XXXIV, fasc. 1-2, 1956, pp. 139-151, complica desnecessária e ousadamente o problema, ligando-o com o tema do cabelo cortado, mediante o suplemento:

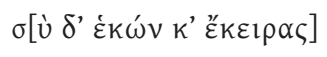

no v. 6, e interpretando os discutidos «campos de jacinto» como «cabeleira». Deste modo, pode também considerar-se como pertencente ao poema o verso de Herotima. Page mantém-se num prudente cepticismo: «The reconstruction is necessarily a chain of guesses, the sense depending on the supplements» 
ser dirigido a uma cortesã. O frg. 11 Diehl ataca alguém da espécie de Ártemon. O frg. 16 é-lhe seguramente dirigido, visto que menciona o seu nome. Os iambos dos frgs. 80 e 87, o 71, 62 Diehl e talvez ainda alguns excertos curtíssimos, como o 151, 154, 161, 162 e 168 Bergk, e ainda um pequeno fragmento citado por J. Martin ${ }^{1}$ devem igualmente ter tido intenção satírica.

Dos restantes versos de Anacreonte, podemos ainda referir uma breve descrição da invernia, contida no frg. 6 Diehl, que seguramente servia de introdução à expressão de qualquer sentimento pessoal, pois a natureza nunca constitui só por si, como é sabido, tema central de um poema grego arcaico. É de conjecturar que se seguisse qualquer convite a beber e a procurar um agradável conforto no interior da casa, como sucede no frg. 338 Lobel-Page de Alceu.

Alguns outros poemas ocupavam-se do momento político. Destes, temos apenas insignificantes fragmentos, como o 10 Bergk, o 19, 25, talvez o 57, 67, 74 e 81 Diehl $^{2}$. O 19 e o 25, pelo menos, devem referir-se a Polícrates, confirmando assim o dito de Estrabão:

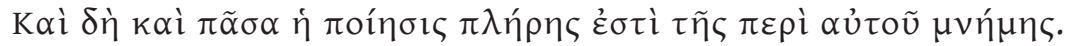
(XIV, 638)

e ainda o de Himério:

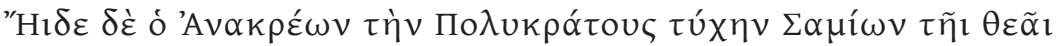
$\pi \varepsilon \mu \pi o ́ v \tau \omega \nu \tau$ q i $\varepsilon \rho \alpha ́$.

(Or. 30 Schenkl)

De uma obrigação destas se deve ter desempenhado o poeta, quanto à cidade de Magnésia, ao compor o hino a Ártemis que consta do frg. 1 Diehl, um hino que sai fora dos moldes habituais desse tipo de obras,

(recensão à edição de Gentili, cit., in The Classical Review, N. S., vol. IX, n. ${ }^{\circ}$, December 1959, p. 237). Para pormenores de crítica textual, veja-se a mencionada edição de Gentili, ad locum, e pp. 179-194, e ainda C. M. Bowra, Greek Lyric Poetry, pp. 286-287, n. 1.

${ }^{1} \mathrm{Na}$ recensão crítica à edição de Gentili, publicada na Revue des Études Grecques, LXXIII, Janvier-Juin 1960, pp. 273-274. Consta dos escólios aos Fenómenos de Arato, contidos na penúltima linha do fol. $43 \mathrm{r}^{\circ}$ do Scorialensis $\Sigma$. III. 3. É o seguinte:

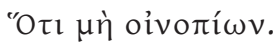

J. Martin supõe que se trata de um jogo de palavras sobre o nome Oinopion e

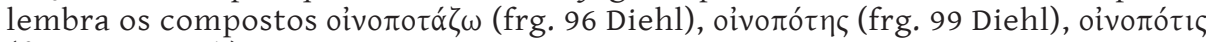
(frg. 162 Bergk).

${ }^{2}$ Sobre estes veja-se a interpretação de M. Treu, Von Homer zur Lyrik, pp. 287-291. 
como observou Wilamowitz ${ }^{1}$, reservando para o final um pequeno jogo de palavras, tanto ao gosto do seu autor ${ }^{2}$.

Quanto ao frg. 2 Diehl, já vimos anteriormente as razões por que não deve incluir-se nesta categoria. O frg. 91 Diehl é endereçado a uma deusa, como afirmou H. Fränkel ${ }^{3}$.

O pequeno dístico à memória de um amigo, contido no frg. 90 Diehl, não é um epigrama, como Bergk supôs, imprimindo-o entre as composições desse tipo, com o número 114, mas um brinde, como demonstrou Wilamowitz ${ }^{4}$.

O frg. 75 Diehl parece pertencer igualmente a um brinde:

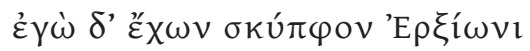

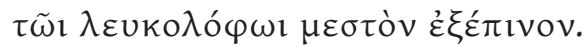

Pelo que acabámos de ver se conclui que as ideias expressas na lírica de Anacreonte não são muito variadas nem profundas ${ }^{5}$. Nem mesmo quando o sentimento religioso poderia manifestar-se com alguma gravidade, o poeta deixa de insuflar um gracioso tom de ironia, conforme sucede no frg. 1 Diehl. A nota mais constante é a do desejo do prazer, embora moderado, com afastamento dos lados sombrios da vida, como tão bem documenta o frg. 96 Diehl. O amor é a paixão dominante, que se polariza em volta de figuras várias, com insistências e reincidências contínuas $(\delta \eta \tilde{u} \tau \varepsilon)$. Especialmente significativas são as metáforas que ligam por forma ousada o vocabulário da embriaguez com o erótico,

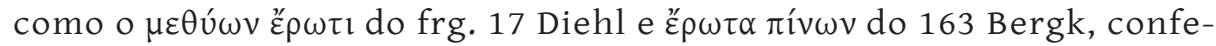
rindo assim à frase um valor expressivo excepcional.

${ }^{1}$ Sappho und Simonides, pp. 113-114. Comparando este fragmento com o 2 Diehl, Crusius afirma no seu artigo sobre Anacreonte in Pauly-Wissowa, I, col. 2041: «Der Arthemishymnus.... scheint religiös gehalten; aber schon in das Gebet an Dionysos tritt ein erotisches Motiv ein».

${ }^{2}$ Hermann Fränkel, «Eine Stileigenheit der frühgriechischen Literatur» in Nachrichten von der Gesellschaft der Wissenschaften zu Göttingen, Phil.-hist. Klasse, 1924 , p. 84 , n. 3 = Wege und Formen frühgriechischen Denkens, pp. 59-60, n. 1, discorda e propõe a emenda:

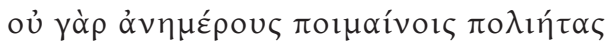

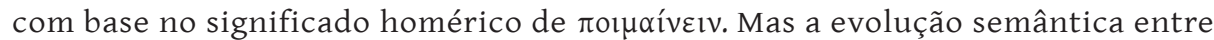
os Poemas Homéricos e a lírica é considerável: lembremos somente o contraste entre a psyche da Ilíada e a do frg. 4 Diehl de Anacreonte. Sobre a interpretação do passo, veja-se ainda C. M. Bowra, Greek Lyric Poetry, p. 274 e n. 3.

${ }^{3}$ Dichtung und Philosophie des frühen Griechentums, pp. 389 seqq. Contra: Weber, Anacreontea, p. 79.

4 Sappho und Simonides, p. 106.

${ }^{5}$ Conforme observa M. Treu, Von Homer zur Lyrik, p. 287, o scholion a Ésquilo, Prom. V. 128

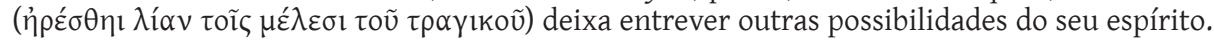




\section{CAPÍTULO II}

\section{OS METROS}

É sabido que Anacreonte empregou um grande número de metros, e, embora ficasse conhecido sobretudo como lírico, e incluído no respectivo cânon alexandrino, cultivou, também a poesia iâmbica e a elegíaca. Desta última, restam quatro fragmentos (96, 97, 98 e 99 Diehl) considerados autênticos. Dos iambos, Diehl apresenta dezanove, de que uns nove devem pertencer a Anacreonte e encontrar-se nesse metro. A versificação trocaica abrange os fragmentos 88, 89, 90, 91, 93 e 94 Diehl.

Os demais metros empregados são os eólicos (em que avultam notoriamente o glicónico e o ferecrateu) e os iónicos. Estes últimos aparecem puros, em tetrâmetros, trímetros ou dímetros, ou numa variedade típica do poeta, que dele tomou o nome ${ }^{1}$ : o anacreôntico, a que os metricistas preferem chamar dímetro iónico anaclómeno. Nesta espécie de metro é que o poeta de Teos se tornou célebre, e foi essa medida, juntamente

1 A. M. Dale, The Lyric Metres of Greek Drama, p. 116, e W. R. Hardie, Res Metrica, p. 172, admitem a possibilidade de ter sido Anacreonte o inventor desta medida. Mas a verdade é que ela aparece já em Safo, nos frgs. 87 Diehl (= 134 Lobel-Page) e 144 Diehl (= 133 Lobel-Page) referidos por Heféstion, 12.4 e 14.7, respectivamente, como anaclómenos. B. Snell, Griechische Metrik, p. 21, cita estes dois exemplos, e ainda o frg. 145 Diehl (= 20 incerti auctoris Lobel $=23$ incertum utrius auctoris fragmenta Lobel-Page). Para o segundo, Gentili, Metrica Greca Arcaica, p. 121, evita a dificuldade com um metr. iam. + enopl. de 8 sílabas. Quanto ao frg. 133, Page, Sappho and Alcaeus, An Introduction to the Study of Ancient Lesbian Poetry, p. 322, analisa-o como anceps seguida de gl. + bacch.

É sabido que, muitas vezes, o nome de um metro é derivado do de um poeta que viveu séculos depois de ele ter sido inventado, mas que o empregou com grande frequência. É o caso, por exemplo do asclepiadeu.

Sobre a análise do ionicus a minore, veja-se ainda o comentário de E. R. Dodds a pp. 72-73 da sua segunda edição das Bacantes de Eurípides (The Plays of Euripides, Oxford, 1960). 
com o dímetro iâmbico cataléctico (ou hemiambo) que os autores das Anacreontea utilizaram com mais frequência ${ }^{1}$.

Os metros empregados por Anacreonte foram já estudados mais do que uma vez. Mesmo pondo de parte os discutidos e ultrapassados trabalhos de Kikauka², dispomos ainda das observações de Wilamowitz ${ }^{3}$, e, mais recentemente, das de Gentili ${ }^{4}$, além das dos tratados sistemáticos de versificação grega. Aqui vamos considerar apenas as relações entre o metro empregado e o tema desenvolvido ${ }^{5}$, pelo que nos limitaremos aos mais bem representados.

Os ritmos eólicos são usados sobretudo para a poesia erótica, quer na combinação estrófica de glicónicos com ferecrateus, quer em asclepiadeus ou em dímetros coriâmbicos.

Exemplos de arranjos estróficos da primeira espécie são os frgs. 3 , 4 e 5 Diehl. A estes podemos ainda acrescentar os frgs. 6 e $8^{6}$ Diehl, de

\footnotetext{
${ }^{1}$ Cf. Koster, Traité de Métrique Grecque 2 , p. 97. Sobre o emprego e vantagens dos iónicos, veja-se Wilamowitz, Isyllos von Epidauros, p. 131:

«Für Anakreon ist vor allem charakteristich, dass er nur aufsteigende loniker hat.... Die glücklichste Vereinigung von Freiheit und Selbstbeschränkung, wie es die Weise jonischer Kunst ist, macht Anakreon zum grössten Meister in der Verskunst seines Stammes».

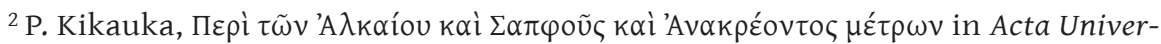
sitatis Latviensis, XVIII, 1928, pp. 3-52, e «Mètres de la poésie grecque monodique», in Acta Universitatis Latviensis, Series Nova, II, 1, 1931, pp. 1-192.

${ }^{3}$ Isyllos von Epidauros, pp. 131-135.

${ }^{4}$ Metrica Greca Arcaica, pp. 155-187.

${ }^{5}$ Apesar das restrições de P. Maas, Griechische Metrik, p. 19, para a época arcaica.

Sobre este assunto, pode ver-se o capítulo «L'Art d'Anacréon et son Expression Rythmique», do estudo de Émile Martin, Essai sur tes Rythmes de la Chanson Grecque Antique, Paris, Klincksieck, 1953, que é por vezes sugestivo, mas nem sempre convincente. De resto, o autor ainda se atém à antiquada escansão logaédica.

Desde Bergk, Anacreontis carminum reliquiae, 1834, pp. 28 seqq., que se aceitou que a obra do poeta constava de cinco livros, divididos de acordo com o metro, consoante a notícia de Suidas e o epigrama 9, 239, da Anthologia Palatina. Refutaram este ponto de vista T. Kehrhahn, "Anacreontea», in Hermes, 1914, pp. 481-507 (que supõe seis) e Gentili, na sua edição, p. XXVIII (que pensa em nove ou dez).
}

${ }^{6}$ A escansão do primeiro verso tem sido bastante discutida.

$\mathrm{Na}$ verdade, o texto conservado:

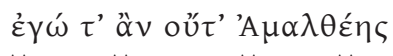

é um dímetro iâmbico (como mede Gentili). Para regularizar o metro, Casaubon emendou para 
que se conserva apenas uma estrofe, mas que, muito provavelmente, eram também de inspiração erótica no resto do contexto.

Ainda neste grupo, podemos considerar o frg. 2 Diehl, que, como vimos, participa ao mesmo tempo da poesia dedicatória, erótica e de symposion. O frg. 1 Diehl mostra que um poema apenas dedicatório, de carácter cívico e religioso, se podia exprimir também nas mesmas medidas.

O glicónico seguido de ferecrateu, ou seja, o priapeu, aparece no frg. 69 Diehl, de timbre marcadamente erótico, o que está de acordo

que dava o desejado glicónio. Seguiu-o Bergk, nos seus Poetae Lyrici Graeci. Diehl, com base em Wilamowitz, Griechische Verskunst, p. 235, e Rupprecht in Bayerische Blätter für das Gymnasial-Schulwesen, 61, 1925, p. 50, regressam ao texto dos manuscritos. A emenda de Mehlhorn,

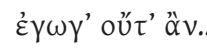

seguida por Koster, melhora o texto sob o ponto de vista métrico, bem como a de Blass:

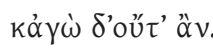

A de Tyrwhitt

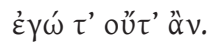

não é estilisticamente recomendável. Gentili mantém o texto tradicional e como Wilamowitz, op. cit., p. 236, n. 1, compara a métrica com a do verso 2 do frg. 16 Diehl, em que a um glicónico sucede um dímetro iâmbico.

O mesmo Wilamowitz, op. cit., p. 235 e n. 2, cita, para demonstrar a equivalência entre esses dois metros, o v. 5 do frg. 2 Bergk (apoiado por dois paralelos, M 282 e Arist. Nub. 279).

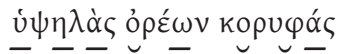

protestando contra a emenda de Barnes, seguida por Bergk (e rejeitada por Diehl):

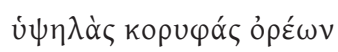

É certo que a tradição manuscrita pode manter-se neste caso, escandindo o verso como um "wilamowitziano» (a que Gentili, Metrica Greca Arcaica, pp. 156 e 159, chama dímetro ou glicónico poli-esquemático). B. Snell, Griechische Metrik, p. 31, tem este passo como incerto, mas inclina-se para aceitar a equivalência entre o dímetro iâmbico e o glicónico em 8,1 e 16,2. Parece-me, no entanto, preferível, atendendo à regularidade do esquema estrófico dos glicónicos com ferecrateus em Anacreonte, aceitar a emenda de Casaubon, seguida por Bergk e Koster, que aponta o verso como exemplo de glicónico a p. 222 do seu Traité de Métrique Grecque ${ }^{2}$. O estado do frg. 16 Diehl = 21 Bergk não permite que nos apoiemos nele como exemplo (cf. Bergk appar. crit. ad locum, e Wilamowitz, Isyllos von Epidauros, p. 133, n. 11). 
com a origem deste ritmo, usado para celebrar o deus da fertilidade, conforme sugere Koster ${ }^{1}$.

O longo asclepiadeu (hipercataléctico), a seguir a um glicónico, no frg. 17 Diehl, ajuda a sugerir o movimento da pesada queda de um corpo que se atira das alturas:

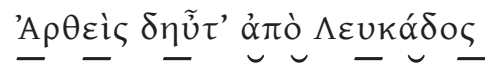

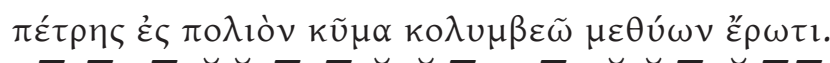

Que os glicónicos podiam igualmente servir para os skoptika, provam-no os três versos incompletos do frg. 11 Diehl.

No entanto, este tipo de poemas prefere o ritmo iâmbico - conforme mandava uma tradição que já vinha de Arquíloco - ou o coriâmbico. É o caso da violenta invectiva contra Ártemon (frg. 54 Diehl) ${ }^{2}$ e dos novos fragmentos do Papiro de Oxirinco 2321 ( = 60 e 65 Gentili) ${ }^{3}$.

Também a indignação do frg. 52 Diehl se exprime nesse ritmo.

Os tetrâmetros trocaicos contribuem, sem dúvida, para dar vida e movimento à graciosa e maliciosa metáfora da poldra da Trácia, no

1 Traité de Métrique Grecque ${ }^{2}$, p. 245.

2 «Choriamben wie die Anakreons auf Artemon sind von lamben kaum zu scheiden, und sie bestehen aus Dimetern» (Wilamowitz, Griechische Verskunst, pp. 285-286).

${ }^{3} \mathrm{O}$ primeiro oferece algumas dúvidas. Cf. as notas métricas, a p. 110 da edição de Gentili. J. Irigoin, «Colon, vers et strophe dans la lyrique monodique grecque» in Revue de Philologie, de Littérature et d'Histoire Ancienne, XXXI, 1957, pp. 234-238, analisa- o como dois dímetros coriâmbicos, seguidos de um trímetro coriâmbico cataléctico. Parece, de facto, predominar o ritmo coriâmbico. A. M. Dale, «Greek Metric 1936-1957» in Lustrum, 2, 1957, p. 7, considera-o uma modificação do metro iónico.

Quanto ao frg. 45 Diehl, hesita-se entre o iónico e o iâmbico. Heféstion dá-o como exemplo de tetrâmetro iónico braquicataléctico. Wilamowitz, Griechische Verskunst, p. 230, classifica-o, e com razão, como uma forma do dímetro coriâmbico (sendo o primeiro membro um dímetro iónico cataléctico e o segundo um dímetro iâmbico, também cataléctico), embora o autor pudesse tê-lo como iónico:

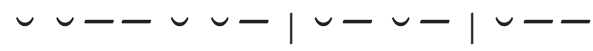

Em Isyllos von Epidauros, p. 134, observa mesmo: «Auch hier zeigt sich die nahe Verwandtschaft der loniker und lamben».

Koster, op. cit., p. 205, tem como predominante o ritmo iónico. Gentili, na sua edição, p. 109, duvida, e propõe, como em Metrica Greca Arcaica, pp. 165-166, analisá-lo em parteneio + dim. iamb. cat.

Nas mesmas condições está o frg. 46. 
frg. 88 Diehl$^{1}$. É, no entanto, no mesmo ritmo trepidante que, no frg. 90 Diehl, o poeta brinda à memória de Aristoclides, e que, no frg. 91 Diehl, se dirige a uma deusa, pedindo-lhe que o escute ${ }^{2}$.

Os iónicos puros ou os anaclómenos, sem dúvida um dos metros favoritos de Anacreonte, aparecem num grande número de fragmentos.

Excluindo deste grupo os que são tão curtos que não se lhes adivinha o contexto, ou até mesmo os que oferecem uma escansão pouco segura, temos ainda uma

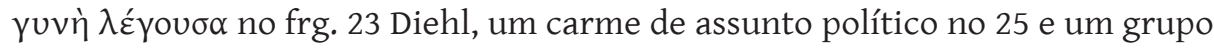
de temas eróticos nos frgs. 26, 29 e 40. É muito provável que este tipo de canções fosse especialmente usado nos banquetes, ao lado das que já vimos, em ritmos eólicos. Seja como for, os frgs. $21,32,36,39,42$ e talvez $48^{3}$, todos em medida iónica, parecem dever colocar-se nesse ambiente festivo. E o 22, 27, 37, 41 e 43 revelam mesmo, no seu conteúdo, as circunstâncias para que foram compostos. Ora, dentre estes, apenas dois são mais extensos, embora não completos: o 27 e o 43, ambos em dímetros iónicos ${ }^{4}$. O primeiro é exclusivamente anaclómeno:

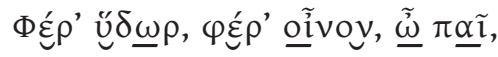

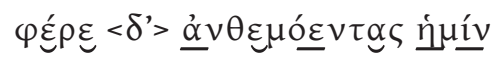

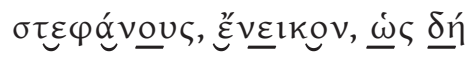

$$
\begin{aligned}
& \pi \rho \dot{\rho} \varsigma \text { ” E } \rho \underline{\omega} \tau \underline{\alpha} \pi \underline{u} \kappa \tau \underline{\alpha} \lambda \underline{\underline{i} \zeta \omega} \text {. }
\end{aligned}
$$

No segundo, alternam os puros com os anaclómenos:

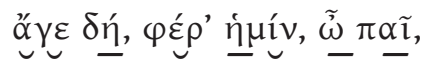

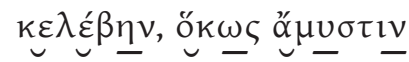

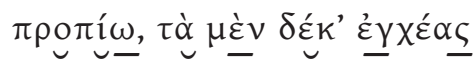

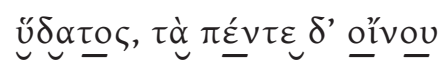

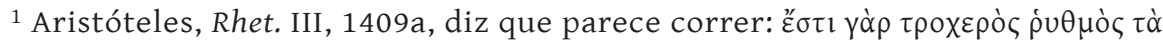
$\tau \varepsilon \tau \rho \alpha ́ \mu \varepsilon \tau \rho \alpha$ (referido por E. Martin, op. cit. pp. 307 e 316).

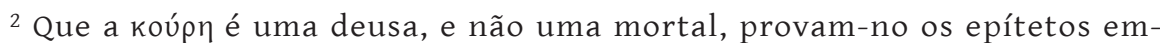
pregados, conforme demonstrou H. Fränkel, Dichtung und Philosophie des frühen Griechentums, pp. 389 seq.

${ }^{3}$ Segundo Heféstion, seguido por Koster, p. 204. Mas cf. Gentili, na sua edição, ad locum, e Metrica Greca Arcaica, pp. 166-167.

${ }^{4}$ Diehl e Snell escandem o primeiro em tetrâmetros iónicos. Bergk escreve-o em quatro dímetros (frg. 62). 


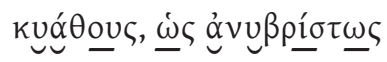

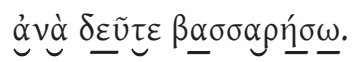

Os quatro primeiros versos têm anáclase, o quinto consta de dois dímetros iónicos e o sexto é de novo anaclómeno.

Na segunda estrofe, temos:

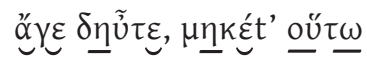

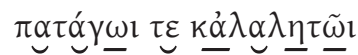

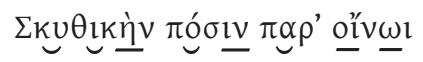

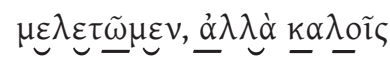

$$
\begin{aligned}
& \text { U் }
\end{aligned}
$$

Portanto, quatro versos anaclómenos e o último formado por um dímetro iónico puro.

O metro, particularmente musical e elegante, parece ter sido empregado de preferência nas canções sympotika. Alguns fragmentos curtos mostram, contudo, que também podia usar-se para versar temas alheios ao grupo definido pelo já citado frg. 96 Diehl. No entanto, a preponderância com que surge neste tipo de composições torna mais compreensível a sua grande voga junto dos imitadores de Anacreonte: para eles, estava ligado aos temas ligeiros que desenvolviam. 


\section{CAPÍTULO III}

\section{LINGUAGEM E ESTILO}

A linguagem de Anacreonte foi já exaustivamente estudada por Weber, na sua dissertação intitulada Anacreontea, Gottingae, 1892, depois de o ter sido parcialmente por outros ${ }^{1}$. Começaremos, portanto, por resumir as suas conclusões.

Encontram-se no vocabulário do poeta termos épicos, especialmente

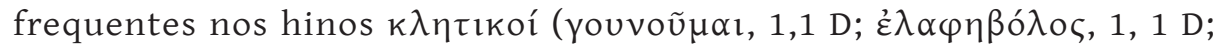

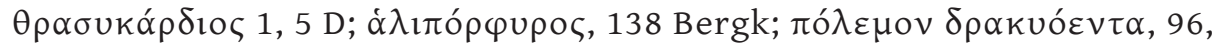
$2 \mathrm{D}$, etc.). Outras palavras são de uso comum ao iónico e eólico, como

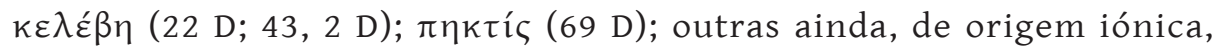

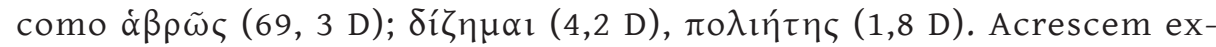
pressões tiradas do uso cotidiano, no género de $\alpha \beta \alpha \kappa i \zeta \omega ~(65,3$ D), $\beta \varepsilon \rho-$

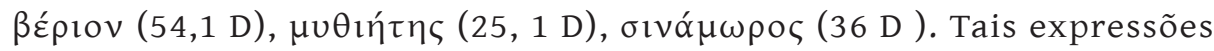
predominam, como é natural, no fragmento de ataque a Ártemon (54 D). A um pequeno número de vocábulos atribui Weber origem estrangeira:

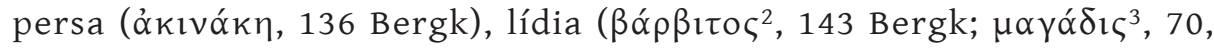

${ }^{1}$ Nomeadamente por C. B. Stark, Quaestionum Anacreonticarum Libri Duo, Leipzig, 1846, Liber I, cap. I, § 3; Holly, Quaestiones Anacreonteae, Marburg, 1885, pp. 25-27; A. Fick, «Die Sprachform der altionischen und altattischen Lyrik» in Beiträge zur Kunde der indogermanischen Sprachen herausgegeben von Dr. Adalbert Bezzenberger, IX. Band, Göttingen, 1886, pp. 242-272.

${ }^{2}$ De origem duvidosa, possivelmente frigia, para J. B. Hofmann, Etymologisches Wörterbuch des Griechischen, München, 1950, s. u., e Hjalmar Frisk, Griechisches etymologisches Wörterbuch, Heidelberg, 1955, s. u.

3 Para Hofmann, apenas «kleinasiat. Fremdwort». 
1 Diehl), trácia ( $\beta \alpha \sigma \sigma \alpha \rho i ́ \varsigma^{1}, 48$ Diehl; $\sigma \alpha \tilde{v} \lambda o \varsigma^{2}, 48$ Diehl e 168 Bergk) ou

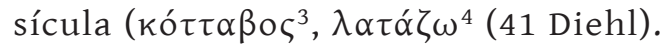

A morfologia e sintaxe foram igualmente estudadas por Weber, que notou, a propósito desta última, a sua simplicidade ${ }^{5}$.

Sobre o estilo, depois de algumas observações de Weber ${ }^{6}$, as primeiras de importância foram as de Wilamowitz, que nota a sua simplicidade, clareza e verdade ${ }^{7}$, qualidades que partilha com Arquíloco e os Lésbios e que contrastam com as do seu contemporâneo, e possivelmente companheiro na corte de Polícrates de Samos, Íbico. Para o demonstrar, analisa os frgs. 1, 2, 14 e 75 Bergk do poeta de Teos, e depois os frgs. 1 e 2 Bergk do de Régio. Tais qualidades, acrescenta, só voltarão a surgir na comédia ática.

Seguidamente, o grande contributo para o estudo do estilo de Anacreonte foi fornecido por Hermann Fränkel, no seu artigo «Eine Stileigenheit der frühgriechischen Literatur», publicado nas Nachrichten von der Gesellschaft der Wissenschaften zu Götingen, Philologisch-historische Klasse, 1924, Heft 1, pp. 63-103, e Heft 2, pp. 105-127, e reproduzido mais tarde no livro Wege und Formen frühgriechischen Denkens, München, 1955, pp. 40-968; a estes trabalhos devem ainda acrescentar-se as pp. 378-390 de outra obra sua, Dichtung und Philosophie des frühen Griechentums, New York, 1951.

Hermann Fränkel refere-se também à «fusão de realidade com poesia», à frescura, à "maravilhosa finura e elegância de apresentação» ${ }^{9}$, mas não se restringe a estas generalidades.

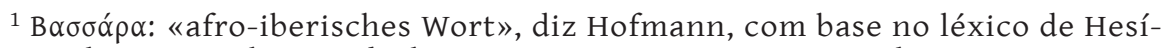
quio. "Ohne Etymologie», declara, mais categoricamente, Frisk.

${ }^{2}$ Hofmann atribui-lhe uma raiz *bhesēu-, de onde também $\psi \tilde{\eta} v$.

${ }^{3}$ Hofmann propõe *qotu-mbos. Frisk declara mais cautelosamente: «Da sich die

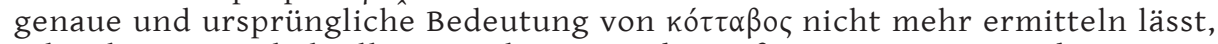
schweben eigentlich alle Etymologien in der Luft... Der Ursprung des Wortes wäre im westlichen Mittelmeerraum zu suchen». No entanto, a proveniência do jogo insinua a origem do nome:

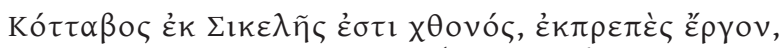

(Crítias, Elegia I, 1 Bergk)

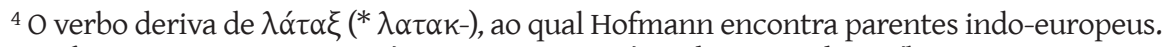
O latim latex, -icis, por sua vez, é que seria originário do grego da Sicília.

${ }^{5}$ Especialmente a pp. 24-25.

${ }^{6}$ Op. cit., pp. 25-30.

7 Sappho und Simonides, p. 121.

${ }^{8}$ A segunda edição, de 1960, conserva a mesma paginação.

9 P. 84 do artigo das GN. Em Dichtung und Philosophie, p. 378, precisa ainda: «Seine Gedichte sind zügig, frisch und beschwingt.» 
Assim, encontra, no frg. 3 D, «eine scharfe Gliederung der Rede nach den metrischen Kola» e verifica que esta adaptação da frase à cadência da estrofe é frequente, e deve ter feito com que as composições de Anacreonte fossem das mais cantáveis.

Nota ainda o agrupamento repetido de três membros, como no frg.

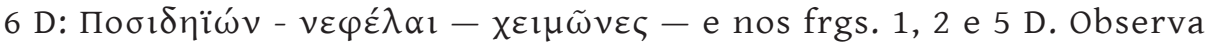
também que, tal como Íbico, o poeta já ultrapassou o «estilo acumula-

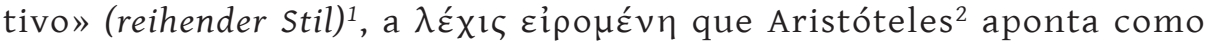
característica dos autores arcaicos.

Mais recentemente ainda, M. Treu, na sua tese Von Homer zur Lyrik, München, 1955, consagra algumas páginas ao mesmo assunto. Verifica que a Anacreonte interessam sobretudo as notações de ordem visual, como

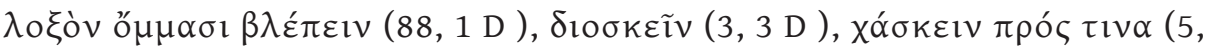

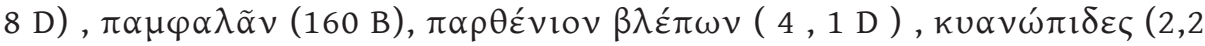

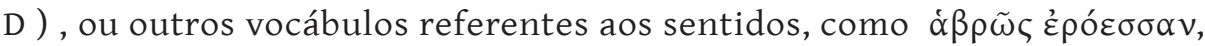

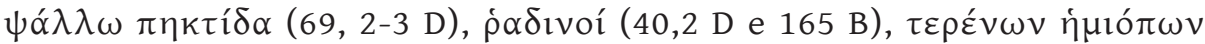
$(18,2$ D), ao andar e movimento, como $\sigma \alpha \tilde{v} \lambda \alpha \beta \alpha i ́ v \omega v(168$ B), $\sigma \alpha \tilde{v} \lambda \alpha 1$

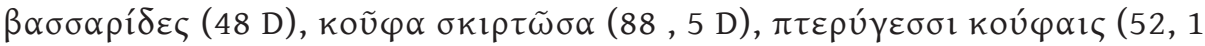
D), ou ainda a contrastes de cores, como em $89 \mathrm{D}^{3}$.

O estudo de B. A. Van Groningen, La Composition Littéraire Archaïque Grecque, deuxième édition, Amsterdam, 1960, não se ocupa especialmente de Anacreonte, como é natural, porquanto, por um lado, os fragmentos com extensão suficiente para serem analisados segundo os métodos propostos pelo autor são muito poucos; e, por outro lado, o processo de composição do poeta de Teos ultrapassa frequentemente, como já vimos, a prática arcaica. Esta mesma característica acabada de mencionar o tornou de tão fácil imitação para a posteridade.

No seu estudo sobre Anacreonte, incluído em Greek Lyric Poetry, second edition, Oxford, 1961, C. M. Bowra insiste na importância da escolha das palavras para alcançar tão brilhantes efeitos.

De quantos fragmentos líricos seguramente autênticos chegaram até nós, apenas oito excedem a reduzida meta de cinco versos seguidos: $1,2,5,43,54,88$ e (embora mutilados) os frgs. 1 e 4 do Oxy. Pap. 2321. A estes poderíamos acrescentar fragmentos como o 3, 4, 6, 8, 27, 69,

\footnotetext{
${ }^{1}$ «Eine Stileigenheit....», pp. 84-86. Em Dichtung und Philosophie, p. 381, apresenta outros exemplos e lembra (nota 6) que Mimnermo, frg. 1,3, e Sólon, frg. 14,4 , também usam os grupos de três membros.

${ }^{2}$ Rhet. III, 1409 a 24.

3 Pp. 286-295, especialmente 293-295. Omitimos os exemplos extraídos de fragmentos de autenticidade duvidosa.
} 
96, que, pelo menos, formam uma frase completa, quanto à sintaxe e quanto ao sentido.

Mais significativo ainda é observar que, de todos estes excertos, apenas os frgs. 2 e 88 são geralmente considerados odes completas. Também o frg. 5 pôde ser tido nessa conta, a despeito da prudente reserva de Wilamowitz ${ }^{1}$; no frg. 1, supunha o mesmo helenista que nada faltava ${ }^{2}$, mas não assim Bergk ${ }^{3}$, Kehrhahn ${ }^{4}$ e Meyer. Com efeito, como nota o primeiro, a frase fica em suspenso no final do carme. Os novos fragmentos, mesmo os mais extensos, são mutilados e incompletos.

Sendo assim, as bases em que assentamos a nossa análise são manifestamente insuficientes. Podemos, no entanto, tirar algumas conclusões, e até mesmo, ocasionalmente, apoiar as nossas deduções em fragmentos menores, dada a simplicidade e clareza dos processos usados pelo poeta.

Cada substantivo é, em regra, imediatamente acompanhado de um

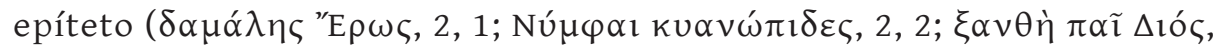

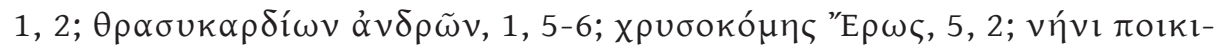

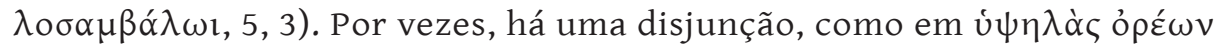

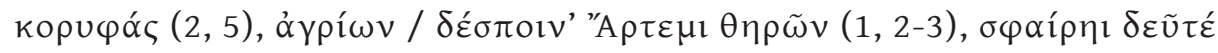
$\mu \varepsilon \pi о \rho \varphi \cup \rho \varepsilon ́ \eta ı(5,1)$, e sobretudo,

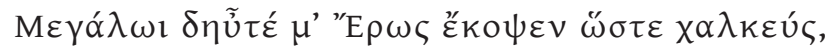

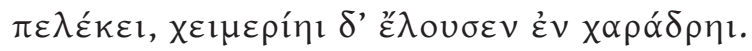

do frg. 45, onde o adjectivo $\mu \varepsilon \gamma$ ýd $\lambda \omega$ i deixa na espectativa o ouvinte até ao começo do próximo verso, embora o sentido entretanto se vá

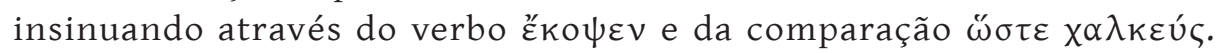
A segunda frase repete o processo exactamente, menos a comparação ${ }^{5}$.

${ }^{1}$ Sappho und Simonides, p. 116: "Auch da brauchen wir nicht mehr als wir haben, wenn auch nicht geleugnet werden soll, dass der Dichter fortfahren konnte.»

${ }^{2}$ Op. cit., pp. 113-114.

3 P. L. G., III, p. 253.

4 «Anacreontea» in Hermes, 1914, pp. 481-507. Para outras opiniões, vide C. M. Bowra, Greek Lyric Poetry, pp. 273-274.

${ }^{5}$ Sobre a natureza das metáforas aqui utilizadas, vide C. M. Bowra, Greek Lyric Poetry, pp. 290-291, que compara a primeira com a situação em y 442-450 e a segunda com Teógnis 347-348. Para Bowra, temos aqui um exemplo de uma atitude característica do poeta:

«In his avoidance of anything which might savour of pomposity and to keep his usual air of not making too much show of his feelings, Anacreon uses familiar phrases.» 
Qualquer destas construções estava, aliás, na tradição poética.

Adjectivação dupla, e ainda com dois compostos, encontra-se no frg. 91 Diehl.

Mais típico é o agrupamento de três membros, de que falámos anteriormente, o qual se torna muito sensível, como já foi notado ${ }^{1}$ nos

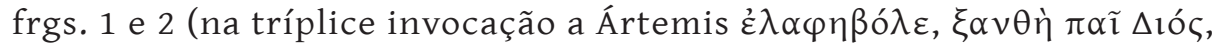

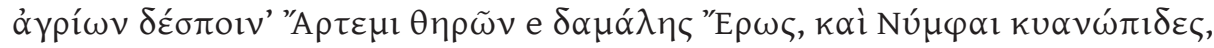

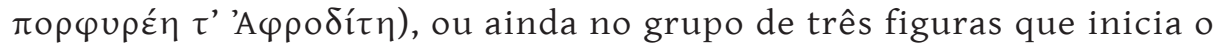

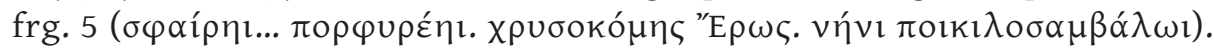

Uma repartição simétrica, não já dos motivos, mas das atitudes de espírito, através das frases que as exprimem, é a que podemos observar no frg. 88. Primeiro, uma invocação com a respectiva pergunta:

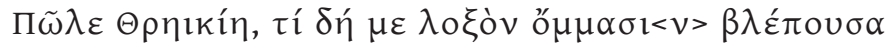

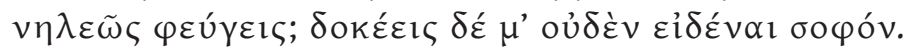

Segue-se uma advertência, em que continua sempre a usar-se o mesmo símile da poldra da Trácia:

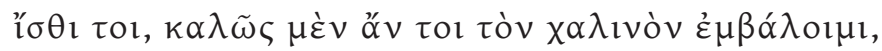

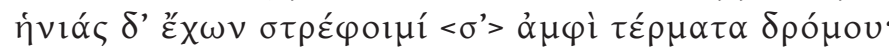

Os dois últimos versos põem em contraste esta perspectiva com o comportamento actual da jovem - sempre desenhada sob o disfarce da metáfora - e fornecem a razão do mesmo:

Deve notar-se que o passo de Teógnis oferece dificuldades: $\delta \dot{\varepsilon}$ kúwv foi emen-

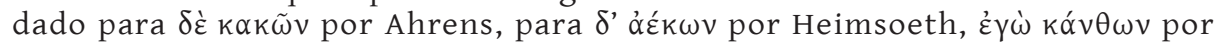

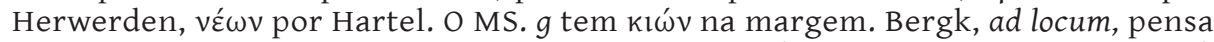
numa fábula desconhecida, hipótese que Carrière (ad locum, p. 44, n. 1 e p. 107) rejeita. Bowra, op. cit., p. 291, n. 1, supõe uma fonte comum na sabedoria popular

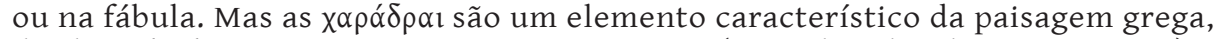
desde a Ilíada, $\Delta$, 452-455, E 87-88 e П 389-392 (consideradas dinamicamente) e Álcman, frg. 58 Diehl (estaticamente apresentadas) até à descrição de Pausânias

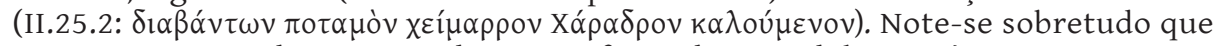
em $\Delta$ 452-455 a adjectivação deve ter oferecido o modelo a Teógnis:

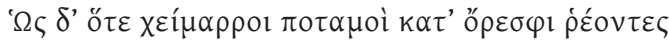

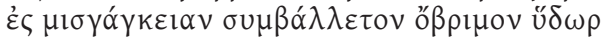

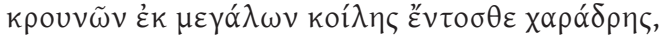

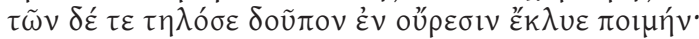

Os versos 282-283 do Canto XXI da Ilíada também apresentam uma imagem algo semelhante a esta.

${ }^{1}$ Por Hermann Fränkel, «Eine Stileingenheit....», p. 85. 


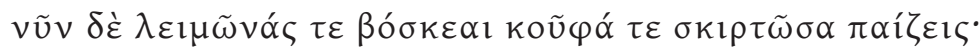

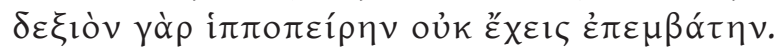

O frg. 5 também conta duas partes simetricamente repartidas, em coincidência com os kola métricos. A primeira traça as premissas do quadro, a segunda, as consequências. O contraste é sublinhado pelo jogo das partículas, como muito bem notou Weber ${ }^{1}$ : «Duo enuntiata sunt, quorum alterum, quod antecedenti contrariam sententiam continet, per

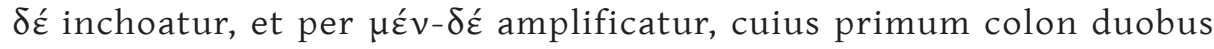

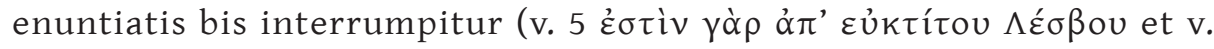

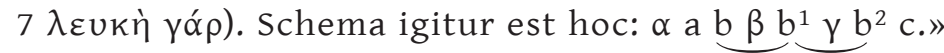

Quase simétrica igualmente a repartição dos dois dísticos elegíacos do frg. 96, em que o primeiro é o negativo, o segundo o positivo do ideal de

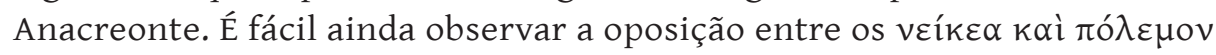

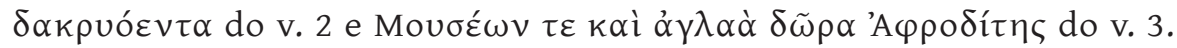

A mesma simetria podemos ainda notar no que resta de outra composição, o frg. 69 Diehl:

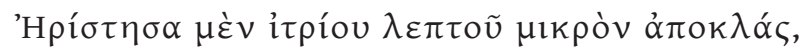
oĺvou $\delta$ ' '̇ं द́ं

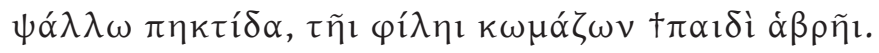

em que o glicónico do segundo verso termina a primeira parte, descritiva de um passado recente, e o ferecrateu que o continua lhe opõe, com um enérgico $v \tilde{v} v \delta \varepsilon$, a actual ocupação do poeta.

O curto, mas expressivo, frg. 4 também conjuga admiravelmente o sentido com a métrica, de onde lhe advém a impressão de elegância formal que se desprende do todo. Um vocativo com seus atributos ocupa o primeiro verso completo. O segundo opõe, na sua primeira metade, a atitude do poeta ( $\delta i ́ \zeta \eta n \mu \alpha i ́$

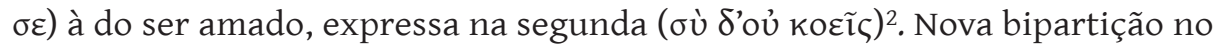

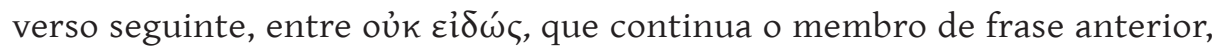
e o seu complemento, que, por sua vez, preencherá o ferecrateu do quarto

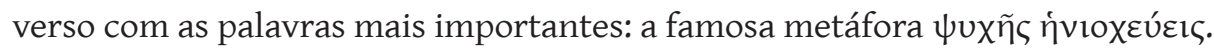

Também no frg. 1 do Oxy. Pap. $2321=60$ Gentili se pode apreciar, apesar das muitas falhas no texto, uma idêntica oposição antitética, nomeadamente entre a primeira e a segunda estrofes conservadas e o resto do poema. De notar, aliás, que o contraste ${ }^{3}$ entre a aparência de

\footnotetext{
${ }^{1}$ Op. cit., p. 28.

${ }^{2}$ Conjectura de Bergk.

${ }^{3}$ Que Anacreonte apreciava estes contrastes, prova-o o frg. 4 Diehl.
} 
Herotima, e a vigilância a que está submetida, e o seu real comportamento deve principiar ${ }^{1}$ a meio do v. 6:

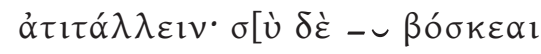

Uma oposição entre o passado e o presente da mesma figura é a que vamos encontrar no frg. 54 Diehl, em que três grupos de três versos, enumerando os antigos hábitos de Ártemon, contrabalançam os três finais, introduzidos por $v \tilde{v} v \delta \varepsilon$. Como não conhecemos a continuação do fragmento, ignoramos se a simetria ia mais longe. Aliás, deve observar-se que a apresentação do sujeito da frase, no v. 5:

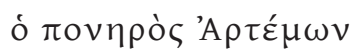

quebra habilmente uma acumulação de particípios descritivos com seus complementos, que poderia tornar-se monótona ${ }^{2}$.

No frg. 1 temos uma série de invocações, que ocupam os três primeiros versos, às quais se segue uma oração relativa, que estabelece a transição dos atributos normais de Ártemis para os que, de momento, permitem que se lhe dirija esta prece, e vai culminar, no v. 7, com o

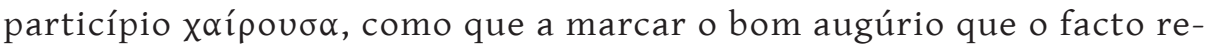
presenta; termina com a razão da preferência da deusa, baseada num pequeno jogo de palavras, com elogiosas implicações políticas, como observaram Wilamowitz ${ }^{3}$ e Bowra ${ }^{4}$.

O frg. 2, sob vários pontos de vista semelhante a este, apresenta uma composição um tanto diversa. O verbo próprio para a prece (үouvoũ $\mu \alpha$ ) só aparece a cinco versos de distância do vocativo inicial, que, por sua

${ }^{1}$ Para outras interpretações deste fragmento, vide supra, pp. 200-201, n. 2.

${ }^{2}$ Weber, op. cit., p. 29, analisa em pormenor o fragmento:

«Schema igitur est hoc: (A:) a b c d e (B:) $\alpha \propto b$ a ex tribus colis per koí inter se coniunctis compositum est, quorum primum et tertium apposi-

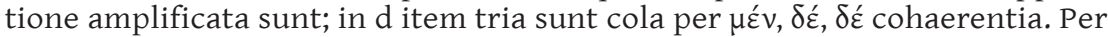
totum primum membrum participia tantum inueniuntur. Hominis nomen v.

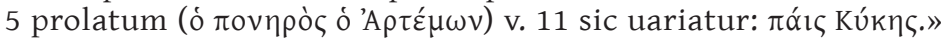

${ }^{3}$ Sappho und Simonides, pp. 113-114. Hermann Fränkel, «Eine Stileigenheit....», p. 84, n. 3, discorda. Cf. supra, pp. 201-202 n. 2. Já notámos a predilecção de Anacreonte por jogos de palavras, supra, p. 201, n. 1.

${ }^{4}$ Greek Lyric Poetry, pp. 273-274, que põe também em relevo o possível signi-

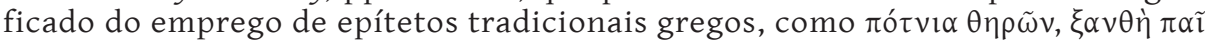
$\Delta$ ıó e e $\dot{\lambda} \lambda \alpha \varphi \eta \beta{ }^{\prime} \lambda \varepsilon$ para a Ártemis asiática, em vez dos seus atributos selvagens, em uso naquela região. 
vez, é seguido da descrição do thiasos, sob a forma de uma oração relativa e de uma aposição ${ }^{1}$. Os versos 6 a 8 contêm a parte genérica do pedido. Conclui com a prece, feita a título particular, de exercer influência sobre Cleobulo, para que este lhe corresponda ${ }^{2}$.

Um bom exemplo de dissimetria, para dar maior variedade, é o da colocação do terceiro sujeito no frg. 6 Diehl:

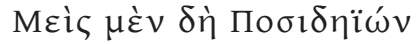

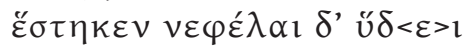

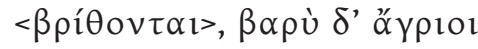

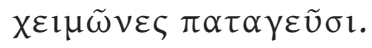

A anáfora é um processo frequente em Anacreonte. Weber aponta

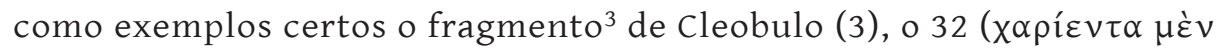

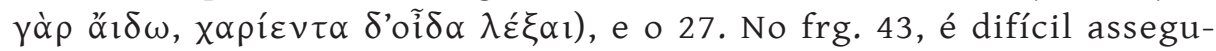
rarmo-nos do seu emprego, em face das dúvidas que impendem sobre a composição a que pertenciam 4 . Mas o novo fragmento 4 do Pap. Oxy. 2321 = 65 Gentili utiliza-o seguramente:

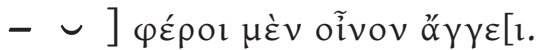

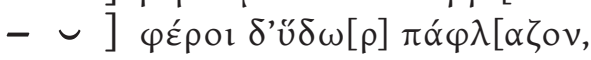

Um particípio de valor causal, lançado no fim da frase, com o seu complemento, dá uma notória expressividade ao frg. 17 e ao frg. 26 Diehl, que assim adquirem verdadeiro valor dramático ${ }^{5}$.

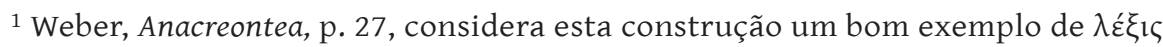

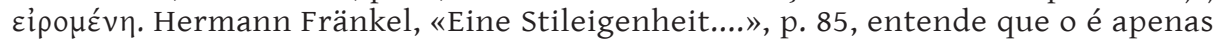

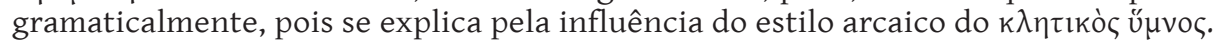

${ }^{2}$ Weber, Anacreontea, p. 27, adopta o seguinte esquema:

$$
\underbrace{a} \beta a^{1} b c d e .
$$

${ }^{3}$ Op. cit., p. 25. Bowra, Greek Lyric Poetry, p. 284, ao analisar este fragmento, sugere como fonte literária provável o frg. 70 Diehl de Arquíloco, mas nota que aqui o poeta «improves upon this device and turns it from complaint to love. It helps to lessen the impact of the forceful words $\varepsilon \varepsilon^{\prime} \omega$ and $\dot{\pi} \pi \mu \alpha i ́ v o \mu \alpha \iota$ and the climax is simply that Anacreon gazes on Cleobulus. He takes the situation as it is, and is not too distressed that it ends in nothing but looks.»

${ }^{4}$ Cf. pp. 37-38 e n. 4 da p. 37.

${ }^{5}$ Apesar das dúvidas de Hermann Fränkel, «Eine Stileigenheit...», p. 86, sobre a seriedade desta afirmação. 


\section{CAPÍTULO IV \\ COMPARAÇAO COM AS «ANACREONTEA»}

Alguns dos processos estilísticos mencionados no capítulo anterior foram amplamente utilizados pelos autores das Anacreontea, em especial o da anáfora, de que chegam a abusar ${ }^{1}$.

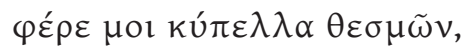

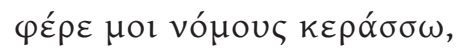

(II, 3-4)

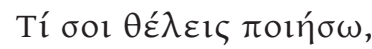

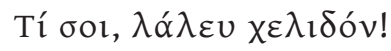

$(\mathrm{X}, 1-2)$

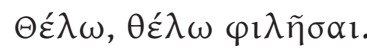

(XIII, 1)

$\pi o ́ \theta \varepsilon v, \pi o ́ \theta \varepsilon v \pi \varepsilon ́ \tau \alpha \sigma \alpha 1 ;$

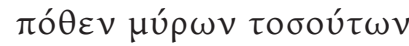

$(\mathrm{XV}, 2-3)$

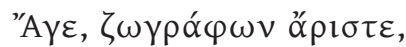

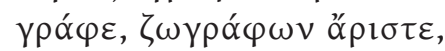

$(\mathrm{XVI}, 1-2)$

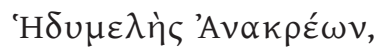

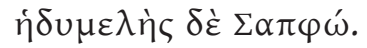

(XX, 1-2)

\footnotetext{
${ }^{1}$ Na citação das Anacreontea usaremos sempre os números da edição de Preisendanz, Lipsiae, Teubner, 1912.
} 
Vejam-se ainda, entre outras, IX, 2,3,9,19; XII, 12; XXIII, 1-2; XXIX, 1-3; XXXVIII, 7-10; XXXIX, 1-2; XLIV, 6-9; XLV; e sobretudo, o exagero da Anacreontea XXI:

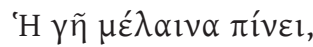
$\pi i ́ v \varepsilon l \delta \varepsilon \dot{\varepsilon} \nu \rho \varepsilon \alpha \delta$ ' $\alpha$ ưंท́v.

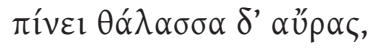

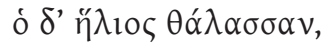

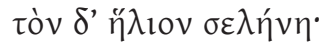

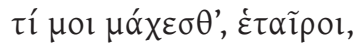

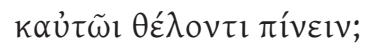

A estreita ligação entre as palavras e o metro, que vimos em composições autênticas, desapareceu, porque a métrica já não era sentida, mas apenas imitada.

Muitos dos temas versados pelo poeta de Teos são também desenvolvidos pelos seus imitadores. Será instrutivo fazer a comparação entre alguns originais e seus derivados, para podermos apreciar as diferenças.

Algumas semelhanças temáticas ${ }^{1}$ foram notadas por Gentili na sua edição, e. g., entre o frg. 8 Diehl e a Anacreontea VIII, entre o frg. 5 Diehl, v. 6 seqq., e a Anacreontea VII, e entre o frg. 82 Diehl e a Anacreontea XLVII.

O primeiro exemplo proclama a ausência de ambições do autor, expressa através de um paradigma mitológico (a cornucópia de Amalteia) e outro suposto histórico (a longevidade do rei de Tartessos). O poeta da Anacreontea VIII faz idênticas declarações nos quatro primeiros versos, mas escolhe um exemplo histórico (Giges), a inveja e a tirania, para compor o quadro negativo do seu ideal de vida. É precisamente essa escolha que nos assegura que o modelo presente deve ter sido Arquíloco, frg. 22 Diehl (facto, aliás, também lembrado por Gentili):

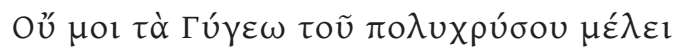

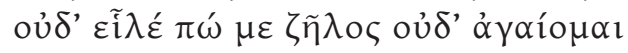

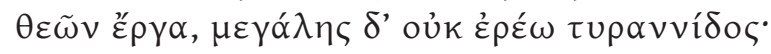

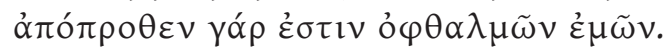

${ }^{1}$ As diferenças principais entre o autêntico Anacreonte e as Anacreontea foram estudadas sobretudo por C. B. Stark, Quaestionum Anacreonticarum Libri Duo, Lipsiae, 1846, e Holly, Quaestiones Anacreonticae, Marburg, 1-855; e resumidas por Crusius, no seu artigo em Pauly-Wissowa, col. 2044-2046, e M. F. Galiano, «Los Problemas de Autenticidad en la Literatura Griega» in Revista de la Universidad de Madrid, cit., pp. 223-226. Para as divergências métricas, veja-se Koster, Traité de Métrique Grecque ${ }^{2}$, pp. 96-97 e 202-203. 
Não sabemos a continuação do texto de Arquíloco, mas é pouco provável que seguisse as mesmas linhas da Anacreontea VIII.

No segundo exemplo, apenas há de comum o desdém das mulheres pelos seus cabelos, reveladores de uma idade avançada: por serem brancos, diz o poema $\operatorname{arcaico}^{1}$; por serem inexistentes, afirma a sua imitação.

O terceiro exemplo é um caso muito discutido, pois já não se trata de influência ou semelhança, mas, pura e simplesmente, de repetição de um dístico, quase pelas mesmas palavras.

$\mathrm{Na}$ verdade, os dois versos do frg. 82:

'O $\mu \dot{\varepsilon} \nu \theta \varepsilon ́ \lambda \omega \nu \mu \alpha ́ \chi \chi \varepsilon \sigma \theta \alpha 1-$

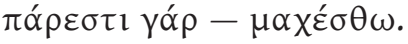

encontram-se enquadrados na Anacreontea XLVII, nos versos 8-9:

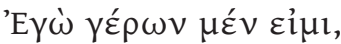

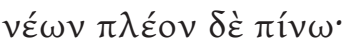

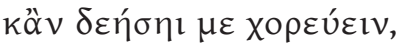
$\Sigma \varepsilon \imath \lambda \eta \nu o ̀ v ~ \varepsilon ่ v ~ \mu \varepsilon ́ \sigma o l \sigma l$

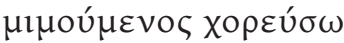

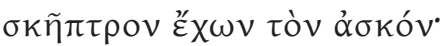

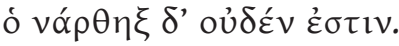
ó $\mu \dot{\varepsilon} \nu \theta \dot{\varepsilon} \lambda \omega \nu \mu \alpha ́ \chi \chi \varepsilon \sigma \theta \alpha 1$,

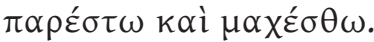

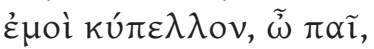
$\mu \varepsilon \lambda i ́ x \rho o u v$ oĩvov $\mathfrak{\delta} \delta$ v

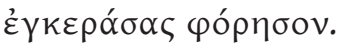

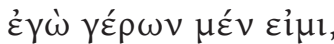

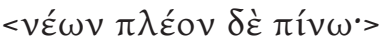

O contexto fala de competição, na bebida e na dança, entre o autor e os jovens, e, portanto, os dois versos não se encontram deslocados.

Citados por Heféstion, $\pi \varepsilon \rho i$ i $\alpha \mu \beta ı \kappa o v ~ V, 3$, como exemplos de dímetros catalécticos, figuram igualmente num escólio a Aristófanes, Plut. 302; no gramático Plotius Sacerdos VI, 520,8; e (só a primeira linha) no

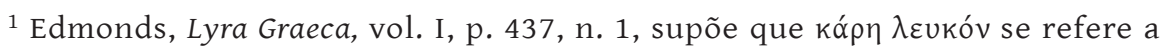
calvície, e não a cabelos brancos. Mas um exemplo homérico como

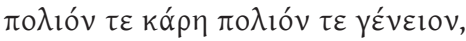

de X 74 (fórmula repetida em O 516) exclui qualquer dúvida. 
anonymus metricus do Papiro de Oxirinco 220, col. X, 3 (possivelmente, todos derivados do primeiro) ${ }^{1}$. Os versos eram, portanto, citados como paradigma métrico.

Mas é precisamente pela sua estrutura rítmica que Holly ${ }^{2}$ lhes nega a autenticidade, afirmando que não há exemplos de dímetros iâmbicos catalécticos seguidos ${ }^{3}$ antes de Herondas e lembrando ainda que Heféstion

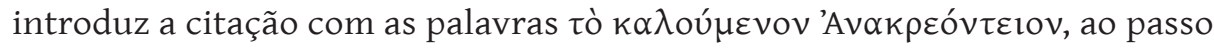

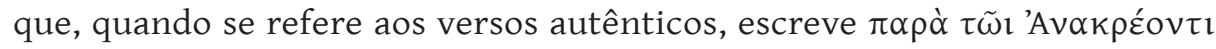

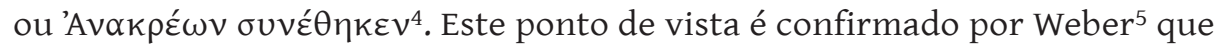
lembra que esse metro apenas figura no frg. $28 \mathrm{Dieh}^{6}$, cuja autenticidade

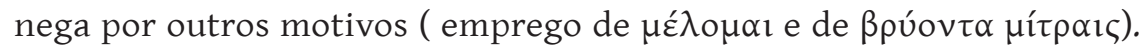

\footnotetext{
${ }^{1}$ Holly, op. cit., pp. 15-16, supõe a derivação para o escoliasta e Plócio a partir de Heféstion.

${ }^{2}$ Op. cit., pp. 15-16, e cf. bibliografia aí referida.

${ }^{3}$ Koster, Traité de Métrique Grecque ${ }^{2}$, pp. 96-97, encontra-os, mas não cita senão este fragmento.

${ }^{4}$ Op. cit., p. 16, remetendo para Mehlhorn 13, e ainda p. 35. Em todos os fragmentos referidos por Heféstion, num total de vinte - e com tal conhecimento das obras de Anacreonte que é por ele que sabemos, por exemplo, que youvoṽuó $\sigma ' \varepsilon ̉ \lambda \alpha \varphi \eta \beta o ́ \lambda \varepsilon$ era o primeiro da colectânea - se pode confirmar a distinção estabelecida, excepto três. São eles:
}

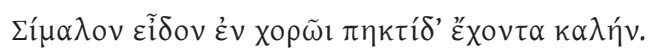

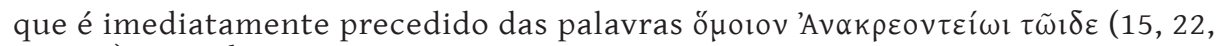
p. 55 C), e ainda:

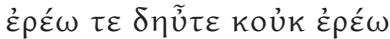

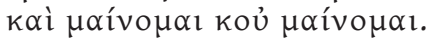

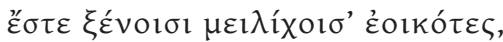

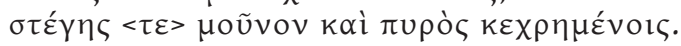

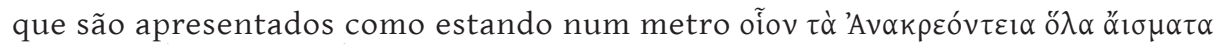

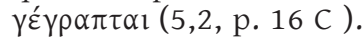

Se o primeiro fragmento apenas foi mencionado por Heféstion, o segundo foi-o também pelo escoliasta a Aristófanes, Plut. 253 - que, aliás, refere só o segundo verso - e o terceiro consta igualmente de Plutarco, Notit. adu. stoic. 20, p. 1068b, que cita os dois versos, ao passo que o metricista antigo só transcreve um. No entanto, o facto de Heféstion derivar um adjectivo do nome do poeta, chamando

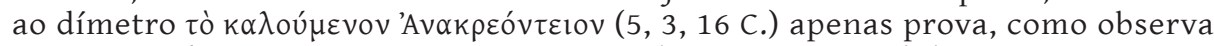
Bowra, Greek Lyric Poetry, p. 271, n. 2, que ele usou essa medida.

${ }^{5}$ Op. cit., p. 12 , n. 6.

${ }^{6}$ Actualmente escande-se de outro modo, em anaclómenos. O facto de o primeiro verso estar incompleto possibilita, de resto, várias divisões. 
Na sua edição, Gentili afirma, no comentário ad locum, que a presença desta citação no texto do Anonymus Oxy., «qui ex Anacreonte non ex cantiunculis Anacreonteis quae dicuntur exempla sumit» prova que é genuína ${ }^{1}$.

Ora o Pap. Oxy. 220 é do final do séc. I A. D. portanto, ligeiramente anterior a Heféstion e à mais antiga referência a uma Anacreontea reconhecida como tal ${ }^{2}$. Poderá, quando muito, fornecer-nos um terminus a quo ${ }^{3}$, e provar-nos que a confusão já existia nessa época.

É possível ainda discernir reflexos das canções de Anacreonte em muitas das Anacreontea. Reflexos por vezes fugidios, ideias afeiçoadas noutro sentido, mas, em todo o caso, derivadas das do poeta arcaico.

Assim, por exemplo, o convite para trazer as taças e o vinho para o symposion, expresso repetidamente nos frgs. 27 e 43 Diehl, ecoa em Anacreont. II, XLVII, XLVIII. Mas o resto das composições diverge: a Anacreont. II lembra os dísticos elegíacos do frg. 96 Diehl, no seu desejo de postergar a gesta épica, em favor das canções de mesa. ${ }^{4} \mathrm{Nada}$ mais elucidativo do que o contraste entre a naturalidade e frescura do poeta antigo, que sugere os feitos guerreiros através de uma expressão homérica ( $\pi$ ó $\lambda \mu$ ov $\delta \alpha \kappa \rho v o ́ \varepsilon v \tau \alpha)$ e o mais recente, que pede a lira de Homero

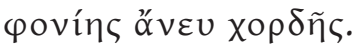

Não menos marcada é a antinomia entre o combate com Eros, dos frgs. 5 e 27 Diehl, e ainda do Pap. Oxy. 2321, frg. 4 = 65 Gentili, e o da Anacreontea XIII. Também nesta última se fala de uma provocação ( $\left.\pi \rho \circ \mathcal{U}_{\kappa} \alpha \lambda \varepsilon \tilde{\imath} \tau o\right)$, mas, em vez da bola purpúrea de Eros, temos toda a

${ }^{1}$ Bowra, Greek Lyric Poetry, p. 271, cita-os como autênticos.

${ }^{2}$ Em Aulo Gélio, XIX, 9.

${ }^{3}$ Diversas são as opiniões acerca da repartição cronológica das Anacreontea. Hanssen (apud Holly, op. cit.) divide-as em três partes: a mais antiga, 1,4, 6-15 (núcleo primitivo, conhecido por Aulo Gélio e os escoliastas de Aristófanes) e 16 a 21, talvez da época de Adriano (sendo 2,3 e 5 bizantinas); 22 a 35, do período romano, e de um só autor; e 36 a 60, já com elementos bizantinos. Crusius apresenta algumas variantes a este esquema, no seu artigo em Pauly-Wissowa. Sitzler (apud Galiano, cit.) considera um grupo mais antigo, talvez helenístico (1-20), outro intermédio (21-34) e outro muito tardio (35-60). Stark vai até ao séc. X A. D. Bergk supõe a existência de duas colectâneas, uma com hemiambos, outra em dímetros iónicos. Reunidas estas, acrescentaram-lhes cantigas novas; e, por último, os bizantinos adicionaram-lhes outras semi-bárbaras. Holly diverge ligeiramente de Hanssen (tendo 1, 4, 6-15 e 22-28 como do séc. 1 a. C. ou A. D.; 16 a 20 como do tempo de Luciano; 22 a 35, da época romana; as restantes, mais tardias, sendo $2,3,5,37,38,42-45,54,59$ e 60 bizantinas, e 40,41, 46, 48, 49, 50 e 58 as mais recentes). Alii alia....

De qualquer modo, teríamos, ou de recuar a data da Anacreontea XLVII para a época romana, ou de supor, como Holly (p.35), que o seu autor aproveitou a citação de Heféstion.

${ }^{4}$ Por sua vez, as Anacreont. XXIII e XLII são variantes desta. 
precisão de contornos e amor do pormenor da arte alexandrina: $\tau o ́ \xi o v$

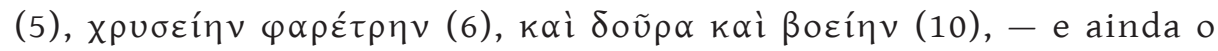
simbolismo dos versos finais.

O motivo dos cabelos brancos, que figura no mesmo frg. 5 Diehl, surge na Anacreont. LI, não já com o importante significado psicológico que assume no desenrolar daquele pequeno drama, mas apenas para dar lugar a uma amaneirada metáfora, que favoreça as pretensões do poeta:

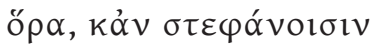

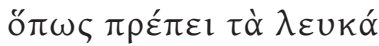

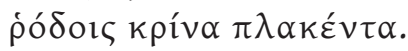

O novo fragmento de Esmérdias, que é o primeiro do Pap. Oxy. $2322=$ 71 Gentili, é, como vimos anteriormente, de atribuição contestada. Fosse qual fosse o seu autor, revela influências de Arquíloco ${ }^{1}$, como já foi notado, na metáfora da cabeleira que ensombra o pescoço, e deve ter dado origem, por sua vez, à hiperbólica imagem do começo da Anacreont. XVIIIb:

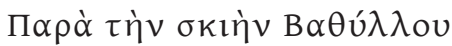

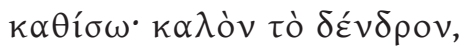

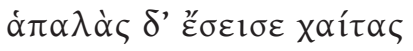

$$
\begin{aligned}
& \mu \alpha \lambda \alpha \kappa \omega \tau \alpha \dot{\tau} \tau \omega \iota k \lambda \alpha \delta i ́ \sigma \kappa \omega l \text {. }
\end{aligned}
$$

A semelhança vocabular com os frgs. 46 e 47 Diehl leva, aliás, a supor que também estes estavam na mente do poeta.

De um modo geral, predominam nas Anacreontea dois ideais de vida que são cantados e desenvolvidos até à saciedade: o amor senil e o gosto da embriaguez.

É, de resto, como um velho apaixonado e apreciador de vinho que a Anacreontea I retrata Anacreonte, aquele poeta que a última peça da colectânea e o autor do poemeto XX declaram querer imitar ${ }^{2}$.

$\mathrm{O}$ amor é frequentemente apresentado sob forma alegórica, em curtas cenas em que Eros é o actor principal (VI, XIII, XIX, XXV, XXVIII, XXX, XXXI, XXXIII, XXXV). O vinho é exaltado, sobretudo, como libertador

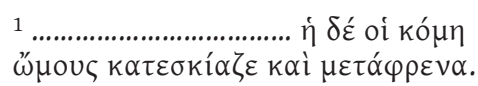

(Frg. 25 Diehl).

${ }^{2}$ É de admitir que, dentro da própria colectânea das Anacreontea, os autores mais recentes tenham imitado os mais antigos, como propôs Holly na segunda parte da sua dissertação Quaestiones Anacreonteae; nomeadamente, que a ode XII derive da IX e a XLIX da XLVIII. 
de cuidados (IX, XII, XVIIIa, XXI, XXXVIII, XLV, XLVIII, XLIX, L, LVI). O tema da velhice e o desejo de gozar ainda a vida, sobretudo os prazeres do amor, é também frequente (VII, XXXIX, XL, XLVII, LI, LII, LIII). Já vimos com quanta moderação Anacreonte tratava o motivo da ebrietas e como, por exemplo, o frg. 53 Diehl apenas afirma que, olhando para a sua barba grisalha, Eros «voa ao largo, com o sopro das suas asas douradas». Quando as contrastamos com as poesias autênticas, as imitações acusam uma divergência, no modo de desenvolver os temas, comparável à que separa a pureza de linhas da arte iónica da deformação barroca da época helenística. 
(Página deixada propositadamente em branco) 
2 P A R TE

NOTÍCIA HISTÓRICA SOBRE O PROBLEMA DA AUTENTICIDADE DO FRG. 44 DIEHL 
(Página deixada propositadamente em branco) 


\section{CAPITULO ÚNICO \\ NOTÍCIA HISTÓRICA DO PROBLEMA}

O fragmento 44 Diehl $=43$ Bergk de Anacreonte foi-nos transmitido unicamente por Estobeu 4, 51, 12, e parece estar completo. É composto de doze versos iónicos, na maioria anaclómenos ${ }^{1}$.

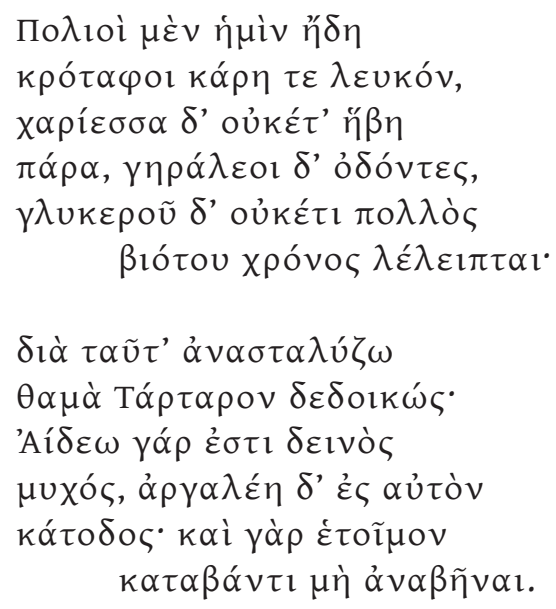

Pela sua pureza rítmica, o fragmento é dado como exemplo de anacreônticos por diversos metricistas ${ }^{2}$.

${ }^{1}$ Bergk, seguido por Crusius, imprimiu-os como dois tetrâmetros, «ohne jeden Schatten eines Grundes», como declara peremptoriamente Wilamowitz (Isyllos von Epidauros, p, 131); "so falsch wie möglich», afirma T. Kehrhahn («Anacreontea» in Hermes, 1914, p. 501), pois a unidade é de seis kola, como mostram os dois iónicos puros do quinto verso.

${ }^{2}$ Por exemplo, por Rupprecht, Einführung in die griechische Metrik, p. 51; Koster, Traité de Métrique Grecque ${ }^{2}$, pp. 201-202 (que, aliás, supõe que são tetrâmetros, e não dímetros); Gentili, La Metrica dei Greci, p. 21. 
Mas algumas vozes se têm levantado, que põem em dúvida a autenticidade do pequeno poema.

A primeira foi a de G. Bernhardy, que, no seu Grundriss der griechischen Literatur ${ }^{1}$, afirma:

"Ohne nähere lokale Bezeichnung redet Anakreon in erotischen Liedern von seinem ergrauten oder greisen Haar, fr. 15. 23. 80. nebst den Nachweisungen bei Bergk p. 200-212. Sie zeigen wie gern man ihn unter der Figur eines Greises dachte; doch ist auszuscheiden (wenn man auch die beiden ersten Verse für älter halten möchte) fr. 41 das widrige Zerrbild eines völlig verwüsteten Greises, dem vor dem Schauern des nahen Todes und der Unterwelt graut; selbst im Stil verrät es nichts von der Anmut und lebendigen Frische dieses Mannes. Über ein so ungünstiges Urteil verwundert sich noch Bergk, Lyr. p. 785.»

E mais adiante, na nota 8 da p. 617 , de novo alude ao mesmo como «das mönchische Fr. 41».

Bergk opôs-se, com efeito, a esta doutrina, e, ainda na quarta edição dos Poetae Lyrici Graeci, onde o fragmento já tem o número 43, nota no aparato crítico:

«Miro iudicio Bernhardy Hist. Litt. Graec. II 500 et 503 (p. 614 ed. 2) hoc carmen a monacho Anacreonti subditum esse censet.»

Muitos anos mais tarde, em 1924, Hermann Fränkel voltou a suspeitar da autenticidade do fragmento, por razões de ordem estilística ${ }^{2}$ :

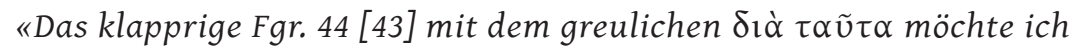
dem Anakreon absprechen und zu den Anakreonteen stellen.»

Diehl refere esta opinião no seu aparato crítico, sem se pronunciar ${ }^{3}$.

Em 1951, ao publicar Dichtung und Philosophie des frühen Griechentums, H. Fränkel declarou, na nota 22 da p. 388, ter abandonado a sua hipótese, convencido por Paul Maas. No entanto, observa, na mesma p. 388, depois de considerar o poemeto como uma daquelas composições em que os Gregos pensavam na morte para se incitarem ao gozo da vida e da juventude:

\footnotetext{
${ }^{1}$ Zweite Bearbeitung, Zweiter Teil: Geschichte der griechischen Poesie, Erste Abteilung: Epos, Elegie, lamben, Metrik. Halle, 1856, p. 614, Anmerkung 6.

2 «Eine Stileigenheit der frühgriechischen Literatur» in Nachrichten von der Gesellschaft der Wissenschaften zu Göttingen, Philologisch-historische Klasse, 1924, pp. 63-103 e 105-127. O passo referido consta da nota 4 da p. 85 .

${ }^{3}$ Ad locum.
} 
"Wehleidig und überdies banal, wirken diese Verse peinlich, auch wenn man, um allen Möglichkeiten gerecht zu werden, eine Ironie des Dichters in sie hineinliest, der sein Selbstmitleid selbst noch belächelt. Welch ein Gegensatz sogar zu Mimnermos, der sich den Tod herbeiwünschte für den Augenblick, wo ihn im Alter die beseligende Liebeskraft verlassen würde!»

Em consequência da mudança de opinião, o artigo das Göttinger Nachrichten, ao ser reimpresso em Wege und Formen des frühgriechischen Denkens, em 1955, excluiu da nota em que se encontrava a frase anteriormente transcrita ${ }^{1}$. A mesma atitude se mantém na segunda edição desta obra, acabada de publicar ${ }^{2}$.

A impressão colhida por Hermann Fränkel no seu primeiro estudo tem sido partilhada por outros especialistas da lírica grega arcaica, entre os quais R. Pfeiffer ${ }^{3}$, que observa que o excerto soa a anacreôntico e que o torna um tanto suspeito o facto de ser o único exemplo de Anacreonte citado na antologia de Estobeu ${ }^{4}$, no capítulo sobre a morte; e nota ainda a sua ausência de profundidade.

Até mesmo alguns comentadores italianos sugerem, por vezes, embora indirectamente, a suspeita de inautenticidade E assim, se Zuretti ${ }^{5}$ por um lado, dá razão a Bergk na sua crítica a Bernhardy, já B. Lavagnini ${ }^{6}$ escreve em nota:

«È uno dei frammenti originali più vicini per lo spirito alle Anacreontee».

Por sua vez, F. M. Pontani ${ }^{7}$ faz, entre outras considerações, as seguintes:

«Ecco questa poesia, ove la confessione della rovina fisica s' apre a sospiri di rimpianto (quant' è bella giovinezza, quanto dolce la vita sull' orlo dell' Ade) e conclude in un brivido e nei singhiozzi. L' ombra $e$ il freddo dell' aldilà sono ormai nelle carni e nel cuore; lo sguardo e il canto si sbarrano nell' evocazione dell'ineluttabile, senza che affiori

${ }^{1}$ Agora n. 4 das pp. 60-61.

${ }^{2}$ C. H. Beck'sche Verlagsbuchhandlung, München, 1960, pp. 60-61, nota 4.

${ }^{3} \mathrm{Em}$ aulas, na Universidade de Oxford.

${ }^{4}$ Além deste, Estobeu apenas refere um fragmento de Anacreonte, no livro

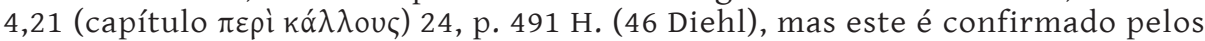
testemunhos concordantes de Ateneio, 12, 540 (que o parafraseia) e de Eliano, V.H., 9.4, como veremos no final.

${ }^{5}$ Anacreonte, Odi Scelte commentate da C. O. Zuretti. Collezione di Classici Greci e Latini. Chiantore, Torino, 1944, p. 9.

${ }^{6}$ Aglaia. Nuova Antologia della Lirica Greca da Callino a Bacchilide. Paravia, terza edizione, p. 172.

7 Pleiadi. Frammenti di Lirica Greca. Convivium, Collana di Autori Greci e Latini, Roma, Gismondi, [1952], p. 207. 
neppure più (se la lirica è integra) il rifugio del carpe diem, il farmaco dell' attimo lieto strappato ancora alla rapacità della morte. Squallore e terrore sono snelliti dal tono e dal ritmo di canzone, apparso cosi vicino alle Anacreontiche da indurre dubbi, ma a torto, sull' attribuzione di questi versi. Anacreonte è quasi sempre uno stilista e uno stilizzatore elegante. È un errore scambiare per freddezza e letteratura la sua pudica misura formale.»

Também a A. Colonna ${ }^{1}$ não passa despercebida a semelhança:

"Piccolo carme completo, in cui il tenue argomento della giovinezza che fugge, cedendo il posto ai malanni della vecchiezza, è trattato con una mestizia dolce e rassegnata, che si ritrova dapertutto nelle imitazioni posteriori (poesie anacreontee).»

Temos, por conseguinte, uma pequena ode, que parece completa, de tom e ideário suficientemente diferenciado do de Anacreonte, para suscitar a alguns estudiosos dúvidas quanto à sua autenticidade.

Em seguida estudaremos o fragmento, considerando a natureza das ideias nele expostas, em confronto com o que sabemos acerca do pensamento do poeta de Teos e dos seus antecessores e contemporâneos, e analisando-o sob o ponto de vista da linguagem e do estilo.

\footnotetext{
${ }^{1}$ L'Antica Lirica Greca, Torino, Lattes, terza edizione, 1956, p. 179.
} 


\section{$3^{\text {a }}$ P A R TE}

FUNDAMENTAÇÃO DAS DÚVIDAS

SOBRE A AUTENTICIDADE

DO FRAGMENTO 44 DIEHL 
(Página deixada propositadamente em branco) 


\section{CAPÍTULO I}

\section{AS IDEIAS}

0 autor do fragmento 44 Diehl começa por se descrever a si mesmo como um velho, a quem pouco tempo resta de vida. Por isso suspira, temendo o Tártaro medonho; terrível é a descida para o Hades, e de lá não se pode regressar.

Há, portanto, nesta composição, um sentido de decadência e de tristeza, que se vai acentuando, à medida que se acumulam as razões

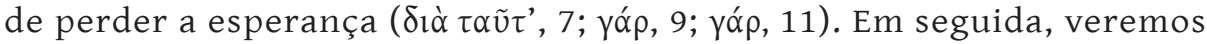
em que medida esta atitude de espírito se coaduna com o que sabemos do poeta de Teos.

\section{1 - Confronto com a ideologia de Anacreonte}

Admitindo mesmo, com Bowra ${ }^{1}$, que este fragmento tivesse sido composto durante a segunda estadia de Anacreonte em Atenas, e, portanto, muito mais tarde do que o 89 Diehl:

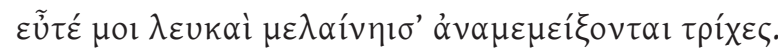

resta-nos ainda a dificuldade de o colocar ao lado do tom despreocupado e ligeiro com que o poeta aborda o tema da velhice no frg. 5 Diehl, em que a donzela de Lesbos desdenha os seus cabelos brancos. O frg. 53, apesar de muito incompleto, parece revelar uma atitude conformada:

\footnotetext{
${ }^{1}$ Greek Lyric Poetry, pp. 305-306.
} 


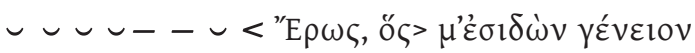

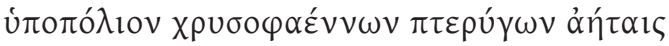

$\pi \alpha \rho \alpha \pi \varepsilon ́ \varepsilon \varepsilon \tau \alpha 1$.

O único verso que constitui o frg. 91 Diehl é uma invocação à Musa ${ }^{1}$ de um poeta já velho, mas que deseja ainda ser inspirado por ela.

É possível que o novo fragmento do Pap. Oxy. 2321, $11+3=$ Gentili 62 , se estivesse menos mutilado, ajudasse a elucidar esse passo, pois nos versos 7-9 se lê:

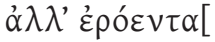 \\ $\delta \tilde{\omega} \rho \alpha \pi \alpha ́ \rho \varepsilon \sigma \tau[1$ \\ $\Pi 1 \varepsilon \rho i ́ \delta \omega v, \beta[$}

Os excertos conservados não mostram, por conseguinte, uma atitude tão pessimista como a revelada pelo frg. 44 Diehl. Pelo contrário, o único que lhe é comparável em extensão, o 5 Diehl, menciona de passagem a razão do desprezo da jovem, para fazer incidir toda a atenção no motivo real do mesmo:

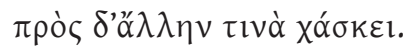

Uma poesia de momento, uma graça improvisada no banquete para atingir a jovem tocadora que usa sandálias coloridas e é natural de Lesbos, conforme conjecturou Wilamowitz ${ }^{2}$. Perpassa nela um ligeiro tom de ironia, que é uma faceta característica do espírito de Anacreonte.

Finalmente, o frg. 42 chama pela morte como libertadora das penas, que tudo leva a crer sejam de amor, como as do frg. 52 e 17:

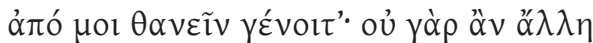

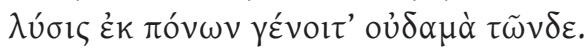

Em qualquer destes três passos acabados de citar encontramos o mesmo desespero amoroso, que procura uma solução extrema para o seu caso. Nada das calculadas, premeditadas e solitárias reflexões do frg. 44 Diehl.

Os outros dois temas que podem distinguir-se neste poemeto - o do Hades e o da irreversibilidade da morte- não foram versados por Anacreonte nos restantes fragmentos conhecidos.

\footnotetext{
${ }^{1}$ Cf. supra, p. 202 e n. 3.

${ }^{2}$ Sappho and Simonides, pp. 116-117. Bowra, Greek Lyric Poetry, pp. 284-286, segue em parte esta interpretação.
} 


\section{2 - Esboço da evolução das ideias contidas no frg. 44 Diehl}

Em seguida consideraremos a evolução das noções dos Gregos sobre os mesmos três assuntos, desde Homero à idade clássica. Não estamos em presença de um pensador. E, portanto, o modo de encarar estes problemas deve ter sido condicionado pelas ideias da época.

\section{$\alpha)$ - A velhice}

Nos Poemas Homéricos fala-se mais do que uma vez sobre a velhice. Entre as figuras principais da Ilíada, há dois anciãos que gozam do maior prestígio e respeito: Príamo e Nestor ${ }^{1}$. Já não combatem, porque as suas poucas forças o não permitem, mas incitam os outros à luta. Agamémnon maravilha-se ante a energia com que Nestor exorta os seus soldados. Este último lamenta não poder entrar na refrega e conclui que guiar os seus homens com a voz é agora o seu papel²:

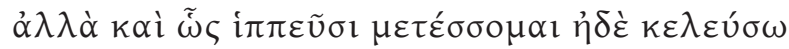

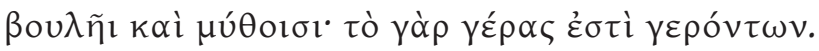

Os velhos valem pela sua eloquência e conselho, como se acentua no canto terceiro, ao descrever a reunião junto das Portas Ceias, na muralha

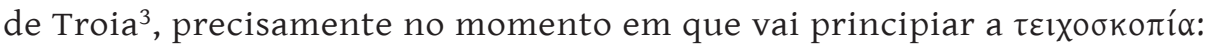

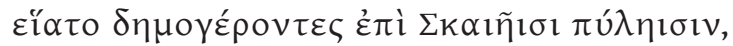

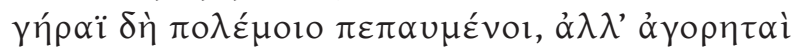

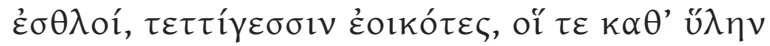

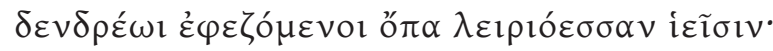

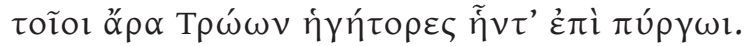
$(\Gamma, 149-153)$

Justamente porque valem pelo conselho é que Agamémnon afirma, na assembleia do Canto $\mathrm{II}^{4}$, que, se tivesse dez homens como Nestor, lhe seria fácil conquistar Tróia.

${ }^{1}$ Uma excelente caracterização destas duas figuras encontra-se em C. M. Bowra, Tradition and Design in the Iliad, Oxford, at the Clarendon Press, 1958, pp. 206-207 e 210-211.

${ }^{2} \Delta$ 322-323. Cf. K 77-79. Em $\Theta$ 99-117, Diomedes salva Nestor de uma tentativa bélica demasiado arriscada para os seus muitos anos.

${ }^{3}$ Também em $\Sigma$ 514-515 os velhos estão a presenciar o combate, das muralhas.

4 369-374. 
Na verdade, os jovens são volúveis, e os velhos, prudentes. É por isso que, para selar o pacto que permitiria substituir a guerra por um duelo, Menelau exige a presença de Príamo ${ }^{1}$.

Os mais novos devem ouvir os conselhos dos anciãos, diz Nestor no Canto $1^{2}$. De resto, a idade só por si merece respeito ${ }^{3}$, como lembra Príamo aos Troianos, quando anuncia o seu projecto de ir pedir a Aquiles o cadáver de Heitor. O Pelida lamenta, por sua vez, não poder prestar assistência ao seu velho $\mathrm{pai}^{4}$. Ele mesmo testemunha a sua consideração para com Nestor, oferecendo-lhe uma taça, apesar de o idoso rei de Pilos não poder tomar parte nas competições desportivas em honra de Pátroclo ${ }^{5}$, e trata afectuosamente Fénix, seu antigo preceptor, por

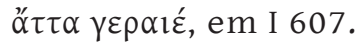

A idade e os seus sinais exteriores, juntos à triste sorte de Príamo, despertam em Aquiles a compaixão, quando aquele vai pedir-lhe a restituição do corpo de Heitor:

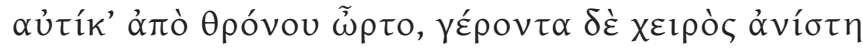

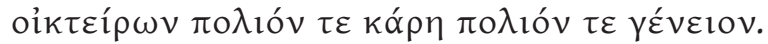

$(\Omega$ 515-516)

Velhice lamentável é, de facto, a de Príamo, como se lembra mais de uma vez na epopeia ${ }^{6}$. Nem se encara outra possibilidade neste poema guerreiro. Mesmo fora do caso particular do rei de Troia ou de Peleu, a senectude é qualificada de forma que não deixa dúvidas ao modo

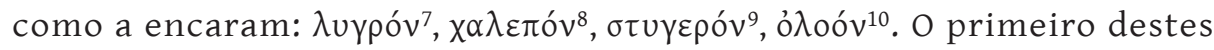
adjectivos é frequentemente empregado, nos Poemas Homéricos, para

${ }^{1} \Gamma$ 108-110. Os imortais honram os anciãos, lê-se em $\Psi 788$.

${ }^{2}$ A 259. Cf. I 60-62.

${ }^{3} \mathrm{X} 418-420$.

${ }^{4} \Omega 540-542$.

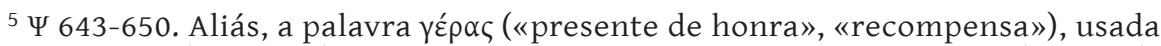
noutros passos (e.g., $\Delta 323$ ), está etimologicamente relacionada com $\gamma \varepsilon ́ p \omega v$ («velho»),

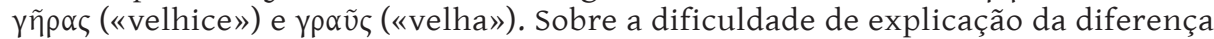

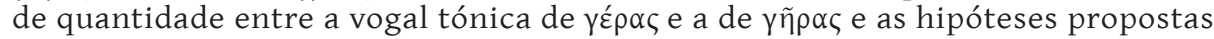
para a resolver, veja-se H. Frisk, Griechisches etymologisches Wörterbuch, vol. I, 305.

${ }^{6}$ X 59-71, 74-76.

${ }^{7} \mathrm{~K} 79 . \Sigma 434 . \Psi 644$.

$8 \Theta 103 . \Psi 623$.

${ }^{9} \mathrm{~T} 336$.

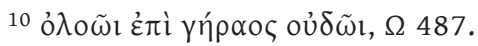


qualificar a morte ${ }^{1}$. O terceiro também se usa para o mesmo efeito ${ }^{2}$, ou para referir a doença ${ }^{3}$. O último aparece em fórmulas relativas à guerra ${ }^{4}$ ou ao destino fatal ${ }^{5}$.

Muito do que acabámos de afirmar vale igualmente para a Odisseia. Assim, por exemplo, a mesma veneração pelos velhos, pelo seu conselho e saber, se evidencia a cada passo neste poema. De Nestor se afirma novamente que é muito sábio ${ }^{6}$. Outro tanto se declara a propósito de Haliterses ${ }^{7}$, que apenas não é respeitado por Eurímaco, porque este, como os demais pretendentes, é insolente ${ }^{8}$. Porque, por exemplo, um jovem bem educado, como Telémaco, tem vergonha, até, de interrogar um ancião, como Nestor ${ }^{9}$. Na corte de Alcínoo, quando todos ficam silenciosos, após a súplica de hospitalidade feita por Ulisses à rainha Arete, é o mais velho dos conselheiros, que é também o mais eloquente, o primeiro a pedir ao rei que se pronuncie ${ }^{10}$; ao passo que, no Canto III, Atena, disfarçada em Mentor, declara que é só por amizade que a equipagem do barco que transportou Telémaco a Pilos obedece a um chefe tão jovem, pois são todos da mesma idade ${ }^{11}$. E, inversamente, Penélope desculpa à ama de Ulisses que a tenha ido chamar no meio do sono, em atenção aos muitos anos que conta:

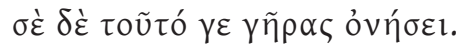

No poema há um velho infeliz, e de aspecto miserável, que é Laertes,

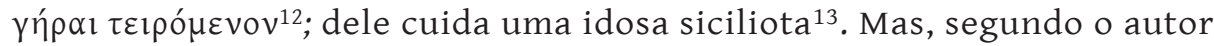

${ }^{1} \lambda$ uүpòv ö $\lambda \varepsilon \theta \rho o v, \gamma$ 93. A velhice associada à morte surge em M 323. E $136=\eta$ $257=\psi 336 . \varepsilon 218$.

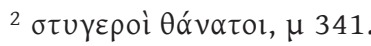

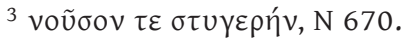

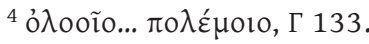

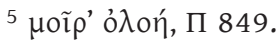

6 Y 243-246.

${ }^{7} \beta$ 15-16, 157-159.

${ }^{8} \beta$ 177-193.

${ }^{9} \gamma 24$.

10 ๆ 155-157. Euricleia já tem poucas forças, mas é sensata e ponderada ( $\tau$ 353-356).

${ }^{11}$ y 363-364.

$12 \omega 233$.

13 a 188-193; $\omega$ 211-212. A descrição mais extensa figura em $\omega$ 226-240. 
do mesmo canto XXIV, Atena infunde-lhe novo vigor, para ajudar Ulisses a defender-se dos partidários dos pretendentes que matara ${ }^{1}$.

Também o rei de Ítaca se apresenta alquebrado no seu palácio, disfarçado em mendigo ${ }^{2}$.

A maior diferença em relação à Ilíada, no que concerne ao tratamento deste tema, é que na Odisseia, surge mais do que uma vez o ideal de uma velhice feliz, rodeada de atenções de uma família respeitadora ${ }^{3}$. E não é só no suspeito canto XXIV que ele se encontra, numa fórmula que parece uma variante de $\Delta 323$ :

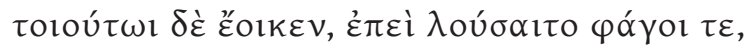

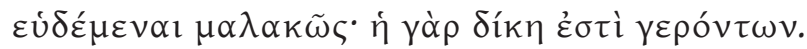

( $\omega$ 254-255)

Também na cena que Aristófanes de Bizâncio e Aristarco consideravam a última da epopeia, quando Ulisses transmite a Penélope a profecia de Tirésias acerca do seu fim, esta acha agradável a perspectiva da longevidade:

“

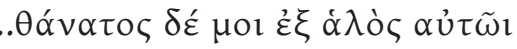

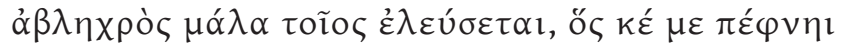

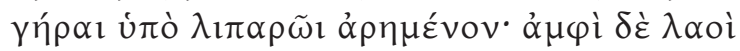

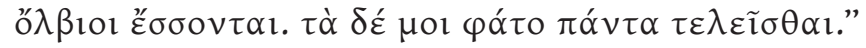

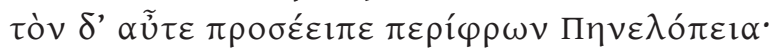

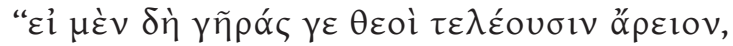

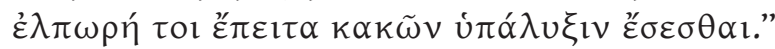

$(\psi 281-287)$

Da fala de Ulisses, quatro versos repetem, salvo no final, as palavras de Tirésias em $\lambda$ 134-137. Mas um quadro de felicidade idêntico, do homem que envelhece calmamente no meio dos seus, encontra-se em $\alpha$ 217-218, em $\delta$ 207-211 e ainda em $\tau$ 367-368:

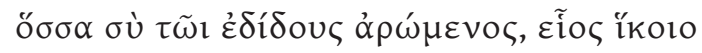

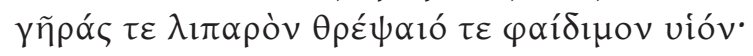

\footnotetext{
$1 \omega 520$.

${ }^{2} \sigma 10,52-53 . \tau 360$, etc.

${ }^{3}$ Esta distinção foi já apontada por Wolfgang Schadewaldt, «Lebenszeit und Greisenalter im frühen Griechentum» in Die Antike, Berlin, vol. 9, 1933, pp. 282-302, especialmente p. 288. O mesmo autor observa ainda que, tanto na Ilíada como na Odisseia, falta «jede Spur davon, dass der Dichter uns das Grauen vor dem kommenden Alter empfinden liesse» (p. 288).
} 
Digna de nota é também a adjectivação que agora cabe à palavra $\gamma \tilde{\eta} \rho \alpha \varsigma$, que igualmente figura, como já vimos, em $\lambda 136=\psi 283$, ou ainda

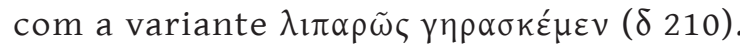

Uma velhice aprazível é a que Ulisses prepara através dos seus longos sofrimentos. É a perspectiva que se oferece ao herói insistentemente qualificado de $\pi 0 \lambda u ́ \tau \lambda \alpha \varsigma$. Semelhante ideal de vida estava vedado aos protagonistas da Ilíada. Mas não é essa, certamente, a única razão justificativa da mudança no modo de considerar a senectude, pois esta corre paralelamente às demais linhas evolutivas que postulam um desnível cronológico de meio século entre os dois poemas.

O texto de Hesíodo refere-se mais do que uma vez à idade avançada, mas em termos que não divergem dos homéricos. Pode deparar-se-nos mesmo numa interpolação como $\tau 360$ = Erga 93, ou numa fórmula idên-

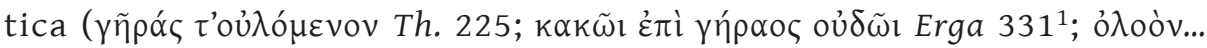

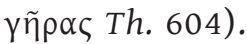

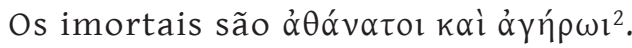

O mito das cinco idades diz-nos algo sobre a maneira de encarar esta época da vida. Um dos grandes privilégios da raça de ouro era que

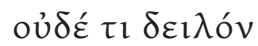

$\gamma \tilde{\eta} \rho \alpha \varsigma \dot{\varepsilon} \pi \tilde{\eta} v$

$($ Erga, 113-114)

E a raça de prata, que ainda gozava de algumas vantagens, vivia cem anos em estado infantil, em casa, junto de suas mães. Mas, quando atingiam o termo da juventude, duravam muito pouco, devido à sua loucura ${ }^{3}$.

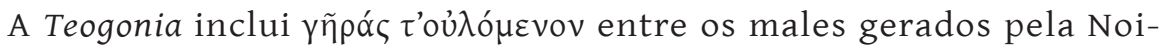
$t^{4}$. Mas, por outro lado, caracteriza favoravelmente a velhice, quando

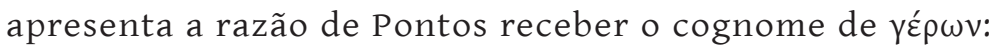

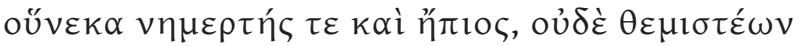

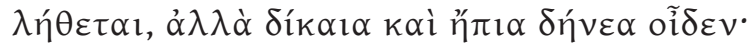

(Th., 235-236)

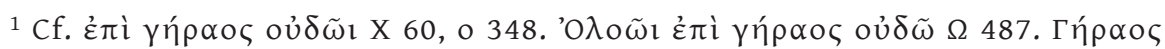
oủó́v o $246, \psi 212$.

${ }^{2}$ Th. 277. Cf. ainda Th. 305 e a fórmula homérica citada na no 1 da p. 237.

${ }^{3}$ Erga, 130-134.

${ }^{4}$ V. 225. 
Os versos 185-188 e 331-332 de Erga supõem o respeito por essa idade da vida, como sentimento normal, e 376-379 do mesmo poema deixam antever o mesmo ideal de feliz longevidade da Odisseia. O frg. 220 Rzach opõe de uma maneira incisiva as três idades:

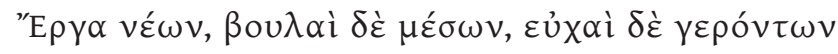

Deste modo, podemos concluir que o pensamento de Hesíodo, neste ponto, não é mais do que uma variante do dos Poemas Homéricos.

Talvez deva datar-se de 700 a. C. ${ }^{1}$ um dos Hinos Homéricos, o quinto, que, não tendo embora grande valor literário, é interessante por nos dar a conhecer, pela primeira vez, um dos mais significativos mitos da antiguidade: o destino de Titono, para quem Eos conseguira a imortalidade, mas se esquecera de pedir também a juventude eterna. Afrodite, que conta a história, não deseja que suceda o mesmo a Anquises, porque:

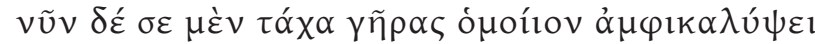

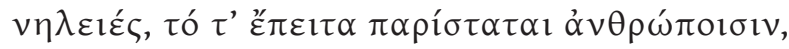

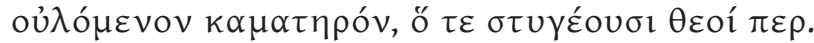

$(244-246)$

A lenda não aparece em Homero ${ }^{2}$, mas surgirá de novo em Safo e em Mimnermo, como veremos adiante.

A eterna juventude estava ligada à imortalidade, como já tivemos

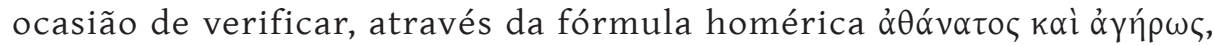
que aparece, por exemplo, em M 323; ع $136=\eta 257=\psi 336$; $\varepsilon 218$; e vai reflectir-se em Hesíodo, Th. 277 e 949 e nos Hinos Homéricos (II. 242, 260; III. 151; V. 214).

No mesmo Hino a Afrodite, a velhice recebe os epítetos tradicionais

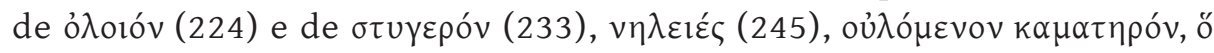

${ }^{1}$ Vide The Homeric Hymns edited by T. W. Allen, W. R. Halliday and E. E. Sikes, second edition, Oxford, at the Clarendon Press, 1936, pp. 350-351.

${ }^{2}$ Conforme observam Allen-Halliday-Sikes, op. cit., p. 366 . O mito foi depois aproveitado para dissertar sobre o tema por um filósofo estóico, Aríston de Quios, ou pelo peripatético Aríston de Ceos (o texto de Cícero, De Senectute, 3, que o cita, não é seguro. Cf. Cicéron, Caton l' Ancien, Texte établi et traduit par P. Wuilleumier, Paris, Les Belles Lettres, 1955, notas ad locum e notice, pp. 54-60).

O mito da longevidade da Sibila de Cumas, que também se esquecera de pedir a Apolo o dom da juventude continuada, segundo Ovídio, Met., XIV, 130-153, é, afinal, um desenvolvimento diverso da mesma ideia básica. 


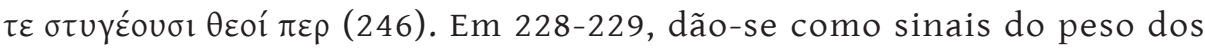
anos o tom grisalho do cabelo e da barba:

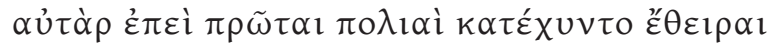

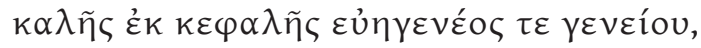

e, mais adiante, no verso 234:

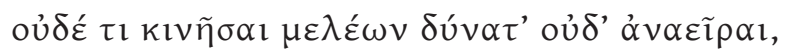

Os três tópicos têm clara ascendência homérica, como aliás quase todos os que se encontram nos Hinos. Basta lembrar $\Psi$ 627-628 e $\Omega 516$.

Outro tanto podemos afirmar quanto ao pedido, feito por Anquises a Afrodite, em V, 105-106, de lhe conceder atingir uma idade avançada, cheio de consideração e de prosperidade.

Em Arquíloco, é provável que a velhice servisse de assunto à sua mordacidade. Os frgs. 113 e 114 Diehl (= 235 Lasserre-Bonnard $=80$ Adrados), que Elmsley reuniu num só, criticam o murchar da pele, sob

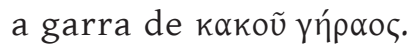

Quanto ao frg. 50 Diehl, já Hiller ${ }^{1}$ afirmou que não deve ser autêntico, e, como observa Bonnard ${ }^{2}$, lembra, pelo estilo e pela métrica, um poeta da comédia nova. É de crer, no entanto, que a obra de Arquíloco contivesse objurgatórias nesse tom.

Outro iambógrafo, Semónides de Amorgo, num fragmento repassado de pessimismo (1 Diehl), em que se põe em foco a inanidade do esforço

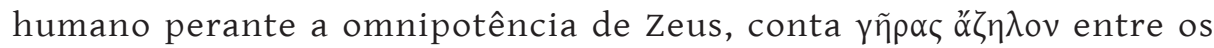
tristes fins que aguardam o homem, ao lado da doença, da guerra, dos naufrágios e dos suicídios.

Muito mais interessante ainda, para o nosso ponto de vista, é o frg. 29 Diehl. A autoria deste texto tem sido contestada, desde que Bergk, pela primeira vez, conjecturou que ele fosse do escritor da «Sátira contra as Mulheres». Tem a seu favor, no entanto, Wilamowitz, Sybel, Pomtow, Kern ${ }^{3}$, e, mais recentemente, Lesky ${ }^{4}$. Não nos propomos discu-

\footnotetext{
${ }^{1}$ Apud Diehl ${ }^{3}$, app. crit. ad locum.

${ }^{2} \mathrm{Na}$ edição Budé de Arquíloco, ad locum.

${ }^{3} \mathrm{Cf}$. Diehl ${ }^{3}$, app. crit. ad locum.

${ }^{4}$ Geschichte der griechischen Literatur, A. Francke Verlag, Bern, p. 108.
} 
tir o problema, porquanto é alheio ao nosso propósito, e, de qualquer modo, ainda que fosse de Simónides de Ceos, como reza o passo de Estobeu, 4,34, 28, que no-lo transmitiu, permaneceria dentro dos limites cronológicos que nos importam. De resto, a semelhança ideológica com o fragmento citado anteriormente é, sem dúvida, favorável à sua inclusão no magro legado poético de Semónides.

Trata-se de um grupo de dísticos elegíacos (talvez mesmo de uma elegia completa), que desenvolve o famoso verso do Canto VI da Ilíada ${ }^{1}$, pronunciado durante o recontro de Glauco e Diomedes:

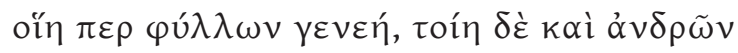

o mesmo que servirá de mote ao frg. 2 Diehl de Mimnermo².

Os homens, continua, não se lembram de que hão-de envelhecer e morrer, que a juventude e a vida são breves. O conhecimento desse facto deve levar-nos a gozar os prazeres até ao fim.

Em Mimnermo, o mesmo tema aparece-nos revestido do esplendor de belas metáforas poéticas, e, além disso, com algumas ideias pessoais. As Keres agora não são somente as da morte, como nota Adrados na sua edição ${ }^{3}$, mas sim

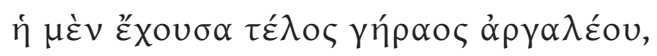

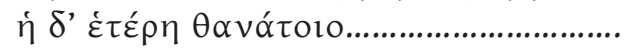

(frg. 2 Diehl,vv. 6-7)

É provável que, tal como em X 210-213, se opunham na balança de

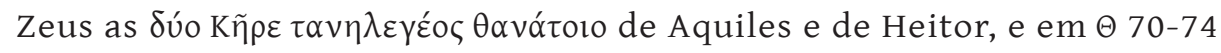
sucedia o mesmo com a dos Troianos e a dos Aqueus, e em I 411 Aqui-

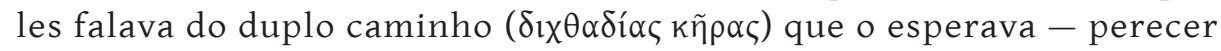
glorioso em ílion ou morrer velho, mas obscuro, na sua pátria - do

${ }^{1}$ V. 146. A este propósito, observa Schadewaldt, «Lebenszeit und Greisenalter....», cit., p. 294, que esta composição é «für uns besonders merkwürdig, weil sie alte homerische Motive aufgreift und seltsam in die neue Lebensstimmung, jetzt die Stimmung gleichgültiger Entsagung, verwandelt.»

2 As duas composições foram comparadas, entre outros, por C. M. Bowra, Early Greek Elegists ${ }^{2}$, pp. 22-24, que aventa a hipótese de Semónides ter escrito o seu poema depois do de Mimnermo. Aquele, diz, retira a parca consolação da juventude para a substituir por um completo nihilismo, em que as únicas coisas agradáveis parecem ser esperanças destinadas a falhar.

3 P. 219, n. 4. 
mesmo modo aqui o poeta se refira a duas Keres como alternativas, ambas desagradáveis ${ }^{1}$.

Em Mimnermo os dois males estão, portanto, equiparados. Os versos seguintes ainda vão mais longe:

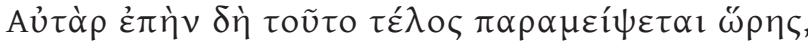

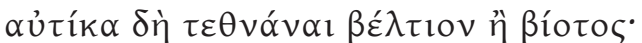

(Vv. 9-10)

E logo surge a enumeração dos flagelos que a acompanham: a pobreza, a carência de filhos, as doenças incuráveis.

O frg. 4 Diehl confirma amplamente o dístico acabado de citar, através de um exemplo mítico:

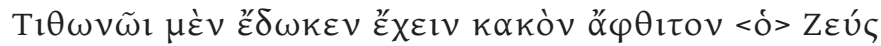

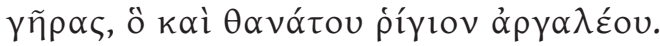

O frg. 6 marca o limite ideal da vida: sessenta anos.

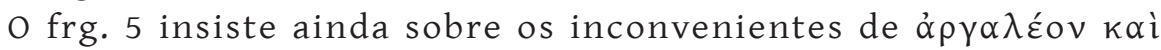

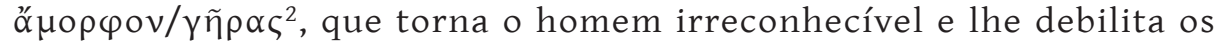
olhos e o espírito.

O frg. 3 vai ao ponto de negar honra e afecto ao pai idoso (contrariamente à tradição homérica).

Bem diferente era a atitude dos Espartanos, pelo menos tal como no-la revela Tirteu, ao afirmar que o antigo combatente é honrado mais do que todos, mesmo depois de avançado em anos ${ }^{3}$, e ao incitar os jovens a que não se submetam ao opróbrio de consentir que os velhos caiam no campo da batalha, comprazendo-se numa pormenorização dramática do quadro, que tem as suas raízes literárias na Ilíada ${ }^{4}$. É de notar que igualmente se descreve o guerreiro idoso à maneira homérica, como

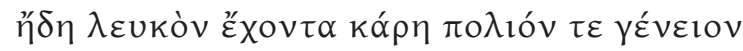

${ }^{1}$ Diferente é o caso de M 326-327, onde são $\mu$ upíal.

${ }^{2}$ Vv. 2-3.

${ }^{3}$ Frg. 9 Diehl, vv. 39-42. Sobre o respeito dos Lacedemónios pelos anciãos, dá-nos um testemunho tardio Cícero, De Senectute, 63-64.

${ }^{4}$ X 71-76. O frg. é o 6.7 Diehl, vv. 21-28. 
No frg. 14 Diehl, Sólon também fala de kakòv $\gamma \tilde{n} \rho \alpha \varsigma^{1}$, como estava na tradição. Mas o legislador de Atenas era um homem que gostava de examinar por si mesmo os problemas da vida e reflectir sobre eles, para emitir uma opinião pessoal, exactamente como no-lo apresenta o famoso episódio narrado por Heródoto ${ }^{2}$, que, se é historicamente falso,é psicologicamente certo. E assim, no frg. 19, analisa as idades da vida, assinalando, como já foi notado ${ }^{3}$, o progresso intelectual trazido pelo volver dos anos. O princípio do frg. 22 contém o que se supõe ser, desde Diógenes Laércio ${ }^{4}$, a resposta aos versos de Mimnermo acima citados:

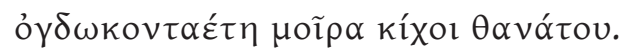

Este desejo, só por si, esclareceria para nós o pensamento do autor acerca das vantagens da velhice. Mas um outro verso, que nos foi transmitido por diversas fontes, e que deve pertencer ao mesmo contexto, explica claramente a razão ${ }^{5}$ :

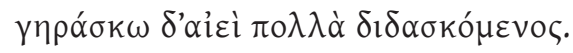

Também Xenófanes, no frg. 7 Diehl, invoca os anos para apoiar a sua autoridade:

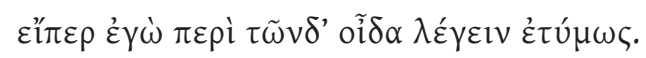

E no frg. 8 refere-se a alguém cuja debilidade é superior à de um velho.

Se considerarmos agora o mais tardio dos grandes elegíacos, Teógnis de Mégara, verificamos que há um retrocesso na atitude perante

\footnotetext{
${ }^{1}$ V. 10.

${ }^{2}$ Livro I, cap. 30-33. A discussão acerca da historicidade da entrevista com Creso pode ler-se em W. W. How and J. Wells, A Commentary on Herodotus, Oxford, at the Clarendon Press, 1950, vol. I, pp. 66-67.

${ }^{3}$ Cf. nota 1 da p. 197 da edição de Adrados. A autenticidade deste curioso fragmento, negada por Porson e Usener, é o tema central do já citado artigo de W. Schadewaldt, "Lebenszeit und Greisenalter im frühen Griechentum». Com razão duvida da influência do culto de Apolo Délio e lhe encontra as fontes na medicina popular e em Hesíodo; pois nada tem de ingénuo, antes é fruto de uma profunda experiência (pp. 300-302). Sobre este assunto, veja-se ainda C. M. Bowra, Early Greek Elegists ${ }^{2}$ pp. 75-76 e 100-102.

${ }^{4}$ I. 60.

${ }^{5}$ Como diz Schadewaldt, «Lebenszeit und Greisenalter...», cit., p. 302, é «der frühe Vorbote einer wieder neuen Lebensgesinnung». Note-se que o mesmo pensamento aparecerá expresso de forma diferente em Ésquilo, Agamémnon, 584.
} 
a idade. O horror à velhice, transparece através de muitos dos seus dísticos, e alguns mesmo, como os 567-570, «Mimnermum sapiunt», conforme declara Diehl no seu aparato crítico. A velhice e as febres são tomadas como termos de comparação, para definir o horror que é a pobreza (173-174), a qual é ainda pior que a morte (181-182). Aparece associada a esta última em 768 (num passo, aliás, datável de c. 480 a. C., pois que fala do assalto dos Medos) e oposta a esta, como flagelo pior, em 1069-1070. A velhice deve ser honrada (271-278; 821-822; e 937-938, onde é manifesto o modelo de Tirteu).

O dístico 527-528 põe em evidência o sentimento de desespero pelo volver dos anos ${ }^{1}$,

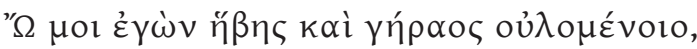

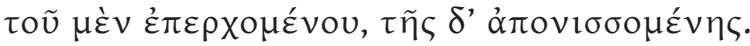

A mesma noção é amplificada em 1129-1132.

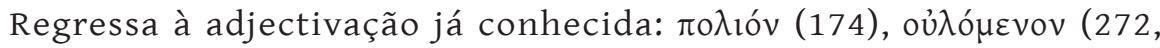

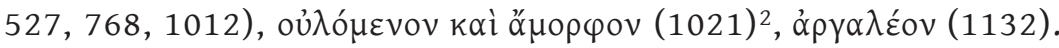

Não surpreende, aliás, que, nesta colectânea, que parece ser de muitas mãos, e na qual prevalece uma concepção utilitarista da vida, se reúnam para qualificar a velhice e exaltar a juventude todos os lugares-comuns até aí acumulados.

Os líricos desenvolvem por vezes os mesmos assuntos dos elegíacos, como é sabido, pois a distinção entre os dois géneros era muito mais formal do que temática.

E assim, é fácil concluir, mesmo através de um rápido exame aos fragmentos conservados, que a antinomia juventude-velhice também os preocupou.

Em Álcman, o frg. 94 Diehl parte de um facto prosaico, embora pertencente à tradição homérica - a debilidade das suas pernas de velho - para as imagens aladas dos alcíones que vogam à flor das ondas, e que apagam a triste realidade, para deixar o ouvinte no domínio da utopia:

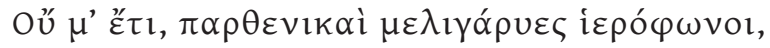

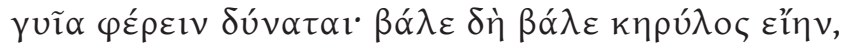

${ }^{1}$ Para Schadewaldt, «Lebenszeit und Greisenalter....», cit., este epigrama é «die denkbar kürzeste Prägung für die neue Lebensstimmung, die Homer noch nicht kannte und die mit dem Zeitalter der Lyrik plötzlich durchbricht: für das Grauen vor der unaufhaltsam verrinnenden Zeit.» (p. 292).

${ }^{2}$ Num verso imitado de Mimnermo. 


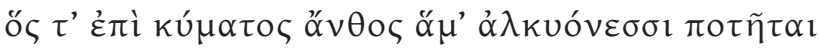

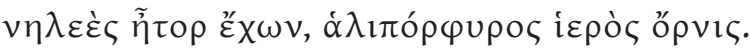

Parece que Alceu se refere à própria velhice no frg. 50 Lobel-Page (= 86 Diehl), ao pedir que vertam perfumes na sua cabeça, que tanto sofreu, e no peito idoso ${ }^{1}$ :

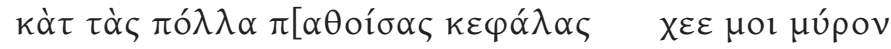

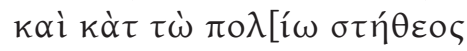

Os dois primeiros versos, restituídos por Bergk (frg. 42), a partir de uma citação de Plutarco, Quaest. Conuiu., III, 1, 3, p. 647e, são confirmados e continuados pelo Papiro 1233, que parece conter um convite à bebida ( $\pi \omega v o ́ v \tau \omega v)$, para esquecer as preocupações. No entanto, o contexto não é seguro. Outro tanto sucede com o fragmento 39 Lobel-Page $=80$ Diehl.

O frg. 119 Lobel-Page = 117 Diehl refere-se talvez à velhice de Pítaco, mas fá-lo sob forma alegórica, comparando-o com o fruto da videira ${ }^{2}$. No entanto, o estado do texto é tal, que tudo o que se possa afirmar não passa de mera conjectura.

Uma citação feita pelo escoliasta de Sófocles, Oed. Col. 954 (= frg. 117 Bergk $=442$ Lobel-Page $=206$ Reinach-Puech) é, paradoxalmente, a informação mais completa que possuímos a este respeito. Nela se assevera que Alceu mencionara, como provérbio muito conhecido, ö

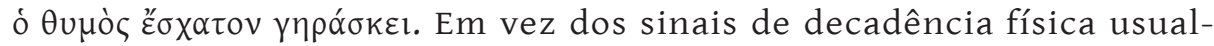
mente apontados como característicos da velhice, teríamos aqui uma observação de natureza psicológica, que, aliás, já andava em curso no seu tempo.

Pelo que toca à insegurança do contexto, a situação não é muito melhor em Safo. E, contudo, dois papiros vieram trazer ao nosso conhecimento fragmentos em que a poetisa descrevia a velhice - possivelmente, a sua própria.

O frg. 21 Lobel-Page $=32$ Diehl apenas deixa adivinhar o tema através de uma referência concreta ${ }^{3}$ :

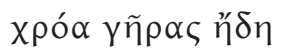

\footnotetext{
${ }^{1}$ Cf. Page, Sappho and Alcaeus, p. 242.

${ }^{2}$ Cf. Page, Sappho and Alcaeus, p. 242, n. 3.

3 «Vetulae corporis delicias tabescentes describi censuit Wil.» - refere Diehl no seu aparato crítico. «La strophe 2 parle de la vieillesse» nota Aimé-Puech a p. 218 da edição de Reinach. Omitimos a ousada reconstituição de Edmonds, Lyra Graeca, vol. I, p. 213.
} 
Esta mesma frase surge no v. 13 do frg. 58 Lobel-Page = 65a Diehl:

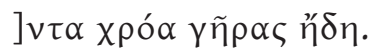

Os dois versos seguintes acrescentam:

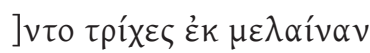

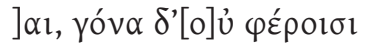

É fácil reconhecer, no primeiro, uma referência ao embranquecimento dos cabelos; no segundo, ao debilitamento dos joelhos, tal como já figurava no frg. 94 de Álcman ${ }^{1}$ que, por sua vez, fora antecedido pelos versos 627-628 do Canto XXIII da Ilíada.

O segundo e o terceiro tópicos eram, portanto, lugares-comuns da tradição poética. O primeiro, a avaliar pela sua presença nestes dois fragmentos, parece ter sido o sinal físico da velhice que mais impressionou a poetisa ${ }^{2}$.

Seria particularmente interessante conhecer a conclusão do poema, e poder aceitar a versão de Manfred Hausmann:

\section{Mich aber verlangt's \\ immer noch nach \\ Anmut und goldner Fülle. \\ Dies Herrliche hat \\ stets mich umglänzt, \\ weil ich die Sonne liebe.}

que Snell transcreve na sua obra Die Entdeckung des Geistes ${ }^{3}$ para induzir que Safo, como, aliás, os poetas arcaicos em geral, não tenta dar sentido ao progresso da idade.

Sucede, porém, que a parte final é extremamente obscura, de tal modo que só podemos repetir com Page: «I have no conception of the meaning of the last two lines ${ }^{4}$.

${ }^{1}$ A semelhança com o texto de Álcman foi já salientada por F. Stiebitz, que tentou reconstituir o poema in Philologische Wochenschrift, 1926, 1259 seqq. (apud Diehl, appar. crit. ad locum).

${ }^{2}$ Aliás, figurava já em Arquíloco, frg. 113 Diehl, possivelmente com referência a uma mulher. Cf. supra, p. 241.

${ }^{3}$ Hamburg, Claassen Verlag, 3. Auflage, 1955, p. 102. O tema da velhice em Safo é sumariamente delineado por Schadewaldt, «Lebenszeit und Greisenalter...», cit., pp. 293-294.

${ }^{4}$ Sappho and Alcaeus, p. 130, n. 1. 
O mesmo editor e comentador inclui este fragmento entre os poemas de Safo em que se faziam alusões às lendas divinas ou heróicas, para ilustrar casos pessoais (e.g., 16, 17, 23). Neste era a de Titono, para quem Eos conseguira duração eterna, mas se esquecera de impetrar também a permanência da juventude. Já vimos como tal mito figura no V. Hino Homérico, a Afrodite ${ }^{1}$. Possivelmente, a autora aproveitava o seu significado para explicar a situação em que se encontrava ${ }^{2}$.

No frg. 121 Lobel-Page = 100 Diehl, declara-se demasiado velha ( $ү \varepsilon-$

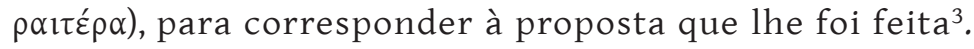

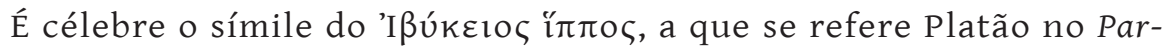
ménides 137a, e cujo contexto foi preservado no comentário de Proclo. O pequeno poema conta uma reincidência amorosa, como tantas outras líricas arcaicas, desde o frg. 101 Diehl de Álcman. De importante, há aqui a circunstância de tal acontecimento se verificar na velhice do autor, como se deduz da metáfora usada na segunda parte e do próprio passo do Parménides que o parafraseia.

Com efeito, depois de descrever a atitude de Eros - a identificar com o objecto da paixão, como disse Wilamowitz ${ }^{4}$ - o poeta compara-se a um cavalo outrora premiado, a quem custa ter de entrar novamente em luta. O confronto com Anacreonte impõe-se: o novo ataque de Eros, através de uma atitude provocante (o lançar da bola purpúrea no frg. 5; aqui, a contemplação «com ternos olhos sob as suas pálpebras escuras» e as inúmeras seduções); depois, o tema da velhice, que neste se

1 Vide supra, p. 240.

${ }^{2}$ Eis como Page comenta o passo: «The earlier lines (13-15) are concerned

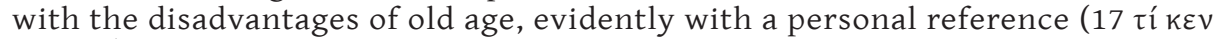
rocínv;). The end of the poem included a brief allusion to Tithonus, for whom the enamoured Dawn obtained eternal life but not eternal youth. It is obvious that the reference to the legendary persons is introduced to illustrate a personal theme» (p. 130). Aimé-Puech, na n. 1 da p. 248 da edição de Reinach, não vê razão convincente para crer que se trate de uma queixa da própria Safo pela sua sorte, com base no v. 16:

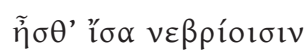

Mas a posição das primeiras letras no papiro dissipa este argumento. É preferível escrever, como Lobel:

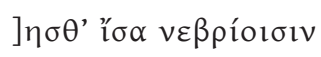

No verso seguinte, figura já a primeira pessoa, como nota Page no passo acima transcrito.

${ }^{3}$ Cf. Sappho and Alcaeus, p. 142, n. 1.

${ }^{4}$ Sappho und Simonides, p. 125. 
expande numa metáfora extraída de um desporto favorito dos Gregos ${ }^{1}$ e no poeta de Teos da maneira que já vimos anteriormente.

Em Píndaro encontram-se inúmeras referências à velhice, de que algumas reflectem a antiga ideia de horror, associando-a com a morte, outras antevêem o quadro tranquilo de uma senectude feliz.

No primeiro caso estão as palavras que Zeus dirige a Pólux, na $X^{\text {a }}$. Nemeia, propondo-lhe o dilema de viver no Olimpo sem o irmão ou de conservar a companhia de Castor, sendo sujeito a perecer:

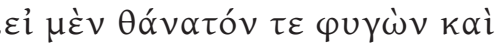

$\gamma \tilde{\eta} \rho \alpha \varsigma \alpha ̉ \pi \varepsilon \chi \theta o ́ \mu \varepsilon v o v$

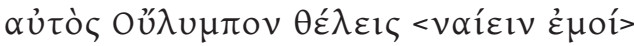

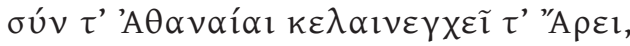

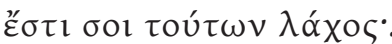

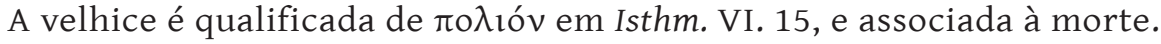
Num contexto idêntico surge em Isthm. VII. 40-42. No Péan I. 1 fala-se de

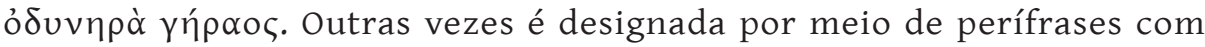
valor de eufemismos, como sucede em Ol. X. 86-87, Pyth. IV. 157-158, Nem. III. 72-74 (neste último passo, com referência às três idades da vida).

Tradicional é também considerar os velhos bons conselheiros. Assim, exalta-se na IV $V^{\underline{a}}$ Pítica (281-282) a ponderação de Damófilo, um jovem de corpo, mas centenário no bom senso.

O ideal da velhice serena, que já vimos delineado mais do que uma vez na Odisseia, surge com frequência nos versos do poeta tebano, quer como anseio próprio, projectado vagamente num futuro distante:

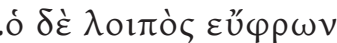

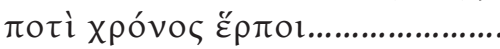

(Nem. VII. 67-68)

quer como voto formulado em favor dos seus clientes:

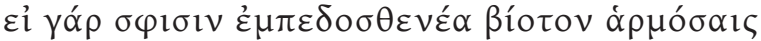

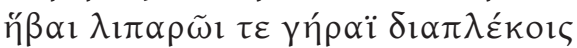

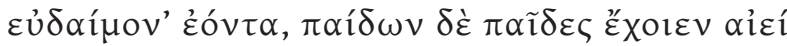

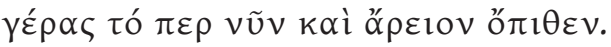

(Nem. VII. 98-101)

${ }^{1}$ A comparação com Anacreonte foi feita também por Wilamowitz, Sappho and Simonides, p. 126, e o tema do 'Ißúkelos ï $\pi$ os seguido pelo mesmo helenista até Euripides, Her. 120 (cf. op. cit., p. 125, n. 2 ). 
É um modo de ver idêntico que leva o poeta da $\mathrm{V}^{\mathrm{a}}$ Olímpica - fosse ele Píndaro ou não - a augurar a Psáumis, o destinatário dessa ode, que já não era muito jovem ${ }^{1}$, uma velhice tranquila, cercado pelos seus filhos, no gozo ainda dos cavalos que eram a sua paixão de 'O $\lambda u \mu \pi \imath$ óvıkoc:

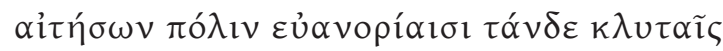

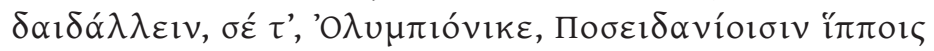

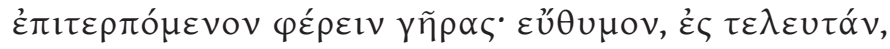

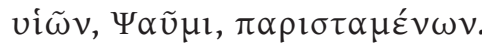

É que os trabalhos da juventude, quando executados sob a égide da justiça, asseguram esse privilégio²:

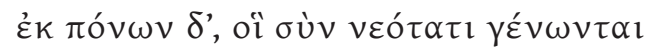

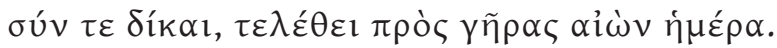

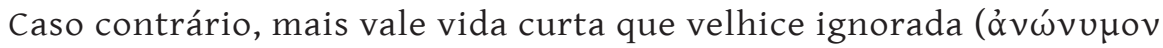

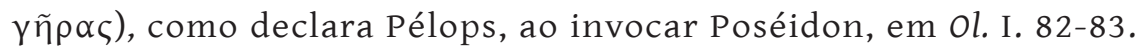

É curioso encontrar, reunidos deste modo, no mesmo poeta, dois conceitos opostos de senectude, um, que vê nela uma idade odiosa ou dolorosa, e outro, que a considera como uma fase doce e tranquila. $O$ primeiro representa a tradição da Ilíada; o segundo, a da Odisseia. Para quem conhece a incoerência do pensamento de Píndaro noutros domínios $^{3}$, nada surpreende que o mesmo se verifique neste.

As escassas referências que se encontram na obra de Baquílides testemunham o emprego de qualificativos tradicionais ( $\pi \circ \lambda_{\imath}$ òv...

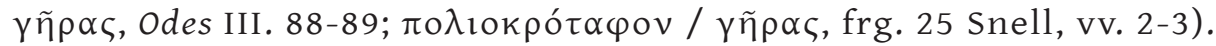
O encómio 20a Snell,vv. 7-10, oferece um texto muito pouco seguro para se tirarem conclusões estáveis.

No único dos grandes trágicos que ainda viveu na época arcaica, encontra-se um fragmento citado por Estobeu IV, 50, 7, que exalta o sentido da justiça alcançado pelos anos. É o $400 \mathrm{Nauck}^{2}$ de Ésquilo:

\footnotetext{
${ }^{1}$ Cf. Ol. IV, 25-27.

${ }^{2}$ Nem. IX, 44. Um pensamento idêntico se exprime no frg. 214 Snell.

${ }^{3}$ Nomeadamente no escatológico. Estudei esse aspecto em Concepções Helénicas de Felicidade no Além, de Homero a Platão, Coimbra, 1955, pp. 30-36 e 99-119.
} 


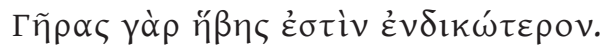

A noção de progresso, de renovamento do espírito que pode animar um corpo alquebrado, transparece do seguinte verso, que retoma o pensamento de Sólon, já citado ${ }^{1}$ :

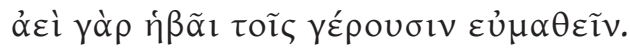

Também digna de nota é uma bela descrição da velhice, em que é fácil reconhecer, numa feliz transposição, o enigma da esfinge e a metáfora homérica das folhas das árvores ${ }^{2}$, para terminar com uma imagem de expressão tipicamente esquiliana:

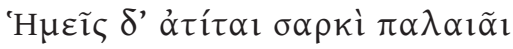

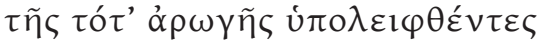 $\mu\{i ́ \mu \nu \rho \mu \varepsilon v$ ioxúv

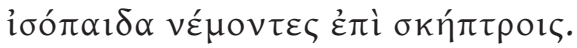

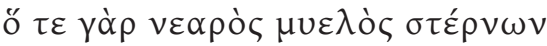

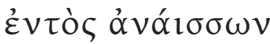

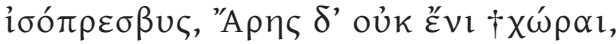

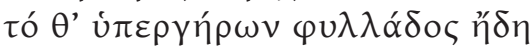

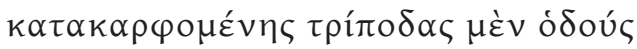

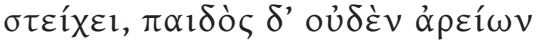

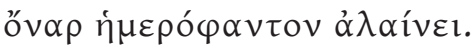

(Ag. 72-82)

Outras ideias sobre a senectude, esparsas pelas tragédias conservadas, enquadram-se sem esforço na tradição já examinada ${ }^{3}$.

\footnotetext{
${ }^{1}$ P. 244.

${ }^{2}$ Em Ag. 966-967 pode distinguir-se uma variante da mesma metáfora, usada, embora, com aplicação diversa.

${ }^{3}$ Respeito pela idade (Eum. 847) ou falta do mesmo (Ag. 1621-1624; Eum, 727-728); superior capacidade de persuasão (Suppl. 774-775); qualidades para governar (Suppl. 666-667); de um jovem sensato, diz-se que o espírito é idoso (Sept. 622); sinais físicos da velhice, como a barba branca e a debilidade dos membros (Pers. 1056 e 913-914, este com uma triste ironia); o ideal da senectude tranquila entrevê-se, como uma nostálgica impossibilidade, em Pers. 263-265 e 580-583; Ag. 328-329; Choeph. 908.

Estes tópicos encontram-se, com pequenas variantes, nos outros grandes trágicos. Por exemplo, em Sófocles, os versos 625 e 632 do Aiax falam das cãs, e os 1017-1018 do azedume aumentado pela idade: tudo nela é mau, entendimento, palavras, pensamento (frg. $863 \mathrm{Nauck}^{2}$ ) e a longa vida é dolorosa (frg. $512 \mathrm{Nau}$ $\mathrm{ck}^{2}$ ); apesar disso, os velhos são mais ávidos de viver (frg. $63 \mathrm{Nauck}^{2}$ ); por outro lado, são sensatos (frg. $239 \mathrm{Nauck}^{2}$ ) e experientes (frg. $603 \mathrm{Nauck}^{2}$ ); no famoso
} 
Em conclusão, depois desta breve análise do desenvolvimento do tema da velhice na época homérica e arcaica, podemos afirmar que a maior parte dos poetas, desde a Ilíada, viu nela um flagelo, comparável à doença e à morte. Tal atitude atinge a nota mais aguda em Mimnermo, que repetidamente ${ }^{1}$ contrasta os amáveis dons da juventude com a lamentável decadência da idade provecta, um dos muitos males com que Zeus atormenta os homens ${ }^{2}$, e proclama a vantagem de morrer antes de alcançar essa fase da vida ${ }^{3}$. A mesma atitude pessimista vamos encontrar num iambógrafo seu contemporâneo, Semónides de Amorgo, que, aliás, conclui de modo diferente: exortando a gozar os prazeres enquanto é tempo - claramente, como sucede no frg. 29 Diehl, ou veladamente, como no frg. 1 Diehl e talvez ainda no frg. 4 Diehl $^{4}$.

A esta corrente se opõe Sólon, que, pela primeira vez, até onde podemos saber, é capaz de apreciar o progresso intelectual decorrente da acumulação dos anos.

estásimo sobre o desencantamento da vida, Oedipus Col. 1211-1248, a senectude é caracterizada como execrável, impotente, insociável, ponto de convergência de todos os males. Em Eurípides, é igualmente descrita como impotente (Her. 110-113), triste e odiosa (Her. 649) e implacável (Suppl. 1108). Cf. ainda Bacch. 1251 e frgs. 25, 575, 637 e 1080 Nauck $^{2}$. O frg. 509 Nauck $^{2}$ diz que é só voz e sombra. Para se corrigirem, os homens precisavam de conhecer duas vezes a adolescência e a velhice (Her. 655-672; Suppl. 1084-1093). Mas o coro, apesar de ancião, ainda gosta de cantar (Her. 676-686), e a idade tem a vantagem da experiência e do bom conselho (Phoin. 528-530 e frgs. 291, 508 e 619 Nauck $^{2}$ ). Muitos outros passos aludem apenas aos sinais físicos da idade, como os cabelos brancos (Andr. 348; Hec. 500, 652; Her. 910; Suppl. 35, 170, 289), à barba grisalha (Her. 693) ou às rugas (Suppl. 50), ou ainda aos membros pesados (Her. 119-120, 230-231; Ion 1041-1042; Suppl. 171-172) ou à falta de forças (Heracl. 636). Cf. ainda o frg. 369 Nauck $^{2}$.

A maneira de ver de Aristófanes não anda longe desta. Os cabelos brancos (Ach. 600, 692-693; Eq. 520, 908; Vesp. 1064, 1192), as rugas (Plut. 1051), as manifestações de debilidade (Vesp. 275-278), o peso dos membros (Ach. 219-221) juntam-se a alguns traços especificamente ao gosto dos cómicos, como os olhos remelosos do coro de anciãos em Lys. 301, a carência de dentes em Ach. 715, Plut. 266, 1057-1059, Vesp. 164 , a calvície em Plut. 266, e os prazeres citados em Vesp. 737-740. Em Ach. 702 e Plut. 266 fala-se do dorso curvado, e em Nub. 129 os velhos são caracterizados como lentos e esquecidos. No entanto, outro passo desta última peça (993) lembra o respeito a observar para com eles. Vesp. 441 declara-os sujeitos a mil males. Ferécrates refere-se à sua incapacidade no frg. 248 Kock, embora no frg. 146 Kock aluda ao saber adquirido pelos anos; e, no frg. 82,3 Kock, censura a falta de dentes. Também Sófron, frg. 54 Kaibel (Stob. IV, 50, 65) afirma que «a velhice destestável consome-nos e seca-nos».

${ }^{1}$ Frgs. 1, 2, 5 Diehl.

${ }^{2}$ Conclusão dos frgs. 1 e 2 Diehl.

${ }^{3}$ Frg. 6 Diehl.

${ }^{4}$ Para Reitzenstein (citado por Diehl, app. crit. ad locum, e Adrados, notas ad locum), os fragmentos 1, 2 e 3 seriam parte de um mesmo poema. Adrados inclina-se para juntar apenas 3 e 4 . Afigura-se-me que 3 ganha mais luz comparado com o final de 1 do que com 2 . 
Dentre os líricos, é Íbico quem mais nos interessa, por celebrar o tema do amor entrelaçado com o da velhice, tal como o seu contemporâneo e provavelmente comensal na corte de Polícrates de Samos, Anacreonte, fizera no frg. 5 Diehl. E, como este, no referido passo ou ainda no frg. 45 Diehl, exprime-se através de metáforas de grande efeito.

Quanto ao tema da velhice tranquila e honrada, verificámos que se anunciava na Odisseia, não só nas partes que podem considerar-se mais recentes, como nas seguramente mais antigas. Encontramo-lo depois num dos mais vetustos Hinos Homéricos ${ }^{1}$, em Tirteu ${ }^{2}$, e em Píndaro ${ }^{3}$, repetidas vezes.

O tópico surge, por conseguinte, como um incitamento a cometer altos feitos, para depois gozar a honra que daí deriva, nos poetas de ideal heróico; como uma advertência para aproveitar o prazer da hora que passa, no espírito amargo dos iambógrafos; como motivo de lamentações sobre a tristeza e brevidade da vida, nos pessimistas; como causa da reflexão sobre o desenvolvimento do espírito humano, nos moralistas. É possível que, se alguns fragmentos estivessem completos, verificássemos que a segunda atitude não era separável da terceira. No estado actual da transmissão manuscrita, porém, elas devem distinguir-se.

O espírito com que se encaram as duas idades opostas - juventude e velhice - altera-se, dos Poemas Homéricos até à época da lírica: é nesta última que ganha expressão literária o terror de envelhecer, como notou Schadewaldt ${ }^{4}$.

Nas composições que apenas tocam no assunto acidentalmente, assinalaremos que há um pequeno número de características físicas que se focam com mais insistência: os cabelos ou a cabeça brancos ${ }^{5}$, a barba grisalha ${ }^{6}$, a pele flácida ${ }^{7}$, os membros débeis ${ }^{8}$. A adjectivação é quase a mesma, de tal modo que podemos dizer que se constituem fórmulas que os poetas

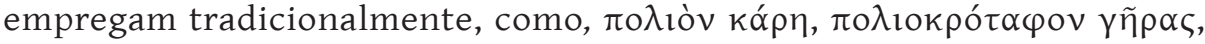
$\pi \circ \lambda_{\imath}$ òv $\gamma \tilde{n} \rho \alpha \varsigma$. Do mesmo modo se opõe a penosa velhice à doce juventude 9 .

${ }^{1}$ V. $105-106$.

${ }^{2}$ Frg. 9, 35-42.

${ }^{3}$ Ol. V 20-23. Nem. VII 67-68, 98-101. Nem. IX 44.

${ }^{4}$ «Lebenszeit und Greisenalter....», cit., p. 285 e passim. Cf. supra, p. 245, n. 1.

${ }^{5}$ X 74. $\Omega$ 516. Safo, frg. 58 Lobel-Page. Anacreonte, frg. 5 Diehl. Baquílides, Ode III 88-89 e frg. 25 Snell. Teógnis de Mégara, 174.

${ }^{6} \mathrm{X} 74 . \Omega 516$.

${ }^{7}$ Arquíloco, frg. 113 Diehl. Safo, frg. 21 e 58 Lobel-Page.

8 ч 627-628. Álcman, frg. 94 Diehl. Safo, frg. 58 Lobel-Page.

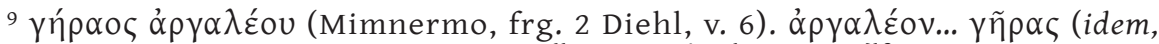

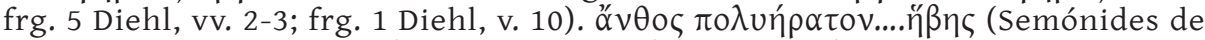

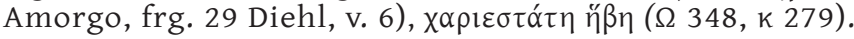




\section{ß) O Hades e o Tártaro}

A Ilíada refere-se inúmeras vezes a Hades, o deus inflexível e impla-

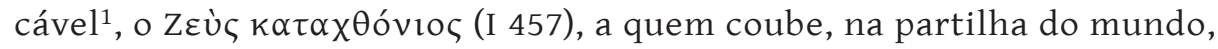
o reino dos mortos:

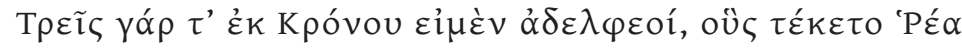

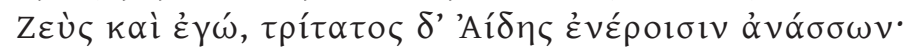

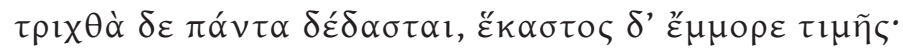

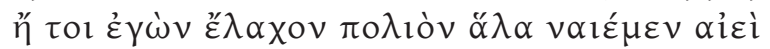

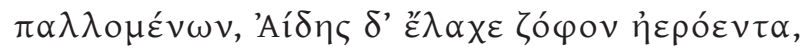

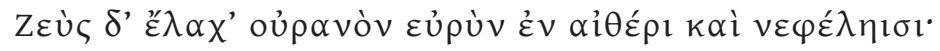

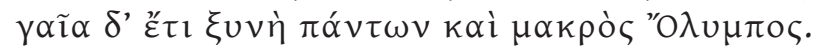

(O 187-193)

Em Y 61-66, quando os deuses voltam a entrar em combate, é tal a violência da refrega que Hades se assusta:

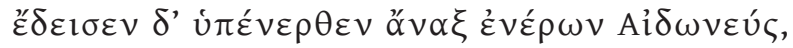

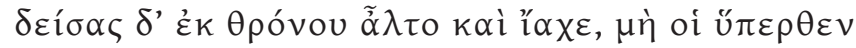

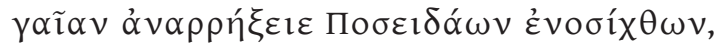

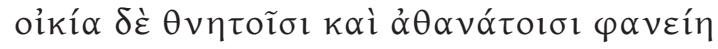

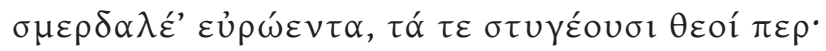

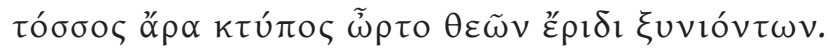

Se algumas vezes aparece com atributos pessoais, como $\kappa \lambda v \tau o ́ \pi \omega \lambda$ o $\varsigma^{2}$, ou se fala do seu barrete, que o torna invisível ${ }^{3}$, na maior parte dos casos ele identifica-se com as regiões que habita, que são tenebrosas e

1 I 158.

${ }^{2}$ E 654. $\Lambda$ 445. П 625. Aliás, o deus quase não tem culto nem mitos, como observa M. P. Nilsson, Geschichte der griechischen Religion, Vol. I, p. 424. Sobre as associações ctónias do epíteto $\kappa \lambda v \tau o ́ \pi \omega \lambda$ os, vide idem, ibidem, p. 425.

${ }^{3}$ E 845. Os antigos explicavam o nome do deus como sendo composto de $\alpha+$ عỉ்́c, «invisível», como lemos em Platão, Crátilo, 403a (que propõe outra origem,

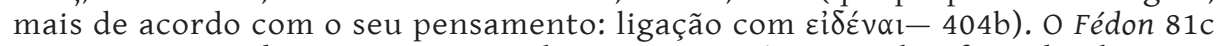
parece seguir a doutrina corrente, bem como o Górgias 493b. Cf. ainda Plutarco, De Lat. Viu. 6,3 e De primo frigido 9, 948e-f. Sobre a posição- nem sempre concordante - dos linguistas actuais e a ligação da etimologia antiga com o mito da «Tarnkappe», veja-se H. Frisk, Griechisches etymologisches Wörterhuch, I, pp. 33-34, e bibliografia aí citada. M. P. Nilsson, Geschichte. der griechischen Religion, vol. I, p. 425 e n. 1, admite que se trata de um conhecido motivo popular, que foi adaptado a Hades, e acrescenta: «Darin liegt aber ein Hinweis darauf, dass das Wort als 'unsichtbar' verstanden wurde.» 
cheias de bolor, como se viu no exemplo citado acima ${ }^{1}$. O seu palácio

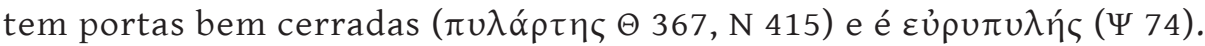
As $\pi u ́ \lambda \alpha \iota$ são referidas em diversos contextos ${ }^{2}$.

Fala-se da existência de um rio, que as $\psi v x \alpha$ á, $\varepsilon i ̂ \delta \omega \lambda \alpha \kappa \alpha \mu o ́ v \tau \omega v$, só podem atravessar depois da cremação, e que não é nomeado em $\Psi 73$ ( $\dot{u} \pi \grave{\varepsilon} \rho \pi \circ \tau \alpha \mu$ õo), mas que $\Theta 369$ identifica com o Estige ${ }^{3}$. É o lugar para onde irão todos os mortos, sem qualquer excepção.

De resto, a maior parte das vezes o Hades é simplesmente mencionado como um sinónimo de morte ${ }^{4}$. Um passo como X 482-483:

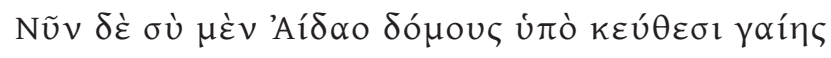
है $\rho \times \varepsilon \alpha 1$

dá uma indicação clara sobre a posição do reino infernal, indicação essa que é confirmada pelo uso do verbo kó $\varepsilon \varepsilon \iota \mu$ em $\Xi 457$ e em Y 294.

Quanto ao Tártaro, apenas dois cantos falam dele.

Em $\Xi 279^{5}$, Hera jura por

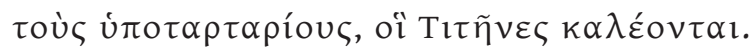

O mesmo canto, nos versos 203-204, referira-se mais vagamente à situação de Cronos:

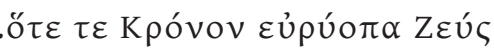

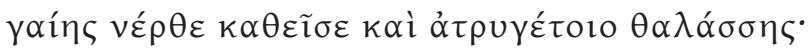

Em 274, a posição é idêntica, bem como em 0 225. Em $\Theta$ 478-481, colhem-se mais informações sobre a sua localização:

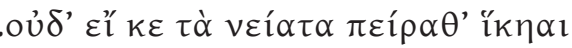

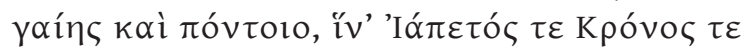

${ }^{1} \mathrm{Cf}$. ainda $\Phi 56 . \Psi 51$.

2 E 646. I 312. $\Psi 71$.

${ }^{3} \mathrm{Em} \mathrm{B} 755, \Xi 271$ e O 37, a água do Estige é mencionada como garantia de juramento inviolável.

${ }^{4}$ Alguns exemplos: A 3. $Г$ 322. E 190, $654=\Lambda 445=\Pi$ 625. Z 487. $\Lambda$ 55. П $856=$ X 362. Y 294. Ф 48. X 52, 213. $\Psi 19,244 . \Omega 246,593$.

${ }^{5}$ É grande a semelhança deste verso com o 851 da Teogonia:

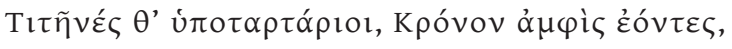

verso que, por sua vez, figura num contexto idêntico ao de Y 61-66. 


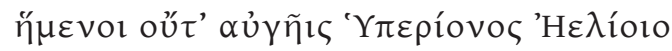

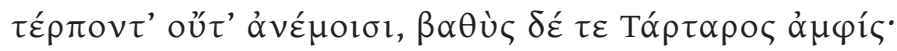

No começo do mesmo canto, em 13-16, Zeus ameaça os deuses de os lançar ao Tártaro, se continuarem a intervir na guerra de Troia, e, ao fazê-lo, informa-nos da posição desse lugar, em relação ao Hades:

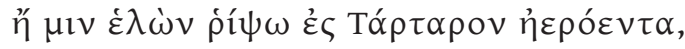

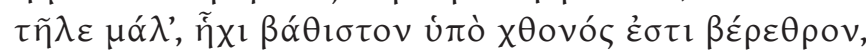

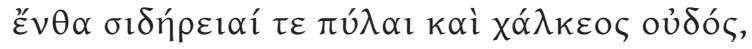

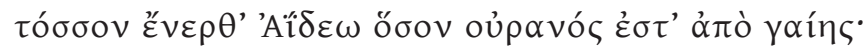

Este passo é muito semelhante a uma das partes da "Titanomachia», contada na Teogonia. O Canto VIII da Ilíada, bem como o Canto XIV, é geralmente considerado tardio, a despeito dos arcaísmos que contém ${ }^{1}$, e por isso não repugna aceitar, como $\mathrm{Mazon}^{2}$, que o modelo aqui tivesse sido Hesíodo.

A Odisseia também se refere com frequência à ida para o Hades como sinónimo de morrer ${ }^{3}$ e às abomináveis portas ${ }^{4}$ que cerram aquele lugar. A água do Estige figura no juramento de Calipso, em $\varepsilon$ 184-187, em condições semelhantes às que encontrámos na Ilíada.

A vékvia de $\lambda$, preparada por $\kappa$ 490-574, e a sua imitação de $\omega$ 1-204 contêm, naturalmente, a maior quantidade de indicações. Na verdade, a topografia do Hades aparece agora muito mais pormenorizada do que anteriormente: fica para além do Oceano, do pequeno promontório e do bosque de Perséfone; ao lado do Estige, mencionam-se, pela primeira vez, mais três rios, o Aqueronte, o Piriflegetonte e o Cócito; e ainda a pedra sita na confluência dos dois cursos de água ${ }^{5}$ e o prado de asfódelo ${ }^{6}$.

${ }^{1}$ Cf. Peter von der Mühll, Kritisches Hypomnema zur Ilias, Schweizerische Beiträge zur Altertumswissenschaft, Basel, 1952, p. 144.

${ }^{2}$ Na sua edição da Ilíada, Paris, Les Belles Lettres, 1956, vol. II, pp. 25-26, n. 1. Para G. S. Kirk e J. E. Raven, The Presocratic Philosophers, Cambridge, 1957, p. 11, Hades «parece ser uma variante ilógica de uma palavra original 'terra', como em Theog. 720».

${ }^{3} \gamma 410=\zeta 11 . \delta 834.1524 . \kappa 175 . \xi 207-208.0$ 350. v 208. $\omega 264$.

4 乡 $156-157$.

${ }^{5}$ К 508-515.

${ }^{6} \lambda$ 539. O mesmo aparece em $\omega 13$, juntamente com outros pormenores que parecem ser da invenção da segunda vékvıа: as Portas do Sol e o País dos Sonhos. A pedra é agora qualificada de branca e a cena decorre nas profundezas da terra

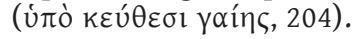


É importante observar que na Odisseia não há referências ao Tártaro. Encontram-se alguns supliciados numa parte do Canto XI, sem dúvida mais recente ${ }^{1}$, mas estão no Hades: Títio, Tântalo ${ }^{2}$ e Sísifo sofrem ali o castigo pela sua hybris para com os deuses.

Omitindo todos os outros aspectos da escatologia homérica, que não interessam ao nosso propósito, vejamos seguidamente quais os dados fornecidos por aqueles dos Hinos Homéricos que podem atribuir-se ao séc. VIII-VII a. C.

No Hino a Deméter, há grande número de referências a Hades, como raptor de Perséfone, portanto, como deus $(2-3,79,336)$. Os qualificativos que então recebe são aproximadamente os mesmos dos Poemas

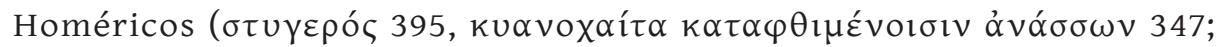

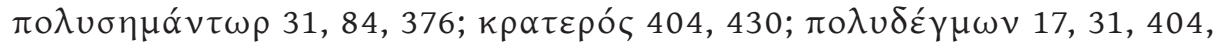

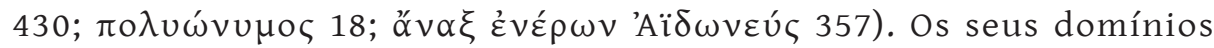

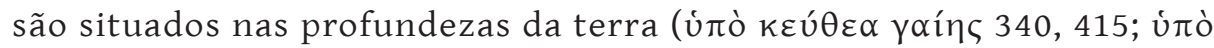

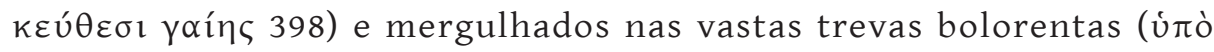

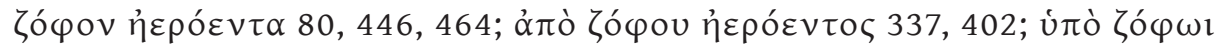

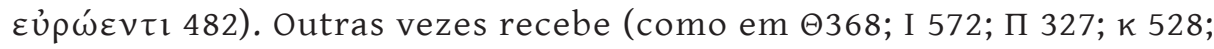

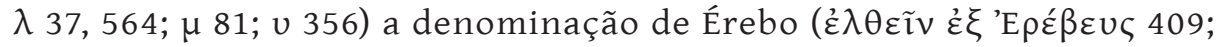

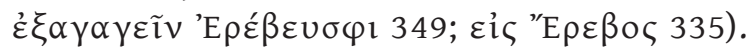

Só em V 154 é que encontramos a fórmula tradicional que equivale a morrer, quando Anquises propõe a Afrodite:

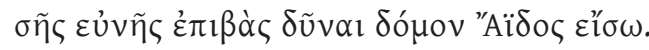

Ao Tártaro encontra-se uma referência, que consta do Hino a Apolo, 335-336, e alude ao castigo dos Titãs, em termos similares aos da Ilíada e da Teogonia ${ }^{3}$ :

${ }^{1}$ Pode ver-se um resumo das teorias propostas sobre a estrutura de $\lambda$ em Van der Valk, Beiträge zur Nekyia, Kampen, 1935, Cap. I, § 2.

${ }^{2}$ Em Álcman, frg. 72 Diehl, o lugar do suplício era o Olimpo (cf. Welcker, «Alcmanis fragmentum de Tantalo» in Rheinisches Museum, 1856, pp. 242-254). Os Nóotol colocavam-no neste mundo. Em Píndaro, Ol. I 55-64 e Isthm. VIII 9-10, não há indicação de lugar. Sobre a repartição das duas versões (castigo pela pedra iminente ou pela sede e fome), veja-se a nota à minha edição de Belchior Beleago, Oração sobre o Estudo de Todas as Disciplinas, Porto, Centro de Estudos Humanísticos, Colecção Amphitheatrum, II, 1959, p. 94.

${ }^{3}$ Vide supra, p. 255 e n. 5.

Sobre a cronologia relativa da Teogonia e desta segunda parte do terceiro dos Hinos Homéricos, veja-se a edição de Allen-Halliday-Sikes, cit., p. 193. 


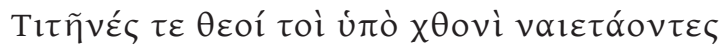

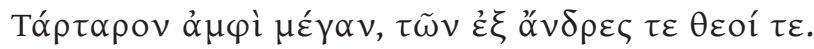

O Tártaro, que, como já vimos, apenas se menciona em cantos tardios da Ilíada e está ausente da Odisseia, é, pelo contrário, diversas vezes referido na Teogonia. Estes factos levam-nos a acatar a hipótese de Thomas $^{1}$, de que esta noção, bem como a das Ilhas dos Bem-aventurados, não estava inicialmente na tradição homérica. O que, a nosso ver, não significa que não fossem ambas antigas, possivelmente até anteriores

Há ainda na colectânea mais duas referências ao Tártaro, mas figuram num poema certamente mais tardio, o Hino a Hermes. Em ambas se menciona a ameaça de Apolo, de castigar o seu jovem irmão de modo idêntico:

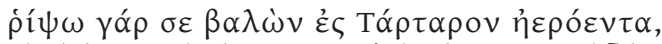

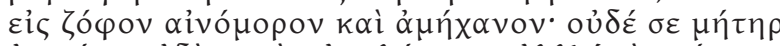

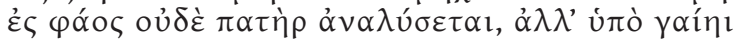

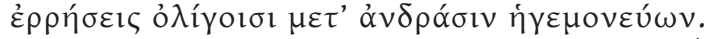

resumido em 374 :

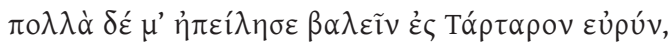

A ameaça de atirar para o Tártaro deuses indisciplinados tem, evidentemente, as suas raízes em $\Theta$ 13-17. Aqui, porém, surge uma novidade inesperada: Hermes vagueará nessa prisão como guia de «homens pequenos». Allen-Halliday-Sikes, no seu comentário ad locum, pp. 318-319, lembram que há crianças no Hades em Virgílio, Aen. VI 427, e Luciano, Catapl. 5, 6, e entendem que Hermes só poderá comandar a quem for pequeno como ele. Humbert, na sua edição, p. 127, n. 1, propõe como alternativa que o deus seja guia das almas, que são representadas como "pequenas figuras humanas». Parece-me mais provável ver aqui simples-

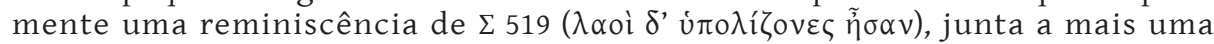
demonstração da atitude jocosa, quase parodística, do autor do hino: Hermes é pequeno, pois nasceu na véspera (v. 376); poderá comandar a quem for pequeno como ele - mas no Tártaro, que é a prisão destinada aos que ofenderam gravemente os deuses. De resto, não deve insistir-se muito, a meu ver, na lógica deste passo, produto de uma época, aliás, mais tardia que a que temos estado a analisar.

As razões apresentadas por Allen-Halliday-Sikes, cit., pp. 275--276, para colocar este poemeto no séc. VII a. C. são pouco convincentes. Humbert, por sua vez, na notícia introdutória da sua edição, pp. 114-115, opta pelo final do séc. VI. A. Lesky, Geschichte der griechischen Literatur, p. 83, propõe a mesma centúria, mas, por outro lado, nota grandes semelhanças com a comédia antiga. Mas à objecção da inobservância do digamma, da lira de sete cordas, da prosperidade de Delfos, junta-se o espírito burlesco da narrativa, que sugere, pelo menos, o séc. V a. C.

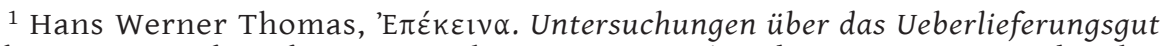
in den Jenseitsmythen Platons, München, 1938, Cap. !. A distinção entre os dois lugares tinha já sido assinalada, entre outros, por M. Th. - H. Martin, «Traditions homériques, et hésiodiques sur le séjour des morts» in Annuaire de l'Association pour l'Encouragement des Études Grecques en France, 1878, pp. 1-21. 
à de Hades e de Planura Elísia. Apenas verificamos que devem ter aparecido pela primeira vez nos poemas de Hesíodo.

Do Hades fala-se nos Trabalhos e Dias 153, usando uma fórmula homérica, mas acrescentando-lhe uma epíteto novo ${ }^{1}$ :

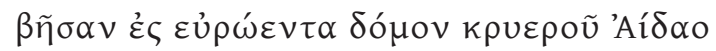

Em 455-456², 821-822 e 850 da Teogonia é apresentado como um deus, e em 309-312 faz-se referência ao seu «cão de voz brônzea, com cinquenta cabeças, insaciável e forte». Nos versos 767-774, trata-se com mais pormenor de Cérbero (agora não nomeado), como guarda do palácio de Hades e Perséfone. $O$ passo interessa-nos, porque faz parte da descrição do lugar do castigo dos Titãs e coloca o Hades em frente ao Tártaro:

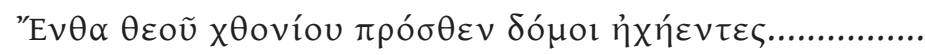

(767)

Em frente a esse mesmo lugar, o texto que chegou até nós coloca ainda a casa da Noite, e o sítio onde esta saúda o Dia, que nunca chega a coabitar com ela ${ }^{3}$ e também a morada dos seus filhos, o Sono e a Morte ${ }^{4}$, o ponto onde Atlas sustenta o céu ${ }^{5}$, a mansão de Estige ${ }^{6}$, e as raízes e extremidades da terra escura, do sombrio Tártaro, do mar estéril e do céu estrelado ${ }^{7}$.

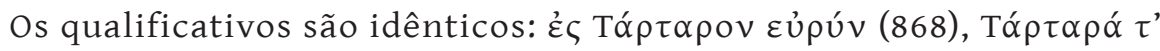

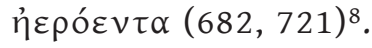

${ }^{1}$ Do seu possível significado tratei já em «Acerca do Hades em Hesíodo», in Humanitas, V-VI, 1954, pp. 65-70. No frg. 96, v. 80, Rzach, ocorre outra fórmula homérica.

2

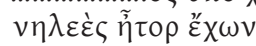

3 746-757.

${ }^{4} 758-766$.

5 746-748.

$6775-806$

7 736-739 $=806-810$.

8 O verso 119 afirma que o Tártaro é um dos quatro primeiros seres existentes, juntamente com Caos, Gaia e Eros. E logo nesse passo o localiza:

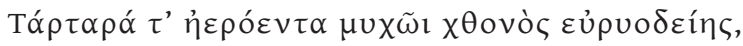

Mas é natural que estejamos em face de uma interpolação tardia, feita para "aperfeiçoar» a descrição dos infernos, e pertencente, portanto, aos fins do séc. VII ou começos do VI, como supõem G. S. Kirk e J. E. Raven, The Presocratic Philosophers, p. 23. Na verdade, são omitidos os versos 118-119 em Platão, Symp. 178b, pseudo-Aristóteles, MXG 1, 957a 11, Sexto Empírico, Adu. Phys. I, 8, e Estobeu I, 
A localização do Tártaro é precisada pelos primeiros versos do passo que de início considerámos, quando se refere que os Titãs foram lança-

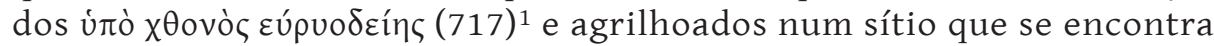

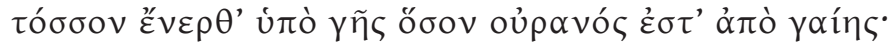

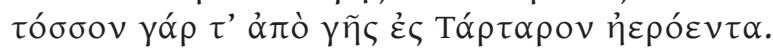

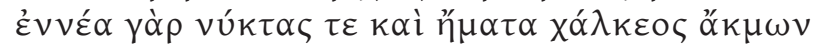

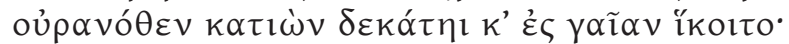

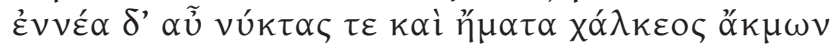

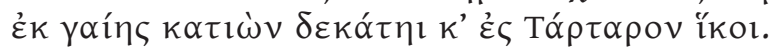

$(720-725)$

O que vimos já sobre um passo muito semelhante do Canto VIII da Ilíada (13-16) leva-nos a seguir a opinião dos que encontram na Teogonia a fonte de tais versos. É de notar, com efeito, que aqui não se alude

9.5, pp. 112-113 Wachsmuth. Sobre o 119, o escoliasta anotou: $\alpha \dot{\alpha} \theta \varepsilon \tau \varepsilon \tilde{\imath} \tau \alpha$ l. Apenas Calcídico o refere in Tim. 122. "The schol.'s doubt, and post-Platonic omissions, may have originated in Plato's omission; or the line may have been felt to be incongruous, having been added at the time when the variant descriptions of Hades accrued»-propõem os mesmos autores ingleses, a p. 25. A p. 23, supõem que tais acrescentos teriam sido feitos no princípio do séc. VI a. C. As relações entre Caos e Tártaro são por eles discutidas a pp. 30-31. Acrescentemos ainda que o verso 693 das Aves de Aristófanes:

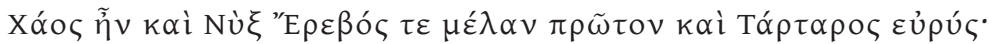

não ajuda a esclarecer o problema, pois a paródia pode referir-se a uma teogonia perdida (a ser a de Hesíodo, datava o acrescento em causa para antes de 414 a. C., ano da estreia da comédia).

Noutro passo interpolado, Th. 822, o Tártaro aparece novamente personificado. Em 841 e 851 é referido como um local profundo, nos recessos da terra.

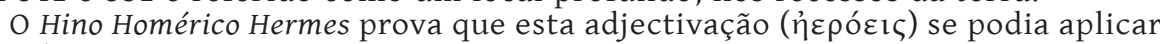
a qualquer gruta:

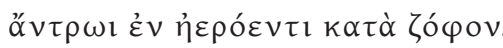

${ }^{1} \mathrm{Em}$ Th. 620 ocorre uma fórmula semelhante para fazer referência à prisão dos Gigantes, e, mais adiante, em 653 e 658, diz-se que eles estavam encarcerados

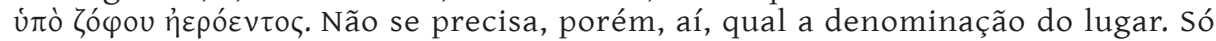
em 669 é que se explica que

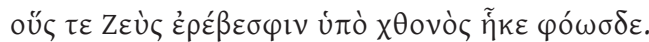

Ora Érebo é filho de Caos (123) e, em 515, um lugar de castigo subterrâneo, para onde Zeus precipita o insolente Menécio, com o seu raio (o caso tem, aliás, um certo paralelismo com o de Tifeu, filho do Tártaro (821-822), que também é arrojado ao vasto Tártaro por Zeus, em 868). Na Odisseia, é sinónimo de Hades ( $\kappa$ 528. $\lambda$ 37, 564. $\mu$ 81. v 356), bem como no Hino Homérico a Deméter $(335,349,409)$.

Ferecides de Siro colocava também o Tártaro nas profundezas, e considerava-o lugar de castigo dos deuses, a avaliar pelo passo de Celso apud Origen. C. Celsum VI, 42 (= Diels-Kranz 7B5). 
sequer ao Hades, que não figurava na tradição que o poeta estava a seguir, embora, sem dúvida alguma, fosse do seu conhecimento. O autor de $\Theta$ é que teve a preocupação de conciliar os dois mitos, supondo o Hades equidistante da Terra e do Tártaro. Idêntica preocupação deve atribuir-se ao aedo dos versos 767 seqq., ao colocar a mansão dos deuses infernais nas cercanias ${ }^{1}$.

O Tártaro é descrito com alguns pormenores: está cercado por uma cinta de bronze e por uma tríplice muralha de sombra, que se difunde em volta da sua abertura ${ }^{2}$, portões de bronze e limiar da mesma sólida

${ }^{1}$ Jacoby, Hesiodi Carmina. Pars 1. Theogonia, Berlin, 1930, considera que todo este longo passo foi composto por oito poetas diferentes, sem contar com as interpolações menores. F. Solmsen, "Chaos and Apeiron», in Studi Italiani di Filologia Clássica, XXIV, fasc. 3-4, Firenze, 1950, não vê contradições, nem a necessidade de supor que um poeta colocou o mundo infernal debaixo da terra e outro nos confins do Ocidente, à maneira homérica. No artigo citado na nota 1 da p. 125, pareceu-me preferível esta interpretação (p. 66). Hoje, porém, entendo que, embora Hesíodo não seja nada dogmático, como acentua Solmsen, passos como 767-774 não devem ser do mesmo autor dos restantes versos.

Mais recentemente, B. A. van Groningen, La Composition Littéraire Archä̈que Grecque $^{2}$, Amsterdam, 1960, pp. 275-281, estudou este passo, aplicando-lhe as teorias acerca da composição literária arcaica desenvolvidas na primeira parte do livro. Em sua opinião, o verso 720 , e talvez o seguinte, foram "comme un rhizome vigoureux qui a fait pousser un rejeton après un autre» (p. 279). Considera cinco ramificações partidas desse verso (p. 281):
a. $732-735$ (a mais directa e a mais antiga, que se liga imediatamente a 881 seq.)
b. $721-725,726-730$
c. 807-810, 811-819, variante imediata de $a$.
d. $736-739,740-745,746-757,758-766$
e. 767-773 e talvez $775-806$.

A propósito desta última, acrescenta: «On y trouve la conception «normale» du royaume d' Hadès et de Perséphone, qui n'intéresse pas Hésiode.»

Nestes grupos, parece-me mais difícil de aceitar a cronologia relativa de a e b. Para apoiar esta última, o autor observa que o passo não afirma expressamente que os Gigantes de Cem Braços guardavam os Titãs, mas que a ideia estava implícita no verso 718. Tal implicação não se me afigura necessária, nem sequer latente. O que poderemos dizer é que a finalidade de 726-727 é reforçar e explicar 718. Kirk e Raven, The Presocratic Philosophers, p. 31, contrastam 736-745 e 811-815, para concluir:

«Both passages contain inconsistencies and impossibilities which indicate that they are somewhat superficial expansions who were either careless or stupid.»

Como observam a seguir os mesmos autores, não é possível aceitar que as raízes da Terra, Mar, Céu e Tártaro estejam neste último.

2 726-727, 732-733. 
liga ${ }^{1}$. Independentemente das diversas autorias que aqui se possam reconhecer, interessa-nos verificar que todo o conjunto revela uma concepção idêntica, nas suas linhas gerais: é um lugar de castigo para as divindades ${ }^{2}$, subterrâneo, medonho e inacessível.

É possível que, ao tratar da descrição de Hesíodo, tenha incluído nela mais do que um dos rapsodos, seus imitadores. De qualquer modo, o poema que vamos ver em seguida é, sem dúvida, obra de um bom conhecedor daquele poeta.

O Escudo de Hércules refere-se ao Hades, como destino das almas, em 151, num passo considerado como uma interpolação por Schwarz, Lehrs, Rzach, Studniczka. Os versos 226-227 mostram conhecer o gorro do deus, que torna invisíveis os seus portadores.

Além destes dois passos pouco significativos, existe ainda um terceiro ${ }^{3}$, a versos 254-255, cujo texto tem sido muito discutido:

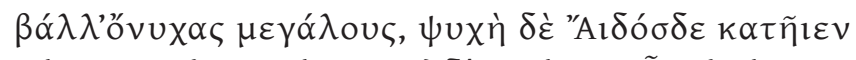

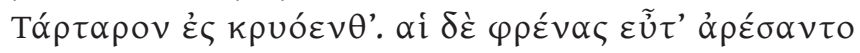

A referência é às Keres, que se apoderam de qualquer dos homens em combate, que tenha sido derrubado ou ferido, para o matarem imediatamente. O texto, como está, postula a identificação entre o Hades e o Tártaro, e, sendo assim, teríamos aqui o exemplo mais antigo dessa confusão ${ }^{4}$, pois, como já vimos, as interpolações à Ilíada ou à Teogonia não a fazem em parte alguma. Por sua vez, os Hinos Homéricos datáveis do séc. VII a. C. apenas falam do Tártaro como lugar subterrâneo, onde os Titãs estão encerrados ${ }^{5}$; do Hades fazem menção algumas vezes, nos termos tradicionais ${ }^{6}$.

1 811-812. É provável que tenhamos aqui unicamente o eco de uma fórmula

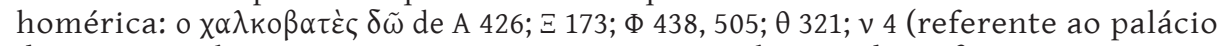
de Zeus no Olimpo, nos quatro primeiros exemplos; ao de Hefestos, no quinto; e ao de Alcínoo, no sexto). Talvez deva ligar-se a este caso a Mansão de Bronze mencionada nos vv. 227-228 da Helena de Eurípides e paralelos citados por H. Grégoire na nota da p. 59 da sua edição, Les Belles Lettres, Paris, 1950.

Para Kirk e Raven, The Presoctatic Philosophers, pp. 10-11, significa que é firme e inamovível como o céu (cf. P 425).

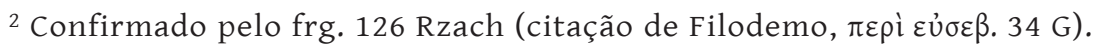

${ }^{3}$ Inspirado certamente em $\Sigma$ 535-540.

${ }^{4}$ O Scutum tem sido datado dos começos do séc. VI a. C., por exemplo, por R. M. Cook in The Classical Quarterly, XXXI, 1937, pp. 204-213, e J. L. Myres in The Journal of Hellenic Studies, LXI, 1941, pp. 17-38 (apud C. M. Bowra, Greek Lyric Poetry, p. 80 e n. 1).

${ }^{5}$ Vide supra, p. 257.

${ }^{6}$ Hino a Afrodite, 153-154. 
Sucede, porém, que o texto não é seguro neste passo. Assim, భuxń é a

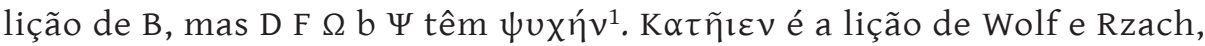

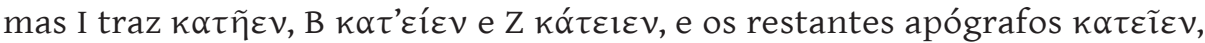
que o mesmo Rzach supõe derivar de uma grafia mais antiga, KATEIEN. Deiters considera todo o passo, de 252 a 255, posterior.

Dodds $^{2}$ sugere a possibilidade de uma interpolação desde $\psi u x \eta ́$ até

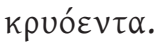

Para além das variantes dos códices, acumulam-se, na verdade, as dificuldades de interpretação. Carlo Russo sumaria-as na sua edição, em nota à p. 141, com a respectiva bibliografia, e no aparato crítico ad

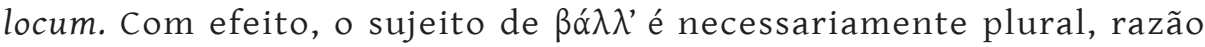

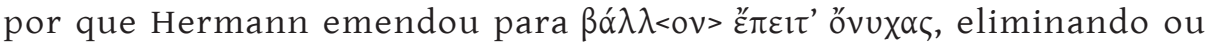

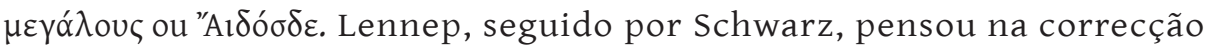

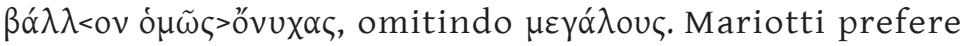

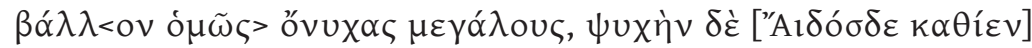

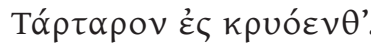

texto que Carlo Russo adopta, embora hesite em apresentar outra emenda, baseada no verso 263:

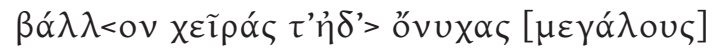

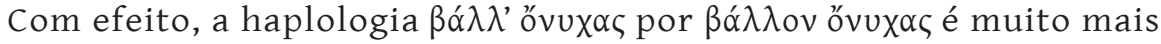

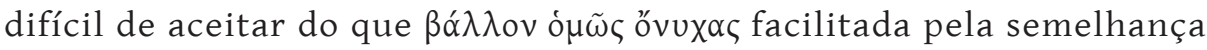
entre $\mu$ e $v$ nos manuscritos medievais.

Qualquer destas correcções acabadas de mencionar elimina do texto a referência ao Hades, com a vantagem, que o mesmo editor aponta, de evitar assim uma identificação que é mais tardia (para ele, o primeiro exemplo é Anacr. 44, 8 seqq.), pois não estava feita em Homero, nem em Hesíodo, nem nos Hinos Homéricos.

A aceitação do acusativo $\psi$ uńv por outro lado, postula a correcção

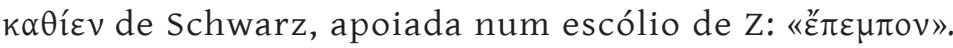

Sendo assim, parece lícito concluir que o autor do Scutum apenas incluíra neste ponto do seu poema o nome do Tártaro, possivelmente porque ao seu espírito era mais impressionante este lugar de castigo,

${ }^{1}$ Aliás, como nota Carlo F. Russo, na sua edição do Scutum (Biblioteca di Studi Superiori, La Nuova Italia Editrice, Firenze, 1950, p. 39), o Ms. B omite muitas vezes o $v$ final.

2 Por carta. 
descrito com tanto pormenor na Teogonia, como prisão de divindades ${ }^{1}$, ou porque entendesse que as Keres levavam os mortos para o sítio que elas mesmas habitavam ${ }^{2}$. Talvez nesta altura já existisse o passo de $\Theta$

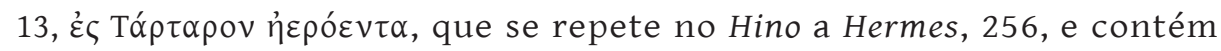
uma fórmula de que esta parece um decalque ${ }^{3}$.

Para uma época posterior, já não havia obstáculos: o Tártaro acabara por se transformar numa parte do Hades, onde se puniam graves criminosos. Por sua vez, todos tinham presentes fórmulas do tipo de

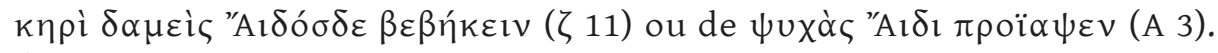
É natural que "Aı $\delta o ́ \sigma \delta \varepsilon$ tenha vindo inserir-se no texto, quando, pela primeira vez, faltaram algumas sílabas no verso, perdidas pela haplologia. A falta de unidade e de estabilidade das crenças escatológicas dos Gregos tudo possibilitava.

Os iambógrafos referem-se ao Hades como destino final de um ho$m^{4} m^{4}$, e outro tanto acontece com os elegíacos ${ }^{5}$. Todos são concordes quanto à sua localização subterrânea, exprimindo-a até, por vezes, em termos homéricos, como sucede no primeiro verso do seguinte dístico de Teógnis de Mégara:

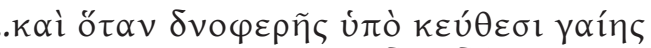

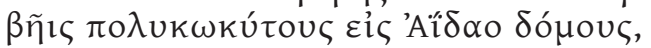

e ainda no verso 427:

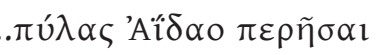

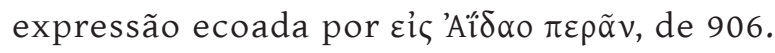

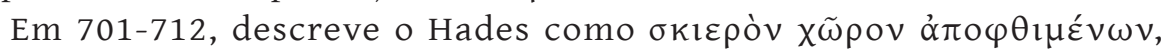

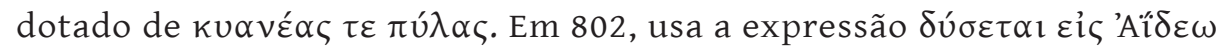

${ }^{1}$ Carlo Russo, op. cit., pp. 18-19, conta esta entre as imagens de gosto hiperbólico do autor do Scutum.

${ }^{2}$ Eurípides, Her. 870, atribui-lhes essa proveniência (embora anteriormente, nos versos 480-484, fizesse delas filhas de Hades). Na Odisseia ainda levavam os mortais para o Hades $(\gamma 410=\zeta 11)$; em $\xi 207-208$, é-se mais claro ainda:

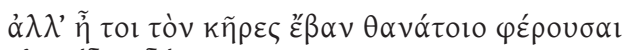

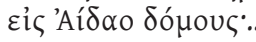

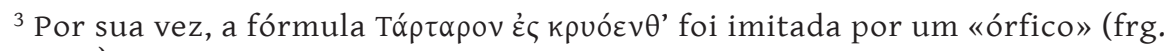
222 Kern).

${ }^{4}$ E.g.: Arquíloco, Pap. Oxy. 2310, frg. 1, col. I, 38 = Lasserre, frg. 35, v. 34. Semónides de Amorgo, frgs. 1, v. 14, e 7, v. 117 Diehl.

${ }^{5}$ E.g.: Tirteu, frg. 9, v. 38 Diehl; Mimnermo, frg. 2, v. 14 Diehl; Teógnis, vv. 725-728. 


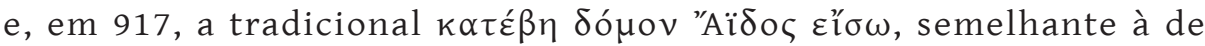

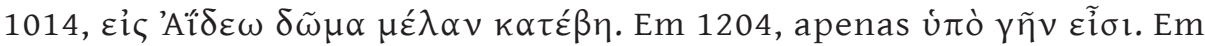
973-978, dá-se-lhe a designação de Érebo e palácio de Perséfone, e, em

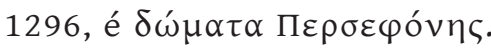

O mesmo Corpus Theognideum refere-se ao Tártaro nos versos 1029-1036:

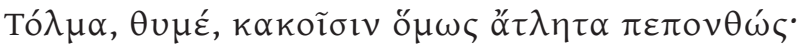

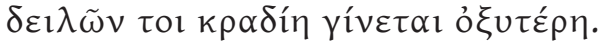

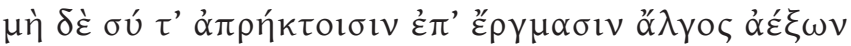

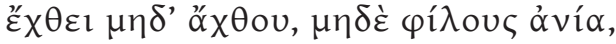

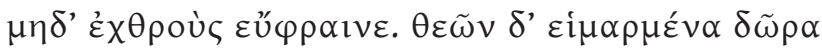

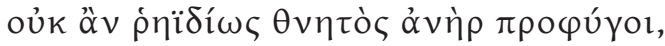

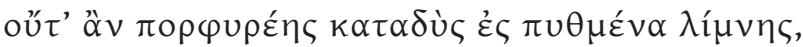

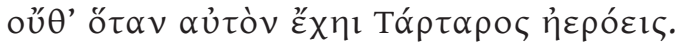

O homem mortal não poderá escapar ao destino que os deuses lhe talharam, quer mergulhe nos recessos do mar, quer o detenha o Tártaro. A adjectivação deste último pertence a uma fórmula que ascende a $\Theta$ 13. Pode supor-se, portanto, que o poeta se refere ao Tártaro com o mesmo sentido do passo da Ilíada; mas a reminiscência literária evidente inclina-nos a admitir que a escolha recaiu sobre esse lugar, por ser

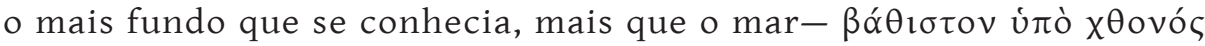
$\dot{\varepsilon} \sigma \tau \imath \beta \varepsilon ́ \rho \varepsilon \theta \rho o v$, como se lia em $\Theta 14$.

Os líricos apresentam, no seu mutilado texto, referências frequentes ao Hades, como termo último da existência dos mortais ${ }^{1}$.

Safo, por exemplo, fala de 'Aí $\delta \alpha \delta$ ó $\mu \omega \imath$ (frg. 55,3 Lobel-Page) e Alceu de 'Aí $\delta \alpha o \delta \tilde{\omega} \mu \alpha$ (frg. 48, 15 Lobel-Page). Qualquer deles alude por vezes ao mesmo lugar, nomeando apenas o rio Aqueronte, como neste passo da poetisa ${ }^{2}$ :

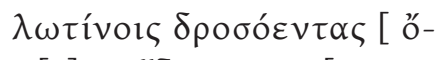

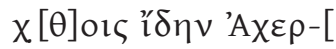

${ }^{1}$ E.g.: Álcman, Parthen. 32; Alceu, frg. 60a, v. 5, talvez 186, v. 4, e 296a, v. 5, e talvez 117b, v. 38 (números de Lobel-Page).

${ }^{2}$ Frg. 95 Lobel-Page, vv. 12-13. Outros exemplos: Safo, frg. 65, 10 Lobel-Page; Alceu, frg. 38a, 2 e 8 Lobel-Page; Melanípides, frg. 3,2 Diehl; Simónides, frg. 13a, 18 Diehl. Cf. Ésquilo, Septem 854-860 e Ag. 1160-1161, que cita o Cócito e o Aqueronte. Quanto ao lótus do frg. 95 de Safo, lembrem-se os campos dessa flor, junto de Tebas, em Eurípides, Phoiniss., 1571, que sugerem uma fórmula literária comparável aos «campos de asfódelo» homéricos. 
O mesmo faz Baquílides ${ }^{1}$ com o Cócito, na sua formosa descrição da Ode V, 56-175, onde imagina as almas aglomeradas ao longo da sua torrente, como as folhas impelidas pelo vento no Monte Ida (63-67).

Do Tártaro fala Alceu, no frg. 77a Lobel-Page, em contexto tão mu-

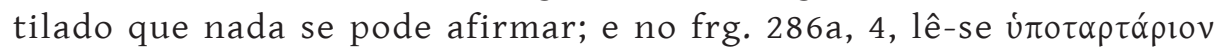
palavra que sugere uma possível referência ao mito dos Titãs.

Sabemos pelo Etymologicon Magnum 427, 48, e por Hesíquio e ainda

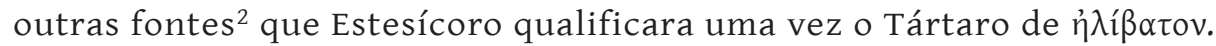
É provável que o autor do poema sobre Cérbero ${ }^{3}$ se expandisse largamente sobre a sua concepção dos lugares infernais. Porém, o que chegou até nós sobre tal assunto limita-se a um curto fragmento que opõe Hades a Apolo:

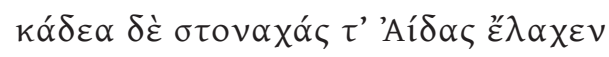

(22, 3 Diehl)

Quanto a Píndaro, ao lado das inúmeras referências, com o sentido habitual, ao Hades ${ }^{4}$ ou apenas a um dos seus rios ${ }^{5}$, encontramos três menções do Tártaro.

Destas, uma dá-o como lugar de prisão de Tifeu, nos moldes delineados por Hesíodo, Theog. 820-828:

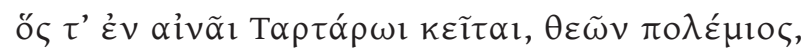

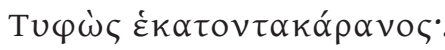

(Py. I, 15-16)

Outra é a que consta do frg. 207 Snell, demasiado curto para se poder reconstituir o seu contexto, embora seja lícito supor que respeitava ao mesmo mito:

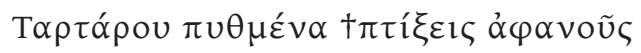

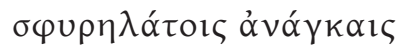

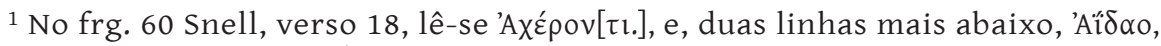
mas o contexto é pouco claro.

${ }^{2}$ Cf. frg. 83 Bergk.

${ }^{3}$ Pollux 10.152.

${ }^{4}$ Ol. VIII 72-73. Ol. X 92-93. Py. III 11. Py. V 96. Ne. VII 30-31. Isthm. I 68. Isthm. VI 15.

${ }^{5}$ Py. XI 21. Ne. IV 85. Frg. 143 Snell.
} 
Diferente é o caso da terceira, que pertence à fala de Exanthios, herói de Ceos, que sobreviveu a um tremor de terra, com que os deuses castigaram aquela ilha:

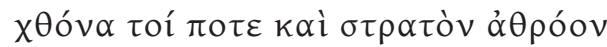

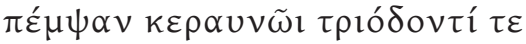

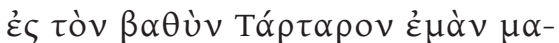

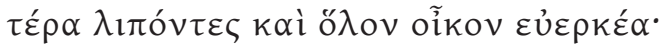

(Paeanes IV, 42-45)

A data provável, atribuída por Snell a este péan, é posterior a 458 . Nesta altura, portanto, era possível afirmar que os deuses castigavam uma população submergindo-a nas profundezas do Tártaro, como primitivamente Zeus fizera aos Titãs vencidos.

São aproximadamente da mesma década ${ }^{1}$ as duas tragédias de Ésquilo que mais interesse oferecem sob este ponto de vista: o Prometeu Agrilhoado e as Euménides.

Na primeira, o verso 236 refere-se ao Hades nos termos tradicionais ${ }^{2}$. Pouco antes, em 219-221, aludira-se ao mito da prisão de Cronos e dos Titãs no Tártaro, acto esse em que Prometeu fora o auxiliar de Zeus:

${ }^{1}$ Quanto ao Prometeu, as opiniões variam. Dada a existência de um terminus a quo em 479/8, fornecido pela referência à erupção do Etna no drama, e o conhecimento de que Ésquilo esteve em Siracusa em 470, quando se cantou a Ia Pítica, o Prof. Dodds (em aulas, na Universidade de Oxford) inclina-se para uma data não muito posterior a esta última. Pode ver-se uma discussão do assunto em A. Lesky, Die tragische Dichtung der Hellenen, Göttingen, Vandenhoeck und Ruprecht, 1956, p. 80 e n. 1, e em M. Pohlenz, Die griechische Tragödie Göttingen, 1954, vol. II, p. 35. Quanto à Oresteia, é sabido que ganhou o primeiro prémio em 458 a. C.

2 Outro tanto sucede em Ag. 1291. O Hades é também a mansão dos mortos em Sept. 321-322, Ag. 1527-1529, Choe. 355-359 (não nomeado), Eum. 95-97 (não nomeado). Da morada subterrânea e tenebrosa dos que partiram se fala ainda em Pers. 222-223, 839, 922-924. Em Pers. 637 apenas se situa Dario vé $\rho \theta \varepsilon v$ e, em

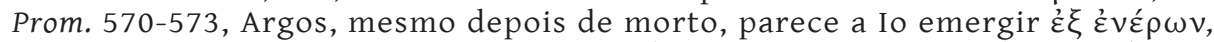

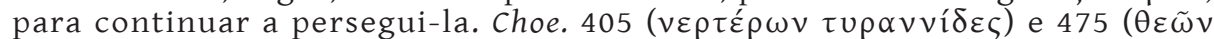
$<\tau \tilde{\omega} v>\kappa \alpha \tau \grave{\alpha} \gamma \tilde{\alpha} \varsigma)$, Choe. 147 e Ag. 1023 e ainda Pers. 222-223 e 624 sugerem ou

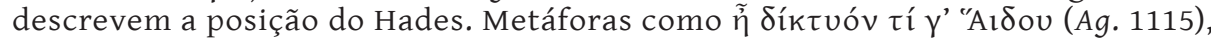

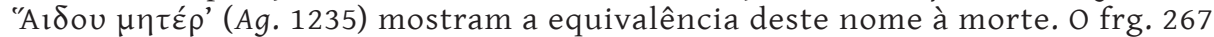
Nauck $^{2}$, citado por Platão, Phaed. 107e-108a, refere-se ao caminho único que conduz até esse lugar.

Em Sept. 856 prefere-se nomear o Aqueronte; em Sept. 690, o Cócito, e em Ag. 1160-1161, os dois rios. Hades é denominado rei dos mortos em Pers. 629, e, em

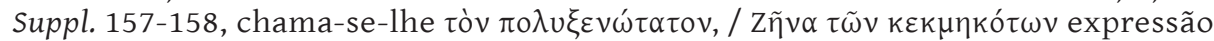

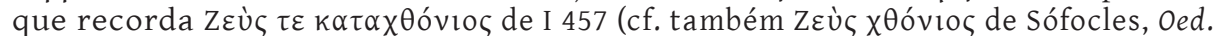
Col. 1606). No verso 231 da mesma tragédia, Ésquilo refere-se ao deus de modo

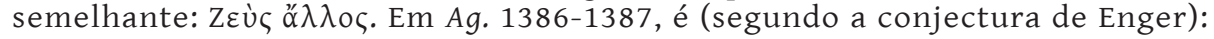




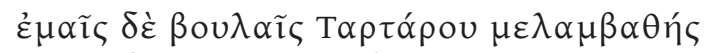

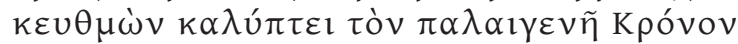

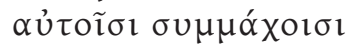

É natural que o mesmo Prometeu imaginasse para si, como alternativa preferível à sua presente situação, um castigo idêntico:

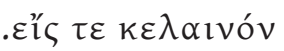

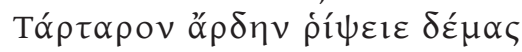

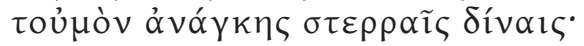

(1050-1052)

Noutro passo, igualmente se propõe uma solução que Prometeu considera menos dolorosa: transferir o seu castigo para debaixo da terra, a fim de que nem homens nem deuses pudessem rejubilar com a sua desgraça:

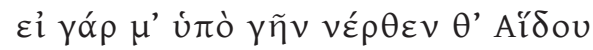

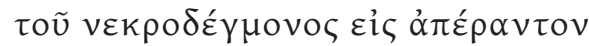

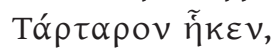

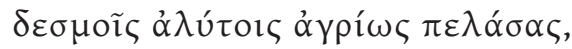

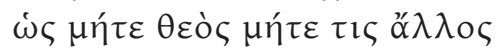

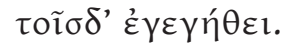

$(152-157)$

Aqui temos o Tártaro colocado a uma profundidade maior do que o Hades, tal como postulava $\Theta$ 13-16. Este facto autoriza-nos a supor que, nos versos 1026-1029, se devam continuar a considerar distintos os dois lugares:

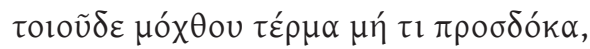

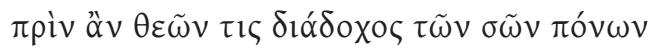

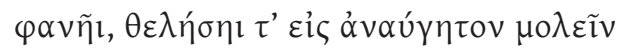

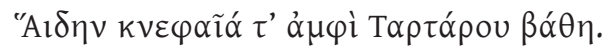

No Prom. 433, uma curta descrição, em termos tradicionais:

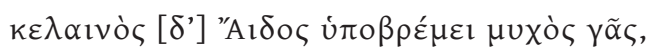

coloca o Hades entre as forças da natureza. 
Com efeito, em 235-236 da mesma tragédia, afirmara-se que os homens iam para o Hades. Só a Cronos e aos Titãs cabia o castigo do Tártaro (219-221). Assim é que em Suppl. 415-416 e em Eum. 267-275, onde se alude às punições aos criminosos, a referência é só e sempre ao Hades.

Nas Euménides, mais de uma vez se afirma que as Erínias habitam no Tártaro, Assim, por exemplo, Apolo declara, referindo-se a elas:

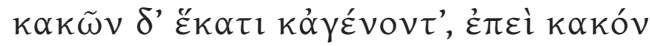

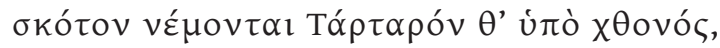

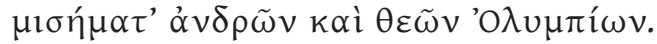

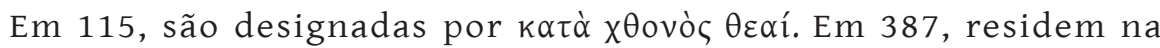

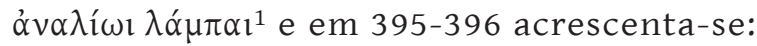

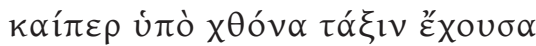

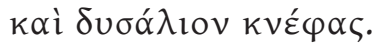

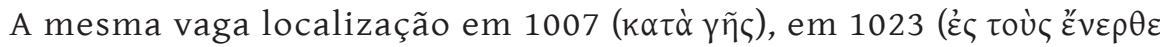

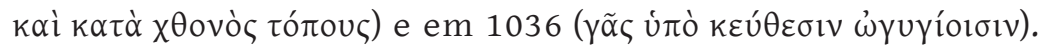

No verso 417, elas mesmas declaram:

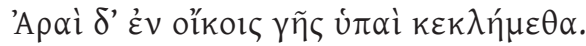

Em 950-952, Atena afirma que $\mu \varepsilon_{\gamma \alpha} \gamma \alpha \grave{\rho} \delta \dot{v} v \alpha \tau \alpha$

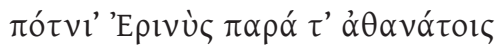

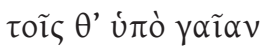

e este valimento das Erínias junto dos deuses ctónios torna compreensível que elas pudessem perseguir os criminosos, não só em terra e no mar (249-251), como até no Hades (334-340; 422-423). Nem depois de mortos lhes escaparão:

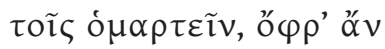

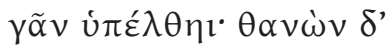

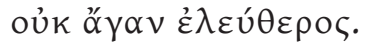

\footnotetext{
${ }^{1}$ Sobre as interpretações possíveis deste passo, vide Concepções Helénicas de Felicidade no Além, de Homero a Platão, p. 43.
} 
Uma afirmação destas liga facilmente duas noções primitivamente distintas, como eram as de Hades e Tártaro. De resto, a transferência das Erínias para este último lugar parece ter sido feita por Ésquilo embora estivesse definida desde Homero a sua localização subterrânea ${ }^{2}$. Uma longa tradição associava o Tártaro à ideia de prisão e castigo, embora só para divindades. Era natural que estas entidades vingadoras viessem a ser lá situadas. Mais ainda: uma vez que os dois lugares subterrâneos tendiam a confundir-se, e introduzida a noção de juízo e castigos no além, compreende-se que se viesse a supor que o Tártaro era uma parte do Hades, onde eram supliciados os grandes culpados. É essa, aproximadamente, a noção que encontraremos depois nos mitos platónicos ${ }^{3}$.

No entanto, a confusão acima aludida não se opera ainda entre os grandes trágicos, como poderemos verificar num rápido exame aos dramas de Sófocles e de Eurípides.

No Édipo em Colono mantém-se ainda a noção de que o Tártaro é destinado aos grandes criminosos, e o Hades à generalidade dos homens ${ }^{4}$. Efectivamente, Édipo, ao lançar as suas maldições sobre Polinices, exclama:

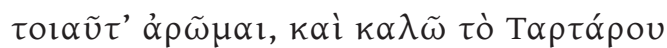

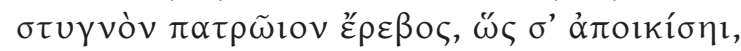

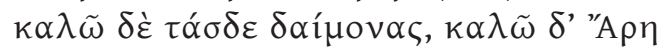

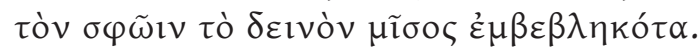

$(1389-1392)$

${ }^{1}$ Sobre a evolução das Erínias, veja-se a introdução de Sidgwick à sua edição comentada das Euménides, Oxford, at the Clarendon Press, 1895, pp. 18-21.

2 I 571-572. T 259-260.

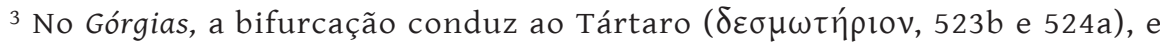
às Ilhas dos Bem-aventurados, sem que se indique a respectiva localização nem se distinga entre o primeiro e o Hades (cf. 525b, 525c, 525e, 526b). No Fédon, as almas caminham para o Hades (107d, 108a), e o Tártaro, com os seus rios, fica nos mais íntimos recessos da terra (112a-113c); as que tiveram uma existência média permanecem nas margens do Aqueronte (113d) e as incuráveis no Tártaro (113e); as culpadas de graves delitos, mas susceptíveis de expiação, são trazidas do segundo destes lugares para as margens dos rios, até obterem o perdão das suas vítimas (113e-114b). O mito de Er e o do Fedro transcendem a topografia habitual, para se colocarem num plano cosmológico. No entanto, no primeiro ainda se alude a uma viagem subterrânea das almas que sofreram castigo (615a) e aos criminosos precipitados no Tártaro (616a), e em 619a fala-se do Hades nos

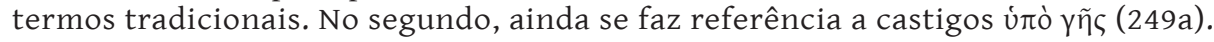

${ }^{4}$ Para uma interpretação diferente, vide G. Iwanowitsch, Opiniones Homeri et tragicorum Graecorum de inferis per comparationem excussae, Diss. Erlangen, Berolini,

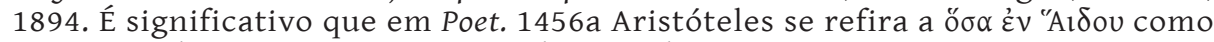
constituindo um grupo numeroso de tragédias. 
Uns versos mais adiante, em 1440, Antígona antevê, para o mesmo Polinices, a ida para o Hades, e, em 1461 e 1547-1548, e 1551-1552, Édipo fala do mesmo lugar como o seu próximo destino. É essa divindade que invoca o Coro, bem como a Cérbero, «guarda indomável» do Hades, filho da Terra e do Tártaro (1556-1578). Hades é sinónimo de morte em 1220-1223, 1689-1692.

Nas restantes tragédias conservadas de Sófocles, são frequentes as alusões ao Hades como destino dos mortais ou sinónimo de trespasse (e.g.: Ájax, 517, 606-608, 635, 660, 865, 1035, 1192-1194; Ant. 361-362, 580-581, 653-654, 804-805, 810-822, 911-912, 1205, 1241, 1284-1285; Electra, 137-139, 463, 542, 832-836, 948-950, 1342; Oedip. Rex, 29-30, 971-972, 1372; Phil. 624, 861, 1211-1212, 1349; Trach., 4, 119-121, 281-283, 1040-1043, 1085, 1161; frg. 478, 615 e 781 Nauck $^{2}$ ) ou como deus (Ant. 519-521, 542, 777-780, 1074-1076; Electra 110, 184; Trach. 497-502, 1097-1098).

Outro tanto se pode afirmar acerca de Eurípides, que se refere inúmeras vezes ao Hades ou figuras a ele associadas, ou simplesmente à sua localização subterrânea, em contextos semelhantes (e.g.: Alc. 24-26, 73, 124-126, 252-263, 357-362, 436-444, 455-463, 743-746, 870-871, 900-902; Andr. 414, 503-505, 543-544, 850, 1078, 1217; Bacch. 857-859, 1156-1158, 1361-1362; El 662; Hec. 1-2, 49, 136-137, 208-210, 367-368,418,483,1032-1033,1105-1106; Hel. 61-62, 175-178, 969-971, 1122-1123, 1161; Heracl. 218-219, 513-514, 911-914, 949-951; Her. 22-25, 45-46, 116-117, 145-146, 296-297, 352-353, 426-435, 562-564, 607-619, 621, 736, 770, 807-808, $1101-1105,1170,1276-1278,1415$ - grupo referente às aventuras de Hércules -, 453, 483-484, 491, 838-839, 1025-1027, 1119, 1247, 1331; Hipp. 56-57, 829, 836-838, 895-896, 1366-1367, 1387-1388, 1416-1419, 1447; Ion 953, 1235, 1273-1274, 1439-1442, 1494-1496; Iph. Aul. 461, 539-540; Iph. Taur. 157-158, 168-169, 184-185, 285-286, 369-370; Med. 1059, 1109-1111, 1233-1235; Or. 1109, 1522, 1584; Phoen. 810-811, 1311-1312, 1575-1576; Suppl. 75, 271-274, 543-546, 773, 796-797, 920-922, 925-927, 1004-1005, 1021-1022; Troad. 445, 597; frg. 860 Nauck $^{2}$. Em Andr. 1192, Hec. 1077, Her. 1119, é usado como termo de comparação.

Todos estes passos provam a existência de uma bem estabelecida tradição acerca do Hades. Quanto ao Tártaro, surge também, no Hércules, Hipólito, Orestes e Fenícias.

O primeiro destes passos, o verso $870^{1}$ de Her., refere-se às Keres como habitantes dessa região, invocadas pelo herói na sua loucura:

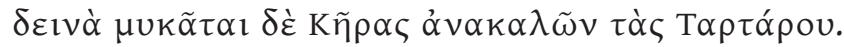

${ }^{1}$ Seguimos a correcção de Canter. O verso é de autenticidade duvidosa para Murray. 
Igual residência parece atribuir-se às Erínias, que são chamadas

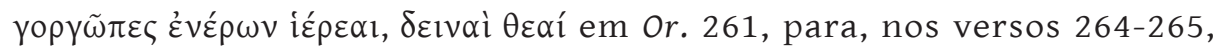
Orestes, no seu delírio, exclamar:

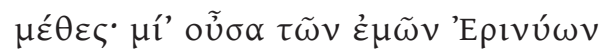

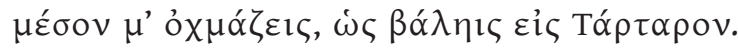

O doente julga que a irmã é uma dessas terríveis divindades, que intenta arrebatá-lo para os lugares temerosos em que habita. Este passo faz entrever a possibilidade de o Tártaro estar já aberto aos simples mortais pecadores, nota E. R. Dodds ${ }^{1}$. Mas o facto é igualmente evidente no Hipólito, quando Ártemis diz a Teseu que a sua vergonha devia ocultar-se nesse lugar:

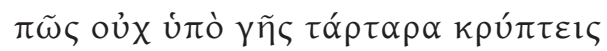

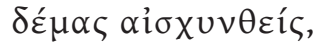

Nas Fenícias, 1604-1605, Édipo desejaria que o Citéron se tivesse precipitado no abismo sem fim do Tártaro, em vez de o criar para tantas desgraças:

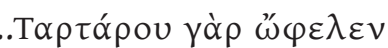

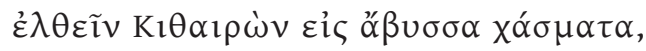

É ainda como abismo que lhe faz referência o coro do Hércules, 906-909, em ligação com um exemplo mitológico:

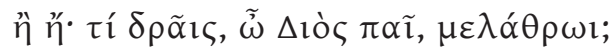

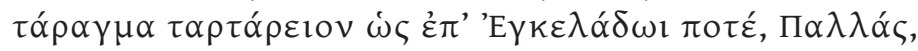

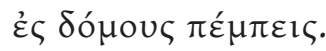

Destes cinco exemplos², pode concluir-se que o Tártaro é apresentado como um lugar subterrâneo onde moram divindades temíveis, invocado pelos loucos nas suas crises, ou por Édipo, na sua situação desesperada, e destinado a crimes extraordinários.

${ }^{1}$ Plato, Gorgias, a revised text with introduction and commentary, Oxford, at the Clarendon Press, 1959, p. 377. O passo do Oed. Col. que citei na p. 270 supõe as mesmas doutrinas.

${ }^{2}$ Segundo Steph. Byz., s. v. Tá $\tau \alpha \propto \rho \varsigma$, p. 696, Eurípides teria empregado a

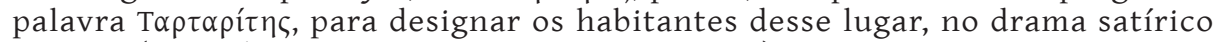
Euristeu (Meineke, Poet. Com. Gr. Frg., p. 756, nº 342). 
Em Aristófanes quase não se menciona, a despeito de se cruzarem nos versos das suas comédias desvairadas tradições escatológicas ${ }^{1}$. Especialmente significativo a este propósito é que as Rãs se situam exclusivamente no $\mathrm{Hades}^{2}$, mesmo quando se referem a expiação de crimes (145-150, 274-275).

Do Tártaro fala-se na parábase das Aves, ao parodiar uma teogonia, e, possivelmente, este nome estará na base de um jogo de palavras do verso 475 das Rãs, sobre a moreia tartéssica ${ }^{3}$. No verso 192 das Nuvens, é colocado muito fundo ${ }^{4}$.

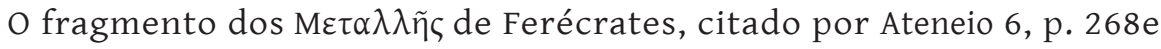
(=108 Kock), contém um diálogo em que uma das interlocutoras, depois de ouvir exaltar os excepcionais requisitos alimentares das regiões inferiores, exclama:

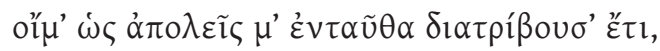

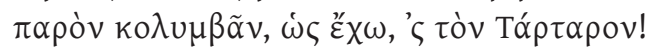

É provável que aqui tenha sido escolhido este lugar terrível, e não o Hades $^{5}$, para acentuar mais a inverosimilhança das afirmações. Seria, pois, uma atitude de espírito comparável à que informa os versos 2-3 do frg. 488 Kock dos Tagenistai de Aristófanes:

${ }^{1}$ Vide Concepções Helénicas de Felicidade no Além, de Homero a Platão, pp. 57 e 121-126.

${ }^{2}$ Embora a mitologia relativa a esses lugares seja jocosamente aproveitada em Ach. 391, Eq. 1030-1032, Lys. 605-607, Pax 313-315, Plut. 278, Thesm. 1040, Vesp. 762-763 (paródia de um verso de Eurípides), frg. 149-150 Kock (e certamente em todo o Gerytades) e na primeira parte das Rãs. É digno de nota o facto de, em Ranae 69-70, se pôr em dúvida que haja lugar mais profundo do que o Hades:

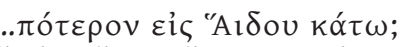

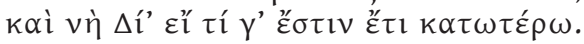

Será interessante lembrar, a este propósito, o frg. 28 Diels de Xenófanes, em que se afirma que "para baixo, a terra continua indefinidamente», usando uma formulação «mais popular do que intelectual», como observam Kirk e Raven, The Presocratic Philosophers, p. 11.

${ }^{3}$ É a interpretação adoptada, por exemplo, por V. Coulon, na sua edição de Aristófanes (Paris, Les Belles Lettres, tome IV, 1954, p. 108 e n. 2), W . W . Merry (Oxford, at the Clarendon Press, repr. 1947, p. 26) e W. B. Stanford (London, MacMillan, 1958, p. 115). Radermacher (Zweite Auflage, Wien, 1954, p. 215) e Süss (Berlin, 1935, p. 35) preferem outras explicações.

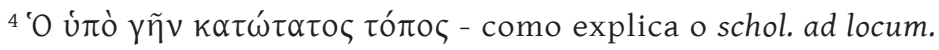

${ }^{5}$ No frg. 81 Kock dos Krapataloi, citado por Ateneio 14,646c, é só do Hades que o poeta fala. Muitas outras comédias perdidas parecem também ter tido como cenário esse lugar. 


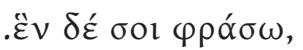

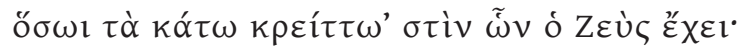

Verifica-se, portanto, que são estas as ideias prevalecentes durante todo o séc. V a. C.: o Tártaro é lugar de castigo, para certos casos; o Hades, a mansão dos que pereceram, de um modo geral.

Talvez estes factos concorram para fornecer a explicação mais plausível para a confusão que parece verificar-se neste skolion de um contemporâneo de Simónides, Timocreonte de Rodes ${ }^{1}$ :

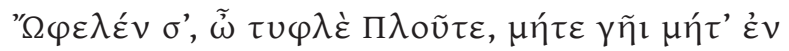

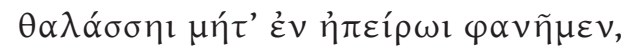

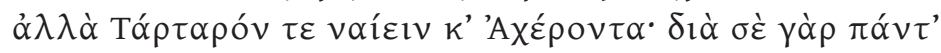

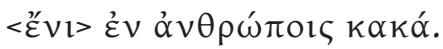

Um dos rios do Hades, aquele que desde os líricos arcaicos se usava mais frequentemente para designar essas paragens, é colocado junto do Tártaro.

Este último lugar é, portanto, invocado como sítio destinado aos grandes castigos, àqueles que se atribuíam às divindades.

A noção de que também os seres humanos poderão ser punidos no além está implícita em $\Gamma$ 276-280 e T 258-260, com relação aos perjuros. Mas a primeira menção conhecida de julgamento no Hades consta de textos de Ésquilo (Suppl. 228-231 e 414-416; Eum. 273-275 e 339-340; Pap. Oxy. 2256.9 (a) ) e de Píndaro (Ol. II 56-60) ${ }^{2}$.

Como observa E. R. Dodds na sua edição do Górgias de Platão ${ }^{3}$, estando a doutrina de Píndaro, neste último passo, associada à metempsicose, poderemos aceitar a informação de Jâmblico (Vita Pythagorea 155, 179; cf. Diog. Laert. VIII.35), de que a doutrina do julgamento foi ensinada por Pitágoras.

Por outro lado, um passo de Aristóteles (Anal. Post. B. 11.94b 33) refere uma doutrina pitagórica, segundo a qual o trovão servia para assustar os que estavam no Tártaro. Aliás, os biógrafos de Pitágoras atribuíam-lhe uma descida às regiões infernais, onde teria presenciado os castigos e

${ }^{1}$ Veja-se, sobre este skolion, C. M. Bowra, Greek Lyric Poetry, p. 350. O poeta é aí estudado de pp. 349 a 358.

${ }^{2}$ Analisei a questão em Concepções Helénicas de Felicidade no Além, de Homero a Platão, pp, 48-50.

${ }^{3}$ Op. cit., pp. 373-374. 
o julgamento que aí se efectuavam ${ }^{1}$. Por sua vez, os tremores de terra

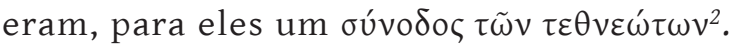

Analisando os dados até agora obtidos, podemos concluir que havia primitivamente dois mitos distintos, certamente também diferenciados quanto à origem: o do Hades, lugar para onde iam os homens depois da morte, tal como se afirma repetidamente ao longo dos Poemas Homéricos ${ }^{3}$, e o do Tártaro, onde estavam prisioneiros Cronos e os Titãs, como explica o texto de Hesíodo ${ }^{4}$. Esta segunda lenda figura em curtas referências na Ilíada, em passos provavelmente mais tardios, e talvez mesmo imitados da Teogonia.

Durante o séc. VII e até ao final do séc. VI a. C., verificamos que a distinção prevalece, uma vez que damos por corrupto o verso 254 do Scutum. Esta afirmação parece poder manter-se para o séc. V a. C., embora possam já discernir-se, num ou noutro autor, indícios de uma confusão que acabará por conduzir à identificação dos dois lugares, em época muito posterior.

Entretanto, tinham-se desenvolvido as doutrinas escatológicas, sob a influência das religiões de Mistérios e do Pitagorismo.

Ora a noção de castigo, que esta última especialmente acentuava, postula, necessariamente, a existência de um local onde ele se execute, diverso daquele para onde vão todos os mortais. Sendo teatro da punição de divindades desde o início, estava naturalmente indicado o Tártaro para esse efeito. É talvez assim, a avaliar pelas escassas indicações que possuimos, que o vêem os Pitagóricos - para não falar dos Órficos, cuja doutrina está muito insuficientemente documentada para as épocas arcaica e clássica - e é assim que o verá Platão ${ }^{5}$.

Deste modo, qualquer mortal continuava a esperar que iria para o Hades, quer fosse o Sócrates da Apologia (40e-41c), quer um daqueles simples desconhecidos que, entre o séc. IV a. C. e o II p. C. levavam consigo uma lâmina de ouro, para saberem o que haviam de responder

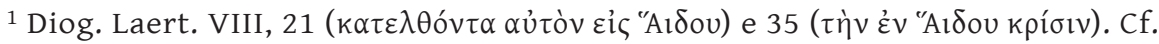
Jâmblico, Vita Pythagorea, 155, 179.

${ }^{2}$ Aelianus, Var. Hist. IV, 17 = VS. 58 (45) C. 2.

${ }^{3}$ Menelau escapa à morte e tem um destino especial, por ser genro de Zeus ( 5 561-569). É um caso excepcional e único.

${ }^{4} \mathrm{O}$ verso 169 dos Trabalhos e Dias situa Cronos nas Ilhas dos Bem-aventurados, e os 169b-e do Papiro de Genebra contam a sua libertação por Zeus. Expus em Concepções Helénicas de Felicidade no Além, de Homero a Platão, pp. 94-96, as razões por que considero esses versos espúrios.

${ }^{5}$ Cf. supra, p. 270, n. 3. Os castigos do final do Canto XI da Odisseia, certamente interpolação tardia, não dizem respeito ao comum dos mortais, mas apenas a figuras mitológicas isoladas. 
aos deuses infernais ${ }^{1}$. Nenhum, pelo menos antes da idade helenística, aceitaria com indiferença a perspectiva de ir para o Tártaro².

Para formarmos uma ideia da época em que se desvaneceu esta distinção, é instrutivo comparar o tratamento de um mesmo tema desejo de, como Orfeu, ir buscar um morto querido - em Eurípides e num poeta alexandrino.

O primeiro diz assim, nos versos 357-362 de Alceste:

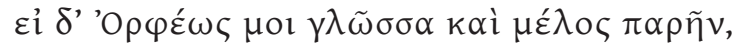

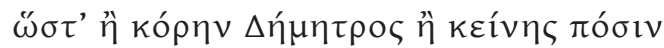

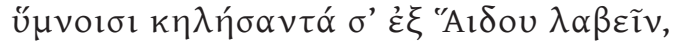

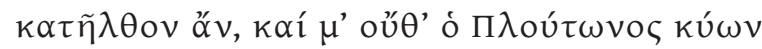

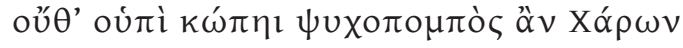

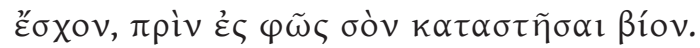

No final do Epitáfio de Bíon, 115-126, Mosco escreveu:

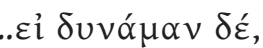

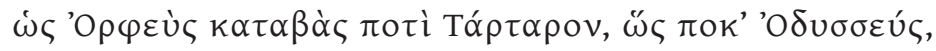

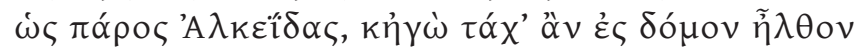

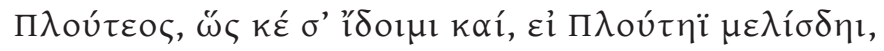

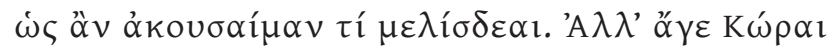

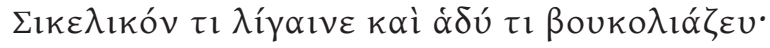

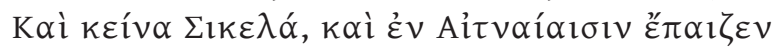

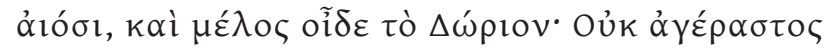

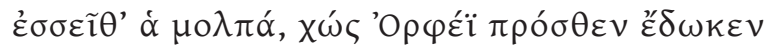

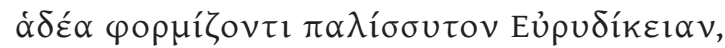

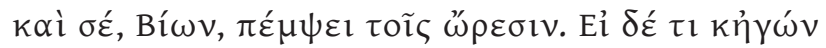

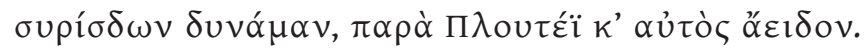

${ }^{1}$ Vide o trabalho citado na nota 4 da página 257 , a pp. 238-243, e, sobre os testemunhos epigráficos, ibidem, pp. 221-222, e ainda Karl Maria Kaufmann, Die Jenseitshoffnungen der Griechen und Römer nach den Sepulcralinschriften. Ein Beitrag zur monumentalen Eschatologie, Freiburg in Breisgau, 1897, que apresenta um esquema comparativo que permite concluir que só se encontram referências ao Tártaro, nesses domínios, na época romana.

Omito aqui a possibilidade de uma sobrevivência feliz, que estudei na obra referida acima.

${ }^{2}$ É curioso notar que mesmo autores mais tardios, como Demóstenes (XVIII, 27. XXXIV, 104), Pseudo-Demóstenes, XXV, 53 - exemplos citados por Nilsson, Geschichte der griechischen Religion, II, p. 230), e até Calímaco (Ai. IV 15. Ep. II 6, IV 2, X 1, XIII 6, XXIII 2, XLI 2. Hy. I 62, III 222, IV 277, V 130) só mencionam o Hades. 
Aqui é evidente que Hades e Tártaro são tomados como sinónimos ${ }^{1}$. Para estabelecer essa equivalência antes da época helenística, não dispomos, porém, de dados seguros.

\section{ү) «Irremeabilis unda»}

Desde os Poemas Homéricos que se estabelecera entre homens e deuses uma diferença fundamental: aqueles são mortais, ao passo que

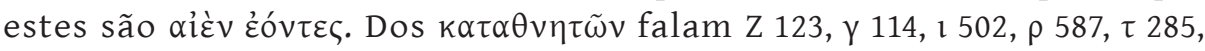
v 76, భ 126. Em K 440-441, a oposição é completa:

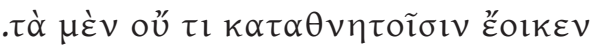

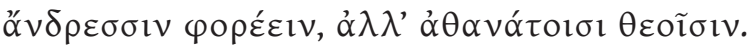

O frg. 82,2 Rzach de Hesíodo junta tudo num só verso:

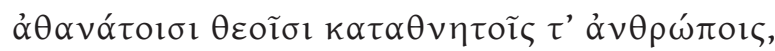

A mesma oposição aparece também, com algumas variantes, no Hino Homérico a Deméter, nos versos 22, 45, 55, 73, 269, 403; no Hino Homérico a Apolo, 68-69; no Hino Homérico a Hermes, 161, 441, 576.

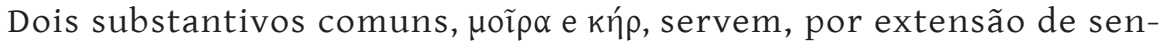
tido, para indicar que chegaram os últimos momentos da vida de um guerreiro.

${ }^{1}$ Em Platão, Symp. 179d, era ainda ao Hades que Orfeu descia, de acordo com a tradição. É curioso que, nos começos do séc. III a. C., Hermesiânax de Cólofon,

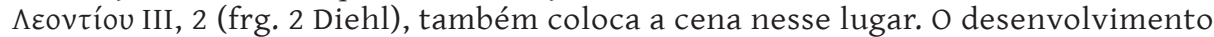
deste tema foi parcialmente estudado por J. Heurgon, «Orphée et Eurydice avant Virgile» in Mélanges d'Archéologie et d'Histoire de l'École Française de Rome, Paris, 1932, pp. 6-60.

O autor de um hino a Deméter, recuperado num papiro do séc. III a. C. (Pap. Berol. 11793 = Diehl, II, 6, p. 130), ao referir-se à partilha do mundo, afirma que:

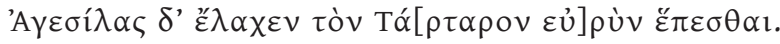

Uma confusão semelhante à do texto citado acima se opera em Plutarco, que situa os castigos no Tártaro em De genio Socratis, 22, p. 592d, e no Hades em De superst., 4, p. 167a. Coloca ambos os lugares nas profundezas da terra em De facie in orbe lunae, 25, p. 940e-f, ao comentar os versos de Homero Y 64 e $\Theta 16$. Lembre-se, a este propósito, que, na época romana, Hades, Tártaro e Elísio acabaram por ser transferidos para a lua (cf. Nilsson, Geschichte der griechischen Religion, II, p. 471).

Sobre a evolução das crenças escatológicas na época helenística e romana, veja-se a mesma obra de Nilsson, vol. II, pp. 220-230 e 520-535, respectivamente. 


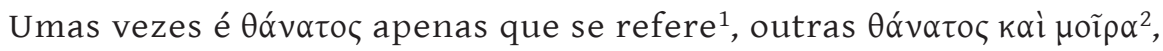

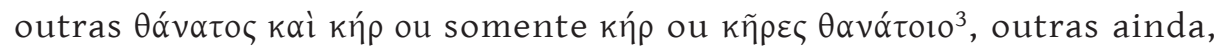
apenas $\mu$ oĩ $\alpha^{4}$ ou $\kappa \eta ́ \rho^{5}$.

De qualquer modo, são sempre os deuses que a enviam ${ }^{6}$ :

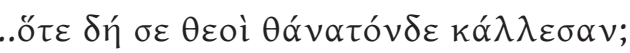

ou, mais explicitamente, como declara Aquiles, quando acaba de matar Heitor:

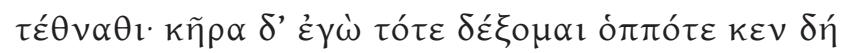

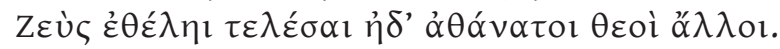

(X 365-366)

Esta decisão, noutros passos, é imputada à Moira irrevogável, sobre a qual apenas Zeus parece ter poder, como se depreende do discutido passo do Canto XVI da Ilíada, versos 441-443 (repetido em X 179-181), em que Hera, escandalizada com a proposta de Zeus, de retirar Sarpédon do combate, exclama7:

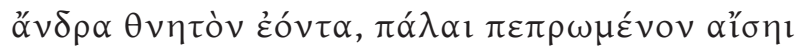

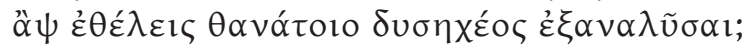

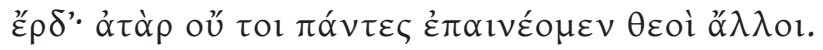

Se alguém ultrapassasse ou antecipasse esta data, fá-lo-ia vंđé $\rho \mu o \rho \alpha$

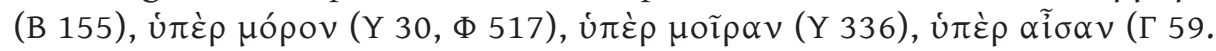
$Z$ 487), v̇đì $\Delta$ iò $\alpha \tilde{i} \sigma \alpha v$ (P 321) - o que nunca chega a suceder, porque acorre sempre algum deus para o evitar.

A Moira é iniludível, e os guerreiros homéricos tinham do facto plena consciência. É o que afirma Sarpédon em M 323-328. O próprio Hércules não conseguiu escapar-Ihe, apesar do amor que Zeus lhe tinha ${ }^{8}$, como lembra Aquiles em $\Sigma$ 115-121, ao anunciar à mãe a sua resolução inabalável de vingar Pátroclo, ainda que com sacrifício da própria vida.

${ }^{1}$ E.g.: Г 173, 309. N 544. $\Sigma$ 464. X 361.

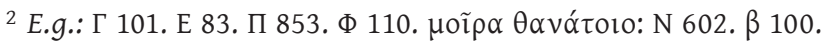

${ }^{3}$ E.g.: B 302, $834=\Lambda$ 332. $\Theta 70=$ X 210. I 411. П 47, 687. Ф 548. X 202. $\lambda 171=\lambda 398 . \xi 207$.

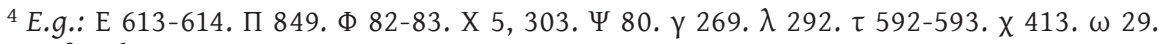
Personificada em $\Omega$ 209-210.

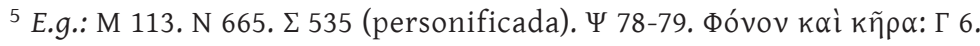

${ }^{6}$ П 693. Сf. Х 297,

${ }^{7}$ Neste passo lê-se $\alpha \tilde{i} \sigma \alpha$, que é nitidamente equivalente a $\mu$ õ $\rho \alpha$ (e.g.: A 416-418.

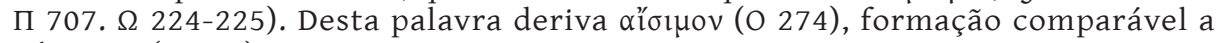
uópoıuov (O 613).

${ }^{8}$ A impossibilidade de os deuses valerem aos seus favoritos é frisada também na Odisseia, y 236-238, em contexto diverso. 
É que a morte derruba igualmente valentes e cobardes, como se lê em Z 487-489:

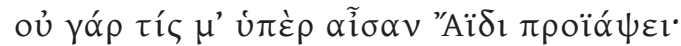

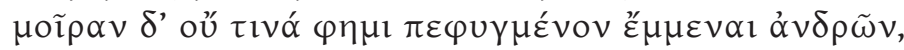

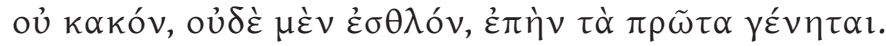

E a psyche, uma vez saída da boca do homem, não mais volta a entrar:

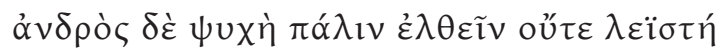

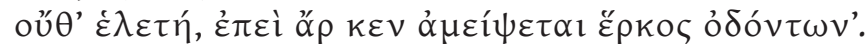

(I 408-409)

Um passo como X 361-363 define bem o processo, tal como era visto pelos aedos homéricos:

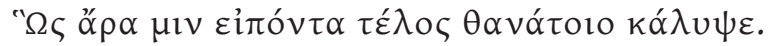

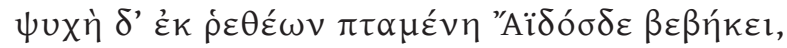

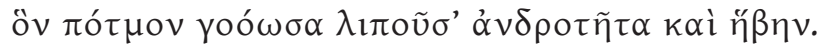

Estas mesmas palavras descrevem também a morte de Pátroclo, em $\Pi$ 855-857.

No Canto XII da Odisseia, Circe põe em contraste o lamentável destino de Ulisses e seus companheiros, acabados de regressar do Hades, com o do comum dos mortais:

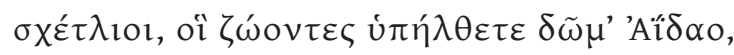

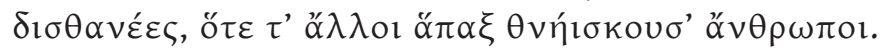

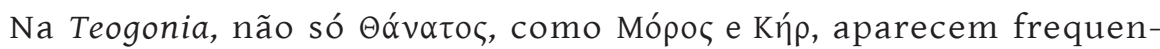
temente personificados, como era de esperar nesse poema ${ }^{1}$. Noutros passos de Hesíodo, encontramos as velhas fórmulas homéricas, do

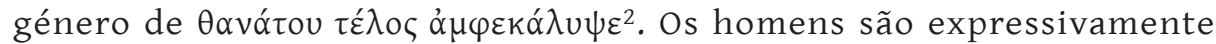

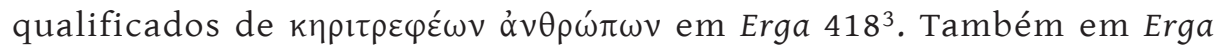
92 se faz referência às Keres.

${ }^{1}$ Th. 211-212, 217, 756, 758-766. Thanatos é considerado como irmão de Hypnos em $\Xi 231, \Pi 454,671-683$.

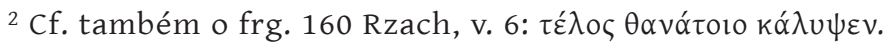

${ }^{3}$ Talvez este epíteto tenha inspirado o aedo de $\Theta$ a chamar aos inimigos kúvaৎ

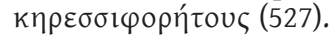


A noção de que é necessário impedir os mortos de sair do Hades, embora implícita em $\Psi$ 72-76 e $\Theta 369$ (referência ao rio) e, de um modo geral, em todos os contextos que falam de portas bem cerradas, aparece pela primeira vez na Teogonia, em passo provavelmente interpolado, que descreve o artifício usado por Cérbero para esse efeito:

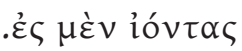

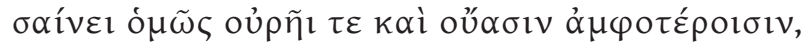

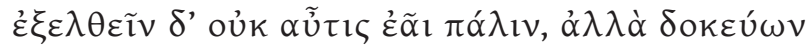

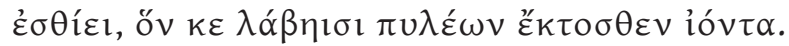

(770-773)

Também os Titãs estavam impossibilitados de sair do Tártaro, porque Poséidon o fechou com portas de bronze (732-733). Poucos versos antes, acentuara-se bem o perfeito hermetismo do local, dizendo-o encerrado por um muro da mesma liga metálica, e cercado por uma tríplice fila de sombras na sua entrada, que se compara a um colo ou gargalo (726-727).

Os outros imitadores do estilo homérico não se afastam do modelo nas

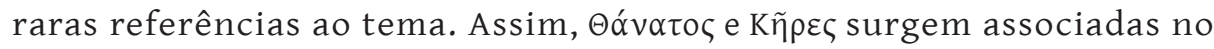

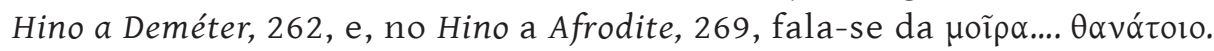

O pseudo-hesiódico Scutum personifica as Keres em 249 e a morte ('Ax入úc) em 264-270.

Os elegíacos referem-se naturalmente a esta última com frequência, sem se desviarem muito da terminologia homérica, como é característico deste género literário ${ }^{1}$.

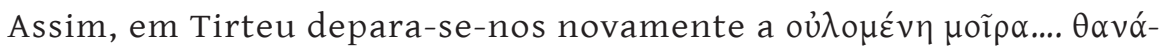

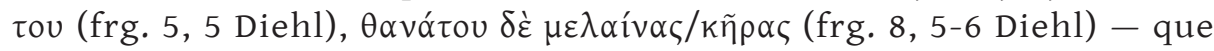
o guerreiro deve agora amar como se fossem os raios do sol - e até a

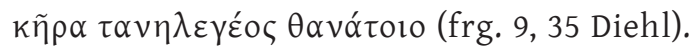

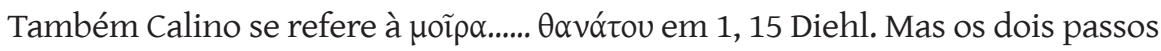
mais significativos, para o nosso propósito, são os versos 8-9 da mesma elegia:

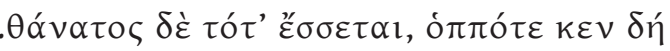

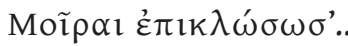

e, sobretudo, os versos 12-13:

\footnotetext{
${ }^{1}$ Sobre a estreita dependência dos elegíacos em relação ao formulário homérico, veja-se C. M. Bowra, Early Greek Elegists ${ }^{2}$, p. 43.
} 


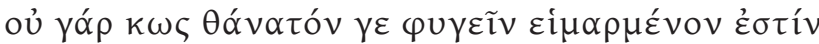

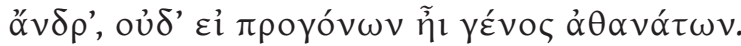

A ambos é fácil, aliás, encontrar precedentes homéricos.

$\mathrm{O}$ autor pretende exortar os soldados ao combate. Esse o motivo por que insiste na inevitabilidade da morte, querendo assim insinuar que ela não ocorrerá mais depressa, pelo facto de se estar no campo de batalha.

Já vimos que Mimnermo apresenta a novidade de reduzir as Keres a duas ${ }^{1}$ (a da velhice e a da morte), em contraposição com as uvpíaı de M 326-327. A

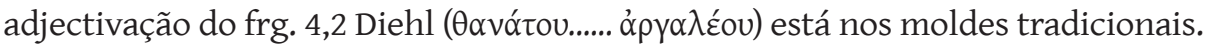

Nos quatro versos finais, apostos a um fragmento de Sólon por Diehl², acentua-se que as riquezas se não podem levar para o Hades e que ninguém foge, nem mesmo pagando, à morte e a outros flagelos que castigam o homem.

A perspectiva iniludível do fim pode notar-se em muitos dísticos do Corpus Theognideum, nomeadamente em 567-570, 767-768, 1007-1012, 1033-1036, 1070a-b e 1187-1190.

Omitindo 725-728, que são certamente de Sólon, resta-nos ainda a elegia 1123-1128, em que se faz referência ao destino de Ulisses, em moldes que têm suscitado dificuldades aos comentadores. Tem-se interpretado como significando a admiração pelo facto de o herói ter conseguido regressar do Hades, ou como a simples afirmação de que ele, apesar de ter escapado a tantos perigos, teve de ir para os infernos, como qualquer mortal vulgar. Esta segunda hipótese, defendida por Carrière na sua edição ${ }^{3}$, é sem dúvida preferível.

Outro autor, possivelmente, o dos versos 703-712, já celebrara a habilidade de Sísifo, que conseguira regressar do Hades, graças às suas palavras astuciosas.

No frg. 1 Diehl de Semónides de Amorgo, enumeram-se as diversas causas que põem termo à vida humana: a velhice, a doença, a guerra, o naufrágio, o enforcamento. E, retomando o dito homérico, prossegue:

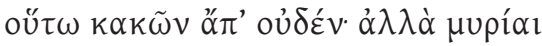

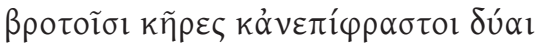

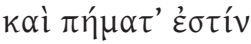

$(20-22)$

${ }^{1}$ Cf. supra, pp. 242-243. O frg. 5 Diehl dos Adespota, a ser de Mimnermo, como sugere Diehl, atribui-lhes de novo um número indeterminado.

${ }^{2}$ Frg. 14 Diehl, vv. 7-10. Sobre as dúvidas de atribuição, veja-se o aparato crítico de Diehl, ad locum.

${ }^{3}$ Paris, Les Belles Lettres, 1948, pp. 128-130. 
Outras breves referências ao tema da morte não interessam ao nosso propósito $^{1}$.

Os líricos tocam com frequência no tópico que temos estado a tratar. Íbico exprime, no frg. 23 Diehl, a irreversibilidade da vida:

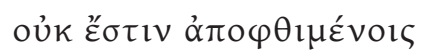

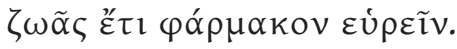

»S

Em Simónides, um fragmento como o 12 Diehl sugere a tradição da elegia guerreira:

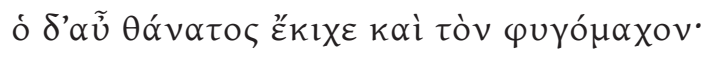

ao passo que o frg. 2 Diehl do mesmo autor lembra a terminologia homérica ${ }^{2}$ :

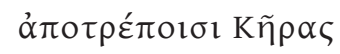

Mas os mais expressivos são os frgs. 8 e 9 Diehl. No primeiro, aproveita uma reminiscência da Odisseia ${ }^{3}$, para definir o aniquilamento que a todos espera, sejam quais forem as qualidades e riqueza das pessoas. O segundo confirma e amplifica a mesma maneira de pensar:

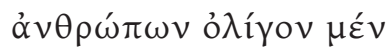

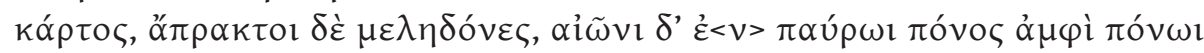

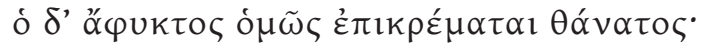

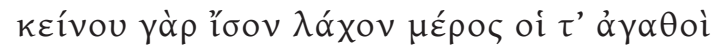

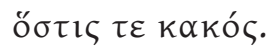

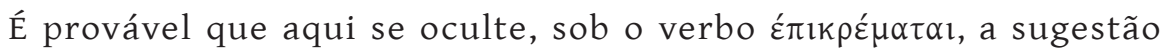
da pedra de Tântalo, que se tinha tornado um lugar-comum da poesia grega, pelo menos desde Arquíloco ${ }^{4}$.

O mesmo sentimento de iminência da morte se patenteia em Píndaro, por exemplo em Ol. I 82, X 104-105; Nem. VII 19-20; Isthm. VII 42-43. Em Nem. VII 30-31, a afirmação é feita em termos mitológicos ( $\kappa \tilde{u} \mu$ ' 'Aí $\delta \alpha . . .$. ),

${ }^{1}$ Frg. 3 e 29,8-9 Diehl.

${ }^{2}$ Sobre a natureza do contexto a que pertenceria este fragmento, vide Wilamowitz, Sappho und Simonides, pp. 206-209.

${ }^{3}$ Sobre o modo deste aproveitamento, vide C. M. Bowra, Greek Lyric Poetry, p. 325.

${ }^{4}$ Frg. 55 Diehl. Cf. Píndaro, Isthm. VIII, 9-10. 
bem como no frg. 143 Snell, onde, ao elogiar a condição dos deuses, se proclama:

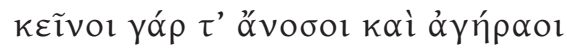

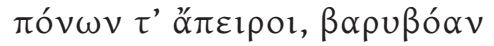

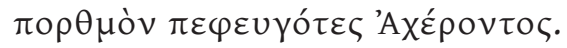

As referências de Baquílides mantêm um acentuado cunho homérico,

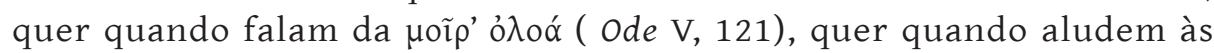
determinações da $\alpha \tilde{i} \sigma \alpha$ (Dith. XVII 24-28 e frg. 24 Snell).

Deixámos para o fim deste exame aos líricos um dos fragmentos mais antigos a considerar. É o 38 Lobel-Page de Alceu, onde se lê:

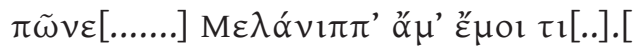

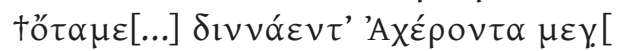

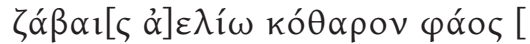

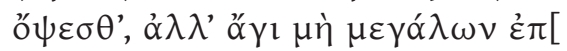

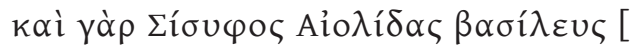

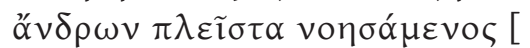

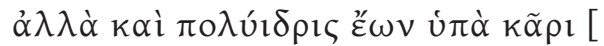

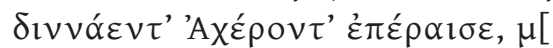

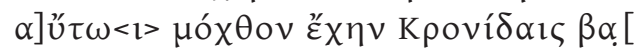

$$
\begin{aligned}
& \mu \varepsilon \lambda \alpha i ́ v \alpha \varsigma \chi \theta \text { ○ovó }
\end{aligned}
$$

Apesar das lacunas do papiro, o sentido geral da composição é claro: o poeta exorta a esquecer no vinho os desgostos, pois todos estamos destinados a atravessar os redemoinhas do Aqueronte - até Sísifo, que escapou da primeira vez, teve de lá voltar. É, como observa Page ${ }^{1}$, o primeiro tratamento literário conhecido desta parte do mito de Sísifo, pois a Odisseia só mencionava o castigo que lhe coube no Hades ${ }^{2}$.

É possível que o autor dos versos 703-712 do Corpus Theognideum, que vimos anteriormente ${ }^{3}$, se tenha inspirado nestes. De resto, a popularidade da história do Eólida encontra-se amplamente documentada no séc. V a. C. ${ }^{4}$.

\footnotetext{
${ }^{1}$ Sappho and Alcaeus, pp. 300-303.

${ }^{2} \lambda$ 593-600.

3 Supra, p. 159.

${ }^{4}$ As referências foram coligidas por D. Page, Sappho and Alcaeus, p. 302.
} 
Em Ésquilo, Persae, 688-690, acentua-se a dificuldade oposta ${ }^{1}$ a quem tem de sair do Hades:

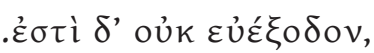

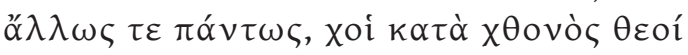

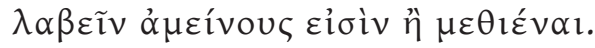

E Prometeu conta entre os benefícios conferidos à humanidade a concessão da esperança, que lhe tirou a obsessão da morte (Prom. 248-250). A irreversibilidade desta encontra-se expressa nos versos 568-569 do Agamémnon:

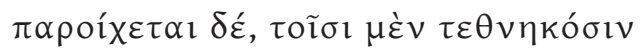

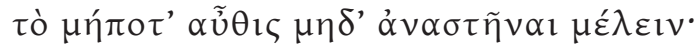

Tal como no final do frg. 14 Diehl de Sólon², põe-se em relevo a inexorabilidade de Thanatos num fragmento muito citado da Níobe ${ }^{3}$ :

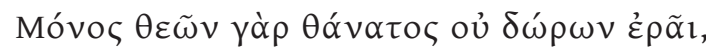

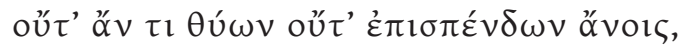

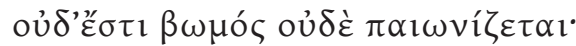

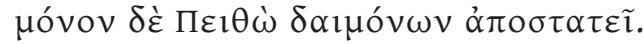

Em resumo, podemos concluir que a noção da inevitabilidade da morte se exprime com frequência nos Poemas Homéricos, quer ligada

${ }^{1}$ A mesma noção vai ecoar neste passo de Eurípides, Her. 297, embora expressa de outro modo:

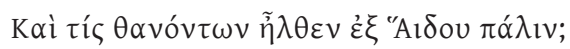

Cf. também Her. 431-432:

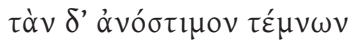

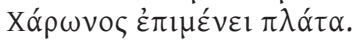

e o frg. 868 Nauck $^{2}$ :

$\theta \varepsilon o i ̀ x$ xóviol

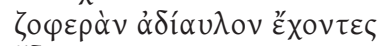

$\varepsilon \tilde{\delta} \rho \alpha v$.

\footnotetext{
${ }^{2}$ Vide supra, p. 281

${ }^{3}$ Frg. 161 Nauck $^{2}$.
} 
às personificações de Moira ou Keres, quer independentemente delas. Tal processo encontra-se também nos líricos arcaicos com frequência.

A psyche não pode tornar a entrar no corpo humano, como assevera a Ilíada, em passo já citado ${ }^{1}$.

Em Hesíodo - ou num seu continuador - essa noção concretiza-se, em ligação com a mitologia escatológica, através da lenda de Cérbero.

É precisamente a este aspecto do problema que nos importa atender. E, neste particular, são os testemunhos do frg. 38 Lobel-Page de Alceu e do frg. 143 Snell de Píndaro, juntos aos de Ésquilo, que mais interesse assumem para nós, pois mostram que a noção de irreversibilidade da travessia do Aqueronte estava firmemente estabelecida na época arcaica.

${ }^{1}$ I 408-409. Vide supra, p. 279 
(Página deixada propositadamente em branco) 


\section{CAPÍTULO II}

\section{A LINGUAGEM}

Se, no que toca à métrica, não há, como vimos, particularidade alguma digna de relevo, outro tanto não sucede no que respeita ao léxico.

É conveniente, portanto, que analisemos a linguagem empregada.

Os dois versos iniciais:

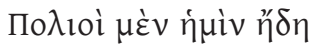

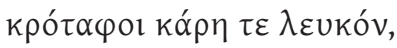

não contêm palavra alguma que não estivesse dentro da tradição homérica. A fórmula da Ilíada X 74 e $\Omega$ 516:

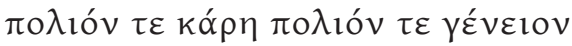

bem como $\lambda \varepsilon u$ kòv...... kó ṕp de Tirteu, frg. 7, 23 Diehl, estão-lhe muito próximas¹ .

Aliás, este tipo de adjectivação ocorre indiferentemente em qualquer época (como pode ver-se pelos exemplos de Eurípides, citados na n. 1 da p. 114), e não é menos frequente na helenística (e.g. Teócrito XXX

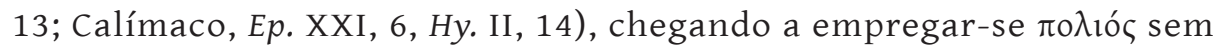
substantivo, para designar as cãs ou pessoas idosas, como nos dois últimos exemplos.

Outro tanto vale para $\chi \alpha \rho i ́ \varepsilon \sigma \sigma \alpha . . . ~ \eta ँ \beta \eta$, que encontra fáceis paralelos

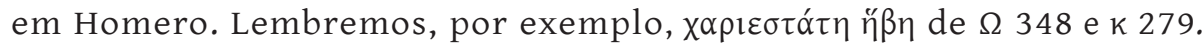

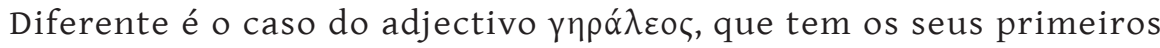
exemplos em Ésquilo, Pers. 171 e em Píndaro, Pyth. IV 121. Aplicado a

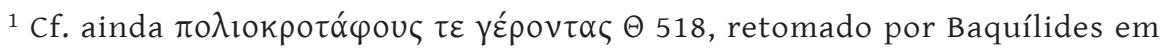

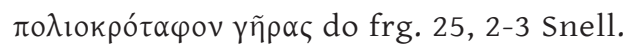


substantivos concretos, é frequente na época alexandrina. Assim Teócrito, XXIX, 27-29, e, sobretudo, XIV, 68-69⒈

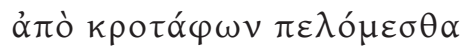

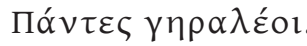

O emprego de ßíotoఢ, por oposição a Hades como sinónimo de morte, está documentado, por exemplo, em Mimnermo, frg. 2 Diehl, vv. 9-10, e, mais tardiamente, em Eurípides (Her. 736; Hipp. 1366-1367; Suppl. 1004-1005). Os excertos citados nas pp. 243 e 253, n. 9, mostram-nos

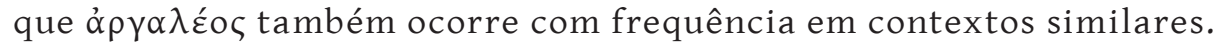

A prosaica construção $\delta i \grave{\alpha} \tau \alpha \tilde{v} \tau \alpha$, do verso 7 , foi a causa desencadeante de dúvida para Hermann Fränkel, como já vimos anteriormente ${ }^{2}$. Lembre-se

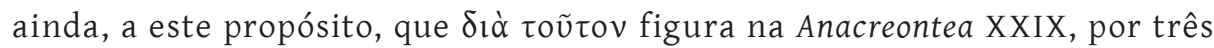
vezes $(10,11,14)$.

Segue-se-lhe um hápax - $\alpha v \alpha \sigma \tau \alpha \lambda u ́ \zeta \omega$ - que tem provocado grandes dificuldades. Scaliger tentou mesmo um impossível $\alpha^{\prime} \lambda \alpha \sigma \tau \alpha \lambda \hat{}^{\prime} \zeta \omega$ e Hartung $\alpha{ }^{\prime}{ }^{\prime}$ $\dot{\alpha} \sigma \tau \alpha \lambda u ́ \zeta \omega$. Nem este composto nem o simples se encontram documentados em autor algum. Apenas se conhece uma glosa pouco segura de Hesíquio:

$$
\dot{\alpha} \sigma \tau \alpha \lambda u ́ \zeta \varepsilon l v \cdot \alpha ̉ v \alpha \beta \lambda u ́ \zeta \varepsilon l v \cdot \kappa \lambda \alpha i ́ \varepsilon 1 v
$$

e ainda:

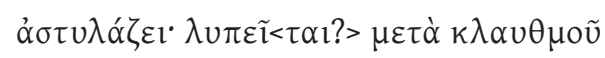

que ajudam a compreender a forma. Weber pensa num $\alpha$ - protético, como em

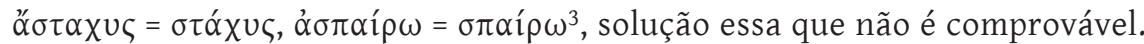

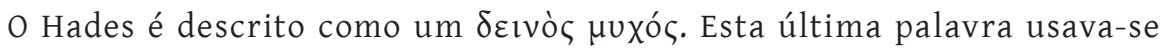
com frequência para designar um íntimo recesso, ou de uma casa ${ }^{4}$ ou de uma gruta $^{5}$. Na Teogonia, 119, em verso certamente interpolado, aparece associada ao Tártaro:

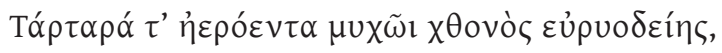

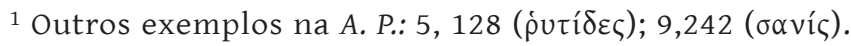

2 P. 228.

${ }^{3}$ Anacreontea, p. 70. Acerca das dúvidas que impendem sobre estes casos de prótese, veja-se H. Frisk, Griechisches etymologisches Wörterbuch, s. u. u.

${ }^{4}$ E.g. X 440. $\gamma$ 402. $\delta$ 304. $\eta$ 346. X 270.

${ }^{5}$ E 226. 1 236. v 363, w 6. Hino Homérico a Hermes, 246 e 252. 
É frequente para descrever o Hades, a partir de Ésquilo, como, por exemplo, no verso 433 do Prometeu ${ }^{1}$ :

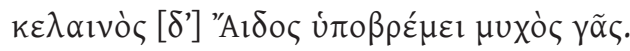

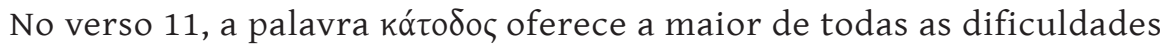
linguísticas implicadas pelo frg. 44 Diehl.

O próprio Gentili observa no seu aparato:

«Kó́

Com efeito, para designar o trajecto para o Hades, usam-se com frequência, desde os tempos homéricos, compostos com o prefixo $\kappa \alpha \tau \alpha-$, mas nunca o que figura no fragmento.

Assim, embora seja mais habitual utilizar-se, neste contexto, o verbo

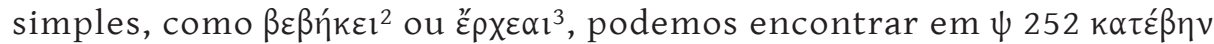

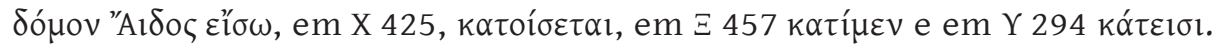

Esta prática mantém-se ainda, por exemplo, em Eurípides, que em-

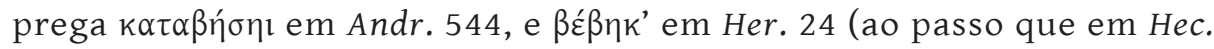

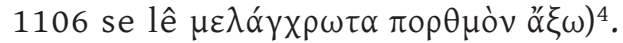

Em Ésquilo, há um verso de Os Persas, já citado, que define a dificuldade de sair do Hades:

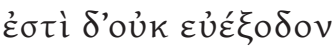

Outro composto de óðós, em contexto semelhante, pode encontrar-se em Teócrito XII, 19, a qualificar o rio infernal:

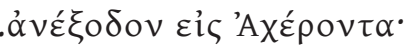

Outro ainda figura num conhecido Epigrama de Calímaco (XIII, 3-4):

${ }^{1}$ Cf. também uuxòv "Aı $\delta$ ov de Timóteo, frg. 3a Diehl, v. 13, em texto, aliás, muito

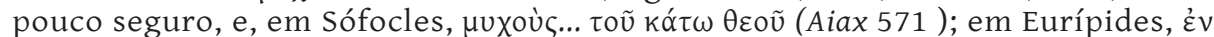

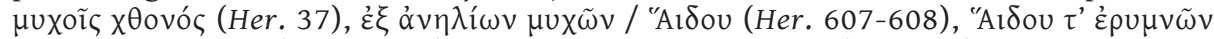

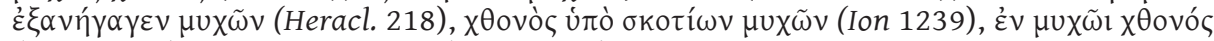

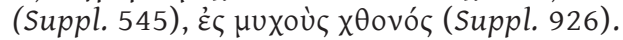

${ }^{2}$ E.g. X 362.

${ }^{3}$ E.g. X 482-483.

${ }^{4}$ Segundo uma notícia de Suidas, havia uma comédia de Nicofonte intitulada

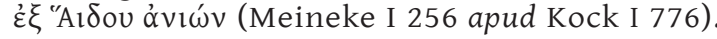




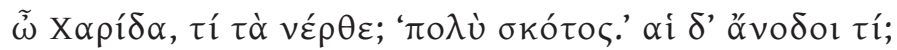

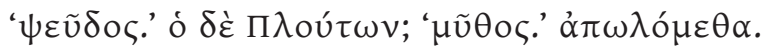

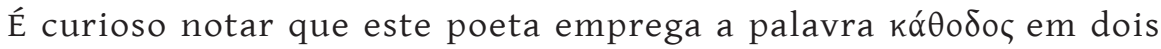
dos fragmentos conservados (115, 15 e 178, 26 Pfeiffer), mas não com o sentido de «descensus».

O seu contemporâneo Apolónio de Rodes, ao referir-se a um caminho de acesso ao Hades, também não usa esse termo:

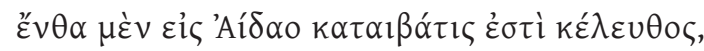

(Argon. II 353)

e, num epigrama anónimo da Anthologia Palatina, lê-se:

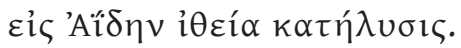

$$
(\mathrm{X}, 3,1)
$$

A noção de que o caminho do Hades é irreversível está, como já vimos, amplamente documentada, embora a grande maioria dos exemplos seja alexandrina, e até romana, como pode deduzir-se da simples observação da lista elaborada por Gow, no seu comentário ao passo citado de Teócrito ${ }^{1}$.

Nada disto, porém, invalida a estranheza do termo, porquanto a pala-

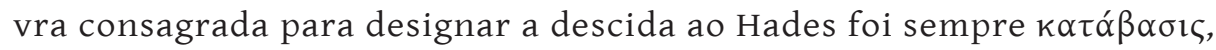
e nunca se deu este sentido a ká $\theta 0 \delta$ os, antes da época romana.

Sob o ponto de vista lexical, podemos, portanto, afirmar que o fragmento contém algumas palavras que levantam dificuldades à sua autenticidade.

Destas, para considerar apenas as maiores, uma é um hápax, outra não aparece documentada com aquele sentido antes da época romana.

Quanto ao primeiro caso, é certo que os compostos com $\alpha$ v $\alpha$-são frequentes em Anacreonte, conforme observa Gentili na sua edição ${ }^{2}$, citando até $\alpha \dot{v} \alpha . . . . \beta \alpha \sigma \sigma \alpha \rho \eta ́ \sigma \omega$, também hápax, do frg. 43, 6 Diehl;

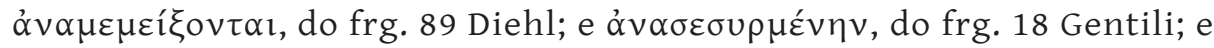
ainda ở $v \alpha \chi \varepsilon i ́ \sigma \theta \omega$, do frg. 22 Diehl e ở $v o \rho \varepsilon ́ \omega \tau \varepsilon$ kở $v \alpha \kappa u ́ \pi \tau \omega$, do frg. 65,2 Gentili ${ }^{3}$. Mas o mesmo comentador não deixa de acrescentar a esta série

\footnotetext{
${ }^{1}$ Cambridge University Press, 1950, vol. II, p. 225.

2 P. 202, n. 2.

${ }^{3}$ P. 16.
} 


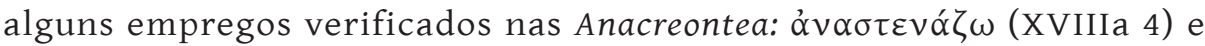

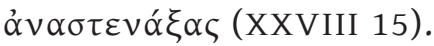

Aos exemplos tirados de Anacreonte podemos adicionar ainda

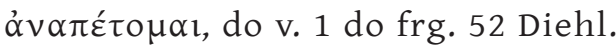

Das Anacreontea não é difícil coligir um elevado número:

\begin{tabular}{|c|c|}
\hline$\dot{\alpha} v \grave{\alpha}-\ddot{\alpha} \lambda \lambda \circ \mu \alpha \iota$ & (XXXIII 29) \\
\hline$\dot{\alpha} v \grave{\alpha}-\not ̈ \alpha \alpha \varsigma$ & (XXXIII 15) \\
\hline$\grave{\alpha} v \grave{\alpha}-\delta o v \eta ́ \sigma \omega$ & (LX 1) \\
\hline ỏvoßaíveıv & (XXXI 8) \\
\hline$\dot{\alpha}^{\prime} v \alpha \theta \dot{\alpha} \lambda \lambda \varepsilon \mathfrak{} v$ & (LV 41) \\
\hline$\dot{\alpha} v \alpha \theta \alpha ́ \lambda \pi \varepsilon \iota v$ & (XXXIII 21) \\
\hline 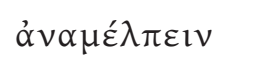 & (XXXVIII 2.27) \\
\hline$v \alpha \pi v \varepsilon \tilde{\imath} v$ & (XLI 4) \\
\hline 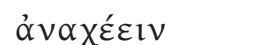 & (LVII 3) \\
\hline
\end{tabular}

Daqui se pode concluir que os compostos com ỏv $\alpha$-tinham grande preferência por parte dos autores de Anacreontea. A prova está longe de ser decisiva, mas também não favorece a hipótese da autenticidade.

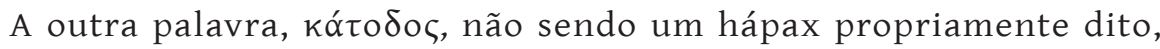
é-o em parte visto que apresenta um sentido nunca exemplificado na época arcaica ou clássica. Weber acentua bem o facto ${ }^{1}$ :

«Hoc loco "descensus" est; ualde igitur differt ab usitata huius uocabuli notione: nam de reditu saepissime inuenies, sed nullo alio loco nisi ab Anacreonte in uetustiore lingua Graeca sic usurpatum esse uidetur.»

E cita seguidamente exemplos de Aristóteles, Part. An. IV, 11, p. $690 \mathrm{~b}$ 30 (com o sentido de «engulir»), de Luciano, Dial. mort. 27,1, e de Plutarco, Is. et Os. 69. Destes, os que nos interessam são o segundo (que alude ao local da descida) e o terceiro (referente ao acto em si), por serem os que apresentam um significado próximo do do nosso texto:

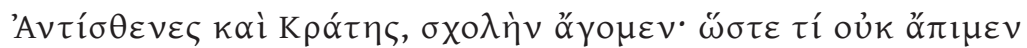

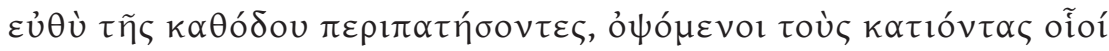

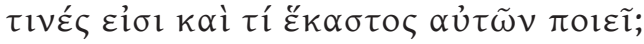

(Luciano, Dial. mort. 27,1)

${ }^{1}$ Anacreontea, p. 81. 


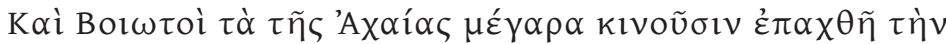

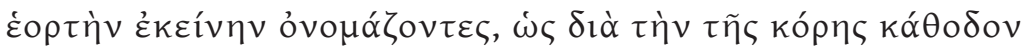

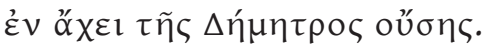

(Plutarco, Is. et Os. 69, p. 378e)

A estes acrescentarei dois de Pausânias e mais outro de Luciano, além de um epigráfico. O primeiro, em II. 13.3 refere-se ao Canto XI da

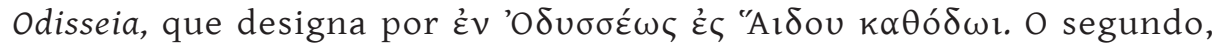
em II. 37.5, diz respeito ao local onde Dioniso desceu ao Hades para ir buscar sua mãe Sémele:

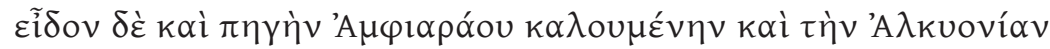

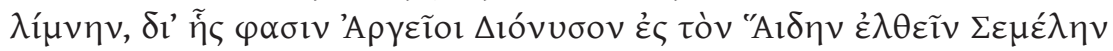

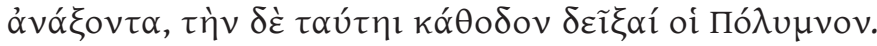

Também uma inscrição da ilha de Rodes, do tempo de Caracala, publicada in Oesterreichísche Jahreshefte, VII, 1904, p. 92 seqq., linha 24 seqq., se refere a este mito dionisíaco, usando a mesma terminologia,

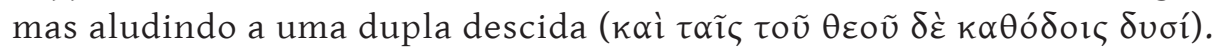

Luciano, no seu diálogo Necyomanteia, emprega igualmente este vocábulo

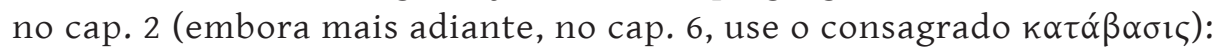

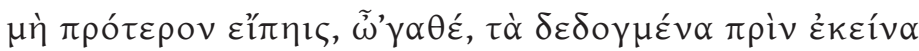

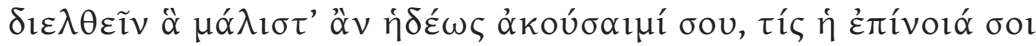

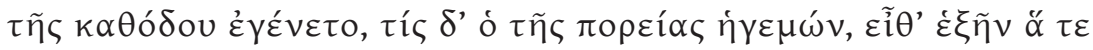

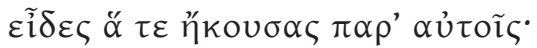

É certo que é considerável o número de expressões que Anacreonte usou pela primeira vez ${ }^{1}$, ou foi mesmo o único a empre-

${ }^{1}$ Enumerando apenas as que se encontram em texto seguro, temos:

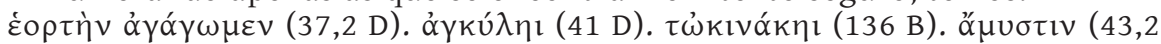

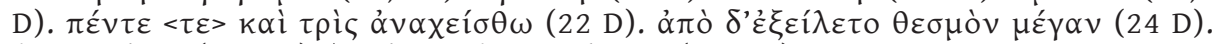

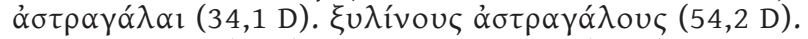

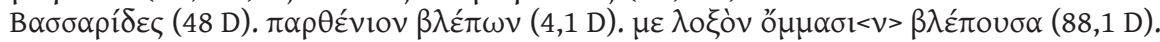

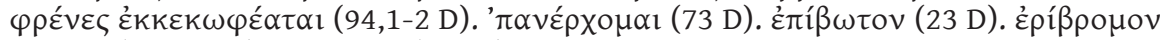

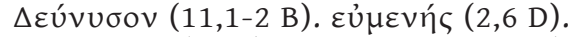

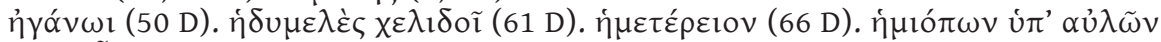
$(18,2 \mathrm{D}) . \tilde{\eta} \sigma \varepsilon(148 \mathrm{~B})$.

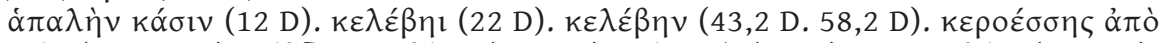

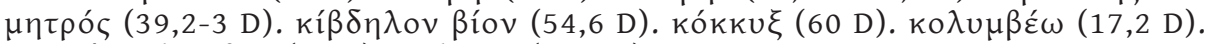

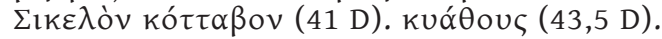

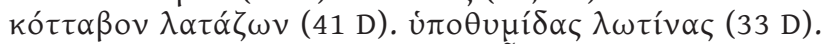

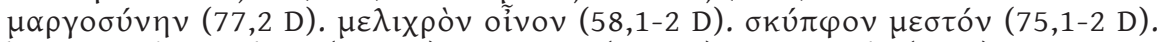

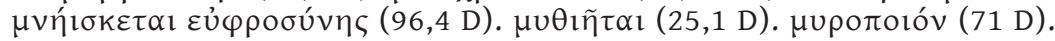


gar $^{1}$, como podemos verificar rapidamente, percorrendo o index uocabulorum da tese de Weber.

De um grande número destes vocábulos, muitos representam ape-

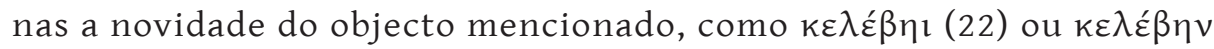

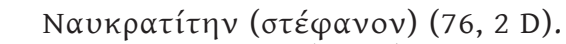

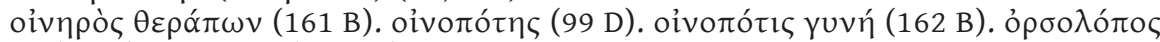
"Apпs (74 D). óxávoio (81,2 D).

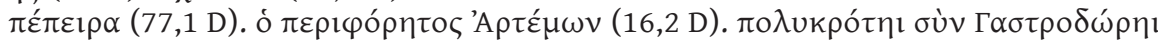

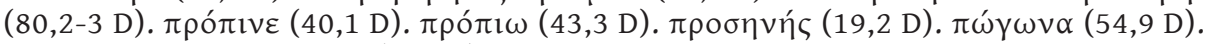

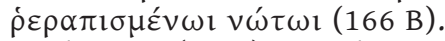

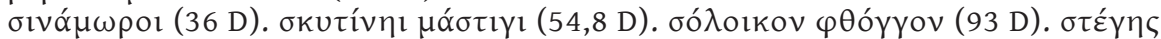
(85,2 D). $\sigma u ́ \mu \beta o u \lambda o \varsigma ~(2,10 ~ D) . ~ \sigma u v \eta \beta \tilde{\alpha} v$ (29 D. 52,2 D).

$\tau \rho u ́ \gamma \alpha(21,2 \mathrm{D})$.

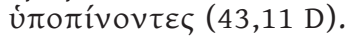

$\varphi \alpha \lambda \alpha \kappa \rho o ̀ \varsigma ~ " A \lambda \varepsilon \xi 1 \varsigma(62 \mathrm{D})$.

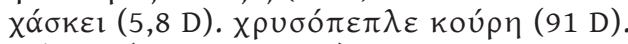

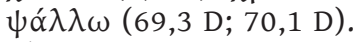

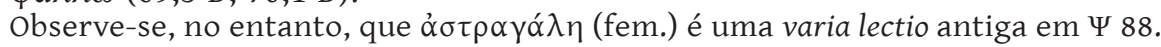

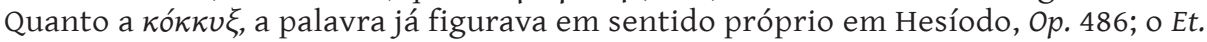
M. 524.51 e Et. Gud. 332.22, que citam o fragmento de Anacreonte, tomam o nome da ave neste passo como símbolo da covardia; Wilamowitz, Isyllos von Epidauros, p. 132, n. 9, e Weber, Anacreontea, p. 86, como o da estultícia. Devem retirar-se desta lista a expressão $\mu \varepsilon \lambda_{\text {lx }}$ ò̀v oĩvov, que se lê no frg. 338, 6-7 Lobel-Page, de Alceu,

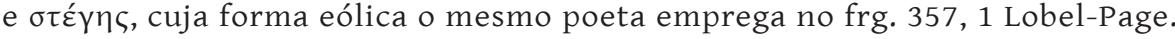

${ }^{1}$ Da lista de hapax, citaremos:

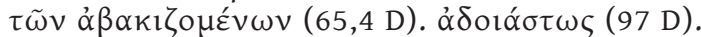

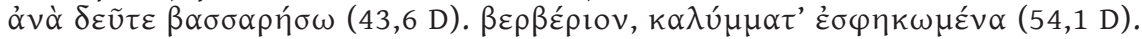

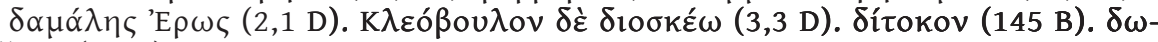

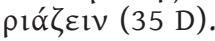

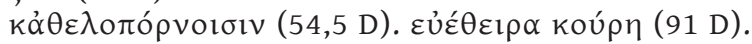

$\theta \omega \mu \mathrm{ux} \theta \varepsilon i ́ c(54,8 \mathrm{D})$.

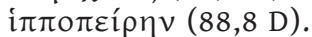

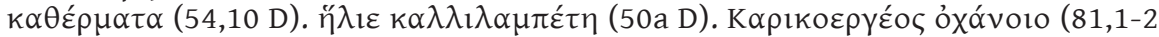

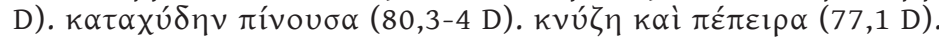

$\lambda \alpha \lambda^{\prime} \alpha \zeta \varepsilon(80,2 \mathrm{D})$.

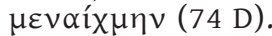

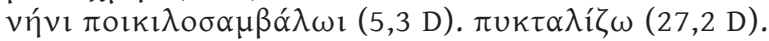

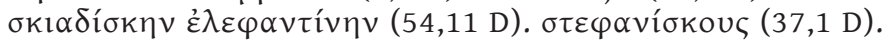

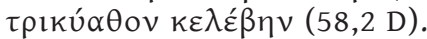

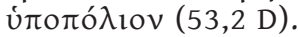

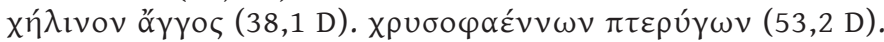

Deste grupo deve agora retirar-se $\pi u k \tau \alpha \lambda i ́ \zeta \omega$, que apareceu num dos poemetos do Pap. Oxy. 2321 (frg. 65,1 Gentili) e ainda outras palavras que têm surgido em documentos epigráficos. É o caso de dítokov, decifrado numa inscrição cirenaica (A. J. A. 17.162), de عủé $\varepsilon \varepsilon 1 \rho \alpha$, que apareceu no Egipto (Sammelbuch gr. Urkunden aus Aegypten 4127.21-referido a Ísis), de $\sigma \tau \varepsilon \varphi \alpha v i ́ \sigma k o u \varsigma$, que se encontrou em Cós (SIG 1106.122) e já figurava em autores como Diosc. 1.30.4, Longo 1.9, Anacreontea XLII, 5, etc. (citações de Liddell-Scott).

Os novos fragmentos permitem ainda acrescentar à primeira série (nota anterior) $\pi \alpha \nu \tau \alpha \dot{\alpha} \pi \alpha \sigma l$ (frg. 65,5 Gentili) e óv $\alpha \kappa u ́ \pi \tau \omega$ (frg. 65,2 Gentili) e, à segunda,

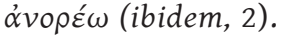




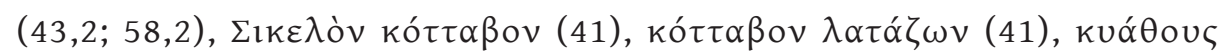
$(43,5)$, бKú $\operatorname{cov}(75)$. Outros são verdadeiros «achados» poéticos, como

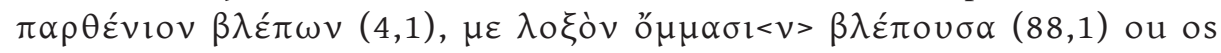

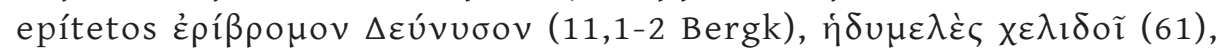

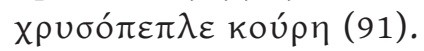

Deve notar-se que uma percentagem considerável das palavras indicadas figura no frg. 54 Diehl, nos violentos tetrâmetros contra Ártemon; outros exemplos pertencem igualmente a excertos de espírito satírico. Ao lado destes, temos os compostos na melhor tradição épica, como $\varepsilon \dot{\varepsilon} \varepsilon \varepsilon \varepsilon 1 \rho \alpha, \chi \rho \cup \sigma o \varphi \alpha \varepsilon ́ v \nu \omega \nu, \kappa \alpha \lambda \lambda_{l} \lambda \alpha \mu \pi \varepsilon ́ \tau \eta \varsigma$.

De qualquer modo, entre os vocábulos aduzidos, é possível encontrar formações paralelas a ỏv $\alpha \sigma \tau \alpha \lambda u ́ \zeta \omega$, mas nenhuma que sugira um

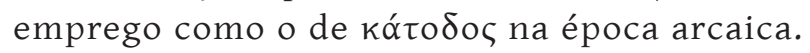


CONCLUSÃO 
(Página deixada propositadamente em branco) 
Já vimos, umas vezes directa, outras indirectamente, que muitos indícios concorrem para pôr em dúvida a autenticidade do frg. 44 Diehl de Anacreonte.

Quanto à temática nele desenvolvida, podemos sistematizar as conclusões decorrentes da análise diacrónica que fizemos.

Pelo que toca aos sintomas do envelhecer, todos eles pertencem à tradição literária que estudámos, com excepção do pormenor da decadência dos dentes, pormenor este, que, aliás, não abona as qualidades de invenção poética do autor, antes o aparenta ao espírito da comédia (cf. os exemplos de Aristófanes e de Ferécrates, citados nas pp. 114-115, nota 1). A própria adjectivação também não é nova. O que quer dizer que, sob este ponto de vista, o fragmento pode situar-se indiferentemente em qualquer época posterior aos Poemas Homéricos. Não está, porém, de acordo com a atitude de Anacreonte perante a velhice. Os fragmentos conservados sobre este tema revelam, efectivamente, uma maneira diversa, permeada de auto-ironia, de considerar a situação.

O segundo tópico, o do Hades confundido com o Tártaro, comporta o maior obstáculo à questão da autoria. Efectivamente, os dois lugares e os mitos que lhes correspondiam eram primitivamente distintos. 0 Hades era o destino comum dos mortais, o Tártaro só para os supliciados divinos. A semelhança de localização e certas características, como a escuridão e o bolor, a transferência das Erínias, que perseguiam e castigavam os criminosos, para o segundo local, a expansão das doutrinas escatológicas das religiões de Mistérios e do Pitagorismo, que dão importante papel às punições, levam a considerar o Tártaro como uma parte do Hades e a colocar nele os pecadores humanos. Este último facto é pressuposto por algumas referências de Sófocles e Eurípides e claramente expresso nos mitos de Platão relativos ao além.

A identificação dos dois lugares, preparada pelo condicionalismo acabado de expor, deve ter tido um processo muito mais longo. Com efeito, uma vez que o Tártaro era um sítio de torturas pelos crimes cometidos, nenhum grego normal encarava a hipótese de ser esse o seu destino, depois de morto. Era, naturalmente, ao Hades que se referia, 
nessas circunstâncias, esse Hades onde as religiões de Mistérios lhe asseguravam um lugar especial. Para falar em ir para o Tártaro, era necessário que os sentidos ligados a esse local durante a época arcaica e clássica se tivessem de todo obliterado. Tal facto parece ter ocorrido na época helenística.

O terceiro tema, contido nos dois versos finais, é fácil de encontrar, desde os Poemas Homéricos, e aparece formulado em termos mitológicos em $\Theta 369$ (caso de Hércules) e em $\Psi$ 72-76 (caso geral). Mais tarde, em Alceu, como aliás também em Píndaro, é ainda a travessia do rio, e não a descida, que é apresentada como símbolo da impossibilidade de regressar. Em Ésquilo, é a saída, sem indicação do sentido em que há-de ser feita. Tal indicação surge-nos num passo de Teócrito, e em outros autores helenísticos, mas o facto pode ser acidental.

Se a métrica não oferece dificuldades (embora tão-pouco as elimine, porquanto os dímetros iónicos anaclómenos eram uma das medidas favoritas dos imitadores do poeta de Teos, além de que eram usados por este último sobretudo em alegres canções de mesa), a linguagem não deixa de apresentar algumas, devido ao emprego de palavras não documentadas, e, sobretudo, ao uso de um termo que não aparece nunca com tal sentido, antes da época romana.

O processo literário de Anacreonte, da adjectivação regular de cada substantivo, por vezes com disjunção, é observado, mas não o característico trikolon ${ }^{1}$. A antítese com que termina o poemeto (oposição de

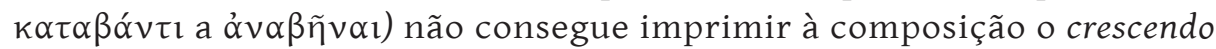
tão característico do velho poeta. Ausente ainda aquela adjectivação de compostos ao gosto épico, e, sobretudo, aquelas inesperadas associações de palavras que dão o timbre da originalidade do lírico iónico. Apenas, em vez disso, o emprego de vocábulos tradicionais e gastos dentro do

${ }^{1}$ Nem sequer podemos encontrar perfeito rigor na artificiosa simetria que lhe aponta Weber, Anacreontea, pp. 29-30:

«Poeta senectute sese esse confectum neque adhuc iuuenem cum dicturus est, hoc ita uariatum reddit, ut utraque res, quae alteri opposita sit (h. e. senectus et iuuentus) exprimatur binis membris eundem sensum indicantibus, quae non iuxta ponuntur, sed alterno ordine ...... Schema igitur non est $a$ a $b$ b, sed hoc: $a b$ a $b$, si ea membra, quae ad idem pertinent, iisdem litteris designamus. Quod toto in enuntiato factum esse uidemus, in primo eius membro repetitur. Nam poeta, qui canum esse caput dicere uult, cum

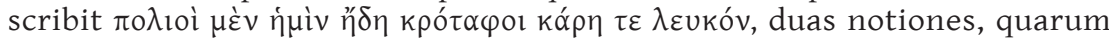
utraque capitis canitiem significat, pro una posuit, easque ex diuerso collo-

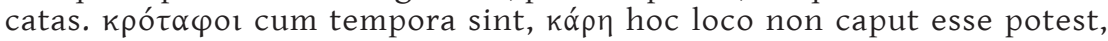

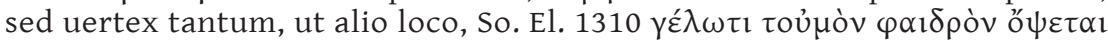
кó $\rho \alpha$, de uultu dicitur. Versu tertio adiectiuo bis a substantiuo suo disiuncto collocationem esse artificiose implicitam uides.» 
respectivo contexto, com excepção dos casos particulares que analisámos no último capítulo.

Em último lugar, lembremos ainda que estamos em presença de um fragmento com uma fonte única: Estobeu.

Este compilador cita Anacreonte duas vezes, no decurso da sua longa

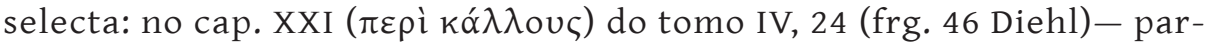
cialmente comprovado por Ateneio XII, 540c e Eliano, Var. Hist. 9,4, e actualmente vinculado à interpretação do novo frg. 71 Gentili - e no

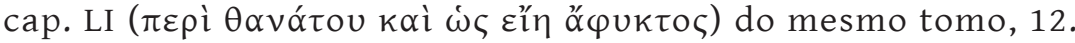

Contrariamente a outros fragmentos de Anacreonte, que têm a aboná-los grande número de autoridades, este é dos que assentam numa única informação. E precisamente em Estobeu se têm verificado enganos de atribuição - que, aliás, não surpreendem, nos milhares de citações feitas por esse autor.

Os exemplos mais flagrantes são os das confusões entre Simónides e Semónides, entre Sólon e Teógnis de Mégara.

Assim, o frg. 1 Diehl de Semónides de Amorgo é atribuído por Estobeu,

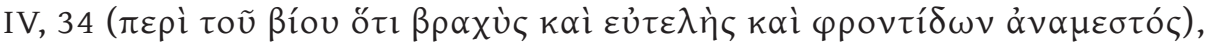
15, a Simónides de Ceos. O mesmo ocorre com o frg. 29 Diehl (idem,

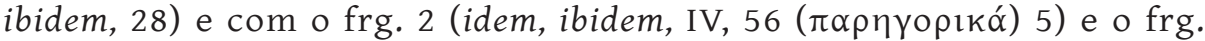

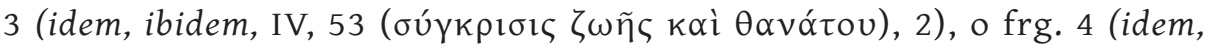

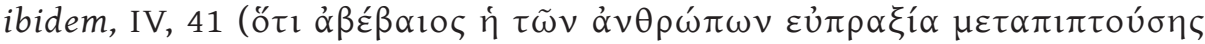

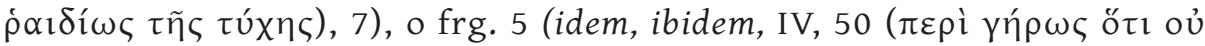

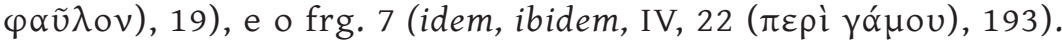

Os versos 719-728, que a mesma fonte atribui a Teógnis (IV, 33

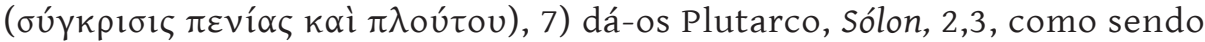
do legislador ateniense (= frg. 14 Diehl). O facto repete-se exactamente do mesmo modo no frg. 4, vv. 9-12 Diehl, de Sólon, que lhe são adjudicados por Plutarco, Sólon, 3,2 e dados a Teógnis por Estobeu em III, 1

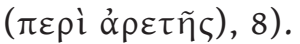

É de notar, no entanto, que, precisamente no número anterior à primeira citação de Semónides que referimos, Estobeu transcrevera um

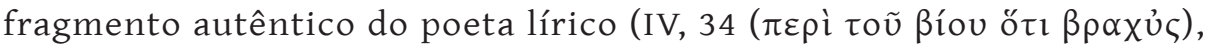
14 = 7 Diehl). Igualmente se consideram genuínos, por exemplo, o frg.

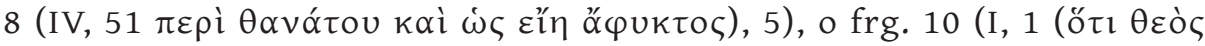

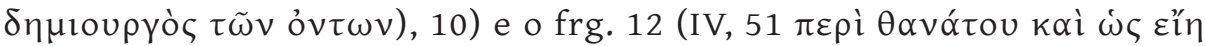

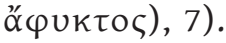

No caso de Semónides e Simónides, a homonímia resultante do itacismo torna compreensível que cedo se tenham confundido os dois autores, apesar da diversidade do seu espírito e da sua arte. O de Sólon e de Teógnis de Mégara é mais uma prova de que o processo de formação do Corpus Theognideum já estava totalmente obliterado no séc. VI p. C. 
É de crer que uma confusão se tenha igualmente produzido na citação 12 do cap. 51 do Livro IV. Desde o séc. II p. C. que se tem como certa a existência de Anacreontea, devido ao texto de Aulo Gélio que contém uma, em XIX, 9. Há motivos para supor que o frg. 82 Diehl, conhecido desde o final do séc. I p. C., fosse outra. É provável, pelas razões expostas, que o frg. 44 Diehl deva também situar-se na época romana. Efectivamente, acusa divergências, nos seus processos literários, de quanto vimos sobre a obra autêntica, nos três primeiros capítulos da primeira parte deste estudo, e semelhanças com os dos imitadores, que delineámos no capítulo quarto. Embora habilmente metrificado, e conservando no início um pouco do ritmo frásico do poeta arcaico, sem conseguir, no entanto, o famoso trikolon, termina num amaneirado e sombrio jogo de palavras, envolvido numa terminologia datável do séc. II p. C. e apoiado numa ideologia que, por sua vez, parece não ser anterior à época helenística. 


\section{BIBLIOGRAFIA}


(Página deixada propositadamente em branco) 


\section{a) EDIÇÕES*}

\section{ANACREONTE E «ANACREONTEA»}

Anacreontis Teii Odae, ab HENRICO STEPHANO luce et Latinitate nunc primum donatae. Lutetiae, apud Henricum Stephanum, MDLIIII.

Anacreontis Teii Carmina ex recensione W. BAXTER. Editio altera. Londinii Augustae. A. D. 1710.

Anacréon. Traduction et étude par F. MATTHEWS. Phototypies du manuscrit et de la reproduction de Spaletti. Paris, Presses Universitaires de France, 1927.

Anacreonte, Odi Scelte. A cura di C. O. ZURETTI. Collezione di Classici Greci e Latini. Chiantore-Torino, 1944.

Anacreon. Edidit BRUNO GENTILI. Romae, in aedibus Athenaei, 1958.

\section{ARISTÓFANES}

Aristophanes. The Frogs. With introduction and notes by W. W. MERRY, Oxford, at the Clarendon Press. Fifth edition, 1947.

Aristophanes, Frösche. Einleitung, Text und Kommentar von LUDWIG RADERMACHER. Oesterreichische Akademie der Wissenschaften. Philosophisch-historische Klasse. Zweite Auflage. Wien, 1954.

Aristophanes. The Frogs. Edited with introduction, revised text, commentary and index by W. B. STANFORD. London, Macmillan \& Co. Ltd., 1958.

* Para abreviar, omitimos a referência às edições da Colecção Teubner, Oxoniense e Budé, que foram consultadas, sempre que existiam. 
Die Frösche des Aristophanes. Mit ausgewählten antiken Scholien herausgegeben, von W. SUESS. Kleine Texte für Vorlesungen und Uebungen, 66. Unveränderter Neudruck. Berlin, Verlag von Walter de Gruyter \& Co., 1935.

\section{ATENEIO}

Athenaeus, The Deipnosophists, with an English translation by CHARLES BURTON GULICK in 7 vols. Loeb Classical Library, London, Heinemann, repr. 1950-1957.

\section{CALÍMACO}

Callimachus. Edidit RUDOLFUS PFEIFFER. Oxford, at the Clarendon Press. Vol. I, Fragmenta, 1949. Vol. II, Hymni et Epigrammata, 1953.

\section{Cómicos (Fragmentos)}

Comicorum Atticorum Fragmenta ed. TH. KOCK, Lipsiae, Teubner, 1880, 3 vols. Poetarum Comicorum Graecorum. Fragmenta post A. MEINEKE recognouit et Latine transtulit FRID. HENRICUS BOTHE, Parisiis, Firmin-Didot, 1855.

\section{ELEGÍACOS}

Líricos Griegos. Elegiacos y yambógrafos arcaicos. Texto y traduction por FRANCISCO R. ADRADOS. Colección Hispánica de Autores Griegos y Latinos. Barcelona, Alma Mater. Vol. I, 1956. Vol. II, 1959.

\section{ÉSQUILO}

Aeschylus, Agamemnon. Edited with a Commentary by EDUARD FRAENKEL. Oxford, at the Clarendon Press, 1950, 3 vols.

Aeschylus, Eumenides. With introduction and notes by A. SIDGWICK. Second Edition. Oxford, at the Clarendon Press, 1895. 
The Persae of Aeschylus. Edited with introduction, critical notes and commentary by H. D. BROADHEAD. Cambridge, at the University Press, 1960. The Prometheus Vinctus of Aeschylus. With introduction and critical and explanatory notes by E. E. SIKES and ST. J. B. WYNNE WILLSON. London, Macmillan and Co., Limited, 1898.

\section{ESTOBEU}

Ioannis Stobaei Anthologium. Recensuerunt CURTIUS WACHSMUTH et OTTO HENSE. Editio altera. Berolini apud Weidmannos, 1958. 5 vols.

\section{EURÍPIDES}

Euripides, Bacchae. Edited with introduction and commentary by E. R. DODDS. The Plays of Euripides. Oxford University Press, second edition, 1960.

\section{FILÓsofos (Fragmentos)}

HERMANN DIELS, Die Fragmente der Vorsokratiker. 6. Verbesserte Auflage herausgegeben von WALTHER KRANZ. Berlin, Weidmannsche Verlagsbuchhandlung, 1951, 3 vols.

\section{HEFÉSTION}

Hephaestionis Alexandrini Enchiridion iterum edidit THOMAS GAISFORD. Oxonii, 1855, 2 vols.

\section{HESÍODO E PSEUDO-HESÍODO}

FELIX JACOBY, Hesiodi Carmina Pars I. Theogonia. Berolini apud Weidmannos, 1930. Hesiodi Scutum a cura di CARLO F. RUSSO. Biblioteca di Studi Superiori. La Nuova Italia Editrice, Firenze, 1950. 


\section{HINOS HOMÉRICOS}

T. W. AlLEN, W. R. HALLIDAY, E. E. SIKES, The Homeric Hymns. Second edition. Oxford, at the Clarendon Press, 1936.

HOMERO

Homeri Odyssea recognouit P. VON DER MUEHLL. Editiones Helueticae. Basileae, in aedibus Helbing \& Lichtenhahn, 1946.

\section{IAMBÓGRAFOS}

Líricos griegos. Elegiacos y yambógrafos arcaicos. Texto y traduccion por FRANCISCO R. ADRADOS. Colección Hispánica de Autores Griegos y Latinos. Barcelona, Alma Mater. Vol. I, 1956. Vol. II, 1959.

\section{LÍRICOS (Excepto Anacreonte)}

Poetae Lyrici Graeci. Quartis curis recensait THEODORUS BERGK. Lipsiae, in aedibus B. G. Teubneri. Vol. II, 1915. Vol. Ill, 1882.

J. M. EDMONDS, Lyra Graeca. Loeb Classical Library, revised and augmented edition. London, Heinemann, 3 vols. 1952.

Poetarum Lesbiorum Fragmenta ediderunt EDGAR LOBEL et DENYS PAGE. Oxford, at the Clarendon Press, 1955.

Alcman: The Partheneion. By DENYS L. PAGE. Oxford, at the Clarendon Press, 1951.

Alcmane, I Frammenti. Testo critico, traduzione, commentario a cura di ANTONIO GARZYA. Hermes, Collana di Testi Antichi, 4. Napoli, Casa Editrice Dr. Silvio Viti, [1954].

Bacchylides. The Poems and Fragments. Edited with introduction, notes and prose tanslation by Sir RICHARD JEBB. Cambridge, at the University Press, 1905.

Pindari Carmina cum Fragmentis edidit ALEXANDER TURYN. Academia Polona Litterarum et Scientiarum, Cracoviae, 1948. 
A. ColonNA, L' Antica Lirica Greca. Torino, S. Lattes \& Co. Editori. Terza edizione riveduta, 1956.

B. LAVAGNINI, Aglaia. Nuova Antologia della lirica greca da Callino a Bacchilide. Torino, G. B. Paravia \& Co. Terza edizione, nona ristampa, s. a.

F. M. PONTANI, Pleiadi. Frammenti di Lirica Greca. Convivium, Collana di Autori Greci e Latini. Roma, Casa Editrice Gismondi, [1952].

\section{LUCIANO}

Lucianus ab IMMANUELE BEKKERO recognitus. Lipsiae, F. A. Brockhaus, 1853, 2 vols.

\section{PAPIROS}

E. LOBEL and C. H. ROBERTS, The Oxyrhinchus Papyri, Part XXII. London, Egypt Exploration Society, 1954.

\section{PAUSÂNIAS}

H. HITZIG und H. BLUEMNER, Pausaniae Graeciae Descriptio. Berolini, apud S. Calvary \& Co. 1896.6 vols.

Pausanias, Description of Greece, with an English translation by W. H. S. JONES. Loeb Classical Library, London, Heinemann, 4 vols., 1959-1961.

\section{PLATÃO}

Plato, Gorgias. A Revised Text with Introduction by E. R. DODDS. Oxford, at the Clarendon Press, 1959.

\section{PLUTARCO}

Plutarchi Chaeronensis Scripta Moralia. Ed. FRIDERICUS DUEBNER. Parisiis, Firmin-Didot, 1841-1844, 3 vols. 
Plutarch's Moralia with an English translation by HARDY CHERNISS and WILLIAM C. HELMBOLD in 15 vols. Loeb Classical Library, London, Heinemann, 1957. Vols. I-XII.

\section{SEXTO EMPÍRICO}

Sextus Empiricus with an English translation by R. G. BURY, in 4 vols. Loeb Classical Library, London, Heinemann, 1953.

\section{TEÓCRITO}

Theocritus edited with a translation and commentary by A. S. F. GOW. Cambridge University Press, 1950. 2 vols.

\section{TRÁGICOS (Fragmentos)}

A. NAUCK, Tragicorum Graecorum Fragmenta. Editio secunda. Lipsiae, in aedibus B. G. Teubneri, 1889. 


\section{b) ESTUDOS}

A. BARIGAZZI, «Sul nuovo Anacreonte» in Athenaeum, N. S., Vol. XXXIV, fasc. I -II, 1956, pp. 139-151.

G. BERNHARDY, Grundriss der griechischen Literatur. Mit einem vergleichenden Ueberblick der Römischen. Zweite Bearbeitung. Zweiter Teil: Geschichte der griechischen Poesie. Erste Abteilung: Epos, Elegie, Iamben, Melik. Halle, 1856.

E. BETHE, Die griechische Poesie. In Einleitung in die Altertumswissenschaft von A. GERCKE und E. NORDEN. Leipzig, Teubner, 1910.

C. M. BOWRA, Early Greek Elegists. Second edition. Heffer Series, Cambrige, 1960.

_—, Greek Lyric Poetry. Second edition. Oxford, at Clarendon Press, 1961.

—_, Problems in Greek Poetry. Oxford, at the Clarendon Press, 1953.

O. CRUSIUS, Anakreon in PAULY WISSOWA, I, 2, Stuttgart, (1894), Sp. 2035-50.

A. M. DALE, The Lyric Metres of Greek Drama. Cambridge, at the University Press, 1948.

——, «Greek Metric 1936-1957» in Lustrum, Band II, Göttingen, 1957, pp. 5-51.

E. R. DODDS, The Greeks and the Irrational. Sather Classical Lectures. University of California, 1951.

H. DUENTZER, «Ueber die mutmassliche Entstehung unserer Sammlung der sogenannten Anacreontea» in Zeitschrift für die Altertumswissenschaft, 1836, Nr. 94, 3, Sp. 754-760. 
G. ETTIG, «Acheruntica siue Descensuum apud Veteres Enarratio» in Leipziger Studien, XIII, 1891, pp. 251-410.

G. S. FARNELL, Greek Lyric Poetry. London, Longmans, Green \& Co. 1891.

A. FICK, «Die Sprachform der altionischen und altattischen Lyrik» in Beiträge zur Kunde der indogermanischen Sprachen herausgegeben von Dr. Adalbert Bezzenberger, XI, 1886, pp. 242-272; XIII, 1888, pp. 173-221.

EDUARD FRAENKEL, Horace. Oxford, at the Clarendon Press, 1957.

HERMANN FRÄNKEL, «Eine Stileigenheit der frühgriechischen Literatur» in Nachrichten von der Gesellschaft der Wissenschaften zu Göttingen, Philologisch-Historische Klasse, 1924, Heft 1, pp. 63-103. Heft 2, pp. 105-127.

-_, Dichtung und Philosophie des frühen Griechentums. Philological Monographs published by the American Philological Association. New York, 1951.

- - Wege und Formen frühgriechischen Denkens. Literarische und philosophiegeschichtliche Studien. München, Beck. Erste Auflage, 1955. Zweite Auflage, 1960.

M. FERNÁNDEZ GALIANO, «Los problemas de autenticidad en la literatura griega» in Revista de la Universidad de Madrid, vol. I, nº 2, 1952, pp. 213-238.

CARLO GALLAVOTTI, «Anacreonte e la chioma recisa» in La Parola del Passato, fasc. XL, Gennaio-Febbraio 1955, pp. 41-47.

- - «Un restauro d' Anacreonte» in La Parola del Passato, fasc. XL, Gennaio-Febbraio 1955, pp. 47-50.

B. GENTILI, Metrica Greca Arcaica. Messina-Firenze, Casa Editrice G. D’Anna, 1950.

——, La metrica dei Greci. Messina-Firenze, Casa Editrice G. D.'Anna, 1952.

W. H. GRUNDIG, De inferorum in Graeca comoedia partibus. Diss. Leipzig. Estr. in Jahrbuch der philosophischen Fakultät zu Leipzig, 1921, pp. 23-26.

G. HAFNER, «Anakreon und Xanthippos» in Jahrbuch des Deutschen Archäologischen Instituts, Band 71, 1956, pp. 1-28.

FRIDERICUS HANSSEN, « Quaestiuncula Pseudoanacreontica» in Commentationes Philologae quibus Ottoni Ribbeckio... congratulantur discipuli Lipsienses. Lipsiae in aedibus B. G. Teubneri, 1888.

W. R. HARDIE, Res Metrica. An Introduction to the Study of Greek and Roman Versification. Oxford University Press, 1934. 
A. E. .HARVEY, «The Classification of Greek Lyric Poetry» in The Classical Quarterly, N. S., Vol. 5, n. 3-4, 1955, pp. 157-175.

- - «Homeric Epithets in Greek Lyric Poetry» in The Classical Quarterly, N. S., Vol. 7, n. ${ }^{3}-4,1957$, pp. 206-223.

F. J. HOLLY, Quaestiones Anacreonteae. Diss. Erlangen. Marburgi, 1885.

JEAN IRIGOIN, Recherches sur les mètres de la lyrique chorale grecque. La structure du vers. Paris, Librairie C. Klincksieck, 1953.

- - «La structure des vers éoliens» in L'Antiquité Classique, tome XXV, fasc. 1, 1956, pp. 5-19.

- - «Colon, vers et strophe dans la lyrique monodique grecque» in $R e$ vue de Philologie, de Littérature et d'Histoire Anciennes, $3^{e}$ Série, Tome XXXI, Fasc. 2, 1957, pp. 234-238.

GEORG IWANOWITSCH, Opiniones Homeri et Tragicorum Graecorum de Inferis per Comparationem Excussae. Diss. Erlangen. Berolini, 1894.

WERNER JAEGER, Paideia. Die Formung des griechischen Menschen. Berlin, Walter de Gruyter, dritte Auflage, Band I, 1954.

C. M. KAUFMANN, Die Jenseitshoffnungen der Griechen und Römer nach den Sepulcralinschriften. Ein Beitrag zur monumentalen Eschatologie. Freiburg in Breisgau, Herdersche Verlagsbuchhandlung, 1897.

T. KEHRHAHN, «Anacreontea» in Hermes, 1914, pp. 481-507.

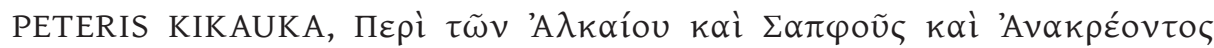

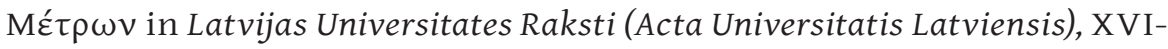
II, Riga, 1928, pp. 3-52.

_—_, «Mètres de la poésie grecque monodique» in Latvijas Universitates Raksti (Acta Universitatis Latviensis). Series Nova, II, Riga, 1931-1933, pp. 1-192.

G. S. KIRK and J. RAVEN, The Presocratic Philosophers, Cambridge University Press, 1957.

W. J. W. KOSTER, Traité de métrique grecque suivi d'un précis de métrique latine. Deuxième édition. Leyde, A. W. Sijthoff, 1953.

J. KROLL, Gott und Höhle. Der Mythus vom Descensuskampfe. Leipzig, Teubner, 1932. GIULIANA LANATA, «La Poetica dei lirici greci arcaici» in Antidoron Hugoni 
Henrico Paoli oblatum. Istituto di Filologia Classica, Facoltà di Lettere, Università di Genova, 1956, pp. 168-182.

R. LATTIMORE, Themes in Greek and Roman Epitaphs. Illinois Studies in Language and Literature, vol. 28. Urbana, 1942.

K. LEHRS, «Vorstellungen der Griechen über das Fortleben nach dem Tode» in Populäre Aufsätze aus dem Altertum, Leipzig Teubner, 1875, pp. 303-362.

A. LESKY, Geschichte der griechischen Literatur. Bern, A. Francke Verlag, 1958.

PAUL MAAS, Griechische Metrik in Einleitung in die Altertumswissenschaft, herausgegeben von ALFRED GERCKE und EDUARD NORDEN. 3. Auflage, Leipzig, Teubner, 1927.

_—_, «Anakreon und Ibykos» in Acme, VIII, 2-3, 1955, pp. 113-114.

EMILE MARTIN, Essai sur les rythmes de la Chanson Grecque Antique. Paris, Librairie C. Klincksieck, 1953.

J. MARTIN, compte-rendu de GENTILI, Anacreon, in Revue des Etudes Grecques, LXXIII, N. ${ }^{\circ}$ 344-346, Janvier-Juin 1960, pp. 273-274.

M. TH.- H. MARTIN, «Traditions Homériques et Hésiodiques sur le Séjour des Morts» in Annuaire de L'Association pour l'Encouragement des Etudes Grecques en France, XII, 1878, pp. 1-27.

F. MARTINAZZOLI, Ethos ed eros nella poesia greca. La Nuova Italia Editrice. Biblioteca di Cultura, 27. Firenze, s. a.

JEAN MONNIER, La Descente aux Enfers. Etude de Pensée Religieuse, d'Art et de Littérature. Thèse... Paris, 1904.

M. P. NILSSON, Geschichte der griechischen Religion. Handbuch der Altertumswissenschaft herausgegeben von WALTER OTTO. C. H. Beck'sche Verlagsbuchhandlung. Müchen, I. Band, 1941; II. Band, 1950.

ANTONIUS FRIDERICUS OZANAM, De Frequenti apud Veteres Poetas Heroum ad Inferos Descensu. Theses... Parisiis, 1839.

DENYS PAGE, Sappho and Alcaeus. An Introduction to the Study of Ancient Lesbian Poetry. Oxford, at the Clarendon Press, 1955

- - , review of GENTILI, Anacreon in The Classical Review, N. S., vol. IX, n. ${ }^{\circ}$ 3, December 1959, pp. 234-237. 
G. PERROTTA, Storia delta Letteratura Greca, Milano 1956, seconda edizione, 3 vols.

RUDOLF PFEIFFER, «Gottheit und Individuum in der frühgriechischen Lyrik» in Ausgewählte Schriften, München, Beck, 1960, pp. 42-54.

CH. PICARD, "Art et Littérature: Sur trois exégèses» in Revue des Etudes Grecques, LXI, n. ${ }^{\circ} 286-288,1948$, pp. 337-357.

L. MASSA POSITANO, «Note ai lirici greci» in La Parola del Passato, I, 1946, pp. 347-372.

L. RADERMACHER, Das Jenseits im Mythos der Hellenen. Untersuchungen über antiken Jenseitsglauben. Bonn, A. Marcus und E. Weber‘s Verlag, 1903.

AMÉRICO DA COSTA RAMALHO, $\Delta \imath \pi \lambda \tilde{\alpha}$ 'Ovó $\mu \alpha \tau \alpha$ no estilo de Aristófanes, Faculdade de Letras, Instituto de Estudos Clássicos, Coimbra, 1952.

G. M. A. RICHTER, Attic Red-Figured Vases. A Survey. New Haven, 1946.

- - Greek Portraits. II. To what extent were they faithful likenesses? Bruxelles, Collection Latomus, XXXVI, 1959.

A. DE RIDDER, L'Idée de la Mort en Grèce à l'Epoque Classique. Thèse. Paris, 1896.

E. ROHDE, Psyche, Seelencult und Unsterblichkeitslehre der Griechen. 9. und 10. Auflage mit einer Einführung von Otto Weinreich. Tübingen, J. C. B. Mohr (Paul Siebeck), 1925.

K. RUPPRECHT, Einführung in die griechische Metrik, 3. Vollständig umgearbeitete Auflage, Max Hueber Verlag, München, 1950.

W. SCHADEWALDT, «Lebenszeit und Greisenalter im frühen Griechentum» in Die Antike, 9, 1933, pp. 282-303.

K. SCHEFOLD» Die Bildnisse der antiken Dichter, Redner und Denker. Benno Schwabe \& Co. Verlag, Basel, 1943.

O. SCHROEDER, Grundriss der griechischen Versgeschichte. Carl Winter Universitätsbuchhandlung. Heidelberg, 1930.

BRUNO SNELL, Die Entdeckung des Geistes. Studien zur Entstehung des Europäischen Denkens bei den Griechen. Hamburg, Claassen Verlag. Dritte Auflage, 1955.

_—, Griechische Metrik. Göttingen, VandenHoeck und Ruprecht, 1955.

F. SOLMSEN, «Chaos and Apeiron». Estratto dagli Studi Iatliani di Filologia Classica, N. S., Vol. XXIV, fasc. 3-4. Firenze, Felice Le Monnier, 1950. 
CAROLUS BERNHARDUS STARK, Quaestionum Anacreonticarum Libri Duo. Lipsiae apud Voigt et Fernan, 1846.

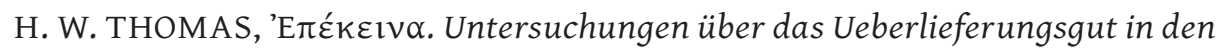
Jenseitsmythen Platons. Diss. München, 1938.

M. TREU, Von Homer zur Lyrik. München, Beck, 1955.

B. A. VAN GRONINGEN, La Composition Littéraire Archaïque Grecque. Procédés et Réalisations. N. V. Noord-Hollandsche Uitgevers Maatschappij. Amsterdam. Deuxième édition, 1960.

CARLOS SIMÕES VENTURA, «A significação de $\pi \varepsilon \tau \alpha \sigma \theta \varepsilon i ́ \varsigma$ numa ode anacreôntica» in Humanitas, IV, 1952, pp. 43-59.

PETER VON DER MÜHLL, Kritisches Hypomnema zur Ilias, Schweizerische Beiträge zur Altertumswissenschaft, Heft 4. Basel, Verlag Friedrich Reinhardt, AG, 1952.

L. WEBER, Anacreontea. Diss. Gottingae, 1892.

C. WELCKER, «Alcmanis fragmentum de Tantalo» in Rheinisches Museum, 1856, pp. 242-254.

G. H, C. WIEDEMANN, Quaestionis de antiquitate carminum Anacreonteorum Particula I. Petropoli, 1843.

U. VON WILAMOWITZ-MOELLENDORF, Der Glaube der Hellenen. [Neuer Druck], Basel, Benno Schwabe \&. Co. Verlag, 1956. 2 vols.

-_, Griechische Verskunst. Zweite unveränderte Auflage, Hermann Gentner Verlag, Darmstadt, 1958.

_- Isyllos von Epidauros. Philologische Untersuchungen, Berlin, Weidmannsche Buchhandlung, 1886.

- - Sappho und Simonides. Untersuchungen über griechische Lyriker. Berlin, Weidmannsche Buchhandlung, 1913. 


\section{ÍNDICE DE AUTORES \\ CONCEPÇÕES HELÉNICAS \\ DE FELICIDADE NO ALÉM \\ DE HOMERO A PLATÃO}


(Página deixada propositadamente em branco) 
Os números em itálico indicam as páginas.

\section{A) Antigos}

Aithiopis uide Cíclicos (poemas).

Alceu, Frgs. Bergk, 1, 34 e n.6; 2, 34 e $n$. $6 ; 4,34$ e n. $6 ; 48 \mathrm{~B}, 30 ; 32 ; 82,53, n .3$. Álcman, Frg. 87 Bergk, 48, n. 7. Anaxágoras, 67, n. 3. Anaxímenes, Frg. 2, 59, n. 1. Andócides, De Mysteriis, 31, 40, n. 3. Anthologia Palatina, App. Noua,461, 30, n. 1.

Apolodoro, Epitome, V, 5, 33. Pseudo-Apolodoro, 2, 5, 11, 38 e n. 3. Apolodoro Tarsense, 122, n. 4.

Apolónio de Rodes, Argonautica, IV, 811 seqq., 33 e n. 4; IV, 1396

seqq., 37, n. 3.

Schol. Apol. Rhod., Argon., IV, 811 seqq., 33 e n. 4; 1396, 37 e n. 3.

Arato, 102.

Aristarco, 112; 101; 122, n. 4.

Aristeas, Frgs. Kinkel 5, 34, e n. 5; 6, 34, e $n .5 ; 7,34$, e n. 5 .

Aristides 22, 10 Keil, 44 e n. 3.

Aristófanes, 57; 121-126; 140; 151; 155.

Equites, 1151, 57, n. 1; 122, n. 2.

Lysistrata, 41, n. 4.

Nubes, 271, 37.

Pax, 374-375, 44, n. 1; 832-834, 57.

Ranae, $65 ; 66 ; 80$, n. 4 ; 121-126; 148;

152; 156; 83, 122, n. 2; 84, 122, n. 2; 85, 57;

122, n. 2; 121-126; 145-146, 43; 145-151, 44; $145-154,123 ; 146-150,51 ; 154,123 ; 148$, n. $4 ; 155,148$, n. $7 ; 156,123 ; 157,123 ; 161$, $125 ; 162-163,125 ; 180,123 ; 186,125 ; 134$; 271-459, 123; 273, 43; 273-276, 44; 274-
275,$51 ; 313,148, n .4 ; 320,123 ; 148, n .4$; 326,$130 ; 324-336,112$ e $n .2 ; 326,124 ; 148$, n. $6 ; 330,123 ; 336,122, n .2 ; 123 ; 148$, n. 5 ; $337-338,122 ; 338,122, n .2 ; 340,123 ; 124$, n. $1 ; 148$, n. $7 ; 342,124$, n. $1 ; 148$, n. $7 ; 343$, 148, n. $6 ; 148$, n. $7 ; 344,124$ e n. $1 ; 130 ; 351$, 124, n. $1 ; 148$, n. $7 ; 352,124 ; 148$, n. $6 ; 354$, $123 ; 148$, n. $5 ; 356,123 ; 357,80 ; 370,123$; 148, n. $4 ; 148$, n. 5; 373-374, 124; 130; 148 , n. $6 ; 379,123 ; 148$, n. $4 ; 382,123$, n. $4 ; 148$; $382-386,122 ; 383,123$, n. $4 ; 148 ; 386,148$, n. $5 ; 388,123 ; 148$, n. $5 ; 392,123 ; 396,123$; $148, n .4$ e $n .5 ; 407,123 ; 415,123 ; 434-436$, $125 ; 441,124 ; 148$, n. $6 ; 442,123 ; 448-449$, $124 ; 130 ; 148$, n. $6 ; 407,148$, n. $5 ; 415,148$, n. $5 ; 452,123 ; 454-455,124 ; 148$, n. $7 ; 1032$, 48, n. 1 . Vespae, 639-640, 30; 57; 110, n. 2; 122, n. 2;

Gerytades, 121.

Frg. 488 Kock, 28, n. 3; 56 e n. 1.

Schol. Ranae, 122, n. 2;

Aristofonte, C. G. F., III, 364 (Meineke), 50 e n. $6 ; 51$.

Aristóteles, 47.

Anal. Post. B. 11.94 b 33, 51; 69 e n. 7; 78 e $n .5$.

Meteor. II. 2.355b 32 seqq., 68.

Peplus Aristoteleus 3, 91 e n. 2.

Frg. 185 Rose, 78 e n. 6. Aristóxeno, Frg. 26 Wehrli, 50, n. 2. Arquitas, 67, n. 3. Arriano, 398, 32, 32, n. 7. Ásio Sâmio, Frg. Diehl, v 4, 43 e n. 3. 
Ateneu, 11.462c, 118-119, n. 5.

Baquílides, Ode III, 58-62, 35-36; 118, $n$. 5; 53, n. 3 ; V, 56-175, 53, n. 3 .

Calcídio, in Tim. 79, p. 143, 17 Wr., 53, n. 2. Calímaco, Hymn. III, 164, 37 e n. 6.

Calino, Frg. 1, 12-13 Diehl, 28, n. 2; 53, n. 3; Cássio Hermina, Non s. u. lacte, p. 483 (= Peter, Fr. H. R. 36), 78.

Cíclicos (poemas) Aithiopis, 30; 32; 33; Epigoni, 34. Minyas, 21, 24, n. 6. Telegoneia, 32; 38;

Clemente Alexandrino, Strom. III, 518, 39, n. 1.

Cónon, Narrationes 18, 32, n. 3.

Cornuto, 41, n. 1.

Cratino, Archilocus, 80. Chiron, 80.

Demóstenes, XVIII, 127, 65, n. 7.

Dídimo in Ol. II, 112.

Diodoro, 93; I, 96, 66; V, 28, 78, n. 3.

Diógenes de Apolónia, 67, n. 3.

Diógenes Laércio, VIII, 1, 14, 52 e n. 2; 78 e $n .4 ; 17-18,78, n .1 ; 21,50, n .4 ; 28,59, n$. $1 ; 38,50$, n. $6 ; 42$.

Dioscórides, 118.

Eliano, Var. Hist. IV, 17 = VS. 58 (45) C 2, 69 e n. 8.

Élio Aristides, Or. Aegyptius 112 (II, p. 298, 21 Keil), 108, n. 1.

Empédocles, Katharmoi, 51-53; 69, n. 4; 71, 72; Frgs. Diels 24, 59, n. $1 ; 115,52, n$. $1 ; 69$, n. $4 ; 71$ e $n .3 ; 117,52 ; 69$, n. $6 ; 121$, 52; 70; 128, 53; 118-119, n. 5; 129, 51; 132, 2,$52 ; 135,2,52$.

Epicuro, III, 124, 53, n. 1.

Epígenes, 47; 50, n. 1;

Epigoni uide Cíclicos (poemas).

Epigrammata Graeca uide Inscrições.

Ésquilo, 58, n. 5; 64. Agam. 1160-1161, 117.

Eumenides, 273-275, 49; 339-340, 49

e n. $4 ; 385-387,43 ; 396,116$, n. 2.

Suppl. 228-231, 49; 414-416, 49.

Prom. Lyom. Apud Strab. 4 p. 183, 37.

P. Oxyr. 2256.9 (a), 49, n. 3.
Estrabão, 4, 183, 37; 7, 91, 110, n. 2; 8, 363, 126.

Etymologicon Magnum, 27.

Êpolis, Demoi, 121.

Eurípides, 57-58; 110. Alc. 359, 58; 743-746, 58; 851-853, 58.

Andr. 1260-1262, 31; 32; 33.

Bacchae 81; 72-77, 128, n. 2; 1338-1339, 58;

109, n. 4.

Cyclops 273-274, 65, n. 7.

Electra 59, 57; 122-123, 58, n. 3; 142-144,

58, n. $3 ; 677,58$, n. 3.

Hec. 67, 27-28, n. 9.

Hel. 1015-1016, 57; 1616-1677, 58; 1677,

109.

Her. 394-399, 37, n. 3; 613, 125, n.1; 1041, 27-28, n. 9.

Hippol. 190, 58; 191-197, 58; 742-751, 37;

829,58, n. $3 ; 952,48$, n. $2 ; 1366-1367,58$,

n. $3 ; 1386,58$, n. $3 ; 1388,58$, n. 3.

Ion $1273-1274,58$, n. 3.

Iph. Taur.158-159, 58, n. 3; 184-185, 58, n. $3 ; 435-438,31 ; 32,33$.

Medea 119-130, 58.

Orestes 1086-1087, 57.

Phoin. 844, 27-28, n. 9.

Suppl. 531-536, 57; 1140-1142, 57-58.

Peirithoos, 121, n. 1.

Frgs. Nauck 506, 49, n. 3; 533, 58, n.3; 534, 58, n. 3; 638, 58; 833, 58; 839, 57; 971, 57.

Schol. Eur., Andr., 229, 32, n.1.

Eustátio ad Dionys. Perieg. 306, 31, n. 1.

Comment. ad Odysseam, 1549, 110, n. $2 ; 1696,45,32$ e $n .7$.

Ferécides, Frg. 33, 37 e n. 5.

Ferécrates, Crapatali, 121.

Metalles Frg. 108 Kock, 57; 121.

Persae, Frg. 130 Kock, 57.

Filémon (?), C. F. G. IV, 67 Meineke, 54, n. $3 ; 64$, n. 2 .

Filóstrato, Heroica, III, 26, 31, n. 2; 32 e n. $1 ; 34$.

Frinico, Musae, 121.

Gregório Coríntio, Dial. Dor. 34, 102, n. 3.

Hérmias Alexandrino, in Plat. Phaedr. 248E Couvreur, 104, n. 1. 
Heródoto, I, 86-88, 36, n. 2; II, 122-123, 116, n. 4; 123, 71, n. 3; III, 26, 110, n. 2; IV, $13,34, n .5 ; 16,34, n .5 ; 32,34$ e n. 3 ; 3235,34 e $n .7 ; 33-35,36, n .1$;

Hesíodo, 28-30; 34; 37; 57; 91-97; 137-138, n. $1 ; 140 ; 147 ; 151$.

Theogonia, 45, 77, n. 2; 105-106, 77, $n$. 2; 215, 36; 215-216, 36, n. 4; 37; 96, n. 1; 215-217, 36, n. 4; 274, 36; 274-275, 36, n. 4; 96, n. 1; 275, 37; 96, n. 1; 513, 96, n. 1; 517-519, 96, n. 1; 517-520, 36, n. 4; 518, $36 ; 37 ; 96, n .1 ; 720$ seqq., 106 e $n .1 ; 726-$ 728,$106 ; 732-733,106 ; 736$ seqq., 106; 744757, 96, n. $1 ; 850-851,105 ; 851,95$ e $n .1$. Op. et D., 41, 129, n. 1; 42-44, 92; 90-92, 93; 106-201, 92-94; 109-126; 93; 95; 112, 93, 96; 113, 93; 113-114, 93; 115, 93; 94; 116-117, 93; 117, 94; 118, 94; 122-123, 97; 135-142, 29; 136, 29; 139, 29; 141, 29; 97; 153-155, 97; 161-163, 97; 164-165, 97; 167, $28 ; 96$ e n. $2 ; 97 ; 146, n .1 ; 167-173,28-30$; 91-97; 146; 168, 35; 91; 96; 146, n. $1 ; 169$, 29, n. $2 ; 94-95 ; 97$, n. $1 ; 106 ; 169^{\mathrm{b}}, 95 ; 169^{\mathrm{b}-\mathrm{e}}$, 94-95; 169c-e $95 ; 170,92 ; 93 ; 96 ; 97 ; 146, n$. 4; 171, 29; 92; 95; 96; 146, n. 2; 172, 28; 92; 172-173, 92; 146, n. 3; 95; 97; 225-237, 92; 96; 228, 96; 238-247, 92.

Schol. Procl. O. Et D. 169, 95; 97, n. 1.

Hesíquio, 25; 27-28, n. 9 ; 41, n. 8.

Hiérocles ad C. Aur. 24 ad v. 54 seqq., 53, n. 2.

Hipócrates, 43.

Homero, 34, n. 1; 57; 89, n. 2; 91; 108; 128; $145 ; 151$.

Ilíada, $24 ; 25 ; 31 ; 54 ; 85 ; 86 ; 87 ; 116$, n. 3. A 44,$87 ; 402,86 ; 87$ e $n .8 ; 420,86 ; 499,86$; 530,$86 ; 87$ e $n .7 ; 532,86$; B $467,129, n .1$; 776, 114, n. 1; 783, 88, п. 1; Г 199, 85, n. 1; 276-280, 48; $128 ; 418,85$, n. 1 ; Е 367, 86; 87, n. $6 ; 399,87$, n. $8 ; 754,86 ; 868,86 ; 87$, n. $7 ; \Theta 13-16,105 ; 106 ; 25,87, n .5 ; 199,87$ e $n .8 ; 373,88 ; 406,88 ; 410,87$ e $n .8 ; 411$, 86; 420, 88; 443, 86; 87e n. 7; 477-481, 105; I 457,$49 ; 569,79, n .2 ; 79$, n. $2 ; \Lambda 77,87, n$. 4; N 243, 86; $\Xi 154,87$, n. 4; 200-204, 105; 106; 225, 87, n. 4; 273-274, 105; 321-322, 113; O 84, 86; 87e n. 6; 187-195, 66; 225, 87, n. $4 ; \Sigma 142,87$ e $n .8 ; 143,105 ; 186,86$; 616, 86; T 114, 87, n. 4; 258-260, 49; 128; Ү 5, 86; 22, 87, n. 4; $\Psi$ 69-81, 86; 72, 24 e $n$.
1; 103-104, 25; 103-107, 86; 104, 24, n. 2; $\Omega$ 121,$87 ; 615,88$, n. $1 ; 694,86 ; 87$, n. 8.

Schol. A 175, 49, n. 3.

Odisseia, 56, 86, 87, 88, 91, n. 2; 151. \& 102, $87 ; \beta 433,88 ; \gamma 135,88 ; \delta$ 561-569, 26-28; $29 ; 85-90 ; 96 ; 115 ; 145 ; 562-569,85 ; 563,88$; 145, n. 5; 564, 85, n. 1; 86; 96; 564 seqq., $113 ; 565,26 ; 90 ; 145$, n. $1 ; 565-568,85 ; 86$; 566,$89 ; 140 ; 145$, n. $2 ; 567-568,109 ; 145$, n. 3,$4 ; 567,89 ; 568,26 ; 89 ; 90 ; 569,85, n$. $1 ; 97 ; 805,26 ; \varepsilon 50,61$, n. $1 ; 55-74,88 ; 55$, 88 ; 64, 89; 65-67, 89; 68-69, 89; 70-71, 89; $72-73,89 ; 72,129$, n. $1 ; 122,26 ; 26$, n. 2 ; 334-335, 26, n. 2; $\zeta 86 ; 42-46,26 ; 86-88$; 96; 42-43, 88; 43-44, 89; 43, 89; 44, 86; 89; $44-45,90 ; 116 ; 46,93 ; 116 ; 47,89 ; 240,87$; $\eta 112-131,88-89 ; 112,88 ; 113 ; 88 ; 89 ; 114$, $89 ; 119,89 ; 122,89 ; 127,89 ; 129-131,89$; 323,$38 ; \theta 331,87 ; \kappa 307,87 ; 491,79, n$. 2; 521, 24 e $n .3 ; 534,79, n .2 ; 536,24$ e $n$. $3 ; 564,79, n .2 ; \lambda 64 ; 86 ; 117 ; 128 ; 29,24 \mathrm{e}$ n. $3 ; 47,79$, n. $2 ; 49,24$ e $n .3 ; 313-316,87$; 489-491, 24; 539, 66; 129-130 e $n .1 ; 568-$ 571, 48, n. 7; 601-603, 58 e n. $1 ; \mu$ 159, 129, n. $1 ; 337,87 ; 382-383,116, n .1 ; v 389,88$;

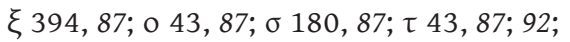
u 55,$87 ; 73,87 ; 102-105,87 ; \omega 13,66 ; 129$; 351,$87 ; 488,87$. Schol. $\delta$ 569, 26. Hinos Homéricos II, 39-45; 42, n. 4; 56; 141; 7, 129, n. 1; 480-482, 39 e n. $1 ; 40 ; 66$, n. 3; 91; 97; 122, n. 3; 141; III, 118, 129, n. 1; IV, 198, 129, n. 1; 221, 129, n. 1; 334, 129, n. 1; V, 29, 34 e n. 4; XIX, 25, 129, n. 1.

Hymni Orphici, 13, 1, 112-113, n. 3.

Íbico Frg. 10 A Bergk, 47 e n. 2. Apud Schol. Pind. Nem. X, 7, 32, Apud Schol. Apol. Rhod., Argon.,

IV, 811 seqq., 33, n. 4; 53.

Inscrições C. I. A., I, 442 = E. G. 21b, 1, 60.

C. I. A., I, $481=$ E. G. 16, 59.

C. I. A., I, 2449, 140, n. 2.

E. G. 16,$59 ; 21$ b, 1, 60; 41, 59, n. 1; 107, 60, n. $2 ; 159,61, n .1 ; 338,1-2,60$, n. 2; 414, 60, n. 2; 511, 60, n. 2; 618 a, 60, n. 2; 648, 60, n. 2;649, 30, n. $1 ; 60$, n. 2.

G. D. I. 5183, 41 e n. 6 .

I. G. 5 (1). 213.11, 41 e n. 5.

I. G. R. 4, 1579, 60, n. 2. 
S. I. G. 712.8, 41 e n. 6 .

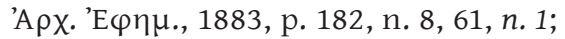
p. 146, n. 20, 60, n. 1.

Bulletin de Correspondance Hellénique, IV, 1880, pp. 177-180, 110, n. 1.

Kaibel in Rheinisches Museum, 34 (1879),

718 a, 3-4, 61, n. 1.

Kumn, n. 426, n. 16, 60, n. 1.

Preger n. 12, 61, n. 1 .

Test. Epict. 2, 7, 33, 41 e n. 7.

Lamellae Aureae, 48; 66; 74-81.

Collitz, Gr. Dial. Inschr. 4959ª, 76 e n. 2; 77-78.

Kaibel, I. G. XIV, 642, 76, n. 4; 77-78; 130.

I. G. S. I. 641, 1, 2, 3; 76, n. 5; 78; 638, 76 e n. $1 ; 77-79$.

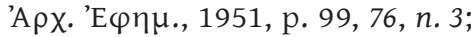
77-78.

Atene e Roma, VI (1903), pp. 161-

170, 76, n. 6; 77-79.

Olivieri, d, 76 e $n .7$.

Íon de Quios, 47; 50, n. 1.

Isócrates, Euagoras 15, 65.

Helena, 24, 37 e n. 4.

Panathenaicus, 205, 65, n. 7.

Jâmblico, Vita Pythagorea 28, 50, n. 1; 64 seq., $50, n .2 ; 82=$ V. S. 58 (45) C $4,58, n$. $2 ; 69$, n. $3 ; 110-114,50$, n. $2 ; 146-147,50, n$. 1; 155, 50, n. 5; 163 seqq., 50, n. 2; 178, 78, n. $3 ; 179,50$, n. 5 .

Lamellae aureaei uide Inscrições

Libânio I, 2, 471 Foerster, 41, n. 1.

Lícofron, 186-187, 32, n. 2; 187-191, 32, n. 2; 200-201, 32, n. 2.

Schol. 172, 33.

Luciano, 121.

Iup. Conf. 17, 30, n. 1.

De Mercede Conductis, 12, 49, n. 3.

Verae Histor. II, 14, 30, n. 1.

Lucrécio, III, 978-1023, 52-53 e n. 1.

Macróbio in Somn. Scip. I, 10, 9, seqq., 53, n. 1.

Marcelo Sidónio, E. G. Kaibel, 1046, 9, 95.

Mimnermo, Frgs. Diehl 2, 13-14, 53, n. 3; 10, 8-9, 37 e $n .2 ; 96, n .1$.
Minyas uide Cíclicos (poemas).

Moscópulo, 101, n. 3; 102 e n. 2; 130.

Olimpiodoro in Gorg. p. 221 Norvin, 66, n. 1.

in Phaed. p. 48, 20 Norvin, 44, n. 2; p. 58 Norvin, 66, n. 1; p. 91 Fickh, 104, n. 1.

ap. Phot. Bibl. 61 a Bekker, 110, n. 2.

Ovídio, Met., I, 168-171, 103.

Papiros P. G. Magicae IV, 1417, 65, n. 2.

P. Oxy. 2092, 113; 2256.9 (a), 49, n. 3. Pausânias, I. XXIV, 6, 34, n. 5; III, XIX, 11-13, 32, n.1, 3; 34; 107; VI, XIX, 8, 37, n. 3; X, XXV-XXXI, 44, n. 2; 61, n. 2; XXVIIIXXXI, 24, n. 6; XXXI, 9-11, 44, n. 2; 73, n. 2; 141, n. 1 .

Píndaro, 48; 53-59; 99-119; 146-147. Ol. I, 109; 107, n. 6; II, 54-56; 125; 12, 55, n. 1; 114; 56-83, 54-56; 99-119; 118, n. 5; 151-152; 56-70, 54-55; 99-103; 114; 56, 99; 57-60, 54-55; 100; 57, 99; 100-101; 58, 100-101; 59, 64; 100-101; 61-62, 54-55; 101; 57,$100 ; 101 ; 58,100 ; 58-60,64 ; 101 ; 61-62$, $55 ; 101 ; 146$, n. $5 ; 61-67,54 ; 100 ; 101 ; 146$; 62,$55 ; 101 ; 63,101-102 ; 63-65,146$, n. 6 ; 65,$103 ; 66,54 ; 101 ; 66-67,55 ; 146$, n. $7 ; 67$, $55 ; 100 ; 68-83,35 ; 36 ; 100 ; 147 ; 68-69,55$; 55-56; 69-70, 101; 69, 101; 70, 103-109; 114; 71-72, 109-110; 147, n. 1; 71-73, 54; 114-115; 72-73, 147, n. 2; 72, 118; 147, n. 3; 73, 147, n. 3; 74, 55; 110-112; 147, n. 4; 75, 113; 76, 113; 77, 113; 76-77, 105; 112-115; 79-80, 33; 79, 56; 79-83, 106; III, 14,118, n. 1; 16, 35, n. 2; 18, 118, n. 1; 23, 107, n. 6; 45, 102, n. 3; IV, 6, 107, n. 3; V, 17, 107, n. 6; VI, 29, 107, n. 4; 64, 107, n. 6; VII, 67, 107, n. 3; 69-74, 108; VIII, 21-23, 113; IX, 33-35, 107, n. 2; 56, 107, n. 4; X, 93, 102, n. 3.

Pyth. I, 15, 107; 16, 107; 71, 107, n. 3; II, 25, 107, n. 4; 73-75, 65, n. 7; 107; III, 57, 107, n. 3; IV, 23, 107, n. 3; 115, 107, n. 5; 291, 106; X, 29-46, 35 e n. 2 e 3; 118, n. 5; 30,$104 ; 107 ; 40,112, n .1 ; 46,35 ; 118, n .5$; XI, 21, 108.

Nem. I, 16, 107, n. 3; III, 24, 109; 29, 109; IV, 17, 111; 49-50, 31; 33, 106; IX, 19 , 107, n. 3; 28, 107, n. 3; X, 7, 32 e n. $8 ; 19-24$, $108 ; 76,107$, n. 3.

Isth. I, 66, 111; VI, 23, 35, n. 2; VIII, 21-24, 65; 57-60, 33; 66-67, 111. 
Paean IV, 44, 107; V, 37-45, 108; VI, 98-99, 33; VIII, (b) 1, 35, n. 2;

Frgs. Snell, 30 (6), 2, 104; 3-5, 103-104.

57, 112-113, n. 3;

129,$56 ; 115-119 ; 125 ; 130 ; 140 ; 1-2$, $116 ; 119 ; 140 ; 147-148 ; 151-152 ; 3-5,116 ; 147$, n. $6 ; 3,119 ; 148$, n. $1 ; 4,117 ; 119 ; 148$, n. 1 ; 5, 118; 148, n. $1 ; 6-7,116 ; 147$, n. 5; 7, 116; 117; 148, n. 3; 8, 117; 148, n. 2; 9-10, 117; 147, n. $5 ; 9,118 ; 148$, n. 1 .

133,$56 ; 71, n .3 ; 101$ e $n .5 ; 102$, n. 2. 137,$39 ; 40 ; 56 ; 115$, n. $2 ; 122$, n. 3. 140 a, 55, 102, n. 3.

144,114 .

$201,1,108$.

207, 107.

Schol. Ol. II, 61-62, 101 e $n .1 ; 65$, 102; 70, 104, n. 1; 70-71, 109; 74, 110; 7677, 112; III, 45, 102, n. 3; N. IV, 49-50, 32, n. $9 ; \mathrm{X}, 7,32$.

Platão, 48; 53; 63-73; 76; 81; 127-138; 139; $140 ; 145 ; 149-150 ; 152$.

Apol. 29B, 63; 40C, 63; 40E, 63; 65; 41A, 64; 127; 41A-C, 63; 41B, 63; 41C, 140.

Crat. 397E-398D, 29, n. 4; 97, n. 2; 398B-C, 128, n. 2; 400C, 48, n. 3; 403A, 64, n. 2; 404A, 105, n. 2; 404B, 127.

Crit. 112E-121C, 137, n. 1; 113A-B, 97, n. 3; 114D-115B, 137, n. 1; 117B, 137, n. 1; 120 seqq., 137, n. 1 .

Gorg. 493B-C, 73; 141; 523A-527E, 65; 66-67; 72; 128-130; 132, n. 2; 138; 149; 150; 523B, 129; 130; 149, n. 1, 2; 524A, 65 e n. $3 ; 66$, n. 3; 127; 129; 525C, 66, n. 3; 526C, 149, n. 1; 527A, 130; 527B, 130.

Leg. 713A-714B, 137, n. 1; 904B905B, 63; 959B, 64, n. 1 .

Menex. 235C, 30; 57; 63, n. 1; 110, n. 2; 127.

Meno 81A, 72, n. 2.

Phaedo 63B-C, 63; 69C, 44-45 e n. 1 ; 80D, 127; 107D, 65 e $n .4 ; 68 ; 131 ; 107 \mathrm{D}-\mathrm{E}$, 67; 107D-114C, 65; 67-68; 72; 131-133; 135; $138 ; 149-150 ; 152 ; 108 \mathrm{C}, 67 ; 131 ; 149 ; 108 \mathrm{C}-$ 110B, 149; 108D, 68; 109B, 149, n. 8; 109E, 131; 110르, 131; 110B, 131; 110B-D, 149, n. 7; 110C, 131; 149, n.8; 110D, 131; 149, n.3 . 5; 110D-E, 131; 110E, 131; 149, n. 8; 11A, 131; 149, n. 3, 4; 111B, 132; 149, n. 4, 6, 9; 111C, 132; 133; 149, n. 9; 111C-113D, 133; 112A,
68; 113A, 67; 113B, 68; 113C, 68; 113D, 132, n. 2; 114A, 67; 70; 114B, 70; 132; 114C, 67; 132; 150, n. 1, 2; 115D, 128.

Phaedrus 246A-257B, 66; 70-72; 135138; 140; 246D-247E, 135; 246E, 103; 247C, 135; 247D, 135; 247D-E, 135; 248B-249B, 71; 248B, 70; 71; 135; 136; 248C, 70; 248E-249B, 71, n. 3; 249A, 55; 71; 101; 249A-B, 65 e n. 6 ; 137; 249B, 150, n. 8; 249C, 72; 249C-256A; 136; 250B, 136; 150, n. 9; 250B-C, 136; 250C, 150, n. 3; 250C-D, 150, n. 9; 256D, 71; 150, n. 10; 256D-257A, 137; 257A, 71.

Politicus 269A-274E, 137, n. 1; 271D272B, 137-138, n. 1.

Rep. I, 330D, 54, n. 3; II, 363C-D, 51; 55; 57; 140, n. 3; 363C-E, 44 e n. 2; 112, n. 2; 364E, 47, n. 4; 364E-365A, 48 e n. 4; 386A387B, 25, n. 2; VI, 498C, 63; VII, 514A517B, 67, n. 2; 519C, 57, 63, n. 1; 110, n. 2; 127; 540B-C, 63 e n. $1 ; 110$, n. 2; 127; 540C, 128 , n. 2; X, 614A, 133; 614A-621D, 66; $68-70 ; 71 ; 72 ; 133-135 ; 138 ; 150 ; 614 \mathrm{~B}-621 \mathrm{~B}$, 133; 614C, 65, n. 5; 70; 133; 614D, 150, n.7; 614E, 70; 133; 615A, 71, n. 3; 135; 150, n. 4; 615E, 69; 70; 133; 616A, 70; 616B, 70; 133; 134; 150, n. 6; 617D-619E, 134; 619E, 134; 621A, 134; 135; 621B, 69; 134; 621C, 134; 621C-D, 133. Sympos. 179E-180B, 30; 33; 63, n. 1; 110, n. 2; 127; 210A, 136, n. 1.

Theaet. 176E, 63, n. 1.

Tim. 34B-40C, 70, n. 2; 42B, 128, n. 2. Schol. Olimp. Gorg. p. 221 Norvin, 66, n. 1; Phaed. 68C, p. 48, 20 Norvin, 44, n. 2; p. 58 Norvin, 66, n. 1; p. 91 Fickh, 104, n. 1 .

Herm. Alexandr. Phaedr. 248E Couvreur, 104, n. 1. Procl. in Timaeum III, 325 Diehl, 53, n. 2.

Pseudo-Platão, Axiocus 371A, 139; 371A-372A, 72-73; 139-141; 151; 371B, 73; 139; 371C, 151, n. 1, 2, 3; 371C-D, 151, n. 4; 371D, 73; 151,n. 5, 6; 372A, 141. Plínio, IV, 16, 32 e n. 4; XXI, 68, 129, n. 1. Plutarco, Moralia II, 21, 42, n. 6; Cons. ad Ap. 35, 120C, 56 e n. 1; 115; 117, n. 1.

De Is. et Osir. c. 12, 117, n. 4. Vita Sertorii VIII, 110. 
Pompónio Mela II, 98, 32 e $n .5$.

Porfírio, Vita Pythagorea 33, 50, n. 2.

Possidónio, 72.

Proclo, Chrest. Gramm. II, pp. 57-58

Kinkel, 30, n. 3.

Schol. Hes. Op. et D. 169, 94; 95; 97,

n. 1.

in Tim. III 325 Diehl, 53, n. 2.

Frg. 222 Kern, 66.

Quinto de Esmirna, IV, 769-779, 31; 770-

776, 31; XI, 224 seqq., 103, n. 1.

Safo, 114 .

V, 4, 11-13 Lobel, 125, n. 2.

Frg. 58 Diehl, 53, n. 3.

óstracon, 118-119, n. 5.

Séneca, Troades, 942-944, 33 e n. 5.

Simónides, Frg. 9, 3-5 Diehl, 53 e n. 4; 40

Bergk, 47 e n. 3; 41 Bergk, 47 e n. 3. apud Schol. Apol. Rod., Argon. IV,

811 seqq., 33, n. 4; 53.

Skolion de Harmódio e Aristogéi-

ton (Frg. 8 Bergk-Hiller), 30 e n. 2; 32;

33; 57; 110, n. 2; 128, n. 1 .

Sófocles, Oed. Col. 1606, 49.

Phil. 1440-1444, 58, n. 5.

Trach. 1099-1100, 37, n. 3.

Frags. Nauck, 297, 37; 668, 80; 753,

$39 ; 40 ; 42 ; 56 ; 58, n .5 ; 122$, n. 3.

Sólon, Frg. 26 Diehl, 97, n. 3.

Suidas, 25, 79.

Telegoneia uide Cíclicos (poemas)

Temístio, Or. XIII, 178, 53, n. 2.

Teo de Esmirna, p. 149, 4 Hiller, 53, n. 2.

Teógnis de Mégara, I, 701, 113, n. 1;

973-976, 117; 973-978, 53, n. 3; 1215-1216, 125, n. 2.

Thomas Magister, 102, n. 2.

Tirteu, Frg. 9 Diehl, 31-32, 53, n. 3; $37-$

38,33, n. 2; 53, n. 3.

Triclínio, 102; 103.

Virgílio, Eneida VI, 273-281, 52; 554, 108.

Xenófanes, Frg. 1, 1-12 Diehl, 112, n. 1;

118-119, n. 5; 6 Bergk, 52 e n. 3.

Zenóbio, III, 86, 95.
B) MODERNOS

Aimé-Puech, 102; 111, n. 4; 118, n. 4.

T. W. Allen, 42, n. 4.

Von Arnim, 67, n. 1.

Autenrieth, 87, n. 1.

H. C. Baldry, 94, n. 2; 105, n. 1.

W. S. Barret, $58, n .4$.

F. Bechtel, 41, n. 4.

Bekker, 85.

V. Bérard, $85, n .1 ; 86 ; 88$ e $n .2,3 ; 88, n$. 2; 129, n. 1.

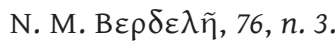

Th. Bergk, 86; 101, n. 1; 111; 117; 124, n. 1.

A. Bernabé, $80 ; 81, n .1$.

Besnault, 110, n. 1.

J. Bidez, 51, n. 2; 68, n. 1; 69, n. 1, 2; 134,

n. 2.

E. Bignone, 52, n. 5.

Blaydes, 124, n. 1.

Böckh, 39, n. 1; 56; 101, n. 3; 103, n. 1; 108;

$111 ; 117 ; 118$ e $n .4$.

E. Boisacq, 27 e $n .7$.

Bothe, 124, n. 1.

C. M. Bowra, 30, n. 2; 102; 118, n. 4.

C. D. Buck, 41, n. 4; 109, n. 2.

R. Bultmann, 116, n. 2.

P. Capelle, 38, n. 2; 86, n. 3; 91, n. 1.

J. Carcopino, 72, n. 3.

H. M. Chadwick, 21, n. 1.

J. Chadwick, 23, n. 1.

M. Chevalier, 72, n. 4; 139, n. 1; 141, n. 2.

W. Christ, 113.

Collitz, 76, n. 2.

Comparetti, 75, n. 1; 76, n. 6, 7; 78, n. 7; 80.

A. B. Cook, 77 e $n .1$.

V. Coulon, 124, n. 1.

J. S. Cristóbal, 81, n. 1.

O. Crusius, $35, n .1 ; 36, n .3$.

Fr. Cumont, 72 e 74, n. 1.

Delatte, $78, n .7$.

Deubner, 100, n. 1 .

E. Diehl, 43; 112, n. $1 ; 113$, n. 1.

H. Diels, $52, n .6 ; 69, n$. 4; 70 e $n .3 ; 76$.

A. Dieterich, 49, n. 1; 54, n. 1; 72 e n. $1 ; 75$, n. $2 ; 78, n .7$.

Dindorf, 26, n. 3; 43; 85, n. $1 ; 124, n .1$. 
Dissen, 101, n. 4; 112; 114, n. 1.

Dittenberg, 41, n. 4.

E. R. Dodds, $18 ; 25$ e $n .1 ; 35, n .4 ; 42, n .3$; 43 e $n .1,2 ; 44$, n. $2 ; 47$, n. $1 ; 48 ; 49$, n. 4; 50, n. $1,2,3 ; 51$, n. $2 ; 52$, n. 5; 56, n. 3; 59, n. 1; 68, n. 1; 72, n. 2; 78, n. 4; 109, n. 4; 116, n. 3; 128, n. $2 ; 135$, n. 1 .

S. Eitrem, 75, n. 1.

Erman, 116, n. 4.

Ettig, 72, n. 4.

A. Evans, 23 e n. 2 .

L. R. Farnell, 29, n. 4; 34, n. 1; 102; 103; 111, n. $2 ; 118$.

C. A. M. Fennell, 102; 103 e n. 3; 109; 111 e n. 3; 113.

A. J. Festugière, 42, n. 5; 60, n. 4; 75, n. 4. Fick, 27 e $n .3 ; 85$.

P. Foucart, 41, n. 4; 42, n. 2.

E. Franck, 70, n. 1.

P. Friedländer, 67, n. 1.

P. Frutiger, $75, n .1$.

M. F. Galiano, 102; 111, n. 4.

H. W. Garrod, 100, n. 1, 2.

Geldart, 124, n. 1.

B. L. Gildersleeve, 102; 104 e n. 2; 111 e n. $1 ; 113 ; 114$, n. 1.

W. J. Goodrich, 100, n. 2.

Gordon, 81, n. 4.

F. Graf, 80 e $n .1 ; 81$ e $n .1$.

W. K. C. Guthrie, 40, n. 1; 47, n. 5; 75, n. 1.

Hall, 124, n. 1.

W. R. Halliday, $42, n .4$.

J. Harrison, 76, n. 1; 79, n. 1.

Am. Hauvette, 110, n. 1.

Hennings, 85.

Hermann, $111 ; 124$, n. 1.

W. W. How, 110, n. 2; 116, n. 4.

J. Irigoin, 109, n. 3.

P. Jacobsthal, $64, n .3$.

F. Jacoby, 95, n. 1.

W. Jaeger, 52, n. 5.

S. I. Johnston, 80 e $n .1$; 81 e $n .3$.

A. Kaegi, 87, n. 1 .

Kaibel, 76, n. 1, 4, 5.
Karsten, 111.

C. M. Kaufmann, 60, n. 3.

Keil, 44, n. 4.

O. Kern, 75, n. 1.

Kirchhoff, 85; 86.

Th. Kock, 124, n. 1.

A. Körte, 35, n. 3.

W. Kranz, 52, n. 5, 6; 70 e n. 4.

R. Lattimore, $60, n .3 ; 141, n .3$.

La Roche, $88, n .1$.

van Leeuwen, $86 ; 124, n .1$.

M. Lejeune, 109, n. 2.

Lidell-Scott, $100 ; 102 ; 129$, n. 1.

E. Lobel, 49, n. 3; 125, n. 2.

A. Rutgers van der Loeff, 41, n. 2.

H. L. Lorimer, 115, n. 1.

Maass, 52, n. 4.

R. Mackrodt, 88, n. 1 .

N. Madvig, 102.

L. Malten, $27-28$, n. 9; 28, n. 3; 34, n. 2; 38,

n. $2 ; 54$, n. $1 ; 79$, n. 1 .

G. Maspero, 110, n. 2.

K. Meister, 72, n. 3.

W. W. Merry, 85, n. 1; 122, n. 2.

A. Meyer, $36, n .4$.

E. Meyer, 29, n. 4; 97, n. 2.

L. Meyer, 27 e n. 6.

Milman Parry, 86, n. 4.

Mommsen, 101, n. 2.

G. Murray, 76, n. 1, 2, 4, 5, 6, 7; 121, n. 1;

126, n. 1.

G. E. Mylonas, 40, n. 2.

M. P. Nilsson, $22 ; 23$ e $n .4,5 ; 24, n .4,7 ; 28$

e $n .1 ; 29 ; 37, n .1 ; 38, n .1 ; 40, n .1,3,4 ; 41$

e $n .3,6 ; 42, n .5 ; 48 ; 54, n .1 ; 75, n .1 ; 86$ e

n. 3,$4 ; 87, n .2 ; 95$ e $n .3 ; 100, n .2 ; 107, n .6$;

123, n. 2.

Nitzsch, 85.

Noack, 40, n. 3.

Medea Norsa, $118, n .5$.

Olivieri, 75, n. 1; 76, n. 1, 2, 4, 5, 6, 7; 78, n. 7; 79, n. 1, 2.

W. Pape, 77, n. 3; 125, n. 2.

C. Pascal, 97, n. 3.

W. R. Paton, 118 e $n .3$. 
Pauly-Wissowa, 29, n. 2; 32, n. 6; 38, n. 4; 75, n. 2.

Pauw, 113.

Pepmüller, 120.

A. W. Persson, 42, n. 2.

R. Pfeiffer, 118-119, n. 5.

Ch. Picard, 115, n. 3.

M. Platnauer, 124, n. 1.

E. Pottier, 110, n. 1.

L. Radermacher, 121, n. 1; 122, n. 1; 122, n. $4 ; 123$, n. $1 ; 124$, n. 1.

Ranke, 116, n. 4.

Rauchenstein, 99.

W. Ridgeway, 21, n. 1 .

L. Robin, 132, n. 1; 136, n. 1.

Rogers, 124, n. 1.

E. Rohde, $24, n .5 ; 26, n .1 ; 27$ e $n .8 ; 28, n$. 3; 33 e $n .1 ; 35, n .2 ; 49$ e $n .2 ; 52, n .5 ; 69$, n. 5,86 e $n .2 ; 86, n .1 ; 91$ e $n .2 ; 95$ e $n .2$; 100-101, n. 2; 103, n. 1.

H. J. Rose, $54, n .1 ; 56$ e n. $3 ; 78, n .6 ; 101$, n. 5.

W. H. Roscher, $35, n .1$.

Ross, $41, n .4$.

J. Rumpel, 104 e n. 1; 108.

A. Rzach, 94; 95.

F. Saussure, 27 e $n .4$.

Schneidewin, 112.

Schoemann, 95.

W. Schubart, $118, n .5$.

A. Schulten, $38, n .4$.

E. Schwyzer, 85, n. 1.

A. Sidgwick, 43.

B. Snell, 102; 104, n. 1; 117.

C. Sourdille, 110, n. 2.

G. Soury, 129, n. 1.

W. Spiegelberg, 110, n. 2.

W. B. Stanford, 85, n. 1; 89, n. 1, 2; 90, n. $1 ; 129$, n. 1.

W. Süss, 122, n. 2.

H. W. Thomas, $51, n .2 ; 54$ e $n .2 ; 66$ e $n .1$, 2, 3; 67 e $n .1,2,3 ; 68, n .1 ; 69, n .4,5,8 ; 70$ e $n .1,5 ; 75$, n. $3 ; 78, n .1 ; 102$, n. $2 ; 128$, n. 4. J. A. K. Thomson, 21, n. 1.

T. G. Tucker, 122 e $n .4 ; 124, n .1$.

A. Turyn, $102 ; 108, n .1 ; 118$ e $n .4 ; 118-119$, n. 5 .
Usener, 29, n. 2.

M. Ventris, 23, n. 1.

A. F. G. Ventura, 129-130, n. 1.

Voss, $124, n .1$.

J. G. Vuertheim, 27 e n. 1.

J. Wackernagel, 27 e $n .5 ; 27-28, n .9 ; 41$;

102, n. 3.

P. Waser, $29, n .5$.

Weil, 95.

Welcker, $48, n .7$.

J. Wells, 110, n. 2; 116, n. 4.

Wiesler, 43.

J. Wiesner, 22, n. 1; 116, n. 3.

J. Wieten, $75, n .5 ; 78$ e n. $2,7$.

E. Wikén, $115, n .3$.

U. von Wilamowitz-Moellendorf, 27; 42, n. $2 ; 43$ e $n .4 ; 47, n .1 ; 51, n .2 ; 52, n .4 ; 54$,

n. $1 ; 55$, n. $1 ; 65$, n. $1 ; 67$, n. $1 ; 75$, n. 4; 100,

n. $2 ; 101, n .1 ; 118$ e $n .2 ; 122$, n. 4.

K. Ziegler, 75, n. 2.

Zuntz, 81 e n. 1, 3. 


\section{ÍNDICE DE AUTORES \\ SOBRE A AUTENTICIDADE DO \\ FRAGMENTO 44 DIEHL \\ DE ANACREONTE}


(Página deixada propositadamente em branco) 


\section{A) Antigos}

\section{Os números em itálico indicam as páginas.}

Alceu 185, n. 5; 191, 246; 298;

Frgs. Lobel-Page: 38 a 265, n. 2; 283; 39 246; 48,15 265; 50 246; 60a, 5 265, n. 1; 77a 266; 117b, 38 265, n. 1; 119 246; 186, 4 265, n. 1; 286a, 4 266; 296a, 5 265, n. 1; 338 201; 292-293, n. 1; 357 292-293, n. 1; 442 246.

Álcman 192; 245-246; 247, n. 1; Parthen. 32 265, n. 1; frg. 58 Diehl 212-213, n. 5; frg. 72 Diehl 122 257, n. 2; frg. 94 Diehl 245246, 247 e n. 1, 253, n. 8; frg. 101 Diehl 248. Anacreonte e Pseudo-Anacreonte 184188, 192, 195 e $n .2, n .3$, n. 4; 196, n. 1; 198; 201; 202 e $n .1 ; 203$ e $n .1 ; 204 ; 204-205, n .6$; 207; 208; 209; 210; 211; 214 e n. 3; 215, n. 3; 216; 218 e $n .1 ; 220, n .4 ; 223 ; 229$ e $n .4 ; 230$; 233; 234; 248; 249, n. 1; 253; 290; 292-293, n. 1; 297-300;

Frgs. Bergk 1 210; 2 204-205, n. 6, 210; 10 201; 11 198, 294; 14 210; 21 204-205, n. 6; 57 184, n. 2; 63 199; 75 210; 99 192; 131 198; 157 184, n. 2; 123 198; 136 209; 138 201; 143 209; 151 201; 154 201; 161 201; 162201 e $n .1 ; 163$ 202; 168 209; 210;

Frgs. Diehl 1 201, 202, 205, 210; 2 197, 198, 202 e n. 1, 205; 3 195, 204; 4 195, 202, n. 1, 204, 214, n. 3; 5 195, 196, 204, 218, 221, 222, 233, 234, 248, 253 e n. 5; 6201,204 , 216; 7 191; 8 192, 204 e n. 6, 218; 11 201, 206; 16 201, 204-205, n. 6; 17 195, 202, 206, 216, 234; 19 201; 20 191; 21 207; 22 199, n. 2, 207, 290; 23 196, 207; 25 201, 207; 26 195, 207, 216; 27 185, 196, 197, 207, 221; 28 191, 220; 29 207; 32 193, 207; 33 198; 36 207; 37
198, 207; 39 196, 207; 40 195, 207; 41 199, n. 1, 207, 210; 42 196, 207, 234; 43 199, 207, 221; 44 188, 191, 226-300; 45 195, 206 e n. 3, 253; 46 222, 299; 47 222; 48, 207 e n. 3, 210; 51a 191; 48 198; 52 187, 206, 234, 290; 53 196, 223, 233; 54 200, 206, 215, 293-294; 55 200; 56 191; 57 201; 58 199, n. 1; 62 201; 64 191; 65 193,n. 1; 67 201; 69 196, 205, 214; 71 201; 72, 220, n. 4; 74 201; 75 202; 76 198; 77 196; 79 195, 220, n. 4; 80 201; 81 201; 82 191, 218, 219, 300; 85, 220, n. 4; 86 187, n. 5, 192; 87 201; 88 196, 203, 207 e n. 1; 89 203, 233, 290; 90 202, 203, 207; 91 202, 203, 207 e n. 2, 213, 234; 92 192; 93 203; 94 203; 95 192; 96 192, 201, n. 1, 202, 203, 208, 221; 97 203; 98 196, 203; 99 200, 201, n. 1, 203; 100 192, n. 2; 101 192, n. 2; 107 192, n. 2; 108 192, n. 2; 145 203, n. 1;

Frgs. Gentili 18 290; 60 184, 200, 206; 65 185, 196, 206, 290 e n. 3, 293, n. 1; 71 185, 299; 72 185;

Frg. apud Schol. in Arati Phaen. Ms. Scorial. $\Sigma$. III. 3. fol. $43 \mathrm{r}^{\circ}$ 201, n. 1 . Anacreontea 185, 186, 188, 198, n. 1, 200; 204; 209; 217-223; 290; 300; I 222; II 217, 221; VI 222; VII 218, 223; VIII 218, 219; IX 218, 222, n. 2, 223; X 217; XII 218, 222, n. 2, 223; XIII 217, 221, 222; XV 217; XVI 217; XVIII 290; XVIIIa 223, 290; XVIIIb 222; XIX 222; XX 217; XXI 218, 223; XXIII 218, 221, n. 4; XXIV 218; XXV 222; XXXVIII 218, 222, 223; XXIX 288; XXX 222; XXXI 222, 291; XXXIII 222, 291; XXXV 222; XXXVIII 291; XXXIX 218, 
223; XL 223, 291; XLI 291; XLII 221, n. 4, 223, 293, n. 1; XLIV 218, 263; XLV 218, 223; XLVII 218, 219, 221 e $n$. 3; XLVIII 221, 222, n. 2, 223; XLIX 222, n. 2, 223; L 223; LI 222, 223; LII 223; LIII 223; LV 291; LVI 223; LVII 291.

Anacreonte-o-Moço 192.

Anthologia Palatina IX, 239 204, n. 5; X, 3, 1290.

Apolónio de Rodes, Argon. II, 353290. Arato

Schol. in Arati Phaen. Ms. Scorial. $\Sigma$. III. 3. 201, n. 1.

Aristarco 238.

Aristófanes: 187, 199, n. 1; 221, n. 3; 273; 297;

Ach. 219-221 251-252, n. 3; 391 273, n. 2; 525 199, n. 1; 600 251-252, n. 3; 692693 251-252, n. 3; 702 251-252, n. 3; 715 251-252, n. 3;

Aues 273; 693 259-260, n. 8; 10301032 273, n. 2; 1373187 e n. 5 ;

Eq. 520 251-252, n. 3; 908 251-252, n. 3;

Lys. 301 251-252, n. 3; 605-607 273, n. 2;

Nub. 129 251-252, n. 3; 192 273; 279 204-205, n. 6;1073 199, n. 1;

Pax 313-315 273, n. 2; 343 199, n. 1; 1244 199, n. 1;

Plut. 253 220, n. 4; 266 251-252, n. 3, 251-252, n. 3; 278 273, n. 2; 302 219; 1002 187, n. 5; 1057-1059 251-252, n. 3; 1075 187, n. 5;

Ranae 273 e n. 2; 69-70 273, n. 2; 145150 273; 274-275 273; 475 273;

Thesm. 160-163 185, n. 5; 1040273 , n. 2;

Vesp. 164 251-252, n. 3; 275-278 251252, n. 3; 441 251-252, n. 3; 737-740 251-252, n. 3; 762-763 273, n. 2;

Gerytades 273, n. 2;

Frgs. Kock 82, 3 251-252, n. 3; 146 251-252, n. 3; 149-150 273, n. 2; 223 185, n. 5; 488 vv. 2-3 273-274;

Schol. in Nubes 192 273, n. 4. Aristófanes de Bizâncio 238.

Aríston de Ceos 240, n. 2.

Ariston de Quios 240, n. 2.

Aristóteles, Anal. Post. B 11.94 b. 33 274;
Part. Anim. IV, 11, p. 690 b 30 291;

Poet. 1456a 270, n. 4;

Rhet. III 1409a 207, n. 1; 211 e n. 2.

Pseudo-Aristóteles MXG, 957a 11 259,

n. 8.

Arquíloco 200;206; 210;241;247, n. 1; 282 en. 4.

Frgs. Diehl 22 192; 25222 e $n .1 ; 50$ 241; 55 282, n. 4; 70 216, n. 3; 111 197, n. 3; 218; 219; 113 241; 114 241, 253, n. 7;

Frgs. Lasserre-Bonnard: 35, v. 34 264, n. 4.

Ateneio 199 e $n .1 ; 6$ 273; 10.427a 199, n. $1 ; 10.429$ b 195, n. 2; 11.475c 199, n. 1 ; 12.540c 299; 13.600d 193-194; 14.646 273, n. 5; 15.646a 193 e $n .2 ; 229$ e $n .4$.

Aulo Gélio XIX 9 221, n. 2, n. 3, 300.

Baquílides 183, 184, 250; 266 e n. 1; 283; Odes III 88-89 250, 253, n.5; V 56-

175 266, 63-67 266, 121 283;

Ditirambos XVII 24-28 283; frg. 24 183; frg. 25 183;

Frgs. Snell 20a 7-10 250; 20b, 5-9 197-198, n. 3; 24 283; 25 2-3 250, 253, n.5, 287, n. $1 ; 60,18266$, n. 1 .

Calcídico in Tim. 122 259-260, n. 8.

Calímaco 289-290;

Ai. IV 15 276, n. 2;

Ep. II, 6 276, n. 2; IV, 2 276, n. 2; X, 1 276, n. 2; XIII, 3-4 289, 6 276, n. 2; XXI, 6 287; XXXIII, 2 276, n. 2; XLI, 2 276, n. 2;

Hy. I 62 276, n. 2; II, 14 287; III, 222

276, n. 2; IV, 277 276, n. 2; V 130 276, n. 2;

Frgs. Pfeiffer 15 290; 26 290; 115

290; 178290.

Calino 280;

Frg. 1 Diehl: 1, 15, vv. 8-9 e 12-13 280.

Cameleonte vide Chamaileon.

Celso apud Orig. C. Celsum VI 260, n. 1.

Chamaileon 193, n. 2.

Cícero

De Senectute 3 240, n. 2; 63-64 243, n. 3;

Tusc. Disp. IV. 71195.

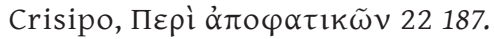

Crítias 187, 193, n. 2; 195, n. 3; 199, n. 1;

210, n. 3; 
Frg. 1 Diehl 199, n. 1; Frg. 8 Diehl 194.

Demóstenes XVIII, 27 276, n. 2; XXXIV, 104 276, n. 2.

Pseudo-Demóstenes XXV, 53 276, n. 2.

Dicearco 195, n. 4.

Diógenes Laércio I. 60244 e n. 4; VIII. 21 275, n. 1, 35 274, 275, n. 1.

Dioscórides 1.30.4 293, n. 1.

Eliano V. H. 4.17 (= VS. 58 (45) C.2) 275, n. 2; 9.4229 e $n .4 ; 299$.

Ésquilo 267-270; 284; 289; 298;

Oresteia 267, n. 1;

Agam. 72-82 251; 238-329 251, n. 3; 584 244, n. 5, 251; $966-967$ 251, n. 2; 1023 267, n. 2; 1115 267, n. 2; 1160-1161 265, n. 2, 267, n. 2; 1235 267, n. 2; 1291 267, n. 2; 1386-1387 267, n. 2; 1527-1529 267, n. 2; 1621-1624 251, n. 3;

Choeph. 147 267, n. 2; 355-359 267, n. 2; 908 251, n. 3;

Eum. 267; 71-73 269; 95-97 267, n. 2; 115 269; 249-251 269; 267-275 269; 273-275 274; 334-340 269; 338-340 269; 387 269; 339-340 274; 395-396 269; 417 269; 422-423 269; 727-728 251, n. 3; 847 251, n. 3; 950-952 269; 1007 269; 1023 269; 1036 269;

Pers. 171 287; 222-223 267, n. 2; 263265 251, n. 3; 580-583 251, n. 3; 624 267, n. 2; 629 267, n. 2; 637 267, n. 2; 688 289; 688-690 284; 839 267, n. 2; 913-914 251, n. 3; 922-924 267, n. 2; 1056 251, n. 3;

Prom. V. 128 202, n. 5; 152-157 268; 219-221 267-268, 269; 235-236 269; 236 267; 248-250 284; 433 267-268, n. 2, 289; 568-569 284; 570-573 267, n. 2; 1026-1029 268; 1050-1052 268;

Sept. 321-322 267, n. 2; 622 251, n. 3; 690 267, n. 2; 854-860 265, n. 2; 856 267, n. 2;

Suppl. 157-158 267, n. 2; 228-231 274; 321 267, n. 2; 414-416 274; 415-416 269; 666-667 251, n. 3; 774-775 251, n. 3;

Frgs. Nauck ${ }^{2} 161284$ e n. 3; 267 267, n. 2; 400 250-251 e n. 2.

Frg. Pap. Oxy. 2256.9(a) 274;

Schol. in Prom. V. 128 202, n. 5.

Estesícoro 184, 266;

Frg. 83 Bergk 266, n. 2;

Frg. 12 Diehl 193; Frg. 22 Diehl 266.
Estêvão de Bizâncio vide Stephanus Bizantius.

Estobeu 1.1.10 299; 1.9.5 259-260, n. 8; 3.1.8 299; 4.21.24 299; 4.22.193 299; 4.33 .7 299; 4.34.14 299; 4.34.28 242; 4.34.15 299; 4.34.28 299; 4.41.7 299; 4.50.7 250; 4.50.19 299; $4.51 .5299 ; 4.51 .7299 ; 4.51 .12227,229$ e $n .4,299,300 ; 4.53 .2$ 299; 4.56 .5299$.

Estrabão XIV.638 201.

Etymol. Gud. 332.22 292-293, n. 1. Etymol. Magn. 42748 266; 524.51 292-293, n. 1.

Eurípides 251-252, n. 3; 270; 271; 272, n. 2; 273, n. 2; 276; 287; 289; 297;

Alc. $24-26$ 271; 73 271; 124-126 271; 252-263 271; 357-362 271, 276; 436-444 271; 455-463 271; 743-746 271; 870-871 271; 900-902 271;

Andr. 348 251-252, n. 3; 414 271; 503-505 271; 544 289; 543-544 271; 850 271; 1078 271; 1192 271; 1217 271;

Bacch. 203, n. 1; 857-859 271; 1156-1158 271; 1251 251-252, n. 3; 1361-1362 271;

Cycl. 68-72 197-198, n. 3;

El. 662 271;

Hec. 1-2 271; 49 271; 136-137 271; 208-210 271; 367-368 271; 418 271; 483 271; 500 251-252, n. 3; 652 251-252, n. 3; 1032-1033 271; 1077 271; 1105-1106 271; 1106 289;

Hel. 61-62 271; 175-178 271; $227-$ 228 262, n. 1; 969-971 271; 1122-1123 271; 1161271 ;

Heracl. 218 289, n. 1; 218-219 271; 513-514 271; 636 251-252, n. 3; 911-914 271; 949-951 271;

Her. 271; 22-25 271; 24 289; 37 289, n. 1; 45-46 271; 110-113 251-252, n. 3; 116-117 271; 119-120 251-252, n. 3;120 249, n. 1; 145-146 271; 230-231 251-252, n. 3; 296-297 271; 297 284, n. 1; 352-353 271; 426-435 271; 431-432 284, n. 1; 453 271; 480-484 264, n. 2; 483-484 271; 491 271; 562-564 271; 607-608 289, n. 1; 607-619 271; 621 271; 649 251-252, n. 3; 655-672 251-252, n. 3; 676-686 251-252, n. 3; 736 271, 288; 770 271; 807-808 271; 838-839 271; 870 264, n. 2, 271; $906-909$ 272; 910 251-252, n. 3; 1025-1027 271; 1101-1105 
271; 1119 271; 1170 271; 1247 271; 1276-1278 271; 1331 271; 1366-1367 288; 1415 271;

Hipp. 271; 272; 56-57 271; 829 271; 836-838 271; 895-896 271; 1290-1291 272; 1366-1367 271; 1387-1388 271; 1416-1419 271; 1447 271; Ion 953 271; 1041-1042 251-252, $n$. 3; 1235 271; 1239 289, n. 1; 1273-1274 271; 1439-1442 271; 1494-1496 271; Iph. Aul. 461 271; 539-540 271; Iph. Taur. 157-158 271; 168-169 271; 184-185 271; 285-286 271; 369-370 271; Med. 1059 271; 1109-1111 271; 1233-1235 271; Or. 271; 261 272; 264-265 272; 1109 271; 1522 271; 1584 271; Phoen. 271; 528-530 251-252, n. 3; 810-811 271; 1311-1312 271; 1571 265, n. 2; 1575-1576 271; 1604-1605 272; Suppl. 35 251-252, n. $3 ; 75$ 271; 170 251-252, n. 3; 171-172 251-252, n. 3; 271-274 271; 289 251-252, n. 3; 543-546 271; 545 289, n. 1; 773 271; 796-797 271; 920-922 271; 925-927 271; 926 289, n. 1; 1004-1005 271, 288; 1021-1022 271; 1084-1093 251252, n. 3; 1108 251-252, n. 3;

Troad. 445 271; 597 271;

Frgs. Nauck 25 251-252, n. 3; 291 251-252, n. 3; 369 251-252, n. 3; 508 251-252, n. 3; 509 251-252, n. 3; 575 251-252, n. 3; 619 251-252, n. 3; 637 251-252, n. 3; 860 271; 868 284, n. 1; 1080 251-252, n. 3;

Frg. Eur. apud Steph, Byz. 272, n. 2. Eustátio 1329. 34 184, n. 2.

Ferecides de Siro, frg. 7B5 Diels-Kranz 260, n. 1.

Ferécrates, Frgs. Kock: 108 273; 297.

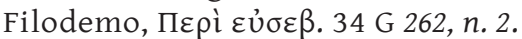

Heféstion 203, n. 1; 206 e n. 3; 207, n. 3; 219; 220 e $n .1 ; 220, n .4 ; 221$ e n. 3. Hermesiânax de Cólofon, frg. 2 Diehl 277, n. 1 .

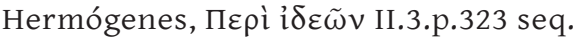
Rabe 196.

Heródoto I. 30-33 244 e n. 2.

Herondas 220.

Hesíodo e Pseudo-Hesíodo 239-240; 244, n. $3 ; 256 ; 259-260$, n. $8 ; 262 ; 263 ; 275$ e n. 4 ; 279;

Theog. 256; 262; 264;275; 279; 119 259 e $259-260, n .8,288 ; 123$ 260, n. $1 ; 151$ 262; 211-212 279, n. 1; 217 279, n. 1; 225 239; 226-227 262; 235-236 239; 252-255 263; 254-255 262; 263 263; 277 239, n. 2, 240; 305 239, n. 2; 309-312 259; 455-456 259; 515 260, n. 1; 604 239; 620 260, n. 1; 653 260, n. 1; 658 260, n. 1; 669 260, n. 1; 682 259; 717 260; 718 261, n. 1; 720 256, n. 2, 261, n. 1; 721 259; 720-725 260; 726-727 261, n. 1, n. 2, 280; 732-733 261, n. 2, 280; 736-739 259, n. 7; 736-745 261, n. 1; 746748 259, n. 5; 746-757 259, n. 3; 756 279, n. 1; 758-766 259, n. 4, 279, n. 1; 767 259; 767774 259, 261 e n. $1 ; 770-773$ 280; 775-806 259, n. 6; 806-810 259, n. 7; 811-812 262; 811-815 261, n. 1; 820-828 266; 821-822 259, 260, n. 1; 822 259-260, n. 8; 841259 260, n. 8; 851 259-260, n. 8; 850 259; 851 255, n. 5; 868 259; 949 240; 257 e n. 3; 258; 259 ;

Op. et D. 92 279; 93 239; 113-114 239; 130-134 239, n. 3; 153 259; 169 275; $185-$ 188 240; 331 239; 331-332 240; 376-379 240; 418 279; 486 292-293, n. 1;

Scutum 275; 249 280; 264-270 280;

Frgs. Rzach 80 259, n. 1; 82, 2 277; 96259, n. 1; 126262 , n. 2; 160, v. $6279, n$. 2; 220 240;

Schol. in Theog. 259-260, n. 8. Hesíquio 210, n. 1; 266; 288.

Himério 194;

Or. Schenkl 19 194; Or. Schenkl 30 201.

Hinos Homéricos vide Homero.

Hipónax 192.

Homero 221, 235, 240; 263; 270; 275 e n. 3; 277; 284-285; 285; 297; 298;

Ilíada 202, n. 1; 235; 238, n. 3; 239; 243; 250; 252; 254; 256; 257; 258; 262; 265; 275;

A $3255, n .4,264 ; 259$ 236, n. 2; 416-418 278, n. 7; 426 262, n. 1;

B $155278 ; 302$ 278, n. 3; 369-374 235 e n. 4; 755 255, n. 3; 834 278, n. 3; Г 6 278, n. 5; 30 278; 59 278; 101 278, n. 2; 108-110 236, n. 1; 133 237, n. 4; 149-153 235; 173 278, n. 1; 276-280 274; 309 278, n. 
$1 ; 322$ 255, n. 4

$\Delta$ 322-323 235 e n. 2; 323 236, n. 5, 238;

452-455 212-213, n. 5;

E 83 278, n. 2; 87-88 212-213, n. 5; 136237 , n. 1; 190 255, n. 4; 654 254; 845 254, n. 3; 613-614 278, n. 4; 646 255, n. 2;

$\Theta 256 ; 261 ; 13264,265 ; 13-16256,260,268$; 13-17 257-258, n. 3; 14 265; 16 277, n. 1; 70 278, n. 3; 99-117 235 e n. 2; 103 236, n. 8; 321 262,n. 1; 367 255; 369 255, 280; 369 298; 478-481 255; 518 287, n. 1; 527 279, n. 3; Z 242; 123 277; 487-489 279; 487 255, n. 4, 278 ;

I 60-62 236, n. 2; 158 254, n. 1; 312 255, n. 2; 408-409 279, 285, n. 1; $411242,278, n$.

3; 457 254, 267, n. 2; 571-572 270, n. 2; 572 257 ;

K 77-79 235 e n. 2; 79 236, n. 7; 440-441 277;

$\Lambda 55$ 255, n. 4; 332 278, n. 3; 445 254, 255, n. 4 ;

M 21-22 279; 113 278, n. 5; 323 237, n. 1; 240; 323-328 278; 326-327 243, n. 1, 281; N 415 255; 544 278, n. 1; 602 278, n. 2; 665 278, n. 5; 670 237, n. 3;

O 37 255, n. 3; 187-193 254; 225 255; 274

278, n. 7; 516 219, n. 1; 613 278, n. 7;

П 47 278, n. 3; 389-392 212-213, n. 5; 625

254, n. 2, 255, n. 4; 687 278, n. 3; 707 278, n. 7; 849 237, n. 5; 856 255, n. 4; 327 257; 441443 278; 693 278, n. 6; 849 278, n. 4; 853 278, n. 2; 855-857 279;

$\Xi 256 ; 173$ 262, n. 1; 203-204 255; 271 255, n. 3; 274 255; 279 255; 457 255, 289;

P 321 278;

ऽ 115-121 278; 434 236, n. 7; 464 278, n. 1; 514-515 235 e n. 3; 519 257-258, n. 3; 535

278, n. 5; 535-540 262, n. 3;

T 258-260 274; 259-260 270, n. 2; 336236 , n. 9;

Y 61-66 254, 255, n. 5; 64 277, n. 1; 294255 , n. 4, 255; 336278 ;

Ф 48 255, n. 4; 56 255, n. 1; 70-74 242; 8283 278, n. 4; 110 278, n. 2; 282-283 212-213, n. 5; 294 289; 368 257; 438 262, n. 1; 505 262, n. 1; 517 278; 548 278, n. 3; X 5 278,n. 4; 52 255,n. 4; 59-71 236, n. 6; 60 239, n. 1; 71-76 243, n. 4; 74 219, n. 1, 253, n.5, n. 6, 287; 74-76 236, n. 6; 179-181 278; 210 278, n. 3; 210-213 242; 213 255, n.
4; 297 278, n. 6; 303 278, n. 4; 361 278, n. 1; 361-363 279; 362 255, n. 4, 289, n. 2; 365366 278; 418-420 236, n. 3; 425 289; 440 288, n. 4; 482-483 255, 289, n. 3;

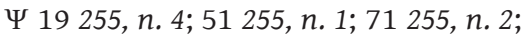
72-76 280, 298; 73 255; 74 255; 78-79 278, $n$. 5; 80 278, n. 4; 88 292-293, n. 1; 244 255, n. 4; 623 236, n. 8; 627-628 241, 247, 253, n. 8; 643-650 236, n. 5; 644 236, n. 7; $\Omega$ 209-210 278,n. 4; 224-225 278, n. 7; 246 255, n. 4; 348 253, n. 9, 287; 487 236, n. 10, 239, n. 1; 515-516 236; 516 241, 253, n.5, n. 6, 287; 540-542 236, n. 4; 593 255, n. 4;

Odisseia 237; 238 e $n .3 ; 240 ; 249 ; 250$; $253 ; 256 ; 257 ; 258 ; 282 ; 283$;

a 188-193 237, n. 13; 217-218 238;

ß 15-16 237, n. 7; 100 278, n. 2; 157-159 237, n. 7; 177-193 237, n. 8; ү 24 237, n. 9; 93 237, n. 1; 114 277; 236238 278, n. 8; 243-246 237, n. 1; 269 278, n. 4; 363-364 237, n. 11; 402 288, n. 4; 410 256, n. 3, 264, n. 2;

б 207-211 238; 210 239; 304 288, n. 4; 561569 275, n. 3; 834 256, n. 3;

E 136 240; 184-187 256; 218 237, n. 1, 240; 226288, n. 5; 346 288, n. 4;

$\zeta 11$ 256, n. 3, 264, n. 2; ๆ 155-157 237, n. 10; 257 237, n. 1; 1 236 288, n. 5; 502 277; 524 256, n. 3; к 175 256, n. 3; 279 253, n. 9, 287; 490-574 256; 508-515 256, n. 5; 528 257, 260, n. 1; $\lambda$ 256; 257; 275, n. 5; 292; 37 257, 260, n. 1; 134-137 238, 136 239; 292 278, n. 4; 539 256, n. 6; 171278, n. 3; 398 278, n. 3; 564 257, 260, n. 1; 593-600 283, n. 2; u 81 257, 260, n. 1; 341 237, n. 2; v 363288, n. 5;

乡11 264; 156-157 256, n. 4; 207 278, n. 3; 207-208 256, n. 3, 264, n. 2;

o 348 239, n. 1; 350 256, n. 3;

587 277;

$\sigma 10$ 238, n. 2; 52-53 238, n. 2;

ᄃ 285 277; 353-356 237, n. 1; 360 238, n. 2; 367-368 238; 592-593 278, n. 4; u 76 277; 208 256, n. 3; 356 257, 260, n. 1; × 270 288, n. 4; 413 278, n. 4; ४ 24 237; 126 277; 212 239, n. 1; 252 289; 281-287 238; 283 239; 336 237, n. 1, 240;

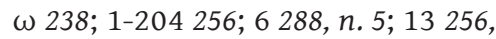
n. $6 ; 29$ 278, n. 4; 211-212 237, n. 13; 204 
256, n. 6; 226-240 237, n. 13; 233 237, n. 12; 264 256, n. 3; 520238, n. 1.

Hinos Homéricos 240-241; 253; 257; 262; 263;

II. Hino a Deméter 2-3 257; 17 257;

18 257; 22 277; 31 257; 45 277; 55 277; 73

277; 79 257; 80 257; 84 257; 242 240; 260

240; 262 280; 269 277; 335 257, 260, n. 1; 336 257; 337 257; 340 257; 347 257; 349 257, 260, n. 1; 357 257; 376 257; 395 257; 398 257; 402 257; 403 277; 404 257; 409 257, 260, n. 1; 415 257; 430 257; 446 257; 464 257; 482 257; III. Hino a Apolo 151 240; 68-69 277; 335-336 257 e n. 3;

IV. Hino a Hermes 161 277; 246

288, n. 5; 252 288, n. 5; 256 264; 256-259

257-258, n. 3; 359 259-260, n. 8; 374 257-258, n. 3; 376 257-258, n. 3; 441 277; 576 277;

V. Hino a Afrodite $240 ; 105-106$ 241, 253, n. 1; 146 242, n. 1; 153-154 262, n. 6; 154 257; 214 240; 224 240; 225 239, n. 4; 228-229 241; 233 240; 234 240, n. 2; 244246 240; 245 240; 246 240-241; 248 e n. 1; 269280 ;

Íbico 210;211; 253; 282.

Frg. 1 Bergk = 6 Diehl 210;

Frg. 2 Bergk = 7 Diehl 210;

Frg. 23 Diehl 282.

Ilíada vide Homero

Inscrições

A. J. A. 17.162 293, n. 1;

Oest. Jahresh. VII 1904 292;

Sammelbuch gr. Urkunden aus

Aegypten

SIG 1106.122 293, n. 1.

Jâmblico, Vita Pythagorea 155 274, 275, n. 1; 179 274, 275, n. 1.

Leónidas, A. P., Ep. 306194 e n. 2; A. P., Ep. 307194 e n. 2.

Longo 1.9 293, n. 1.

Luciano 221, n. 3; 292;

Catapl. 5.6 257-258, n. 3;

Dial. Mort. 27.1 291;

Necyomanteia 292;

Ver. Hist. II, 113 195, n. 3.

Maximus Tyrius XXXVII.42 Hob 186, n. 1.
Melanípides, frg. 3, 2 Diehl 136, n. 1;265, n. 2. Mimnermo 240; 242 e n. 2; 243; 244; 245, n. 2; 252 e n. 1, n. 2, n. 3; 281;

Frgs. Diehl 1 211, n. 1, 252, n. 1, n. 2, 253, n. 9; 2 242, 243, 252, n. 1, n. 2, 253, n. 9; 2, 9-10 288; 2, 14 264, n. 5; 3 243; 4 243; 4,2 281; 5243 e n. 2, 252, n. 1, 253, n. 9; 6243 , 252, n. 3;

adespota frg. 5 Diehl 281, n. 1.

Mosco, Ep. Bion. 115-126 276.

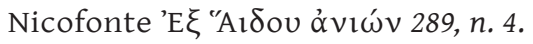

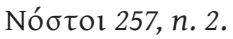

Odisseia vide Homero.

Orph. frg. 222 Kern 133 264, n. 3.

Ovídio, Met. XIV 130-153 240, n. 2.

Panécio 183.

Papiros

Pap. A do British Museum, de Ba-

quílides 184;

Pap. 1233, de Alceu 246;

Pap. Berol. 11793 = Diehl II, 6, p.

130 277, n. 1;

Pap. Berol. 16139183.

Pap. Mus. Ash. Inv. 20183.

Pap. Oxy. 220, col. X, 3 220; 221;

Pap. Oxy. 221, col. VII, 5-12 192;

195, n. 3;

Pap. Oxy. 2256.9(a) 274;

Pap. Oxy. 2310, frg. 1, col. I, 38 264,

n. 4.

Pap. Oxy. 2321 184, 185, 187, 196, 200;

206; 211; 214; 216; 221; 234; 293, n. 1;

Pap. Oxy. 2322184 e n. 3; 185, 192;

222;

Pap. Oxy., vol. 23 (1956) 183, n. 4;

184, n. 1.

Pausânias 194, n. 3; 292;

I. $25.1186, n .1 ; 194$;

II.13.3 292;

II.25.2 212-213, n. 5;

II.37.5 292;

Píndaro 183, 184, 192; 249-250; 253 e n. 3; 266; 282-283; 298;

Ol. I 55-64 257, n. 2, 82 282; 82-83 250; II 56-60 274; IV 25-27 250, n. 1; V 20-23 250, 253, n. 3; VIII 72-73 266, n. 4; X 86-87 249, 92-93 266, n. 4; 104-105 282;

Pyth. I 267, n. 1; 15-16 266; III 11 266, 
n. 4; IV 121 287, 157-158 249, 281-282 249;

V 96 266, n. 4; XI 21 266, n. 5;

Nem. III 72-74 249; IV 85 266, n. 5;

VII 19-20 282; 30-31 266, n. 4, 282; 67-68

249, 253, n. 3; 98-101 249-250; IX 44 250, n.

2, 253, n. 3; X 83-85 249;

Isthm. VI 15 249, 266, n. 4; VII 40-42

249, 42-43 282; VIII 9-10 257, n. 2, 282, n. 4;

Paeanes I 1 249; IV 42-45 267;

Frgs. Snell 143 266, n. 5, 283; 207

266; 214 250, n. 2;

Frg. dubia Snell 336 183, 343183.

Platão 187, 275 e n. 5; 297;

Apologia 40e-41c 275;

Charmides 187, n. 4;

Cratylus 403a 254, n. 3; 404b 254, n. 3;

Gorgias 274; 493b 254, n. 3; 523b 270,

n. 3; 524a 270, n. 3; 525b 270, n. 3; 525c

270, n. 3; 525e 270, n. 3; 526b 270, n. 3;

Parmenides 137a 248;

Phaedo 183, 81c 254, n. 3; 107d 270,

n. 3;107e-108a 267, n. 2; 108a 270, n. 3;

112a-113c 270, n. 3; 113d 270, n. 3; 113e

270, n. 3; 113e-114b 270, n. 3;

Phaedrus 187, n. 4; 270, n. 3; 235c 195

e n. $1 ; 249$ a 270, n. 3;

Respublica 183, 615a 270, n. 3; 616a

270, n. 3; 619a 270, n. 3;

Sympos. 178 b 259, n. 8; 179d 277, n. 1.

Pseudo-Platão, Theages 125d-e 187, n. 4.

Schol. in Gorg. 451e 195, n. 4.

Plotius Sacerdos VI.520.8 219; 220, n. 1.

Plutarco, Moralia:

De facie in orbe lunae p. 940e-f 277, n. 1;

De genio Socratis 22, p. 592d 277, n. 1;

Is. et Osir. 69, p. 378e 291, 292;

De lat. uiu. 6, 3 254, n. 3;

Not. adu. Stoicos 20, p. 1068 b 220, n. 4;

De primo frigido 9, p. 948e-f 254, n. 3;

Quaest. Conu. III.1.3, p. 647e 246;

De superst. 4, p. 167a 277, n. 1;

Vitae:

Solo $2.3299 ; 3.2299$.

Poemas Homéricos vide Homero.

Pollux 10.152266 e n. 3.

Proclo 183; in Plat. Parm. 137a 248.

Safo 191,195, n. 4; 240; 246-248;

Frgs. Lobel-Page 21246 e n. 3, 253, n.7; 55,3 265; 58 247, 253, n.5, n. 7, n. 8; 59-
60 247; 81b 198, n. 2; 65, 10 265, n. 2; 95, 12-13 265 e n. $2 ; 133$ 203, n. $1 ; 121$ 248; 134 203, n. 1.

Semónides de Amorgo 241; 242 e n. 2; 252; 281-282; 299;

Frgs. Diehl 1 241, 252 e n. 4, 264, n. 4, 281, 299; 2 252, n. 4, 299; 3 252, n. 4, 282, n. 1, 299; 4252 e n. 4, 299; 5 299; 7 264, n. 4, 299; 8 299; 10 299; 12 299; 29 241, 252, 253, n. 9, 282, n. 1, 299.

Séneca, Ep. 88.37 195, n. 2.

Sexto Empírico, Adu. Phys. 1.8 259, n. 8.

Simónides de Ceos 242, 282; 299;

Frgs. Diehl: 2 282; 8 282; 9 282; 12

282; 13a 265, n. 2; 18 265, n. 2.

Sófocles 270; 297;

Ajax 517 271; 571 289, n. 1; 606-608 271; 625 251, n. 3; 632 251, n. 3; 635 271; 660 271; 865 271; 1035 271; 1017-1018 251, n. 3; 1192-1194 271;

Ant. 361-362 271; 519-521 271; 542

271 ; 580-581 271; 653-654 271; 777-780

271; 804-805 271; 810-822 271; 911-912

271; 1074-1076 271; 1205 271; 1241 271;

1284-1285 271;

El. 110 271; 137-139 271; 184271 ;

463271 ; 542 271; 832-836 271; 948-950

271; 1342 271;

Oed. Col. 270-271; 954 246; 1211-1248

251-252, n. 3; 1220-1223 271; 1389-1392

270; 1440 271; 1461 271; 1547-1548 271;

1551-1552 271; 1556-1578 271; 1606 267, n. 2; 1689-1692 271;

Oed. Rex. 29-30 271; 971-972 271;

1372 271;

Phil. 624 271; 861 271; 1211-1212 271; 1349 271;

Trach. 4 271; 119-121 271; 281-283

271; 497-502 271; 1040-1043 271; 1085 271;

1097-1098 271; 1161 271;

Frgs. Nauck 263 251, n. 3; 239 251, n. 3; 478 271; 512 251, n. 3; 603 251, n. 3; 615 271; 781 271; 863 251, n. 3.

Schol. in Oed. Col. 954246.

Sófron, frg. 54 Kaibel 251-252, n. 3.

Sólon 244; 251; 252; 281; 299;

Frgs. Diehl 4 299; 14 211, n. 1, 244, 281, n. 2, 284, 299; 20 197-198, n. 3; 19244 e n. 3; 22244.

Stephanus Byzantius, p. 696 272, n. 2. 
Suidas 204, n. 5; 289, n. 4.

Teócrito 290; 298; XII, 19 289; XIV, 68-69 288; XXIX, 27-29 288; XXX, 13287.

Teógnis de Mégara 244-245; $281 ; 299$; 173-174 245; 174 245, 253, n.5; 181-182 245; 243-244 264; 271-278 245; 272 245; 347-348 212-213, n. 5; 212-213, n. 5; 427 264; 527 245; 527-528 245; 567-570 245, 281; 701-712 264; 703-712 281, 283; 719728 299; 725-728 264, n. 5, 281; 767-768 281; 768 245; 802 264; 821-822 245; 906 264; 917 265; 937-938 245; 973-978 265; 1007-1012 281; 1012 245; 1014 265; 1021 245; 1029-1036 265; $1033-1036$ 281; 1069 1070 245; 1070a-b 281; 1129-1132 245; 1132 245; 949 240; 257 e n. 3; 258; 259; 1123-1128 281; 1187-1190 281; 1204 265; 1296265.

Timocreonte de Rodes 192;

Frg. 5 Diehl 274.

Timóteo, frg. 3a Diehl, v. 13 289, n. 1. Tirteu 243; 245; 253 e n. 2; 280;

Frgs. Diehl 5.5 280; 6.7243 e n. 4; 8, 5-6 280; 7.23 287; 9243, n. 3, 9, 35 280; 35-42 253, n. 2; 9.38 264, n. 5; 14244.

Virgílio, Aen. VI 427 257-258, n. 3.

Xenófanes 200 e $n .1 ; 244$;

Frgs. Diehl 1 200, n. 1; 7 244; 8 244;

Frg. 28 Diels 273, n. 2. 


\section{B) MODERNOS}

F. R. Adrados 242 e n. 3; 244, n. 3; 252, n. 4. Ahrens 212-213, n. 5.

Aimé-Puech 246, n. 3; 248, n. 2.

L. Alfonsi 184, n. 4.

T. W. Allen 240, n. 1, n. 2; 257-258, n. 3.

A. Barigazzi 184, n. 4; 196; 200, n. 2. Barnes 186, 204-205, n. 6.

Baxter 186.

J. Beazley 185, n. 4.

Bentley 186.

Bergk 186, 191 e $n .1,192$ e n. 1; 193, n. 2; 196; 202; 204, n. 5; 204-205, n. 6; 207, n. 4;

212 e n. 3; 212-213, n. 5; 214, n. 2; 221, n. 3; 227, n. 1; 228; 229; 241; 246.

Bernhardy 186, 228 e $n .1 ; 229$.

Fr. Blass 183, n. 3; 191, 204-205, n. 6.

Bluemner 194, n. 3.

Bonnard 241 e $n .2$.

C. M. Bowra $184, n .4 ; 192$, n. 2, n. 3; $195-$ 196, n. 5; 196, n. 1; 198, n. 1; 200, n. 1, n. 2; 202, n. 1; 211; 212, n. 4, n. 5; 212-213, n. 5;

215 e $n .4 ; 216, n .3 ; 220, n .4 ; 221, n .1 ; 233$ e n. $1 ; 234, n .2 ; 235$, n. $1 ; 242$, n. 2; 244, n. 3; 262, n. $4 ; 274$, n. $1 ; 280$, n. $1 ; 282$, n. 3.

Canter 271, n. 1.

Carrière 212-213, n. 5; 281 e n. 3.

Casaubon 204, n. 6; 204-205, n. 6.

Castilho 186.

A. Colonna 230 e $n .1$.

R. M. Cook 262, n. 4.

V. Coulon 273, n. 3.

Crusius 191 e $n .1 ; 202, n .1 ; 218, n .1 ; 221$, n. 3; 227, n. 1 .

A. M. Dale 184, n. 5; 203, n. 1; 206 e n. 3.

Deiters 263.

Diehl 191, n. 1; 192 e n. 1; 203; 204-205, n. 6; 207, n. 4; 228 e $n .3 ; 241, n .1, n .3 ; 245$;

246, n. 3; 252, n. 4; 281 e n. 1, n. 2.

E. R. Dodds 203, n. 1; 263 e n. 2; 267, n. 1; 272 e n. $1 ; 274$ e $n .3$.

Duentzer 186.

Edmonds 219, n. 1;246, n. 3.

Elmsley 241.
Enger 267-268, n. 2.

H. Étienne 186 e $n$. 7 .

A. Ferreira 187, n. 1.

A. Fick 209, n. 1.

Fischer 186.

Eduard Fraenkel 181; 199 e n. 4.

Hermann Fränkel 198, n. 1; 199 e n. 4;

202 e n. 2, n. 3; 207, n. 2; 210 e n. 8, n. 9;

211, n. 1; 213, n. 1; 215, n. 3; 216, n. 1, n. 5;

228 e n. 2; 229 e $n .1, n .2 ; 288$ e $n .2$.

H. Frisk 209, n. 2; 210, n. 1, n. 3; 236, n. 5; 254, n. 3; 288, n. 3.

M. F. Galiano 183, n. 5; 218, n. 1; 221, n. 3.

C. Gallavotti 184; n. 3, n. 4; 192.

B. Gentili 184 e n. 2, n. 3, n. 4; 185 e $n .1$, n. 2, n. 4; 191 e $n .1,192$ e $n .1 ; 193 ; 197 ; 198$, n. $1 ; 200$, n. 2; 201, n. $1 ; 203$, n. $1 ; 204$ e n. 4 , n. 5, n. 6; 204-205, n. 6; 206 e n. 3; 207, n. 3; 218; 221; 227, n. 2; 289; 290 e n. 2.

Goethe 186.

A. S. F. Gow 290 e n. 1.

H. Grégoire 262, n. 1.

Grenfell 192.

G. Hafner 186, n. 1; 194, n. 3.

W. R. Halliday $240, n$. 1, n. 2; 257-258, n. 3.

Hanssen 221, n. 3.

W. R. Hardie 203, n. 1.

Hartel 212-213, n. 5.

Hartung 288.

A. E. Harvey 195, n. 4.

Manfred Hausmann 247.

Hecker 191.

Heimsoeth 212-213, n. 5.

Hermann 263.

Herwerden 212-213, n. 5.

J. Heurgon 277, n. 1.

Hiller 241 e n. 1.

Hitzig 194, n. 3.

J. B. Hofmann 209, n. 2, n. 3; 210, n. 1, n. 2, n. 3, n. 4 .

Holly 186, 191, 209, n. 1; 218, n. 1; 220 e $n$.

1, n. 2, n. 3, n. 4; 221, n. 3; 222, n. 2.

W. W. How $244, n .2$.

Humbert 257-258, n. 3. 
Hunt 192.

J. Irigoin 206 e n. 3.

G. Iwanowitsch 270, n. 4.

F. Jacoby 261, n. 1.

O. Jahn 199, n. 1.

K. M. Kaufmann 276, n. 1.

T. Kehrhahn 204, n. 5; 212 e n. 4; 227, n. 1.

F. G. Kenyon 184.

Kern 241 e n. 3.

P. Kikauka 204 e n. 2.

G. S. Kirk 256, n. 2; 259, n. 8; 261, n. 1; 262, n. $1 ; 273$, n. 2.

Knox 192.

Koster 204,n. 1; 204-205, n. 6; 206 e n. 1, n. 3; 207, n. 3; 218, n. $1 ; 220$, n. 3; 227, n. 2.

K. Latte 184, n. 4; 185; 192; 200, n. 2.

B. Lavagnini 229 e n. 6.

Lehrs 262.

Lennep 263.

Leopardi 186.

A. Lesky 241 e n. 4; 376 257-258, n. 3; 267, n. 1. Liddell-Scott 293, n. 1.

Lindau 186.

E. Lobel 183 e n. 4; 184, n. 1, n. 2, n. 3; 185; 192; 196; 197; 203, n. 1; 248, n. 2.

Ludwich 192.

Paul Maas 184, n. 4; 204, n. 5; 228.

J. Maia 187, n. 1.

Mariotti 263.

E. Martin 204, n. 5.

J. Martin 201 e n. 1; 207, n. 1.

M. Th.-H. Martin 258, n. 1.

P. Mazon 256 e n. 2.

Mehlhorn 204-205, n. 6; 220, n. 4.

Meineke 192, 272, n. 2; 289, n. 4.

R. Merkelbach 184, n. 4; 192; 200, n. 2.

W. W. Merry 273, n. 3.

Meyer 212.

L. A. Michelangeli 187, n. 1.

Mueller 186.

G. Murray 271, n. 1.

J. L. Myres 262, n. 4.

M. P. Nilsson 198, n. 2; 254, n. 2, n. 3; 276, n. $2 ; 277$, n. 1.

D. L. Page 184, n. $4 ; 191,197$, n. $2 ; 200$, n. 2; 203, n. 1; 246, n. 1, n. 2; 247, n. 4; 248 e n. 2, n. $3 ; 283$ e n. 1, n. 4.

S. Papaspyridi-Karouzou 185, n. 4.

E. Paratore 184, n. 4; 200, n. 2.

W. Peek 184, n. 1, n. 4; 185; 192; 196.

R. Pfeiffer 229 e n. 3.

Cfa. Picard 185, n. 4.

Platt 192.

M. Pohlenz 267, n. 1.

Pomtow 241.

F. M. Pontani 229 e n. 7; 230.

Preisendanz 217, n. 1.

L. Radermacher 273, n. 3.

J. E. Raven 256, n. 2; 259, n. 8; 261, n. 1; 262,

n. $1 ; 273$, n. 2.

Reinach $246, n .3$.

Reitzenstein 252, n. 4.

G. M. A. Richter 185, n. 4; 194, n. 3.

C. H. Roberts 184, n. 3.

Fr. Robortellus 186.

Ronsard 186.

Rose 186.

Rupprecht 204-205, n. 6; 227, n. 2.

C. Russo 263 e n. $1 ; 264$, n. 1.

Rzach 262; 263.

Scaliger 288 .

W. Schadewaldt 238, n. 3; 242, n. $1 ; 244$, n. 3, n. 5; 245, n. $1 ; 247$, n. 3; 253, n.4.

K. Schefold 185, n. 4; 194, n. 1, n. 3.

Schwarz 263.

Sidgwick 270, n. 1.

E. E. Sikes 240, n. 1, n. 2; 257-258, n. 3.

Sitzler 191, 192; 221, n. 3.

B. Snell 183, n. 1, n. 2, n. 3; 184, n. 4; 192;

195-196, n. 5; 203, n. 1; 204-205, n. 6; 207, n.

4; 247, n. 3; 267.

F. Solmsen 261, n. 1.

J. Souilhé $187, n .4$.

W. B. Stanford 273, n. 3.

C. B. Stark 186 e n. 6 ; 209, n. $1 ; 218$, n. 1 ;

221, n. 3.

F. Stiebitz 247, n. 1.

Studniczka 262.

W. Suess 183, n. 3.

Süss 273, n. 3.

Sybel 241. 
H. W. Thomas 258 e $n .1$.

Tillyard 199, n. 1.

M. Treu 201, n. 2; 202, n. 5; 211 e n. 3.

M. Tyrius 186, n. 1 .

Tyrwhitt 204-205, n. 6.

B. A. Van Groningen $211 ; 261, n .1$.

M. H. Van der Valk 257, n. 1.

P. von der Mühll 199; 256, n. 1 .

Weber 191; 202, n. 2; 209; 210 e n. 2, n. 5, n. 6; 214 e $n .1 ; 215, n .2 ; 216$ e n. $1, n .2, n .3$, n. $4 ; 220$ e $n .5 ; 288 ; 291$ e $n .1 ; 292-293, n .1$; 293, n. 1; 298, n. 1.

F. G. Welcker 186, 192 e n. 1; 257, n. 2.

J. J. Wells 244, n. 2.

Wilamowitz-Moellendorff 185; 191; 192; 193, n. 2; 194 e n. 1, n. 3; 195, n. 2, n. 4; 196, n. 1, n. 2; 197; 198; 202 e n. 1, n. 4; 204 e $n$. 3; 204,n. 1; 204-205, n. 6; 206 e n. 2, n. 3; 210 e $n .7 ; 212$ e $n .1, n .2 ; 215$ e $n .3 ; 227, n$. $1 ; 234$ e $n .2 ; 241 ; 248$ e $n .4 ; 249, n .1 ; 282, n$. 2; 292-293, n. 1 .

Wolf 186; 263.

P. Wuilleumier 240, n. 2.

O. Zuretti 229 e n. 5 . 
(Página deixada propositadamente em branco) 
ÍNDICE DE PALAVRAS E EXPRESSÕES ANACREÔNTICAS 
(Página deixada propositadamente em branco) 
As formas ou expressões assinaladas com asterisco figuram só nas Anacreontea.

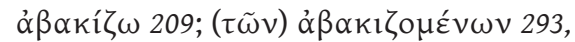
n. 1

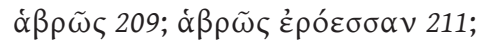

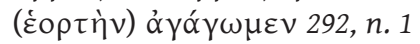

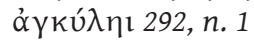

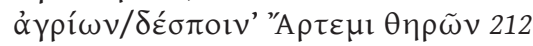

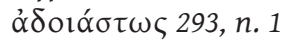

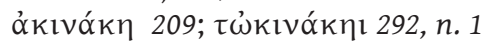

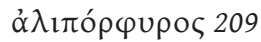

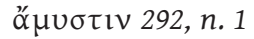

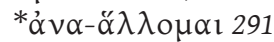

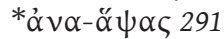

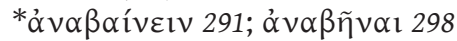

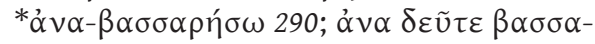

рท́б 293, n. 1

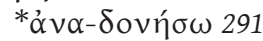

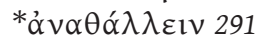

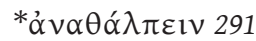

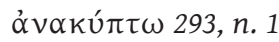

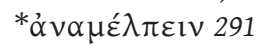

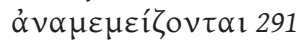

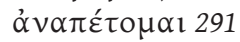

*ả $v \alpha \pi v \varepsilon \tilde{\imath} v 291$

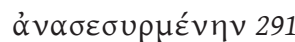

$\dot{\alpha} v \alpha \sigma \tau \alpha \lambda u ́ \zeta \omega 227 ; 294$

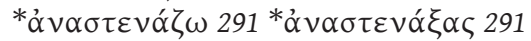

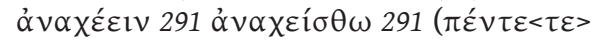

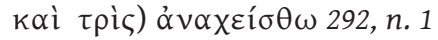

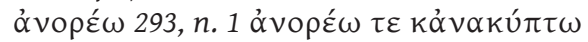

196

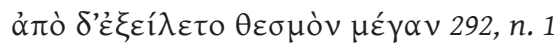

$\dot{\alpha} \rho \gamma \alpha \lambda \varepsilon \dot{\varepsilon} \circ \varsigma 288$

$\dot{\alpha} \sigma \tau \rho \alpha \gamma \alpha \dot{\lambda} \alpha 1292, n .1$

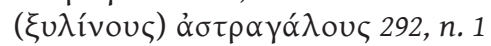

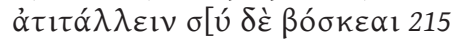

ßó́pßıто 209

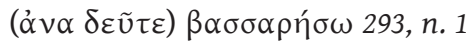

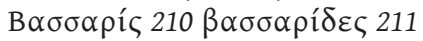

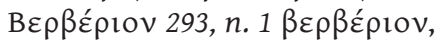

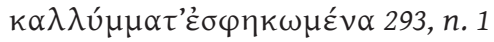

Bíotos 243

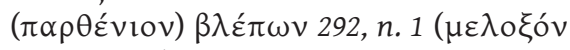

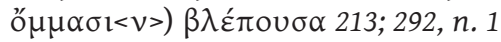

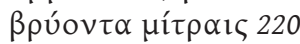

үớ 227 (bis)

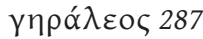

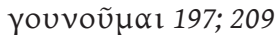

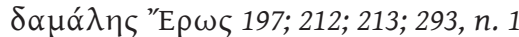

ठغ่ 214

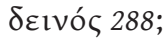

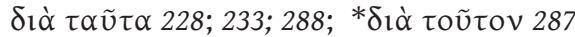

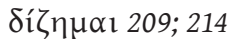

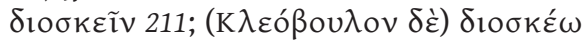
293, n. 1

Sítokov 293, n. 1

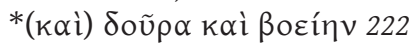

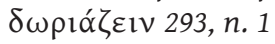

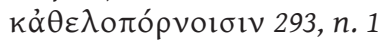

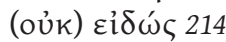

(

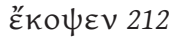

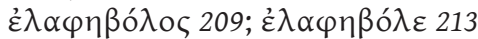

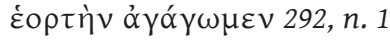

' $\pi \alpha v \varepsilon \rho \chi о \mu \alpha 1292, n .1$

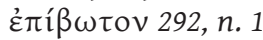

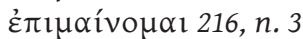

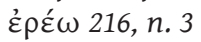

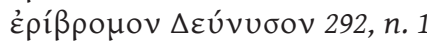

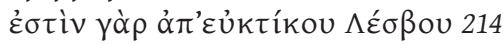

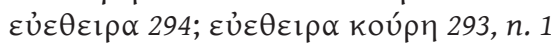

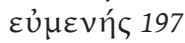

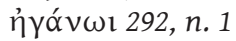




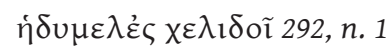

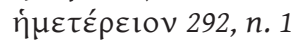

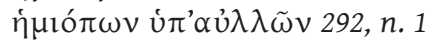

$\tilde{\eta} \sigma \varepsilon 292, n .1$

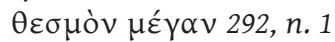

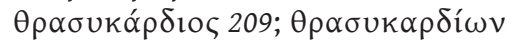

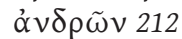

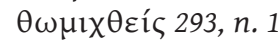

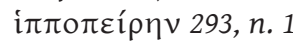

$\kappa \alpha \theta \varepsilon ́ \rho \mu \alpha \tau \alpha 293, n .1$

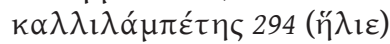

$\kappa \alpha \lambda \lambda_{1} \lambda \alpha \alpha_{\mu} \pi \varepsilon \dot{\tau} \tau$ 293, n. 1

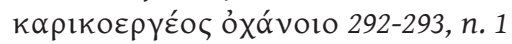

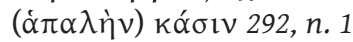

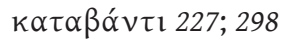

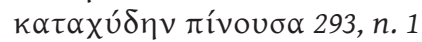

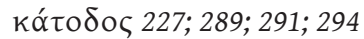

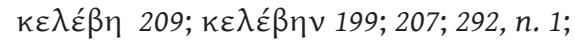

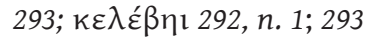

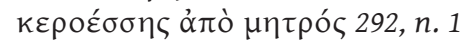

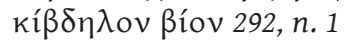

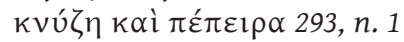

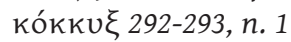

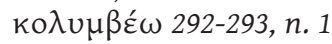

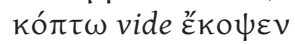

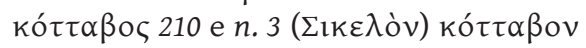

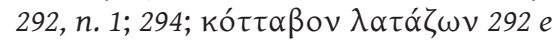

n. 1;

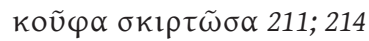

К৩ó日ous 199; 294

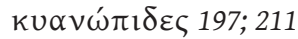

$\lambda \alpha \lambda^{\prime} \alpha \zeta \varepsilon$ 293, n. 1

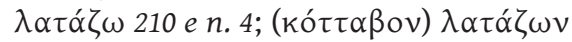
292; 294

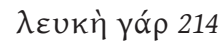

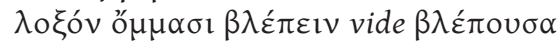

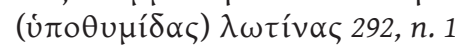

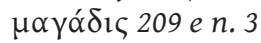

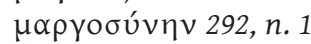

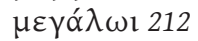

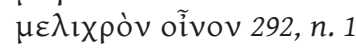

$\mu \varepsilon \dot{\lambda}$ o $\mu \alpha 1220$

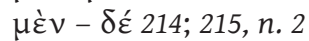

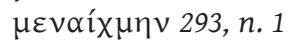

( $\sigma \kappa u ́ \pi \varphi \circ v) \mu \varepsilon \sigma \tau o ́ v ~ 292, n .1 \mu \nu \eta ́ 1 \sigma \kappa \varepsilon \tau \alpha 1$

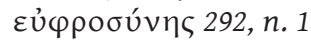

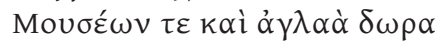

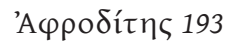

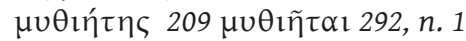

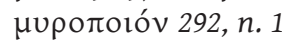

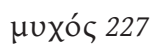

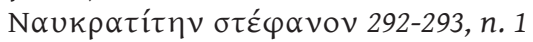

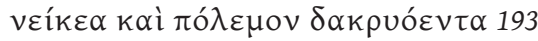

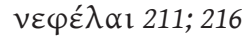

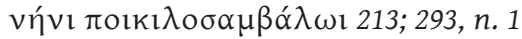

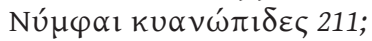

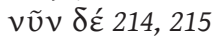

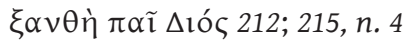

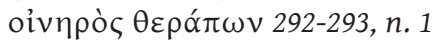

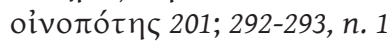

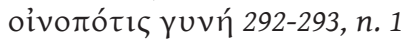

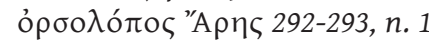

óxóv volo 292-293, n. 1

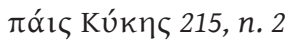

$\pi \alpha \mu \varphi \alpha \lambda \tilde{\alpha} \nu 211$

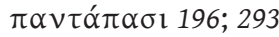

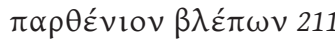

$\pi \varepsilon ́ \pi \varepsilon 1 \rho \alpha 292-293$, n. 1

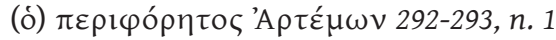

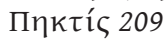

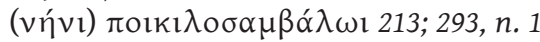

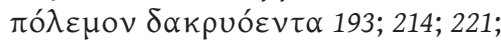

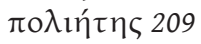

$\pi \circ \lambda_{\text {ló }} 287$

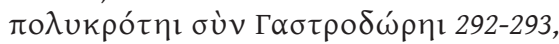

n. 1

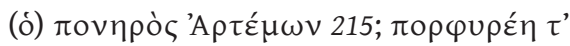

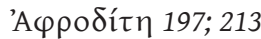

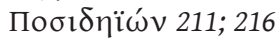

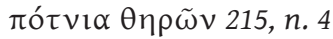

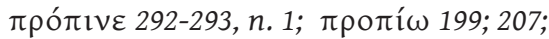

292-293, n. 1

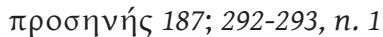

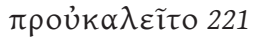

$\pi \tau \varepsilon \rho u ́ \gamma \varepsilon \sigma \sigma l$ koú $\propto \alpha 1 \varsigma$ 187; 211

$\pi \cup \kappa \tau \alpha \lambda i ́ \zeta \omega$ 196; 207; 293, n. 1

$\pi \omega ́ \gamma \omega \nu \alpha 292-293, n .1$

$\propto \alpha \delta$ เvoí 211

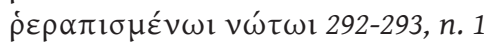

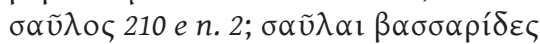

211; $\sigma \alpha \tilde{v} \lambda \alpha \beta \alpha i ́ v \omega v 211$

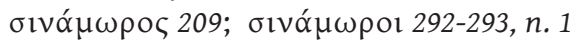

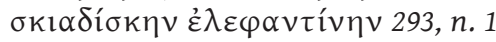

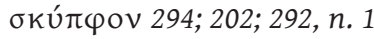

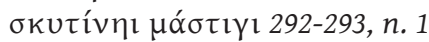

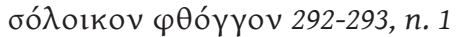

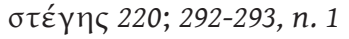

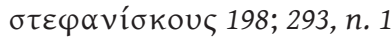

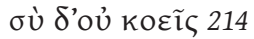

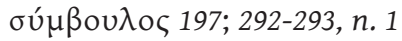




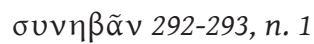

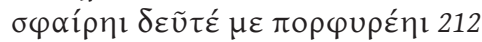

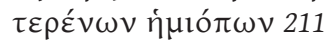

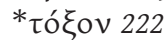

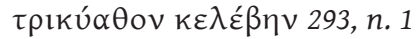

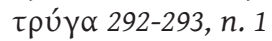

ن்

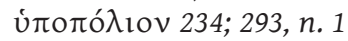

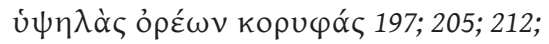

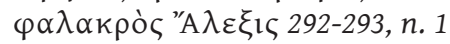

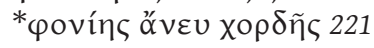

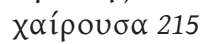

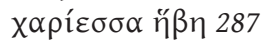

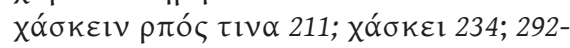

293, n. 1

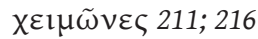

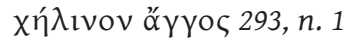

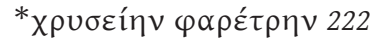

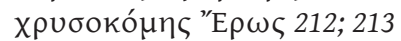

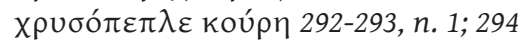

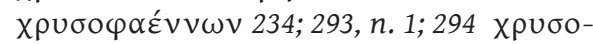

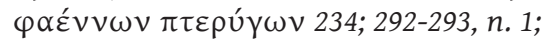

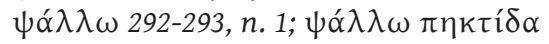

211; 214

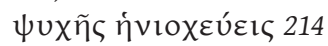

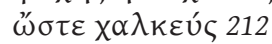


